\title{
FEDERAL CIVIL APPELLATE JURISDICTION: AN INTERLOCUTORY RESTATEMENT
}





\section{Introduction}

The following presentation adheres to the format of the Restatements of the American Law Institute, for which we beg indulgence. This format is used here to suggest the nature of what is attempted; our aims generally adhere to the familiar aims of the Institute's Restatements. Thus, we have striven to state as directly as possible the existing case law which has evolved around Sections 1291, 1292, and 1651 of Title 28 of the United States Code. Where there is a conflict in the case law, we have striven to identify the "better view"; by this we mean the rule which seems most harmonious with the whole, not always the majority rule. But we have not departed from the existing case law that is firmly established, even where there are abundant reasons for doing so. Within the framework of that case law, we have striven to identify and illuminate the operative principles, even if these are not always articulated in the decisions which we presume to synthesize.

Like the Institute, we share the purpose of stimulating interest in law reform. It is the premise of our document that the present law is unnecessarily and unacceptably complex, uncertain, and sometimes even inscrutable. In our effort to restate the law, we have attempted to restructure it in a way that might admit of greater simplicity and predictability in application, and thus to suggest an approach to reformation of the law.

Our most important step, we believe, is to discard much of the present body of doctrine surrounding the hoary concepts of mandamus and collateral order. We attempt to integrate the various doctrinal exceptions and qualifications to the final decision requirement into one coherent conception of the role and limits of interlocutory appeal that is compatible with the existing patterns of decisions.

The manner in which this synthesis is attempted is through use of the several kinds of trial court actions that might be subject to interlocutory review as the organizing features of the landscape, describing the limits of the review to which each type of order is subject. The idea which emerges from this effort is that interlocutory appeal, in whatever guise, is permitted in the federal system only to the extent needed to provide effective enforcement of substantial rights that cannot adequately be protected by means of review after final decisions. We attempted to specify, albeit not completely, the rights to be so protected.

A question posed for readers is the appropriate process for reforming this body of law if in fact it is to be reformed. Should reform await the evolution of case law as guided by this and other efforts to simplify and clarify these issues? Should there be substantial recodification in Title 28 of the United States Code? Or should there be some rules-enabling legislation to be followed by substantial additions to the Federal Rules of Appellate Procedure?

Obviously, we do not intend to represent this document as having the authority of the American Law Institute. An earlier draft was the subject of discussion by a conference held at Duke University in 1983. We are grateful for the helpful criticism received from our conferees including: the Honorable Richard S. 
Arnold; Wallace R. Baker; the Honorable Edward R. Becker; the Honorable Winslow Christian; the Honorable Robert L. Clifford; Professor Edward H. Cooper; William P. Eldridge; the Honorable Wilfred Feinberg; Professor Peter Fish; the Honorable John H. Gibbons; Professor Eugene Gressman; Stephen P. Johnson; the Honorable Nathaniel R. Jones; the Honorable Thomas C. Kleinschmidt; Professor Daniel J. Meador; the Honorable Wilbur F. Pell, Jr.; the Honorable J. Dickson Phillips; Professor Maurice Rosenberg; Professor Laurens Walker; Professor Garry Watson; the Honorable Gerald T. Wetherington; and the Honorable Willis P. Whichard. We have in several places adhered to their collective wisdom, but none bears responsibility for our product.

We hope our work will stimulate others speaking with greater authority to promulgate a genuine Restatement. It is with that hope in mind that we have entitled our own product an Interlocutory Restatement.

THE EDITORS 


\section{Table of Contents}

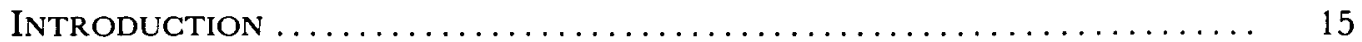

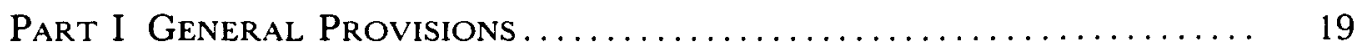

A. Appellate Jurisdiction Generally ............................. 19

Section 1. The Right to Appeal ............................. 19

2. Forum for Appeal ............................... 22

3. Form of Final Decision .......................... 26

4. Partial Final Decision ........................... 28

B. Form and Time of Appeal from Final Decision ................... 000

Section 5. Commencement of Appeal: Notice.................... 36

6. Time for Appeal .............................. 38

7. Commencement of Running of Time for Appeal ......... 42

8. Untimely Appeals and Extensions of Time .............. 45

C. Action of Appellate Court .................................. 000

Section 9. Scope of Review of Final Decisions .................. 47

10. Rescript ..................................... 67

Part II InTERLOCUTORY ReVIEW ............................ 000

A. General Provisions ......................................... 000

Section 11. Certified Appeal .............................. 75

12. Interlocutory Appeal Restricted in Purpose ............. 82

13. Commencement of Interlocutory Appeals.............. 92

B. Review of Orders Regarding Choice of Forum ...................... 96

Section 14. Service of Process and Jurisdiction Over Person of Defendant 96

15. Venue and Change of Venue...................... 99

16. Federal Jurisdiction ........................... 108

17. Litigation in Agencies and Other Courts: Stays and

18. Arbitration .................................. 128

C. Review of Orders Regarding Provisional and Partial Remedies and Sanctions ... 135

Section 19. Provisional Security ................................. 135

20. Preliminary Injunctions and Temporary Restraining Orders . 141

21. Receiverships.................................. 151

22. Partial Remedies.............................. 157

23. Orders Imposing Contempt Sanctions ............... 161

D. Review of Orders Regarding Judges, Magistrates, Masters, and Jurors ...... 168

Section 24. Disqualification of Judges and Magistrates .............. 168

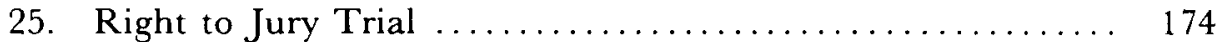

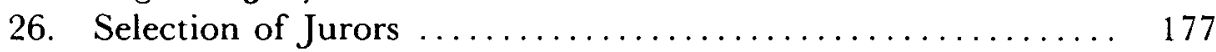

27. References .................................. 183

E. Review of Dispositions before Trial ........................... 188

Section 28. Judgments on Pleadings and Summary Judgments ........ 188

29. Joinder of Claims and Parties ....................... 193

30. Class Certification............................. 199 


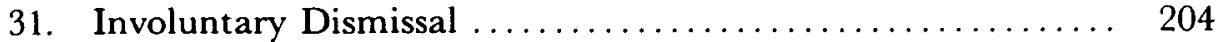

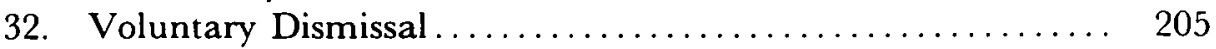

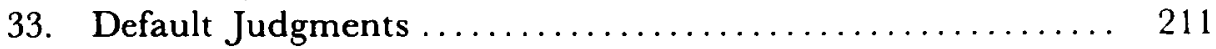

F. Review of Orders Regarding Counsel ......................... 214

Section 34. Appointment of Counsel ...................... 214

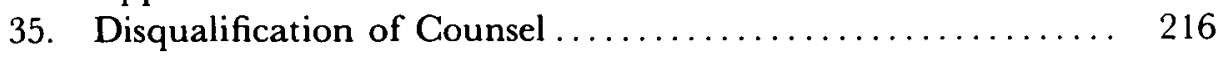

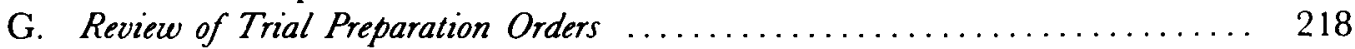

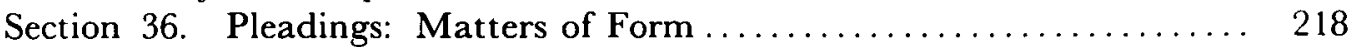

37. Orders Compelling or Refusing to Compel Discovery ....... 219

38. Protective Orders .......................... 225

39. Discovery Sanctions Against Parties .................. 229

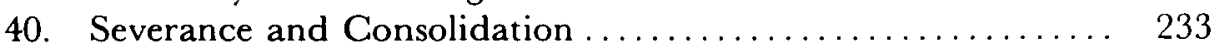

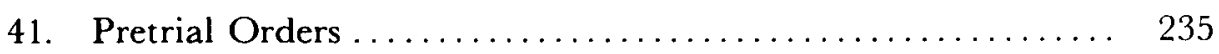

H. Review of Post-Trial Orders .............................. 237

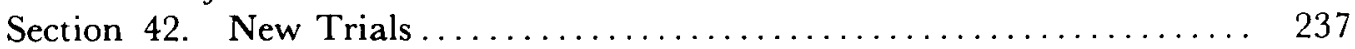

43. Relief from Judgment ..................... 243 


\section{PART I \\ GENERAL PROVISIONS}

A. Appellate Jurisdiction Generally

§ 1. The Right to Appeal.

A PARTY TO A CIVIL ACTION WHO IS ADVERSELY AFFECTED BY A FINAL DECISION OF A DISTRICT COURT MAY APPEAL OF RIGHT. NONFINAL ACTIONS OF A DISTRICT COURT ARE APPEALABLE ONLY TO THE LIMITED EXTENT PROVIDED IN SECTIONS 14-43 OF THIS INTERLOCUTORY RESTATEMENT. NONFINAL ACTIONS NOT EXPLICITLY COVERED BY THOSE RULES ARE APPEALABLE ONLY IN CONFORMITY WITH THE PRINCIPLES EXPRESSED IN SECTIONS 11 AND 12.

\section{COMMENT}

a. Appeals and the Constitution. The traditional view is that the U.S. Constitution does not create a right to appellate review but instead leaves that matter, like the creation of inferior federal courts and their jurisdiction, to Congress. ${ }^{1}$ The Supreme Court has frequently asserted the necessity of statutory authorization: "If Congress has provided no rule to regulate our proceedings, we cannot exercise appellate jurisdiction." 2 For such jurisdiction to exist, the Court has held that "two things must concur: the Constitution must give the capacity to take [the case], and an act of Congress must supply the requisite authority. . . . [Appellate jurisdiction] is wholly the creature of legislation."3

Thus, appellate review has not always been available. For example, for one hundred years there was no general right of appeal to the Supreme Court in criminal cases, ${ }^{4}$ and in Ex parte McCardle, the Court upheld the repeal of a statute authorizing its review of denials of the writ of habeas corpus. ${ }^{5}$ As rights of appeal

1. U.S. CONST. art. III, $\S 2$, cl. 2. In pertinent part: "[T] Jurisdiction, both as to Law and Fact, with such Exceptions, and under such Regulations as the Congress shall make." See also U.S. ConsT. art. III, §1. In pertinent part: "The judicial Power of the United States, shall be vested in one supreme Court, and in such inferior Courts as the Congress may from time to time ordain and establish." These provisions represent a compromise reached at the Constitutional Convention between the Randolph proposal, which called for a constitutionally established lower federal court system and the Paterson plan, which called for leaving all trial litigation to the state courts. See generally Fran, Historical Bases of the Federal Judicial System, 13 LAW \& ContemP. Probs. 3, 10 (1948).

2. Wiscart v. Dauchy, 3 U.S. (3 Dall.) 321, 327 (1796) (opinion of Ellsworth, C.J.). See also Clark v. Bazadone, 5 U.S. (1 Cranch) 212, 214 (1803); of. Turner v. Bank of N. Am., 4 U.S. (4 Dall.) 3, 11 (1799).

3. Daniels v. Railroad Co., 40 U.S. (3 Wall.) 250, 254 (1865). See also Barry v. Mercein, 46 U.S. (5 How.) 103, 119 (1847) ("[T]he Supreme Court possesses no appellate power in any case, unless conferred upon it by act of Congress."):

4. F. Frankfurter \& J. Landis, The Business of The Supreme Court 109-20 (1927).

5. 74 U.S. (7 Wall.) 506, 514 (1869) ("Without jurisdiction the court cannot proced at all in any cause. Jurisdiction is power to declare the law, and when it ceases to exist, the only function remaining to the court is that of announcing the fact and dismissing the cause."). The McCardle Court emphasized, however, that the congressional action had not foreclosed all avenues of review of denials of habeas corpus, $i d$. at $\mathbf{5 1 5}$, and in fact just over six months later the Supreme Court held that it had jurisdiction when such an 
are creations of statute, they may also be abolished at Congress's discretion. ${ }^{6}$

Despite this categorical language in the cases, as summarized above, certain constitutional foundations-for example, express prohibitions on governmental actions, the separation of powers, and the nature of the judicial function-have been suggested as limits on congressional power over appellate jurisdiction. ${ }^{7}$ The Supreme Court found a violation of separation of powers when Congress attempted through manipulation of the right to appeal to control specific judicial decisions; ${ }^{8}$ and the Court has held that once an avenue of appellate review is established it must be open and equally accessible to all, free of unreasoned distinctions. ${ }^{9}$ Furthermore, due process may require an adequate opportunity for at least one impartial hearing, be it through appeal, writ of mandamus, or federal habeas corpus, of a claim of violation of constitutional rights during the underlying trial. ${ }^{10}$

b. Statutory Avenues of Appeal. The most fundamental statutory right of appeal is codified in 28 U.S.C. $\S 1291$, which provides:

[t]he courts of appeals . . . shall have jurisdiction of appeals from all final decisions of the district courts of the United States . . . except where a direct review may be had in the Supreme Court. ${ }^{11}$

In addition, three potential avenues of appeal exist for parties seeking review of nonfinal decisions. First, 28 U.S.C. $§ 1292$ provides for immediate review of certain interlocutory orders involving preliminary injunctions or receiverships ${ }^{12}$ or rulings on questions of law that have been certified by the district court and accepted for review by the court of appeals. ${ }^{13}$ Moreover, 28 U.S.C. $\S 1651$ (the All Writs Act) authorizes a court of appeals to grant review through the issuance of "all writs necessary or appropriate in and of their respective jurisdictions and agreeable to the usages and principles of law." 14 Finally, 28 U.S.C. $\$ 1291$ has been interpreted as encompassing certain interlocutory orders within the concept of "final decision" for purposes of appellate review. ${ }^{15}$

c. Parties Who May Appeal. Any individual adversely affected by a final decision has standing under 28 U.S.C. $§ 1291$ to seek an appeal. Generally this encompasses only parties to the litigation below; but the statute is not thus expressly limited $;{ }^{16}$ and standing may commonly be sought in the cases of intervenors, attorneys seeking fee awards, and nonparties (including attorneys) facing civil contempt

action came to it through certiorari and its original habeas corpus power, Ex parte Yerger, 75 U.S. (8 Wall.) 85 (1869).

6. See Ex parte McCardle, 74 U.S. (7 Wall.) 506 (1869).

7. See generally Hart, The Power of Congress to Limit the Jurisdiction of Federal Courts: An Exercise in Dialectic, 66 HaRV. L. Rev. 1362 (1953).

8. United States v. Klein, 80 U.S. (13 Wall.) 128, 146 (1872).

9. Griffin v. Illinois, 351 U.S. 12 (1956).

10. Cf. Van Alstyne, In Gideon's Wake: Harsher Penalties and the "Successful" Criminal Appellant, 74 YALE L.J. 606,613 n.25 (1965).

11. 28 U.S.C. $\S 1291$ (1976).

12. 28 U.S.C.A. $\$ 1292(a)$ (1) \& (2) (West Supp. 1983).

13. 28 U.S.C. $\S 1292(\mathrm{~b})(1976)$.

14. 28 U.S.C. $\S 1651(1976)$.

15. The types of orders subject to such review are summarized infra $\S 12$ of this Interlocutory Restatement, notes 8-16 and accompanying text.

16. United States v. Chagra, 701 F.2d 354, 358 (5th Cir. 1983). 
or other monetary sanctions. ${ }^{17}$

An intervenor upon being granted such status may appeal subsequent orders ${ }^{18}$ adversely affecting the interests warranting the intervention. ${ }^{19}$ Indeed, a court may grant intervention primarily to allow the intervenor to prosecute an appeal. ${ }^{20}$ However, one who could have, but did not, intervene or one who has been denied intervention generally has no standing to appeal subsequent orders. ${ }^{21}$

Also, an attorney will have standing to appeal on final decision the denial of a fee award. ${ }^{22}$ Though the award is made to the client, the attorney as a practical matter may be the only one harmed if the appellate court fails to reverse; furthermore, to allow the protest is consistent with the intent of underlying fee award provisions to encourage attorneys to pursue certain types of litigation. ${ }^{23}$

A nonparty subjected to a civil contempt sanction, however, has no standing to appeal from the final decision in the action ${ }^{24}$ because that judgment will not affect his rights. The nonparty therefore may seek immediate review of the contempt order itself. ${ }^{25}$ Similarly, an attorney generally may immediately appeal an order imposing sanctions under Rule $37(a)(4)^{26}$ or Rule $37(b)(2)^{27}$ of the Federal Rules of Civil Procedure for his failure to comply with discovery. As in the case of civil contempt, "[u]nless [an attorney] . . . can obtain a review of the order and sanction [awarding attorney fees] at the time it is imposed, a non-party will have no right of review at all." 28 This practice should also apply as to new sanctions authorized by the August 1983 amendments to the Rules. ${ }^{29}$

17. A nonparty may also seek standing to appeal when his rights will be adversely affected by an order concerning an injunction, a receivership, or discovery. See id. at 359 .

18. Fishgold v. Sullivan Drydock \& Repair Corp., 328 U.S. 275 (1946). But see Cerro Metal Prods. v. Marshall, 620 F.2d 964 (3d Cir. 1980) (intervenor allowed to appeal interlocutory order entered prior to intervention notwithstanding district court proviso in grant of leave to intervene to the contrary).

19. Boston Tow Boat Co. v. United States, 321 U.S. 632 (1944). See also Smuck v. Hobson, 408 F.2d 175 (D.C. Cir. 1969) (en banc). For a discussion of the rights of intervenors seeking discovery to appeal protective orders, see infra $\S 38$ of this Interlocutory Restatement, notes $9-11$ and accompanying text.

20. See, e.g., Smuck v. Hobson, 408 F.2d 175 (D.C. Cir. 1969) (en banc).

21. Moten v. Bricklayers Int'l Union, 543 F.2d 224 (D.C. Cir. 1976); Pennsylvania v. Rizzo, 530 F.2d 501 (3d Cir.), cert. denied, 426 U.S. 921 (1976). But see Smartt v. Coca-Cola Bottling Corp., 337 F.2d 950 (6th Cir. 1964)(where no formal order of intervention was entered but district judge treated would-be intervenors as parties, would-be intervenors were allowed to prosecute appeal)

22. Liscomb v. Wise, 643 F.2d 319 (5th Cir. 1981).

23. Id. at $320-21$.

24. David v. Hooker, Ltd., 560 F.2d 412, 415-16 (9th Cir. 1977).

25. Id. See infra $\$ 23$ of this Interlocutory Restatement, commente, for a further discussion of nonparty civil contempt appeals.

26. See, e.g., Reygo Pac. Corp. v. Johnston Pump Co., 680 F.2d 647, 648 (9th Cir. 1982). But see Eastern Maico Distribs., v. Maico-Fahrzeugfabrik, 658 F.2d 944, 949-50 (3d Cir. 1981)(holding Rule 37 (a) (4) sanction not immediately appealable by a nonparty attorney because the purpose of the sanction is simply the prevention of delay caused by the filing of groundless motions).

27. See, e.g., Liew v. Breen, 640 F.2d 1046, 1048 (9th Cir. 1981); David v. Hooker, Ltd., 560 F.2d 412 (9th Cir. 1977); of. Cheng v. GAF Corp., 713 F.2d 886, 890 (2d Cir. 1983)(holding an order imposing attorney fees on a party under 28 U.S.C. $\$ 1927$ immediately appealable in light of the hardship suffered by the party's attorney if such appeal were not available). But see Independent Investor Protective League v. Touche Ross \& Co., 542 F.2d 156, 158 (2d Cir. 1976)(dictum suggesting that a nonparty attorney may in some circumstances be "so allied with a party as to preclude interlocutory review of an order to pay compensatory expenses"). See generally infra $\$ 23$ of this Interlocutory Restatement, text accompanying notes $42-$ 45 .

28. David v. Hooker, Ltd., 560 F.2d 412, 417 (9th Cir. 1977).

29. Amendments to the Federal Rules of Civil Procedure, 97 F.R.D. 165 (Apr. 28, 1983)(effective 


\section{§2. Forum for Appeal.}

(A) AN APPEAL FROM A DECISION OF A DISTRICT COURT SHALL BE TAKEN TO THE UNITED STATES COURT OF APPEALS FOR THE CIRCUIT IN WHICH THE DISTRICT COURT IS LOCATED, EXCEPT WHERE DIRECT REVIEW MAY BE HAD IN THE SUPREME COURT OF THE UNITED STATES OR REVIEW MAY BE HAD IN THE UNITED STATES COURT OF APPEALS FOR THE FEDERAL CIRCUIT.

(B) AN APPEAL FROM A DECISION ENTERED, AT THE AGREEMENT OF THE PARTIES, BY A MAGISTRATE SHALL BE TAKEN TO THE COURT OF APPEALS FOR THE CIRCUIT IN WHICH THE DISTRICT COURT MAKING THE REFERRAL TO THE MAGISTRATE IS LOCATED, EXCEPT THAT, BY FURTHER AGREEMENT OF THE PARTIES, APPEAL IN THE FIRST INSTANCE MAY BE TO THAT DISTRICT COURT.

\section{COMMENT}

a. Generally. Sections 1291, 1292, and 1294 of Title 28 of the United States Code $^{1}$ provide generally that an appeal from a reviewable decision of a district court be taken to the court of appeals for the circuit in which the district is located. Section 1294 makes further provisions for the proper forum for appeals from territorial district courts, ${ }^{2}$ and 28 U.S.C. $\$ 41$ provides for the geographic organization of the twelve judicial circuits. ${ }^{3}$ The regional courts of appeals do not, however, have jurisdiction over all appealable decisions of the district courts.

b. Direct Appeal to Supreme Court. Sections 1291 and 1292(a)(1) of Title 28 both except from the jurisdiction of the courts of appeals those cases for which direct review may be had in the Supreme Court of the United States. ${ }^{4}$ Such review is provided in 28 U.S.C. $\$ \S 1252 \& 1253^{5}$ and in provisions of certain other acts of Congress. ${ }^{6}$ The rules of appealability stated in sections 14-43 of this Interlocutory Restatement may not be applicable to appeals taken pursuant to these statutes. ${ }^{7}$

Section 1252 grants direct Supreme Court review of the district court decisions that hold an act of Congress unconstitutional in a civil proceeding to which the United States or one of its agencies or any officer or employee thereof is a party.

\footnotetext{
Aug. 1, 1983). Sanctions, again in the form of assessments of opposing parties' costs, are now authorized in conjunction with Rule 11, which requires that attorneys certify pleadings and motions as well-grounded in fact and law based on reasonable inquiry, and with new rules $16(f)$ and $26(\mathrm{~g})$, which deal with misconduct as to pretrial conferences and discovery requests respectively.
}

1. 28 U.S.C. $\S \S 1291,1294$ (1976); 28 U.S.C.A. $§ 1292$ (1976 \& West Supp. 1983).

2. 28 U.S.C. $\S 1294$ (1976).

3. 28 U.S.C. $\$ 41$ (1976 \& Supp. V 1981)

4. 28 U.S.C. $\S 1291$ (1976); 28 U.S.C.A. $§ 1292(a)(1)$ (West Supp. 1983).

5. 28 U.S.C. $\$ \$ 1252,1253$ (1976).

6. See, e.g., Presidential Election Campaign Fund Act of 1971, 26 U.S.C. $\$ 9011$ (b)(2) (1976); Civil Rights Act of 1964, 42 U.S.C. $\$ \S 1971(\mathrm{~g}), 2000 \mathrm{a}-5(\mathrm{a}), 2000 \mathrm{a}-5(\mathrm{~b}), 2000 \mathrm{e}-6(\mathrm{a}), 2000 \mathrm{e}-6(\mathrm{~b})$ (1976); Voting Rights Act of 1965, 42 U.S.C. $\S \S 1973 b(a), 1973 c, 1973 \mathrm{~h}(c), 1973 b b(a)(2)$ (1976); Regional Rail Reorganization Act of 1973, 45 U.S.C. $\$ \S 719(\mathrm{e})(3), 743(\mathrm{~d})$ (1976).

7. See, e.g., infra $\S 17$ of this Interlocutory Restatement, note 1 (stays issued by three-judge panels). 
Finality of the district court decision is not required, ${ }^{8}$ and appeal to the Supreme Court is exclusive under the statute. ${ }^{9}$ This provision has been liberally construed in order to faciliate speedy Supreme Court review of attacks in the lower courts on the constitutionality of federal statutes. ${ }^{10}$

Section 1253 provides for direct review in the Supreme Court where, except as otherwise provided by law, an interlocutory or permanent injunction has been granted or denied in a civil proceeding required by an act of Congress to be heard and determined by a district court of three judges." "The three-judge court must be properly convened (that is, required by act of Congress) $;^{12}$ otherwise, the Supreme Court must dismiss the appeal. ${ }^{13}$ Furthermore, when the district court refuses to convene a three-judge panel ${ }^{14}$ or such panel subsequently dissolves itself, ${ }^{15}$ jurisdiction over the appeal lies only with the court of appeals and not with the Supreme Court.

c. Appeals to the Federal Circuit. The newly created ${ }^{16}$ Court of Appeals for the

8. $12 \mathrm{~J}$. Moore, H. Bendix \& B. Ringle, Moore's Federal Practice 9411.10 , at $5-23$ \& n.1 (2d ed. 1982).

9. Id. ๆ 411.09 , at $5-22$ \& n.3.

10. See, e.g., McLucas v. DeChamplain, 421 U.S. 21, 31 (1975); United States v. American Friends Serv. Comm., 419 U.S. 7 (1974) (direct appeal permitted when act of Congress held unconstitutional as applied as well as when held unconstitutional on its face); United States v. Raines, 362 U.S. 17, 20 (1960) (district court's holding of unconstitutionality properly appealed to Supreme Court regardless of what parties contended should have been basis of decision, and whole case, not just constitutional issue, to be heard by Supreme Court), Reid v. Covert, 351 U.S. 487 (1956) (superintendent of District of Columbia jail, as party to action, held to be "employee" of United States within meaning of 28 U.S.C. $\S 1252$ ). See generally 12 J. MOORE, H. BENDIX \& B. RinGLE, supra note 8, at " 411.04.

The statute has been construed much more liberally than 28 U.S.C. $§ 1253$. Id. at 5-18.

11. This provision is now of limited applicability because of the minor role of three-judge district courts. Three main statutes once required such panels: 28 U.S.C. $\S 2281$ (suits to enjoin enforcement of state statutes); 28 U.S.C. $§ 2282$ (suits to enjoin enforcement of federal statutes); and 28 U.S.C. § 2325 (suits to enjoin enforcement of orders of the Interstate Commerce Commission). All three have been repealed. See Act of Aug. 12, 1976, Pub. L. No. 94-381, §§ 1-2, 90 Stat. 1119, 1119 (repealing 28 U.S.C. $\S \S 2281,2282$ ); Act of Jan. 2, 1975, Pub. L. No. 93-584, § 7, 88 Stat. 1917, 1918 (repealing 28 U.S.C. $\S 2325)$; see also Act of Dec. 21, 1974, Pub. L. No. 93-528, §§ 4-5, 88 Stat. 1706, 1708-09 (eliminating the requirement of a three-judge court under the Expediting Acts, 15 U.S.C. $\S \S 28-29 ; 49$ U.S.C. $\S \S 43-45$ ).

The Act of August 12, 1976, however, added the requirement that three-judge district courts be convened in suits challenging the apportionment of statewide legislative bodies. These are now virtually the only cases in which 28 U.S.C. $\$ 1253$ applies. See 12 J. MOORE, H. BENDiX \& B. RINGLE, supra note 8, I 421.03[0].

12. See, e.g., Pennsylvania Pub. Util. Comm'n v. Pennsylvania R.R., 382 U.S. 281, 282 (1965)(per curiam). Although this and other cases cited infra interpret 28 U.S.C. $\S 1253$ in conjunction with acts of Congress that have since been repealed (see supra note 11), it has been observed that "a good deal of the jurisprudence interpreting $\S 1253$ prior to 1974,1975 and 1976 is still relevant to the application of $\S 1253$ today." 12 J. MOORE, H. BENDIX \& B. RiNGLE, supra note 8, ๆ 421.05[4], at 5-142.

13. Norton v. Mathews, 427 U.S. 524, 531 (1976). In Norton the Court followed the practice of vacating the district court's judgment and remanding for entry of a new judgment from which a timely appeal to the appropriate court of appeals could be taken. Such action is not necessary where a "protective appeal" has been filed in the court of appeals. See Pennsylvania Pub. Util. Comm'n v. Pennsylvania R.R., 382 U.S. 281, 282 (1965) (per curiam); Annot., 26 L. Ed. 2d. 947, 956 (1960). The appellant's problem could now also now be solved by a transfer of the appeal to the appropriate court of appeals. See 28 U.S.C. $\S 1631$ (West Supp. 1983).

14. Schackman v. Arnebergh, 387 U.S. 427 (1967) (per curiam).

15. Mengelkoch v. Industrial Welfare Comm'n, 393 U.S. 83, 83-84 (1968) (per curiam).

16. The Court of Appeals for the Federal Circuit was established by the Federal Courts Improvement Act of 1982, Pub. L. No. 97-164, 96 Stat. 25. The jurisdiction of the court is defined in sections 125 and 127. Id. at $36-39$ (codified at 28 U.S.C.A. $§ \S 1292,1295$ (West Supp. 1983)). 
Federal Circuit has jurisdiction over appeals from certain district court decisions which would once have been heard by the regional courts of appeals for the circuits in which the district courts were located. This jurisdiction encompasses final decisions of district courts in certain patent and government contracts cases; ${ }^{17}$ the legislation, however, makes only limited provision for interlocutory appeals in such litigation.

If the interlocutory appeal is one authorized by 28 U.S.C. $\S 1292(a)$, then it is clear that the Federal Circuit has exclusive jurisdiction under 28 U.S.C. $\$ 1292$ (c) (1). ${ }^{18}$ An interlocutory appeal may also be taken exclusively to the Federal Circuit from a judgment in a patent infringement action that is final except for an accounting; this carries forward an old exception formerly found in 28 U.S.C. $\S 1292(\mathrm{a})(4) .^{19}$

The Federal Circuit, however, has held that it has no jurisdiction to consider interlocutory appeals certified by district courts pursuant to 28 U.S.C. $\S 1292(\mathrm{~b})^{20}$ because of the absence of specific statutory authorization. ${ }^{21}$ It is not clear why such provision was omitted. The certified appeal can be a means to economical litigation if the appellate court can provide an authoritative statement on a controlling question of substantive law. Thus, if the district court were in doubt about such a question of patent or government contract law, certified appeal to the Federal Circuit would seem appropriate. In its absence, however, certified appeal to a

17. 28 U.S.C.A. $§ 1295$ (a)(1) \& (2) (West Supp. 1983):

(a) The United States Court of Appeals for the Federal Circuit shall have exclusive jurisdiction-

(1) of an appeal from a final decision of a district court of the United States, the United States District Court for the District of the Canal Zone, the District Court of Guam, the District Court of the Virgin Islands, or the District Court for the Northern Mariana Islands, if the jurisdiction of that court was based, in whole or in part, on section 1338 of this title, except that a case involving a claim arising under any Act of Congress relating to copyrights or trademarks and no other claims under section 1338(a) shall be governed by sections 1291, 1292, and 1294 of this title;

(2) of an appeal from a final decision of a district court of the United States, the United States District Court for the District of the Canal Zone, the District Court of Guam, the District Court of the Virgin Islands, or the District Court for the Northern Mariana Islands, if the jurisdiction of that court was based, in whole or in part, on section 1346 of this title, except that jurisdiction of an appeal in a case brought in a district court under section $1346(\mathrm{a})(1), 1346(\mathrm{~b}), 1346(\mathrm{e})$, or $1346(\mathrm{f})$ of this title or under section 1346(a)(2) when the claim is founded upon an Act of Congress or a regulation of an executive department providing for internal revenue shall be governed by sections 1291,1292 , and 1294 of this title.

18. 28 U.S.C.A. $\$ 1292$ (c)(1) (West Supp. 1983): "The United States Court of Appeals for the Federal Circuit shall have exclusive jurisdiction .. . of an appeal from an interlocutory order or decree described in subsection (a) of this section in any case over which the court would have jurisdiction of an appeal under section 1295 of this title." Subsection (a) generally provides for interlocutory review of decisions concerning injunctive relief and certain orders pertaining to receiverships.

19. 28 U.S.C.A. $§ 1292$ (c)(2) (West Supp. 1983):

(c) The United States Court of Appeals for the Federal Circuit shall have exclusive jurisdiction-

(2) of an appeal from a judgment in a civil action for patent infringement which would otherwise be appealable to the United States Court of Appeals for the Federal Circuit and is final except for an accounting.

20. The purposes of and requirements for certified appeals are discussed infra $\S 11$ of this Interlocutory Restatement.

21. Harrington Mfg. Co. v. Powell Mfg. Mfg. Co., 709 F.2d 710 (Fed. Cir. 1983). This conclusion is further supported by the explicitness of the Federal Circuit provisions as to 28 U.S.C. $\S 1292$ (a) appeals and by the fact that 28 U.S.C.A. $\$ 1292$ (d)(1) \& (2) (West Supp. 1983) provide, in language essentially the same as that of 28 U.S.C. $\S 1292(\mathrm{~b})$, for certified appeals from the U.S. Claims Court and Court of International Trade to the Federal Circuit. 
regional court of appeals, while not limited by statutory provision, would seem illadvised. Any answer provided by the regional court might establish the law of the case, thus foreclosing the Federal Circuit from giving a different, perhaps more correct, and certainly more authoritative, answer to the disputed legal question on later appeal from a final decision. And if, in the alternative, the Federal Circuit were to disregard the certified answer of the regional court, that interlocutory appeal would have been dilatory and wasteful. Should regional courts thus refuse to accept such certified appeals, an exception will have been created to 28 U.S.C. $\S 1292(b)$; certified appeal will simply not be available in patent or government contract cases.

Certain other interlocutory appeals, as that term is used in this Interlocutory Restatement, ${ }^{22}$ are rationalized by courts of appeals as taken from orders which are final decisions within the meaning of 28 U.S.C. $\$ 1291$ even though the proceedings below have not yet run their full course. ${ }^{23}$ Presumably, all such appeals are similarly within the exclusive jurisdiction granted the Federal Circuit to hear appeals from "final" decisions in cases involving patents or government contracts. ${ }^{24}$

An argument can, however, be made for directing interlocutory appeals, including those based on the collateral order doctrine, ${ }^{25}$ to the regional circuits. The issues raised in such appeals are generally separable from the merits. Questions of patent and government contract law will rarely arise, and the procedural questions more frequently presented will not be within the special competence of the Federal Circuit. Moreover, there would be an unseemly disorder in having two different courts of appeals giving potentially different directions to the same district court with respect to procedural issues.

Nevertheless, acknowledging these difficulties, it would seem clearly not worth the cost to draw a line between substantive and procedural appeals, directing the former to the Federal Circuit and the latter to the regional circuits. Too many litigants would be confounded and find themselves in the wrong court; ${ }^{26}$ too many court of appeals panels would find themselves driven across the invisible line in writing opinions and in making decisions which would intrude on the turf of the brother court. For these reasons, it seems appropriate to abide by the implication of the statute and direct all "final" appeals in patent and government contract cases to the Federal Circuit.

The same general issue also arise with respect to mandamus proceedings, which this Interlocutory Restatement treats as interlocutory appeals not to be distin-

22. See infra $\S 12$ of this Interlocutory Restatement, comment $a$.

23. Examples include the collateral order doctrine, see infra $\S 12$ of this Interlocutory Restatement, notes 10-13 and accompanying text, designations of partial finality under Rule 54(b) of the Federal Rules of Civil Procedure, see supra $\S 4$ of this Interlocutory Restatement, and the "practical finality" doctrine as applied to stays. See infra $\S 17$ of this Interlocutory Restatement, comments c-e.

24. In C.P.C. Partnership \& Bardot Plastics v. Nosco Plastics, 719 F.2d 400 (Fed. Cir. 1983), the Federal Circuit dismissed an attempted collateral order appeal on the ground that that doctrine was inapplicable without suggesting the appeal had been filed in the wrong court of appeals. The implication is that an appeal from a true collateral order would be entertained.

25. See infra $\S 12$ of this Interlocutory Restatement, notes 10-23 and accompanying text.

26. Such a situation can now be corrected by transfer. See 28 U.S.C.A. $\S 1631$ (West Supp. 1983). 
guished from collateral order appeals. ${ }^{27}$ Here, however, the legislative provision to be interpreted, 28 U.S.C. $\S 1651,{ }^{28}$ does clearly authorize both the regional circuits and the Federal Circuit to issue writs of mandamus or prohibition; but for the reasons stated above with respect to collateral order appeals, the correct rule would seem to be that mandamus should lie only to the Federal Circuit to correct rulings in cases that are within its exclusive subject matter jurisdiction. Such a rule draws support from two recent holdings of the Federal Circuit ${ }^{29}$ and can be reconciled with the language of 28 U.S.C. $\S 1651$ in that when a case was within the Federal Circuit's exclusive jurisdiction, any intervention by a regional court could not be "in aid of its jurisdiction." 30

d. Appeal from Judgment of Magistrate. A final decision entered by a magistrate pursuant to 28 U.S.C. $\S 636$ (c)(1) ${ }^{31}$ is normally appealable directly to the court of appeals. ${ }^{32}$ With consent of the parties, however, such appeal may be taken instead to the district court for review on the record. ${ }^{33}$ In such instances the district court's determination may then be reviewed by the court of appeals if such court grants a petition for leave for appeal. ${ }^{34}$ Only the appeal to the district court will be an appeal of right; and furthermore, the court of appeals will no longer have jurisdiction to hear a direct appeal from the magistrate's decision and should dismiss or transfer if review is initially sought before it. The rules stated in sections 14-43 of this Interlocutory Restatement may not apply to appeals from magistrates' decisions taken to district courts.

B. Procedure for Appeal From Final Decision

\section{§ 3. Form of Final Decision.}

A FINAL DEGISION OF A DISTRICT COURT SHALL BE SET FORTH ON A SEPARATE DOCUMENT, SHALL BE SIGNED BY THE DISTRICT JUDGE OR MAGISTRATE, SHALL BE ENTERED IN THE CIVIL DOCKET, AND SHALL MANIFEST AN INTENT THAT PROCEEDINGS

27. See infra $\S 12$ of this Interlocutory Restatement, comment a; see also infra $\S 13$ of this Interlocutory Restatement, notes $14-21$ and accompanying text.

28. 28 U.S.C. $\S 1651$ (1976): "The Supreme Court and all courts established by Act of Congress may issue all writs necessary or appropriate in aid of their respective jurisdictions . . ."

29. In re Snap-On Tools Corp., 720 F.2d 654 (Fed. Cir. 1983); Mississippi Chem. Corp. v. Swift Agric. Chem. Corp., 717 F.2d 1374 (Fed. Cir. 1983). But cf. C.P.C. Partnership \& Bardot Plastics v. Nosco Plastics, 719 F.2d 400 (Fed. Cir. 1983). In that case, a panel of the Federal Circuit dismissed an appeal on the ground that the collateral order doctrine was inapplicable and refused an alternative petition for mandamus for lack of any general supervisory authority over district courts. Id. at $40 \mathrm{l}$. Three days earlier a different panel of the Federal Circuit in Mississippi Chem. Corp. v. Swift Agric. Chem. Corp., 717 F.2d 1374, 1379 (Fed. Cir. 1983), had found mandamus available in aid of its jurisdiction but had suggested in dictum that a distinction be maintained between such use and supervisory mandamus. Such a distinction should be disregarded. The resulting complexity in patent and government contract cases cannot be justified by any benefit from a reticence of the Federal Circuit to exercise supervisory powers in such instances.

30. See statutory language quoted supra note 28.

31. 28 U.S.C. $\$ 636$ (c) (Supp. IV 1980). For a further discussion, including reproduction of the relevant statutory provisions and arguments as to their constitutionality, see infra $\$ 27$ of this Interlocutory Restatement, notes $32-41$ and accompanying text.

32. 28 U.S.C. $\$ 636$ (c)(3) (Supp. IV 1980).

33. 28 U.S.C. $\$ 636$ (c)(4) (Supp. IV 1980).

34. 28 U.S.C. $\$ 636$ (c) (5) (Supp. IV 1980). 
IN THE CASE BE THEREBY TERMINATED, SAVE FOR THE TAXATION OF COSTS AND FURTHER PROCEEDINGS IF NECESSARY TO ENFORCE THE DECISION MADE. THE ABSENCE OF A SEPARATE DOCUMENT SHALL NOT PRECLUDE REVIEW OF THE MERITS UNLESS TIMELY OBJECTION IS MADE.

\section{COMMENT}

a. Requirements. Rule 58 of the Federal Rules of Civil Procedure, ${ }^{1}$ to eliminate uncertainty as to when appellate jurisdiction may be invoked, ${ }^{2}$ mandates the occurrence of two events before a final decision is rendered: The judgment must be set forth on a separate document, and it must be entered in the civil docket as provided in Rule 79(a) of the Federal Rules of Civil Procedure. ${ }^{3}$ Failure to perform either one or both of these requirements will not result in a final decision sufficient to commence the time for appeal. ${ }^{4}$ For example, even if a separate document exists in proper form, no effective final decision has been rendered until it is entered in the docket. ${ }^{5}$

The requirement that a final decision, to be appealable, be set forth on a separate document distifict from the jury verdict or nonjury decision by the court ${ }^{6}$ forecloses the possibility that an opinion will have the effect of a judgment. ${ }^{7}$ This requirement is applied strictly. ${ }^{8}$

Indeed, some circuits early held that the proper entry of judgment was essential to appellate jurisdiction and that an appeal from a judgment which had not been set forth on a separate document had to be dismissed, thereby forcing the party to return to the district court to secure a judgment which conformed with Rule $58 .{ }^{9}$ Other circuits held that the absence of a separate document would not preclude review of the merits when both parties treated the order as validly entered. ${ }^{10}$ The

1. FED. R. CIV. P. 58. The substance of the rule is expressed in the black letter here.

2. Bethlehem Mines Corp. v. United Mine Workers, 476 F.2d 860, 863 (3d Cir. 1973).

3. On the need for requiring a separate document, see Bankers Trust Co. v. Mallis, 435 U.S. 381,384 (1978). See also generally Judicial Conf. of the U.S., Report of Proposed Amendments to Certain Rules of Civil Procedure for the United States District Courts, 31 F.R.D. $621,649-50$ (1962) [hereinafter cited as Report of Proposed Amendments ]. Note that in certain situations the clerk is to prepare, sign, and enter the judgment without awaiting any direction by the court. The clerk has the authority to act on his own upon a general verdict of a jury, upon a decision by the court that a party shall recover only a sum certain or costs, or upon a decision by the court that all relief shall be denied. Any other relief, special verdict, or general verdict accompanied by answers to interrogatories necessitates court approval before judgment may be entered.

4. Levin v. Wear-Ever Aluminum, 427 F.2d 847, 848-49 (3d Cir. 1970).

5. Id.

6. This requirement applies when the court decides that all relief should be denied as well as when total or partial relief is granted. Richland Trust Co. v. Federal Ins. Co., 480 F.2d 1212, 1213 (6th Cir. 1973).

7. See generally Report of Proposed Amendments, supra note 2 , at 650 .

8. E.g., Communications Workers v. United Tel. Co., 491 F.2d 207 (6th Cir. 1974)(neither order indicating findings of fact would follow nor memorandum opinion was sufficient separate document for appeal); State Nat'l Bank v. United States, 488 F.2d 890 (5th Cir. 1974)(judgment tacked at end of memorandum insufficient final decision to allow appeal); see also Nunez v. Superior Oil Co., 535 F.2d 324 (5th Cir. 1976); Moore v. St. Louis Music Supply Co., 526 F.2d 801 (8th Cir. 1975).

9. See, e.g., Sassoon v. United States, 549 F.2d 983 (5th Cir. 1977); Baity v. Ciccone, 507 F.2d 717 (8th Cir. 1974); Lyons v. Davoren, 402 F.2d 890 (1st Cir. 1968), cert. denied, 393 U.S. 1081 (1969). The appeal then had to be prosecuted anew.

10. W.G. Cosby Transfer \& Storage Corp. v. Froehlke, 480 F.2d 498, 501 n.4 (4th Cir. 1973). 
Supreme Court in Bankers Trust Co. $v$. Mallis resolved this conflict in favor of the latter position, noting that it would be pointless to require an appellant to return to the district court." The Court stated that the separate judgment rule "should be interpreted to prevent the loss of the right of appeal, not to facilitate loss." 12 An appellate court, when parties act under the mistaken impression that the judgment has been properly entered, should not dismiss for lack of jurisdiction and require the appeal process to begin anew unless the appeal, measured from the improperly entered judgment, would be untimely, ${ }^{13}$ in which case the appellate court should allow the perfection of form to open a new time for appeal.

Illustration. P files suit against D. The district court dismisses for lack of diversity jurisdiction and issues an order of dismissal which, while set forth in the opinion, explicitly states the court's disposition of the case. P appeals. If $\mathrm{D}$ moves to dismiss the appeal, the motion should be granted since no final decision was rendered-there was no separate document for purposes of evaluating the timeliness of appeal. However, if both parties act under the assumption that the judgment was properly entered, the court should not dismiss the appeal. ${ }^{14}$

b. Taxation of Costs. Since entry of judgment and taxation of costs are separate legal acts, the latter is not necessary under Rule 58 to begin the time for appeal from a final decision. ${ }^{15}$ This permits judgments to be entered promptly without delay for the taxing of costs. ${ }^{16}$ It is not, however, necessary to stay taxation of costs until final disposition of a petition for certiorari. ${ }^{17}$

c. Manifestation of Intent. Although no particular words are necessary to constitute a final decision, if the instrument relied upon leaves room for doubt as to whether the trial judge intended it to be such, its notation in the docket does not constitute an entry of judgment. ${ }^{18}$ As one court observed, "Such entry should be unambiguous on its face so that counsel or parties consulting the docket will have no reasonable basis for doubt as to the nature or effect of what has been or as to the timeliness of further proceedings." 19

\section{§4. Partial Final Decisions.}

AN ADJUDICATION COMPLETE WITH RESPECT TO ONE OR MORE BUT FEWER THAN ALL OF MULTIPLE PARTIES OR CLAIMS PRESENTED IN A SINGLE ACTION IS REVIEWABLE AS A PARTIAL FINAL DECISION IF THE DISTRICT COURT EXPLICITLY DIRECTS

11. 435 U.S. 381,385 (1978) (disavowing anything to the contrary in United States v. Indrelunas, 411 U.S. $216,220-22(1973))$.

12. Id. at 386 (citing 9 J. MoOre, MoOre's Federal Practice If 110.08[2], at 119-20 (1970)).

13. See infra $\S \S 6 \& 7$ of this Interlocutory Restatement.

14. See Caperton v. Beatrice Pocahontas Coal Co., 585 F.2d 683 (4th Cir. 1978).

15. Maryland Casualty Co. v. Jacobson, 37 F.R.D. 427, 430 (W.D. Mo. 1965).

16. See Report of Proposed Amendments, supra note 2, at 650.

17. American Infra-Red Radiant Co. v. Lambert Indus., 41 F.R.D. 161, 163-64 (D. Minn. 1966)

18. United States v. Evans, 365 F.2d 95, 97 (10th Cir. 1966).

19. Danzig v. Virgin Isle Hotel, 278 F.2d 580, 582 (3d Cir. 1960). 


\section{ENTRY OF JUDGMENT AFTER FINDING THAT THERE IS NO JUST REASON TO DELAY.}

\section{COMMENT}

a. History of Rule 54(b). Prior to the adoption of Rule 54(b) of the Federal Rules of Civil Procedure, the single judicial unit theory controlled the doctrine of finality, and therefore the concept of what consituted an appealable final decision under 28 U.S.C. $§ 1291 .^{1}$ The rule was that an action remained a single judicial unit although it contained multiple claims or involved multiple parties. A judgment which disposed of some but fewer than all of the claims made by a plaintiff against a defendant ${ }^{2}$ or terminated the action as to one or more but fewer than all of the defendants ${ }^{3}$ was not final. It was said that "the judgment to be appealable should be final not only as to all the parties, but as to the whole subject matter and as to all the causes of action involved." 4

The single judicial unit theory was adequate within the paradigm of two parties litigating a single cause, but it became inadequate as litigation became increasingly complex. As the Supreme Court recognized,

The liberalization of our practice to allow more issues and parties to be joined in one action and to expand the privilege of intervention by those not originally parties has increased the danger of hardship and denial of justice through delay if each issue must await the determination of all issues as to all parties before a final judgment can be had. ${ }^{5}$

Therefore, Rule 54(b) was created to replace the single judicial unit theory with the concept of the adjudication of a single "claim" as a basis for the entry of a judgment. 6

Under Rule 54(b) a court may, upon an express determination that there is no just reason to delay, direct entry of judgment as to one or more but fewer than all parties or claims presented in a single action. ${ }^{7}$ In the absence of such court

1. See generally 6 J. MoOre, W. Taggart \& J. Wicker, MoOre's Federal Practice If 54.19 (2d ed. 1983); 10 C. Wright, A. Miller \& M. Kane, Federal Practice and Procedure $§ 2653$ (2d ed. 1983) [hereinafter cited as C. Wright \& A. Miller]; Note, Federal Procedure-Rule 54(b) and the Final Judgment Rule, 28 N.Y.U. L. REv. 203 (1953).

2. Collins v. Miller, 252 U.S. 364, 370-71 (1920); Ex parte National Enameling \& Stamping Co., 201 U.S. 156, 160 (1906); Sheppy v. Stevens, 200 F. 946, 948 (2d Cir. 1912).

3. Hohorst v. Hamburg-American Packet Co., 148 U.S. 262 (1893); United States v. Girault, 52 U.S. (11 How.) 22 (1850)

4. Collins v. Miller, 252 U.S. 364, 370 (1920).

5. Dickinson v. Petroleum Conversion Corp., 338 U.S. 507, 511 (1950). See also Sears, Roebuck \& Co. v. Mackey, 351 U.S. 427, 432 (1956):

With the Federal Rules of Civil Procedure, there came an increased opportunity for the liberal joinder of claims in multiple claims actions. This, in turn, demonstrated a need for relaxing the restrictions upon what should be treated as a judicial unit for purposes of appellate jurisdiction. Sound judicial administration did not require relaxation of the standard of finality in the disposition of the individual adjudicated claims for the purpose of their appealability. It did, however, demonstrate that, at least in multiple claims actions, some final decisions, on less than all of the claims, should be appealable without waiting for a final decision on all of the claims.

6. Bowling Machs. v. First Nat'l Bank, 283 F.2d 39, 42 (1st Cir. 1960) ("In general, Rule 54(b) was originally adopted to ameliorate the harshness which would have resulted from the operation of the singlejudicial-unit rule in the context of the increasingly complex litigation brought about by the Rules' liberal joinder provisions."); 10 C. WRIGHT \& A. MILLER, supra note 1, § 2653, at 20.

7. FED. R. CIV. P. 54(b). The text of the Rule reads as follows:

When more than one claim for relief is presented in an action, whether as a claim, counterclaim, cross- 
designation a partial decision is not final (and therefore not subject to immediate review $^{8}$ ) and may be modified at any time before entry of a judgment adjudicating the rights and liabilities of all the parties as to all claims. ${ }^{9}$

Rule 54(b) thus does not abandon the policy against piecemeal appellate review 10 but attempts to "strike a balance between the undesirability of piecemeal appeals and the need for making review available at a time that best serves the needs of the parties." 11 Interlocutory review will be the "exception" rather than the "rule" 12 because Rule 54(b) allows an appeal only from an actual conclusive disposition of a separate claim or as to one or more parties. Furthermore, the trial court may decide to delay review and refuse to designate partial finality if there is a risk of repetitive appeals. ${ }^{13}$

b. Multiple Claims or Parties. Rule 54(b) is applicable only when the underlying litigation involves either multiple claims for relief or multiple parties. This requirement is stated in the alternative; ${ }^{14}$ thus a case with multiple parties need raise only a single claim. ${ }^{15}$ The identification of multiple party cases poses little difficulty.

The courts have, however, had trouble determining whether a case involves multiple claims or a single claim based on multiple legal theories. ${ }^{16}$ As a recent decision states, "[C]ourts have been completely unable to settle on a single test for determining when claims are separate."17 The clearest view seems to be that of the

claim, or third-party claim, or when multiple parties are involved, the court may direct the entry of a final judgment as to one or more but fewer than all of the claims or parties only upon an express determination that there is no just reason for delay and upon an express direction for the entry of judgment. In the absence of such determination and direction, any order or other form of decision, however designated, which adjudicates fewer than all the claims or the rights and liabilities of fewer than all the parties shall not terminate the action as to any of the claims or parties, and the order or other form of decision is subject to revision at any time before the entry of judgment adjudicating all the claims and the rights and liabilities of all the parties.

8. Note, however, that a Rule 54(b) designation is not necessary when the partial final decision is independently appealable, for example, by statute, Cutting Room Appliances Corp. v. Empire Cutting Mach. Co., 186 F.2d 997, 998 (2d Cir. 1951) (order had effect of denial of injunction, appealable under 28 U.S.C. $\$ 1292(a)(1))$, or under the collateral order doctrine, Hooks v. Washington Sheraton Corp., 642 F.2d 614, 617 (D.C. Cir. 1980); Redding \& Co. v. Russwine Constr. Corp., 417 F.2d 721, 726 n.33 (D.C. Cir. 1969). But cf. infra $\S 22$ of this Interlocutory Restatement, comment c, (Rule 54(b) designation required when partial final decision would, except for its incompleteness, fall within the doctrine of Forgay $v$. Conrad).

9. FED. R. CIV. P. 54(b) (quoted supra note 7).

10. Page v. Preisser, 585 F.2d 336, 339 (8th Cir. 1978); Harms, Inc. v. Tops Music Enters., 160 F. Supp. 77, 85 (S.D. Cal. 1958) ("It was not the object of this section to depart from the fundamental principle obtaining in federal procedure against splitting a claim and determining it piecemeal."); FED. R. CIV. P. Rule 54 advisory committe note on 1946 amendment. See also infra note 22 and accompanying text.

11. Allis-Chalmers Corp. v. Philadelphia Elec. Co., 521 F.2d 360, 363 (3d Cir. 1975). See also Panichella v. Pennsylvania R.R., 252 F.2d 452, 454 (3d Cir. 1958).

12. 10 C. WRIGHT \& A. MILLER, supra note $1, \S 2654$, at 37 .

13. See infra note 51 and accompanying text.

14. The language of the Rule is quoted supra note 7.

15. Note that a party who has not been properly served will not be considered in determining if a designation of partial finality is necessary. Leonhard v. United States, 633 F.2d 599, 608 (2d Cir. 1980). Prior to amendment in 1961, Rule 54(b) dealt only with multiple claims and not with multiple parties. See FED. R. CIV. P. 54(b) advisory committee note on 1961 amendment.

16. Page v. Preisser, 585 F.2d 336, 339 (8th Cir. 1978); see also Liberty Mut. Ins. Co. v. Wetzel, 424 U.S. 737,743 n.4 (1976). Absent multiple parties, a single claim based on several legal theories is of course not within the purview of Rule 54(b).

17. Local P-171, Amalgamated Meat Cutters v. Thompson Farms Co., 642 F.2d 1065, 1070 (7th Cir. 
Second Circuit: "The ultimate determination of multiplicity of claims must rest in every case on whether the underlying factual bases for recovery state a number of different claims which could have been separately enforced."18

Claims cannot be separate unless separate recovery is possible on each. ${ }^{19}$ Mere variations of legal theory, therefore, do not constitute separate claims. ${ }^{20}$ In addition, allegations so closely related that they would run afoul of the rule against splitting claims if brought separately do not qualify. ${ }^{21}$ As one court stated, "[Rule $54(\mathrm{~b})$ ] did not . . . purport to amend or dilute the fundamental rule against splitting a cause of action and deciding appellate cases piecemeal."'22

An early test for separate claims, that of "differing occurrences or transactions, was eliminated by the 1946 amendments to Rule 54(b), ${ }^{23}$ and the Supreme Court has since expressly recognized that there can be multiple claims arising from a single occurrence or transaction. ${ }^{24}$ Reference to the repudiated criteria, however, has been surprisingly persistent. ${ }^{25}$

Illustration 4-1. P, a group of workers displaced by a factory closing, brings suit against $\mathrm{D}$, the former employer, seeking additional vacation pay and overtime pay under a collective bargaining agreement. The district court grants summary judgment on the vacation issue and orders that the unemployed workers be paid immediately. If the judge deems it appropriate, he may designate partial finality under Rule 54(b); the two claims are separate because they could be enforced individually even though arising out of the same transaction. ${ }^{26}$

Illustration 4-2. $\mathrm{P}$ sues $\mathrm{D}$ to establish the validity of an agreement granting $\mathrm{P}$ an exclusive license to a manufacturing process in exchange for royalty payments in an amount to be determined later. D files a counterclaim concerning the amount of the royalties. The district court

1981). See generally 6 J. MoOre, W. TAGGart \& J. Wicker, supra note 1, Iி 54.24, 54.33; C. Wright \& A. MILLER, supra note $1, \S 2657$.

18. Rieser v. Baltimore \& O. R.R., 224 F.2d 198, 199 (2d Cir. 1955). See also United States v. Kocher, 468 F.2d 503, 509 (2d Cir. 1972), cert. denied, 411 U.S. 931 (1973); Aetna Casualty \& Sur. Co. v. Giesow, 412 F.2d 468, 470 (2d Cir. 1969).

19. Local P.171, Amalgamated Meat Cutters v. Thompson Farms Co., 642 F.2d 1065, 1070-71 (7th Cir. 1981); Page v. Preisser, 585 F.2d 336, 339 (8th Cir. 1978); see also Liberty Mut. Ins. Co. v. Wetzel, 424 U.S. 737, 743 n.4 (1976) ("[A] complaint asserting only one legal right, even if seeking multiple remedies for the alleged violation of that right, states a single claim for relief."); McIntyre v. First Nat'l Bank, 585 F.2d 190, 192 (6th Cir. 1978); Schexnaydre v. Travelers Ins. Co., 527 F.2d 855, 856 (5th Cir. 1976).

20. Page v. Preisser, 585 F.2d 336, 339 (8th Cir. 1978) ("It is clear that a claimant who presents a number of alternative legal theories, but whose recovery is limited to only one of them, has only a single claim of relief for purposes of 54(b).”); CMAX Inc. v. Drewry Photocolor Corp., 295 F.2d 695, 697 (9th Cir. 1961); Schwartz v. Eaton, 264 F.2d 195, 197 (2d Cir. 1959).

21. United States v. Kocher, 468 F.2d 503, 509 (2d Cir. 1972), cert. denied, 411 U.S. 931 (1973); Campbell v. Westmoreland Farm, Inc., 403 F.2d 939, 941 (2d Cir. 1968).

22. Page v. Preisser, 585 F.2d 336, 339 (8th Cir. 1978). See In re Bromley-Heath Modernization Co., 448 F.2d 1271, 1271 (Ist Cir. 1971); see also Sears, Roebuck \& Co. v. Mackey, 351 U.S. 427 (1956).

23. United States v. Kocher, 468 F.2d 503, 509 (2d Cir. 1972), cert. denied, 411 U.S. 931 (1973).

24. Cold Metal Process Co. v. United Eng'g \& Foundry Co., 351 U.S. 445, 452 (1956).

25. Page v. Preisser, 585 F.2d 336, 339 (8th Cir. 1978); Acha v. Beame, 570 F.2d 57, 62 (2d Cir. 1978); Note, Appealability in the Federal Courts, 75 HARv. L. REV. 351, 359-61 (1961).

26. See generally Local P-171, Amalgamated Meat Cutters v. Thompson Farms Co., 642 F.2d 1065 (7th Cir. 1981). 
enters judgment declaring the contract valid. If the judge deems it appropriate, he may designate partial finality under Rule 54(b); the claims are separate even though they arise out of the same contract. ${ }^{27}$ Illustration 4-3. $\mathrm{P}$ brings suit against $\mathrm{D}$ to recover money in connection with a securities transaction, alleging a claim under federal securities law plus common law fraud. The district court finds no liability on federal grounds. The judge may not, however, designate partial finality; the action involves only a single claim for relief although based on different theories of liability. $\mathrm{P}$ can be entitled to only a single recovery. ${ }^{28}$

c. Requirement of Final Decision. Rule 54(b) applies only when at least one claim or the rights and liabilities of at least one party have been finally decided. The test of finality is the same as that used in single-claim cases. ${ }^{29}$ A partial judgment that decides just some of the issues pertinent to a single claim is interlocutory and not within the scope of Rule $54(\mathrm{~b}) ;^{30}$ the decision must completely and finally dispose of one of several claims to be a candidate for immediate review under Rule 54(b). ${ }^{31}$ As the Supreme Court has stated,

Rule 54(b), in its amended form . . . does not supersede any statute controlling appellate jurisdiction. It scrupulously recognizes the statutory requirement of a "final decision" under $\S 1291$ as a basic requirement for an appeal to the Court of Appeals. It merely administers that requirement in a practical manner in multiple claims actions and does so by rule instead of by judicial decision. ${ }^{32}$

The final decision does not have to reach the substantive issues alleged; for example, dismissal for lack of subject matter ${ }^{33}$ or personal jurisdiction ${ }^{34}$ will satisfy this aspect of Rule 54(b). ${ }^{35}$ The disposition, however, must be "on the merits" in the sense that it does not leave a party free to pursue the claim in a separate proceeding. Thus, Rule 54(b) will not apply when a counterclaim is dismissed or impleader or intervention denied for reasons having to do with the appropriate structuring of the litigation. ${ }^{36}$

27. See generally Cold Metal Process Co. v. United Eng'g \& Foundry Co., 351 U.S. 445 (1956).

28. See generally McIntyre v. First Nat'l Bank, 585 F.2d 190, 192 (6th Cir. 1978).

29. Fireman's Fund Ins. Co. v. Myers, 439 F.2d 834, 838 n.9 (3d Cir. 1971) ("Read together, Section 1291 of Title 28 and Federal Rule 54(b) thus present two essential ingredients for rendering a judgment final. First, the substance of the matter litigated and upon which the order is entered must be "final" within the statutory conception of Section 1291, and second, in a multiple claim action, the district court must conform its judgment to the requirements of Rule 54(b).").

30. Liberty Mut. Ins. Co. v. Wetzel, 424 U.S. 737, 744 (1976); National Corn Growers Ass'n v. Bergland, 611 F.2d 730, 732 (8th Cir. 1980); County of Hennepin v. Aetna Casualty \& Sur. Co., 587 F.2d 945, 946 (8th Cir. 1978). See also infra $\$ 22$ of this Interlocutory Restatement, notes 1-3 and accompanying text.

31. Sears, Roebuck \& Co. v. Mackey, 351 U.S. 427, 437-38 (1956).

32. Id. at 438 .

33. E.g., Oyster Shell Prods. Corp. v. United States, 197 F.2d 1022 (5th Cir.), cert. denied, 344 U.S. 885 (1952).

34. E.g., Farrell v. Piedmont Aviation, 411 F.2d 812, 814-15 (2d Cir.), cert. denied, 396 U.S. 840 (1969); cf. DeMelo v. Woolsey Marine Indus., 677 F.2d 1030 (5th Cir. 1982).

35. Note, however, that Rule 54(b) will not apply when the defect giving rise to dismissal may be cured by amendment, as the claim will not have been finally decided. E.g., American Broadcasting Co. v. Wahl Co., 121 F.2d 412, 413 (2d Cir. 1941) (dismissal for failure to state claim, with leave to amend). $C f$. infra $\S 14$ of this Interlocutory Restatement, notes 2-4 and accompanying text; infra $\S 16$ of this Interlocutory Restatement, note 2 and accompanying text; infra $\$ 28$ of this Interlocutory Restatement, comment f.

36. See cases cited infra $\S 29$ of this Interlocutory Restatement, notes 11, 21, 26 \& 32, plus Illustrations $26-1,26-4 \mathfrak{F} 26-6$ and text accompanying notes $7,14,18,24 \& 46$ and those notes previously cited. Contra 
d. No Just Reason to Delay. Even when the requirements of Rule 54(b) are otherwise met, the district court still has discretion ${ }^{37}$ whether to make the express determination that there is no just reason to delay, as necessary to give the partial decision immediate effect and release it for appellate review. ${ }^{38}$ This discretion is to be exercised in the interest of sound judicial administration; ${ }^{39}$ as the Supreme Court has said, "The timing of such a release [of a partial final decision is, with good reason, vested by the rule primarily in the discretion of the District Court as the one most likely to be familiar with the case and with any justifiable reasons for delay. The determination that there is no just reason to delay will be reviewable for abuse of discretion, ${ }^{40}$ but the judgment of the district court will be given "substantial deference... The reviewing court should disturb the trial court's assessment of the equities only if it can say that the judge's conclusion was clearly unreasonable." 41

The decision whether there is just reason to delay involves "weighing the overall policy against piecemeal appeals against whatever the case at hand may present."42 The trial court should exercise its power under Rule 54(b) only where necessary to avoid significant danger of hardship and denial of justice. ${ }^{43}$ Designations of partial finality "should not be entered routinely or as a courtesy or accommodation to counsel; 44 some clear showing of special need should be required of the party desiring that, contrary to normal rules, the judgment be given immediate effect. ${ }^{45}$

Although no precise test can exist "because the number of possible situations is

Blair v. Cleveland Twist Drill Co., 197 F.2d 842, 845 (7th Cir. 1952) (dismissal of cross-claim without prejudice was "final" in the sense that it deprived appellant of the asserted right to have that claim adjudicated in the ongoing proceeding).

37. Sears, Roebuck \& Co. v. Mackey, 351 U.S. 427, 437 (1956). See also Cold Metal Process Co. v. United Eng'g \& Foundry Co., 351 U.S. 445, 452 (1956); Prudy Mobile Homes v. Champion Home Builders Co., 594 F.2d 1313, 1316 (9th Cir. 1979).

38. See the language of the Rule quoted supra note 7.

39. Sears, Roebuck \& Co. v. Mackey, 351 U.S. 427, 437 (1956). See also id. at 435: "[T] District Court is used as a 'dispatcher.' It is permitted to determine, in the first instance, the appropriate time when each 'final decision'. . . is ready for appeal."

40. Curtiss-Wright Corp. v. General Elec. Co., 446 U.S. 1, 10 (1980); Sears, Roebuck \& Co. v. Mackey, 351 U.S. 427, 437 (1956); Cold Metal Process Co. v. United Eng'g \& Foundry Co., 351 U.S. 445, 452-56 (1956); Davis v. Fendler, 650 F.2d 1154, 1164 (9th Cir. 1981). Statements in cases to the effect that the matter is solely within the discretion of the trial court thus may be misleading. E.g., Illinois Tool Works v. Brunsing, 378 F.2d 234, 236 (9th Cir. 1967) ("These are matters exclusively within the discretion of the district court."); Miles v. City of Chandler, 297 F.2d 690,691 (9th Cir. 1961) ("these being matters exclusively within the District Court's discretion").

Note, however, that an order denying Rule 54(b) certification will not be reviewable. Makuc v. American Honda Motor Co., 692 F.2d 172, 173-74 (1st Cir. 1982). Such an order, unlike a designation of partial finality, is clearly interlocutory, and review would promote piecemeal appeals contrary to the policy Rule 54(b) was intended to support. Id.

41. Curtiss-Wright Corp. v. General Elec. Co., 446 U.S. 1, 10 (1980).

42. Panichella v. Pennsylvania R.R., 252 F.2d 452, 455 (3d Cir. 1958).

43. Curtiss-Wright Corp. v. General Elec. Co., 446 U.S. 1, 9-12 (1980); Morrison-Knudsen Co. v. Archer, 655 F.2d 962, 965 (9th Cir. 1981).

44. Panichella v. Pennsylvania R.R., 252 F.2d 452, 455 (3d. Cir. 1958); see Page v. Preisser, 585 F.2d 336, 339 (8th Cir. 1978); see also Curtiss-Wright Corp. v. General Elec. Co., 446 U.S. 1, 10 (1980).

45. Allis-Chalmers Corp. v. Philadelphia Elec. Co., 521 F.2d 360, 365 (3d Cir. 1975); Campbell v. Westmoreland Farm, Inc., 403 F.2d 939, 942 (2d Cir. 1968). 
large," 46 several criteria are customarily used in determining if there is just reason to delay. A major factor is the amount of harm that is likely to occur absent certification. ${ }^{47}$ Another consideration is the relationship between the decided and undecided claims; ${ }^{48}$ the district court should consider whether an immediate appeal could either result in an unnecessary delay of the trial ${ }^{49}$ or perhaps simplify the issues and avoid the need for further proceedings. ${ }^{50}$ Particularly a Rule 54(b) designation should not be made when the appellate court then would likely have to review facts or questions of law again in connection with the subsequently decided claims. ${ }^{51}$ Finally, the district court should consider the possibility that the need for review might be mooted by future developments at trial. ${ }^{52}$

e. Mechanics of Rule 54(b). An order partially disposing of multiclaim or multiparty litigation to be subject to immediate review must expressly include both the direction for entry of judgment and the determination of no just reason to delay; otherwise, the appellate court will lack jurisdiction ${ }^{53}$ because there will have been no final decision. ${ }^{54}$ Although these declarations need appear in no special form,${ }^{55}$ the requirement that they be express is to be given a technical rather than a practical construction. ${ }^{56}$ Thus, it is not sufficient that the order, though not certified, be of the nature that Rule $54(\mathrm{~b})$ intended to make appealable. ${ }^{57}$ The Rule was further designed to eliminate uncertainty, and the resulting hazards to litigants, as to what constitutes a final decision commencing the running of the time to appeal; 58 to allow review without the required express declarations would

46. Curtiss-Wright Corp. v. General Elec. Co., 446 U.S. 1, 10-11 (1980).

47. Id. Cf. infra $\$ 32$ of this Interlocutory Restatement, text following note 3 . Note that the focus thus is not just on whether there is reason to delay appeal but also on whether there is reason to delay the other incidents of final decision that accompany designation under Rule 54(b). Bank of Lincolnwood v. Federal Leasing, 622 F.2d 944, 950 n.7 (7th Cir. 1980). In particular, an order in which Rule 54 (b) has been invoked will be enforceable through liens and writs of execution, Local P-171, Amalgamated Meat Cutters v. Thompson Farms Co., 642 F.2d 1065, 1071 n.7 (7th Cir. 1981); cf. Redding \& Co. v. Russwine Constr. Corp., 417 F.2d 721, 727 (D.C. Cir. 1969), will commerce the accumulation of postjudgment interest, Hooks v. Washington Sheraton Corp., 642 F.2d 614, 61 7-18 (D.C. Cir. 1980), and will have res judicata effects. Cf. Government of the V.I. v. 2.6912 Acres of Land, 396 F.2d 3, 5-6 (3d Cir. 1968); Republic of China v. American Express Co., 190 F.2d 334, 339 (2d Cir. 1951). The potential for setoff between the decided and undecided claims thus is frequently a major factor in a determination whether to find no just reason to delay. See, e.g., Curtiss-Wright Corp. v. General Elec. Co., 446 U.S. 1,9 (1980).

48. Cold Metal Process Co. v. United Eng'g \& Foundry Co., 351 U.S. 445, 452 (1956); Deboles v. Trans World Airlines, 552 F.2d 1005, 1008 (3d Cir.), cert. denied, 434 U.S. 837 (1977).

49. Campbell v. Westmoreland Farm, Inc., 403 F.2d 939, 942 (2d Cir. 1968).

50. Al Barnett \& Son, Inc. v. Outboard Marine Corp., 611 F.2d 32, 34 n.4 (3d Cir. 1979); Hunt v. Mobil Oil Corp., 550 F.2d 68, 70 (2d Cir.), cert. denied, 434 U.S. 984 (1977).

51. E.g., Zangardi v. Tobriner, 330 F.2d 224 (D.C. Cir. 1964).

52. Thompson v. Trent Maritime Co., 343 F.2d 200, 204-06 (3d Cir. 1965).

53. Golden Villa Spa v. Health Indus., 549 F.2d 1363, 1364 (10th Cir. 1977) (per curiam); see also Clark v. United States, 624 F.2d 3 (2d Cir. 1980) (per curiam)(requirement of express designation jurisdictional rather than discretionary). Cf. infra $\S 6$ of this Interlocutory Restatement, notes 5-6 and accompanying text; infra $\S 8$ of this Interlocutory Restatement, note 2.

54. Gaulter v. Capdeboscq, 594 F.2d 127, 128 (5th Cir. 1979).

55. Sargent v.Johnson, 521 F.2d 1260, 1263 n.4 (8th Cir. 1975). The direction to enter judgment and determination of no just reason to delay must be apparent, however, and the order must leave no doubt that the district judge intended to certify it for immediate appeal. Id.

56. Id. at 1263 .

57. Clark v. United States, 624 F.2d 3, 4 (2d Cir. 1980)(per curiam). Cf. Lamp v. Andrus, 657 F.2d 1167, 1169 (10th Cir. 1981).

58. Dickinson v. Petroleum Conversion Corp., 338 U.S. 507, 512 (1950): 
undermine this purpose. ${ }^{59}$

The order, however, need not include a statement of the trial judge's reasons for finding no just reason for delay, although that practice is generally preferred. ${ }^{60}$ A district court may designate partial finality sua sponte. ${ }^{61}$

Since an order in which Rule 54(b) has been invoked bears with it all the important consequences of finality, ${ }^{62}$ time for appeal is calculated from entry of that order. ${ }^{63}$ Review must be sought immediately and cannot be delayed until a final adjudication as to all parties and claims or the right to review will be forfeited. ${ }^{64}$

Furthermore, the designation of partial finality must be made before the appeal is filed; ${ }^{65}$ the majority of courts hold there is no power to grant Rule 54(b) certification nunc pro tunc, that is, to enter an order making the required express declarations retroactive to the time of the initial partial final decision. ${ }^{66}$ The rationale underlying this position is that the district court loses jurisdiction upon the filing of the appeal and thus is without power to amend the underlying judgment. ${ }^{67}$ In addition, it is argued that the requirement that certification precede the filing of the appeal is not unduly harsh because it does not foreclose appeal all together but merely delays it until proper certification or final decision; this procedure is seen as reducing confusion and delay in keeping with the purposes of Rule $54(b){ }^{68}$ The contrary position ${ }^{69}$ allowing nunc pro tunc certification rests on the

The obvious purpose of this section, as indicated by the notes of the advisory committee, is to reduce as far as possible the uncertainty and the hazard assumed by a litigant who either does or does not appeal from a judgment of the character we have here. It provides an opportunity for litigants to obtain from the District Court a clear statement of what that court is intending with reference to finality, and if such a direction is denied, the litigant can at least protect himself accordingly.

(footnote omitted). See also Sears, Roebuck \& Co. v. Mackey, 351 U.S. 427, 435-36 (1956).

59. Sargent v. Johnson, 521 F.2d 1260, 1263 n.4 (8th Cir. 1975) (citing 10 C. WRIGHT \& A. MIL.LER, supra note $1, \S 2660$, at 122-24). See also Pettinelli v. Danzig, 644 F.2d 1160, 1162-63 (5th Cir. 1981).

60. Bank of Lincolnwood v. Federal Leasing, 622 F.2d 944, 948-49 \& nn.4-5 (7th Cir. 1980).

61. Id. at 948 n.3.

62. See supra note 47; see also infra $\$ 9$ of this Interlocutory Restatement, note 232 and accompanying text; $c f$. id. notes $225-26$ and accompanying text.

63. Local P-171, Amalgamated Meat Cutters v. Thompson Farms Co., 642 F.2d 1065, 1071 n.7 (7th Cir. 1981); see also Scholl v. District of Columbia, 331 F.2d 1018 (D.C. Cir. 1964). Modification of a Rule 54(b) judgment does not toll the running of the time for appeal. Encoder Communications v. Telegen, Inc., 654 F.2d 198, 202 (2d Cir. 1981). Compare the practice as to certain motions subsequent to final decision, discussed infra $\$ 7$ of this Interlocutory Restatement, comment a.

64. E.g., Encoder Communications v. Telegen, Inc., 654 F.2d 198, 202 (2d Cir. 1981); Scholl v. District of Columbia, 331 F.2d 1018, 1019 n.4 (D.C. Cir. 1964).

65. A.O. Smith Corp. v. Sims Consol., 647 F.2d 118, 120 (10th Cir. 1980); Kirtland v. J. Ray McDermott \& Co., 568 F.2d 1166, 1169 (5th Cir. 1978). Cf. Lamp v. Andrus, 657 F.2d 1167, 1169 (10th Cir. 1981) (holding that jurisdictional requirements must be satisfied at time of appeal when subsequent dismissal as to all claims rather than Rule 54 (b) certification was at issue).

66. Kirtland v. J. Ray McDermott \& Co., 568 F.2d 1 166, 1169 (5th Cir. 1978); TMA Fund, Inc. v. Biever, 520 F.2d 639, 642 (3d Cir. 1975). Courts note that this rule is contrary to the practice of accepting notices of appeal from final decisions filed before all the technicalities have been complied with, Leonhard v. United States, 633 F.2d 599, 611 (2d Cir. 1980), but they distinguish the Rule 54(b) situation as involving discretionary rather than ministerial duties on the part of the trial court, Kirlland, 568 F.2d at 1169 , and as affecting substantive rights of the parties. Mullins v. Nickel Plate Mining Co., 691 F.2d 971, 973-74 (11th Cir. 1982). Compare supra $\S 3$ of this Interlocutory Restatement, notes 9-13 and accompanying text.

67. Kirtland v. J. Ray McDermott \& Co., 568 F.2d 1166, 1169-70 (5th Cir. 1978).

68. A.O. Smith Corp. v. Sims Consol., 647 F.2d 118, 120-21 (10th Cir. 1980). Consider in this regard 
reasoning that an appeal from a nonappealable (in this instance because it is not yet certified) order does not deprive the district court of jurisdiction ${ }^{70}$ or in the alternative that an exception, similar to existing exceptions, to the general rule of loss of jurisdiction would be appropriate with regard to subsequent certifications pursuant to Rule 54(b). ${ }^{71}$ Avoidance of waste and confusion is also said to be on the side of this practice. ${ }^{72}$

Commentators suggest that proper nunc pro tunc certification pursuant to Rule 54(b) should require permission of the court of appeals; otherwise, the reviewing court may dismiss and remand so the district court can recertify the order for a timely appeal. ${ }^{73}$ In keeping with concerns for expense and delay, the general practice is, upon proper appeal, to allow the parties to be heard on the initial record and briefs. ${ }^{74}$

\section{§ 5. Commencement of Appeal: Notice.}

AN APPEAL FROM A FINAL DECISION IS COMMENCED BY FILING A NOTICE OF APPEAL WITH THE CLERK OF THE DISTRICT COURT WHICH MADE THE DECISION FROM WHICH THE APPEAL IS TAKEN. THE NOTICE SHALL SPECIFY THE PARTY OR PARTIES TAKING THE APPEAL, SHALL DESIGNATE THE DECISION APPEALED FROM, AND SHALL NAME THE COURT TO WHICH APPEAL IS TAKEN. AN APPEAL SHALL NOT BE DISMISSED FOR NAMING THE WRONG COURT TO WHICH THE APPEAL IS TAKEN, NOR FOR ANY OTHER DEFECT OF FORM, IF THE NOTICE IS ADEQUATE TO INFORM THE

Mullins v. Nickel Plate Mining Co., 691 F.2d 971 (1 lth Cir. 1982), in which giving the Rule 54(b) designation retroactive effect would actually have denied the party adversely affected of the right to review because no notice of appeal had been filed from the initial noncertified order.

69. A recent case identifies this position only with the Seventh Circuit. A.O. Smith Corp. v. Sims Consol., 647 F.2d 118, 120 (10th Cir. 1980)

70. Local P-171, Amalgamated Meat Cutters v. Thompson Farms Co., 642 F.2d 1065, 1074 (7th Cir. 1981). For a summary of the conflicting positions on this proposition, see Leonhard v. United States, 633 F.2d 599, 610 (2d Cir. 1980).

71. Local P-171, Amalgamated Meat Cutters v. Thompson Farms Co., 642 F.2d 1065, 1073-75 (7th Cir. 1981). The exceptions mentioned by the court allowed a district court to consider a motion for relief from judgment under Rule 60(b) of the Federal Rules of Civil Procedure made after the filing of an appeal, although the trial judge must then ask the appellate court to remand the case if he decides to grant the motion, see Washington v. Board of Educ., 498 F.2d 11, 15-16 (7th Cir. 1979), and a motion to delete or amend a finding of fact pursuant to Rule 52(b) of the Federal Rules of Civil Procedure when made by the party other than the one filing the appeal, see Elgen Mfg. Corp. v. Ventfabrics, Inc., 314 F.2d 440, 444 (7th Cir. 1963).

72. Local P-171, Amalgamated Meat Cutters v. Thompson Farms Co., 642 F.2d 1065, 1074 (7th Cir. 1981). The court specifically identified the purpose of the rule of loss of district court jurisdiction upon the filing of an appeal as preventing overlap, waste, and confusion between the two levels of the judiciary and concluded that requiring dismissal of an appeal of a retroactively certified partial final decision would cause exactly such waste. Further, the court's holding contemplated granting retroactive effect only when the trial court had already found no just reason to delay and certified the order prior to appellate consideration of the prematurely filed appeal, thus avoiding the problem raised in A.O. Smith Corp. v. Sims Consol., 647 F.2d 118, 121 (10th Cir. 1981), of retention of numerous cases pending on the appellate docket while parties return to district court for Rule 54(b) designations.

73. 6 J. MOORE, W. TAGgart \& J. Wicker, supra note 1, I 54.41[4], at 773, 775.

74. E.g., In re Yarn Processing Patent Validity Litig., 680 F.2d 1338, 1340 (11th Cir. 1982); Kirtland v. J. Ray McDemott \& Co., 568 F.2d 1166, 1171 n.9 (5th Cir. 1978). 


\section{ADVERSARY THAT AN APPEAL IS BEING TAKEN IN AN IDENTIFI- ABLE PROCEEDING.}

\section{COMMENT}

a. Filing of Notice. An appeal to a court of appeals from a final decision of a district court "shall be taken by filing a notice of appeal with the clerk of the district court within the time allowed . . . ." Filing is complete only upon the clerk's actual receipt of the notice. Service on the opposing parties is not sufficient if no actual filing is made to the clerk of the district court. ${ }^{2}$ Similarly, oral notice is not sufficient ${ }^{3}$ and neither is deposit in the mails unless the notice arrives at the clerk's office prior to the end of the filing period. ${ }^{4}$ The fact that the clerk refuses or fails to file the notice for one reason or another, however, has no effect on the sufficiency of the filing as of the date of receipt. ${ }^{5}$

b. Contents. Given the language of Rule 3(b) of the Federal Rules of Appellate Procedure that "[ $\mathrm{t}]$ he notice of appeal shall specify the party or parties taking the appeal . . . ," courts generally require that all parties taking an appeal be individually named on the notice in order to perfect their appeals. ${ }^{7}$ Under "unusual circumstances" where inclusion of the unnamed appellants would not prejudice the appellee, however, names have not been required. ${ }^{8}$ Furthermore, the rules do not require that the notice include a listing of the appellees. ${ }^{9}$

The notice must also designate the judgment or order from which the appeal is taken. ${ }^{10}$ Generally, this element is given a liberal interpretation, and a "mistake in designation of the judgment is not always fatal, so long as the intent to appeal from a specific ruling can be fairly inferred by probing the notice and the other party was not misled or prejudiced." " Where a judgment is separable, however, the notice must designate which portion is being appealed. A notice of appeal

1. FED. R. APP. P. 3(a); see infra $\S 6$ of this Interlocutory Restatement for a discussion of the time restraints on filing.

2. See Shaw v. Merritt-Chapman \& Scott Corp., 554 F.2d 786, 789 n.2 (6th Cir.), cert. denied, 434 U.S. 852 (1977); Federal Deposit Ins. Corp. v. Congregation Poiley Tzedeck, 159 F.2d 163 (2d Cir. 1946).

3. Smith v. United States, 425 F.2d 173 (9th Cir. 1970).

4. See infra $\S 6$ of this Interlocutory Restatement, note 11 and accompanying text.

5. See Gee v. Tenneco, Inc., 615 F.2d 857, 859 (9th Cir. 1980) (clerk's refusal to file notice because of appellant's failure to pay filing fee did not affect validity of filing); Stevens v. Heard, 674 F.2d 320, 321-23 (5th Cir. 1982) (clerk's failure to file a notice of appeal, because document failed to include a caption identifying it as a notice of appeal and therefore clerk had no reason to examine it, did not deny effect of filing where appellant showed that document was functionally sufficient); see also United States v. Miller, 666 F.2d 991, 993-94 (5th Cir.), cert. denied, 456 U.S. 964, (1982) (failure of clerk to either stamp date on notice or actually file it does not affect validity of filing).

6. FED. R. APP. P. 3(c).

7. See Williams v. Treen, 671 F.2d 892, 895 (5th Cir. 1982); Covington v. Allsbrook, 636 F.2d 63, 6364 \& n.2 (4th Cir.), cert. denied, 451 U.S. 914 (1981) ("Covington, et al.," insufficient to include the plaintiffs other than Covington attempting to appeal under the notice); Van Hoose v. Eidson, 450 F.2d 746 (6th Cir. 1971).

8. Williams v. Frey, 551 F.2d 932, 934 n.1 (3d Cir. 1977) (class action in which an appeal naming only the original plaintiff was allowed to be taken by other class members after the original plaintiff ceased to be a member of the class).

9. Perrington Wholesale v. Burger King Corp., 631 F.2d 1369, 1379 (10th Cir. 1980).

10. FED. R. APP. P. 3(c).

11. Sanabria v. United States, 437 U.S. 54, 67 n.21 (1978); see also Williams v. General Motors Corp., 656 F.2d 120, 125-26 (5th Cir.), cert. denied, 455 U.S. 943 (1982). 
referring to only one portion of a separable judgment will not serve as notice that the undesignated portion is also being appealed from unless there is an apparent mistake in the designation ${ }^{12}$ or the issues are inextricably intertwined. ${ }^{13}$

Finally, the notice must state the name of the court to which the appeal is taken. ${ }^{14}$ A mistake in naming such court will not result in a dismissal, however. ${ }^{15}$ As in all cases of defects in the wording of the notice, a court will overlook the defect if the intentions of the appellant can be fairly ascertained, the court is not misled, and there will be no prejudice to other parties. ${ }^{16}$

Illustration. P files a timely notice of appeal with the clerk of the federal district court. The notice mistakenly names the supreme court of the state in which the federal district court is located as the court to which the appeal is taken. D moves to dismiss the appeal. The motion should be denied and the appeal heard because the notice is sufficient to give the appellate court jurisdiction; the parties could not be misled by the error, and the intent to appeal was clear. ${ }^{17}$

\section{§6. Time for Appeal.}

AN APPEAL FROM A FINAL DECISION MUST BE COMMENCED WITHIN THIRTY DAYS OF THE DATE OF THE DECISION APPEALED FROM, EXCEPT THAT IF THE UNITED STATES OR AN OFFICER OR AGENCY THEREOF IS A PARTY, THE TIME WITHIN WHICH THE APPEAL MUST BE COMMENCED SHALL BE SIXTY DAYS. THE REQUIREMENT OF TIMELINESS MAY NOT BE WAIVED, AND A COURT OF APPEALS NOTICING UNTIMELINESS MUST DISMISS THE APPEAL WITHOUT CONSIDERING ITS MERITS.

\section{COMMENT}

a. Limitation Period. An appeal from a final decision of a district court is commenced by filing a notice thereof with the clerk of that court within thirty days after the date of entry of the judgment or order from which the appeal is taken. ${ }^{1}$ If the United States or an officer or agency thereof is a party, then the appeal may be commenced within sixty days after the entry of the judgment or order. ${ }^{2}$ The thirty- or sixty-day filing period is applicable to all parties to the district court judgment; therefore, notices of cross-appeals and appeals by collateral parties such

12. Simpson v. Norwesco, Inc., 583 F.2d 1007, 1009 n.2 (8th Cir. 1978).

13. Marshall v. Kirkland, 602 F.2d 1282, 1302 n.17 (8th Cir. 1979); see also Comfort Trane Air Conditioning v. Trane Co., 592 F.2d 1373 (5th Cir. 1979).

14. FED. R. APP. P. 3(c).

15. See Graves v. General Ins. Co., 381 F.2d 517 (10th Cir. 1967); Trivette v. New York Life Ins. Co., 270 F.2d 198 (6th Cir. 1959).

16. See Robinson v. Moreland, 655 F.2d 887, 888-89 (8th Cir. 1981); Smith v. Atlas Off-Shore Boat Serv., 653 F.2d 1057, 1059 n.1 (5th Cir. 1981).

17. Graves v. General Ins. Co., 381 F.2d 517 (10th Cir. 1967).

1. FED. R. APP. P. 4(a)(1). See supra $\S 5$ of this Interlocutory Restatement for a discussion of the contents and filing of the notice.

2. FED. R. APP. P. 4(a)(1). 
as third party defendants ${ }^{3}$ must also be filed within the applicable time. If the underlying notice of appeal is filed within the last fourteen days of the prescribed period, the time for filing cross-appeals or third party appeals will extend to fourteen days after the actual filing of the initial notice. ${ }^{4}$ A timely filing of the notice of appeal in any case is both mandatory and jurisdictional, and an untimely filing will result in dismissal of the appeal. ${ }^{5}$ Therefore, a court will inquire into the issue of timely filing even if that issue is not raised by the parties. ${ }^{6}$

The soundness of the mandatory and jurisdictional nature of the rule, however, is questionable. Although judicial economy requires that at some point litigation must come to a close, ${ }^{7}$ the rule should not be applied so strictly that it prevents unresolved issues from being decided. When parties are uncertain as to whether a final decision has been rendered and the court recognizes the potential for such a misapprehension, a strict application of the rule is unjustified. As Justice Black commented in his dissent in Dickinson v. Petroleum Conversion Corp. :

[L]itigants have too often been thrown out of court because their lawyers failed to guess that an order would be held 'final' by an appellate court . . . . A rational system of jurisprudence should not attach inexorable consequences to failure to guess right on a legal question for the solution of which neither statutes nor court opinions have provided even a reasonably certain guide. Where, as here, arguments as to which of two decrees is 'final' may be considered relatively even, an appellate court should be free to find 'finality' in either decree appealed from. Under such a rule a court could consider the many circumstances relevant to orderly appellate administration without penalizing litigants merely because it finds that an earlier decree falls on the 'finality' side of what remains a twilight zone. $^{8}$

This flexibility advocated by Justice Black would furthermore be more consistent with the practice as to the sixty-day time limitation for filing a petition for certiorari to the Supreme Court in a federal criminal case. ${ }^{9}$ This time limit, like those in Rule 4 of the Federal Rules of Civil Procedure, was promulgated not by Congress but by the Supreme Court. ${ }^{10}$ In Schacht $v$. United States, the Supreme Court used that distinction in holding that its then-applicable limit for filing certiorari was not jurisdictional and could be relaxed at its discretion when justice so

3. See Kurdziel v. Pittsburgh Tube Co., 416 F.2d 882, 883-85 (6th Cir. 1969).

4. Fed. R. App. P. 4(a)(3). See Kurdziel v. Pittsburgh Tube Co., 416 F.2d 882, 883-85 (6th Cir. 1969).

5. E.g., Cel-A.Pak v. California Agric. Labor Rel. Bd., 680 F.2d 664, 666 (9th Cir.), cert. denied, 103 S. Ct. 491 (1982); Phillips v. Insurance Co. of N. Am., 633 F.2d 1165, 1166-67 (5th Cir. 1981); Lashley v. Ford Motor Co., 518 F.2d 749, 750 (5th Cir. 1975); Maryland Casualty Co. v. Conner, 382 F.2d 13, 15 (10th Cir. 1967). Cf. infra $\S 13$ of this Interlocutory Restatement, text accompanying note 3. As to crossappeals and third party appeals, see further infra $\S 10$ of this Interlocutory Restatement, notes 81-85 and accompanying text ("jurisdictional" nature of failure to file such notice at all).

6. See Williams v. Bolger, 633 F.2d 410 (5th Cir. 1980); Terket v. Lund, 623 F.2d 29 (7th Cir. 1980).

7. In re Orbitec Corp., 520 F.2d 358, 362 (2d Cir. 1975).

8. 338 U.S. 507, 517-18 (1950) (Black, J., dissenting). In Dickinson the court entered a decree granting part of the relief sought by an intervenor and dismissing that party's remaining claims but reserving several issues as to other intervenors. The dismissed intervenor was uncertain as to whether to appeal then or await a "final" decree.

In some circumstances where the court creates confusion as to finality the rule of excusable neglect may provide some recourse for a potential appellant, but action is still required within thirty days after the normal deadline for filing the appeal. See infra $\S 8$ of this Interlocutory Restatement.

9. Sup. CT. R. 20.1.

10. 28 U.S.C. $\S 2101$ (d)(1976); see also 28 U.S.C. $\$ 2072$ (1976). 
required." There appears to be no reason why the Schacht rationale should not be similarly applied to Rule 4 in cases taken to the courts of appeals.

b. Filing of Notice. Filing of the notice of appeal, and hence the commencement of the appeal, is complete upon tender of the notice of appeal to the clerk of the district court. ${ }^{12}$ Mere deposit of the notice in the mail prior to the limitation date does not constitute filing for the purposes of Rule 4 unless the notice in fact reaches the clerk of the district court before the deadline. ${ }^{13}$ Should the deadline date fall on a weekend or holiday, an appeal filed the following business day is considered timely filed. ${ }^{14}$ The time limit set in Rule 4 is conclusive and cannot be suspended by the court under Rule 2 of the Federal Rules of Appellate Procedure. ${ }^{15}$

c. United States a Party. In general, the sixty-day limitation period applies only when the United States or an agency or officer thereof is more than a nominal party to the action from which the appeal is taken. ${ }^{16}$ The nominal party status of the United States is best exemplified by the treatment of appeals in bankruptcy proceedings. In those cases, the mere fact that the United States may be a tax creditor in the proceeding does not automatically cause courts to invoke the sixtyday limitation period; rather, the longer filing period is applied only when the United States is a participant in the particular controversy which leads to the appeal. ${ }^{17}$ This treatment is consistent with the judicial notion that the longer period should not apply if the interest of the United States has been finally determined prior to the entry of the judgment from which the appeal is sought. ${ }^{18}$

Similarly, in cases where the United States has no actual interest in the outcome of the case but where its name is in the proceeding merely as a "statutory formality," the longer period will not be applied. ${ }^{19}$ If, however, an appeal is taken from a judgment entered after a trial solely between private parties, yet the action is one in which the United States remained an inactive party and in which it retains a "continuing interest" in the outcome even though not participating in the

11. 398 U.S. 58,64 (1970). The filing limit for certiorari petitions in criminal cases was then thirty days under Supreme Court Rule 22(2). Note that today only the filing limit for criminal cases is set by Supreme Court rule. 28 U.S.C. $§ 2101$ (1976).

12. See supra $\S 5$ of this Interlocutory Restatement, comment a.

13. See Reynolds v. Hunt Oil Co., 643 F.2d 1042, 1043 (5th Cir. 1981). But cf. Gibbs v. Town of Frisco City, 626 F.2d 1218, 1220-21 (5th Cir. 1980) (reliance by an attorney on the fact that mail was usually delivered in one day, but when delivery in fact was accomplished in three days and notice was not received until after deadline, was held to be "excusable neglect" and notice was found to be timely filed). For a discussion of extension of the deadline for excusable neglect, see infra $\$ 8$ of this Interlocutory Restatement.

14. See Newson v. First Ala. Bank, 604 F.2d 316 (5th Cir. 1979); Winchell v. Lortscher, 377 F.2d 247 (8th Cir. 1967).

15. See Caperton v. Beatrice Pocahontas Coal Co., 585 F.2d 683 (4th Cir. 1978).

16. See United States v. American Soc'y of Composers, Authors \& Publishers, 331 F.2d 117 (2d Cir.), cert. denied, 377 U.S. 997 (1964).

17. See In re Combined Metals Reduction Co., 557 F.2d 179, 204 (9th Cir. 1977). But see Lloyd, Carr \& Co., 617 F.2d 882, 883 n.1 (1st Cir. 1980) (court cited the general rule yet found that the United States was "sufficiently active" in the proceeding to justify application of the sixty-day limit).

18. See Maryland Casualty Co. v. Conner, 382 F.2d 13 (10th Cir. 1967).

19. See United States ex rel Petrofsky v. Van Cott, Bagley, Cornwall, McCarthy, 588 F.2d 1327 (10th Cir. 1978), cert. denied, 444 U.S. 839 (1979) (United States had declined to enter into the action taken by private citizens under False Claims Act). 
appeal, the sixty-day limitation will be applied. ${ }^{20}$

Where the United States or any agency thereof is not a party but a party is claimed by appellant to be an officer of the United States, the application of the sixty-day limitation depends upon a showing that the party is, for the purposes of the action, an officer of the United States. Two methods of analysis have been used.

The first, and better, method was announced in Hare v. Hurwitz. ${ }^{21}$ In that case plaintiffs sued an employee of the Civil Aeronautics Administration for damages arising from an automobile accident involving a government vehicle driven by the employee. A third party was also made a defendant. Both were represented by a government lawyer, and judgment was rendered against both. The third party filed a notice of appeal fifty-nine days after entry of judgment, and the appeal was dismissed as untimely. The court found that the sixty-day limitation was enacted for the purpose of allowing the various decisionmaking levels of government the time to adequately consider whether to prosecute appeals, thereby avoiding rushed decisions and improvident apppeals. ${ }^{22}$ Where the purpose behind the rule would not be served, the longer filing period was not to apply. ${ }^{23}$ Hare, involving a personal injury suit against an individual and not an officer as such, was such a situation.

The second method of analysis was announced in Wallace v. Chappel, ${ }^{24}$ in which the Ninth Circuit attempted to develop a "clear" test which would more closely track a literal reading of Rule 4 . The court stated that

$[w]$ henever the alleged grievance arises out of a government activity, the 60-day filing period of Rule 4(a) applies if: (a) the defendant officers were acting under color of office, or

(b) the defendant officers werre acting under color of lawful authority, or (c) any party in the case is represented by a government attorney. ${ }^{25}$

Unfortunately, the rule has not been applied in any situations where the term "government activity" has been further defined, and thus the scope of the standard is unclear. In Wallace $v$. Chappel itself, the test clearly obtains the correct result: The case involved a race discrimination action brought by enlisted navy personnel against their superior officers for damages and injunctive relief. The

20. See In re Paris Air Crash of March 3, 1974, 578 F.2d 264, 265 \& n.1 (9th Cir. 1978) (United States interested in result of appeal because of an agreement for contribution was involved); $c f$. United States $e x$ rel. Romero v. Douglas Constr. Co., 531 F.2d 478 (9th Cir. 1976) (United States' interest in outcome of claimant laborer's action for enforcement of minimum wage provision of the Miller Act continued into appeal).

21. 248 F.2d 458 (2d Cir. 1957).

22. Id. at $461-62$.

23. Id. at 462 .

24. 637 F.2d 1345 (9th Cir. 1981) (per curiam)

25. Id. at 1348. Part of the reason for the court's construction of Rule 4 probably can be traced to the "dilemma" presented to litigants in Michaels v. Chappell, 279 F.2d 600 (9th Cir. 1960), which Wallace overruled. In Michaels the lower court had found that a suit brought against government narcotics investigators for abuse of process failed to state a cause of action upon which relief could be granted. A notice of appeal was filed more than thirty but fewer than sixty days after entry of judgment. The Ninth Circuit dismissed the appeal, stating that since the investigators, to avoid an immunity defense, were alleged in the pleadings to have acted "in excess of their authority," the appellants could not claim that the agents were officers for the purpose of applying the sixty-day filing period. In Wallace the "dilemma" was again presented, and the court was forced either to affirm an unworkable rule or create a new one. 
imposition of injunctive relief would so affect a government function that an appeal by the government could be contemplated, and therefore the Hare purpose test would have been satisfied. However, the Wallace rule seems overbroad in that the "government attorney" element could arguably have extended the sixty-day filing period to the Hare case-a result clearly contrary to the purpose of Rule 4(a).

\section{§ 7. Commencement of Running of Time for Appeal.}

(A) THE TIME FOR APPEAL FROM A FINAL DECISION OF THE DISTRICT COURT SHALL COMMENCE TO RUN ON THE DATE OF SUCH DECISION EXCEPT THAT THE TIME SHALL NOT COMMENCE TO RUN UNTIL THE DATE OF ANY OF THE FOLLOWING ORDERS MADE UPON TIMELY REQUEST:

(1) GRANT OR DENIAL OF A MOTION FOR JUDGMENT NOTWITHSTANDING A VERDICT,

(2) GRANT OR DENIAL OF A MOTION TO AMEND OR MAKE ADDITIONAL FINDINGS OF FACT, WHETHER OR NOT AN ALTERATION OF THE JUDGMENT WOULD BE REQUIRED IF THE MOTION WERE GRANTED,

(3) GRANT OR DENIAL OF A MOTION TO ALTER OR AMEND THE JUDGMENT, OR

(4) DENIAL OF A MOTION FOR NEW TRIAL.

(B) A JUDGMENT OR ORDER IS MADE, FOR THE PURPOSE OF COMMENCING THE TIME FOR APPEAL, WHEN IT IS ENTERED IN THE CIVIL DOCKET OF THE DISTRICT COURT. IT IS THE DUTY OF THE CLERK TO NOTIFY THE PARTIES OF THE ENTRY OF JUDGMENT, BUT A FAILURE OF THE CLERK TO PERFORM THIS DUTY DOES NOT AFFECT THE RUNNING OF THE TIME FOR APPEAL.

\section{COMMENT}

a. Commencement of Time for Appeal. Pendency of a posttrial motion suspending the finality of a judgment will toll the running of the time for giving notice of appeal ${ }^{1}$ from the time of judgment until the entry ${ }^{2}$ of a decision on such motion. Rule 4(a) of the Federal Rules of Appellate Procedure provides that this measure of the time for appeal shall apply as to orders granting or denying motions for judgment notwithstanding the verdict, ${ }^{3}$ to amend or make additional findings of fact, ${ }^{4}$ or to alter or amend the judgment, ${ }^{5}$ and as to orders denying motions for

1. See supra $\S \S 5 \& 6$ of this Interlocutory Restatement for a discussion of the contents of the notice of appeal and time for filing such respectively.

2. See infra notes 13-15 and accompanying text for a discussion of the requirements for entry.

3. E.g., Century Laminating, Ltd. v. Montgomery, 595 F.2d 563 (10th Cir.), cert. granted, 444 U.S. 897, cert. dismissed, 444 U.S. 987 (1979); see also FED. R. CIV. P. 50(b).

4. E.g., Spampinato v. City of New York, 311 F.2d 439 (2d Cir. 1962); see also Fed. R. Civ. P. 52(b) Note that the measure of the time to appeal is the same whether or not grant of such a motion would require alteration of the judgment. FED. R. APP. P. 4(a)(4).

5. E.g., Hammond v. Public Fin. Corp., 568 F.2d 1362 (5th Cir. 1978); see also FED. R. Crv. P. 59(e). 
new trials. ${ }^{6}$ The concern is with motions that affect the finality of judgments; other types of motions will not toll the time for appeal. ${ }^{7}$ Moreover, a motion to reconsider the court's denial of one or more of the four specified motions will not operate to further suspend the running of the appeal period. ${ }^{8}$

There is a further requirement in Rule 4 that the posttrial motion be timely; an untimely motion cannot affect the finality of the decision and thus cannot toll the commencement of the running of the time for appeal. ${ }^{9}$

Illustration 7-1. $\mathrm{P}$ prevails in a suit against $\mathrm{D}$, and judgment is entered on a verdict in his favor on May 11. On Niay $19 \mathrm{D}$ files a motion for judgment notwithstanding the verdict, and on June $11 \mathrm{D}$ files notice of appeal of the judgment of May 11. This appeal should be dismissed as premature because the motion for judgment notwithstanding the verdict, which suspends the finality of the decision, is still pending. The motion is denied June 9, and on August 9 D again appeals the May 11 judgment. This appeal also should be dismissed because the thirty-day filing period, measured from the date of denial of the timely motion for judgment notwithstanding the verdict, expired before $\mathrm{D}$ acted. ${ }^{10}$

Illustration 7-2. A judgment, including attorney fees in a specified amount, is entered on June 23 against $\mathrm{D}$ and in favor of $\mathrm{P}$. On July $5 \mathrm{P}$ files a motion for reconsideration of the amount of the fee award. The motion is denied on July 28, and on August $26 \mathrm{D}$ files an appeal of the judgment of June 23. The appeal should not be dismissed; it is timely under Rule 4(a) since the running of the thirty-day period for appeal commenced upon entry of the denial of the motion for reconsideration. ${ }^{11}$ Note that had not the intervention of holidays made the motion for reconsideration timely, ${ }^{12}$ such motion would not have tolled the time for appeal and the appeal would have been dismissed.

b. Entry of Judgment. A judgment or order is made for the purpose of commencing the time for appeal when it is entered in the civil docket of the court; ${ }^{13}$ and that date, not the date of the order, begins the running of time for posttrial motions and appeals from these motions. ${ }^{14}$ For entry to occur, the essentials of a

6. Rathborne v. Rathborne, 683 F.2d 914 (5th Cir. 1982); see also FeD. R. Civ. P. 59.

7. Textile Banking Co. v. Rentschler, 657 F.2d 844, 848-50 (7th Cir. 1981) (motion for relief from judgment or order under Rule 60(b) of the Federal Rules of Civil Procedure does not affect the finality of the judgment and thus does not affect the time to appeal); Mir v. Fosburg, 646 F.2d 342, 344 (9th Cir. 1980).

8. Marten v. Hess, 176 F.2d 834, 835 (6th Cir. 1949).

9. See, e.g., Hulson v. Atchison, T. \& S.F. Ry., 289 F.2d 726, 729 (7th Cir.), cert. denied, 368 U.S. 835 (1961).

10. See generally Century Laminating, Ltd. v. Montgomery, 595 F.2d 563 (10th Cir.), cert. granted, 444 U.S. 897, cert. dismissed, 444 U.S. 987 (1979).

11. Hammond v. Public Fin. Corp., 568 F.2d 1362 (5th Gir. 1978).

12. Rule 59(e) of the Federal Rules of Civil Procedure requires that a motion for reconsideration be filed within ten days of entry of the judgment. The deadline for D's motion, July 3, was a Sunday, and July 4 was a legal holiday; thus it was considered timely filed on July 5. See supra $\S 6$ of this Interlocutory Restatement, note 14 and accompanying text.

13. Yaretsky v. Blum, 592 F.2d 65, 66 (2d Cir. 1979).

14. Id.; Barksdale v. Blackburn, 670 F.2d 22, 23 (5th Cir.), cert. denied, 457 U.S. 1109 (1982). 
judgment or order must be set forth in a written document separate from the court's opinion or memorandum, and the substance of this document must be reflected in an appropriate notation on the docket sheet assigned to the action. ${ }^{15}$

Immediately upon the entry, the clerk shall serve notice of such by mail upon each party who is not in default for failure to appear. ${ }^{16} \mathrm{~A}$ failure by the clerk to perform this duty, however, does not affect the running of the time for appeal. ${ }^{17}$ This result follows from the 1948 amendment ${ }^{18}$ of Rule 77 (d) of the Federal Rules of Civil Procedure, enacted in response to the Supreme Court's holding in Hill v. Hawes that a party was entitled to rely on a clerk's notice and that if the clerk failed to send notice the court could, at its discretion, vacate its judgment and enter a new judgment from which a timely appeal could be taken. ${ }^{19}$ The Advisory Committee on Rules for Civil Procedure explained that the amendment was added to make it clear that "[n]otification by the clerk is merely for the convenience of the litigants. And lack of such notification in itself has no effect upon the time for appeal . . . .", 20

Although the courts may seem to be inconsistent in their application of this rule, ${ }^{21}$ a careful reading reveals a common approach. A mere failure by the clerk to notify the parties is not enough to extend the time for running of the appeal; ${ }^{22}$ however, when this failure is accompanied by something else, such as diligence on the part of counsel to ascertain if judgment has been entered, then the court may exercise discretion to proceed as in Hill $v$. Hawes. ${ }^{23}$ This practice seems sound, as it discourages undue reliance on the court clerk's actions and preserves the finality of judgments while recognizing that if no party knew of the entry of judgment, the losing party cannot be said to have made a " free, calculated, deliberate' choice

15. Caperton v. Beatrice Pocahontas Coal Co., 585 F.2d 683 (4th Cir. 1978). See also supra $\$ 3$ of this Interlocutory Restatement.

16. FED. R. Civ. P. 77(d).

17. Lathrop v. Oklahoma City Hous. Auth., 438 F.2d 914, 915 (10th Cir.), cert. denied, 404 U.S. 840 (1971). It may, however, justify an extension of time for the filing of appeal; see infra $\S 8$ of this Interlocutory Restatement.

18. Rule 77(d) of the Federal Rules of Civil Procedure now includes the following language: "Lack of notice of the entry by the clerk does not affect the time to appeal or relieve or authorize the court to relieve a party for failure to appeal within the time allowed, except as permitted in Rule 4(a) of the Federal Rules of Appellate Procedure."

The amendment establishes a duty on the part of the appellant to follow the progress of the action and advise himself when the court makes the order against which he wishes to protest. Nichols-Morris Corp. v. Morris, 279 F.2d 81, 83 (2d Cir. 1960).

19. 320 U.S. $520,523-24$ (1944).

20. Advisory Comm. on Rules for Civil Procedure, Report of Proposed Amendments to Rules of Civil Procedure for the District Courts of the United States, 5 F.R.D. 433, 492 (1946).

21. Compare In re Morrow, 502 F.2d 520 (5th Cir. 1974) (ruling in conformity with the advisory committee's comment on Rule 77(d)), with Buckeye Cellulose Corp. v. Braggs Elec. Constr. Co., 569 F.2d 1036 (8th Cir. 1978) (wooden reading of Rule 77(d) would thwart rather than promote the ends of justice).

22. In re Morrow, 502 F.2d 520 (5th Cir. 1974); Kramer v. American Postal Workers Union, 556 F.2d 929 (9th Cir. 1977).

23. Buckeye Cellulose Corp v. Braggs Elec. Constr. Co, 569 F.2d 1036 (8th Cir. 1978). In this case, none of the parties knew that judgment had been entered. They inquired as to the status of the case and were assured that notification would be forthcoming. See also In re Morrow, 502 F.2d 520 (5th Cir. 1974), in which the court states that had there been more than a simple failure on the part of the clerk to notify, the outcome might have been different. 
not to appeal."24

\section{§ 8. Extension of Time for Appeal.}

(A) UPON MOTION FILED WITHIN THIRTY DAYS AFTER EXPIRATION OF THE TIME FOR APPEAL AND A SHOWING OF EXCUSABLE NEGLECT, THE DISTRICT COURT MAY EXTEND THE TIME FOR FILING A NOTICE OF APPEAL FOR A PERIOD NOT TO EXCEED THIRTY DAYS OR TEN DAYS FROM DECISION ON THE MOTION, WHICHEVER IS LATER. FURTHER EXTENSIONS MAY NOT BE GRANTED BY ANY COURT.

\section{COMMENT}

The district court upon a showing of excusable neglect or good cause may extend the time for filing a notice of appeal. ${ }^{1}$ Such an extension will be granted only upon motion filed not later than thirty days ${ }^{2}$ after the expiration of such time for appeal ${ }^{3}$ and courts generally hold that a notice of appeal filed within that grace period may not be treated as a motion for an extension. ${ }^{4}$ The duration of the filing extension is discretionary with the district judge, ${ }^{5}$ except that in no case may it exceed thirty days past the prescribed time for filing or ten days past the decision

24. Expeditions Unlimited Aquatic Enter. v. Smithsonian Inst., 500 F.2d 808, 809 (D.C. Cir. 1974) (quoting Ackerman v. United States, 340 U.S. 193, 198 (1950)).

1. FED. R. ApP. P. 4(a)(5).

2. Mayfield v. United States Parole Comm'n, 647 F.2d 1053, 1055 (10th Cir. 1981) ("Appellant's failure to make a motion before the end of the thirty-day grace period extinguished his right of appeal beyond revival by either this court or the district court."); see also Pryor v. Marshall, 711 F.2d 63, 65 (6th Cir. 1983) (appeal dismissed for lack of jurisdiction when extension not properly sought within thirty-day grace period); Brooks v. Britton, 669 F.2d 665, 667 (11 th Cir, 1982) (failure to properly move for extension of time to appeal makes any finding of excusable neglect by the district court ineffectual); Wesley v. Israel, 525 F. Supp. 646 (E.D. Wis. 1981) (district court denial of motion for extension of time to appeal made more than three months after date of final decision). For a discussion of the jurisdictional nature of the time for appeal, see supra $\S 6$ of this Interlocutory Restatement, notes 5-11 and accompanying text.

3. See supra $\S \S 6 \& 7$ of this Interlocutory Restatement.

4. E.g., Briggs v. Lucas, 678 F.2d 612, 613 (5th Cir. 1982); Pettibone v. Cupp, 666 F.2d 333, 335 (9th Cir. 1981); Wyzik v. Employee Benefit Plan of Crane Co., 663 F.2d 348, 348 (1st Cir. 1981); Bond v. Western Auto Supply Co., 654 F.2d 302, 303 (5th Cir. 1981); cf. Pryor v. Marshall, 711 F.2d 63, 65 (6th Cir. 1983) (implication that notice of appeal might be sufficient petition for extension of time if it contained specific allegations of excusable neglect).

This refusal to construe notice of appeal as a motion for extension constitutes a reversal of earlier practice in light of the 1979 amendments to Rule 4(a)(5) of the Federal Rules of Appellate Procedure; courts now hold that all past conventions recognizing implicit motions for extensions are not to be followed. Brooks v. Britton, 669 F.2d 665, 667 (11th Cir. 1982). For example, the acceptance and filing of a late notice of appeal by a district court is not tantamount to granting an extension, Mayfield v. United States Parole Comm'n, 647 F.2d 1053, 1055 (10th Cir. 1981), nor does a subsequent district court action such as the granting of a motion to proceed in forma pauperis have that effect. Briggs v. Lucas, 678 F.2d 612 , 613 (5th Cir. 1982). To the contrary was Shah v. Hutto, 704 F.2d 717 (4th Cir. 1983), in which the Fourth Circuit held that a notice of appeal filed within the thirty-day grace period by its very existence implied that the pro se appellant, if properly notified, would have filed a motion for extension of time to appeal; the court then found excusable neglect so clear that it retained the appeal on its docket rather than remanding the case to the district court for determination of that issue. This opinion was, however, reversed by a close vote in Shah v. Hutto, 722 F.2d 1167 (4th Cir. 1983) (en banc) (following other circuits).

5. National Life Ins. Co. v. Hartford Accident \& Indem. Co., 475 F. Supp. 282, 283 (E.D. Pa. 1979). 
on the excusable neglect motion, whichever is later. ${ }^{6}$ The district court may not grant more than one such extension, ${ }^{7}$ nor may the time for filing be extended by the appellate court. ${ }^{8}$

A motion for extension of time filed before the expiration of the normal time for appeal may be ex parte, ${ }^{9}$ and commentary to the Federal Rules of Appellate Procedure suggests that in such instances only good cause need be shown. ${ }^{10}$ When the motion for extension is filed within the thirty-day grace period after expiration of the time for appeal, notice must be given to the other party in conformity with local court rules, ${ }^{11}$ and a strict standard will be applied to the existence of neglect. ${ }^{12}$

The major reason advanced as warranting an extension of time for filing a notice of appeal is failure to learn of entry of the judgment, ${ }^{13}$ though the standard is no longer limited to such situations. ${ }^{14}$ Tardiness will also be excusable as required for justice because it would be unfair to dismiss an appeal because of a late filing. ${ }^{15}$ In general, error and ambiguity on the part of a court or its personnel may excuse lateness ${ }^{16}$ while failure of a party to ascertain facts of which it has

6. FED. R. APP. P. 4(a)(5). The ten-day provision was added by amendment in 1979 to make it clear that the motion for extension did not have to be ruled on and the notice of appeal filed within the thirt $y$ day grace period but that the court could rule on the motion in due course and grant an extension of up to ten days from that time. Id. advisory committee note; see also In re GAC Corp., 640 F.2d 7, 8 (5th Cir. 1981). This clarification eliminated the need for the prior practice of some courts of requiring appellants to file notices of appeal within the thirty-day grace period which would then be "validated" by later findings of excusable neglect. E.g., In re Orbitec Corp., 520 F.2d 358, 360-61 (2d Cir. 1975).

7. In re GAC Corp., 640 F.2d 7, 8-9 (5th Cir. 1981) (construing rule to allow a new thirty-day grace period after each extension of the time for appeal would defeat the policies of finality of judgment and an end to litigation from which the time requirements are derived).

8. See Wyzik v. Employee Benefit Plan of Crane Co., 663 F.2d 348, 348 (1st Cir. 1981); Bond v. Western Auto Supply Co., 654 F.2d 302, 303 (5th Cir. 1981); Martinez v. Trainor, 556 F.2d 818, 819 (7th Cir. 1977).

9. FED. R. APP. P. 4(a)(5); e.g., National Indus., Inc. v. Republic Nat'l Life Ins. Co., 677 F.2d 1258 , 1263 (9th Cir. 1982). Note that special considerations may arise upon appellate review of trial court dispositions of requests for extensions made before actual expiration of the time for appeal. For example, if a trial court first grants the extension and then, upon reconsideration, holds that there was no excusable neglect, the appellate court may accept jurisdiction without actually reversing that finding because the appellant will have relied to his detriment on the initial grant of an extension when otherwise he still would have been able to file a timely appeal. Id. at 1264 ; accord Harris Truck Lines, Inc. v. Cherry Meat Packers, Inc. 371 U.S. 215 (1962).

10. FED. R. APP. P. 4(a)(5) advisory committee note; see Oregon v. Champion Int'l Corp., 680 F.2d 1300, 1301 (9th Cir. 1982) (dictum) (per curiam); cf. Chipser v. Kohlmeyer \& Co., 600 F.2d 1061, 1063 n.2 (5th Cir. 1979). The "good cause" language, added by the 1979 amendments, does not appear yet to have been the basis for a reported decision.

11. FED. R. APP. P. 4(a)(5).

12. Oregon v. Champion Int'l Corp., 680 F.2d 1300, 1301 (9th Cir. 1982) (per curiam); Chipser v. Kohlmeyer \& Co., 600 F.2d 1061, 1063 (5th Cir. 1979); Milwee v. Peachtree Cypress Inv. Co., 510 F. Supp. 290, 291 (E.D. Tenn. 1979).

13. Chipser v. Kohlmeyer \& Co., 600 F.2d 1061, 1063 (5th Cir. 1979); Dugan v. Missouri Neon \& Plastic Advertising Co., 472 F.2d 944, 948 (8th Cir. (1973); Milwee v. Peachtree Cypress Inv. Co., 510 F. Supp. 290, 291 (E.D. Tenn. 1979); e.g., National Life Ins. Co. v. Hartford Accident \& Indem. Co., 475 F. Supp. 282 (E.D. Pa. 1979).

14. Feeder Line Towing Serv. v. Toledo P. \& W. R.R., 539 F.2d 1107, 1109 (7th Cir. 1976) (citing Stern, Changes in the Federal Appellate Rules, 41 F.R.D. 297, $298-99$ (1966)).

15. See Oregon v. Champion Int'l Corp., 680 F.2d 1300, 1301 (9th Cir. 1982) (per curiam) (citing various sources); Chipser v. Kohlmeyer \& Co., 600 F.2d 1061, 1063 (5th Cir. 1979).

16. E.g., Chipser v. Kohlmeyer \& Co., 600 F.2d 1061 (5th Cir. 1979) (judge compounded confusing initial order by declaring that new trial had been granted without qualification when it was actually only 
notice, ${ }^{17}$ inadvertence, or mistake by counsel will not. ${ }^{18}$

The district courts have discretion to determine whether given circumstances constitute excusable neglect sufficient to justify an extension of the time for filing a notice of appeal. ${ }^{19}$ Such a determination will be overturned by a court of appeals only upon a showing of abuse of discretion. ${ }^{20}$

Illustration. D, immediately following the grant of summary judgment for $P$ in a civil suit, receives copies of the trial court's opinion and order. The clerk, however, neglects to send notice of the subsequent entry of final judgment. D fails to file a timely notice of appeal, the district court, upon proper motion, finds excusable neglect and grants an extension. Upon challenges by $P$ before the appellate court, the appeal should be dismissed as untimely. The finding of excusable neglect was an abuse of discretion because $\mathrm{D}$ had sufficient notice to inquire as to the exact time of entry of the judgment. ${ }^{21}$

\section{§ 9. Standard of Review.}

(A) A FINAL DECISION IN A CIVIL CASE SHALL BE REVERSED ON APPEAL IF, AND ONLY IF, THE REVIEWING COURT FINDS

(1) ERROR IN THE CONTROLLING LAW MANIFESTED IN
(a) A SUMMARY JUDGMENT, JUDGMENT ON THE PLEADINGS, OR DISMISSAL FOR FAILURE TO STATE A CLAIM UPON WHICH RELIEF CAN BE GRANTED,
(b) AN INSTRUCTION TO THE JURY TO WHICH TIMELY OBJECTION WAS MADE OR WHICH IS SO ERRONEOUS THAT THE RESULTING VERDICT IS A PLAIN MISAPPLICATION OF THE LAW, OR
(c) A CONCLUSION OF LAW STATED BY THE COURT

\footnotetext{
an alternative); see also Fairway Center Corp. v. U.I.P. Corp., 491 F.2d 1092, 1093 (8th Cir. 1974) (excusable neglect when court inadvertently granted an extension of time for a motion for a new trial).

17. E.g., Gooch v. Skelly Oil Co., 493 F.2d 366 (10th Cir.), cert. denied, 419 U.S. 997 (1974) (no excusable neglect when one of two plaintiff's counsel received notification relevant to the commencement of time to appeal); Harlan v. Graybar Elec. Co., 442 F.2d 425 (9th Cir. 1971) (no excusable neglect when plaintiff's counsel, but not plaintiff, received notice of entry of judgment); Winchell v. Lortscher, 377 F.2d 247 (8th Cir. 1967) (no excusable neglect when counsel received notification though client was on extended vacation).

18. E.g., Sprout v. Farmers Ins. Exch., 681 F.2d 587 (9th Cir. 1982) (per curiam); Oregon v. Champion Int'l Corp., 680 F.2d 1300 (9th Cir. 1982) (per curiam). But see Milwee v. Peachtree Cypress Inv. Co., 510 F. Supp. 290 (E.D. Tenn. 1979) (counsel's misunderstanding of law, though generally not sufficient, was excusable neglect when it did not result from lack of good faith or improper attention to the case); Karstetter v. Cardwell, 399 F. Supp. 1298 (D. Ariz. 1975) (extension granted in habeas corpus proceeding, although attorney error as to filing period generally would not be found excusable neglect in civil case).

19. Gann v. Smith, 443 F.2d 352, 353 (5th Cir. 1971).

20. E.g., National Indus., Inc. v. Republic Nat'l Life Ins. Co., 677 F.2d 1258, 1264 (9th Cir. 1982); Gooch v. Skelly Oil Co., 493 F.2d 366, 368 (10th Cir.), cert. denied, 419 U.S. 997 (1974).

21. Fase v. Seafarers Welfare \& Pension Plan, 574 F.2d 72 (2d Cir. 1978).
} 
BELOW IN EXPLANATION OF A FINAL DECISION MADE WITHOUT A JURY; OR

(2) AFTER REVIEW OF THE RECORD THAT

(a) THERE IS CLEAR ERROR IN FINDING OF FACT MADE BY THE COURT WITHOUT A JURY, OR

(b) THE JURY VERDICT ON WHICH THE DECISION IS BASED IS NOT SUPPORTED BY SUBSTANTIAL EVIDENCE; OR

(3) PROCEDURAL ERROR SO GRAVE AS TO CAST DOUBT ON THE FAIRNESS AND REGULARITY OF THE PROCEEDING AND INVOLVING

(a) AN ABUSE OF DISCRETION, OR

(b) A DENIAL OF A SUBSTANTIAL PROCEDURAL RIGHT OF AN APPELLANT; OR

(4) THAT THE DISTRICT COURT LACKED JURISDICTION OVER THE SUBJECT MATTER OF THE DISPUTE.

(B) EXCEPT FOR THE LACK OF SUBJECT MATTER JURISDICTION, AN OTHERWISE REVERSIBLE ERROR OF LAW OR FACT WILL NOT BE GROUND FOR REVERSAL IF IT PROVES NOT TO BE PREJUDICIAL TO THE APPELLANT OR IF THE APPELLANT BY HIS CONDUCT WAIVES THE ERROR. AN ERROR BY THE COURT BELOW WILL NOT BE DEEMED TO HAVE BEEN WAIVED BY REASON OF THE FAILURE OF THE PARTY ADVERSELY AFFECTED TO HAVE SOUGHT APPELLATE REVIEW AT THE TIME OF THE ERROR, EVEN IF SUCH REVIEW MIGHT HAVE BEEN AVAILABLE, UNLESS THE ORDER CHALLENGED ON APPEAL WAS PROPERLY DESIGNATED A PARTIAL FINAL DECISION AS PROVIDED IN SECTION 4 OF THIS INTERLOCUTORY RESTATEMENT.

\section{COMMENT}

a. Errors of Law. It is axiomatic that errors of law are to be corrected. The function of appellate courts is to assure that trial court decisions are made in conformity with controlling law.

At the same time, not all errors made by a trial courts are within the duty of appellate courts to correct. Distinguishing those errors of law which should be corrected from those other errors which should be left at rest is a subtle task; it may be that at a high level of generality it is not possible to draw the line in other than circular terms - that is, "errors of law are the kinds of errors which appellate courts correct." Yet it is possible to give greater meaning to this concept through specific enumerations such as those provided in this section of this Interlocutory Restatement.

In an action tried to a jury as of right, the seventh amendment purports to limit the scope of review to questions of law. ${ }^{1}$ In an action tried without a jury, the

1. Tsai v. Rosenthal, 297 F.2d 614, 618 (8th Cir. 1961). 
scope of review is also limited to questions or conclusions of law if the findings of fact of the trial court are not challenged on appeal. ${ }^{2}$ An appellate court may, in exceptional circumstances, consider questions of law that were not presented to or passed on by the trial court if necessary to avoid a miscarriage of justice. ${ }^{3}$ As a general rule, however, wholly new questions of law may not be raised on appeal. ${ }^{4}$

Under 28 U.S.C. $\$ 2105$, an appellate court shall not reverse for error in rulings upon matters in abatement which do not involve jurisdiction. ${ }^{5}$ The language of this statute reflects technical eighteenth-century pleading concepts and was once applied to rulings on motions for stays pending the resolution of proceedings in other courts. ${ }^{6}$ Despite the plain language of the statute, however, it has not been interpreted as a significant limitation on appellate jurisdiction. ${ }^{7}$

b. Summary Judgment. A grant of summary judgment is not discretionary on the part of the trial judge and is freely reviewable by an appellate court. ${ }^{8}$ Although such a determination initially is not limited to the formal pleadings, ${ }^{9}$ the reviewing court may consider only the record developed before the trial court. ${ }^{10}$ If the appellate court, applying the same standards ${ }^{11}$ as the trial court, finds a genuine issue of material fact, it must reverse. ${ }^{12}$ While the party who sought summary judgment bears the burden of persuasion that there is no genuine issue of fact, ${ }^{13}$ the court must consider the opponent's access to proof in determining whether that burden has been met. ${ }^{14}$ A summary judgment granted in violation of the proper standards need not be reversed if the decision is correct for an alternative reason which has support in the record. ${ }^{15}$

An appellate court generally may not, however, reverse a summary judgment due to issues of fact raised by the opposing party which were not disclosed to the trial court, ${ }^{16}$ though an exception may be made if the opponent's failure to previously raise the issues was not in bad faith and injustice will be avoided by reversal. ${ }^{17}$ Furthermore, the district court's determination regarding whether to

2. Osborn v. Sinclair Ref. Co., 286 F.2d 832, 834 (4th Cir. 1960), cert. denied, 366 U.S. 963 (1961).

3. Hormel v. Helvering, 312 U.S. 552, 556-57 (1941); Noritake Co. v. M/V Hellenic Champion, 627 F.2d 724, 732 (5th Cir, 1980).

4. Helvering v. Wood, 309 U.S. 344, 348-49 (1940). For a discussion of the right of the party prevailing below to raise certain issues absent cross-appeal, see infra $\S 10$ of this Interlocutory Restatement, notes $79-80$ and accompanying text.

5. 28 U.S.C. $\S 2105(1976)$.

6. See Stephens v. Monongahela Nat'l Bank, 111 U.S. 197, 198 (1884); Piquignot v. Pennsylvania R.R., 47 U.S. (16 How.) 104, 105 (1853).

7. United States v. Alcon Laboratories, 636 F.2d 876, 885 n.2 (1st Cir.), cert. denied, 451 U.S. 1017

(1981). See also infra $\S 17$ of this Interlocutory Restatement, note 1.

8. Roberts v. Browning, 610 F.2d 528, 536-37 (8th Cir. 1979).

9. Keiser v. Coliseum Properties, 614 F.2d 406, 410 (5th Cir. 1980).

10. Adickes v. S.H. Kress \& Co., 398 U.S. 144, 157-58 (1970).

11. Baw Mfg. Co. v. Saks Fifth Ave., 547 F.2d 928, 930 (5th Cir. 1977).

12. Fristoe v. Reynolds Medals Co., 615 F.2d 1209, 1213 (9th Cir. 1980).

13. Frank C. Bailey Enter. v. Cargill, Inc., 582 F.2d 333, 333 (5th Cir. 1978).

14. Alabama Farm Bureau Mut. Casualty Co. v. American Fidelity Life Ins., 606 F.2d 602 , 609 (5th Cir. 1979), cert. denied, 449 U.S. 820 (1980).

15. Fristoe v. Reynolds Medals Co., 615 F.2d 1209, 1213 (9th Cir. 1980); Charbonnages de France v. Smith, 597 F.2d 406, 416 (4th Cir. 1979).

16. Adickes v. S.H. Kress \& Co., 398 U.S. 144, 157-61 (1970).

17. Roberts v. Hollandsworth, 582 F.2d 496, 499-500 (9th Cir. 1978). 
accept a party's affidavit that he cannot present facts essential to justify his position is discretionary; the appellate court may not disturb this exercise of discretion absent abuse. ${ }^{18}$

The labeling of an order as a summary judgment by the trial court is not controlling on the appellate court. ${ }^{19}$ If the district court erroneously decides a different motion as a summary judgment, the appellate court may not review it as a summary judgment; ${ }^{20}$ but if it appears that the district court treated a motion before it as a summary judgment but erroneously labeled it as some other motion, the determination may be so reviewed. ${ }^{21}$

The appellate court upon reversing will generally remand a summary judgment for further development of the facts ${ }^{22}$ or for trial of limited issues. ${ }^{23}$ Where the district court has erroneously applied the law, however, the appellate court may reverse and grant summary judgment for the appellant. ${ }^{24}$

c. Judgment on the Pleadings and Dismissal for Failure to State a Claim. The standard of appellate review for judgment on the pleadings is the same as that applied by the trial court. ${ }^{25}$ Only the undisputed facts from all of the pleadings may be considered. ${ }^{26}$ If, on such facts, it cannot be determined that the movant is clearly entitled to judgment, the judgment on the pleadings should be reversed. ${ }^{27}$

Similarly, in reviewing a dismissal under Rule 12(b)(6) of the Federal Rules of Civil Procedure for failure to state a claim, the appellate court is again bound by the same standards as applied by the trial court. ${ }^{28}$ The court must review the record, ${ }^{29}$ accept all facts alleged in the complaint as true ${ }^{30}$ and construe the complaint in the light most favorable to the plaintiff. ${ }^{31}$ In the absence of legal merit, ${ }^{32}$ the appellate court should affirm the dismissal. ${ }^{33}$ Reversal is appropriate if it does not appear to a certainty that the plaintiff is entitled to no relief under any state of

18. First Nat'l Bank v. Cities Serv. Co., 391 U.S. 253, 298 (1968).

19. Zweig v. Hearst Co., 594 F.2d 1261, 1263-64 (9th Cir. 1979). Cf. infra notes $35 \& 59$ and accompanying text; infra $\S 20$ of this Interlocutory Restatement, comments $g$ $\sigma^{2} h$; infra $\S 21$ of this Interlocutory Restatement, notes $11-13$ and accompanying text.

20. Thornhill Publishing Co. v. General Tel. \& Elecs. Corp., 594 F.2d 730, 733 (9th Cir. 1979).

21. Id.

22. International Union, UAW v. National Right to Work Legal Def. \& Educ. Fund, Inc., 590 F.2d 1139, 1151-52 (D.C. Cir. 1978).

23. Blonder-Tongue Laboratories v. University of Ill. Found., Inc., 402 U.S. 313, 350 (1971). See generally infra $\S 10$ of this Interlocutory Restatement.

24. Abrams v. Occidental Petroleum Corp., 450 F.2d 157, 165-66 (2d Cir. 1971), affd sub nom. Kern Land Co. v. Occidental Petroleum Corp., 411 U.S. 582 (1973). But see Fountain v. Filson, 336 U.S. 681 , 683 (1949). For a further discussion see infra $\S 10$ of this Interlocutory Restatement, notes $16-19$ and accompanying text.

25. Lanasa Fruit S.S. \& Importing Co. v. Universal Ins. Co., 302 U.S. 556, 559 (1938); Frissell v. Rizzo, 597 F.2d 840, 845 (3d Cir.), cert. denied, 444 U.S. 841 (1979).

26. Fed. R. CrV. P. 12(c); see McDonnell v. Estelle, 666 F.2d 246, 249-50 (5th Cir. 1982).

27. Link v. Wabash R.R., 237 F.2d 1, 4 (7th Cir. 1956), cert. denied, 352 U.S. 1003 (1957); McDonnell v. Estelle, 666 F.2d 246, 249-50 (5th Cir. 1982).

28. Holt Civic Club v. City of Tuscaloosa, 439 U.S. 60, 66 (1978).

29. Black v. Payne, 591 F.2d 83, 86 (9th Cir.), cert. denied, 444 U.S. 867 (1979).

30. Western Mining Council v. Watt, 643 F.2d 618, 624 (9th Cir.), cert. denied, 454 U.S. 1031 (1981)

31. Id.

32. Johnsrud v. Carter, 620 F.2d 29, 32-33 (3d Cir. 1980) (nonjusticiable political question); Place v Shepherd, 446 F.2d 1239, 1244 (6th Cir. 1971) (insufficient allegations of fact in the pleadings).

33. Holt Civic Club v. City of Tuscaloosa, 439 U.S. 60, 66 (1978). 
facts which can be construed to support the claim. ${ }^{34}$

The appellate court is not bound by the trial court's labeling of the motion. ${ }^{35}$

d. Jury Instructions. Parties are entitled to insist that a jury be correctly instructed as to the controlling law. Rule 51 of the Federal Rules of Civil Procedure explicitly states that an error in the instruction is not reviewable unless an objection is made before the jury retires to consider its verdict. ${ }^{36}$ The objection must state the matter to which the party objects and the basis for the objection. ${ }^{37}$

On review of timely challenged jury instructions the appellate court is to determine whether the instructions were likely to mislead or confuse the jury with respect to the applicable principles of law. ${ }^{38}$ The court must presume that the jury followed the instructions as given; ${ }^{39}$ and in considering correctness and adequacy, it must consider the charge as a whole and read it in its entirety, even though only a portion is challenged. ${ }^{40}$ An error in even a simple instruction, however, may require reversal if it is substantial and prejudicial. ${ }^{4}$

Despite the mandate of Rule 51 that timely objection is a prerequisite to appellate review of jury instructions, many courts have, in the civil context, borrowed the "plain error" doctrine from Rule 52 of the Federal Rules of Criminal Procedure. ${ }^{42}$ Under this doctrine the reviewing court may reverse for error in a jury instruction as to which objection was not properly raised if the error is patent on the face of the record, that is, if the instruction plainly misstates the controlling legal principles, ${ }^{43}$ and if reversal is necessary to prevent a miscarriage of justice. ${ }^{44}$

While this practice may be criticized as contrary to the express language of Rule 51 and the principle of finality and as burdensome to the appellate courts, ${ }^{45}$ it may also be defended as consistent with the spirit of the Rules. As the Supreme Court has observed,

Rules of practice and procedure are devised to promote the ends of justice, not to defeat them. A rigid and undeviating judicially declared practice under which courts of review would invariably and under all circumstances decline to consider all questions which had not previously been specifically urged would be out of harmony with this policy. Orderly

34. Hospital Bldg. Co. v. Trustees of the Rex Hospital, 425 U.S. 738, 746 (1976); White v. United States, 588 F.2d 650, 651 (9th Cir. 1978); Ballou v. General Elec. Co., 393 F.2d 398, 399 (1st Cir. 1968), cert. denied, 401 U.S. 1009 (1971).

35. E.g., Black v. Payne, 591 F.2d 83, 86 n.1 (9th Cir.) (trial court denominated dismissal as for lack of subject matter jurisdiction but appellate court held it more properly characterized as for failure to state a claim), cert. denied, 444 U.S. 867 (1979); Carr v. Learner, 547 F.2d 135, 137 (1st Cir. 1976). Cf. supra notes 19-20 and accompanying text.

36. Platis v. Stockwell, 630 F.2d 1202, 1205 (7th Cir. 1980); Coca-Cola Bottling Co. v. Hubbard, 203 F.2d 859, 862 (8th Cir. 1953).

37. FED. R. CIV. P. 51.

38. Delancey v. Motichek Towing Serv., 427 F.2d 897, $901-02$ (5th Cir. 1970).

39. Pittman v. Littlefield, 438 F.2d 659, 662 (1st Cir. 1971).

40. Nolan v. Greene, 383 F.2d 814, 816 (6th Cir. 1967).

41. Sunkist Growers v. Winckler \& Smith Citrus Prods. Co., 284 F.2d 1, 23 (9th Cir. 1960).

42. Frederic P. Weidersum Assocs. v. National Homes Constr. Corp., 540 F.2d 62, 66 (2d Cir. 1976); Modave v. Long Island Jewish Medical Center, 501 F.2d 1065, 1072 (2d Cir. 1974); see United States v. Atkinson, 297 U.S. 157, 160 (1936).

43. Miller v. Premier Corp., 608 F.2d 973, 983 (4th Cir. 1979).

44. Batesole v. Stratgord, 505 F.2d 804, 808 (6th Cir. 1974); McNello v. John B. Kelly, Inc., 283 F.2d

96, 102-03 (3d Cir. 1960); Smith v. Welch, 189 F.2d 832, 836 (10th Cir. 1951)

45. C. Wright, Law of Federal Courts 630 (1983). 
rules of procedure do not require sacrifice of the rules of fundamental justice. ${ }^{46}$

The discretion thus implied is rarely exercised by appellate courts and is clearly limited to exceptional cases where the "error [is] so serious and flagrant that it goes to the very integrity of the trial." 47 Review in the absence of timely objection is most frequently invoked in the context of jury instructions, but the doctrine has been extended to other errors of law and procedural errors as well. ${ }^{48}$

e. Conclusions of Law. Rule 52(a) of the Federal Rules of Civil Procedure delineates the scope of review which appellate courts are to apply to findings of fact. ${ }^{49}$ The Rules provide no standard of review for conclusions of law. Given this silence and the long-established principles of law and equity, it is clear that the appellate court may freely review the trial courts' conclusions of law. ${ }^{50}$ Therefore, although Rule 52 requires the trial court to separately state its conclusions of law or legal premise, the appellate court is not bound by that view of the law or application of a legal standard. ${ }^{51}$

Rule 44.1 of the Federal Rules of Civil Procedure explicitly states that the trial judge's determination regarding the law of a foreign country "shall be treated as a ruling on a question of law." 52 Similarly, a determination of state law is generally freely reviewable as a question of law, though appellate courts give great weight to a lower court's conclusion in consideration of the district judge's experience in the law of that state. ${ }^{53}$ The Tenth Circuit, however, accords the district court's views even greater deference, holding that an appellate court is to accept the determinations of state law made by the district court unless such determinations are clearly in error. ${ }^{54}$

f. Distinction between Law and Fact. The distinction between law and fact comes into play not only in distinguishing questions for the jury from questions for the court but also in determining the scope of appellate review of the findings and conclusions of a decision made without a jury. While conclusions of law are freely reviewable, findings of fact by the trial court are subject to only limited review. ${ }^{55}$ A telling illustration of this distinction is the suggestion that an unscrupulous factfinder might say, "Let me find the facts for the people of my country, and I care little who lays down the general principles." 56

46. Hormel v. Helvering, 312 U.S. 552, 557 (1941).

47. Modave v. Long Island Jewish Medical Center, 501 F.2d 1065, 1072 (2d Cir. 1974).

48. See, e.g., United States v. Harrell, 133 F.2d 504, 506-07 (8th Cir. 1943); Colonial Refrigerated Trans. v. Mitchell, 403 F.2d 541, 552 (5th Cir. 1968); San Antonia v. Timko, 368 F.2d 983, 986 (2d Cir. 1966).

49. FED. R. CiV. P. 52(a).

50. Pullman-Standard v. Swint, 456 U.S. 273, 287 (1982); United States v. Mississippi Valley Generating Co., 364 U.S. 520, 526 (1961).

51. Van Ooteghem v. Gray, 628 F.2d 488, $491-92$ (5th Cir. 1980), cert. dismissed, 451 U.S. 935 (1981), cert. denied, 455 U.S. 909 (1982); Campana Corp. v. Harrison, 114 F.2d 400, 405-06 (7th Cir. 1940).

52. Fed. R. Giv. P. 44.1.

53. Freeman v. Continental Gin Co., 381 F.2d 459, 466 (5th Cir. 1967).

54. Sta-Rite Indus. v. Johnson, 453 F.2d 1192, 1194-95 (10th Cir. 1971), cert. denied, 406 U.S. 958 (1972).

55. FED. R. CIv. P. 52; DeMarco v. United States, 415 U.S. 449, 450 (1974).

56. United States v. Forness, 125 F.2d 928, 942 (2d Cir.) (quoting Chief Justice Hughes regarding administrative factfinding), cert. denied, 316 U.S. 694 (1942). 
In the debates over the scope of appellate review under the proposed Federal Rules, it was warned that questions of fact and law are often so intermingled that any distinction for purposes of appellate review would be impractical. ${ }^{57}$ Even prior to that time it had been suggested that "law" and "fact" "readily accommodate themselves to any meaning we desire to give them . . . . The man who could succeed in defining them would be a public enemy." 58

The label as to fact versus law given by the district court to its determination is not decisive, ${ }^{59}$ and a mislabeling will not be a ground for reversal unless a party can show prejudice. ${ }^{60}$ Examination of the cases and literature reflects the bewildering nature of the problem-courts addressing similar questions frequently come to opposite conclusions as to whether a specific determination is one of law or fact. The Supreme Court recently noted the "vexing nature" of the distinction: "[N]or do we yet know of any . . . rule or principle that will unerringly distinguish a factual finding from a legal conclusion." 61

Various functional tests have been developed, mostly in the context of determining jury and nonjury questions, to distinguish law from fact. Issues as to historical events, acts which occurred, or conditions which existed are questions of fact ${ }^{62}$ as are issues involving mental events such as the existence of intent, knowledge, belief, good faith, or malice. ${ }^{63}$ Particularity, specificity, and concreteness are characteristic of factual questions. ${ }^{64}$ Courts may also look to whether the underlying evidence is disputed. ${ }^{65}$ Thus, while interpretation of a legal document is generally held to be a question of law, and therefore freely reviewable, ${ }^{66}$ the Supreme Court has said that where such an interpretation depends "not merely on [the document's] construction and meaning, but also upon extrinsic facts and circumstances, the inferences to be drawn from it are inferences of fact and not of law."67

Whether reasonable men could differ as to a given issue is another indication of a question of fact. ${ }^{68}$ This test suggests that factual questions are resolved through

57. Blume, Review of Facts in Non-jury Cases, $20 \mathrm{~J}$. AM. Judicature SOC'y 68 (1936).

58. L. GREen, JUdGE AND JURY 270 (1930).

59. East v. Romine, 518 F.2d 332, 338-39 (5th Cir. 1975). Cf. supra notes 19-20 and accompanying text.

60. Westley v. Southern Ry., 250 F.2d 188, 189 (4th Cir. 1957).

61. Pullman-Standard v. Swint, 456 U.S. 273, 288 (1982).

62. Weiner, The Civil Jury Trial and the Law-Fact Distinction, 54 CALIF. L. REV. 1867, 1870 (1966). See Mamiye Bros. v. Barber S.S. Lines, 360 F.2d 774, 777-78 (2d Cir.), cert. denied, 385 U.S. 835 (1966).

63. Pullman-Standard v. Swint, 456 U.S. 273, 288 (1982)

64. See Cook, 'Facts' and 'Statements of Fact,' 4 U. CHI. L. REv. 233 (1937) (discussing meaning of "fact" in the context of pleading). Cook argues that the communication of facts necessarily involves a process of abstraction and categorization and thus the characteristic of abstraction is insufficient to distinguish law from fact.

65. See Carrington, The Power of District Judges and the Responsibility of Courts of Appeals, 3 GA. L. REV. 507, 522 (1969); Note, Federal Rule of Civil Procedure 52(a) and the Scope of Appellate Fact Review: Has Application of the Clearly Erroneous Rule Been Clearly Erroneous.', 52 ST. JoHN's L. REv. 68, 88-89 (1977).

66. Weismueller v. Interstate Fire \& Casualty Co., 568 F.2d 40, 42 (7th Cir. 1978); Mackay v. National Football League, 543 F.2d 606, 612 (8th Cir. 1976), cert. dismissed, 434 U.S. 801 (1977).

67. West v. Smith, 101 U.S. 263, 270 (1879). See United Truck \& Bus Serv. Co. v. Piggott, 543 F.2d 949, 950 (1st Cir. 1976); Emor, Inc. v. Cyprus Mines Corp., 467 F.2d 770, 773-75 (3d Cir. 1972).

68. Weiner, The Civil Nonjury Trial and the Law-Fact Distinction, 55 CALIr. L. REv. 1020, 1024 (1967) (distinguishing fact and law in jury-nonjury context). 
the factfinder's instinct, not through reason. ${ }^{69}$

The most widely cited test distinguishes a finding of fact as a "finding based on the "fact-finding tribunal's experience with the mainsprings of human conduct' [while a] conclusion of law would be a conclusion based on application of a legal standard."70 In addition to again emphasizing the instinct of the factfinder, this definition also reflects the classic test of a question of law-whether there is a declared rule or existing standard which has developed through a repeated pattern of resolution to guide the court. ${ }^{71}$ Justice Holmes took this reasoning one step further to suggest that the functional need for certainty and uniformity requires that questions and fact patterns which are likely to arise repeatedly should be treated as questions of law. ${ }^{72}$

A commonly applied but seldom articulated test distinguishes fact and law on the basis of the relative competence and reliability of the trial court and the reviewing court. ${ }^{73}$ This test seems to "put the cart before the horse," by affixing the labels "fact" and "law" only after the decision to defer or to review has been made, as is reflected in Jabez Fox's proposed definition in the context of jurynonjury questions: "That part of the case which is left to the jury is fact, as it seems to me because it is left to the jury; and that part which is decided by the judge is law because he chooses to decide it and to decide it in such a way that it shall be used as a precedent for future cases."74 This view suggests a "skepticism about the circularity of the distinction," 75 which is borne out by examination of the cases.

The plasticity of the fact-law distinction has perpetuated the debate about where the lines of restraint on appellate review of a trial court's factfinding are to be drawn. ${ }^{76}$ The tests may successfuly distinguish questions of pure law from questions of pure fact but they appear to be less useful when applied to the cases most in need of such tests. For example, cases involving mixed questions of law and fact illustrate that legal reasoning is involved in any finding of ultimate fact.

While findings of fact which lead to a conclusion of law are not freely reviewable by an appellate court, ${ }^{77}$ findings of fact which are induced by an erroneous

69. Griswold, The Supreme Court, 1959 Term-Foreword: Of Time and Altitudes-Professor Hart and Judge Amold, 74 HaRv. L. Rev. 81, 87 (1960) (quoting Jerome Michael); Carrington, supra note 65, at 519.

70. Lundgren v. Freeman, 307 F.2d 104, 115 (9th Cir. 1962) (quoting Commissioner v. Duberstein, 363 U.S. 278, $289(1960))$.

71. Weiner, supra note 62, at 1893. See Fox, Law and Fact, 12 HARV. L. REV. 545 (1899) (rejecting this test as proposed by Thayer).

72. O. HOLMES, THE COMMON LAW 123-24 (1881) (speaking of negligence questions in context of jury trials).

73. See Carrington, supra note 65 , at 520; Weiner, supra note 68 , at 1031; 5A J. MOORE \& J. LUCAS, MoOre's Federal. Practice 52.03[1], At 2627 (2D ED. 1982).

74. Fox, supra note 71 , at 551 .

75. Carrington, supra note 65 , at 518 .

76. See, e.g., Blume, Review of Facts in Nonjury Cases, 20 J. AM. Judicature Soc'Y. 68 (1936); Blume, supra note 57; Carrington, supra note 65; Clark, Revieie of Facts Under Proposed Federal Rules, $20 \mathrm{~J}$. AM. JuDICATURE SOC'Y 129 (1936); Clark \& Stone, Review of Findings of Fact, 4 U. CHI. L. REV. 190 (1937); Weiner, supra note 68; Wright, The Doubtful Omniscience of Appellate Courts, 41 MINN. L. REv. 751 (1957).

77. Weisel v. Singapore Joint Venture, Inc., 602 F.2d 1185, 1189 n.11 (5th Cir. 1979); Detroit Police Officers' Ass'n. v. Young, 608 F.2d 671, 686 (6th Cir. 1979), cert. denied, 452 U.S. 938 (1981). The appellate 
view of the law are subject to such review. ${ }^{78}$ Thus, mixed questions of law and fact and questions of ultimate fact have generally been held to be freely reviewable. ${ }^{79}$ Many courts, however, add that if the trial court's determination of a mixed question is not tainted by an error of law, then the mixed question is subject to only limited review. ${ }^{80}$

Some commentators have suggested that recent cases illustrate a trend toward a broader review of trial court fact determinations under the guise of reviewing mixed questions of fact and law or questions of ultimate fact. ${ }^{81}$ The Supreme Court has rejected any notion of such subversion. ${ }^{82}$ In a recent case it found that whether the differential impact of a seniority system reflected an intent to discriminate on the basis of race was a "pure question of fact," not a question of law or a mixed question of law and fact." 83 The Court rejected the argument that "ultimate facts," taken as meaning facts upon which a result turns, are more freely reviewable by an appellate court, ${ }^{84}$ by noting that Rule 52 , which narrowly restricts appellate review of findings of fact, makes no such dichotomy. ${ }^{85}$ The Court distinguished its own decisions suggesting that "ultimate facts" were freely reviewable as referring to findings which involved application of standards of law. ${ }^{86}$

g. Nonjury Findings of Fact. If the district court has made findings of fact without a jury, Rule 52(a) explicitly mandates that they "not be set aside unless clearly erroneous." 87 The Rule also governs when a district court has tried a case with an advisory jury; ${ }^{88}$ because the judge is responsible for the decision and has the duty to make findings of fact in either instance, the scope of appellate review is the same as if the trial had been conducted without a jury. ${ }^{89}$

Under this "clearly erroneous" rule, the district court's findings of fact are not conclusive on the appellate court. ${ }^{90}$ However, the presumption supporting those findings imposes a heavy burden on the appellant seeking to overcome it. ${ }^{91}$ In reviewing findings of fact, the appellate court may examine all the evidence in the

court should remand unless the record permits only one resolution of the actual issue. Pullman-Standard v. Swint, 456 U.S. 273, 292 (1982).

78. United States v. Parke, Davis \& Co., 362 U.S. 29, 44 (1960); United States v. United States Gypsum Co., 333 U.S. 364, 394 (1948)

79. Industrial Instrument Corp. v. Foxboro Co., 307 F.2d 783, 786 n.2 (5th Cir. 1962); see Van Ooteghem v. Gray, 628 F.2d 488, 491 (5th Cir. 1980), cert. dismissed, 451 U.S. 395 (1981), cert. denied, 455 U.S. 909 (1982).

80. Famous Knitwear Corp. v. Drug Fair, Inc., 493 F.2d 251, 253 (4th Cir. 1974).

81. See Van Ooteghem v. Gray, 628 F.2d 488, $491-92$ (5th Cir. 1980), cert. dismissed, 451 U.S. 935 (1981), cert. denied, 455 U.S. 909 (1982); Nangle, The Ever Widening Scope of Fact Review in Federal Appellate Courts-Is the "Clearly Erroneous" Rule Being Avoided?, 59 WASH. U.L.Q. 409 (1981).

82. Pullman-Standard v. Swint, 456 U.S. 273, 287 (1982).

83. Id. at 288 .

84. Id. at 287 n. 16 .

85. Id. at 287 .

86. Id. at 287 n. 16 (discussing Baumgartner v. United States, 322 U.S. 665, 671 (1944)).

87. FED. R. Civ. P. 52(a).

88. Id.

89. See Reachi v. Edmond, 277 F.2d 850, 854 (9th Cir. 1960); 5 J. MOORE, J. LuCAS \& J. WiCKER, Moore's Federal Practice I 39.10[1] at 39-39 (2d. ed. 1983).

90. See United States v. United States Gypsum Co., 333 U.S. 364, 395 (1948).

91. Arkansas Educ. Ass'n. v. Board of Educ. of Portland, Ark. Sch. Dist., 446 F.2d 763, 770 (1971). 
record ${ }^{92}$ but may not consider the evidence de novo. ${ }^{93}$ The reviewing court is to presume that the findings of fact are based only on admissible evidence. ${ }^{94}$

Many attempts have been made to define "clearly erroneous." Judge Hand, suggesting that such a pursuit is an "idle" task, concluded that the phrase "clearly erroneous" means that an appellate court will "reverse [a trial judge's findings of fact] most reluctantly and only when well-persuaded."95 The most frequently quoted test is that "[a] finding is 'clearly erroneous' when although there is evidence to support it, the reviewing court on the entire evidence is left with the definite and firm conviction that a mistake has been committed."96

Other decisions hold that an appellate court may declare a trial court's findings clearly erroneous where they are induced by an erroneous view of the law, ${ }^{97}$ where the court misapprehended the effect of the evidence, ${ }^{98}$ where the findings are contrary to the clear weight of the evidence, ${ }^{99}$ where the findings are significantly contradictory, ${ }^{100}$ or where the findings are not supported by substantial evidence. ${ }^{101}$ "Clearly erroneous" and "not supported by substantial evidence" are not synonymous; ${ }^{102}$ even where findings are supported by substantial evidence, they can be set aside if the reviewing court has the definite and firm conviction that they are mistaken. ${ }^{103}$

An appellate court is not justified, however, in setting aside a trial court's choice between two permissible views of the weight of the evidence just because the reviewing court would have reached a different result. ${ }^{104}$ In a recent trademark infringement action the Supreme Court held that evaluation of the weight and credibility of evidence was the province of the trial judge: "An appellate court cannot substitute its interpretation of the evidence for that of the trial court simply because the reviewing court 'might give the facts another construction, resolve the ambiguities differently, and find a more sinister cast to actions which the District Court apparently deemed innocent.' "105

Rule 52(a) additionally mandates that "due regard should be given to the opportunity of the trial judge to judge of the credibility of the witnesses."106 To the extent that the trial court's findings are based on demeanor testimony they are

92. Buckley v. Littell, 539 F.2d 882, 888 (2d Cir. 1976), cert. denied, 429 U.S. 1062 (1977).

93. Zenith Radio Corp. v. Hazeltine Research, 395 U.S. 100, 123 (1969).

94. United States v. 396 Corp., 264 F.2d 704, 709 (2d Cir.), cert. denied, 361 U.S. 817 (1959).

95. United States v. Aluminum Co. of Am., 148 F.2d 416, 433 (2d Cir. 1945).

96. United States v. United States Gypsum Co., 333 U.S. 364, 395 (1948).

97. United States v. Singer Mfg. Co., 374 U.S. 174, 194 n.9 (1963).

98. Nee v. Linwood Sec. Co., 174 F.2d 434, 437 (8th Cir. 1949).

99. Cleo Syrup Corp. v. Coca-Cola Co., 139 F.2d 416, 418 (8th Cir. 1943), cert. denied, 321 U.S. 781

100. In re U.S.A. Motel Corp., 450 F.2d 499, 503 (9th Cir. 1971).

101. Western Cottonoil Co. v. Hodges, 218 F.2d 158, 161 (5th Cir. 1954).

102. W.R.B. Corp. v. Geer, 313 F.2d 750, 753 (5th Cir. 1963).

103. Id. See also Case v. Morrisette, 475 F.2d 1300, 1307 (D.C. Cir. 1973).

104. United States v. Yellow Cab Co., 338 U.S. 338, 341-42 (1949). Cf. infra note 166 and accompanying text (review of trial court discretion).

105. Inwood Laboratories v. Ives Laboratories, 456 U.S. 844, 857-58 (1982) (quoting United States v. Real Estate Bds., 339 U.S. 485, 495 (1950)).

106. FED. R. CIV. P. 52(a). 
generally treated as "unassailable."107 This rule applies to the trial court's appraisal of expert testimony as well. ${ }^{108}$

While the clearly erroneous standard is one of deference to the factfinder, it also imposes an unavoidable duty on the reviewing court to set aside findings which do not meet the test. 109

An unsettled question regarding interpretation of the clearly erroneous standard is the degree to which an appellate court must defer to a trial court's findings of fact when those findings rest on documentary evidence or inferences drawn from undisputed facts. Three different tests seem to be current, and decisions from every circuit can be found to support each.

One view is that the appellate court can more readily hold the trial court's findings clearly erroneous when they do not rest on demeanor evidence and evaluation of the credibility of the witnesses. ${ }^{110}$ Other decisions stretch this test to conclude that, where the record is entirely documentary, the reviewing court is in as good a position to evaluate the evidence as the trial court and thus may conduct de novo review without the constraint of the clearly erroneous rule. ${ }^{111}$ Proponents of this view argue that the purpose of that rule is not applicable when the findings do not rest on the trial court's evaluation of credibility of witnesses.

Given that Rule 52(a) itself makes no exceptions based on the nature of the testimony, however, the best view is that the clearly erroneous rule applies in all cases tried without a jury, whether the findings are based on oral evidence, documentary evidence, or inferences drawn from undisputed facts. ${ }^{112}$ The Supreme Court seemingly favors this position, although it has not explicitly discussed this question; ${ }^{13}$ and proponents of this view argue that blurring the lines between factfinder and reviewing court will be detrimental to the interest of judicial economy, will undermine the legitimacy of the district courts in the public eye, and will multiply appeals by encouraging appellate second-guessing. ${ }^{114}$

The proposed amendments to the Federal Rules of Civil Procedure would

107. United States v. Aluminum Co. of Am., 148 F.2d 416, 433 (2d Cir. 1945); see e.g., Zenith Radio Corp. v. Hazeltine Research, 395 U.S. 100, 122 (1969).

108. Graver Tank \& Mfg. Co. v. Linde Air Prods. Co., 336 U.S. 271, 274-75 (1949); but see Hicks v. United States, 368 F.2d 626, 631 (4th Cir. 1966) (appellate court will not accept finding based on expert testimony which clearly conflicts with other uncontroverted findings).

109. See Dayton Bd. of Educ. v. Brinkman, 443 U.S. 526, 534 n.8 (1979).

110. See, e.g., Marcum v. United States, 621 F.2d 142, 144-45 (5th Cir. 1980); Toms v. Country Quality Meats, 610 F.2d 313, 315 n.5 (5th Cir. 1980).

111. See, e.g., Atari, Inc. v. North Am. Philips Consumer Elec. Corp., 672 F.2d 607, 714 (7th Cir.), cert. denied, 103 S. Ct. 176 (1982); Swanson v. Baker Indus., 615 F.2d 479, 483 (8th Cir. 1980); Orvis v. Higgins, 180 F.2d 537, 539-540 (2d Cir.), cert. denied, 340 U.S. 810 (1950); Hicks v. United States, 368 F.2d 626, 63031 (4th Cir. 1966).

112. See, e.g., Maxwell v. Sumner, 673 F.2d 1031, 1036 (9th Cir.), cert. denied, 103 S. Ct. 313 (1982); In Re Sierra Trading Corp., 482 F.2d 333, 337 (10th Cir. 1973); Case v. Morrisette, 475 F.2d 1300, 1306-07 (D.C. Cir. 1973).

113. United States v. United States Gypsum Co., 333 U.S. 364, 394 (1948) (clearly erroneous standard applies to "inferences drawn from documents or undisputed facts"); see Pullman-Standard v. Swint, 456 U.S. 273 (1982); United States v. General Motors Corp., 384 U.S. 127, 141 n. 16 (1966); United States v. Singer Mfg. Co, 374 U.S. 174, 194 n.9 (1963); Commissioner v. Duberstein, 363 U.S. 278,291 (1960).

114. See Blunt v. Marion County Sch. Bd., 515 F.2d 951, 958 (5th Cir. 1975); Lundgren v. Freeman, 307 F.2d 104, 113-14 (9th Cir. 1962); Pendergrass v. New York Life Ins. Co., 181 F.2d 136, 138 (8th Cir. 1950). 
resolve this conflict as to the scope of applicability of the clearly erroneous rule by providing that "[f]indings of fact, whether based on oral or documentary evidence, shall not be set aside unless clearly erroneous" and adding that due regard is to be accorded "the need for finality." 115

h. Jury Findings. The seventh amendment provides that "no fact tried by jury shall be otherwise re-examined in any Court of the United States, than according to the rules of the common law." The directed verdict mechanism existed at common law and permitted appellate review of the trial court's decision to direct or refrain from directing a jury's verdict, ${ }^{16}$ and although the judgment n.o.v. mechanism is a relatively new development, Supreme Court discussions of the procedure have implicitly found it constitutional when predicated on a motion for directed verdict. ${ }^{117}$

A threshold requirement for appellate review of a jury verdict is a motion for judgment n.o.v. in the trial court. ${ }^{118}$ Without such a motion, the appellate court is powerless to review the question of the sufficiency of the evidence, even if a directed verdict motion was made. ${ }^{119}$ And since a motion for judgment n.o.v. must be preceded by a motion for a directed verdict at the close of all the evidence, ${ }^{120}$ both motions are prerequisite to appellate review of jury findings. ${ }^{121}$ This requirement is justified as promoting due deference to the discretion of the trial judge $\mathrm{I}^{122}$ and the right of both parties to have the question passed upon in the first instance by the trial court ${ }^{123}$ and as deterring the use of appeals to evade the ten-day time limit on motions for judment n.o.v. imposed by Rule 50 (b) of the Federal Rules of Civil Procedure. ${ }^{124}$ While this may seem strangely technical in light of the purpose of the Rules to serve the "just, speedy and inexpensive determination of every action," 125 its effect is softened by the liberal view many courts have taken regarding what constitutes a sufficient directed verdict motion. ${ }^{126}$

In reviewing a directed verdict or a judgment n.o.v., the appellate court applies the same standard as used by the trial court. ${ }^{127}$ In addition, the standard is the

115. Comm. on Rules of Practice and Procedure of the Jud. Conf. of the United States, Proposed Amendments to the Federal Rules of Civil Procedure 5-7 (Preliminary Draft, August 1983).

116. Baltimore \& Carolina Line v. Redman, 295 U.S. 654, 647 (1935).

117. Cone v. West Virginia Pulp \& Paper Co., 330 U.S. 212, $217-18$ (1947). Cf. Baltimore \& Carolina Line v. Redman, 295 U.S. 654 (1935). For a further discussion of judgment n.o.v., see infra $\S 10$ of this Interlocutory Restatement, notes 20-23 and accompanying text.

118. Globe Liquor Co. v. San Roman, 332 U.S. 571, 573 (1947); Cone v. West Virginia Pulp \& Paper Co., 330 U.S. 212, 21 7-18 (1947); Borger v. Yamaha Int'l Corp., 625 F.2d 390, 395 (2d Cir. 1980) (Rule 50(b) motion not useless formality).

119. Globe Liquor Co. v. San Roman, 332 U.S. 571, 573 (1947).

120. FED. R. CIV. P. 50(b).

121. Powell v. Merrimack Mut. Fire Ins., 667 F.2d 26, 28 (11th Cir. 1981).

122. Cone v. West Virginia Pulp \& Paper Co., 330 U.S. 2 12, 215-16 (1947).

123. Globe Liquor Co. v. San Roman, 332 U.S. 571, 573-74 (1947).

124. Cone v. West Virginia Pulp \& Paper Co., 330 U.S. 212, 218 (1947).

125. FED. R. CIV. P. 1.

126. See, e.g., Miller v. Premier Corp., 608 F.2d 973, 979 n.3 (4th Cir. 1979); Quinn v. Southwest Wood Prods., 597 F.2d 1018, 1026 (5th Cir. 1979); Pittsburg-Des Moines Steel Co. v. Brookhaven Manor Water Co., 532 F.2d 572, 577 (7th Cir. 1976). But see Lowenstein v. Pepsi-Cola Bottling Co., 536 F.2d 9, 11.12 (3d Cir.), cert. denied, 429 U.S. 966 (1976).

127. United States v. 329.73 Acres of Land, 666 F.2d 281, 284 (5th Cir. 1982); Lane v. Chwoming, 610 F.2d 1385, 1388 (8th Cir. 1980); Samuels v. Health \& Hosps. Corp., 591 F.2d 195, 198 (2d Cir. 1979). 
same for both motions. ${ }^{128}$ A case may be taken from the jury only when the evidence is insufficient to create an issue of fact for the jury. ${ }^{129}$ The sufficiency of the evidence is a question of law to be decided by the court ${ }^{130}$ and, as such, is entitled to full review without special deference to the conclusions of the trial court. ${ }^{131}$ The reviewing court may not, however, pass on the credibility of the evidence, ${ }^{132}$ weigh the evidence, ${ }^{133}$ or substitute its judgment of the facts for that of the jury. ${ }^{134}$

It is said that the court must view the evidence in the light most favorable to the party against whom the motion is made. ${ }^{135}$ It is not settled, however, whether this means that the court is to consider all the evidence or only the evidence favorable to that party. The better rule seems to be the latter; ${ }^{136}$ the Supreme Court has held that a court "need look only to the evidence and reasonable inferences which tend to support the case of a litigant against whom a preemptory instruction has been given." 137 At least one circuit has added that the court may also take into account unfavorable evidence if it is unimpeached, uncontradicted, or from disinterested witnesses-that is, evidence that the jury is required to believe. ${ }^{138}$ Other courts continue to examine all of the evidence. ${ }^{139}$

The court must also give the benefit of all reasonable inferences from the evidence to the party against whom the motion is made. ${ }^{140}$ No certain test, however, is available to distinguish permissible legitimate inferences from impermissible unreasonable inferences. One frequently cited standard is that an inference is legitimate when the evidence offered makes the existence of the fact to be inferred more probable than the nonexistence of that fact. ${ }^{141}$ The Supreme Court has suggested that the line depends more on "a measure of speculation and conjecture" than on mathematical probability ${ }^{142}$ and instead holds that where there is evi-

128. O'Neil v. W.R. Grace \& Co., 410 F.2d 908, 911 (5th Cir. 1969); Dun \& Bradstreet, Inc. v. Miller, 398 F.2d 218, 223-24 (5th Cir. 1968).

129. See Fireman's Fund Ins. Co. v. Videfreeze Corp., 540 F.2d 1171, 1177 (3d Cir. 1976), cerl. denied, 429 U.S. 1053 (1977).

130. Miller v. Premier Corp., 608 F.2d 973, 981 n.8 (4th Cir. 1979); United States $e x$ rel. Weyerhauser Co. v. Bucon Constr. Co., 430 F.2d 420, 423 (5th Cir. 1970); Dunn \& Bradstreet, Inc. v. Miller, 398 F.2d 218, 224 (5th Cir. 1968).

131. Bridges v. Groendyke Transp., 553 F.2d 877, 878 (5th Cir. 1977).

132. Morelock v. NCR Corp., 586 F.2d 1096, $1104-05$ (6th Cir. 1978), cert. denied, 441 U.S. 906 (1979); Simblest v. Maynard, 427 F.2d 1, 4 (2d Cir. 1970); Powell v. Lititz Mut. Ins. Co., 419 F.2d 62, 64 (5th Cir. 1969).

133. Morelock v. NCR Corp., 586 F.2d 1096, $1104-05$ (6th Cir. 1978), cert. denied, 441 U.S. 906 (1979); Cockrum v. Whitney, 479 F.2d 84, 85 (9th Cir. 1973); Simblest v. Maynard, 427 F.2d 1, 4 (2d Cir. 1970).

134. Tennant v. Peoria \& P.U. Ry., 321 U.S. 29, 35 (1944); Morelock v. NCR Corp., 586 F.2d 1096, $1104-05$ (6th Cir. 1978), cert. denied, 441 U.S. 906 (1979).

135. Abshire v. Seacoast Prods., 668 F.2d 832, 837 (5th Cir. 1982); Fireman's Fund Ins. Co. v. Videfreeze, 540 F.2d 1171, 1178 (3d Cir. 1976), cert. denied, 429 U.S. 1053 (1977).

136. Nodak Oil Co. v. Mobil Oil Corp., 533 F.2d 401, 407-08 (8th Cir. 1976); C. WRIGHT, supra note 45 , at 642 .

137. Wilkerson v. McCarthy, 336 U.S. 53, 57 (1949).

138. Simblest v. Maynard, 427 F.2d 1, 4-5 (2d Cir. 1970).

139. Quinn v. Southwest Wood Prods., 597 F.2d 1018, 1019-24 (5th Cir. 1979); Spurlin v. General Motors Corp., 528 F.2d 612, 614-15 (5th Cir. 1976).

140. United States v. 329.73 Acres of Land, 666 F.2d 281, 284 (5th Cir. 1982); Morelock v. NCR

Corp., 586 F.2d 1096, $1104-05$ (6th Cir. 1978), cert. denied, 441 U.S. 906 (1979).

141. Wratchford v. S.J. Groves \& Sons Co., 405 F.2d 1061, 1066 (4th Cir. 1969).

142. Lavender v. Kurn, 327 U.S. 645, 653 (1946). 
dence from which an inference might reasonably be drawn, it is for the jury to accept or reject the inference, however probable or improbable. ${ }^{143}$ If conflicting inferences can legitimately be drawn from facts, which may even be undisputed, the case must go to the jury. ${ }^{144}$

The prevailing test for determining the sufficiency of the evidence declares that the motion for directed verdict or judgment n.o.v. must be denied by the trial court, or a grant of such a motion reversed by the appellate court, where there is substantial evidence to support a verdict for the party against whom the motion is granted. ${ }^{145}$ Substantial evidence is then defined as "evidence of such quality and weight that reasonable and fair-minded men in the exercise of impartial judgment might reach different conclusions." 146 An alternative formulation of the test looks to "whether the evidence is such that, without weighing the credibility of the witnesses or otherwise considering the weight of the evidence, there can be but one conclusion as to the verdict that reasonable men could have reached."147

i. Procedural Error: Abuse of Discretion. Judicial decisions are shaped by rules of procedure as well as by substantive laws. Thus, since our view of justice has created a multitiered system in which significant decisions are subject to some degree of review, the appellate function of assuring correctness, uniformity, and fidelity to controlling principles and the interest in preserving the integrity of the judicial system extend equally to the enforcement of adjective, as well as substantive, laws. Review of procedural decisions, however, is subject to a broader range of constraints, including the principles of judicial discretion, harmless error, and waiver.

While it would be false to suggest that the element of discretion inheres only in procedural rules and not in substantive law, many procedural decisions fall within the realm of the trial court's "discretion." Appellate interpretations frequently measure the meaning of this concept in light of underlying policies, and some commentators question whether the policy of "doing justice" should be considered a function of appellate courts sufficient to justify the apparent trend toward broadening the scope of appellate review. ${ }^{148}$ Unlike judicial review of statutory law, appellate review of trial court procedural decisions is not limited by considerations of federalism or separation of powers; appellate restraint must be self-imposed. As Justice Jackson cautioned, "We are not final because we are infallible, but we are infallible only because we are final." 149 The limitation on review imposed by deference to judicial discretion clearly reflects the policy of finality of judgments ${ }^{150}$ as

143. Id. at 652-53; Dick v. New York Life Ins. Co., 359 U.S. 437, 445 n.8 (1959).

144. Continental Ore Co. v. Union Carbide \& Carbon Corp., 370 U.S. 690, 700-01 (1962); Onufer v. Seven Springs Farm, 636 F.2d 46, 50 (3d Cir. 1980); Equitable Life Assurance Soc'y v. Fry, 386 F.2d 239, 248 (5th Cir. 1967); Ford Motor Co. v. McDavid, 259 F.2d 261, 266 (4th Cir.), cert. denied, 388 U.S. 908 (1958).

145. Tackett v. Kidder, 616 F.2d 1050, 1053 (8th Cir. 1980).

146. Boeing Co. v. Shipman, 411 F.2d 365, 374 (5th Cir. 1969).

147. Simblest v. Maynard, 427 F.2d 1, 4 (2d Cir. 1970).

148. Wright, supra note 76 , at 779 .

149. Brown v. Allen, 344 U.S. 443, 540 (1953) (Jackson, J., concurring).

150. Seven Elves, Inc. v. Eskenazi, 635 F.2d 396, 401 (5th Cir. 1981). 
well as that of judicial economy. ${ }^{151}$

Another important interest served by deference to "discretion" is preservation of the integrity of and respect for district court decisions. In reviewing an appellate reversal of a district court's discovery sanction under Rule 37 of the Federal Rules of Civil Procedure, the Supreme Court noted the "natural tendency" of reviewing courts "employing the benefit of hindsight" to be easily influenced by a particular sanction's severity. ${ }^{152}$ To leave such a tendency unchecked would be to ignore the deterrent function of Rule 37 and the need to reinforce district court decisions by refusing to encourage parties to flout discovery orders and seek appellate secondguessing. ${ }^{153}$

Furthermore, trial court procedural decisions are often fact-specific, with varying circumstances making it impracticable to frame a binding rule of law. ${ }^{154}$ Discretion permits individualized treatment based upon the circumstances and procedural decision at stake.

The final justification for deference to trial court discretion is that the district judge "felt the 'climate' of the trial," 155 and thus is better able to gauge the complexity and procedural needs of the case. ${ }^{156}$ In the Supreme Court's words, the district judge exercises his discretion "with a fresh personal knowledge of the issues involved, the kind of evidence given, and the impression made by witnesses."157 A discretionary determination calls for just such "judgment in the first instance of the judge who saw and heard the witnesses and has the feel of the case which no appellate printed transcript can impart . . a perspective peculiarly available to him alone." 158

Some circuits have suggested that appellate deference to the discretion of the trial judge can be relaxed if the issue at hand is susceptible of rule - for example, a voluntary pretrial dismissal under Rule 41(a)(2), ${ }^{159}$ - or when the "contours" of the rule or controlling policies have developed through a series of decisions. ${ }^{160}$ It is also suggested that appellate review is broader when the decision at hand is not dependent upon the "superior vantage point" of the trial judge. ${ }^{161}$

About ten of the Federal Rules of Civil Procedure use the term "discretion," and that element has been judicially implied in another thirty Rules to the point of restraining appellate review. ${ }^{162}$ Discretion-signalling phrases include "the court may," and qualifying concepts such as "for good cause," "in the interests of jus-

80 .

151. United Mine Workers v. Gibb, 383 U.S. 715, 726 (1966). See also Wright, supra note 76, at 779 -

152. National Hockey League v. Metropolitan Hockey Club, Inc., 427 U.S. 639, 642 (1976)

153. Id. at 643. See also Wright, supra note 76 , at 779-80.

154. See United States v. Criden, 648 F.2d 814, 818 (3d Cir. 1981); Noonan v. Cunard S.S. Co., 375

F.2d 69, 71 (2d Cir. 1967); Atchison, T. \& S.F. Ry. v. Barrett, 246 F.2d 846, 849 (9th Cir. 1957).

155. Atchison, T. \& S.F. Ry. v. Barrett, 246 F.2d 846, 849 (9th Cir. 1957).

156. See Wright, supra note 76, at 781-82.

157. Cone v. West Virginia Pulp \& Paper Co., 330 U.S. 212, 216 (1947).

158. Id.

159. Noonan v. Cunard S.S. Co., 375 F.2d 69, 71 (2d Cir. 1967).

160. United States v. Criden, 648 F.2d 814, 818 (3d Cir. 1981).

161. Id. Contra Belo Broadcasting Corp. v. Clark, 654 F.2d 423, 431 n. 18 (5th Cir. 1981).

162. Rosenberg, Judicial Discretion of the Trial Court, Viewed From Above, 22 SYRACuSE L. REv. 635,655 
tice," and the avoidance of delay and prejudice. Discretion is not limited to administrative matters such as pretrial conferences or extensions of time but is often involved in substantive decisions such as discovery rulings, the use of special verdicts, and the declaration of mistrials.

Discretion as to procedural rulings rests only with the district court. Although the appellate court must review the entire record, ${ }^{163}$ it is not free to reach an independent conclusion, ${ }^{164}$ regarding matters committed to trial court discretion, and it may reverse only for abuse of discretion. ${ }^{165}$ Even if the reviewing court feels that the decision is wrong or it would have made a different decision, it may not reverse unless a ruling is "so unreasonable or arbitrary as to amount to a prejudicial abuse of the discretion necessary to repose in trial judges during the conduct of a trial.",166

Abuse of discretion is thus a nebulous concept which remains essentially undefined. Decisions reversed on this ground have been characterized as "so unreasonable or arbitrary,"167 "so unwarranted,"168 "unreasonable,"169 and as a "misuse" of discretion. ${ }^{170}$ Furthermore, the refusal to exercise discretion is clearly an abuse of discretion; ${ }^{171}$ the district court cannot abdicate discretion by claiming that it has none. ${ }^{172}$

Discretionary decisions fall into three categories, with corresponding limitations on appellate review. The first class consists of decisions involving absolute discretion. For example, Rule 49(a) of the Federal Rules of Givil Procedure has been construed to give the trial court "full, uncontrolled discretion" to request special verdicts. ${ }^{173}$ As a result, the appellate court "cannot hold that a district judge errs when . . ., for any reason or no reason whatever, he refuses to demand a special verdict." 174

The second class of situations involves limited discretion. Such discretion may be exercised only according to standards which are written into the Rules themselves, ${ }^{175}$ which have developed from judicial interpretation of the Rules, ${ }^{176}$ or which have been imposed by the courts. ${ }^{177}$ For example, Rule 37(b)(2) provides that a district court has discretion to impose sanctions if two requirements are met-the sanction must be "just" and it must be specifically related to the partic-

163. National Hockey League v. Metropolitan Hockey Club, Inc., 427 U.S. 639, 643 (1976),

164. Id. at 642 .

165. Id.

166. Napolitano v. Compania Sud Americana de Vapores, 421 F.2d 382, 384 (2d Cir. 1970). Cf. supra notes 104-05 and accompanying text (review of trial court's evaluation of weight of evidence).

167. Napolitano v. Compania Sud Americana de Vapores, 421 F.2d 382, 384 (2d Cir. 1970).

168. Seven Elves, Inc. v. Eskenazi, 635 F.2d 396, 402 (5th Cir. 1981).

169. Piper Aircraft Co. v. Reyno, 454 U.S. 235, 257-59 (1981).

170. Pearson v. Dennison, 353 F.2d 24, 28 n.6 (9th Cir. 1965)

171. See Will v. Calvert Fire Ins. Co., 437 U.S. 656, 661-62 (1978); Pollard v. Metropolitan Life Ins. Co., 598 F.2d 1284, 1293 (3d Cir.) (Adams, J., dissenting), cert. denied, 444 U.S. 917 (1979).

172. Adney v. Mississippi Lime Co., 241 F.2d 43, 45 (7th Cir. 1957).

173. Skidmore v. Baltimore \& O. Ry., 167 F.2d 54, 66 (2d Cir.), cert. denied, 335 U.S. 816 (1948).

174. Id. at $66-67$.

175. Insurance Corp. of Ireland v. Compagnie des Bauxites de Guinee, 456 U.S. 694, 705 (1982)

176. National Hockey League v. Metropolitan Hockey Club, Inc., 427 U.S. 639, $642-43$ (1976).

177. Moses H. Cone Memorial Hosp. v. Mercury Constr. Corp., 103 S. Ct. 927, 938 (1983). 
ular claim which was at issue in the order to provide discovery. ${ }^{178}$ Similarly, Rule 24(b) of the Federal Rules of Civil Procedure provides that the district court may permit intervention when there is a common question of law or fact and when the intervention will not "unduly delay or prejudice the adjudication of the rights of the original parties." 179

A discretion-narrowing judicial "gloss" placed upon a Rule through the settled course of decision can be no more disregarded than may the text of the Rule. ${ }^{180}$ Illustrative is the requirement that a sanction not be imposed unless a party's failure to comply with discovery was willful or in bad faith. ${ }^{181}$ Also, a party's "inadvertence" in failing to make a timely jury demand is not a proper ground for the district court to exercise its discretion; ${ }^{182}$ and it has been held that Rule 54 (b) of the Federal Rules of Civil Procedure was intended to authorize designation of a partial final judgment only in the "infrequent harsh case."183

Finally, in other cases, discretion-limiting standards are prescribed and developed by the courts. In reviewing a district court's decision to stay an action pending completion of a state court proceeding, the Supreme Court held: "To say that the district court has discretion is not to say that its decision is unreviewable; such discretion must be exercised under the relevant standard prescribed by this Court."184 This suggests that there are some circumstances in which the district court's discretion will not be insulated from review. It has been held, for example, that a "slight" abuse of discretion is sufficient to warrant reversal of the denial of a motion for relief from judgment under Rule 60(b) of the Federal Rules of Civil Procedure where judgment was by default and the denial thus would preclude any examination of the merits of the action. ${ }^{185}$

Where the district court's discretion is not absolute, appellate courts require an articulation of the reasons and findings underlying the exercise of such power. ${ }^{186}$ This practice discourages ad hoc reversals and confines appellate review to its proper scope - that is, to a determination whether the relevant factors were considered and given appropriate weight. ${ }^{187}$

j. Denial of Substantial Procedural Rights. Under 28 U.S.C. $\$ 2111$, an appellate court may not reverse on the ground of "errors or defects which do not affect the substantial rights of the parties." 188 The "harmless error" rule ${ }^{189}$ also reflects this

178. Insurance Corp. of Ireland v. Compagnie des Bauxites de Guinee, 456 U.S. 694, 707 (1982).

179. FED. R. Civ. P. 24(b).

180. Noonan v. Cunard S.S. Co., 375 F.2d 69, 70 (2d Cir. 1967).

181. National Hockey League v. Metropolitan Hockey Club, Inc., 427 U.S. 639, 640 (1976)

182. Noonan v. Cunard S.S. Co., 375 F.2d 69, 70 (2d Cir. 1967).

183. Allis-Chalmers Corp. v. Philadelphia Elec. Co., 521 F.2d 360, 365 (3d Cir. 1975). See also supra $\S 4$ of this Interlocutory Restatement, notes $42-45$ and accompanying text.

184. Moses H. Cone Memorial Hosp. v. Mercury Constr. Corp., 103 S. Ct. 927, 938 (1983). See also Piper Aircraft Co. v. Reyno, 454 U.S. 235, 257-61 (1981).

185. Bridoux v. Eastern Air Lines, 214 F.2d 207, 210 (D.C. Cir.) (citing various cases), cert. denied, 348 U.S. 821 (1954).

186. Quality Prefabrication v. Daniel J. Keating Co., 675 F.2d 77, 81 (3d Cir. 1982); Allis-Chalmers

Corp. v. Philadelphia Elec. Co., 521 F.2d 360, 364 (3d Cir. 1975).

187. Insurance Corp. of Ireland v. Compagnie des Bauxites de Guinee, 456 U.S. 694, 707 (1982);

United States v. Criden, 648 F.2d 814, 819 (3d Cir. 1981).

188. 28 U.S.C. $\$ 2111(1976)$. 
mandate, stating that "no error or defect in any ruling or order or in anything done or omitted by the court or by any of the parties is grounds for . . . disturbing judgment . . . unless refusal to take such action appears to the court inconsistent with substantial justice." 190 One court has commented that "[n]o litigant in a civil case . . . is entitled to a trial free of all error. A litigant is merely entitled to a fair trial without an error which would do violence to substantial justice."191 When read in conjunction with the direction that the Federal Rules be "construed to secure the just, speedy, and inexpensive determination of every action,"192 this requirement of harm to substantial rights clearly reflects the overriding policy of preserving the integrity of final judgments since no reversible error can arise absent substantial prejudice to an appellant. ${ }^{193}$

There is no presumption in favor of the existence of error. ${ }^{194}$ As the Supreme Court has stated, "Mere 'technical errors' which do not 'affect the substantial rights of the parties' are not sufficient to set aside a jury verdict in an appellate court [citation omitted]. He who seeks to have a judgment set aside because of an erroneous ruling carries the burden of showing that prejudice resulted." 195

Reversible error may arise when a substantial procedural right is denied through a trial court's failure to adhere to a nondiscretionary procedural rule, for example, by attempting to compel a stipulation of facts ${ }^{196}$ or by attempting to compel a party to engage in discovery in the first instance. ${ }^{197}$ Intervention of right also is not a matter of trial court discretion. ${ }^{198}$ Furthermore, while application of the work product rule is in part a matter of discretion, the court must protect against disclosure of the "mental impression, conclusion, opinions, or legal theories of an attorney. ${ }^{199}$ The court is not free to impose sanctions beyond those authorized by Rule 37 for refusal to comply with discovery orders, ${ }^{200}$ nor can it treat refusal to comply with its order to submit to a physical or mental examination as contempt. ${ }^{201}$ It is error to deny a timely demand for a jury trial of legal issues, however "incidental" they may seem, ${ }^{202}$ or to strike a proper and timely notice of voluntary dismissal. ${ }^{203}$ Counsel must be permitted to see special verdict interroga-

189. See infra comment $k$.

190. Newman v. A.E. Staley Mfg. Co., 648 F.2d 330, 335 (5th Cir. 1981).

191. Vess v. Gardner, 301 F. Supp. 505, 508 (S.D. Miss. 1968), affd, 413 F.2d 424 (5th Cir. 1969).

192. FED. R. Civ. P. 1.

193. Dixon v. Southern Pacific Transp. Co., 579 F.2d 511, 514 (9th Cir. 1978); Commercial Credit Corp. v. United States, 175 F.2d 905, 908 (8th Cir. 1949).

194. Higgins v. Carr Bros. Co., 317 U.S. 572, 574 (1943).

195. Palmer v. Hoffman, 318 U.S. 109, 116 (1943).

196. J.F. Edwards Constr. Co. v. Anderson Safeway Guard Rail Corp., 542 F.2d 1318, 1324-25 (7th Cir. 1976).

197. Identiseal Corp. v. Positive Identification Sys., 560 F.2d 298, 301 (7th Cir. 1977).

198. See Cascade Natural Gas Corp. v. El Paso Natural Gas Co., 386 U.S. 129, $132-36$ (1967).

199. Duplan Corp. v. Moulinage et Retorderie de Chavanoz, 509 F.2d 730, 734 (4th Cir. 1974), cert. denied, 420 U.S. 997 (1975). See generally Upjohn Co. v. United States, 449 U.S. 383 (1981).

200. Societe Internationale Pour Participations Industrielles et Commerciales v. Rogers, 357 U.S. 197, 206 (1958).

201. Sibbach v. Wilson \& Co., 312 U.S. 1, 16 (1941).

202. Dairy Queen v. Wood, 369 U.S. 469, 470 (1962).

203. See Plains Growers v. Ickes-Braun Glasshouses, 474 F.2d 250, 254-55 (5th Cir. 1973). 
tories prior to closing argument ${ }^{204}$ and to object to instructions outside the hearing of the jury and receive rulings thereon before the case is submitted. ${ }^{205}$ In addition, the requirement that a court make findings of fact and separately state conclusions is nondiscretionary; failure to comply is reversible error. ${ }^{206}$

k. Harmless Error. Rule 61 of the Federal Rules of Civil Procedure furnishes a standard of "harmless error" for district court orders vacating or modifying judgments; such measures are not warranted as to any error unless "refusal to take such action appears to the court inconsistent with substantial justice."207 This practice exemplifies the pervasive liberal spirit of the Rules in general in repeatedly conditioning a party's remedy upon whether or not an error was prejudicial. ${ }^{208}$ Similarly, virtually every circuit has adopted the harmless error standard for appellate reversal of judgments. ${ }^{209}$ As the Second Circuit noted, '[t]he doctrine . . . has led to a marked reduction of reversals based upon procedural errors which do no real harm."210

In determining whether an error is harmless the reviewing court is to consider the entire record 211 and the probable effect of the error in light of all of the evidence. $^{212}$ The majority view is that the appellant bears the burden of showing that the error is prejudicial. ${ }^{213}$ One commentator, furthermore, has suggested that the appellate court should not reverse if it believes it is "highly probable" that the error did not affect the judgment of the lower court. ${ }^{214}$ The Supreme Court, however, has held that "egregious" error on the part of the trial court, although not prejudicial to the appellant, is still grounds for reversal. ${ }^{215}$

Error as to subject matter jurisdiction, even absent prejudice, is never "harmless error." The parties may neither waive subject matter jurisdiction nor confer it through their consent. ${ }^{216}$ The appellate court has a continuing duty to review whether the court below lacked subject matter jurisdiction; ${ }^{217}$ and even if no timely objection is made by either party, it must examine the question of jurisdictional error sua sponte and reverse if jurisdiction is lacking. ${ }^{218}$

1. Waiver. Rule 46 of the Federal Rules of Civil Procedure, while providing

204. Smith v. Danyo, 585 F.2d 83, 87-88 (3d Cir. 1978) (despite the lack of express language to this effect in Rule 49(a))

205. Hopkins v. Chip-in-Saw, Inc., 630 F.2d 616, 622 (8th Cir. 1980) (Rule 51).

206. H. Prang Trucking Co. v. Local Union No. 469, 613 F.2d 1235, 1238 (3d Cir. 1980).

207. FED. R. CIV. P. 61.

208. E.g., FED. R. CIV. P. 4(h) (amendment of process); FeD. R. Civ. P. 8(f) (construction of pleadings); FED. R. CIV. P. 13(f) (inclusion of omitted counterclaim by amendment); FED. R. CIV. P. 15 (amended and supplemental pleadings); FED. R. CIV. P. 21 (improper joinder of parties); FED. R. CIV. P. 32 (errors in depositions); FED. R. CIV. P. 59 (new trials); FED. R. CIV. P. 60(a) (correction of clerical errors); FED. R. CIV. P. 60(b) (relief from judgment).

209. See, e.g., Halderman v. Pennhurst State Sch. \& Hosp., 612 F.2d 131, 134 (3d Cir. 1979).

210. In re Barnett, 124 F.2d 1005, 1011 (2d Cir. 1942).

211. Joyce v. Atlantic Richfield Co., 651 F.2d 676, 682 (10th Cir. 1981).

212. See Kotteakos v. United States, 328 U.S. 750, 762 (1946)

213. Palmer v. Hoffman, 318 U.S. 109, 116 (1943).

214. R. Traynor, The Riddle of Harmless Error 35 (1970).

215. Thiel v. Southern Pac. Co., 328 U.S. 217, 225 (1946) (trial court discriminated in selecting jury).

216. United States v. Griffin, 303 U.S. 226, 229 (1938). See also FED. R. Civ. P. 12(h)(3).

217. Warren G. Kleban Eng'g Corp. v. Caldwell, 490 F.2d 800, 802 n.1 (5th Cir. 1974).

218. Louisville \& N. R.R. v. Mottley, 211 U.S. 149, 152 (1908). See also infra $\$ 16$ of this Interlocutory Restatement, notes 74-76 and accompanying text. 
that formal exceptions are unnecessary to preserve errors for review, still impose the threshold requirement that a party make his objection known to the trial court and state the grounds therefor and the action he desires the court to take. ${ }^{219}$ Failure to raise and preserve points of objection below constitutes waiver of the objection on appeal. ${ }^{220}$ However, if a party has no opportunity to object at the time of the trial court's ruling or order, he will not be so prejudiced upon seeking to appeal. ${ }^{221}$ Furthermore, an appellate court will take judicial notice of an objection which, although unassigned as error in the lower court, constitutes a plain error or fundamental error. ${ }^{222}$

A party's failure to take an available interlocutory appeal does not constitute a waiver of the right to seek reversal of the final decision on those grounds that might have been raised earlier. ${ }^{223}$ Where interlocutory orders are appealable, appeal is permissive; the parties are not bound to seek immediate review. ${ }^{224}$ As long as the district court's decision is interlocutory in nature, all questions are still open and the order has no res judicata effect. ${ }^{225}$ Furthermore, because the "law of the case" doctrine requires a final decision, the failure to appeal an interlocutory order does not render the ruling embodied therein the law of the case for the appellate court. ${ }^{226}$

Illustration 9-1. P, a common carrier, seeks to enjoin enforcement of an order of a federal regulatory agency. The district court rules that there is no evidence to sustain the finding on which the order is based, grants a temporary injunction, and remands to the agency. The agency restates the grounds for its actions and issues a cease and desist order against $P$. P again petitions the district court and this time wins a permanent injunction against enforcement of the agency orders. The agency appeals from the permanent injunction. Possible error in the grant of the preliminary injunction should also be considered as a ground for reversal; although that order was subject to interlocutory appeal ${ }^{227}$ the agency was not required to seek immediate review and did not waive any error which

219. FED. R. Grv. P. 46.

220. See Hormel v. Helvering, 312 U.S. 552, 556 (1941); Stewart v. Banks, 397 F.2d 798, 799 n.1 (5th Cir.), cert. denied, 393 U.S. 801 (1968); Cleary v. Indiana Beach, Inc., 275 F.2d 543, 546 (7th Cir.), cert. denied, 364 U.S. 825 (1960).

221. FeD. R. Giv. P. 46

222. Sibbach v. Wilson \& Co., 312 U.S. 1, 16 (1941); Citron v. Aro Corp., 377 F.2d 750, 753 (3d Cir.) (although appellant failed to object to eleven-day recess called by judge for personal reasons, unnecessary intermittent delays by judge in conduct of trial affected substantial rights of appellant, constituting reviewable error), cert. denied, 389 U.S. 973 (1967).

223. Victor Talking Mach. Co. v. George, 105 F.2d 697, 699 (3d Cir. 1939). Cf. infra $\S 16$ of this Interlocutory Restatement, notes 77-79 and accompanying text.

224. United States v. United States Smelting Ref. \& Mining Co., 339 U.S. 186, 199 (1950). See supra $\S 18$ of this Interlocutory Restatement, comment d; supra $\$ 20$ of this Interlocutory Restatement, comment c ; supra $\S 22$ of this Interlocutory Restatement, note 9 and accompanying text. Interlocutory orders, of course, are generally not appealable. See 28 U.S.C. $§ 1291$ (1976); see generally infra $\$ \S 14-43$ of this Interlocutory Restatement.

225. United States v. United States Smelting Ref, \& Mining Co., 339 U.S. 186, 199 (1950).

226. Id.

227. For a discussion of the appealability of preliminary injunctions, see infra $\S 20$ of this Interlocutory Restatement. 
might have been grounds for reversal by the failure to do so. ${ }^{228}$ lllustration 9-2. $\mathrm{P}$, a former employee brings suit against $\mathrm{D}$, a pension fund trustee, to recover benefits. Arbitration, as provided in the trust agreement, has already commenced; and D alternatively seeks dismissal or a stay of the court proceeding pending this arbitration. The trial court grants a stay, threatening to dismiss $P$ 's suit if he does not pursue arbitration within 120 days. After $\mathbf{P}$ loses the arbitration the trial court dismisses his action, invoking res judicata. $\mathbf{P}$ appeals. Error in the stay order should be a ground for reversal; neither the failure to take an interlocutory appeal ${ }^{229}$ nor submission to arbitration (if the objection is properly preserved) ${ }^{230}$ constitutes a waiver of review of such errors.

Once an order is properly embodied in a final decision or a partial final decision under Rule 54(b) of the Federal Rules of Civil Procedure, ${ }^{231}$ it is conclusive upon the parties unless set aside by a timely appeal. ${ }^{232}$ Failure to so act will result in loss of the right to appeal; the parties will be deemed to have waived the error for which review might have been sought. ${ }^{233}$

§10. Rescript. IN

(A) IF A FINAL DEGISION IS REVERSED ON ACCOUNT OF ERROR

(1) THE CONCLUSIONS OF LAW STATED BY THE COURT TO EXPLAIN A NONJURY DEGISION, OR

(2) THE GRANT OR DENIAL OF A MOTION FOR JUDGMENT NOTWITHSTANDING THE VERDICT,

THE REVIEWING COURT WILL ENTER JUDGMENT ACCORDING TO LAW UNLESS IT DETERMINES THAT THERE IS CAUSE FOR A NEW TRIAL OR POSSIBLE CAUSE FOR A NEW TRIAL WHICH SHOULD BE CONSIDERED BY THE COURT BELOW. IN ALL OTHER CIRCUMSTANCES, REVERSAL SHALL RESULT IN REMAND FOR NEW TRIAL OR OTHER APPROPRIATE PROCEEDING IN ACCORDANCE WITH DIRECTIONS WHICH THE REVIEWING COURT SHALL SUPPLY IN ITS OPINION TO ENABLE THE COURT BELOW TO PROCEED WITH DISPATCH TO FINAL DECISION WITHOUT ERROR.

(B) A REVIEWING COURT MAY UPON CROSS-APPEAL MODIFY THE FINAL DECISION TO GRANT FURTHER RELIEF TO THE PARTY PREVAILING BELOW.

228. United States v. United States Smelting Ref. \& Mining Co., 339 U.S. 186 (1950)

229. For a discussion of the appealability of orders staying judicial proceedings pending arbitration, see infra $\$ 18$ of this Interlocutory Restatement, comment $c$.

230. For further discussion of this point, see $i d$, comment $d$.

231. For a discussion of the operation of this rule, see supra $\$ 4$ of this Interlocutory Restatement

232. For a discussion of the time for appeal of final decisions, see supra $\$ \S 6-8$ of this Interlocutory Restatement.

233. United States v. Nysco Laboratories, 318 F.2d 817, 817-18 (2d Cir. 1963); see supra $\$ 4$ of this Interlocutory Restatement, notes 63-64 and accompanying text. 


\section{COMMENT}

a. Determination. The powers of appellate courts to dispose of cases properly are delineated in 28 U.S.C. $\$ 2106$, which provides that:

The Supreme Court or any other court of appellate jurisdiction may affirm, modify, vacate, set aside or reverse any judgment, decree, or order of a court lawfully brought before it for review, and may remand the cause and direct the entry of such appropriate judgment, decree, or order, or require such further proceedings to be had as may be just under the circumstances. ${ }^{1}$

This statute reflects the limitations on appellate courts at common law. In reviewing a writ of error, such a court could consider only the record of the trial below, and its authority was limited to affirming, reversing, vacating, or modifying the lower court's decision. ${ }^{2}$ In contrast, an appeal in equity vacated the lower court's decision and brought up the entire case for de novo review. ${ }^{3}$ The statute, however, cannot be read technically without defeating its purpose. While presentday review is more like that associated with the writ of error, permissible appellate determination encompasses a broad range of dispositions, as justice may require. The Supreme Court has held that the appellate court may dispose of the cause, not just the appeal; ${ }^{4}$ thus, the appellate court has plenary power "to do what plainly ought to be done," ${ }^{5}$ including rendering final judgment. ${ }^{6}$

Entry of judgment by the appellate court, however, while reflecting concern for judicial economy, imposes on such court, through the resulting retention of jurisdiction, the increased burden of ensuring that the judgment is carried out. ${ }^{7}$ The more common practice is for the reviewing court to remand to the trial court with directions to render a specific judgment. ${ }^{8}$

b. Nonjury Decision. A court of appeals may by the terms of 28 U.S.C. $\S 2106$ modify a judgment in a proper case. ${ }^{9}$ For example, if the case has been tried to a court without a jury, the reviewing court may direct or render final judgment where the facts are undisputed ${ }^{10}$ and where the only issue is a dispositive question

1. 28 U.S.C. $\$ 2106(1976)$.

2. i B J. Moore, J. Lucas \& T. Currier, Moore's Federal. Practice 0.416[3], at 522-23 (2d ed. 1983).

3. Id. at 524

4. Kendall v. Ewert, 259 U.S. 139, 143 (1922).

5. 9 J. Moore, B. Ward, \& J. Lucas, Moore's Federal Practice | 110.25[1], at 273 (2d ed. 1983).

6. Pullman Palace Car Co. v. Metropolitan St. Ry., 157 U.S. 94 (1895); United States v. Tatcher, 131 F.2d 1002, 1003 (3d Cir. 1942); United States v. Bornn, 104 F.2d 641, 647 (2d Cir.), cert. denied, 308 U.S. 606 (1939). For a discussion of the propriety of extending relief to nonappealing parties or expanding the relief awarded to the party prevailing below, see infra comment $e$.

7. See NLRB v. Deena Artware, 251 F.2d 183, 186 (6th Cir. 1958) (not customary for appellate court to retain jurisdiction to assure that judgment is carried out).

8. See, e.g., Hurwitz v. Directors Guild of Am., Inc., 364 F.2d 67, 70 (2d Cir.), cert. denied, 385 U.S. 971 (1966).

9. Provident Tradesmens Bank \& Trust Co. v. Patterson, 390 U.S. 102, 112 (1968); Goland v. CIA 607 F.2d 339, $371-72$ (D.C. Cir. 1978), cert. denied, 445 U.S. 927 (1980). The statutory language is quoted supra text accompanying note 1 .

10. First Nat'l Bank v. Maryland Casualty Co., 290 F.2d 246, 251 (2d Cir.), cert. denied, 368 U.S. 939 (1961). 
of law. ${ }^{11}$ If reversing a decision for jurisdictional error, the court of appeals may render judgment of dismissal, ${ }^{12}$ although a better practice may be to remand and allow the trial court to dismiss if the parties cannot amend their pleadings to show jurisdiction. ${ }^{13}$ Also, a reviewing court may render judgment where a cause of action is insufficient, where a defense is sufficient, ${ }^{14}$ or where a cause of action is sufficient and the defense insufficient. ${ }^{15}$

On reversal of a summary judgment, the appellate court may order summary judgment for the appellant where there is clearly no factual dispute and the appellant is entitled to summary judgment as a matter of law. ${ }^{16}$ Although the Supreme Court reversed such a grant of summary judgment in Fountain v. Filson, it emphasized the lack of full development of the facts and found that the summary judgment order would deprive the appellee of a trial of a genuine issue of fact. ${ }^{17}$ In Kern County Land Co. v. Occidental Petroleum Corp., the Supreme Court affirmed the appellate court's grant of summary judgment to the appellant even though that party had not made a motion for summary judgment in the trial court. ${ }^{18}$

Illustration 10-1 $\mathrm{P}$ brings suit against $\mathrm{D}$, claiming a resulting trust in realty held by $\mathrm{D}$. The trial court grants summary judgment for $\mathrm{D}$ on the basis that state law does not permit imposition of a resulting trust under the circumstances disclosed in the complaint. P appeals, and the court of appeals reverses because the complaint reveals facts upon which $\mathrm{P}$ could recover under a theory of personal obligation. The appellate court should not, however, render summary judgment for $\mathrm{P}$ because there remains a dispute as to material fact; $\mathrm{D}$ is entitled to the opportunity to dispute the facts showing a personal obligation. The appellate court should remand for further proceedings. ${ }^{19}$

c. Judgment Notwithstanding the Verdict. Where a proper and timely judgment n.o.v. is erroneously granted or denied by the trial court, the appellate court may enter judgment for the appellant. ${ }^{20}$ There is no seventh amendment bar to a judgment n.o.v. by an appellate court; such judgment is no greater restriction on the province of the jury than when made by the trial judge. ${ }^{21}$ Where, however,

11. See Black Warrior Elec. Membership Corp. v. Mississippi Power Co., 413 F.2d 1221, 1226 (5th Cir. 1969).

12. Latham v. Baltimore \& O. R.R., 274 F.2d 507, 511 (2d Cir. 1960).

13. Levering \& Garrigues Co. v. Morrin, 61 F.2d 115, 121 (2d Cir. 1932), affd, 289 U.S. 103 (1933)

14. Hurwitz v. Directors Guild of Am., Inc., 364 F.2d 67, 70 (2d Cir.), cert. denied, 385 U.S. 971 (1966) (appellate court reversed an order denying a preliminary injunction and instructed the district court to grant a permanent injunction absent the development of triable issues).

15. Kirkland v. Wallace, 403 F.2d 413, 415-16 (5th Cir. 1968).

16. Morgan Guar. Trust Co. v. Martin, 466 F.2d 593, 600 (7th Cir. 1972). See Fountain v Filson, 336 U.S. $681,682-83(1949)$.

17. 336 U.S. $681,682-83$ (1949). Professor Moore argues that this case "does not deny the existence of appellate power to dispose of a case in accordance with the law and the facts; and under certain circumstances this will include a reversal with directions to enter judgment for the appellant." $6 \mathrm{~J}$. MOORE \& J. Wicker, MOORE's Federal Practice | 56.27[2], at 56-1562 (2d ed. 1982).

18. 411 U.S. 582, 591 (1973), affg Abrams v. Occidental Petroleum Corp., 450 F.2d 157 (2d Cir. 1971). Accord Ithaca College v. NLRB, 623 F.2d 224, 229 (4th Cir.), cert. denied, 449 U.S. 975 (1980).

19. Fountain v. Filson, 336 U.S. 681 (1949).

20. Neely v. Martin K. Eby Constr. Co., 386 U.S. 317, 322 (1967).

21. Id. 
directed verdict and judgment n.o.v. motions were not properly made as required by Rule 50(b) of the Federal Rules of Civil Procedure, the appellate court upon reversal can grant only a new trial. ${ }^{22}$ Section 2106 of 28 U.S.C. does not authorize a reviewing court to render judgment where the basic procedural requirement of a judgment n.o.v. has not been met. ${ }^{23}$

The reviewing court's power is also limited in certain cases where a party moves for judgment n.o.v. and alternatively for a new trial. If judgment n.o.v. is granted, Rule 50 (b) requires that the trial court conditionally rule on the new trial motion. Thus, when the trial court grants judgment n.o.v. but does not rule on the new trial motion and the judgment n.o.v. is reversed, the appellate court should remand for a ruling on the new trial motion. ${ }^{24}$ Failure of the verdict winner to move for a new trial after a judgment n.o.v., however, does not preclude the appellate court upon reversal from remanding for a new trial instead of entering judgment on the verdict. ${ }^{25}$

If the new trial motion is conditionally granted and the judgment n.o.v. is reversed on appeal, Rule 50(c)(1) states that "the new trial shall proceed unless the appellate court has otherwise ordered."26 The appellate court thus may reverse the conditional grant of the new trial and direct that judgment be entered on the verdict ${ }^{27}$ in appropriate circumstances as, for example, when the only question is whether the case was a proper one for the jury. ${ }^{28}$ If the appellate court finds, as a matter of law, that a plaintiff's case was insufficient to go to the jury, it may order dismissal on remand. ${ }^{29}$

If the motion for a new trial has been conditionally denied and the judgment n.o.v. is reversed, the appellee may not only seek to uphold the judgment n.o.v. but may also assert error in the conditional denial of the new trial motion without taking a cross-appeal. ${ }^{30}$ Rule 50 (c)(1) provides that "subsequent proceedings shall be in accordance with the order of the appellate court;" thus the appellate court may either reinstate the verdict or order a new trial. ${ }^{31}$

If both judgment n.o.v. and a new trial are denied by the trial court, Rule 50 (d) provides that the appellee may similarly assert grounds for a new trial in addition to seeking to uphold the verdict. Upon reversal, the appellate court may

22. Id. at 325; Cone v. West Virginia Pulp \& Paper Co., 330 U.S. 212, 217-18 (1947).

23. Neely v. Martin K. Eby Constr. Co., 386 U.S. 317, 325 (1967).

24. Montgomery Ward \& Co. v. Duncan, 311 U.S. 243, 255 (1940).

25. Neely v. Martin K. Eby Constr. Co., 386 U.S. 317, 328 n.6 (1967) (citing advisory committee's notes to Rule 50(c)(2), 31 F.R.D. 645, 646 (1962))

26. 6 FED. R. CiV. P. 50(c)(1). See, e.g., Bennett v. D.C. Transit Sys., Inc., 298 F.2d 325, 326-27 (D.C. Cir. 1962). But see Lind v. Schenley Indus., 278 F.2d 79, 88-91 (3d Cir.), cert. denied, 364 U.S. 835 (1960).

27. Lind v. Schenley Indus., 278 F.2d 79, $88-91$ (3d Cir.), cert. denied, 364 U.S. 835 (1960); Moist Cold Refrigerator Co. v. Lou Johnson Co., 249 F.2d 246, 251 (9th Cir. 1957), cert. denied, 356 U.S. 968 (1958); Bailey v. Slentz, 189 F.2d 406, 409 (10th Cir. 1951)

28. Hansen v. Firestone Tire \& Rubber Co., 276 F.2d 254, 255 (6th Cir. 1960).

29. Neely v. Martin K. Eby Constr. Co., 386 U.S. 317, 329 (1967).

30. Fed. R. Civ. P. 50(c)(1). See Neely v. Martin K. Eby Constr. Co., 386 U.S. 317, 328-29 (1967); Patterson v. Pennsylvania R.R., 238 F.2d 645, 650 (6th Cir. 1956). Cf. supra notes $77-80$ and accompanying text.

31. Montgomery Ward \& Co. v. Duncan, 311 U.S. 243, 254 (1940). 
direct judgment n.o.v., ${ }^{32}$ order a new trial, ${ }^{33}$ or remand to the trial court for reconsideration of the new trial motion. ${ }^{34}$

The Supreme Court has cautioned that in deciding whether to exercise its power to render a judgment n.o.v., to order a new trial, or to remand for a district court decision on a new trial, the appellate court should consider the nature of the grounds asserted for a new trial. ${ }^{35}$ Although one purpose of Rule 50 is to speed litigation and avoid unnecessary retrials, the court must also be concerned with protecting the rights of the verdict winner, who may have grounds for a new trial which should be passed on in the first instance by the trial court because of its superior "feel" for the case. ${ }^{36}$ Thus, where the asserted grounds involve dispositive issues of law which the appellate court must address, there is no reason why that court should not terminate the litigation; ${ }^{37}$ but where the record reveals a new unresolved trial issue or where sufficiency of the evidence is challenged on appeal, it is less clear that the litigation should be terminated. ${ }^{38}$ The Supreme Court has said that the appellate court may address new issues presented on appeal as grounds for a new trial unless, in its informed discretion, it considers such issues more appropriate for trial court resolution. ${ }^{39}$

Illustration 10-2. $\mathrm{P}$, a passenger raped by a steamship employee, sues $\mathrm{D}$, the operator of the government-owned steamship, under a theory of common carrier liability. The jury returns a verdict for $\mathrm{P}$ and the trial judge denies judgment n.o.v. D appeals. The court of appeals reverses, holding that $\mathrm{D}$ was not a common carrier but an agent. Since $\mathrm{D}$ might be independently accountable for its negligence in procuring dangerous crewmen, a theory of liability not raised at trial, the reviewing court should not render judgment n.o.v. for D. ${ }^{40}$

d. Remand for New Trial or Other Appropriate Proceedings. In all instances an appellate court retains discretion to remand and will not render judgment where improper, ${ }^{41}$ as where a decision cannot be reached as a matter of law, ${ }^{42}$ a significant factual issue has been left undetermined by the trial court, ${ }^{43}$ the facts are not fully developed, ${ }^{44}$ or a party would be denied the right to a trial on the merits. ${ }^{45}$ The power to remand, however, also will not be exercised whenever the ends of

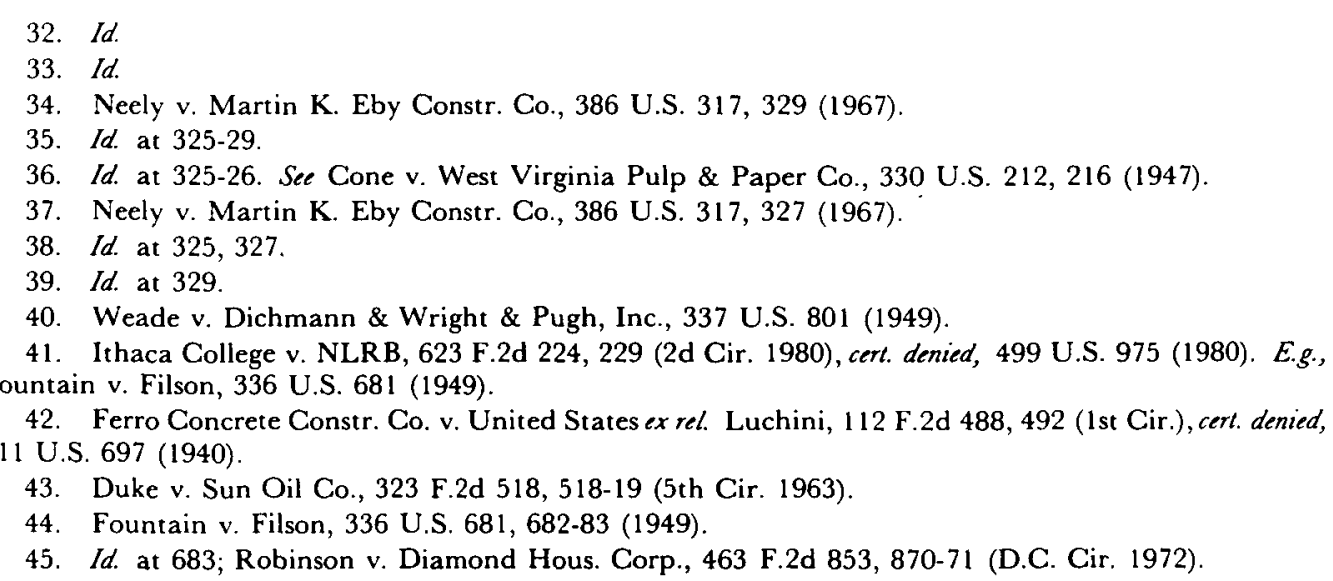


justice will not be best served, ${ }^{46}$ as when remand will be futile ${ }^{47}$ or when retrial would be unjust. ${ }^{48}$

Illustration 10-3. $\mathrm{P}$, the widow of an employee killed in the line of work, brings a loss of consortium claim against $\mathrm{D}$, the employer. $\mathrm{D}$ moves for summary judgment on the ground that P's exclusive remedy is under the workers compensation statute. $\mathbf{P}$ appeals, and the court of appeals reverses. The reviewing court further should remand with directions to the trial court to permit $P$ to amend to bring in the proper parties. Although the complaint states no cause of action for the specific relief sought, it does reveal a claim which may entitle $\mathrm{P}$ to relief; the court is therefore bound to remand. ${ }^{49}$

The nature and extent of proceedings upon remand are also within the appellate court's discretion. ${ }^{50}$ Generally, further proceedings are to be consistent with the appellate court's mandate, which is the law of the case. ${ }^{51}$ This mandate may require nothing less than a full trial of all issues, ${ }^{52}$ absent some new legal issue, not foreclosed by the mandate, which is dispositive as a matter of law. ${ }^{53}$ A new trial is also warranted where there is error as to all issues and parties, where there is error as to an issue which is so intertwined with the others that a separate trial would be unjust, ${ }^{54}$ or where there are procedural irregularities which cannot be corrected otherwise $^{55}$

Illustration 10-4. P, a mail clerk injured in a train accident, brings suit against $\mathrm{D}$, the employer railroad. The trial court renders judgment for $\mathrm{P}$ but erroneously instructs the jury that it has a duty to bring in a verdict for both compensatory and punitive damages. D appeals. Because of error in the instruction, a new trial on the issue of punitive damages is necessary; however, since the evidence of willful conduct is so inextricably tied up with primary negligence, the court of appeals should order trial of all issues. ${ }^{56}$

When a full new trial is not appropriate, an appellate court may on remand call for further proceedings or for further development of the case. ${ }^{57}$ For example,

46. Cooper v. Lish, 318 F.2d 262, 264 (D.C. Cir. 1963).

47. Horton v. Orange County Bd. of Educ., 464 F.2d 536, 538 (4th Cir. 1972).

48. Nixon v. Warner Communications, 435 U.S. 589, 611 n. 20 (1978) (remand not required where "outcome . . readily apparent"); Dwyer v. Socony-Vacuum Oil Co., 276 F.2d 653, 654 (2d Cir. 1960).

49. Cooper v. Lish, 318 F.2d 262 (D.C. Cir. 1963).

50. Baber v. Akers Motor Lines, 215 F.2d 843, 846 (D.C. Cir. 1954); Thompson v. Camp, 167 F.2d 733, 734 (6th Cir.), cert. denied, 355 U.S. 824 (1948); Constitution Publishing Co. v. Dale, 164 F.2d 210,213 (5th Cir. 1947).

51. In Re Sanford Fork \& Tool Co., 160 U.S. 247, 255-56 (1895).

52. McCart v. Indianapolis Water Co., 302 U.S. 419, 423 (1938); Sylvania Elec. Prods. v. Flanagan, 352 F.2d 1005, 1008-09 (1st Cir. 1965); Commercial Nat'l Bank v. Parsons, 144 F.2d 231, 241-42 (5th Cir.), cert. denied, 323 U.S. 796 (1944).

53. Ernst \& Ernst v. United States Dist. Ct., 439 F.2d 1288, 1293 (5th Cir. 1971).

54. Sylvania Elec. Prods. v. Flanagan, 352 F.2d 1005, 1008-09 (1st Cir. 1965); Atlantic Coast Line

R.R. v. Bennett, 251 F.2d 934, 938 (4th Cir. 1958).

55. Citron v. Aro Corp., 377 F.2d 750, 753 (3d Cir.), cert. denied, 389 U.S. 973 (1967).

56. Atlantic Coast Line R.R. v. Bennett, 251 F.2d 934 (4th Cir. 1958).

57. Adickes v. S.H. Kress \& Co., 398 U.S. 144, 173-74 (1970). 
where an involuntary dismissal pursuant to Rule $41(\mathrm{~b})$ of the Federal Rules of Civil Procedure is reversed on appeal, a remand would permit a party to present his evidence ${ }^{58}$ but would not necessarily require the re-presentation of evidence. ${ }^{59}$ The appellate court in appropriate circumstances may direct that litigants be permitted to amend nonfatal defects in their pleadings ${ }^{60}$ or cure defect as to parties joined. ${ }^{61}$ Cases may also be remanded for further evidence, ${ }^{62}$ for further findings or conclusions, ${ }^{63}$ or simply for modification of the judgments. ${ }^{64}$

Illustration 10-5. $\mathrm{P}$ brings a securities fraud action against $\mathrm{D}$, a corporation. The trial court renders judgment for $D$, although its findings of fact do not support that conclusion. $P$ appeals, and the judgment is reversed. The appellate court should remand not for a complete new proceeding but merely for a more detailed statement of findings of fact and conclusions of law. ${ }^{65}$

A partial new trial restricted to particular issues may be appropriate on remand in other cases, ${ }^{66}$ for example, where a factual question exists or error was committed as to one or more issues ${ }^{67}$ which can without injustice be severed from the properly adjudicated issues for retrial. ${ }^{68}$ This practice reflects the view that a party who has had his day in court should not be permitted to relitigate the same issue. Thus, damages are retried without retrial of liability if the issues are not interwoven and if the liability determination is supported by sufficient evidence. ${ }^{69}$ Where the doctrine of comparative negligence is involved and the amount of damages is related to contributory negligence, however, it is inappropriate to retry damages separate from liability. ${ }^{70}$ A new trial on the issue of damages is also inappropriate if there is reason to believe that the jury verdict is tinged with compromise among jurors with conflicting views of liability. ${ }^{71}$ Furthermore, a partial new trial cannot be used to deprive a party of the right to a jury trial on an issue. ${ }^{72}$

58. Riegel Fiber Corp. v. Anderson Gin Co., 512 F.2d 784, 793 (5th Cir. 1975).

59. Id. See United States v. United States Gypsum Co., 333 U.S. 364, 402 n.20 (1948).

60. Hunter v. United States, 388 F.2d 148, 155 (9th Cir. 1967)

61. Cooper v. Lish, 318 F.2d 262, 265 (D.C. Cir. 1963).

62. Fountain v. Filson 336 U.S. 681,683 (1949); Illinois Cent. Gulf R.R. v. Southern Rock, Inc., 644 F.2d 1138, 1140-41 (5th Cir. 1981).

63. D.C. Fed'n of Civic Ass'ns v. Volpe, 459 F.2d 1231, 1243 (D.C. Cir. 1971), cert. denied, 405 U.S. $1030(1972)$

64. Green v. Sante Fe Indus., 562 F.2d 4 (2d Cir. 1977).

65. Rochez Bros., Inc. v. Rhoades, 491 F.2d 402 (3d Cir. 1974), cert. denied, 425 U.S. 993 (1976).

66. Atlantic Coast Line R.R. v. Bennett, 251 F.2d 934, 938 (4th Cir. 1958); Great Am. Indem. Co. v. Ortiz, 193 F.2d 43, 47 (5th Cir. 1951); Thompson v. Camp, 167 F.2d 733, 734 (6th Cir.), cert. denied, 335 U.S. 824 (1948).

67. Board of Regents v. Roth, 408 U.S. 564, 569, 579 (1972); Blonder-Tongue Laboratories, Inc. v. University of Ill. Found., 402 U.S. 313, 350 (1971).

68. Thompson v. Camp, 167 F.2d 733, 734 (6th Cir.), cert. denied, 335 U.S. 824 (1948). See Barnd v. City of Tacoma, 664 F.2d 1339 (9th Cir. 1982).

69. Hadra v. Herman Blum Consulting Eng'rs, 632 F.2d 1242 (5th Cir. 1980), cert. denied, 451 U.S. 912 (1981).

70. Cosentino v. Royal Neth. S.S. Co., 389 F.2d 726 (2d Cir.), cert. denied, 393 U.S. 977 (1968).

71. National R.R. Passenger Corp. v. Koch Indus., Inc., 701 F.2d 108 (10th Cir. 1983); Hadra v. Herman Blum Consulting Eng'rs, 632 F.2d 1242, 1245-46 (5th Cir. 1980), cert. denied, 451 U.S. 912 (1981); Vizzini v. Ford Motor Co., 569 F.2d 754, 761-63 (3d Cir. 1977).

72. Tsai v. Rosenthal, 297 F.2d 614 (8th Cir. 1961). 
Illustration 10-6. $\mathrm{P}$ brings an action against $\mathrm{D} 1$ and $\mathrm{D} 2$, alleging negligence. A jury verdict finds negligence but no proximate cause as to D1 but holds D2 liable and denies contribution from D1. P and D2 appeal, and the judgment is reversed. The reviewing court, however, should not direct a new trial on the issue of damages alone because to do so would effectively direct a verdict against D1 on the issue of liability, which would be a violation of the seventh amendment in the absence of proper and timely directed verdict and judgment n.o.v. motions in the trial court. ${ }^{73}$

A new trial or partial new trial may also be limited as to parties where fewer than all of the original parties have been prejudiced by the error. ${ }^{74}$ For example, where multiple defendants are subject to separate liability, reversal of judgment against one does not necessarily warrant retrial as to the others. Where multiple defendants are held jointly and severally liable and the judgments against some of them are reversed, however, a new trial of the damages issue as to all the remaining defendants may be appropriate ${ }^{75}$ because in such a case it may be unjust to assume that the jury award was made without regard to the number or nature of the defendants.

Illustration 10-7. $\mathrm{P}$, a passenger injured in a two car collision sues the drivers, D1 and D2. D1 obtains a directed verdict, and D2 wins a jury verdict. $P$ appeals, and the directed verdict is reversed. The appellate court should remand for retrial as to both D1 and D2. Clearly one of them is liable for the plaintiff's injuries absent any suggestion of contributory negligence or unavoidable accident; because the jury was unable to judge the liability of both D1 and D2, the liability of D2 may have been improperly determined in isolation. ${ }^{76}$

e. Cross-Appeals and Collateral Parties. The reviewing court may, upon proper notice of cross-appeal, ${ }^{77}$ enlarge the rights of the party prevailing below or restrict those of the appellant. ${ }^{78}$ Situations where cross-appeals are required, however, are to be distinguished from the appellee's right to assert in support of his judgment "any matter appearing in the record, although his argument may involve an attack upon the reasoning of the lower court or an insistence upon matter overlooked or ignored by it."79 Thus, an appellee may on appeal urge claims from his complaint rejected by the trial court as additional or alternative grounds in sup-

73. Id.

74. Constitution Publishing Co. v. Dale, 164 F.2d 210, 213 (5th Cir. 1947). Cf. Juneau Square Corp. v. First Wis. Nat'l Bank, 624 F.2d 798, 811 (7th Cir. 1980), cert. denied, 449 U.S. 1013 (1980).

75. Washington Gas Light Co. v. Lansden, 172 U.S. 534, 555-56 (1899).

76. Williams v. Slade, 431 F.2d 605 (5th Cir. 1970).

77. For a discussion of the time for filing a cross-appeal, see supra $\S 6$ of this Interlocutory Restatement, notes 3-4 and accompanying text.

78. See United States v. American Ry. Express Co., 265 U.S. 425, 435 (1924); Alford v. City of Lubbock, 664 F.2d 1263, 1272-73 (5th Cir.) (cross-appeal required when appellee sought to challenge denial of attorney fees), cert. denied, 456 U.S. 975 (1982).

79. United States v. American Ry. Express Co., 265 U.S. 425, 435 (1924). See also Schweiker v. Hogan, 457 U.S. 569, 585 n.24 (1982); Colautti v. Franklin, 439 U.S. 379, 397 n.16 (1979); Langnes v. Green, 282 U.S. 531, 535-39 (1931). 
port of the decree but not as an attack upon the scope of the relief awarded. ${ }^{80}$

While many courts flatly state that the cross-appeal requirement is jurisdictional, ${ }^{81}$ others, in the analogous area ${ }^{82}$ of appeals in cases involving third party claims and cross-claims, for example, suggest that the considerations are prudential and lack of notice of appeal will not bar appellate modification of a judgment in the proper circumstances. ${ }^{83}$ For example, a reviewing court may also extend relief to a nonappealing codefendant when a reversal "wipes out all basis for recovery against a non-appealing, as we!l as against an appealing, defendant."84 This principle has also been used to overturn the liability of a nonappealing defendant vis-à-vis the plaintiff when that defendant's judgment against a third party defendant was reversed. ${ }^{85}$

\section{Procedure for Interlocutory Appeal}

\section{$\S 11$. Certified Appeal.}

\section{(A) A NONFINAL ORDER IS SUBJECT TO INTERLOCUTORY REVIEW WHEN}

(1) THE JUDGE OR MAGISTRATE MAKING THE ORDER CERTIFIES THAT THERE IS
(a) SUBSTANTIAL DOUBT REGARDING THE CONTROL- LING PRINGIPLE OF SUBSTANTIVE OR ADJECTIVE LAW AND

80. United States v. American Ry. Express Co., 265 U.S. 425, 435-36 (1924). E.g., Massachusetts Mut. Life Ins. Co. v. Ludwig, 426 U.S. 479 (1976) (per curiam) (appellee could argue improper choice of law by trial court as additional ground for upholding judgment granted under the law actually selected); cf. Champagne v. Schlesinger, 506 F.2d 979, 982 \& n.3 (7th Cir. 1974) (lack of cross-appeal excused on ground that abstention to allow exhaustion of administrative remedies, like subject matter jurisdiction, was an issue which could have been raised sua sponte by the court; seemingly, however, lack of exhaustion was merely an alternative ground argued in support of the summary judgment, not an attempt to increase the rights of the party prevailing below, so that cross-appeal was not necessary anyway).

81. E.g., Martin v. Hamil, 608 F.2d 725, 730-31 (7th Cir. 1979); Ortega Cabrera v. Municipality of Bayamon, 562 F.2d 91, 97 n.3 (1st Cir. 1977) Gomez v. Wilson, 477 F.2d 411,414 n.10 (D.C. Cir. 1973).

82. Cf. 15 C. Wright, A. Miller \& E. Cooper, Federal Practice and Procedure $\$ 3904$, at 418-19 (1976).

83. Bryant v. Technical Research Co., 654 F.2d 1337, 1341-43 (9th Cir. 1981) (third party defendant allowed to contest without notice of appeal the dismissal of his own third party claims when a summary judgment in his favor as to the underlying defendant was reversed). Cf. United States v. ITT Continental Baking Co., 420 U.S. 223, 226 n.2 (1975) (discussing power of the Supreme Court to hear questions not raised by cross-petition for certiorari versus the Court's practice of not entertaining such questions).

84. In re Barnett, 124 F.2d 1005, 1009 (2d Cir. 1942). E.g., Daniels v. Gilbreath, 668 F.2d 477, 480 (10th Cir. 1982) (reversal made it clear that nonappealing party had no liability as a matter of law); $c f$. Hegger v. Green, 646 F.2d 22, 30 (2d Cir. 1981) (possible basis of liability for nonappealing party remained despite the reversal).

85. Kicklighter v. Nails by Jannee, Inc., 616 F.2d 734, 742-45 (5th Cir. 1980) (appeal by third party defendant also acted as appeal of main judgment when that party's liability was derivative and the only error asserted was as to the underlying judgment); see also Arnold's Hofbrau v. George Hyman Constr. Co., 480 F.2d 1145, 1150 (D.C. Cir. 1973) (new trial on damages ordered as to all parties, even those not appealing, in case involving cross-claim as to relative obligations of the defendants); $c f$. Zapico v. BucyrusErie Co., 579 F.2d 714, 725 (2d Cir. 1978) (defendant and third party plaintiff could not, without notice of appeal, seek to have the judgment against him reduced to a proportionate share of the damages when his award of fifty-percent contribution from the third party defendant was reversed). 
(b) A PROSPECT THAT SUBSTANTIAL LITIGATION COSTS AND/OR JUDICIAL ENERGIES MAY BE SAVED BY AN EARLY DECISION ON THE MATTER BY THE COURT OF APPEALS; AND

(2) LEAVE TO APPEAL IS GRANTED BY THE COURT OF APPEALS.

(B) AFTER LEAVE TO APPEAL IS GRANTED, THE COURT OF APPEALS IS NOT CONSTRAINED TO ANSWER ONLY THE QUESTION CERTIFIED BUT MAY ADDRESS ANY ISSUE RAISED BY THE ORDER. CAVEAT: CERTIFIED APPEAL MAY NOT BE AVAILABLE EVEN AS TO ORDERS MEETING THE REQUIREMENTS OF (A)(1) ABOVE WHEN THE ACTION INVOLVES PATENT OR GOVERNMENT CONTRACT ISSUES WITHIN THE EXCLUSIVE JURISDICTION OF THE FEDERAL CIRGUIT.

\section{COMMENT}

a. Certified Appeal. A nonfinal order,' although generally not appealable, is subject to interlocutory review if so certified by the district court. ${ }^{2}$ This system of certified interlocutory appeals promotes institutional efficiency ${ }^{3}$ by permitting litigants to effectively challenge interlocutory orders of serious, and perhaps irreparable, consequence while still strictly limiting piecemeal adjudications. ${ }^{4}$

The legislative history of 28 U.S.C. $\S 1292($ b), the statute which authorizes certified interlocutory appeals, suggests that certification should only be granted "in exceptional cases where a decision of the appeal may avoid protracted and expensive litigation, as in antitrust and similar protracted cases." 5 This statement has universally been taken to mean that certification should not be granted "in ordinary suits for personal injuries or wrongful death that can be tried and disposed of on the merits in a few days of trial." 6 However, the decisions have disagreed as to

1. See generally supra $\S \S 3$ \& 4 of this Interlocutory Restatement plus infra $\S 22$ of this Interlocutory Restatement, notes $1-3$ and accompanying text, for a discussion of finality.

2. See 28 U.S.C. $\$ 1292(b)$ (1976):

When a district judge, in making in a civil action an order not otherwise appealable under this section [\$1292], shall be of the opinion that such order involves a controlling question of law as to which there is substantial ground for difference of opinion and that an immediate appeal from the order may materially advance the ultimate termination of the litigation, he shall so state in writing in such order. The Court of Appeals may thereupon, in its discretion, permit an appeal to be taken from such order, if application is made to it within ten days after the entry of the order: Provided, however, that application for an appeal hereunder shall not stay proceedings in the district court unless the district judge or the Court of Appeals or a judge thereof shall so order.

3. See Forsyth v. Kleindienst, 599 F.2d 1203 (3d Cir.), cert. denied, 453 U.S. 913 (1979); Ford Motor Credit Co. v. S.E. Barnhart \& Sons, Inc., 664 F.2d 377 (3d Cir. 1981).

4. See Gardner v. Westinghouse Broadcasting Co., 559 F.2d 209 (3d Cir. 1977), affd, 437 U.S. 478 (1978); Donaldson v. Pillsbury Co., 529 F.2d 979 (8th Cir. 1976); Jones v. Diamond, 519 F.2d 1090 (5th Cir. 1975).

5. Report of the Comm. On Appeals From Inter locutory Orders of the District Courts, 1958 U.S. CODE CONG. \& AD. News 5260.

6. Kirchen v. Guaranty Nat'l Ins. Co., 422 F.Supp. 58, 61 (E.D. Wis. 1976). See also Cardwell v. Chesapeake \& O. Ry., 504 F.2d 444, 446 (6th Cir. 1974); Kraus v. Board of County Road Comm'rs, 364 
the qualities, beyond the absence of "ordinariness," a case must possess before certification is merited.

Some decisions in construing the statute heavily emphasize this "exceptional case" language found in the legislative history. ${ }^{7}$ These decisions look beyond the statutory requirements of 28 U.S.C. $\S 1292$ (b) and restrict certification to use in situations where the issues are exceptionally complex ${ }^{8}$ or where the risks of repeating expensive and protracted litigation are high. ${ }^{9}$

Other decisions, however, concentrate on the merits of the particular appeal at issue. Such an approach, enunciated in Hadjipateras v. Pacifica, S.A., ${ }^{10}$ seems more consistent with the statutory language, which makes no reference to the "exceptional case." The provision authorizes a district judge to certify an appeal from an interlocutory order when, in the judge's opinion, "such order involves a controlling question of law as to which there is substantial ground for difference of opinion and .. . an immediate appeal from the order may materially advance the ultimate termination of the litigation." 1

In the end, the two approaches to 28 U.S.C. $\$ 1292(\mathrm{~b})$ displayed by the decisions are reconcilable; the cases reveal that although certification has not been restricted to exceptionally complex or protracted litigation, it has been used, and remains especially suited for use, in those cases. ${ }^{12}$

b. Requirements of Certified Appeal. A certified appeal may be taken where the district judge (or the magistrate ${ }^{13}$ ) making the order in his discretion ${ }^{14}$ certifies an otherwise unappealable ${ }^{15}$ order for immediate review.

F.2d 919, 922 (6th Cir. 1966); United States Rubber Co. v. Wright, 359 F.2d 784, 785 (9th Cir. 1966). Cf. infra text accompanying note 28 .

7. See supra note 5 .

8. See In re Uranium Antitrust Litig., 617 F.2d 1248, 1263 (7th Cir. 1980).

9. See Arizona v. Ideal Basic Indus. (In re Cement Antitrust Litig.), 673 F.2d 1020, 1026 (9th Cir. 1982), aff d sub nom. Arizona v. Ash Grove Cement Co., 103 S. Ct. 1172 (1983); Mazzella v. Stineman, 472 F. Supp. 432, 435-36 (E.D. Pa. 1979). See also Vaughn v. Regents of the Univ. of Cal., 504 F. Supp. 1349, 1355 (E.D. Cal. 1981).

10. 290 F.2d 697 (5th Cir. 196l).

11. The complete statutory language is quoted supra note 2

12. See Zenith Radio Corp. v. Matsushita Elec. Indus. Co., 494 F. Supp. 1190, 1243-45 (E.D. Pa. 1980).

13. Central Soya Co. v. Voktas, Inc., 661 F.2d 78 (7th Cir. 1981) (U.S. magistrates have authority to certify appeals under $\S 1292$ (b) by virtue of Federal Magistrate Act of 1979, Pub. L. No. 96-82, § 2, 93 Stat. 643,643 (codified at 28 U.S.C. $\$ 636$ (c) (Supp. V 1981)); for further discussion of these provisions, see infra $\S 27$ of this Interlocutory Restatement, notes 32-36 and accompanying text.

14. See S. Rep. No. 2434, 85th Cong., 2d Sess., reprinted in 1958 U.S. Code Cong. \& AD. News 5255, 5257; see also Coopers \& Lybrand v. Livesay, 437 U.S. 463 (1978).

15. See Oklinsky v. Philadelphia, B. \& N.E. R.R., 282 F.2d 70, 71 (3d Cir. 1960). See also FernandezRogue v. Smith, 671 F.2d 426, 430 n.6 (11th Cir. 1982); New York Health \& Hosps. Corp. v. Blum, 678 F.2d 392, 396 (2d Cir. 1982).

The "otherwise unappealable" requirement is, however, disregarded when it appears that the order from which the certified appeal is taken could be subject to appeal as a partial final decision under Rule 54(b) of the Federal Rules of Civil Procedure (discussed supra $\S 4$ of this Interlocutory Restatement). In such instances, the decisions recognize that as long as the more restrictive 28 U.S.C. $\$ 1292$ (b) criteria are met, the court may certify under Rule 54(b) and alternatively under 28 U.S.C. § $1292(\mathrm{~b})$. See DeMelo v. Woolsey Marine Indus., 677 F.2d 1030, $1034 \mathrm{n} .9$ (5th Gir. 1982) (stating that where a district court feels that prompt appeal is appropriate but is uncertain that Rule 54(b) judgment is proper, it should certify under Rule 54(b) and alternately under 28 U.S.C. § 1292(b)); Local P-171, Amalgamated Meat Cutters v. Thompson Farms Co, 642 F.2d 1065, 1069-73 (7th Cir. 1981) (criticizing the distinctions between Rule 
This discretion is not unlimited, however, and has been held to be subject to the guidelines created by the criteria found in 28 U.S.C. $\S 1292(\mathrm{~b}) .{ }^{16}$ Lack of certification forecloses appeal under 28 U.S.C. $§ 1292$ (b); such certification cannot be compelled by mandamus. ${ }^{17}$

The statute requires that the order involve "a controlling question of law as to which there is substantial ground for difference of opinion." 18 At the very least, this includes "orders which [if incorrect] would be reversible errors on final appeal," 19 and it certainly excludes questions of fact or matters within a trial court's discretion. ${ }^{20}$ However, orders falling between these extremes have been certified for appeal where, although incorrect disposition would not qualify as reversible error on final decision, an interlocutory reversal would advance the purposes of the statute by saving time for the district court and time and expense for the litigants. ${ }^{21}$

Even a controlling question, however, will not be subject to certification if there is not "substantial ground for difference of opinion" as to the district court's

54(b) and 28 U.S.C. $\$ 1292$ (b) made in the Luckenback Steamship case (see infra) and stating that the purposes of both appeals are the same-to accelerate review of select portions of the litigation); CAB v. Tour Travel Enters., 605 F.2d 998, 1003 (7th Cir. 1979) (alternative certification under Rule 54 (b) and 28 U.S.C. $\S 1292(\mathrm{~b})$ is permissible). This approach is contrary to Luckenback Steamship Co. v. H. Muehlstein \& Co., 280 F.2d 755, 757 (2d Cir. 1960), where the court refused to hear a 28 U.S.C. $\$ 1292$ (b) appeal on the ground that it was inappropriate where a multiparty case was involved as Rule $54(\mathrm{~b})$ should be utilized where it is applicable, but it seems to be the better approach. See 16 C. WRIGHT, A. MILLER, E. COOPER \& E. Gressman, Federal Practice \& Procedure $\$ 3929$ [hereinafter cited as C. Wright \& A. Miller].

16. See Control Data Corp. v. International Bus. Machs. Corp., 421 F.2d 323, 325 (8th Cir. 1980); Haddendorf v. Goldfine, 263 F.2d 887 (1st Cir. 1959).

17. See Arthur Young \& Co. v. United States Dist. Court, 549 F.2d 686, 698 (9th Cir.), cert. denied, 434 U.S. 829 (1977); Green v. Occidental Petroleum Corp., 541 F.2d 1335, 1338 (9th Cir. 1976) (per curiam); White Indus. v. Cessna Aircraft Co. (In re Cessna Aircraft Distrib. Antitrust Litig.), 518 F.2d 213, $216-17$ (8th Cir. 1975). But of. Fernandez-Rogue v. Smith, 671 F.2d 426 (11th Cir. 1982) (the court, treating an appeal from a temporary restraining order as a petition for mandamus, directed the district court to decide disputed questions of subject matter jurisdiction and also directed that upon resolution of those issues, any party would be entitled to certification due to the fact that the controlling issue-the power of the courts and the executive branch in dealing with refugees - was of national significance, thus presenting a rare situation in which an appellate court could compel certification). See also Gillespie v. United States Steel Corp., 379 U.S. 148, 152-54 (1964) ("marginal" case treated as final and appealable when immediate review would serve the same purposes Congress sought to promote in 28 U.S.C. $\$ 1292$ (b); appellate court on mandamus to compel district judge to certify had instead considered case on merits as if appeal had been proper). For a suggestions that Gillespie is limited to its facts, see Coopers \& Lybrand v. Livesay, 437 U.S. 463,477 n.30 (1978).

18. The complete statutory language is quoted supra note 2. See also Association of Co-op Members v. Farmland Indus., 684 F.2d 1134, 1137 n.3 (5th Cir. 1982), cert. denied, 103 S. Ct. 1428 (1983); Wimberly v, Rogers, 557 F.2d 671, 672-73 (9th Cir. 1977).

19. Katz v. Carte Blanche Corp., 496 F.2d 747, 754-56 (3d Cir.), cert. denied, 419 U.S. 885 (1974).

20. See Johnson v. Alldredge, 488 F.2d 820, 822 (3d Cir.), cert. denied, 419 U.S. 882 (1973); Garner v. Wolfinbarger, 433 F2d 117, 119 (5th Cir.), cert. denied, 401 U.S. 974 (1970); DeWitt v. American Stock Transfer Co., 440 F. Supp. 1084, 1087-88 (S.D.N.Y. 1977).

21. See Katz v. Carte Blanche Corp., 496 F.2d 747, 755 (3d Cir.), cert. denied, 419 U.S. 885 (1974). The focus is on any savings of time and expense between the filing and termination of the lawsuit. E.g., E.F. Hutton \& Co. v. Brown, 305 F. Supp. 371,403 (S.D. Tex. 1969) (disqualification of plaintiff's counsel certified since need for new counsel to familiarize himself with facts and for further discovery would delay proceedings for months). But see In Re Cement Antitrust Litig., 673 F.2d 1020, 1027 (9th Cir. 1982) (focus on savings of time and expense essentially reads the "controlling question of law" requirement out of 28 U.S.C. $\$ 1292(\mathrm{~b})$ ), affd by an equally divided court sub nom. Arizona v. Ash Grove Cement Co., 103 S. Ct. 1172 (1983). 
resolution of the question. ${ }^{22}$ The determination of the existence of a "substantial doubt" is, of course, within the district court's discretion, ${ }^{23}$ and generally a district judge will find that no substantial doubt exists where probability of reversal is low-even if the question is one of first impression. ${ }^{24}$ Substantial doubt may be found lacking, and therefore certification denied, even where there is a conflict between circuits, if the court in which the appeal would be heard has a strong disposition on the question and there appears to be no strong reason for change. ${ }^{25}$ It does appear, however, that judges appropriately weigh the degree of doubt as to the correctness of the order against the importance of the question in the context of the complexity and potential length of the litigation. Initial questions, such as jurisdiction or application of statutes of limitations, are particularly susceptible to this balancing when the case is to be a lengthy and expensive one. ${ }^{26}$

Finally, 28 U.S.C. $§ 1292$ (b) requires that the appeal "materially advance the ultimate termination of the litigation." 27 This language clearly makes certification unavailable in trials that can be disposed of on the merits in a few days' time $^{28}$ or in instances where certification would raise the possibility of a further appeal, as in the case of a an order granting a new trial. ${ }^{29}$ In fact, certification has been uniformly denied where it has been found that immediate review would only delay the proceedings. ${ }^{30}$

Decisions as to whether appeal would "materially advance the termination of the litigation" have focused on savings both of costs to the parties and of judicial energies. ${ }^{31}$ This timesaving aspect, although not in itself a sufficient basis for certi-

22. The complete statutory language is quoted supra note 2.

23. See supra notes $14,16-17$, and accompanying text.

24. See 16 C. WRIGHT \& A. Millet, supra note $15, \S 3929$, at 147.

25. See Berger v. United States, 170 F. Supp. 795, 796-97 (S.D.N.Y. 1959). Cf. Giglio v. Farrell Lines, 424 F. Supp. 927, 930-31 (S.D.N.Y. 1977) (certification granted even though there was clear precedent in the circuit; intervening changes in the law and precedent in other circuits presented substantial question as to the continued viability of the older local rulings).

26. See Atlantic City Elec. Co. v. General Elec. Co., 207 F. Supp. 613, 620 (S.D.N.Y.), affd, 312 F.2d 236 (2d Cir. 1962), cert. denied, 373 U.S. 909 (1963). See also infra $\$ 14$ of this Interlocutory Restatement, comment $c$; infra $\S 16$ of this Interlocutory Restatement, comment $i$.

27. The complete statutory language is quoted supra note 2.

28. See Kraus v. Board of County Road Comm'rs, 364 F.2d 919, 922 (6th Cir. 1966). See also Kliban v. United States, 65 F.R.D. 6, 9-10 (D. Conn. 1974); Laverne v. Corning, 316 F. Supp. 629,639 (S.D.N.Y. 1970); Ratner v. Chemical Bank N. Y. Trust Co., 309 F. Supp. 983, 989 (S.D.N.Y. 1970). Cf. supra text accompanying note 6 .

29. See Cardwell v. Chesapeake \& O. Ry., 504 F.2d 444, 446-47 (6th Cir. 1974); Steele v. Wiedemann Mach. Co., 280 F.2d 380, 383-84 (3d Cir. 1960); Winston v. Roe, 246 F. Supp. 246, 250 (E.D. Tenn. 1965). Cf. Gallimore v. Missouri Pac. R.R., 635 F.2d 1165, 1168-69 n.4 (5th Cir. 1981) (denial of leave to appeal by the court of appeals may rest on grounds unrelated to the merits such as the probability of a second appeal where appeals from orders granting new trials are certified). For further discussion of certification of orders granting new trials, see infra $\S 42$ of this Interlocutory Restatement, text accompanying notes 28 30.

30. See In re Paris Air Crash of March 3, 1974, 399 F. Supp. 732, 739 (C.D. Cal. 1975); First Del. Valley Citizens Television, Inc. v. CBS, 398 F. Supp. 917, 924-25 (E.D. Pa. 1975); Mattlack, Inc. v. Hupp Corp., 57 F.R.D. 151, 158-59 (E.D. Pa. 1972); Struthers Sci. \& Int'l Corp. v. General Foods Corp., 290 F. Supp. 122, 130 (S.D. Tex. 1968).

31. See, e.g., Katz v. Carte Blanche Corp., 496 F.2d 747, 755 (3d Cir.), cert. denied, 419 U.S. 885 (1974); E.F. Hutton \& Co. v. Brown, 305 F.Supp. 371, 403 (S.D. Tex. 1969); Atlantic City Elec. Co. v. General Elec. Co, 207 F. Supp. 613, 620 (S.D.N.Y.), affd, 312 F.2d 236 (2d Cir. 1962), cert. denied, 373 U.S. 909 (1963). 
fication, is clearly a necessary component, ${ }^{32}$ and its existence can be established only by the circumstances surrounding the particular case. ${ }^{33}$

Illustration. $\mathrm{P}$ brings suit against $\mathrm{D}$, asserting claims pursuant to both express and implied rights of action under the Securities Exchange Act of 1934. ${ }^{34} \mathrm{D}$ moves to dismiss both counts, and his motion is denied in full. The decision involves controlling questions of law, but there is substantial ground for difference of opinion only as to refusal to dismiss the implied action. D seeks certification for interlocutory appeal. Certification should be denied because reversal of the failure to dismiss the implied action will lead to no substantial savings of time as the issues therein overlap with those in the express action and would thus have to be tried anyway. ${ }^{35}$

c. Leave to Appeal. Once the district judge has certified a question, the court of appeals has authority under 28 U.S.C. $\$ 1292(\mathrm{~b})$ to exercise its discretion to refuse to accept the appeal. ${ }^{36}$ The exercise of this discretion is not proscribed by the statutory guidelines, ${ }^{37}$ and, although in most cases the courts of appeals tend voluntarily to look to those requirements, they "may deny the appeal for any reason, including docket congestion." 38 Furthermore, a court of appeals may dismiss the certified appeal if it appears-even after briefs and oral arguments-that permission has been improvidently granted. ${ }^{39}$

d. Cases within the Exclusive Jurisdiction of the Federal Circuit. Leave for certified appeal should seemingly always be denied in patent and government contract cases within the exclusive jurisdiction of the newly created Court of Appeals for the Federal Circuit. ${ }^{40}$ Because of the lack of specific statutory authorization, the Federal Circuit has held it has no jurisdiction to accept an appeal certified under

32. See Berry v. School Dist., 467 F. Supp. 721,727 (W.D. Mich. 1978). See also Wolgin v. Magic Marker Corp., 472 F. Supp. 436 (E.D. Pa. 1979); SEC v. Penn Central Co., 450 F. Supp. 908,918 (E.D. Pa. 1978).

33. See, e.g., In re Virginia Elec. \& Power Co., 539 F.2d 357, 364 (4th Cir. 1976) (certification appropriate because order by which trial judge recused himself would cause delay due to new judge having to take time to familiarize himself with case's complexities); Stong v. Bucyrus-Erie Co., 476 F. Supp. 224 (E.D. Wis. 1979) (ruling that provision of private pension plan violated ERISA was certified for review; reversal would end proceedings and affirmance might make settlement of damage and entitlement to recovery issues easier). See also Hughes Aircraft Co. v. General Instrument Corp., 374 F. Supp. 1166,1178 (D. Del. 1974); Lemelson v. Ampex Corp., 372 F. Supp. 708, 715 (N.D. Ill. 1974); Arkansas-Best Freight Sys. v. Youngblood, 359 F. Supp. 1125, 1129-30 (W.D. Ark. 1973).

34. 15 U.S.C. $\$ \S 77-78$ (1976 \& Supp. V 1981).

35. Wolgin v. Magic Marker Corp., 472 F. Supp. 436 (E.D. Pa. 1979).

36. The statutory language is quoted supra note 2 . See infra $\S 13$ of this Interlocutory Restatement, comment $a$, for a discussion of the time constraints on and formalities of petitioning for permission to appeal.

37. See Gallimore v. Missouri Pac. R.R., 635 F.2d 1165, 1168-69 n.4 (5th Cir. 1981); see also Coopers \& Lybrand v. Livesay, 437 U.S. 463 (1978).

38. Coopers \& Lybrand v. Livesay, 437 U.S. 463, 475 (1978).

39. See Sandler v. Eastern Airlines, 649 F.2d 19, 20 (1st Cir. 1981). See also New York Health \& Hosps. Corp. v. Blum, 678 F.2d 392, 398 (2d Cir. 1982); United States v. 5.96 Acres of Land, 593 F.2d 884, 886-87 (9th Cir. 1979).

40. The Court of Appeals for the Federal Circuit was established by the Federal Courts Improvement Act of 1982, Pub. L. No. 97-164, 96 Stat. 25. The jurisdiction of the court is defined in sections 125 and 127. Id. at 36-39 (codified at 28 U.S.C.A. $\S \S 1292,1295$ (West Supp. 1983)). See supra $\S 2$ of this Interlocutory Restatement, note 17. 
28 U.S.C. $\S 1292(\mathrm{~b}) ;{ }^{41}$ and while there is no provision limiting the discretion of the regional courts of appeals to decide certified questions on matters otherwise reviewable only in the Federal Circuit, they should nevertheless decline to do so. As developed in Section 2 of this Interlocutory Restatement, ${ }^{42}$ a contrary practice would either lead to delay and waste or foreclose the Federal Circuit from providing different, possibly more correct, and certainly more authoritative, answers to patent and government contract questions in contravention of Congress's intent in establishing a special court to dispose of controversies in those substantive areas.

Nor should regional courts of appeals hear certified questions on purely procedural issues arising in patent and government contract cases. A threshold difficulty would be determination of whether the question certified was purely procedural or whether it sufficiently touched the merits or was otherwise determinative of the outcome of the substantive issues such that for the reasons discussed above it should properly be addressed to the Federal Circuit on appeal from a final decision. It would seem, however, that if the certified question were sufficiently "controlling" that the court would be inclined to entertain it, it would be sufficiently outcome-determinative that to answer it would be to invade the domain of the Federal Circuit.

e. Scope of Review. The courts of appeals have found that once leave to appeal is granted they are "not restricted to a decision of the question of law which in the district judge's view was controlling." 43 The circuits that have squarely confronted this issue base this conclusion on the language of 28 U.S.C. $\$ 1292$ (b) that " $\mathrm{t}]$ he Court of Appeals may, . . . in its discretion, permit an appeal to be taken from such order;" 44 the statute thus places the entire order before the court and directs the court "not to answer the question certified but to decide an appeal." 45 Such a practice of broad review is in keeping with the purpose of 28 U.S.C. $§ 1292$ (b) to promoting judicial economy. For example, courts have found and determined controlling questions other than those certified by the district judge $^{46}$ and have decided issues, in addition to those certified, which were addressed in the order. ${ }^{47}$

41. Harrington Mfg. Co. v. Powell Mfg. Co., 709 F.2d 710-711 (Fed. Cir. 1983).

42. See supra $\S 2$ of this Interlocutory Restatement, para. 3 of comment $c$.

43. Katz v. Carte Blanche Corp., 496 F.2d 747, 754 (3d. Cir.), cert. denied, 419 U.S. 885 (1974). See also Bersch v. Drexel Firestone, Inc., 519 F.2d 974, 994 (2d Cir.), cert. denied, 423 U.S. 1018 (1975); Capital Temporaries, Inc. v. Olsten Corp. 506 F.2d 658, 660 (2d Cir. 1974); Johnson v. Alldredge, 488 F.2d 820 , 822-23 (3d Cir. 1973), cert. denied, 419 U.S. 882 (1974). Cf. United States v. Connolly, 716 F.2d 882, 884-85 (Fed. Cir. 1983) (presenting an analogous construction of 28 U.S.C.A. $\$ 1292$ (d) (2) (West Supp. 1983)-the counterpart of 28 U.S.C. $\$ 1292$ (b) for certified appeals from the Court of 'Claims to the new Federal Circuit). But of. Briggs v. Goodwin, 569 F.2d 10, 25 (D.C. Cir. 1977) (discussing reluctance to accept a broad construction of the scope of 28 U.S.C. $\$ 1292(\mathrm{~b})$, though district judge had in fact refused certification; appeal was being heard under the collateral order doctrine), cert. denied, 437 U.S. 904 (1978).

44. Emphasis added. The complete statutory text is quoted supra note 2.

45. Johnson v. Alldredge, 488 F.2d 820, 823 (3d Cir. 1973), cert. denied, , 419 U.S. 882 (1974).

46. Id. at $822-23$ (appellate court decides general question as to availability of immunity and standards therefor, as briefed and argued by the parties, rather than narrower immunity question stated by the district judge).

47. Dersch v. Drexel Firestone, Inc., 519 F.2d 974, 993-95 (2d Cir.) (appellate court considered appropriateness of class action after determining question certified as to ability of certain class members to bring suit under the given statute), cert. denied, 423 U.S. 1018 (1975); Capital Temporaries, Inc. v. Olsten Corp., 


\section{$\S 12 . \quad$ Noncertified Interlocutory Appeal}

(A) A NONFINAL ORDER IS SUBJECT TO INTERLOCUTORY REVIEW WITHOUT GERTIFICATION BY THE DISTRICT COURT ONLY FOR THE RESTRICTED PURPOSE OF PROTECTING SPECIFIC SUBSTANTIAL RIGHTS OF THE APPELLANT WHICH CANNOT BE ADEQUATELY ENFORCED BY REVIEW AFTER FINAL DECISION. THE SPECIFIC RIGHTS TO BE SO PROTECTED AS TO MOST NONFINAL ORDERS ARE IDENTIFIED IN SECTIONS 14-43 OF THIS INTERLOCUTORY RESTATEMENT. INTERLOCUTORY APPEAL FROM OTHER NONFINAL ORDERS OF DISTRICT COURTS IS RESTRICTED TO THE PROTECTION OF SIMILAR SPECIFIC SUBSTANTIAL RIGHTS.

(B) ON INTERLOCUTORY REVIEW, THE COURT OF APPEALS WILL CONSIDER THE CORRECTNESS OF THE ORDER CHALLENGED ONLY TO THE EXTENT NECESSARY TO SERVE THE RESTRICTED PURPOSE OF THE APPEAL.

(C) A NONCERTIFIED APPEAL FROM A NONFINAL ORDER WHICH DOES NOT IRREPARABLY JEOPARDIZE A SPECIFIC SUBSTANTIAL RIGHT OF THE APPELLANT SHALL BE DISMISSED FOR LACK OF JURISDICTION REGARDLESS OF WHETHER SUCH OBJECTION IS RAISED BY THE APPELLEE.

\section{COMMENT}

a. Noncertified Interlocutory Appeal. Noncertified interlocutory appeals, although found to be authorized under three statutory provisions, ${ }^{1}$ may be synthesized as serving the common function of enabling courts of appeals to assure appropriate observance of rights which cannot be adequately protected by review after full trial.

Explicit statutory authorization for a limited range of interlocutory appeals is now found in 28 U.S.C. $\S 1292(\mathrm{a}),{ }^{2}$ having initially been set forth in the legislation creating the courts of appeals in 1891. ${ }^{3}$ These explicit provisions for the most part have some ancestry in chancery practice; the finality requirement was never well established in equity. ${ }^{4}$ As currently written, the statute provides for interlocutory

506 F.2d 658, 660 (2d Cir. 1974) (appellate court considered propriety of summary judgment as well as certified question as to elements which plaintiff had to allege on the issue on which such judgment was granted). See generally Katz v. Carte Blanche Corp., 496 F.2d 747, 754 (3d Cir.), cert. denied, 419 U.S. 885 (1974). But see Anderson v. Air West, 542 F.2d 1090, 1093 (9th Cir. 1976) (appellate court refused to decide summary judgment question on certification of propriety of discovery sanction; it did not, however, specifically address the issue of its power to determine the noncertified issue had it so chosen).

1. See supra $\S 1$ of this Interlocutory Restatement, notes 12-15 and accompanying text.

2. 28 U.S.C.A. § 1292(a) (West Supp. 1983).

3. Act of Mar. 3, 1891, ch. 517, $\S 7,26$ Stat. 826, 828. This provision authorized only interlocurory review of orders granting or continuing injunctions. The course of early amendments is traced in Baltimore Contractors v. Bodinger, 348 U.S. 176, 180 n.6 (1955). See also infra $\S 21$ of this Interlocutory Restatement, note 1 .

4. See generally Crick, The Final Judgment as a Basis for Appeal, 41 YALE L.J. 539, 545-48 (1932). 
appeal of orders relating to injunctions ${ }^{5}$ and of certain orders dealing with receiverships. ${ }^{6}$ Courts emphasize that the purpose of these provisions is to make relief available when interlocutory orders portend serious and perhaps irreparable consequences. ${ }^{7}$

Appeal of other interlocutory orders has been justified by characterizing them as "final" within the meaning of 28 U.S.C. $\$ 1291^{8}$ even though the underlying proceeding has not terminated and there has been no compliance with the formal requirements for entry of judgment. ${ }^{9}$ Exemplary of this practice is the collateral order doctrine which was established in Cohen v. Beneficial Industrial Loan Corp., wherein the Supreme Court addressed the need for interlocutory review of rights "too important to be denied review and too independent of the cause [of action] itself to require that appellate consideration be deferred until the whole case is adjudicated." 10 Recent cases require that an order, to be collateral and thus immediately appealable, "[1] conclusively determine the disputed question, [2] resolve an important issue completely separate from the merits of the action, and [3] be effectively unreviewable on appeal from a final judgment." 11 The latter factor embodies the same concern as addressed in the black letter here and in the statutes explicitly providing for immediate review of certain interlocutory orders; ${ }^{12}$ the other factors, however, do act as independent limitations on the availability of immediate review under the collateral order doctrine. ${ }^{13}$

5. See infra $\S 20$ of this Interlocutory Restatement; infra $\S 22$ of this Interlocutory Restatement, notes $5-6$ and accompanying text.

6. See infra $\S 21$ of this Interlocutory Restatement. An additional subsection of 28 U.S.C. $\$ 1292$ (a) provides for interlocutory review of certain orders in admiralty proceedings; these are beyond the scope of this Interlocutory Restatement.

7. E.g., Gardner v. Westinghouse Broadcasting Co., 437 U.S. 478, 480 (1978); Martin v. Partridge, 64 F.2d 591, 592 (8th Cir. 1933). This purpose in fact defines the occasions on which certain orders may be appealable as having the effect of refusing injunctions. See infra $\$ 17$ of this Interlocutory Restatement, notes 38-40 and accompanying text; $c$. infra $\S 28$ of this Interlocutory Restatement, notes 9-10 and accompanying text; infra $\S 30$ of this Interlocutory Restatement, comment $d$.

8. 28 U.S.C. $\$ 1291$ (1976).

9. Formal requirements for the entry of judgment are discussed supra $\S 3$ of this Interlocutory Restatement.

10. 337 U.S. 541,546 (1949). The Supreme Court drew on historical recognition of this doctrine, citing three prior decisions: Cobbledick v. United States, 309 U.S. 323, 328 (1940); United States v. River Rouge Improvement Co., 269 U.S. 411,414 (1926); Bank of Columbia v. Sweeney, 26 U.S. (1 Pet.) 567, 569 (1828) (per Marshall, C.J.). The collateral order doctrine thus developed in the context of provisional remedies, and its application is exemplified in the immediate review of orders denying or vacating pretrial security requirements or attachments (see infra $\S 19$ of this Interlocutory Restatement, comment a), as rights to such are moot after final decision. Note that even those orders, however, are not subject to interlocutory appeal when the right to security rests with the trial judge's discretion or when in the individual case there is no risk to the appellant arising from the denial of security. Id., comments $a \mathcal{E}^{\circ} b$.

11. Coopers \& Lybrand v. Livesay, 437 U.S. 463, 468 (1978). Additional examples of application of the collateral order doctrine may be found infra $\S 35$ of this Interlocutory Restatement, comment $b$ (grant of motion to disqualify counsel); infra $\S 28$ of this Interlocutory Restatement, comments $d \mathcal{G}^{2} e$ (refusal to terminate litigation on merits before trial when immunity is asserted or when appellant alleges a violation of a right to be heard on the pretrial motion); infra $\$ 17$ of this Interlocutory Restatement, Illustration 17-5 (stay order when right to be free from contempt proceeding asserted). Note also that the collateral order doctrine is not affected by the operation of Rule 54(b) of the Federal Rules of Civil Procedure. See supra $\S 4$ of this Interlocutory Restatement, note 8.

12. See supra text accompanying note 7 .

13. For example, entanglement with the merits forecloses collateral order review of district court refusals to appoint counsel, as the frivolity of the underlying claim is a factor to be considered in the 
Three additional circumstances in which orders which are actually interlocutory may be appealable as "final" within the meaning of 28 U.S.C. $\S 1291$ are detailed elsewhere in this Interlocutory Restatement. The most ancient of those doctrines, that of Forgay $v$. Conrad, addresses the possibility of irreparable harm where a partial remedy requires immediate transfer of property. ${ }^{14}$ Rule 54(b) of the Federal Rules of Civil Procedure now allows appeal from a decision as to one of multiple claims in a single action when the district judge has expressly found no just reason for delay. ${ }^{15}$ And finally, as recently expanded by the Supreme Court in Moses H. Cone Memorial Hospital v. Mercury Construction Corp., the doctrine of practical finality of stays looks to whether an order staying federal court litigation pending termination of proceedings in another forum is final in effect because the federal court will never resume proceeding or will not later be able to independently determine the issues initially before it. ${ }^{16}$

Finally, a practice of granting interlocutory review of certain types of orders has evolved from the power of the federal courts to grant writs of mandamus and prohibition under 28 U.S.C. $\$ 1651 .{ }^{17}$ This authority dates to the initial act establishing federal courts in $1789 .^{18}$ The first cases using the writ as a means of internal judicial control (rather than as a means of forcing executive officers to perform ministerial tasks) looked to the statutory language that such writs were to be used in aid of appellate jurisdiction ${ }^{19}$ and asserted that such jurisdiction was aided and protected by confining lower courts to the exercise of their lawful jurisdiction. ${ }^{20}$ "Jurisdiction" in this sense held little resemblance to traditional notions of subject matter or territorial jurisdiction; ${ }^{21}$ the focus was on whether the lower court had merely erred on a question which it was competent to decide and which would be reviewable in regular course or whether it had acted outside its authority. ${ }^{22}$ Additional formulations of the mandamus test looked to "usurpation of power" by the trial court ${ }^{23}$ or a "clear and indisputable" right to the writ. ${ }^{24}$

appointment. Appleby v. Meachum, 696 F.2d 145, 147 (1983); see also infra $\$ 34$ of this Interlocutory Restatement, note 1 . The same factor may also make the collateral order doctrine inapplicable to an order vacating an attachment when the ruling is based on a conclusion that the party seeking pretrial security is not likely to succeed on the merits. See infra $\S 19$ of this Interlocutory Restatement, note 5 . The requirement of a conclusive determination is not met in the case of orders denying class certification because such decisions are specifically subject to reconsideration under Rule 23(c)(1) of the Federal Rules of Civil Procedure. See infra $\$ 30$ of this Interlocutory Restatement, notes 2-5 and accompanying text.

14. 47 U.S. (6 How.) 201 (1948). See infra $\$ 22$ of this Interlocutory Restatement, comment $b$.

15. See supra $\S 4$ of this Interlocutory Restatement.

16. $103 \mathrm{~S}$. Ct. 927 (1983). See infra $\$ 17$ of this Interlocutory Restatement, comments c-e.

17. 28 U.S.C. $\$ 1651$ (1976).

18. Judiciary Act of 1789, ch. 20, $§ 14,1$ Stat. $73,81-82$.

19. E.g., Roche v. Evaporated Milk Ass'n, 319 U.S. $21,26,32$ (1943). See also Berger, The Mandamus Power of the United States Courts of Appeals: A Complex and Confused Means of Appellate Conirol, 31 BurraLo L. REV. 37, 42 (1982).

20. Roche v. Evaporated Milk Ass'n, 319 U.S. 21, 26 (1943).

21. Berger, supra note 19 , at 42 .

22. Id. at $44-45$.

23. DeBeers Consol. Mines v. United States, 325 U.S. 212, 217 (1945)

24. Bankers Life \& Casualty Co. v. Holland, 346 U.S. 379, 384 (1953). Thus, mandamus may issue to confine a court to statutory language that leaves no room for discretion; examples include certain of the new judicial disqualification standards, infra $\$ 24$ of this Interlocutory Restatement, notes $30-37$ and accompanying text, and the limitation on remands to state courts, infra $\S 16$ of this Interlocutory Restatement, comment d. See also, e.g., $\$ 17$ of this Interlocutory Restatement, notes $29-30$ and accompanying text 
Next, what may be labeled a "supervisory" use of mandamus developed. ${ }^{25}$ The Supreme Court issued the writ to gain adherence to appellate rulings on the proper interpretation of the Federal Rules of Civil Procedure that were being ignored by the district courts. ${ }^{26}$ Such use of the writ protects appellate jurisdiction by recognizing the limits, because of the harmless error doctrine, of review after final decision in providing the ordinary check on judicial action. ${ }^{27}$ Finally, mandamus has been used to serve what may be characterized as an "advisory" function in the review of questions of first impression to promote uniformity and forestall recurring error. ${ }^{28}$ Note that this Interlocutory Restatement does not embrace this use; ${ }^{29}$ the principal Supreme Court case affirming this practice also includes the more traditional mandamus element of lack of power of the lower court to enter the given order. ${ }^{30}$

Today, mandamus is an ill-defined jurisdiction for challenging interlocutory orders, even though the statutory language provides no clue as to this role. ${ }^{31}$ Where an order falls within an established category where mandamus is available, ${ }^{32}$ where special circumstances exist, or where review after final decision is inadequate, an interlocutory appeal is assured of full consideration on the merits; ${ }^{33}$ however, such factors are not "jurisdictional" in the sense that their absence causes cursory dismissal for lack of appealability. ${ }^{34}$ Some consideration of the merits is inherently involved under current standards in determining the appropriateness of mandamus, ${ }^{35}$ and relief can in effect be obtained without issuance of the writ. ${ }^{36}$

While mandamus, collateral orders, and explicit statutory interlocutory appeals can rarely be said to overlap, ${ }^{37}$ the lines distinguishing them-particularly

(exclusive federal jurisdiction); $§ 27$ of this Interlocutory Restatement, comment $b$ (references to magistrates); $\S 43$ of this Interlocutory Restatement, comment $c$ (improper reopening of judgment).

25. Berger, supra note 19 , at 49 .

26. LaBuy v. Howes Leather Co., 352 U.S. 249 (1957). This case is discussed further infra $\S 27$ of this Interlocutory Restatement, notes $6-18$ and accompanying text.

27. Berger, supra note 19 , at 50 .

28. Id. at 51-52.

29. See infra $\$ 37$ of this Interlocutory Restatement, comment d.

30. Schlagenhauf v. Holder, 379 U.S. 104, 110-11 (1964).

31. "The Supreme Court and all courts established by Act of Congress may issue all writs necessary or appropriate in aid of their respective jurisdictions and agreeable to the usages and principles of law." 28 U.S.C. 1651 (a) (1976).

32. Berger, supra note 19, at 61-64, lists these categories as denial of right to a jury trial (see infra $\$ 25$ of this Interlocutory Restatement, comment b), refusal of a judge to disqualify himself (see infra $\S 24$ of this Interlocutory Restatement, comment $c$ ), and privilege (see infra $\$ 23$ of this Interlocutory Restatement, text accompanying notes 6-7; infra $\S 35$ of this Interlocutory Restatement, note 9 and accompanying text; infra $\S 37$ of this Interlocutory Restatement, comment $c$; cf. id. comment $h$ ).

33. Berger, supra note 19 , at 76, 78. For examples of these additional uses of mandamus, see infra $\S 19$ of this Interlocutory Restatement, comment $g$ (civil arrest); infra $\S 20$ of this Interlocutory Restatement, comment $f$ (irreparable harm); infra $\S 37$ of this Interlocutory Restatement, comment $d$ (privacy); infra $\S 39$ of this Interlocutory Restatement, comment $d$ (right to be heard before impositions of sanctions).

34. Berger, supra note 19, at 77. Mandamus is strictly jurisdictional only in that it is not available if another avenue of interloctory review is available.

35. Id. at 77,78 .

36. Id. at $65-68,85-86$.

37. Privilege claims, however, have been found subject to interlocutory review both under the collateral order doctrine and through the use of mandamus. Compare infra $\S 37$ of this Interlocutory Restatement, comment $c$ (absolute privilege against discovery asserted by a party; review through mandamus) with id., comment h (privilege of third party asserted by nonparty to action reviewable as collateral); compare also 
the lines between the first two-are quite evanescent. Moreover, any distinction seems to be lacking in genuine importance. In general, a proceeding in a court of appeals that can be sustained in any form will be heard even though the party seeking the noncertified interlocutory appeal has asserted the incorrect statutory basis. ${ }^{38}$ It is an important purpose of this Interlocutory Restatement to urge abandonment of the unhelpful language of these various doctrines and to state the law governing interlocutory appeals in a manner that will clarify the nature and purpose of all such proceedings.

b. Scope of Review. An order subject to interlocutory appeal without certification will be reviewed only as to portions relevant to the ruling justifying such appeal. This practice furthers the policy against piecemeal appeals. ${ }^{39}$ Courts, however, while reaching generally similar results, disagree as to whether this limitation is jurisdictional or a matter of judicial restraint. ${ }^{40}$

Though the Supreme Court itself has reserved this issue, ${ }^{41}$ the Third Circuit recently interpreted high court precedents as pointing toward a jurisdictional limit on the review of claims "pendent" to immediately appealable injunctive orders. ${ }^{42}$ Two cases had restricted the concept of an order being appealable under 28 U.S.C. $\S 1292(a)(1)$ as having the effect of an injunction on the basis of a narrow construction of that statute, given its function as an exception to the final decision rule to protect against irreparable consequences. ${ }^{43}$ The same narrow construction would allow incidental review of otherwise unappealable orders only where the injunction could not "properly be decided without reference to" the pendent question. ${ }^{44}$ It would not be sufficient that the orders were factually related; they were to be "inextricably bound." 45 Such a jurisdictional limit, the Third Circuit continued, would avoid the disruption of the trial court function caused by taking matters out

cases cited within id., comment $d$ (right of privacy asserted as to discovery request; both mandamus and collateral order used to justify interlocutory review).

38. See infra $\S 13$ of this Interlocutory Restatement, notes 17-20 and accompanying text.

39. Alexander v. Chicago Park Dist., 709 F.2d 463, 470 (7th Cir. 1983); Rosenfeldt v. Comprehensive Account Serv. Corp., 514 F.2d 607, 711 n.5 (7th Cir. 1975). See also Kershner v. Mazurkiewicz, 670 F.2d 440, 450 (3d Cir. 1982) (Seitz, C.J., concurring). For a recent reiteration of the concerns underlying the policy against piecemeal appeals, see Firestone Tire \& Rubber Co. v. Risjord, 449 U.S. 368, 374 (1981); Berger, supra note 19, at 93-95.

40. Association of Co-op Members v. Farmland Indus., 684 F.2d 1134, 1138 (5th Cir. 1982), cert. denied, 103 S. Ct. 1428 (1983) (recognizing both positions but finding it unnecessary on the facts to choose between them).

41. Gardner v. Westinghouse Broadcasting Co., 437 U.S. 478,479 n.3 (1978).

42. Kershner v. Mazurkiewicz, 670 F.2d 440 (3d Cir. 1982). The opinion traces the various positions once taken even within the Third Circuit and ends up overruling several decisions. Id. at 445-49.

43. Gardner v. Westinghouse Broadcasting Co., 437 U.S. 478 (1978) (discussed infra $\$ 30$ of this Interlocutory Restatement, comment d); Switzerland Cheese Ass'n v. E. Horne's Market, 385 U.S. 23 (1966) (discussed infra $\S 28$ of this Interlocutory Restatement, text accompanying notes 9-10).

44. Kershner v. Mazurkiewicz, 670 F.2d 440, 449 (3d Cir. 1982). The court also looked to whether failure to consider the pendent issue would in effect deprive the appellant of the right to meaningful interlocutory review under 28 U.S.C. $\$ 1291$ (a)(1). Id. Cf. Long v. Bureau of Econ. Analysis, 646 F.2d 1310, 1318 (9th Cir.), vacated on other grounds, 454 U.S. 934 (1981).

45. Kershner v. Mazurkiewicz, 670 F.2d 440, 449 (3d Cir. 1982). In declining to extend jurisdiction to the incidental order in the case before it, where the plaintiff sought review of the denial of class certification on appeal from the denial of a preliminary injunction, the Third Circuit noted that the district judge had made the decision on injunctive relief first and without reference to the class issue and that such decision could have gone either way while still denying class status. Id. at $450-51$. 
of the district judge's hands prematurely. ${ }^{46}$ Furthermore, a broad finding of appealability would undermine the final decision rule, invite abuse, and encourage parties to assert frivolous claims and counterclaims for injunctive relief as mechanisms to gain review of other orders. ${ }^{47}$

The Third Circuit similarly finds limited jurisdiction to review other issues in a case when a portion of an order is immediately appealable under the collateral order doctrine. For example, in Akerly v. Red Barn System, that court reviewed an order disqualifying counsel for conflict of interest as collateral, ${ }^{48}$ but held it could not also consider the trial judge's refusal to dismiss the complaint for the same conflict of interest. ${ }^{49}$ The Third Circuit justified this finding of no jurisdiction as consistent with the general restrictive attitude toward use of the collateral order doctrine and distinguished the broader scope of review allowed incidental to orders certified for immediate appeal under 28 U.S.C. $\$ 1292$ (b) in that that statute is in part addressed to judicial economy and the avoidance of unnecessary trials. ${ }^{50}$ The collateral order doctrine, in contrast, looks in part to separability of the issue to be reviewed from the merits. ${ }^{51}$ Other circuits have found support for this position in a Supreme Court decision in a criminal case which held that each claim, to be immediately reviewable along with a collateral order, had to itself fall within that doctrine. ${ }^{52}$

The contrary view that considerations of judicial administration govern review of pendent issues in conjunction with review of orders properly subject to interlocutory appeal is illustrated in the opinions of the Second Circuit. Decisions there hold that a preliminary injunction brings the entire order before the appellate court $^{53}$ and that such court has discretion to review the entire order or as much of

\footnotetext{
46. Id. at 449 .

47. Id.

48. See infra $\S 35$ of this Interlocutory Restatement, comment $b$.

49. 551 F.2d 539 (3d Cir. 1977).

50. Id. at 543. See supra $\S 11$ of this Interlocutory Restatement, comment e, for a discussion of scope of review of certified appeal.
}

51. Kershner v. Mazurkiewicz, 670 F.2d 440, 453 (3d Cir. 1982). See supra text accompanying note 11 for a listing of the requirements of the collateral order doctrine.

52. Abney v. United States, 431 U.S. 651 (1977). In that case a motion to dismiss based on the double jeopardy clause of the Constitution was immediately appealable as collateral, but the Court found no jurisdiction to review also the failure to dismiss the indictment as insufficient to charge an offense. This holding was based on the need to limit collateral review to circumstances giving rise to the special considerations underlying that doctrine; the Court also expressed the same concern as noted by the Third Circuit (supra text accompanying note 47) for assertion of frivolous but appealable claims to gain review of other orders. 431 U.S. at 663.

For an example of a circuit case relying on Abney, see MacKethan v. Peat, Marwick, Mitchell \& Co., 557 F.2d 395 (4th Cir. 1977). An initial per curiam decision finding pendent jurisdiction to review the dismissal of a third party complaint along with review as collateral order of a refusal to disqualify counsel (note that the Supreme Court has since resolved a circuit conflict as to this use of the collateral order doctrine in a contrary fashion; see infra $\S 35$ of this Interlocutory Restatement, comment a) was modified on rehearing to withdraw the decision on the third party complaint on the ground that it was made in the absence of appellate jurisdiction. Id. at 396. See also Babcock \& Wilcox Co. v. Marshall, 610 F.2d 1128, 1133 n.10 (3d Cir. 1979) (Abney "casts doubt on" the principle that an order otherwise not subject to interlocutory review will be considered on appeal of an immediately reviewable order).

53. Erving v. Virginia Squires Basketball Club, 468 F.2d 1064, 1067 (2d Cir. 1972). 
it as it deems appropriate. ${ }^{54}$ The test applied to determine the propriety of incidental review is generally that of "overlap," that is, whether the injunction involves factors relevant to the otherwise nonappealable order. ${ }^{55}$ For example, the Second Circuit has exercised its power to review a pendent denial of class certification when such order reflected the same fundamental error as to the nature of the right asserted as did the decision on the preliminary injunction, 56 but it has declined to exercise its discretion to consider a partial grant of dismissal for failure to state a claim when the denial of the preliminary injunction was based on the lack of an irreparable injury rather than on the slim likelihood of success on the merits. ${ }^{57}$ This practice is justified by time savings and judicial efficiency, as the broader review is granted only when such would require no greater effort on the part of the court of appeals than if review were to be strictly confined to the independently appealable order. ${ }^{58}$ The Second Circuit applies the same standard when the pendent issues arise in connection with an interlocutory appeal under the collateral order doctrine. ${ }^{59}$ The circuit's most recent decision, however, although allowing incidental review of a denial of class certification with appeal of the denial of a preliminary injunction, spoke of the "substantial interdependence" and "inextricable relationship" of the orders, ${ }^{60}$ language more generally associated with the Third Circuit's "limited jurisdiction" approach.

Decisions of other circuits all require significant degrees of interrelation before otherwise nonappealable orders will be considered along with appealable orders on interlocutory review, but many give similarly ambiguous signals as to whether such limitation is jurisdictional or discretionary or fail to address that underlying point. Both the Fifth and Ninth Circuits, for example, in the past have asserted that appellate jurisdiction extends to the entire interlocutory order and that scope of review is dictated by judicial economy and concerns with the orderly administration of justice. ${ }^{61}$ Subsequent decisions in the Ninth Circuit combine this concept with a requirement that orders to be so considered be "inextricably intertwined"62 or that the nonappealable order "underlie" the appealable order, ${ }^{63}$

54. Marcera v. Chinlund, 595 F.2d 1231, 1236 n.8 (2d Cir.), vacated on other grounds sub nom. Lombard v. Marcera, 442 U.S. 915 (1979); New York v. Nuclear Regulatory Comm'n, 550 F.2d 745, 760 (2d Cir. 1977).

55. New York v. Nuclear Regulatory Comm'n, 550 F.2d 745, 759 \& n.8 (2d Cir. 1977).

56. Marcera v. Chinlund, 595 F.2d 1231, 1236 n.8 (2d Cir.), vacated on other grounds sub nom. Lombard v. Marcera, 442 U.S. 915 (1979).

57. New York v. Nuclear Regulatory Comm'n, 550 F.2d 745, 760-62 (2d Cir. 1977).

58. Id. at 760; Marcera v. Chinlund, 595 F.2d 1231, 1236 n.8 (2d Cir.), vacated on other grounds sub nom. Lombard v. Marcera, 442 U.S. 915 (1979).

59. E.g., Sanders v. Levy, 558 F.2d 636 (2d Cir. 1976) (sufficient overlap in relevant factors to justify review of grant of class certification with review as collateral order of requirement that the defendant bear the costs of identifying members of the plaintiff class for purposes of notice), affd en banc, $558 \mathrm{~F} .2 \mathrm{~d} 646$ (1977), rev'd on other grounds sub nom. Oppenheimer Fund v. Sanders, 437 U.S. 340 (1978); General Motors Corp. v. City of New York, 501 F.2d 639 (2d Cir. 1974) (insufficient overlap to warrant review of grant of class status with review of order denying disqualification of counsel then appealable (see infra $\S 35$ of this Interlocutory Restatement, comment $a$ ) as a collateral order).

60. Port Authority Policy Benevolent Ass'n v. Port Authority, 698 F.2d 150, $152-53$ (2d Cir. 1983).

61. Yamamoto v. Omiya, 564 F.2d 1319, 1325 n.11 (9th Cir. 1977); Mercury Motor Express v. Brinke, 475 F.2d 1086, 1091 (5th Cir. 1973).

62. Long v. Bureau of Econ. Analysis, 646 F.2d 1310, 1317 (9th Cir.), vacated on other grounds, 454 U.S. 934 (1981).

63. Fentron Indus. v. National Shopman Pension Fund, 674 F.2d 1300, 1304 (9th Cir. 1982). 
while a more recent Fifth Circuit decision speaks of whether the two orders are "directly tied" and whether the nonappealable order "underpins" the appealable one. ${ }^{64}$ Courts of the Seventh and Eighth Circuits, which make no assertions as to discretion to hear the entire order, look to whether the appealable and nonappealable portions of an order are "interdependent" 65 or whether the nonappealable portion "directly controls," 66 "underlies,"67 or "becomes a part of"68 the appealable portion.

The type of order for which incidental review is most often sought is seemingly that dealing with class certification. Further, such review is seemingly frequently available, as decisions as to the scope or existence of the class affect the injury that can be alleged and thus the appropriateness and scope of injunctive relief. For example, an injunction denied because of mootness as to the individual plaintiff might be warranted in regard to the potential class for which certification had been requested. ${ }^{69}$ Incidental review will not be available, however, when the immediately appealable order was based on reasons independent of whether the suit was maintained individually or as a class action. ${ }^{70}$

Sufficient interrelation to justify immediate pendent review is also likely to be found when a transfer of venue is sought because of the existence of parallel litigation in two or more federal districts ${ }^{71}$ or when severance of claims ${ }^{72}$ or interpleader is involved. ${ }^{73}$ On occasion, a motion concerning pleading may be held to be "inextricably intertwined" with an injunction so as to warrant immediate review, ${ }^{74}$ but

64. Payne v. Travenol Laboratories, 673 F.2d 798, 808 (5th Cir.), cert. denied, 103 S. Ct. 451 (1982).

65. In re Federal Skywalk Cases, 680 F.2d 1175, 1180 (8th Cir.), cert. denied, 103 S. Ct. 342 (1982); Adashunas v. Negley, 626 F.2d 600 (7th Cir. 1980).

66. Jenkins v. Blue Cross Mut. Hosp. Ins., 522 F.2d 1235, 1238 (7th Cir.), affd on rehearing, 538 F.2d 164, 166 n.2 (1975), cert. denied, 429 U.S. 986 (1976).

67. Helene Curtis Indus. v. Church \& Dwight Co., 560 F.2d 1325, 1335 (7th Cir. 1977), cert. denied, 434 U.S. 1070 (1978); Rosenfeldt v. Comprehensive Account Serv. Corp., 514 F.2d 607, 611 n.5 (7th Cir. 1975).

68. Helzberg's Diamond Shops v. Valley West Shopping Center, 564 F.2d 816, 818 (8th Cir. 1977).

69. Adashunas v. Negley, 626 F.2d 600 (7th Cir. 1980). See also Port Authority Police Benevolent Ass'n v. Port Authority, 698 F.2d 150 (2d Cir. 1983) (denial of preliminary injunction based on unlikelihood of success on merits, which finding was based solely on the denial of class certification); Payne v. Travenol Laboratories, 673 F.2d 798 (5th Cir.) (injunctive relief limited by exclusion of black males from class and improper determination of relevant time for class membership. The injunction here was not preliminary but instead constituted part of the requested relief, a factor which weighed in the discussion of judicial economies in a broad scope of immediate review, id. at 808 n.6. Interrelatedness, however, seemed to be controlling as to reviewability. Similarly, see Alexander v. Aero Lodge No. 735, 565 F.2d 1364 (6th Cir. 1977), cert. denied, 436 U.S. 946 (1978)), cert. denied, 103 S. Ct. 451 (1982).

For examples of pendent review of class certification where the relationship of the orders was less dramatic, see Fentron Indus. v. National Shopman Pension Fund, 674 F.2d 1300 (9th Cir. 1982); Marcera v. Chinlund, 595 F.2d 1231 (2d Cir.) (applying Second Circuit "overlap" test), vacaled on other grounds sub nom. Lombard v. Marcera, 442 U.S. 915 (1979); Yamamoto v. Omiya, 564 F.2d 1319 (9th Cir. 1977); Sanders v. Levy, 558 F.2d 636 (2d Cir. 1967) (applying Second Circuit "overlap" test), affd en banc, 558 F.2d 646 (1977), rev'd on other grounds sub nom. Oppenheimer Fund v. Sanders, 437 U.S. 340 (1978).

70. Loya v. Immigration \& Naturalization Serv., 583 F.2d 1110 (9th Cir. 1978). See also Kershner v. Mazurkiewicz, 670 F.2d 440 (3d Cir. 1982); General Motors Corp. v. City of New York, 501 F.2d 639 (2d Cir. 1974) (applying Second Circuit "overlap" test).

71. See infra $\S 15$ of this Interloctory Restatement, notes 66-67 and accompanying text. Note that absent the entanglements of parallel litigation, a transfer decision generally will not be sufficiently related to warrant pendent review. E.g., Brick v. CPC Int'l, Inc., 547 F.2d 185 (2d Cir. 1978).

72. See infra $\S \mathbf{4 0}$ of this Interlocutory Restatement, comment $c$.

73. See infra $\$ 29$ of this Interlocutory Restatement, notes $50-52$ and accompanying text.

74. Long v. Bureau of Econ. Analysis, 646 F.2d 1310 (9th Cir.) (denial of motion to amend complaint 
generally such orders ${ }^{75}$ and discovery orders $^{76}$ would appear to lack the necessary nexus to the immediately appealable order.

Illustration. $\mathrm{P}$ brings suit against $\mathrm{D}$, an employer, alleging discrimination in certain promotional and employee evaluation practices. P's request to have a class of employees certified is denied. Then, a request for a preliminary injunction as to the challenged practices is denied because $P$, who is no longer employed by $D$, can show no irreparable injury. $P$ properly appeals the denial of the injunction under 28 U.S.C. $\S 1292(a)(1)^{77}$ and seeks also to raise the issue of denial of class certification. P should be heard as to both issues because the refusal to grant class status limited the availability of injunctive relief. ${ }^{78}$

Even courts which share the Third Circuit's position that limitations on pendent appeals are jurisdictional generally recognize two "exceptions."79 The first of these holds that an order imposing civil contempt sanctions for violation of a prior order, such as an injunction, subject to interlocutory appeal may be reviewed in conjunction with the appeal from that prior order. ${ }^{80}$ The second exception, drawn from the Supreme Court decision in Deckert v. Independence Shares Corp., holds that an appellate court on interlocutory review should consider any otherwise nonappealable order which might constitute an "insuperable objection to maintaining the bill."81 In Deckert, the Court reviewed on appeal from the grant of a preliminary injunction the denial of the defendant's motion to dismiss for failure to state a claim and lack of subject matter jurisdiction. ${ }^{82}$ Additional traditional examples of orders subject to incidental review as possibly giving rise to "insuperable objections" are refusals to dismiss for improper venue or for lack of personal

to assert new defense reviewed with appeal of grant of injunction because such defense might affect appropriateness of injunctive relief), vacated on other grounds, 454 U.S. 934 (1981).

75. Concerned Citizens of Bushkill Township v. Costle, 592 F.2d 164 (3d Cir. 1979) (denial of motion seeking leave to file supplemental answer including cross-claims not reviewable on appeal of denial of preliminary injunction).

76. Williams v. Curtiss-Wright Corp., 681 F.2d 161 (3d Cir. 1982) (order requiring the production of documents not reviewable on appeal of grant of injunction); NLRB v. Interstate Dress Carriers, Inc., 610 F.2d 99 (3d Cir. 1979) (discovery order not reviewable on appeal of grant of injunction).

77. See infra $\S 20$ of this Interlocutory Restatement on appealability of preliminary injunctions.

78. Jenkins v. Blue Cross Mut. Hosp. Ins., 522 F.2d 1235 (7th Cir.), affd on rehearing, 538 F.2d 164 (1975), cert. denied, 429 U.S. 986 (1976).

79. Kershner v. Mazurkiewicz, 670 F.2d 440, 449 nn. 10 \& 12 (3d Cir. 1982).

80. E.g., In re Arthur Treacher's Franchisee Litig., 689 F.2d 1150 (3d Cir. 1982); see also infra $\S 23$ of this Interlocutory Restatement, notes 33-38, and accompanying text.

81. 311 U.S. 282, 287 (1940) (quoting Meccano, Ltd. v. Wanamaker, 253 U.S. 136, 141 (1920))

82. For subsequent examples of such pendent review, see Fentron Indus. v. National Shopman Pension Fund, 674 F.2d 1300 (9th Cir. 1982) (standing reviewed on appeal of grant of preliminary injunction); San Filippo v. United Bhd. of Carpenters \& Joiners, 525 F.2d 508 (2d Cir. 1975) (absence of subject matter jurisdiction reviewed on appeal of denial of preliminary injunction); Genosick v. Richmond Unified Sch. Dist., 479 F.2d 482 (9th Cir. 1973) (refusal to dismiss for failure to state facts on which relief could be granted reviewed on appeal of grant of preliminary injunction); cases cited infra $\S 16$ of this Interlocutory Restatement, note 73. See also NLRB v. Interstate Dress Carriers, Inc., 610 F.2d 99, 104 (3d Cir. 1979) (dicta). But cf. Fano v. Meachum, 520 F.2d 374, 377 n.4 (1st Cir. 1975) (refusing to review denial of motion to dismiss in conjunction with appeal of grant of injunction. The court, however, cited as precedent a case where a denial of summary judgment was refused pendent review; such an order is distinguishable as going only to the existence of a material issue of fact and not raising an insuperable objection to maintenance of the underlying action), rev'd on other grounds, 427 U.S. 215 (1976). 
jurisdiction. ${ }^{83}$

Newer decisions suggest how orders falling within this "exception" may also be characterized merely as examples of sufficient interrelation to justify review. For example, consideration of a refusal to dismiss for lack of subject matter jurisdiction could be seen as necessary to full and meaningful review ${ }^{84}$ of the grant of a preliminary injunction in that lack of jurisdiction would be a ground for attacking the injunction and would, if decided in favor of the appellant, require reversal regardless of other issues as to the merits of the injunction. Similarly, the Third Circuit has suggested in dicta that a failure to abstain under the Younger or Burford ${ }^{85}$ doctrines might be advanced as a ground for overturning a grant of injunctive relief, thus making the denial of a stay reviewable incident to the appealable interlocutory order. ${ }^{86}$ A refusal to dismiss for failure to join an indispensable party who was outside the jurisdiction of the $\operatorname{court}^{87}$ or a refusal by a judge to disqualify himself with the result that his other orders could be vacated for bias ${ }^{88}$ might also be seen either as giving rise to an "insuperable objection" to the independently appealable interlocutory order or as being "inextricably intertwined" so as to justify pendent review.

Some question as to the "insuperable objection" doctrine might be raised, however, through the cases in which it seemingly might have been applied but was not even discussed. ${ }^{89}$ Such examples may be mere anomalies, or they may indicate a new reluctance to invoke the doctrine when the pendent objection is failure to state a claim, which, in contrast to an issue such as jurisdiction, is not independent of a final decision on the merits such that error could warrant reversal even though such final decision was, in a sense, "correct."

c. No Waiver of Nonappealability. Federal appellate courts possess only those powers of review granted by acts of Congress, ${ }^{90}$ and thus the issue as to whether a

83. E.g., Lee v. Ply*Gem Indus., 593 F.2d 1266 (D.C. Cir.), cert. denied, 441 U.S. 967 (1979).

84. See supra note 44 .

85. These doctrines, so titled from the Supreme Court cases in which they were announced (Younger v. Harris, 401 U.S. 37 (1971), and Burford v. Sun Oil Co., 319 U.S. 315 (1943), respectively), hold that for various reasons certain litigations are more appropriately resolved in state courts and that federal courts presented with such cases should thus stay the exercise of their jurisdiction or dismiss. See infra $\S 17$ of this Interlocutory Restatement, note 6.

86. Hotel \& Restaurant Employees Int'l Union Local 54 v. Danziger, 709 F.2d 815, 821 (3d Cir.), petition for cert. fled, 52 U.S.L.W. 3294 (U.S. Oct. 11, 1983) (No. 83-573). Cf. Mercury Motor Express v. Brinke, 475 F.2d 1086, 1091 (5th Cir. 1973) (grant of stay pending administrative proceedings within scope of review of denial of preliminary injunction as being "necessary" for orderly administration of justice) (also cited infra $\S 17$ of this Interlocutory Restatement, note 41).

87. Helzberg's Diamond Shops v. Valley West Shopping Center, 564 F.2d 816, 818 (8th Cir. 1977).

88. In re Federal Skywalk Cases, 680 F.2d 1175, 1180, 1184 (8th Cir.), cert. denied, 103 S. Ct. 342 (1982). But see Alexander v. Chicago Park Dist., 709 F.2d 463, 470 (7th Cir. 1983) (refusal of judge to disqualify himself not reviewable in conjunction with appeal of denial of preliminary injunction as orders were substantially unrelated).

89. E.g., Abney v. United States, 431 U.S. 651 (1977) (discussed supra note 52); New York v. Nuclear Regulatory Comm'n, 550 F.2d 745 (2d Cir. 1977).

90. Save the Bay, Inc. v. United States Army, 639 F.2d 1100, 1102 (5th Cir. 1981). See also Carroll v. United States, 354 U.S. 394, 399 (1975). For a fuller discussion of this issue and possible arguments to the contrary, see supra $\S 1$ of this Interlocutory Restatement, comment $a$. . 
given appeal is authorized by any such statute is jurisdictional. ${ }^{91}$ A court has no discretion to hear an appeal without jurisdiction; 92 and as with underlying subject matter jurisdiction of initial suits, ${ }^{93}$ lack of appealability cannot be waived, nor may appellate jurisdiction be conferred by agreement of the parties. ${ }^{94}$ When a question exists on the record, a court has a duty to raise the issue of appealability on its own motion. ${ }^{95}$ Failure of the parties to raise the issue does not preclude its consideration. ${ }^{96}$

There is no apparent functional reason, however, why objection to the absence of appellate jurisdiction should be nonwaivable. While the characterization of the availability of appellate review as subject matter jurisdiction may be apt, it is difficult to see what substantial harm might result from allowing an appellee to waive objection. A court of appeals might imaginably reverse an erroneous ruling of a district court which might otherwise have survived, but the relationship between trial and appellate courts seems neither so fragile nor substantial that a court of appeals should be required to take leave of the adversary process in order to avoid damage to that relationship resulting from an untimely but correct reversal of an erroneous ruling.

\section{§ 13. Commencement of Interlocutory Appeal.}

(A) A CERTIFIED APPEAL MAY BE COMMENCED BY FILING A PETITION FOR PERMISSION TO APPEAL, WITH PROOF OF SERVICE ON ALL PARTIES TO THE ACTION, WITH THE CLERK OF THE COURT OF APPEALS WITHIN TEN DAYS AFTER THE ENTRY OF THE ORDER AND CERTIFICATE BY THE DISTRICT COURT. THE PETITION MUST IDENTIFY THE QUESTION OF LAW TO BE PRESENTED FOR DECISION AND MUST ALSO EXPLAIN THE BEARING OF THE QUESTION ON THE OUTCOME OF THE CASE.

(B) A NONCERTIFIED INTERLOCUTORY APPEAL MAY BE COMMENCED BY FILING A NOTICE OF APPEAL WITH THE CLERK OF EITHER THE DISTRICT COURT OR THE COURT OF APPEALS. IF THE APPEAL IS FILED IN THE DISTRICT COURT, IT SHALL BE THE DUTY OF THE CLERK TO NOTIFY ALL PARTIES; BUT IF THE APPEAL IS FILED IN THE COURT OF APPEALS, IT MUST BE ACCOMPANIED BY PROOF OF SERVICE ON ALL PARTIES. AN APPEAL FILED WITH

91. Save the Bay, Inc. v. United States Army, 639 F.2d 1100, 1102 (5th Cir. 1981); see also Firestone Tire \& Rubber Co. v. Risjord, 449 U.S. 368, 379 (1981).

92. Firestone Tire \& Rubber Co. v. Risjord, 449 U.S. 368, 379 (1981).

93. See supra $\S 9$ of this Interlocutory Restatement, notes 216-18 and accompanying text; infra $\S 16$ of this Interlocutory Restatement, notes 74-76 and accompanying text.

94. Association of Co-op Members v. Farmland Indus., 684 F.2d 1134, 1137 (5th Cir. 1982), cert. denied, 103 S. Ct. 1428 (1983). See also In re General Motors Engine Interchange Litig., 594 F.2d 1106 (7th Cir.) (appealability not determined by a majority vote of counsel), cert. denied, 444 U.S. 870 (1979).

95. Liberty Mut. Ins. Co. v. Wetzel, 424 U.S. 737, 740 (1976). E.g., In re Yarn Processing Patent Validity Litig., 680 F.2d 1338 (11 th Cir. 1982) (parties allowed to file supplemental briefs on jurisdiction issue); In re Grand Jury Proceedings, 636 F.2d 81 (5th Cir. 1981); Arango v. Guzman Travel Advisors Corp., 621 F.2d 1371 (5th Cir. 1980).

96. Oswalt v. Scripto, 616 F.2d 191, 192 (5th Cir. 1980). 
THE DISTRICT COURT MUST BE FILED WITHIN THE USUAL TIME LIMITS AS DEFINED IN SECTION 6 OF THIS RESTATEMENT, THE TIME FOR APPEAL RUNNING FROM THE DATE OF THE ORDER FROM WHICH THE APPEAL IS TAKEN. AN APPEAL FILED WITH THE COURT OF APPEALS IS SUBJECT TO LACHES. WHEREVER FILED, THE NOTICE SHOULD BE ACCOMPANIED BY A BRIEF STATEMENT EXPLAINING THE PURPOSE OF THE APPEAL.

\section{COMMENT}

a. Certified Appeals. A certified interlocutory appeal' ${ }^{1}$ is commenced by filing a petition for permission to appeal with the clerk of the court of appeals within ten days after the entry of the certified order by the district court. ${ }^{2}$ Failure to file such a petition within this time span "is a jurisdictional defect that deprives the appellate court of power to entertain the appeal." 3 If, however, the order is amended or vacated and reentered, the ten-day limitation period begins on the date of such amendment or reentry, unless allowance of the appeal would disserve judicial efficiency. ${ }^{4}$ Furthermore, the required petition for permission to appeal itself must be filed within the ten-day period; a notice of appeal is not sufficient to satisfy the jurisdictional requirement. ${ }^{5}$ The petition must be accompanied by proof of service on all parties to the action. ${ }^{6}$

In content, the petition must contain a statement of the facts necessary to an understanding of the controlling question of law certified by the order of the district court, a statement of the question itself, a statement of the reasons why a substantial basis exists for a difference of opinion on the question, and a statement of why an immediate appeal may materially advance the termination of the litigation. ${ }^{7}$ The petition further must have the order and opinion annexed, ${ }^{8}$ and it must include independent arguments as to why the court of appeals should exercise its discetion in allowing the appeal. ${ }^{9}$

b. Noncertified Interlocutory Appeals. An interlocutory appeal available without certification for a restricted purpose ${ }^{10}$ may be commenced by filing a notice of appeal with the clerk of either the district court or the court of appeals. By filing

1. See supra $\S 11$ of this Interlocutory Restatement.

2. See 28 U.S.C. § 1292(b) (1976); FED. R. APP. P. 5(a)

3. Aparicio v. Swan Lake, 643 F.2d 1109, 1111 \& n.3 (5th Cir. 1981). See also Local P-171, Amalgamated Meat Cutters v. Thompson Farms Co., 642 F.2d 1065, 1068-69 (7th Cir. 1981); Cole v. Tuttle, 540 F.2d 206, 207 n.2 (5th Cir. 1976). Cf. supra $\S 6$ of this Interlocutory Restatement, notes 3-4 and accompanying text (failure to file notice of appeal from final decision within time allowed is jurisdictional defect).

4. See Nuclear Eng'g Co. v. Scott, 660 F.2d 241 (7th Cir. 1981); Nakhleh v. Chemical Constr. Corp., 366 F. Supp. 1221, 1223 (S.D.N.Y. 1973) (reconsideration must be genuine). Note that the amendment may be for the sole purpose of adding the grant of certification; clearly the ten-day period cannot start to run until this time as this is when the certified order was entered.

5. See Aparicio v. Swan Lake, 643 F.2d 1109, 1111 \& n.3 (5th Cir. 1981); In re La Providencia Dev. Corp., 515 F.2d 94 (1st Cir. 1975).

6. See FED. R. APP. P. 5(a).

7. FED. R. APP. P. 5(b).

8. Id.

9. See 16 C. Wright, A. Miller, E. Cooper \& F. Gressman, Federal Practice and Procedure $\S 3951$, at 369 (1971) [hereinafter cited as C. WRIGHT \& A. MILLER].

10. See supra $\S 12$ of this Interlocutory Restatement, comment $a$. 
the notice of appeal in the district court, the appellant satisfies the notice requirements of Rule 3(a) of the Federal Rules of Appellate Procedure, and it is the duty of the clerk to notify all parties. ${ }^{1}$ If the interlocutory appeal is filed with the clerk of the court of appeals, however, the appellant under Rule 21 of the Federal Rules of Appellate Procedure must accompany such appeal with proof of service on all parties. ${ }^{12}$

Theoretically, these notice requirements apply to two different types of interlocutory review: Rule 3 applies to appeals as of right whereas Rule 21 applies to applications for writs. ${ }^{13}$ Either method, however, suffices to notify the nonappealing party of the appellant's intention to have an order of the district court reviewed. ${ }^{14}$ Despite the doctrine that a writ may not be used as a substitute for appeal, ${ }^{15}$ proper practice recognizes that notice of one type of interlocutory review can serve as notice for another type where the appeal could be presently taken under that other procedure. ${ }^{16}$ Thus, applications for writs alone have been found to properly invoke the power of the courts of appeals to review what were in fact presently appealable orders ${ }^{17}$ even where the writ could not properly issue. ${ }^{18}$ Similarly, where notices of appeal alone have been filed when the order for which review was sought was not presently appealable, courts have disregarded the fact that filing was made in the "wrong" forum and have treated the appeals as applications for writs where such applications would have been the proper method of review. ${ }^{19}$ These cases properly disregard the unnecessary reliance on formal dis-

11. FED. R. APP. P. 3(a).

12. FED. R. APP. P. 21 (a) \& (c)

13. See FED. R. APP. P. 3 \& 21.

14. See, e.g., Yates v. Mobile County Personnel Bd., 658 F.2d 298 (5th Cir. 1981); United States v. Green, 499 F.2d 538, 540 n.5 (D.C. Cir. 1974).

15. See Roche v. Evaporated Milk Ass'n, 319 U.S. 21, 27-31 (1943) (Supreme Court's enunciation of the doctrine); Kerr v. United States Dist. Ct., 426 U.S. 394 (1976); Will v. United States, 389 U.S. 90 (1967); Schlagenhauf v. Holder, 379 U.S. 104 (1964).

16. See, e.g., Fuchs v. Hood Indus., 590 F.2d 395, 396 n.1 (1st Cir. 1979); Federal Deposit Ins. Corp. v. Santiago Plaza, 598 F.2d 634 (1st Cir. 1979); United States v. Green, 499 F.2d 538, 540 n.5 (D.C. Cir. 1974); Nixon v. Sirica, 487 F.2d 700 (D.C. Cir. 1973); Continental Oil Co. v. United States, 330 F.2d 347, 349 (9th Cir. 1964).

17. See Yates v. Mobile County Personnel Bd., 658 F.2d 298 (5th Cir. 1981); United States v. RMI Co., 599 F.2d 1183, 1187 (3d Cir. 1979); Exchange Nat'l Bank v. Wyatt, 517 F.2d 453 (2d Cir. 1975); National Org. for Reform of Marijuana Laws v. Ingersoll, 497 F.2d 654, 656 n.3 (D.C. Cir. 1974); Jordan v. United States Dist. Ct., 233 F.2d 362, 365 (D.C. Cir.), vacated on other grounds, 352 U.S. 904 (1956). Cf. Cobb v. Lewis, 488 F.2d 41, 45 (5th Cir. 1974) (petition for certified appeal under 28 U.S.C. $§ 1292$ (b), filed in the appellate court, used as notice of appeal as of right).

18. See United States v. RMI Co., 599 F.2d 1183, 1187 (3d Cir. 1979) (writ not proper remedy, but order for which review was sought was appealable as collaterally final and therefore application for writ served as notice of appeal); Exchange Nat'l Bank v. Wyatt, 517 F.2d 453 (2d Cir. 1975) (petition for mandamus or prohibition not proper since interlocutory appeal available, but petition served as notice and appeal was heard); National Org. for Reform of Marijuana Laws v. Ingersoll, 497 F.2d 654, 656 n.3 (D.C. Cir. 1974) (petition for mandamus denied but considered as notice of appeal, which was decided). $C f$. National City Bank v. Battisti, 581 F.2d 565 (6th Cir. 1977) (after mandamus found not appropriate form of review, motion to amend petition submitted by parties considered as motion for expedited appeal); Nixon v. Sirica, 487 F.2d 700, 707 n.21 (D.C. Cir. 1973) (mandamus found proper form of review; however, court emphasized that it could also obtain jurisdiction as order was immediately appealable).

19. See Liddell v. Board of Educ., 677 F.2d 626, 643 (8th Cir.), cert. denied, 103 S. Ct. 172 (1982); Fernandez-Rogue v. Smith, 671 F.2d 426 (11th Cir. 1982); Acton Corp. v. Borden, Inc., 670 F.2d 377,382 (1st Cir. 1982); Unified Sewerage Agency v. Jelco Inc., 646 F.2d 1339, 1343-44 (9th Cir. 1981); Three J. Farms v. Alton Box Board Co., 609 F.2d 112, 115 (4th Cir.), cert. denied, 445 U.S. 911 (1979); Iowa Beef 
tinctions in procedure found in some decisions, ${ }^{20}$ and they are reasonable in that either method suffices to inform the appellee of the appellant's intention to seek review and in that some type of review is presently available to the appellant. ${ }^{21}$ This practice does, however, put into question the necessity of maintaining the two distinct notice procedures.

A noncertified interlocutory appeal filed in the district court, and thus subject to the requirements of Rule 3(a), must be filed within thirty days (sixty days if the United States or an officer or agency thereof is a party) of the entry of the order from which the appeal is taken. ${ }^{22}$ Furthermore, there is some authority for the position that the thirty-day requirement also applies to applications for writs, filed in the circuit court, which are treated as appeals. ${ }^{23}$ Generally, however, appeals filed in the appellate court are not subject to any specific time limitations; rather, because of the equitable nature of the remedies thus sought, they are subject to laches. ${ }^{24}$

In addition, Rule 3 requires that a notice of a noncertified interlocutory appeal filed in the district court specify the parties seeking review, the order appealed from, and the court to which appeal is taken, ${ }^{25}$ while an application to the court of appeals under Rule 21 requires a statement of the issues, the facts necessary to an understanding of those issues, the relief sought, and the reasons why the writ should issue. ${ }^{26}$ Note, however, that failure to comply with the formalities of Rule 3 is not a ground for dismissal as long as the intent of the party seeking appeal is clear and the error does not cause confusion or prejudice. ${ }^{27}$ Thus, any form of filing sufficient to give notice of the intent to appeal and the subject matter thereof

Processors v. Bagley, 601 F.2d 949, 953 \& n.3 (8th Cir.), cert. denied, 441 U.S. 907 (1979); Federal Deposit Ins. Corp. v. Santiago Plaza, 598 F.2d 634, 636 (1st Cir. 1979); Scarrella v. Midwest Fed. Sav. \& Loan, 536 F.2d 1207, 1210 (8th Cir.), cert. denied, 429 U.S. 885 (1976); International Union, UAW v. National Caucus of Labor Comms., 525 F.2d 323 (2d Cir. 1975); Pfizer Inc. v. Lord, 456 F.2d 532 (8th Cir.), cert. denied, 406 U.S. 976 (1972). Cf. Poriss v. Aaacon Auto Transp., 685 F.2d 56, 60 (2d Cir. 1982) (court, in dismissing the appeal as inappropriate, recognized that it might treat the appeal as mandamus but declined to do so while instructing the lower court to reconsider its denial of the appealed motion); United States v. Hankins, 581 F.2d 431, 438 n.10 (5th Cir.), cert. denied, 440 U.S. 909 (1978) (where appeal was dismissed due to lack of final decision, an implicit decision that mandamus was not proper was also made).

20. See, e.g., Jones \& Guerrero Co. v. Sealift Pac., 650 F.2d 1072 (9th Cir. 1981) (appeal was dismissed as improper and court refused to consider whether a writ could issue because Rule 21 (a) had not been complied with); Baltimore Bank for Coops. v. Farmers Cheese Coop., 583 F.2d 104, 107 (3d Cir. 1978) (mandamus did not lie and court dismissed action but recognzied that an appeal would lie and directed the petitioner to file notice of appeal). Cf. National City Bank v. Battisti, 581 F.2d 565 (6th Cir. 1977) (petition for mandamus was dismissed, but court, recognizing appeal was appropriate, resorted to the fiction that parties' motion to amend the petition served as notice for expedited appeal).

21. See 16 C. Wright \& A. Miller, supra note 9, § 3932, at 203-04.

22. See supra $\S 6$ of this Interlocutory Restatement.

23. See, e.g., United States v. Davis, 677 F.2d 495 (5th Cir. 1982); Steele v. Thomas, 488 F.2d 604 (6th Cir. 1973). Both of these cases, however, involve criminal appeals.

24. See Equal Employment Opportunity Comm'n v. K-Mart Corp., 694 F.2d 1055, 1060-61 (6th Cir. 1982); In re United Shoe Mach. Corp., 276 F.2d 77, 79 (1st Cir. 1960). See also United States v. Olds, 426 F.2d 562 (3d Cir. 1970); Veatch v. Resor, 266 F. Supp. 893, 895 (D. Colo.), vacated on other grounds, 388 F.2d 310 (10th Cir. 1967). Cf. Dow Chem. Co. v. Taylor, 519 F.2d 352, 355 (6th Cir.), cert. denied, 423 U.S. 1033 (1975).

25. See supra $\S 5$ of this Interlocutory Restatement, comment $b$.

26. Fed. R. Civ. P. 21 (a). See Equal Employment Opportunity Comm'n v. K-Mart Corp., 694 F.2d 1055, 1060 (6th Cir. 1982).

27. See supra $\S 5$ of this Interlocutory Restatement, comment $b$. 
should suffice to bring the merits of a noncertified interlocutory appeal before a court of appeals. This practice is in effect already recognized by courts which treat either a notice of appeal or application for a writ as its counterpart when the avenue of review opposite to that sought is the one properly available to the petitioner. ${ }^{28}$

\section{PART II SPECIFIC APPLICATIONS}

A. Review of Orders Regarding Choice of Forum

$\S 14$. Service of Process and Jurisdiction over Person of Defendant.

(A) AN ORDER DISMISSING AN ACTION FOR WANT OF PERSONAL JURISDICTION, FOR INSUFFICIENGY OF PROCESS, OR FOR INSUFFICIENCY OF SERVICE OF PROCESS IS A FINAL DECISION. AN ORDER GRANTING A MOTION TO DISMISS ONLY A COMPLAINT IS A FINAL DEGISION IF IT IS BASED ON A JURISDICTIONAL DEFECT THAT THE PLAINTIFF CANNOT GURE, AND AN ORDER DISMISSING AN ACTION AS TO ONE OR MORE BUT FEWER THAN ALL PARTIES IS REVIEWABLE AS A PARTIAL FINAL DECISION IF SO DESIGNATED BY THE DISTRICT COURT; SUCH ORDERS ARE OTHERWISE REVIEWABLE ONLY ON APPEAL FROM A FINAL DEGISION OR ON CERTIFIED APPEAL.

(B) AN ORDER DENYING A MOTION TO DISMISS FOR WANT OF PERSONAL JURISDICTION, FOR INSUFFICIENCY OF PROCESS, OR FOR INSUFFICIENCY OF SERVICE OF PROCESS IS REVIEWABLE ON APPEAL FROM A FINAL DECISION, ON CERTIFIED APPEAL, OR ON INTERLOCUTORY APPEAL TO PREVENT A MANIFEST OVEREXTENSION OF THE POWER OF THE DISTRICT COURT OVER THE PERSON OF THE DEFENDANT.

\section{COMMENT}

a. Dismissal of Action or Complaint. An order dismissing an action for lack of personal jurisdiction, insufficiency of process, or insufficiency of service of process is appealable as a final decision ${ }^{1}$ provided there is reasonable compliance with the formal requirements of Section 3 of this Interlocutory Restatement.

Where the motion granted effects no dismissal of the action, finality is less clear. The grant of a motion to quash service of process was once characterized as a final decision by the Supreme Court, ${ }^{2}$ but more recent cases make finality con-

28. See supra text accompanying notes $14 \& 21$.

1. Stanga v. McCormick Shipping Corp., 268 F.2d 544 (5th Cir. 1959).

2. Rosenberg Bros. \& Co. v. Curtis Brown Co., 260 U.S. 516 (1923). For appellate court cases following this position, see Elkhart Eng'g Corp. v. Dornier Werke, 343 F.2d 8611863 (5th Cir. 1965); Edwin Raphael Co. v. Maharam Fabrics Corp., 283 F.2d 310, 311 (7th Cir. 1960). 
should suffice to bring the merits of a noncertified interlocutory appeal before a court of appeals. This practice is in effect already recognized by courts which treat either a notice of appeal or application for a writ as its counterpart when the avenue of review opposite to that sought is the one properly available to the petitioner. ${ }^{28}$

\section{PART II SPECIFIC APPLICATIONS}

A. Review of Orders Regarding Choice of Forum

$\S 14$. Service of Process and Jurisdiction over Person of Defendant.

(A) AN ORDER DISMISSING AN ACTION FOR WANT OF PERSONAL JURISDICTION, FOR INSUFFICIENGY OF PROCESS, OR FOR INSUFFICIENCY OF SERVICE OF PROCESS IS A FINAL DECISION. AN ORDER GRANTING A MOTION TO DISMISS ONLY A COMPLAINT IS A FINAL DEGISION IF IT IS BASED ON A JURISDICTIONAL DEFECT THAT THE PLAINTIFF CANNOT GURE, AND AN ORDER DISMISSING AN ACTION AS TO ONE OR MORE BUT FEWER THAN ALL PARTIES IS REVIEWABLE AS A PARTIAL FINAL DECISION IF SO DESIGNATED BY THE DISTRICT COURT; SUCH ORDERS ARE OTHERWISE REVIEWABLE ONLY ON APPEAL FROM A FINAL DEGISION OR ON CERTIFIED APPEAL.

(B) AN ORDER DENYING A MOTION TO DISMISS FOR WANT OF PERSONAL JURISDICTION, FOR INSUFFICIENCY OF PROCESS, OR FOR INSUFFICIENCY OF SERVICE OF PROCESS IS REVIEWABLE ON APPEAL FROM A FINAL DECISION, ON CERTIFIED APPEAL, OR ON INTERLOCUTORY APPEAL TO PREVENT A MANIFEST OVEREXTENSION OF THE POWER OF THE DISTRICT COURT OVER THE PERSON OF THE DEFENDANT.

\section{COMMENT}

a. Dismissal of Action or Complaint. An order dismissing an action for lack of personal jurisdiction, insufficiency of process, or insufficiency of service of process is appealable as a final decision ${ }^{1}$ provided there is reasonable compliance with the formal requirements of Section 3 of this Interlocutory Restatement.

Where the motion granted effects no dismissal of the action, finality is less clear. The grant of a motion to quash service of process was once characterized as a final decision by the Supreme Court, ${ }^{2}$ but more recent cases make finality con-

28. See supra text accompanying notes $14 \& 21$.

1. Stanga v. McCormick Shipping Corp., 268 F.2d 544 (5th Cir. 1959).

2. Rosenberg Bros. \& Co. v. Curtis Brown Co., 260 U.S. 516 (1923). For appellate court cases following this position, see Elkhart Eng'g Corp. v. Dornier Werke, 343 F.2d 8611863 (5th Cir. 1965); Edwin Raphael Co. v. Maharam Fabrics Corp., 283 F.2d 310, 311 (7th Cir. 1960). 
tingent upon a showing that personal jurisdiction likely will never be obtained. ${ }^{3}$ When appeal from such orders has not been allowed, courts have pointed to district judges' discretion to retain cases to allow further attempts to serve process and have assumed that judges intended such when their orders did not expressly dismiss the actions. ${ }^{4}$ Thus, in a case where the issue was sufficiency of a national union's contacts with the forum district for the purposes of determining personal jurisdiction, the Tenth Circuit held that appealability turned on whether

[i]t is clear that the trial court determined that the action could not be saved by an amendment of the complaint which the plaintiff could reasonably be expected to make and that the plaintiff assumed, with reason, that he had no choice but to stand on his complaint and the evidence adduced at the hearing. ${ }^{5}$

Illustration 14-1. $\quad \mathrm{P}$ brings suit against $\mathrm{D}$, who makes a motion to quash service of process for lack of an affidavit of compliance with proper substituted service. D's motion is granted, but the district court retains jurisdiction to allow $\mathrm{P}$ to correct the problem. $\mathrm{P}$ appeals from the quashing of service. The appeal should be dismissed. There is no final decision because further attempts at service may be made ${ }^{6}$

Illustration 14-2. $\mathrm{P}$ brings suit against $\mathrm{D}$, who makes a motion to quash service of process for failure to comply with state provisions regarding service on foreign corporations. The motion is granted, and the statute of limitations runs. $P$ appeals the process decision. The appeal should be dismissed. It is still possible that the service defect may be cured because the statute of limitations must be raised as a defense and may be waived. ${ }^{7}$

An order granting a motion to dismiss will not be final when it is incomplete as to multiple parties. ${ }^{8}$ Litigation will continue as to the remaining claimants and defendants. Such an order is subject to immediate review, however, when so designated by the trial court. ${ }^{9}$

Illustration 14-3. $\mathrm{P}$ brings suit against $\mathrm{D} 1$ and $\mathrm{D} 2$, and a motion to quash service is granted as to D1. P appeals. The appeal should be dis-

3. See Associated Metals \& Minerals Corp. v. S.S. Geert Howaldt, 348 F.2d 457 (5th Cir. 1965). Cf. infra $\S 16$ of this Interlocutory Restatement, note 2 and accompanying text; infra $\S 28$ of this Interlocutory Restatement, commen $f$. An attempt to classify an order quashing service of process as a collateral order was rejected in Stevens v. Security Pac. Nat'l Bank, 538 F.2d 1387, 1389 (9th Cir. 1976) (process order still left the underlying issue of personal jurisdiction unresolved).

4. Haley v. Simmons, 529 F.2d 78 (8th Cir. 1976). See also Stanga v. McCormick Shipping Corp., 268 F.2d 544 (5th Cir. 1959) (reversing a dismissal following an order quashing service because not all conceivable means of acquiring jurisdiction, such as attachment, had been exhausted).

5. Sherman v. American Fed'n of Musicians, 588 F.2d 1313, 1315 (10th Cir. 1978), cert. denied, 444 U.S. 825 (1979).

6. Miller v. Cousins Properties, 378 F. Supp. 711 (D. Vt. 1974).

7. Grabner v. Willys Motors, 282 F.2d 644 (9th Cir. 1960).

8. See, e.g., Peralta v. Quad Tool \& Dye Supply Co., 370 F.2d 103 (3d Cir. 1966); Lee v. Porcelain Patch \& Glaze Corp., 240 F.2d 763 (5th Cir. 1957); Beury v. Beury, 222 F.2d 464 (4th Cir. 1955).

9. E.g., Nu-way Systems v. Belmont Marketing, 635 F.2d 617 (7th Cir. 1980); Farrell v. Piedmont Aviation, 411 F.2d 812 (2d Cir. 1968), cert. denied, 396 U.S. 840 (1969). See supra $\$ 4$ of this Interlocutory Restatement for a discussion of the requirements for a designation of partial finality under Rule 54(b) of the Federal Rules of Civil Procedure. See also supra $\$ 11$ of this Interlocutory Restatement, note 15, for a discussion of the appropriateness of certified appeal under 28 U.S.C. $\S 1292$ (b) when a Rule 54(b) designation would be available. 
missed because the order is not final as to the whole action even if the defect cannot be cured. ${ }^{10}$ The result may be otherwise if the court properly designates partial finality; also, the order may become final and appealable if P's suit against D2 is dismissed. ${ }^{11}$

b. Denial of Dismissal. An order refusing to quash service of process or denying a motion to dismiss for lack of personal jurisdiction is never a final decision. ${ }^{12}$ Objections may be preserved, and, despite active defense on the merits, error will be grounds for reversal upon review of the final decision. ${ }^{13}$ In addition, an unfavorable ruling as to jurisdiction may be raised incidental to review of an immediately appealable order such as an injunction, since jurisdiction will go to the court's ability to even enter such subsequent order. ${ }^{14}$

Mandamus is not generally used as a substitute for appeal from orders exercising jurisdiction over persons. ${ }^{15}$ However, Ex parte Chicago, Rock Island and Pacific Railroad theoretically approved such interlocutory review in limited circumstances-when the lower court is "clearly" without jurisdiction and the party aggrieved has properly preserved his rights and has no other remedy. ${ }^{16}$ The Supreme Court further concluded that mandamus will not issue if the lower court's jurisdiction is merely "doubtful" or if the issue turns upon a finding of fact based on evidence not in the record. ${ }^{17}$ Review was denied in the Chicago, Rock Island case on the latter basis, and subsequent cases have reached the same result by saying that the lower court might take up the issue of personal jurisdiction again and the parties would then have the opportunity to present more evidence. ${ }^{18}$ It seems likely that the Chicago, Rock Island dictum would be applied in an appropriate case, especially to the extent that the power being exercised could be said to infringe the defendant's due process rights which underlie the limits on a court's power.

c. Certification. Certified appeal is generally available following the denial of a motion to dismiss for lack of personal jurisdiction or insufficiency of process if the requirements of 28 U.S.C. $\$ 1292$ (b) are otherwise met. ${ }^{19}$ Resolution of the issue generally will advance the termination of the litigation because if the lower court

10. See, e.g., cases cited supra note 8 .

11. See Cook v. Bostitch, Inc., 328 F.2d 1 (2d Cir. 1964).

12. Murphy v. Helena Rubenstein Co., 355 F.2d 553 (3d Cir. 1965); American Concrete Agric. Pipe Ass'n v. No-Joint Concrete Pipe Co., 331 F.2d 706 (9th Cir. 1964).

13. Harkness v. Hyde, 98 U.S. 476 (1878).

14. See generally supra $\S 12$ of this Interlocutory Restatement, notes 81-83 and and accompanying text.

15. In re Centrotextil, 620 F.2d 690 (8th Cir. 1980); see also Columbia Boiler Co. v. Hutcheson, 222 F.2d 718 (4th Cir. 1955).

16. 255 U.S. $273,275-76$ (1921).

17. Id.

18. American Concrete Agric. Pipe Ass'n v. No-Joint Concrete Pipe Co., 331 F.2d 706 (9th Cir. 1964); Massey-Harris-Ferguson v. Boyd, 242 F.2d 800 (6th Cir.), cert. denied, 355 U.S. 806 (1957).

19. See supra $\S 11$ of this Interlocutory Restatement. But see Haraburda v. United States Steel Corp., 187 F. Supp. 86 (W.D. Mich. 1960) (additional requirement that the litigation in question be complex or protracted and not an ordinary suit that could be disposed of in a few days). See also Speizman Knitting Machine Co. v. Terrot Strickmaschinen, 505 F. Supp. 200 (W.D.N.C. 1981)(denying certification because issue was merely an alternative theory and a factual determination was involved); Martinez v. M.A. Karageorgis, 235 F. Supp. 1012 (D.P.R. 1963)(denying certification absent grounds for difference of opinion). 
is reversed, a trial will no longer be necessary. If the jurisdictional issue involves a third party complaint, this may not be true and certification may be limited or unavailable. ${ }^{20}$ Commonly certified personal jurisdiction questions have been those involving long arm statutes and sufficient contacts with the forum state ${ }^{21}$ and jurisdiction over federal employees. ${ }^{22}$ The only apparent example of certification of a process issue involved extraterritorial service. ${ }^{23}$

\section{$\S 15 . \quad$ Venue and Change of Venue.}

(A) AN ORDER DISMISSING AN ACTION FOR IMPROPER VENUE IS A FINAL DECISION.

(B) AN ORDER REFUSING TO DISMISS AN ACTION FOR IMPROPER VENUE OR GRANTING OR DENYING A MOTION TO TRANSFER FOR THE PURPOSE OF CURING IMPROPER VENUE IS REVIEWABLE ON APPEAL FROM A FINAL DECISION, ON CERTIFIED APPEAL, OR ON INTERLOCUTORY APPEAL TO PREVENT EXTRAORDINARY HARDSHIP RESULTING FROM A DENIAL OF ACCESS TO A PARTICULAR FORUM PROVIDED IN LEGISLATION SPECIFIC TO THE SUBJECT MATTER OF THE ACTION.

(C) AN ORDER GRANTING OR DENYING A MOTION TO TRANSFER FOR CONVENIENCE IS REVIEWABLE ON APPEAL FROM A FINAL DECISION, ON CERTIFIED APPEAL, OR ON INTERLOCUTORY APPEAL TO PREVENT

(1) TRANSFER TO A LEGALLY IMPROPER VENUE,

(2) MANIFEST IMPAIRMENT OF THE APPELLANT'S RIGHT TO A REASONABLY ACCESSIBLE FORUM, OR

(3) TRANSFER MADE WITHOUT PROPER NOTICE AND HEARING.

20. Shawe v. Wendy Wilson, Inc., 171 F. Supp. 117 (S.D.N.Y. 1959), rev'd sub nom. Jaftex Corp. v. Randolph Mills, Inc., 282 F.2d 508 (2d Cir. 1960). The defendant in a tort liability suit entered a third party complaint, which was dismissed for lack of personal jurisdiction over the third party. If underlying liability were to be found, certification would have advanced termination of the litigation because all parties would then have been bound by the decision. However, if there were no underlying liability, certification would have resulted merely in delay since the third party would have had no liability anyway. The court certified the question on the condition that the parties follow a shortened time schedule.

21. Insurance Co. of N. Am. v. Marina Salina Cruz, 649 F.2d 1266 (9th Cir. 1981); Hutson v. Fehr Bros., 584 F.2d 833 (8th Cir.), cert. denied, 439 U.S. 983 (1978); Edy Clover Prods. v. NBC, 572 F.2d 119 (3d Cir. 1978); Interstate Indus. v. Barclay Indus., 540 F.2d 868 (7th Cir. 1976); Rebozo v. Washington Post Co., 515 F.2d 1208 (5th Cir. 1975); Bland v. Kentucky Fried Chicken Corp., 338 F. Supp. 871 (S.D. Tex. 1971); Northland Paper Co. v. Mohawk Tablet Co., 271 F. Supp. 763 (S.D.N.Y. 1967). See also O'Connor v. Lee-Hy Paving Corp., 579 F.2d 194 (2d Cir.), cert. denied, 439 U.S. 1034 (1978). But see School Dist. v. Missouri, 460 F. Supp. 421 (W.D. Mo. 1978), appeal dismissed, 592 F.2d 493 (8th Cir. 1979) (certification refused by appellate court).

22. Blackburn v. Goodwin, 608 F.2d 919 (2d Cir. 1979); Driver v. Helms, 577 F.2d 147 (1st Cir. 1978), rev'd sub nom. Stafford v. Briggs, 444 U.S. 527 (1980).

23. Robinson v. Penn Cent. Co., 484 F.2d 553 (3d Cir. 1973) (authorities split on issue and question of first impression in circuit). 


\section{COMMENT}

a. Dismissal. An order dismissing an action for lack of venue is final and appealable ${ }^{l}$ although there has been no decision on the merits and renewal of the claim in another forum is not precluded. This is consistent with the rule with respect to other dismissals that are not preclusive. ${ }^{2}$

b. Denial of Dismissal and Transfers to Correct Venue. A denial of a motion to dismiss for lack of venue ${ }^{3}$ is not a final decision as it contemplates the proceeding will continue, and an improper refusal to dismiss is ground for reversal on appeal from a final decision. ${ }^{4}$ Federal law does, however, through 28 U.S.C. $\$ 1406(\mathrm{a})$, contemplate that a transfer be used to correct improper venue when proper venue can be laid elsewhere in the federal system. ${ }^{5}$ Thus, an action should be dismissed only if there is no proper federal venue.

An order granting or denying a transfer under 28 U.S.C. $\S 1406$ (a) has substantially the same effect as to the posture of the case for appellate review as an order denying a motion to dismiss for improper venue. The district court has decided only that the action will proceed in a federal court, be it the one in which the action was commenced or another to which it may be transferred. Thus, a 28 U.S.C. $\S 1406$ (a) transfer ruling also is not a final decision. ${ }^{6}$ If, on appeal from a final decision, the venue of the court entering that decision is found to be unlawful, the error will be reversed and a second proceeding will be held in a proper forum. ${ }^{7}$ Error may occur equally either in retaining a case in which the venue is not lawful or in transferring a case to a district in which venue cannot properly be laid.

The question of propriety of venue may be suitable for certified appeal in the

1. Sutain v. Shapiro \& Lieberman, 678 F.2d 115 (9th Cir. 1982).

2. See generally $\$ \$ 31$ \& 32 of this Interlocutory Restatement.

3. Often today a party seeking dismissal will ask for transfer in the alternative or the court will transfer on its own motion. American Concrete Agric. Pipe Ass'n v. No-Joint Concrete Pipe Co., 331 F.2d 706 (9th Cir. 1964); Goldlawr, Inc. v. Heiman, 288 F.2d 579 (2d Cir.), rev'd, 369 U.S. 463 (1961). But see Alcoa S.S. Co. v. M/V Nordic Regent, 654 F.2d 147 (2d Cir. 1980).

4. Olberding v. Illinois Cent. R. R., 346 U.S. 338 (1953). See also Davis v. Hill Eng'g, 549 F.2d 314 (5th Cir. 1977).

5. The text of 28 U.S.C. $\S 1406$ (a) (1976) reads as follows:

The district court of a district in which is filed a case laying venue in the wrong division or district shall dismiss, or if it be in the interest of justice, transfer such case to any district or division in which it could have been brought.

6. See, e.g., Fischer v. First Nat'l Bank, 466 F.2d 511 (8th Cir. 1972); Stelly v. Employers Nat'l Ins. Co., 431 F.2d 1251 (5th Cir. 1970), cert. denied, 401 U.S. 908 (1971). The Third Circuit did once apply "death knell" type reasoning--that is, that the order, though not final, would as a practical matter terminate the litigation-to allow a denial of a transfer to be reviewed as a final decision. United States v. Berkowitz, 328 F.2d 358 (3d Cir.), cert. denied, 379 U.S. 821 (1964). The court, however, felt the circumstances were "unique" in that the defendant could not be properly served in the original district and the statute of limitations had expired so that a new suit could not have been filed in a more appropriate district.

7. United States ex rel. Harvey Gulf Int'l Marine v. Maryland Casualty Co., 573 F.2d 245, 247-48 (5th Cir. 1978) (doctrine of "harmless error" disregards congressional intent and expands venue beyond what Congress has mandated; venue further to be strictly construed when a restrictive provision-enacted for the benefit of defendants, rather than a general diversity provision-is at issue). But see Whittier v. Emmet, 281 F.2d 24, 30-31 (D.C. Cir. 1960), cert. denied, 364 U.S. 935 (1961) ("Once the case has been heard fully and fairly on the merits, the reasons for reversing the judgment on grounds of improper venue are substantially diminished;" as a result, however, the party challenging venue actually only had to try one consolidated proceeding rather than the three separate ones that would have been necessary had the court corrected the venue as urged). 
context of either denial of a dismissal for improper venue ${ }^{8}$ or grant or denial of a 28 U.S.C. $\S 1406$ (a) transfer, ${ }^{9}$ provided the issue otherwise meets the requirements of 28 U.S.C. $\S 1292$ (b) of substantial doubt as to a controlling principle of law and an absence of factual uncertainty or trial court discretion. ${ }^{10}$

There is a limited role for interlocutory appeal with respect to legality of venue. In Banker's Life $\mathcal{E}^{\circ}$ Casualty Co. $v$. Holland, the Supreme Court, while reversing a writ of mandamus issued by a court of appeals, left open the possibility that such a remedy might be available upon a showing of sufficient extraordinary hardship." One court of appeals has said it will not issue mandamus if a "rational and substantial legal argument" can be made for the venue decision, ${ }^{12}$ while others have emphasized that the burden of possibly having to undertake a second trial on the same issues is not sufficient to justify appellate court intervention. ${ }^{13}$ The only apparent reported case finding "irreversible hardship" such as would warrant use of mandamus also emphasized that special legislative provisions intended to ease venue burdens on the particular class of parties generally involved would be jeopardized by failure to entertain interlocutory review. ${ }^{14}$

Illustration 15-1. P brings suit against D1 and D2 alleging conspiracy to injure its business. The action as to D2 is severed and transferred to another district to correct venue, leaving $P$ faced with parallel litigation against the two defendants in different courts. $P$ appeals the transfer order. The appeal should be dismissed because an adequate remedy may be had on appeal from the final decision. ${ }^{15}$

Illustration 15-2. P, proceeding in forma pauperis and with Legal Services counsel, brings suit against the trustees and administrators of the Employees Retirement Income Security Act. P's only source of income is his security benefit entitlement. The suit is transferred to another district under 28 U.S.C. $\$ 1406(a)$, with the court misinterpreting special ERISA venue provisions ${ }^{16}$ to hold that there is no venue in the original district. $P$ seeks review. Given that this decision is a clear error of law, the appeal

8. E.g., Piedmont Label Co. v. Sun Garden Packing Co., 598 F.2d 491 (9th Cir. 1979); Driver v. Helms, 577 F.2d 147 (1st Cir. 1978), rev'd sub nom. Stafford v. Briggs, 444 U.S. 527 (1980).

9. E.g., Armor Elevator Co. v. Phoenix Urban Corp., 493 F. Supp. 876 (D. Mass. 1980), affd, 655 F.2d 19 (1st Cir. 1981); Penrod Drilling Co. v. Johnson, 414 F.2d 1217 (5th Cir. 1969), cert. denied, 396 U.S. 1003 (1970). But see Mazzella v. Stineman, 472 F. Supp. 432, 435-36 (E.D. Pa. 1979) (Third Circuit uses 28 U.S.C. $\$ 1292(b)$ sparingly with the requirement that the case certified involve exceptionally protracted or expensive litigation as an "additional independent criterion").

10. See supra $\S 11$ of this Interlocutory Restatement.

11. 346 U.S. 379, 383 (1953). See also Gulf Research \& Dev. Co. v. Leahy, 193 F.2d 302 (3d Cir. 1951), affd by an equally divided court, 344 U.S. 861 (1952).

12. American Fidelity Fire Ins. Co. v. United States Dist. Ct., 538 F.2d 1371, 1374 (9th Cir. 1976).

13. Varsic v. United States Dist. Ct., 607 F.2d 245, 251-52 (9th Cir. 1979). Cf. infra $\S 16$ of this Interlocutory Restatement, note 61 and accompanying text; infra $\S 17$ of this Interlocutory Restatement, note 25 and accompanying text; infra $\S 24$ of this Interlocutory Restatement, note 33 and accompanying text.

14. Varsic v. United States Dist. Ct., 607 F.2d 245 (9th Cir. 1979).

15. Banker's Life \& Casualty Co. v. Holland, 346 U.S. 379 (1953). The Court did note that both district courts were within the same circuit for appeal, id. at 384 , but it is not clear that this circumstance is necessary to the denial of mandamus.

16. 29 U.S.C. $§ 1132(\mathrm{e})(2)$ (1976). 
should be heard. If the transfer is not rescinded $\mathrm{P}$ will either, if he wins, have incurred the additional expenses of a distant trial in the transferee district or, if he loses and the venue decision is then reversed, bear the expense of a second trial. These alternatives constitute prejudice not correctable on appeal from a final decision because of the financial situation of $\mathrm{P}$ and because of a specific congressional intent to provide special liberal venue provisions for ERISA suits. ${ }^{17}$

c. Transfers for Convenience. An order transferring a case between two federal venues, as authorized by 28 U.S.C. $\S 1404(\mathrm{a}),{ }^{18}$ may be subject to interlocutory review even though the power thus created vests district courts with substantial discretion. While a transfer decision under 28 U.S.C. $\S 1404(\mathrm{a})$ is as clearly nonfinal as a similar ruling under 28 U.S.C. $\S 1406(a),{ }^{19}$ the two are significantly different in terms of reviewability on appeal from final decision. Postjudgment review of the grant or denial of a 28 U.S.C. $\S 1404$ (a) transfer will be extremely limited because of the discretionary nature of the order and the difficulty of demonstrating prejudice from an unfavorable ruling. ${ }^{20}$ Reversible error is likely to be found only when transfer has been granted to a legally improper venue, that is, one in which the action could not originally have been brought in conformity with venue statutes.

This unavailability of postjudgment review of convenience transfer rulings appears to have prompted courts of appeals to be more aggressive in reviewing them by mandamus. It has also been said that convenience, in contrast to issues of law, can be effectively reviewed only before trial. ${ }^{21}$ However the 28 U.S.C. $\S 1404$ (a) cases most certain of review are those that involve issues of law rather than convenience. ${ }^{22}$

Also, justification for interlocutory common review of 28 U.S.C. $\S 1404$ (a) orders has been based on practices pertaining to the old forum non conveniens doctrine, which the statute largely replaced. Under that doctrine, if the original forum were found to be inconvenient, the case would be dismissed rather than

17. Varsic v. United States Dist. Ct., 607 F.2d 245 (9th Cir. 1979). The court distinguished an earlier case involving corporations on the ground that, for them, trial in the transferee district would not be significantly more burdensome. Id. at 251 .

18. The text of 28 U.S.C. $\$ 1404$ (a) (1976) reads as follows: "For the convenience of parties and witnesses, in the interest of justice, a district court may transfer any civil action to any other district or division where it might have been brought."

19. See e.g., Aacon Auto Transp. v. Nimfo, 490 F.2d 83, 84 (2d Cir. 1974); D'Ippolito v. American Oil Co., 401 F.2d 764, 765 (2d Cir. 1968) (per curiam).

20. Berger, The Mandamus Power of the United Slates Courts of Appeals: A Complex and Confused Means of Appellate Control, 31 Buffalo L. Rev. 37, 62, 82 (1982).

21. Gulf Research \& Dev. Co. v. Leahy, 193 F.2d 302, 305 (3d Cir. 1951), affd by an equally divided court, 344 U.S. 861 (1952).

22. Courts, even while offering the rationale for appealability, have noted this contradiction themselves. Id. Those cases where interlocutory review most clearly is available are those where there is a jurisdictional question about the new district; see infra comment $d$. Such review is justified as going to the "power" of the court to make the transfer. For example, a court may be seen as acting beyond its statutory authority when it transfers a case to an improper venue in contravention of 28 U.S.C. $\$ 1404$ (a); but it will merely err, such that mandamus is not available (see supra $\S 12$ of this Interlocutory Restatement, note 22 and accompanying text), when it makes an improper decision under 28 U.S.C. $\S 1406$ (a), as such provision authorizes it to consider legality of venue. 
transferred, allowing the plaintiff to appeal from the final decision. Now, when the plaintiff's forum is rejected às inconvenient, the case is transferred and no final decision appeal is available. ${ }^{23}$ This, however, would suggest that interlocutory review might be available only if the transfer were granted and not if the transfer were denied. Neither the language nor the results of recent decisions support such a distinction. ${ }^{24}$

Finally, the Ninth Circuit in Pacific Car $\mathcal{E}^{\circ}$ Foundry Co. v. Pence has justified interlocutory review of 28 U.S.C. $\$ 1404$ (a) motions as consistent with the underlying purpose of the final decision rule. ${ }^{25}$ The court characterized venue as a separable issue, complete in itself, and not a step toward final decision that would merge in the verdict, thus alleviating the concern with piecemeal appeals addressed by the ban on early review. ${ }^{26}$ It further reasoned that requiring the litigants to wait until after final decision would subject them to the very disruption, expense, and inconvenience 28 U.S.C. $\$ 1404$ (a) was designed to prevent. ${ }^{27}$

d. Transfer to Legally Improper Venue. An order transferring a case pursuant to 28 U.S.C. $\S 1404(\mathrm{a})$ is subject to interlocutory review when the opposing party challenges it as beyond the transferring court's power ${ }^{28}$ because the transferee court is not, as required by statute, in a "district or division where [the case] might have been brought." 29

Illustration 15-3. $\mathrm{P}$ brings suit against D. D's motion for a 28 U.S.C. $\S 1404$ (a) transfer is granted despite P's allegations that D has insufficient contacts with the forum state of the transferee district such that personal jurisdiction would have been lacking had $P$ tried to bring the suit there originally. $\mathrm{P}$ appeals. The appeal should be entertained to prevent a possible transfer, in violation of venue legislation, to a district in which the action could not have been brought. ${ }^{30}$

e. Reasonable Forum Selection. Most appellate courts entertain petitions for mandamus to consider the fairness and convenience of venue when there is a clear abuse of discretion or exceptional circumstances, but the circuits vary in the degree of scrutiny exercised in evaluating transfer decisions. The narrowest and earliest

23. Note, Appealability of 1404(a) Orders: Mandamus Misapplied, 67 YALE L.J. 122 (1957).

24. See infra notes 50-52 and accompanying text. See also infra note 33 and accompanying text for the view that the change from forum non conveniens should make venue decisions less reviewable.

25. 403 F.2d 949, 952 (9th Cir. 1968).

26. Id.

27. Note that this merely restates-with the same contradiction-the earlier rationale that convenience can only effectively be reviewed before trial. See supra note 22 and accompanying text.

28. Hoffman v. Blaski, 363 U.S. 335 (1960). For examples from the various circuits see In re Amarnick, 558 F.2d 110 (2d Cir. 1977); Caleshu v. Wangelin, 549 F.2d 93 (8th Cir. 1977); Scriptomatic, Inc. v. United States Dist. Ct., 545 F.2d 1156 (9th Cir. 1976); Commercial Lighting Prods. v. United States Dist. Ct., 537 F.2d 1078 (9th Cir. 1976); Wilkins v. Erickson, 484 F.2d 969 (8th Cir. 1973); Johnson \& Johnson v. Picard, 282 F.2d 386 (6th Cir. 1960); Lemon v. Druffel, 253 F.2d 680 (6th Cir.), cert. denied, 358 U.S. 821 (1958). Of these cases, only In re Amarnick clearly puts the burden on the petitioner to "demonstrate conclusively" that the new venue is improper. 558 F.2d at 113 . Cf. Cessna Aircraft Co. v. Brown, 348 F.2d 689 (10th Cir. 1965) (jurisdiction in the new district already upheld in related suit but transfer vacated anyway because that decision was being challenged on appeal).

29. The complete statutory language is quoted supra note 18.

30. Scriptomatic, Inc. v. United States Dist. Ct., 545 F.2d 1156 (9th Cir. 1976); Commercial Lighting Prods. v. United States Dist. Ct., 537 F.2d 1078 (9th Cir. 1976). 
position followed by courts was stated in All States Freight v. Modarelli in 1952: "We do not propose to grant such review where the judge in the district court has considered the interests stipulated in the statute and decided thereon." 31 The court reasoned that the expense and inconvenience of appeal were contrary to the purposes of 28 U.S.C. $\S 1404$ (a) and that the "certainty" of such harm was greater than the risk of injury through a transfer or failure to transfer under that provision. ${ }^{32}$ Further, district judges were to have wider discretion in their decisions than under the old forum non conveniens doctrine because their decisions would not result in dismissals. ${ }^{33}$

Though the Third Circuit, author of the Modarelli opinion, has moved away from this position, ${ }^{34}$ it was adopted two years later by the First Circuit, which warned that leave even to file a petition for mandamus would be denied if the petition were based on abuse of discretion in deciding a transfer motion. ${ }^{35}$ The most contemporary statements of this position have been by the Ninth Circuit, starting with Kasey v. Molybdenum Corp. of America: "We decline to issue the writ when it appears from a well-reasoned holding by the trial judge that he has considered the issues listed in $\S 1404(\mathrm{a})$ and has made his decision accordingly." 36 Furthermore, Kasey and later cases have held that the judge need not make his reasons clear in his opinion ${ }^{37}$ nor even give reasons ${ }^{38}$ if it is obvious from the record that all of the appropriate factors were considered. The Fifth ${ }^{39}$ and Tenth ${ }^{40}$ Circuits also refuse interlocutory review when the correct factors have been considered.

A contrary position, that the district judge's purported consideration of all the relevant factors does not shield further review, has been announced in the Second, ${ }^{41}$ Third, ${ }^{42}$ and Fourth ${ }^{43}$ Circuits. These courts have reserved some power of review because abuses involving venue cause expense and inconvenience not correctable after final decision. While they reconsider the factors, however, these courts still generally set strict standards, such as "clear-cut" abuse, for reversing trial judges, who are better situated to decide convenience issues. ${ }^{44}$

The remaining circuits entertain interlocutory appeal in the form of mandamus to consider whether the lower court's decision was "impermissible, unreasonable or arbitrary" 45 or "so clear and arbitrary as to amount to an abuse of

31. 196 F.2d 1010, 1012 (3d Cir. 1952)

32. Id. at 1011-12.

33. Id. at 1011 .

34. Solomon v. Continental Am. Life Ins. Co., 472 F.2d 1043, 1045 (3d Cir. 1973). See infra text accompanying note 42 .

35. In re Josephson, 218 F.2d 174, 182 (1st Cir. 1954).

36. 408 F.2d 16, 20 (9th Cir. 1969)

37. Id. at 20 .

38. A.J. Indus. v. United States Dist. Ct., 503 F.2d 384 (9th Cir. 1974); Westinghouse Elec. Corp. v. Weigel, 426 F.2d 1356 (9th Cir. 1970).

39. Ex parte Chas. Pfizer \& Co., 225 F.2d 720 (5th Cir. 1955).

40. Texas Gulf Sulphur Co. v. Ritter, 371 F.2d 145 (10th Cir. 1967).

41. A. Olinick \& Sons v. Dempster Bros., 365 F.2d 439 (2d Cir. 1966).

42. Solomon v. Continental Am. Life Ins. Co., 472 F.2d 1043 (3d Cir. 1973).

43. Akers v. Norfolk \& W. Ry., 378 F.2d 78 (4th Cir. 1967).

44. A. Olinick \& Sons v. Dempster Bros., 365 F.2d 439, 444 (2d Cir. 1966).

45. Toro Co. v. Alsop, 565 F.2d 998, 1001 (8th Cir. 1977), cert. denied, 435 U.S. 952 (1978) 


\section{discretion."46 The Eighth Circuit expounded further:}

The only relief which a party will be permitted to seek . . . is against manifest judicial arbitrariness. Unless it is made clearly to appear that the facts and circumstances are without any basis for a judgment of discretion, the appellate court will not proceed further to examine the district court's action in the situation. If the facts and circumstances are rationally capable of providing reasons for what the district court has done, its judgment based on those reasons will not be reviewed. ${ }^{47}$

This position, in fact, requires some review-to see if the circumstances are "rationally capable of providing reasons"-before the decision is made that the question is not reviewable, ${ }^{48}$ though the Eighth Circuit's last phrase could again imply review merely to determine that the judge listed the proper factors. ${ }^{49}$

A sampling of about twenty-seven reported post-Modarelli cases from varying circuits where review of strictly discretionary 28 U.S.C. $\$ 1404$ (a) transfer decisions was requested finds mandamus granted only four times, ${ }^{50}$ and all of those in instances where transfer was initially denied. ${ }^{51}$

46. Butterick Co. v. Will, 316 F.2d 111, 113 (7th Cir. 1963).

47. McGraw-Edison Co. v. Van Pelt, 350 F.2d 361, 363 (8th Cir. 1965).

48. For example, in Starnes v. McGuire, 512 F.2d 918 (D.C. Cir. 1974), the court spent nine or ten pages reviewing the various arguments for and against transfer before denying mandamus. See also supra $\S 12$ of this Interlocutory Restatement, note 35 and accompanying text.

49. Several circuits have opinions of this split nature. For example, in Sypert v. Miner, 266 F.2d 196 (7th Cir.), cert. denied, 361 U.S. 832 (1959), the court spent two pages discussing the relevance of several factors and the validity of various arguments before denying mandamus; however, more recent cases suggest the Seventh Circuit may be moving closer to the first position discussed above. See Butterick Co. v. Will, 316 F.2d 111, 113 (7th Cir. 1963) (noting that the district judge had considered the elements and given reasons for his decision). Similarly, Pennsylvania R.R. v. Connell, 295 F.2d 32 (6th Cir. 1961), where the court specifically mentions an affidavit from the district judge declaring that he had weighed all the criteria, could indicate the Sixth Circuit is also closer to the limited position on degree of scrutiny. However, just three years earlier, a panel of that court in Lemon v. Druffel, 253 F.2d 680 (6th Cir.), cert. denied, 358 U.S. 821 (1958), did list the factors on each side of the transfer before holding there was no clear abuse of discretion.

50. Many requests for mandamus, of course, are decided summarily without reported opinion, Berger, supra note 20 , at $40 \& \mathrm{n} .18$; and furthermore, most petitions handled in that manner are dismissed. Id. at $65 \&$ n. 143.

51. See cases cited infra note 52; Pacific Car \& Foundry Co. v. Pence, 403 F.2d 949 (9th Cir. 1968); General Tire \& Rubber Co. v. Watkins, 373 F.2d 361 (4th Cir.), cert. denied, 386 U.S. 960 (1967). Expense and inconvenience seem to be particularly weighty considerations when a possible consolidation of cases is at issue. For example, in General Tire, an initial denial of a motion to transfer was proper because the first trial was to be concluded before the start of a second trial involving the same patent in another district. But when the first trial was delayed so that the two would overlap, it was an abuse of discretion, reversible by mandamus, to deny a new motion for transfer. One case, apparently an anomaly, has suggested that a winning party, when his transfer was earlier denied, may still appeal and be awarded his extra expenses if the transfer decision was incorrect. In re GAF, 416 F.2d 1252 (Ist Cir. 1969); $c f$. Solomon v. Continental Am. Life Ins. Co., 472 F.2d 1043, 1048 (3d Cir. 1973) (no abuse of discretion in failing to stipulate that party subject to an adverse 28 U.S.C. $\$ 1404$ (a) transfer ruling could recover cost of lodging and travel in addition to usual expenses if prevailing party).

Also, in a different procedural posture, the appellate court in United States v. Lord, 542 F.2d 719 (8th Cir. 1976), suggested a transfer would be an abuse of discretion because the district judge had accepted the case on assignment from the multidistrict litigation panel and had transferred it to the current district himself, a partial trial had been held, more of the evidence was located in the current district than in the proposed transferee district, and the case would be delayed because of docket congestion in the new district. The trial judge was considering discharging the jurors for prejudice and declaring a mistrial and suggested he might transfer the case regardless of whether a mistrial was declared. The matter went to the appellate court for a writ to prevent the juror discharge, which was denied, but the court did make the above prohibition of the contemplated transfer. 
Illustration 15-4. $\mathrm{P}$ brings suit against D, a corporation, in a state court in the county of D's major place of business. D properly removes to the nearby federal court. D seeks, but is denied, transfer to the district where the claim arose, where the witnesses reside and would be subject to compulsory process, where the jurors would be able to view the premises, and where the court docket would be less congested. D appeals. The appeal should be entertained because the balance of convenience is so overwhelmingly in favor of $\mathrm{D}$ that transfer is required to protect $\mathrm{D}$ 's right to a reasonably accessible forum. ${ }^{52}$

f. Inadequate Procedure on Transfer. Interlocutory review is available to redress a lack of notice before a transfer for convenience is granted. ${ }^{53}$ Given the discretionary nature of a 28 U.S.C. $\$ 1404$ (a) order, it is appropriate to insist that the party adversely affected have an opportunity to be heard with respect to the balance of fairness and convenience before the court's power is exercised.

Illustration 15-5. $\mathrm{P}$ brings suit against $\mathrm{D}$. The court sua sponte transfers the case to another district. P appeals. The appeal should be entertained because P's choice of forum is a factor to be considered in the transfer and he is entitled to a hearing on the issue. ${ }^{54}$

g. Certification of Convenience Transfers. Certified appeal under 28 U.S.C. $\S 1292(\mathrm{~b})$ has limited applicability to 28 U.S.C. $\S 1404(\mathrm{a})$ transfers except insofar as such transfers are challenged on the ground that the new district is not one where the suit could initially have been brought, as that is a question of law. ${ }^{55}$ When, however, the power is strictly discretionary, as where the issue is convenience, 28 U.S.C. $\S 1292(\mathrm{~b})$ is generally considered inappropriate because there is no "controlling question of law" and because an error in discretion is not likely to be cause for reversal after final decision so that interlocutory review does not materially advance the termination of the litigation. ${ }^{56}$

52. Chicago, Rock Island \& Pac. R.R. v. Igoe, 220 F.2d 299 (7th Cir.), cert denied, 350 U.S. 822 (1955). See also Akers v. Norfolk \& W. Ry., 378 F.2d 78 (4th Cir. 1967).

53. Fine v. McGuire, 433 F.2d 499 (D.C. Cir. 1970); Swindell-Dressler Corp. v. Dumbauld, 308 F.2d 267 (3d Cir. 1962). But see Starnes v. McGuire, 512 F.2d 918 (D.C. Cir. 1974) (hearing upon application for stay of and reconsideration of transfer adequate). The right to notice and hearing before imposition of discovery sanctions may also be protected by interlocutory appeal. See infra $\$ 39$ of this Interlocutory Restatement, comment $d$.

54. Fine v. McGuire, 433 F.2d 499 (D.C. Cir. 1970).

55. Houston Fearless Corp. v. Teter, 318 F.2d 822 (10th Cir. 1963); Farnsworth \& Chambers Co. v. Phinney, 297 F.2d 681 (5th Cir. 1962). But see Arkansas-Best Freight Sys. v. Youngblood, 359 F. Supp. 1125 (W.D. Ark. 1973) (review would not materially advance the termination of the litigation since trial on the merits would be necessary regardless of the transfer decision). A controlling question of law is required for certification under $\S 1292$ (b); see supra $\S 11$ of this Interlocutory Restatement for a further discussion of this and other aspects of certified appeals.

56. A. Olinick \& Sons v. Dempster Bros., 365 F.2d 439, 443 (2d Cir. 1966). Cf. Mobil Oil Corp. v. W.R. Grace \& Co., 334 F. Supp. 117, 131 (S.D. Tex. 1971) (certification inappropriate because issue not question of law but application of settled legal principles to the given facts); In re Antibiotic Antitrust Actions, 333 F. Supp. 299 (S.D.N.Y. 1971) (issue in dispute not controlling of outcome). The Olinick assumption regarding reversible error may not be correct; cases can be found where appellate courts reviewed (but did not reverse) 28 U.S.C. $\$ 1404$ (a) discretionary transfers on appeal from final decision. Texas E. Transmission Corp. v. Marine Office-Appleton \& Cox Corp., 579 F.2d 561 (10th Cir. 1978); Marbury-Pattillo Constr. Co. v. Bayside Warehouse Co., 490 F.2d 155 (5th Cir. 1974). Some early cases 
Illustration 15-6. $\mathrm{P}$ brings suit against $\mathrm{D}$, who seeks and is granted a 28 U.S.C. $\S 1404$ (a) transfer. The legality of the transferee venue is not controverted. P requests that the transfer order be certified for appeal, citing as a "question of law" the respect due to a plaintiff's choice of forum. Certification will be denied because expansion of the concept of "question of law" to include one factor in a discretionary ruling erodes the policy against piecemeal appeals. ${ }^{57}$

h. Proper Circuit for Appeal. It has been held that when a transfer is granted to a court in another circuit, the transferor district court and its court of appeals lose jurisdiction when the papers have been physically conveyed to the transferee district court. ${ }^{58}$ In Stames $v$. McGuire, the court indicated that this rule may not apply when interlocutory review is sought on the ground that the district court had no power to make the transfer; ${ }^{59}$ but it otherwise suggested that a proper procedure would be to seek retransfer and then appeal denial of the request in the transferee circuit. ${ }^{60}$ Since many courts, however, might be reluctant to make de novo decisions on the retransfer, considering them collateral attacks, ${ }^{61}$ the Starnes court concluded that "adequate and orderly review" required a routine delay between entry of the transfer order and physical transfer of the papers. ${ }^{62}$ In a recent case mandamus issued to correct a failure to delay transfer of the papers to allow for reconsideration and review of the order. ${ }^{63}$

i. Incidental Review. An order refusing to dismiss an action for improper venue may be reviewed pendent to another interlocutory order, such as an injunction, properly before the appellate court, since venue goes to the underlying power of the district judge to make the subsequent order. ${ }^{64}$ Generally a transfer or denial of transfer, however, will not be reviewable in similar circumstances. ${ }^{65}$ Such review may be possible when both the injunction and the transfer motion were aimed at eliminating or consolidating duplicative litigation. ${ }^{66}$ In those cases appeal of the transfer may actually contest the underlying basis for the denial of

did allow certification of strictly discretionary transfer decisions. See Wyndham Assoc. v. Bintliff, 398 F.2d 614 (2d Cir.), cert. denied, 393 U.S. 977 (1968); Humble Oil \& Ref. Co. v. Bell Marine Serv., 321 F.2d 53 (5th Cir. 1963).

57. Garner v. Wolfinbarger, 433 F.2d 117 (5th Cir. 1970) (appeal dismissed as improvidently granted).

58. Starnes v. McGuire, 512 F.2d 918, 924 (D.C. Cir. 1974). See also Magnetic Eng'g \& Mfg. Co. v. Dings Mfg. Co., 178 F.2d 866, 869 (2d Cir. 1950).

59. 512 F.2d 918,924 n.6 (D.C. Cir. 1974).

60. Id. at 924 .

61. See Hayman Cash Register Co. v. Sarokin, 669 F.2d 162 (3d Cir. 1982); Skil Corp. v. Millers Falls Co., 541 F.2d 554 (6th Cir.), cert. denied, 429 U.S. 1029 (1976); Technitrol, Inc. v. McManus, 405 F.2d 84 (8th Cir. 1968), cert. denied, 394 U.S. 997 (1969). But see Sypert v. Miner, 266 F.2d 196 (7th Cir.), cert. denied, 361 U.S. 832 (1959). Another ploy sometimes attempted is bringing a second suit in the district to which transfer was denied and seeking a stay of the initial proceeding. See Elliott Mach. Corp. v. Modern Welding Co., 502 F.2d 178 (4th Cir. 1974).

62. Stames, 512 F.2d at 935 .

63. In re Nine Mile Limited, 673 F.2d 242 (8th Cir. 1982).

64. See supra $\S 12$ of this Interlocutory Restatement, notes 80-83 and accompanying text.

65. Magnetic Eng'g \& Mfg. Co. v. Dings Mfg. Co., 178 F.2d 866 (2d Cir. 1950). See supra $§ 12$ of this Interlocutory Restatement, note 71.

66. E.g., Factors Etc., Inc. v. Pro Arts, Inc., 579 F.2d 215 (2d Cir. 1978), cert. denied, 440 U.S. 908 (1979); Codex Corp. v. Milgo Elec. Corp., 553 F.2d 735 (1st Cir.), cert. denied, 434 U.S. 860 (1977); Mary- 
the injunction. For example, in Emerson Electric Co. v. Black E Decker Manufacturing Co, the petitioner's motion to enjoin the first proceeding was made moot by the grant of the respondent's motion to transfer the second proceeding and consolidate it with the first. Thus, the transfer was reviewable on appeal of denial of the injunction. ${ }^{67}$

\section{$\S 16$. Federal Jurisdiction.}

(A) AN ORDER DISMISSING AN ACTION FOR LACK OF SUBJECT MATTER JURISDICTION IS A FINAL DECISION. AN ORDER DISMISSING ONLY THE COMPLAINT IS A FINAL DECISION IF BASED ON A DEFEFT THE PLAINTIFF CANNOT CURE, AND AN ORDER DISMISSING AS TO ONE OR MORE BUT FEWER THAN ALL PARTIES OR CLAIMS IS REVIEWABLE AS A PARTIAL FINAL DECISION IF SO DESIGNATED BY THE DISTRICT COURT; SUCH ORDERS ARE OTHERWISE REVIEWABLE ONLY ON APPEAL FROM A FINAL DECISION OR ON CERTIFIED APPEAL.

(B) AN ORDER REMANDING AN ACTION TO THE STATE COURT FROM WHICH IT WAS REMOVED IS REVIEWABLE ONLY ON INTERLOCUTORY APPEAL

(1) TO PROTECT A RIGHT OF REMOVAL BASED ON FEDERAL CIVIL RIGHTS LEGISLATION,

(2) TO PREVENT A REJECTION OF JURISDICTION ON GROUNDS NOT PERMITTED BY THE LEGISLATION DEFINING THE DUAL JURISDICTIONAL SYSTEM, OR

(3) TO PRESERVE A FEDERAL COURT DECISION THAT WOULD BE FINAL BUT FOR THE REMAND.

(C) AN ORDER DENYING A MOTION TO DISMISS FOR LACK OF SUBJECT MATTER JURISDICTION OR REFUSING TO REMAND AN ACTION IS REVIEWABLE ON APPEAL FROM A FINAL DECISION, ON CERTIFIED APPEAL, OR ON INTERLOCUTORY APPEAL

(1) TO PREVENT A MANIFEST OVEREXTENSION OF FEDERAL JUDICIAL JURISDICTION, OR

(2) TO PROTECT THE EXCLUSIVE JURISDICTION OF A FEDERAL AGENCY.

\section{COMMENT}

a. Dismissal. Dismissal for lack of subject matter jurisdiction generally constitutes an appealable final decision.' The dismissal is not a final decision, however,

land ex rel. Costas v. Atlantic Aviation Corp., 361 F.2d 873 (3d Cir.), cert. denied, 385 U.S. 931 (1966). See generally $\$ 12$ of this Interlocutory Restatement, comment $b$.

67. 606 F.2d 234 (8th Cir. 1979).

1. Catlin v. United States, 324 U.S. 229, 236 (1945). See, e.g., Williamson v. Tucker, 645 F.2d 404 (5th Cir.), cert. denied, 454 U.S. 897 (1981); Fairview Park Excavating Co. v. Al Monza Constr. Co., 560 F.2d 1122 (3d Cir. 1977). 
if only the complaint, not the action, is dismissed and there is a possibility of amendment to cure the jurisdictional defect (for example, to state additional facts to bring the action within the reach of the applicable federal statute ${ }^{2}$ or to comply with the pleading requirements of Rule $8(a)$ of the Federal Rules of Civil Procedure).

In addition, the dismissal will not terminate the litigation, and thus will not be a final decision, if it is not complete as to all parties and claims. ${ }^{3}$ Such an order will be subject to immediate review, however, as a partial final decision when so designated by the district court. ${ }^{4}$

b. General Rule for Remands. Interlocutory review of remands to state courts ${ }^{5}$ is governed by 28 U.S.C. $\S 1447$ (d), which provides with one exception that "[a]n order remanding a case to the State court from which it was removed is not reviewable on appeal or otherwise." This provision traces its roots to the Judiciary Act of $1887,{ }^{6}$ which early Supreme Court cases interpreted as expression of a congressional purpose of contracting the jurisdiction of the federal courts. ${ }^{7}$ More recently, this purpose has been stated as preventing interruptions and delays in reaching judgments on the merits because of prolonged jurisdictional litigations 8 and as promoting judicial economy and respect for state courts by limiting interference with actions therein. ${ }^{9}$

To be consistent with these purposes, the Supreme Court has long interpreted the statutory language "by appeal or otherwise" as also precluding review by mandamus. An additional clause in the early version, declaring that remands would be immediately carried into effect, was seen as supporting this conclusion. ${ }^{10}$ Further, the Supreme Court held that remands could not be reviewed even after final decisions because Congress, through the statute, had determined that a district court's ruling on jurisdiction would be final and that it would be an "uncalled for

2. Midwestern Devs. v. City of Tulsa, 319 F.2d 53 (10th Cir. 1963), cert. denied, 379 U.S. 989 (1965). Cf. supra $\S 14$ of this Interlocutory Restatement, notes $2-4$ and accompanying text; infra $\S 28$ of this Interlocutory Restatement, comment $f$.

3. See infra $\S 14$ of this Interlocutory Restatement, note 8 and accompanying text.

4. E.g., Beverly Hills Fed. Sav. \& Loan v. Webb, 406 F.2d 1275 (9th Cir. 1969). For a discussion of the requirements for a designation of partial finality under Rule 54(b) of the Federal Rules of Civil Procedure, see supra $\S 4$ of this Interlocutory Restatement. See also supra $\S 11$ of this Interlocutory Restatement, note 15, for a discussion of the appropriateness of certified appeal under 28 U.S.C. $\S 1292(\mathrm{~b})$ when a Rule 54(b) designation would be available.

5. It should be noted that this statute does not apply to remands to administrative agencies. Such remands, however, are also considered nonappealable under the final decision rule. See, e.g., Leffland Bros. Co. v. Rougeau, 655 F.2d 1031 (10th Cir. 1981); Eluska v. Andrus, 587 F.2d 996 (9th Cir. 1978); Silver v. Secretary of the Army, 554 F.2d 664 (5th Cir. 1977). Scattered decisions have held to the contrary. See 15 C. Wright, A. Miller \& E. Cooper, Federal Practice and Procedure $\$ 3914$, at 550-53 (1976).

6. Ch. $373, \S 2,24$ Stat. 552, 553 (superseded in 1948 revision of Title 28, ch. 646, 62 Stat. 869). Prior to that, review of remands by appeal was held to be prohibited by the final decision rule, except for a brief period when such review was statutorily authorized. For histories of reviewability of remand, see United States v. Rice, 327 U.S. 742, 748-51 (1946); Employers Reinsurance Corp. v. Bryant, 299 U.S. 374, 378-81 (1937).

7. In re Pennsylvania Co., 137 U.S. 451,454 (1890).

8. United States v. Rice, 327 U.S. 742, 751 (1946).

9. Thermtron Prods. v. Hermansdorfer, 423 U.S. 336, 361 (1976) (Rehnquist, J., dissenting); In re La Providencia Dev. Corp., 406 F.2d 251, 252 (1st Cir. 1969) (specifically addressing diversity cases). 1946) 
hardship" for a party who did not seek federal jurisdiction to have his state court judgment on the merits thrown out because of an error by a federal court that was not really a part of the trial. ${ }^{11}$ Over the years it has been established that the prohibition against review extends to a district judge's reconsideration of his own remand decision ${ }^{12}$ but that it does not preclude Supreme Court review when a court of appeals awards a remand following postjudgment review of the trial court's denial of such motion. ${ }^{13}$

c. Right to Forum in Civil Rights Cases. A remand may be reviewed insofar as it presumes to return to state court a case removed under civil rights legislation. ${ }^{14}$ Amendment to allow this appellate review was prompted by the perceived hostility of some federal district judges toward civil rights plaintiffs; the statute now assures a right of appeal in cases where the initial removal was based on inability to enforce civil rights in the state courts. ${ }^{15}$ Such review has rarely resulted in reversals because of the narrow interpretation given to the underlying removal provision. ${ }^{16}$

d. Unauthorized Rejection of Jurisdiction. A remand may also be reviewed if the district judge states palpably inappropriate grounds for his action. This exception was recognized by the Supreme Court in Thermtron Products v. Hermansdorfer. ${ }^{17}$ In that case a district court remanded a diversity auto accident suit to state court to avoid delays of a federal docket crowded with coal miners' black lung disease claims and other cases accorded priority. The district judge balanced the defendant's right to removal against the plaintiff's right to a speedy trial in the forum of his choice and came down on the side of the latter, since the defendant made no specific showing of prejudice from having the suit litigated in state court. ${ }^{18}$ The defendant sought review by writ of mandamus.

11. Missouri Pac. Ry. v. Fitzgerald, 160 U.S. 556, 583 (1896) (diversity case)

12. Three J Farms v. Alton Box Board Co., 609 F.2d 112 (4th Cir. 1979), cert. denied, 445 U.S. 911 (1980); Federal Deposit Ins. Corp. v. Santiago Plaza, 598 F.2d 634 (1st Cir. 1979).

13. Gray v. Ruff, 292 U.S. 25 (1945). See also Grubbs v. General Elec. Credit Corp., 405 U.S. 699 (1972); Aetna Casualty \& Sur. Co. v. Flowers, 330 U.S. 464 (1947)

14. The complete text of 28 U.S.C. $\$ 1447(\mathrm{~d})$ reads as follows:

An order remanding a case to the State court from which it was removed is not reviewable on appeal or otherwise, except that an order remanding a case to the State court from which it was removed pursuant to section 1443 of this title shall be reviewable by appeal or otherwise.

The last clause was added by the Civil Rights Act of 1964, Pub. L. No. 88-352, § 901, 78 Stat. $241,266$. The removal provision is 28 U.S.C. $§ 1443$ :

Any of the following civil actions or criminal prosecutions, commenced in a State court may be removed by the defendant to the district court of the United States for the district and division embracing the place where it is pending:

(1) Against any person who is denied or cannot enforce in the courts of such State a right under any law providing for the equal civil rights of citizens of the United States, or of all persons within the jurisdiction thereof;

(2) For any act under color of authority derived from any law providing for equal rights, or for refusing to do any act on the ground that it would be inconsistent with such law.

15. Note, Remand Order Review Afler Thermtron Products, 1977 U. ILL. L.F. 1086, 1096.

16. Id. at 1099. The Supreme Court interprets the removal provision (quoted supra note 14) as requiring that the right asserted be guaranteed by a statute specifically addressing racial equality and that the inability to enforce such right be openly manifest in state law. Georgia v. Rachel, 384 U.S. 780, 792, 800-01 (1966). See also Greenwood v. Peacock, 384 U.S. 808 (1966).

17. 423 U.S. 336 (1976).

18. Id. at $340-41$. 
The Supreme Court first held that the only grounds on which a district court could base a remand were those provided for in 28 U.S.C. $\S 1447$ (c) - that it appeared the case had been "removed improvidently and without jurisdiction." 19 The Court then concluded that mandamus ${ }^{20}$ could be used to prevent the "nullification" of removal statutes on grounds with no warrant in law. ${ }^{21}$ The district court's basis for remand, "delay," was "irrelevant" to jurisdiction because "an otherwise properly removed action may no more be remanded because the district court considers itself too busy to try it than an action properly filed in federal court in the first instance may be dismissed or referred to state courts for such reason." 22 Declaring that Congress did not intend the ban on review "to extend carte blanche authority to the district courts to revise the federal statutes governing removal by remanding cases on grounds that seem justifiable to them but which are not recognized by the controlling statute,"'23 the Supreme Court concluded that subsections (c) and (d) of 28 U.S.C. $§ 1447$ should be read together so that only remand orders invoking the improvident removal or jurisdictional grounds of 28 U.S.C. $\S 1447$ (c) would be immune from review. ${ }^{24}$ The Court clearly regarded the remand order in Thermtron as an open challenge to the authority of Congress to define the federal jurisdiction, and it sustained the power of the court of appeals to withdraw such a challenge.

While creating this exception, the decision in Thermiron reinforced the doctrine of nonreview of remands by stating that it was "unquestioned" that neither appeal nor mandamus was available to challenge an order pursuant to 28 U.S.C. $\S 1447$ (c) even if the jurisdictional determination were erroneous. ${ }^{25}$ This distinction between erroneous application of the statute and use of factors not authorized by the statute was attacked as "unworkable" by Justice Rehnquist in dissent. ${ }^{26} \mathrm{He}$ said that district courts might give unclear or no explanations of their grounds for remand or that the 28 U.S.C. $§ 1447$ (c) language could be inserted as "magic words" to shield review but that appeals would have to be allowed in such instances if the Thermtron decision were to have any meaning. To expand review to that degree, however, would be to permit the delays the statute sought to prevent and to overturn the congressional determination that the advantages of no delays

19. Id. at 342. The text of 28 U.S.C. $\$ 1447$ (c) reads as follows:

If at any time before final judgment it appears that the case was removed improvidently and without jurisdiction, the district court shall remand the case, and may order the payment of just costs. A certified copy of the order of remand shall be mailed by its clerk to the clerk of the State court. The State court may thereupon proceed with such case.

20. The Ninth Circuit recently held in Jones \& Guerrero Co. v. Sealift Pac., 650 F.2d 1072, 1074 (9th Cir. 1981), that attempts to invoke the Themeron exception must be brought as mandamus rather than on appeal, though the more general practice seems to be for courts to treat an appeal as an application for the writ when the improper format is used. See Three J Farms v. Alton Box Board Co., 609 F.2d 112,115 n.1 (4th Cir. 1979), cert. denied, 445 U.S. 911 (1980); see also supra $\S 13$ of this Interlocutory Restatement, notes $14,17-21$ and accompanying text.

21. Thermiron, 423 U.S. at 353.

22. Id. at 344 .

23. Id. at 351 .

24. Id. at $345-46$.

25. Id. at 343 .

26. Id. at 356-57 (Réhnquist, J., dissenting). 
outweighed the burdens of occasional erroneous remands. ${ }^{27}$

Two subsequent decisions involving Supreme Court Justices confirm that remands within 28 U.S.C. $\$ 1447$ (c) but based on erroneous jurisdictional determinations cannot be reviewed even by mandamus. In Gravitt v. Southwestern Bell Telephone Co., the district court looked to sworn pleadings filed by the company in an unrelated state case to determine corporate citizenship and thus found no diversity jurisdiction. ${ }^{28}$ The appellate court labeled this use of "judicial estoppel" an inappropriate basis for decision within 28 U.S.C. $\$ 1447$ (c) and granted mandamus; ${ }^{29}$ but the Supreme Court reversed because the remand, however inappropriate and erroneous, was assertedly based on lack of jurisdiction and involved no manifest refusal to perform the duty imposed on the federal courts by Congress. Also, Justice Rehnquist, sitting as a Circuit Justice in Volvo of America v. Schwarzer, declined to stay a remand order pending appeal when the remand was based on a determination that a class action could not be maintained because of failure to meet jurisdictional amount requirements. ${ }^{30}$ The handful of appellate court decisions reported to this date have followed this interpretation of Thermtron whenever the district judge has cited any facially appropriate reason for removal; ${ }^{31}$ and indeed an appeal from a remand order where such a reason has been given may be considered "frivolous" so that costs and damages may be awarded to the respondent. ${ }^{32}$

The problem noted by Rehnquist of ambiguity in the district court's remand order arose in In re Merrimack Mutual Fire Insurance Co. ${ }^{33}$ The Fifth Circuit was unable to determine if the remand had been based on lack of jurisdiction arising after removal, a reason within 28 U.S.C. $\$ 1447$ (c), yet it still declined to review. Citing Gravitt, the court reasoned that while the power to ask a district court for clarification of its views was necessary to give Thermtron significance and to prevent shielding of gross violations by giving no reasons, the logical next step from such a position would be to allow review when there was clear error even though the district judge had stated a jurisdictional reason. ${ }^{34}$ That result would be contrary to the Supreme Court's Gravitt decision. Furthermore, use of mandamus to compel a district court to give its reasons would promote more delay, contrary to statutory purpose, and it would be open to potential abuse. ${ }^{35}$ Thus, the appellate court concluded, "[i]t is now clear that Thermtron announced only a narrow rule that was intended to be limited to the extreme facts of the case, in which a district judge stated openly that he was relying on a non-1447(c) ground for remand." 36

\footnotetext{
27. Id.

28. 430 U.S. 723 (1977).

29. In re Southwestern Bell Tel. Co., 535 F.2d 859 (5th Cir. 1976), rev'd sub nom. Gravitt v. Southwestern Bell Tel. Co., 430 U.S. 723 (1977).

30. 429 U.S. 1331 (1976).

31. Encoder Communications v. Telegen, Inc., 654 F.2d 198 (2d Cir. 1981); Tolefree v. Ford Motor Credit Co., 571 F.2d 1088 (9th Cir. 1977); Robertson v. Ball, 534 F.2d 63 (5th Cir. 1976); Midland Mortgage Co. v. Winner, 532 F.2d 1342 (10th Cir. 1976).

32. Self v. Self, 614 F.2d 1026 (5th Cir. 1980) (attorney was personally liable)

33. 587 F.2d 642 (5th Cir. 1978).

34. Id. at $647-48$.

35. Id. at 648 .

36. Id. at 647 (emphasis added). This interpretation was reaffirmed by the same circuit in In re Weaver, 610 F.2d 335 (5th Cir. 1980).
} 
Despite this narrow construction of Thermtron, some cases have still arisen in which a nonjurisdictional reason for remand was clearly stated and thus review was granted. For example, in Levy $v$. Weissman, the district judge ordered a remand for failure to comply with a local rule requiring a special filing when a party wished to serve as his own counsel. ${ }^{37}$ The remand was vacated by the Third Circuit as not based on grounds touching the propriety of removal. ${ }^{38} \mathrm{Also}$, in Sheet Metal Workers Intemational Association v. Seay, a district court rationale that state court would be the "most equitable" forum because of limitations on remedies available in federal court was found not to be a ground for remand within 28 U.S.C. $§ 1447(\mathrm{c})$, and thus mandamus issued. ${ }^{39}$

Illustration 16-1. $\mathrm{P}$ brings suit in state court against $\mathrm{D}$, who petitions for removal after the expiration of the thirty-day period during which such procedure is allowed (28 U.S.C. $\$ 1446(\mathrm{~b})$ ). Upon P's motion to remand, $\mathrm{D}$ pleads excusable delay in removing, but the district judge grants the remand anyway. D appeals. The appeal should be dismissed because the remand was based on a procedural defect which district courts are entitled to consider under 28 U.S.C. $\$ 1447$ (c), and the statute clearly reposes full authority in the district judge to make a nonreviewable order with respect to the issue. ${ }^{40}$

Illustration 16-2. $\mathrm{P}$ brings suit in state court against $\mathrm{D}$, who petitions for removal. The district judge denies $\mathrm{P}$ 's attempt to amend his complaint to add a federal question but allows an amendment introducing a tort claim which destroys diversity. The district judge then remands the case for lack of federal jurisdiction. D appeals. The appeal should be dismissed. The decision may not be reviewed because it was based on jurisdictional grounds clearly within 28 U.S.C. $\$ 1447$ (c) and involved no open affront to the power of Congress to define the federal jurisdiction. ${ }^{41}$ Illustration 16-3. $\quad \mathrm{P}$ brings suit in state court against $\mathrm{D}$, who petitions for removal. $\mathrm{P}$ files a motion for remand and requests a hearing; $\mathrm{D}$ fails, however, to receive notice of the motion and thus does not file a statement of opposition as required by a local district court rule. The district judge grants the remand on the sole basis of D's failure to meet the requirements of the local rule. $\mathrm{D}$ appeals. The appeal should be heard because this remand was clearly not authorized by 28 U.S.C. $\S 1447$ (c) and thus constitutes a refusal to perform a judicial duty imposed on the court by Congress. ${ }^{42}$

37. 671 F.2d 766 (3d Cir. 1982).

38. Id. at 769 .

39. 693 F.2d 1000, 1002, 1005 (10th Cir. 1982)(the court of appeals specifically rejected arguments that the difference in available relief constituted a jurisdictional defect, id. at 1005). Cf. In re Snap-On Tools Corp., 720 F.2d 654 (Fed. Cir. 1983)(mandamus granted to compel removal on the ground that the complaint stated a patent claim exclusive to federal jurisdiction; effect was to vacate a remand, but the decision addressed neither the 28 U.S.C. $§ 1447$ (d) ban on review nor the Therntron exception).

40. See London v. United States Fire Ins. Co., 531 F.2d 257 (5th Cir. 1976). See also State Farm Mut. Auto. Ins. Co. v. Baasch, 644 F.2d 94 (2d Cir. 1981); Wilkins v. Rogers, 581 F.2d 399 (4th Cir. 1978).

41. Encoder Communications v. Telegen, Inc., 654 F.2d 198 (2d Cir. 1981).

42. In re Shell Oil Co., 631 F.2d 1156 (5th Cir. 1980). 
Illustration 16-4. $\quad \mathrm{P}$ brings suit in state court against $\mathrm{D}$, asserting a right protected by both state and federal law. D removes, asserting that P's claim arises under federal law. $P$ moves for remand and simultaneously files for voluntary dismissal of his claim insofar as it arises under federal law. The district judge holds that the dismissal is effective to terminate federal jurisdiction and remands the remaining state law claims. D appeals. The appeal should be dismissed. The remand is not reviewable because the judge's determination that he had discretion is an application (though possibly erroneous) of a jurisdictional principle which is at least arguably consistent with the statutory scheme. ${ }^{43}$

e. Remand After Final Decision. Another exception to the ban on reviewability of remands, ostensibly drawn from Thermtron (though some courts treat it as a separate exception ${ }^{44}$ ), has been approved at the appellate court level. The Fifth Circuit in In re Carter held that a remand may be reviewed when it is granted after a final decision on the merits has been reached in federal court. ${ }^{45}$ Though the reason for that remand, lack of a federal question, was within 28 U.S.C. $\S 1447$ (c) as a jurisdictional concern, the remand was outside the time frame of the statutory provision. ${ }^{46}$ The court stated, "[I]t does not necessarily follow from the holding in Thermtron that every departure from the literal prescriptions governing remand in $\S 1447$ (c) is sufficient to avoid the proscription of review"47, but it found review desirable under the Carter circumstances. Delay was no longer of great concern because a decision on the mertis had already been reached such that a remand might just set back eventual enforcement of the federal decision and because the concern for interference with state courts was offest by a greater federal stake since those latter courts had already expended resources. ${ }^{48}$

The delay issue in Carter cases, however, is different from the delay issue in Thermtron cases. The Supreme Court in Thermiron stated that the grounds in 28 U.S.C. $§ 1447$ (c) were the only legitimate grounds for remand; ${ }^{49}$ thus, it would seem that any remand reviewed as not being within 28 U.S.C. $\S 1447$ (c) would a fortiori be vacated and that there would be no delay for frivolous appeals. A remand reviewed under Carter circumstances, however, could be upheld because of

43. But see In re Greyhound Lines, 598 F.2d 883 (5th Cir. 1979). The court there held that the district judge had no discretion to remand since the dismissal was taken by the plaintiff to defeat removal. Thus, "discretion" was an affirmatively stated non-1447(c) reason for remand subject to review under the Thermiron exception. The relation of discretion to jurisdiction seems to be handled differently by various courts. Compare IMFC Prof. Servs. v. Latin Am. Home Health, 676 F.2d 152, 160 (5th Cir. 1982) (making the point that discretion is a proper consideration in remands involving 28 U.S.C. $\S 1441$ (c) independent claims, pendent jurisdiction, and abstention and thus that misuse of discretion is merely an erroneous determination of jurisdiction) with Ryan v. State Bd. of Elections, 661 F.2d 1130, 1133-34 (7th Cir. 1981) (following the reasoning of Greyhound in holding that discretion to abstain was not a proper ground for remand within 28 U.S.C. $\$ 1447$ (c). The issue reached the appellate court through 28 U.S.C. $§ 1292$ (b) certification rather than through mandamus.).

44. See, e.g., State Farm Mut. Auto. Ins. Co. v. Baasch, 644 F.2d 94, 96 (2d Cir. 1981 ).

45. 618 F.2d 1093 (5th Cir. 1980), cert. denied, 450 U.S. 949 (1981).

46. For the language of 28 U.S.C. $\$ 1447(\mathrm{c})$, see supra note 19.

47. Carter, 618 F.2d at 1098.

48. Id. at 1099 .

49. See supra note 19 and accompanying text 
strict policies against deciding cases in excess of federal jurisdiction, and the necessary retrial in state court would indeed be delayed. ${ }^{50}$ As the Fifth Circuit pointed out, however, a remand after final decision may be seen as more similar to a remand ordered by an appellate court in postjudgment review, which is, of course, immediately appealable. ${ }^{51}$ Also, district judges may easily avoid the Carter rule by staying execution of the judgment verdict pending consideration of the remand motion, so that the remand technically is ordered before final decision. ${ }^{52}$

f. Denial of Remand or Dismissal. A denial of a motion to remand to state court is not a final decision and is thus not subject to immediate review. ${ }^{53}$ Nor has mandamus been provided to protect the right to a hearing in federal court insofar as it merely functions as an appeal. ${ }^{54}$ For example, recent cases have denied the writ when removal was proper on its face and removability had been recognized under similar facts. ${ }^{55}$ As long as the judge's exercise of jurisdiction is not blatantly offensive to the removal order of the dual jurisdictional system, review is reserved for appeal after final decision. Similarly, the Supreme Court has held that a denial of a motion to dismiss for lack of subject matter jurisdiction is not immediately reviewable. ${ }^{56}$ The fact that an error on a jurisdictional question may lead to a decision on the merits beyond the court's authority does not amount to a usurpation of power such as to make interlocutory appeal appropriate. ${ }^{57}$ The most widely quoted standard on when mandamus is available is that of American Airlines v. Forman:

The challenged assumption or denial of jurisdiction must be so plainly wrong as to indicate a failure to comprehend or refusal to be guided by unambiguous provisions of a statute or settled common law doctrine. If a rational and substantial legal argument can be made in support of the questioned jurisdictional ruling, the case is not appropriate for mandamus or prohibition even though on normal appeal a reviewing court might find reversible error. ${ }^{58}$

Thus, mandamus is not available when the jurisdictional issue is one of first impression ${ }^{59}$ or of statutory interpretation where there is conflicting legislative history on the meaning of the language. ${ }^{60}$

As the Supreme Court early announced the rationale, the inconvenience or

50. The delay issue is discussed by Justice Rehnquist in his dissent to denial of certiorari in Sheet Metal Workers' Int'l Ass'n v. Carter, 450 U.S. 949, 952 (1981).

51. Carter, 618 F.2d at 1100 .

52. Live \& Let Live, Inc. v. Carlsberg Mobile Home Properties, 592 F.2d 846 (5th Cir. 1979). For a discussion of when a judgment may be considered "final" for the purposes of remand, see Marsh Inv. Corp. v. Langford, 494 F. Supp. 344 (E.D. La. 1980).

53. Ex parte Hoard, 105 U.S. 578 (1881). For more recent cases, see, e.g., Melancon v. Texaco, 659 F.2d 551 (5th Cir. 1981); Poirrier v. Nicklos Drilling Co., 648 F.2d 1063 (5th Cir. 1981); Wilkins v. American Export-Isbrandtsen Lines, 401 F.2d 151 (2d Cir. 1968).

54. Ex parte Hoard, 105 U.S. 578, 579 (1881). See also Ex parte Roe, 234 U.S. 70 (1914).

55. Poirrier v. Nicklos Drilling Co., 648 F.2d 1063 (5th Cir. 1981). See also Melancon v. Texaco, 659

F.2d 551 (5th Cir. 1981); Wilkins v. American Export-Isbrandtsen Lines, 401 F.2d 151 (2d Cir. 1968).

56. Catlin v. United States, 324 U.S. 229 (1945); Fleming v. Beradi, 441 F.2d 732 (3d Cir. 1971);

Pennsylvania v. Brown, 373 F.2d 771 (3d Cir. 1967), cert. denied, 391 U.S. 921 (1968). But see infra comment g.

57. Pfizer, Inc. v. Lord, 522 F.2d 612, 615 (8th Cir. 1975), cert. denied, 424 U.S. 950 (1976)

58. 204 F.2d 230, 232 (3d Cir.), cert. denied, 346 U.S. 806 (1953).

59. Pfizer, Inc. v. Lord, 522 F.2d 612, 615 (8th Cir. 1975), cert. denied, 424 U.S. 950 (1976); National Right to Work Legal Defense Found. v. Richey, 510 F.2d 1239 (D.C. Cir.), cert. denied, 422 U.S. 1008 (1975).

60. Formica Corp. v. Lefkowitz, 590 F.2d 915, 920-21 (C.C.P.A.), cert. denied, 442 U.S. 917 (1979). 
expense of an unnecessary trial if jurisdiction were later found to be lacking was not sufficient justification for interlocutory review because it would be the greater inconvenience in the greater number of cases to depart from orderly methods of review established by law to correct errors. ${ }^{61}$ The "orderly method" of correcting errors was, of course, review upon final decision, and mandamus would not issue unless there was no review on final appeal and extraordinary circumstances. ${ }^{62}$ Cases today, even while denying mandamus, have by implication dropped the former requirement, noting only a lack of special circumstances. ${ }^{63} \mathrm{~A}$ denial of a dismissal for lack of subject matter jurisdiction or a denial of a remand (at least as to jurisdiction had the suit initially been brought in federal court) is reviewable upon final decision. ${ }^{64}$

Interlocutory review was granted in Three $J$ Farms $v$. Alton Box Board Co., following a denial of a remand, for the traditional purpose of confining the lower court to the lawful exercise of its jurisdiction. ${ }^{65}$ The challenged order was entered following reconsideration of a grant of a remand, in contravention of the statutory ban on review of such decisions. The denial of the remand thus presented the same concerns of interference with the functioning of state courts as underlie the ban and constituted a usurpation of and palpable threat to the role of state courts, as proclaimed by Congress, in our system of dual jurisdiction. ${ }^{66}$

Abuse was also found in Bancohio Corp. v. Fox, where the district court ignored the rule that a state court on removal can transmit no more jurisdiction to the federal court than it had at the time of commencement of the suit. ${ }^{67}$ Because the rule of federal jurisdiction invoked by the court of appeals in that case seems to be a quaint, indeed irrational, fetish, the case seems wrong. Nevertheless, it illustrates a willingness of courts of appeals to entertain interlocutory appeals from jurisdictional decisions which egregiously affront the statutory and constitutional scheme of dual sovereignties.

A grant of mandamus following a refusal to dismiss for lack of subject matter jurisdiction may also be rooted in a concern for interference with agency functions as established by Congress. The Supreme Court in United States Alkali Export Ass'n $v$. United States reviewed a denial of a motion to dismiss on the basis that exclusive

61. Ex parte Park Square Auto. Station, 244 U.S. 412, 416 (1917). Cf. supra $\S 15$ of this Interlocutory Restatement, note 13 and accompanying text; infra $\S 24$ of this Interlocutory Restatement, note 33 and accompanying text.

62. Id. at 415

63. Poirrier v. Nicklos Drilling Co., 648 F.2d 1063 (5th Cir. 1981); Wilkins v. American ExportIsbrandtsen Lines, 401 F.2d 151 (2d Cir. 1968).

64. See, e.g., D.J. McDuffie, Inc. v. Old Reliable Fire Ins. Co., 608 F.2d 145 (5th Cir. 1979), cert. denied, 449 U.S. 830 (1980); Jones v. General Tire \& Rubber, 541 F.2d 660 (7th Cir. 1976). See generally infra comment h.

65. 609 F.2d 112 (4th Cir. 1979), cert. denied, 445 U.S. 911 (1980).

66. Id. at 115-16. The reconsideration was prompted by the defendant's protest that he had had no chance to argue in opposition to the remand. (For further discussion of reconsideration of remands, see supra note 12 and accompanying text.)

This concern with overextension of federal jurisdiction and interference with state processes makes mandamus more available when the issue is removal of criminal prosecutions and the state interest is that of enforcing its laws. See Pennsylvania v. Newcomer, 618 F.2d 246 (3d Cir. 1980).

67. 516 F.2d 29 (6th Cir. 1975). Thus, since the complaint stated an exclusively federal question, the state court never had jurisdiction and there was nothing to be removed. 
jurisdiction was with the Federal Trade Commission. ${ }^{68}$ The Justices expressed reluctance to interfere when final decision review was available and agreed that waiting for such review was not alone sufficient hardship, but they granted interlocutory review anyway to avoid possible "frustration of the functions which Congress had directed the Commission to perform and of the policy which Congress presumably sought to effectuate by their performance."69 To grant federal jurisdiction if the FTC were meant to have exclusive power would thwart a congressional purpose of allowing export associations violating regulations to conciliate and reform without being subject to the penalties of law. ${ }^{70}$ Subsequent cases have used similar language in granting mandamus to review denials of dismissals raising jurisdictional issues touching on agency functions. ${ }^{71}$

g. Incidental Review. An exercise of federal jurisdiction embodied in a denial of remand or dismissal may be reviewed prior to final decision in connection with an appeal from a partial final decision if the district court dismisses as to one or more but fewer than all parties or claims and specially designates partial finality. ${ }^{72}$ Such issues may also be considered on appeal from an order granting or denying a preliminary injunction. ${ }^{73}$

h. Revieze on Final Decision. The absence of federal subject matter jurisdiction cannot be waived by a party and may be raised for the first time on appeal ${ }^{74}$ or may be raised by the court sua sponte. ${ }^{75}$ In American Life $\mathscr{G}^{\circ}$ Casualty Co. $v$. Finn, the defendant who removed the action was permitted to upset an adverse judgment on appeal by asserting the impropriety of his own removal. ${ }^{76}$

The Supreme Court, however, also announced the rule in Grubbs v. General Electric Credit Corp. that review of removal, after a trial on the merits without objection, will look only to whether federal jurisdiction would have been proper had the

68. 325 U.S. $196(1945)$.

69. Id. at 203

70. Id.

71. First Jersey Sec. v. Bergen, 605 F.2d 690, 702 (3d Cir. 1979), cert. denied, 444 U.S. 1074 (1980) (also language that the district court's action was the equivalent of an injunction without the availability of appeal); United States v. Boe, 543 F.2d 151, 160 (C.C.P.A. 1976) (also language that the initial jurisdictional decision was "clearly beyond unambiguous provisions of the statute"). The early position, stated in American Airlines v. Forman, 204 F.2d 230, 232 (3d Cir.), cert. denied, 346 U.S. 806 (1953), was that mandamus would be granted only if the administrative agency clearly had exclusive first jurisdiction, the same "plainly wrong" standard applied to general jurisdictional questions.

72. B., Inc. v. Miller Brewing Co., 663 F.2d 545 (5th Cir. 1981). See also Nu-Way Systems v. Belmont Marketing, 635 F.2d 617 (7th Cir. 1980); Sell v. Volkswagen of Am., 505 F.2d 953 (6th Cir. 1974). Designations of partial finality are governed by Rule 54(b) of the Federal Rules of Civil Procedure; see supra $\S 4$ of this Interlocutory Restatement.

73. Beech-Nut, Inc. v. Warner-Lambert Co., 480 F.2d 801 (2d Cir. 1973); Kysor Indus. Corp. v. Pet, Inc., 459 F.2d 1010 (6th Cir.), cert. denied, 409 U.S. 980 (1972); Johnson v. England, 356 F.2d 44 (9th Cir. 1966). h See also supra $\S 12$ of this Interlocutory Restatement, notes 81-82 and accompanying text. A contrary result as to review of denial of a remand was reached in La Chemise LaCoste v. Alligator Co., 506 F.2d 339 (3d Cir. 1974), cert. denied, 421 U.S. 937 (1975). Three Supreme Court Justices, however, in dissenting from the denial of certiorari, approved the position of Beech-Nut and Kysor that there was no reason to delay such review. 421 U.S. at 938.

74. See, e.g., Eagerton v. Valuations, Inc., 698 F.2d 1115, 1118 (11th Cir. 1983).

75. Treinies v. Sunshine Mining Co., 308 U.S. 66, 70 (1939); Mansfield, C. \& L. Mich. Ry. v. Swan, 111 U.S. 379,384 (1884). See also supra $\S 9$ of this Interlocutory Restatement, notes $216-18$ and accompanying text.

76. 341 U.S. 6 (1951). 
suit initially been filed in federal court. ${ }^{77}$ A motion to remand is generally sufficient to preserve the issue unless the plaintiff has the opportunity to and fails to challenge the denial of the remand in connection with other permissible interlocutory review, such as appeal from an injunction or certification, ${ }^{78}$ or otherwise ratifies the exercise of federal jurisdiction. ${ }^{79}$

Illustration 16-5. P brings suit in state court against $\mathrm{D}$, who removes. P's motion for remand is denied. $\mathrm{P}$ subsequently amends his complaint to state a federal question. Summary judgment is granted for D. P appeals this final decision. Since $\mathrm{P}$ objected to removal by seeking remand and has had no previous opportunity for review, he ordinarily would have retained his right to raise the removal issue in a subsequent appeal. Here, however, the amendment cured the jurisdictional defect, and $\mathrm{P}$ is deemed to have waived his objection to what was, at the time it was made, an improper removal. ${ }^{80}$

i. Certification. Denial of a motion to remand or to dismiss for lack of subject matter jurisdiction is considered a suitable order for certification under 28 U.S.C. $\S 1292$ (b) when the determining issue otherwise fits the requirements of the statute. ${ }^{81}$ Certification will almost always "advance the ultimate termination of the litigation" since a finding of lack of jurisdiction will either prevent a trial altogether or foreclose a federal trial which would be voided later in favor of a state trial or administrative proceeding.

Subject matter jurisdiction questions certified have included standing under the expedited appeal provision of the Federal Election Campaign Act, ${ }^{82}$ standing in parens patriae for a state attorney general, ${ }^{83}$ choice of law issues which affected standing, ${ }^{84}$ "defensive" use of a federal question, ${ }^{85}$ bankruptcy jurisdiction, ${ }^{86}$ and administrative filing requirements for employment discrimination suits. ${ }^{87}$

Remand questions certified have generally focused on the underlying jurisdic-

77. 405 U.S. 699 (1972). See also Mackay v. Unita Dev. Corp., 229 U.S. 173, 176-77 (1913); Baggs v. Martin, 179 U.S. 206 (1900); Stone v. Stone, 632 F.2d 740 (9th Cir. 1980), cert. denied, 453 U.S. 922 (1981).

78. Shetran v. General Elec. Co., 593 F.2d 93 (9th Cir.), cert. denied, 444 U.S. 868 (1979).

79. Brough v. United Steelworkers, 437 F.2d 748 (1st Cir. 1971). See also Vitarroz Corp. v. Borden, Inc., 644 F.2d 960 (2d Cir. 1981) (plaintiff's claim stated facts sufficient to constitute trademark infringement under either state or federal law; by failing to assert a preference for the state claim by protesting removal, plaintiff may be found to have invoked federal jurisdiction).

80. Brough v. United Steelworkers, 437 F.2d 748 (1st Cir. 1971).

81. See supra $\S 11$ of this Interlocutory Restatement.

82. Bread Political Action Comm. v. Federal Election Comm'n, 591 F.2d 29 (7th Cir. 1979).

83. Burch v. Goodyear Tire \& Rubber Co., 554 F.2d 633 (4th Cir. 1977).

84. Junco v. Eastern Airlines, 399 F. Supp. 666 (S.D.N.Y. 1975), affd, 538 F.2d 310 (1976). The judge stated he was disinclined to certify the issue but would do so because it would cause no delay since the case could not be tried for four months anyway. A dismissal for lack of standing had been granted, but certification was necessary because some plaintiffs remained.

85. Home Fed. Sav. \& Loan Ass'n v. Insurance Dep't, 571 F.2d 423 (8th Cir. 1978). For another certification of a federal question issue, see Yancoskie v. Delaware River Port Auth., 528 F.2d 722 (3d Cir. 1975).

86. In re Pacific Homes, 456 F. Supp. 851 (C.D. Cal. 1978), rev'd, 611 F.2d 1253 (9th Cir. 1980) (jurisdictional issue raised an "important question" which could have meant the difference between plenary and summary proceedings).

87. Myles v. Schlesinger, 436 F. Supp. 8 (E.D. Pa. 1976) (jurisdictional issue was "unnecessarily complex due to the lack of guidance from Congress and the courts"). 
tional issues rather than on procedural points-for example, application of 28 U.S.C. § 1441 (c) separable and independent claims provisions when third party litigants initiate the removal, ${ }^{88}$ interpretation of a state law making insurance companies residents of the state of the insured for the purposes of certain actions, ${ }^{89}$ and propriety of remand when the federal court does have jurisdiction of a labor dispute but lacks the state court's power to issue injunctions against work stoppages. ${ }^{90}$ Apparently the only certification of failure to remand based on a procedural question was in Tri-Cities Newspapers $v$. Tri-Cities Printing Pressman and Assistants Local 349, where the issue was whether a defendant was "nominal" such that he did not have to join the removal petition. ${ }^{91}$

$\S 17$. Litigation in Agencies and Other Courts: Stays and Injunctions.

(A) AN ORDER GRANTING OR DENYING AN INJUNCTION AGAINST PROCEEDING IN AN AGENCY OR OTHER COURT PENDING FINAL DECISION IN THE ACTION AT HAND IS REVIEWABLE ON INTERLOCUTORY APPEAL TO PROTECT A RIGHT TO PRESENT A CLAIM OR DEFENSE IN AN AGENCY OR OTHER COURT.

(B) AN ORDER DISMISSING AN ACTION IN DEFERENCE TO PROCEEDINGS IN AN AGENCY OR OTHER COURT IS A FINAL DECISION.

(C) AN ORDER GRANTING A STAY PENDING THE OUTCOME OF LITIGATION IN AN AGENCY OR OTHER COURT IS REVIEWABLE AS A FINAL DECISION IF

(1) NO FURTHER PROCEEDING IS CONTEMPLATED AFTER TERMINATION OF THE ALTERNATE LITIGATION,

(2) THE ALTERNATE LITIGATION HAS NOT BEEN FILED OR IS UNLIKELY TO CONCLUDE SEASONABLY FOR REASONS NOT WITHIN THE CONTROL OF THE APPELLANT, OR

(3) THE ALTERNATE LITIGATION BY ITS VERY CONTINUANCE VIOLATES THE RIGHT WHICH THE APPELLANT SEEKS TO SECURE.

(D) A NONFINAL ORDER GRANTING A STAY PENDING THE OUTCOME OF LITIGATION IN AN AGENCY OR OTHER COURT MAY BE REVIEWED ON CERTIFIED APPEAL OR ON INTERLOCUTORY APPEAL TO PREVENT

88. Bond v. Doig, 433 F. Supp. 243 (D.N.J. 1977) (conflicting decisions within the district on question which the court of appeals had not yet considered). For other certifications of 28 U.S.C. $\$ 1441$ (c) issues underlying denials of remands, see Union Planters Nat'l Bank v. CBS, 557 F.2d 84 (6th Cir. 1977); Climax Chem. Co. v. C.F. Braun \& Co., 370 F.2d 616 (10th Cir. 1966), cert. denied, 386 U.S. 981 (1967).

89. White v. United States Fidelity \& Guar. Co., 356 F.2d 746 (1st Cir. 1966) (question of first impression).

90. Sealtest Foods Div. of Nat'l Dairy Prods. Corp. v. Conrad, 262 F. Supp. 623 (N.D.N.Y. 1966) (split of authorities on question).

91. 427 F.2d 325 (5th Cir. 1970). 
(1) A MANIFEST REFUSAL TO PERFORM A JURISDICTIONAL DUTY, OR

(2) A WITHHOLDING OF PROVISIONAL INJUNGTIVE RELIEF TO WHICH THE APPELLANT IS ENTITLED.

(E) AN ORDER DENYING A STAY PENDING THE OUTCOME OF LITIGATION IN AN AGENCY OR OTHER COURT IS REVIEWABLE ON APPEAL FROM A FINAL DECISION, ON CERTIFIED APPEAL, OR ON INTERLOCUTORY APPEAL TO PREVENT A MANIFESTLY PREMATURE AND INAPPROPRIATE INVOLVEMENT OF A DISTRICT COURT IN MATTERS RESERVED FOR DECISION IN THE ALTERNATE FORUM.

\section{COMMEnT}

a. Introduction. Rules concerning the appealability of stays and injunctions issued by district courts in actions which are or could be proceeding simultaneously in other forums are generally the same no matter whether the second forum is an agency, state court, or other district court. ${ }^{1}$ (Arbitration proceedings are treated separately; see infra $\S 18$ of this Interlocutory Restatement.) Substantive doctrine concerning the availability of such interlocutory measures differs, of course, depending on whether the relationship between two federal courts or between a state and a federal court is at issue.

b. Injunctions Against Proceeding. An order granting or denying an injunction to foreclose a duplicate or overlapping proceeding in another forum in deference to the action in which the order is entered is immediately appealable under the general provision as to review of injunctive relief, 28 U.S.C. $\S 1292(a)(1) .^{2}$ Federal courts, however, are generally constrained from staying state court proceedings by the express provisions of the federal anti-injunction statute. ${ }^{3}$

1. This comment does not cover direct appeals to the Supreme Court from stays issued by three-judge panels; such appeals are governed by 28 U.S.C. $§ 1253$ (1976). See MTM, Inc. v. Baxley, 420 U.S. 799 (1975).

Consider also 15 C. Wright, A. Miller \& E. Cooper, Federal Practice and Procedure $\$ 3903$, at $412-15$ (1976), suggesting that 28 U.S.C. $\$ 2105$ (1976), addressing matters in abatement, arguably could be applied as a ban on all appeals of stays and injunctions of proceedings in other courts. The expansion of the concept of "jurisdiction," however, would now provide a broad exception to the statute, and the authors suggest that 28 U.S.C. $\S 2105$ is "justifiably" ignored. The provision reads: "There shall be no reversal in the Supreme Court or a court of appeals for error in ruling upon matters in abatement which do not involve jurisdiction."

2. See e.g., Kerotest Mfg. Co. v. C-O-Two Fire Equip. Co., 342 U.S. 180 (1952) (refusal to enjoin second district court proceedings involving the same parties); Pacific Live Stock Co. v. Lewis, 241 U.S. 440 (1916) (refusal to enjoin state administrative proceeding); Compagnie des Bauxites de Guinea v. Insurance Co. of N. Am., 651 F.2d 877 (3d Cir. 1981) (injunction against suit in progress in England, reversed), cert. denied, 456 U.S. 694 (1982); In re Macon Uplands Venture, 624 F.2d 26 (5th Gir. 1980) (injunction against outside proceedings, though none yet filed); Wilkins v. Rogers, 581 F.2d 399 (4th Cir. 1978) (refusal to enjoin state litigation); Gipson v. New Jersey Sup. Ct., 558 F.2d 701 (3d Cir. 1977) (refusal to enjoin state bar disciplinary proceeding); American Radio Ass'n v. Mobile S.S. Ass'n, 483 F.2d 1 (5th Cir. 1973) (refusal to enjoin state proceedings); Lynch v. Snepp, 472 F.2d 769 (4th Cir. 1973) (enjoining enforcement of state court injunction), cert. denied, 415 U.S. 983 (1974).

Note that not all circuits follow this rule when the alternate forum is an arbitration proceeding. See infra $\S 18$ of this Interlocutory Restatement, comment $b$.

3. 28 U.S.C. $\$ 2283$ (1976): "A court of the United States may not grant an injunction to stay pro- 
c. Dismissal and Stays Where No Further Proceedings Contemplated. An order dismissing an action in deference to litigation in another forum is an appealable final decision, while an order staying an action for the same reason is nonfinal and nonappealable. ${ }^{4}$ When there is no contemplation of proceeding further in the staying forum, however, such an order is tantamount to a dismissal and is thus reviewable on the same basis. ${ }^{5}$ This rule applies whether the stay is merely a technical error under a doctrine such as Burford abstention where a dismissal is always appropriate ${ }^{6}$ or whether the stay rather than dismissal may actually be proper but the terminal effect is still the same. ${ }^{7}$

A stay will be the practical equivalent of a dismissal, and thus appealable, when the substantive issues in the federal case are identical to those in the suit in the alternate forum; such issues will at the termination of the alternate action be res judicata so that there can effectively be no further proceedings in the federal court. $^{8}$ Thus, the stay must require all or an essential part of the federal suit to be litigated in the alternate forum ${ }^{9}$ - the Supreme Court speaks of a federal forum "surrendering jurisdiction" of the case before it. ${ }^{10}$

ceedings in a State court except as expressly authorized by Act of Congress, or where necessary in aid of its jurisdiction, or to protect or effectuate its judgments."

A major area in which such injunctions are granted is in certain civil rights cases; federal interference with state proceedings is held to have been specifically authorized under 42 U.S.C. $\S 1983$ (1976). Mitchum v. Foster, 407 U.S. 225 (1972). Issuance of such injunctions, however, is still controlled by the equitable principles of Younger v. Harris, 401 U.S. 37 (1971).

4. Jensenius v. Texaco, 639 F.2d 1342, 1343 (5th Cir. 1981); Cotler v. Inter-County Orthopaedic Ass'n, 526 F.2d 537, 540 (3d Cir. 1975); Jackson Brewing Co. v. Clarke, 303 F.2d 844, 845-46 (5th Cir.), cert. denied, 371 U.S. 891 (1962); Arny v. Philadelphia Transp. Co., 266 F.2d 869, 870 (3d Cir. 1959).

5. Moses H. Cone Memorial Hosp. v. Mercury Constr. Corp., 103 S. Ct. 927 (1983).

6. Baltimore Bank for Coops. v. Farmers Cheese Coop., 583 F.2d 104 (3d Cir. 1978). Cf. Federman v. Empire Fire \& Marine Ins. Co., 597 F.2d 798 (2d Cir. 1979).

The doctrine of Burford abstention, announced by the Supreme Court in Burford v. Sun Oil Co., 319 U.S. 315 (1943), requires dismissal when the federal litigation presents issues of state law which are in their entirety better resolved in a state court or agency.

7. Moses H. Cone Memorial Hosp. v. Mercury Constr. Corp., 103 S. Ct. 927 (1983). Note that the Supreme Court specifically found it unnecessary to decide whether a stay or dismissal was appropriate under the "wise judicial administration" abstention doctrine (drawn from Colorado River Water Conserv. Dist. v. United States, 424 U.S. 800 (1976)) invoked there. Moses Cone, $103 \mathrm{~S}$. Ct. at 935, 943. A stay is generally considered appropriate in cases involving Pullman abstentions (from Railroad Comm'n v. Pullman Co., 312 U.S. 496 (1941)) and deferrals to the primary jurisdiction of administrative agencies. Even before Moses Cone, when a district court dismissed an action when it should have abstained and retained jurisdiction, the appellate court would not impute the proper procedure and determine appealability on that basis but would accept the appeal from the dismissal. Vinyard v. King, 655 F.2d 1016 (10th Cir. 1981); but see State Farm Mut. Auto. Ins. Co. v. Scholes, 601 F.2d 1151, 1153-54 (10th Cir. 1979).

8. Moses H. Cone Memorial Hosp. v. Mercury Constr. Corp., 103 S. Ct. 927, 934 (1983). This decision seemingly casts doubt on lower court cases such as Andrews v. Southern Discount Co., 662 F.2d 772 , 724 (11th Cir. 1981), and Arny v. Philadelphia Transp. Co., 266 F.2d 869, 870 (3d Cir. 1959), which had held that it was not sufficient to characterize a stay as a final decision by speculating that the alternate litigation might resolve all the issues of fact and have a res judicata effect on the proceeding stayed.

9. Moses H. Cone Memorial Hosp. v. Mercury Constr. Corp., 103 S. Ct. 927, 934 n.11 (1983).

10. Id. The stay could not be a mere "housekeeping" order, and furthermore, the plaintiff had to be effectively out of federal court as a result of the operation of law rather than as a practical result of his own conduct or failure to proceed. Id.

The language of Moses Cone, however, creates uncertainty as to whether the doctrine announced therein would apply to make Pullman abstentions appealable as final orders. The Pullman doctrine (from Railroad Comm'n v. Pullman Co., 312 U.S. 496 (1941)) allows a federal judge to stay a proceeding before him to obtain a state ruling on a specific issue of state law, with resolution of that question to be "plugged into" the federal determination of a federal or constitutional issue. The Supreme Court in Moses Cone identifies 
Illustration 17-1. P brings suit in state court against $\mathrm{D}$, seeking a declaration that $\mathrm{D}$ has no right to arbitration of their contract dispute. $\mathrm{D}$ then brings suit in federal court against $P$ to compel such arbitration. The district judge, citing the ground of "wise judicial administration," 1 determines that exercise of federal jurisdiction should be withheld to allow the state to determine the declaratory judgment action. Whether the judge orders a stay or a dismissal, D may appeal. In either case the order will require that the only issue in the federal suit - arbitrabilitybe tried in state court, and the decision there will be res judicata such that there can be no contemplation of proceeding further in the federal forum. ${ }^{12}$

Illustration 17-2. P brings suit in federal court against D, alleging breach of contract. At the same time, other plaintiffs bring a suit in state court based on an identically worded contract. The district judge stays the

Idlewild Bon Voyage Liquor Corp. v. Epstein, 370 U.S. 713 (1962) (discussed infra text accompanying notes 15-17), as involving Pullman abstention and does not disapprove the finding of appealability there. $103 \mathrm{~S}$. Ct. at 933. Since the state determination of the state question might make it unnecessary to reach the federal question, an appellant challenging a Pullman abstention could be seen as effectively out of federal court. For a case using Moses Cone in this manner, see Hovsons, Inc. v. Secretary of the Interior, 711 F.2d 1208, 1211-12 (3d Cir. 1983).

An alternate characterization, however, would suggest that the federal court had not so much "surrendered jurisdiction" of a claim it could have heard as it had looked to state law to determine no true federal claim existed. The Supreme Court itself in Moses Cone defines Pullman abstention in language - "entered with the expectation that the federal litigation will resume in the event that the plaintiff does not obtain relief in state court on state law grounds," id. at 934-which would make appealability contrary to its emphasis on lack of contemplation of further proceedings in the federal forum. The phrasing of the Idlewild rationale as approved, $i d$. at $934 \mathrm{n} .11$, is seemingly inconsistent with the denomination of the case as a Pullman abstention, and the Court holds that finality was less clear in Idlewild than on the facts before it. Id. at 933 .

Finally, though the Moses Cone opinion is couched in terms of alternate proceedings in state courts, such usage is presumably a result of the given factual setting rather than a limitation. The rationale for appealability announced by the Supreme Court would also seemingly apply to stays deferring to federal agencies under the doctrine of primary jurisdiction when the effect of the stay would be to require determination of all the appellant's facts and claims outside federal court. Immediate review of stays based on primary jurisdiction has sometimes been obtained by invoking the collateral order doctrine. See, e.g., Civil Aeronautics Bd. v. Aeromatic Travel Corp., 489 F.2d 251 (2d Cir. 1973); $c f$. supra $\S 16$ of this Interlocutory Restatement, text accompanying notes 68-71 (mandamus to review refusal to dismiss when appellant asserts exclusive agency jurisdiction). Other appellate courts, however, have questioned such exercise of jurisdiction, pointing out that jurisdictional rights are generally deemed to be adequately protected by review after final decision. United States Tour Operators Ass'n v. Trans World Airlines, 556 F.2d 126, 129-30 \& n.6 (2d Cir. 1977).

For an initial indication of how lower courts will apply Moses Cone, see Herrington v. County of Sonoma, 706 F.2d 938 (9th Cir. 1983) (stay appealable); Bridge Constr. Corp. v. City of Berlin, 705 F.2d 582 (1st Cir. 1983) (stay not appealable); Cheyney State College Faculty v. Hufstedler, 703 F.2d 732 (3d Cir. 1983) (stay not appealable).

11. This doctrine of discretionary withholding of the exercise of authorized federal jurisdiction is drawn from Colorado River Water Conserv. Dist. v. United States, 424 U.S. 800 (1976). Citing the "extraordinary circumstances" language of Kerotest Mfg. Co. v. C-O-Two Fire Equip. Co., 342 U.S. 180 , 183 (1952), the Supreme Court in Colorado River authorized federal courts to refuse to exercise jurisdiction in the face of contemporaneous exercises of concurrent state jurisdiction as warranted by "wise judicial administration, giving regard to conservation of judicial resources and comprehensive disposition of litigation." 424 U.S. at 817 . Factors to be considered in making this determination include the order in which the state and federal forums obtained jurisdiction; the degree of progress in the federal forum; the relative inconvenience of that forum; the need, given the issues involved, to avoid piecemeal litigation; and the extent to which resolution of the action will involve extensive questions of state law. Id. at 818-20.

12. Moses H. Cone Memorial Hosp. v. Mercury Constr. Corp., 103 S. Ct. 927 (1983). 
federal suit pending state determination of the contract issue in the suit there. $P$ appeals. The appeal should be dismissed. The stay has not effectively terminated P's federal suit since he is not a party to the state suit; his claim will still be determined in the federal forum, which will apply state law, as clarified in the state suit, to his facts. ${ }^{13}$

Illustration 17-3. $\mathrm{P}$ brings a civil rights suit against $\mathrm{D}$, a college, alleging racial discrimination. The district judge stays the action pending the outcome of an ongoing administrative proceeding in which a voluntary desegregation plan is being negotiated but requests progress reports. $P$ appeals. The appeal should be dismissed. P's suit is not effectively terminated because he is not a party to the negotiations and any resulting settlement might not cover the issues he wishes to raise; further, the district court in requesting progress reports has indicated that it intends that P's suit continue. ${ }^{14}$

d. Stays Pending Outcome of Litigation that Is Not Active. A stay order may properly be appealed as a final decision if the proceeding to which deference is shown has not yet been filed or is unlikely to conclude seasonably for reasons not within the appellant's control. The rule with respect to stays pending actions not yet filed rests on the authority of a footnote in the opinion in Idlewild Bon Voyage Liquor Corp. v. Epstein in which the Supreme Court approved a rationale of the court of appeals. ${ }^{15}$ The case involved an appeal from a Pullman ${ }^{16}$ abstention stay; and the lower court had reasoned that inasmuch as no action was then pending in the state court to provide the needed interpretation of state law, the stay had the effect of putting the plaintiff "out of court" and was therefore final.17

An appellate court may also find finality such as to allow review when a stay defers to a proceeding which is dormant and not likely to be revived. The leading case is Amdur $v$. Lizars, in which a stay of federal proceedings was challenged by an appellant who had refused to comply with a state court order requiring a posting of security and, after the stay, had even sought a voluntary dismissal of the state proceeding. ${ }^{18}$ Finality was found by the court of appeals because the state litigation was effectively halted; thus the federal proceeding could never resume, and

13. See Bridge Constr. Corp. v. City of Berlin, 705 F.2d 582 (1st Cir. 1983).

14. Cheyney State College Faculty v. Hufstedler, 703 F.2d 732 (3d Cir. 1983).

15. 370 U.S. 713 (1962) (per curiam).

16. See discussion supra note 10.

17. Idlewild, 370 U.S. at 715 n.2. Appealability of a stay when no alternate litigation is pending has since still often been handled in a footnote, now citing to Idlewild or one of it successors. Rancho Palos Verdes Corp. v. City of Laguna Beach, 547 F.2d 1092, 1093 n.1 (9th Cir. 1976); Vickers v. Trainor, 546 F.2d 739, 747 (7th Cir. 1976); Indiana State Employees Ass'n v. Boehning, 511 F.2d 834, 835 (7th Cir.), rev'd on other grounds, 423 U.S. 6 (1975); Drexler v. Southwest Dubois School Corp., 504 F.2d 836, 838 (7th Cir. 1974); Druker v. Sullivan, 458 F.2d 1272, 1274 n.3 (1st Cir. 1972). See also United States v. Elrod, 627 F.2d 813, 816 (7th Cir. 1980) (stay pending administrative proceedings).

Note, however, that the Supreme Court recently in Moses H. Cone Memorial Hosp. v. Mercury Constr. Corp., 103 S. Ct. 927, 933 n.8 (1983), rejected the "no alternate litigation pending" distinction as the rationale for appealability in Idlewild; thus, this means of obtaining review may have been undermined. The lack of alternate proceedings may still be seen as contributing to the indefiniteness of the stay and uncertainty of resumption of the federal proceedings as discussed infra this comment.

18. 372 F.2d 103 (4th Cir. 1967). 
the stay had the same practical consequence as a dismissal. ${ }^{19}$ On its facts, Amdur seems questionable in light of the Supreme Court's more recent dictum that the finality of the stay order cannot be derived from a voluntary act of the appellant; ${ }^{20}$ but the principle has been applied in other circumstances where the federal proceeding was unlikely to resume, such as when a grand jury proceeding was stayed and the term of such body would likely expire before the conclusion of the state action to which deference was shown ${ }^{21}$ and when a federal suit was stayed pending the outcome of a bankruptcy reorganization proceeding which had already run ten years and was likely to continue similarly. ${ }^{22}$

Illustration 17-4. $\mathrm{P}$, an oil company, brings suit in a federal district court contesting an administrative agency determination as to parties it was required to supply with oil. The judge stays the proceeding pending the outcome of a related supply suit in another district in which a preliminary injunction has been granted. $P$, however, is not actually a party to the other suit, and because of intervening administrative decisions neither litigant in the other action any longer has an interest in either vacating or making permanent that injunction. $P$ appeals the stay order. His appeal should be entertained. A final outcome will never be reached in the other action, so the proceeding involving $P$ will never resume. Therefore, the stay has effectively terminated P's suit, and the order is appealable. ${ }^{23}$

e. Impairment of Rights by Alternate Litigation. A stay may be held to be final, and thus appealable, when it defers to a proceeding which by its very continuance impairs the right which the appellant seeks to protect through the litigation stayed. ${ }^{24}$ Such an order effectively terminates that action because the issue as to the right asserted will be moot after the alternate litigation has proceeded. There is, however, no general right to be free of unwarranted litigation when the only loss will be the expense of an unnecessary or repeated trial and the error can be remedied by denying enforcement of or vacating the improper judgment. ${ }^{25}$

19. Id. at 105-06.

20. Moses H. Cone Memorial Hosp. v. Mercury Constr. Corp., 103 S. Ct. 927,934 n.11 (1983) (see supra note 10). E.g., United States v. Mellon Bank, N.A., 545 F.2d 869 (3d Cir. 1976) (stay of civil proceeding pending outcome of criminal trial not final because it was within the defendant's control to submit to criminal jurisdiction); of. Equal Employment Opportunity Comm'n v. Neches Butane Prods. Co., 704 F.2d 144 (5th Cir. 1983) (proceeding brought by agency to enforce subpoena stayed until agency complied with defendant's discovery request).

21. In re Grand Jury Proceedings, 525 F.2d 151 (3d Cir. 1975).

22. Haberern v. Leigh \& N.E. Ry., 554 F.2d 581 (3d Cir. 1977). See also Hines v. D'Artois, 531 F.2d 726, 730 (5th Cir. 1976); of. McKnight v. Blanchard, 667 F.2d 477 (5th Cir. 1982) (stay for reasons other than pending litigation).

23. Sun Oil Co. v. Federal Energy Admin., 572 F.2d 867 (Temp. Emer. Ct. App. 1978).

24. See, e.g., McSurely v. McClellan, 426 F.2d 664 (D.C. Cir. 1970).

25. See, e.g., Compare Central States, Southeast \& Southwest Areas Health \& Welfare Fund v. Old Sec. Life Ins. Co., 600 F.2d 671 (7th Cir. 1979), where the defendant insurance company requested that a federal suit against it, seeking to recover funds allegedly misappropriated by fraud, be dismissed because it had been adjudged insolvent in a state court order which enjoined other attempts to reach the company's assets. The denial of the dismissal was not collateral because the company would lose no right by being subjected to the federal litigation; any judgment rendered therein, if improper, could be vacated on appeal from the final decision, and the company would have lost only the expense of litigation. Id. at 676-77. 
Illustration 17-5. $\mathrm{P}$ refuses to comply with a subpoena duces tecum issued by a state court, asserting that production of the information requested would violate his first and fourth amendment rights. $P$ files suit in federal court seeking a declaratory judgment that he does not have to comply with the subpoena and an injunction barring the institution of state criminal contempt proceedings. Such state proceedings are instituted, and the federal court grants a motion staying its proceeding pending the outcome in state court. $P$ appeals. His appeal should be heard. His claim of a right to be free from the state contempt proceeding will be moot if not decided before such trial commences; hence the stay has the practical consequence of disposing of his claims. ${ }^{26}$

f. Enforcement of Jurisdictional Rights. The Supreme Court has also recently suggested as an alternate rationale for its finding of appealability of a stay that an order putting a plaintiff effectively out of federal court might always be immediately reviewable under the collateral order doctrine. ${ }^{27}$ The Court noted that such a stay would terminate the appellant's jurisdictional rights and would be nonreviewable on final decision because, even if the order were erroneous, a new federal trial would be blocked by the res judicata effect of the state proceeding to which the stay deferred. ${ }^{28}$

Interlocutory appeal from a stay order to protect jurisdictional rights previously has been provided by mandamus. In the leading case of Will $v$. Calvert Fire Insurance Co., a district court faced with a proceeding substantially similar to one in progress in a state court abstained as to all but the one claim which was exclusive to federal jurisdiction. ${ }^{29}$ The court of appeals issued mandamus to compel the exercise of authorized federal jurisdiction as to all the claims, but the Supreme Court reversed, upholding the discretion of the district judge with respect to the assertion of the concurrent jurisdiction over matters already in litigation in state

Similarly, litigation expenses have been held not to constitute sufficient extraordinary hardship when mandamus has been sought to review refusals to remand or dismiss for lack of personal jurisdiction. Cf. supra $\S 15$ of this Interlocutory Restatement, note 13 and accompanying text; supra $\S 16$ of this Interlocutory Restatement, note 61 and accompanying text; infra $\$ 24$ of this Interlocutory Restatement, note 33 and accompanying text.

See also Equal Employment Opportunity Comm'n v. Neches Butane Prods. Co., 704 F.2d 144 (5th Cir. 1983), where a federal court stayed a subpoena enforcement proceeding pending the issuing agency's compliance with discovery sought by the respondent company in challenging the subpoena. Immediate review was not available under the collateral order doctrine because the expense of going through unwarranted discovery did not give rise to loss of an irretrievable right and the nonreviewability of the order on final decision arose not from any effect of the stay but was merely the general nonreviewability associated with most discovery orders.

26. McSureley v. McClellan, 426 F.2d 664 (D.C. Cir. 1970). Appealability on these facts could also have been reached on the ground that the stay was the equivalent of denial of the injunction, as discussed infra text accompanying notes 38-40. Such may frequently be the case when preservation of a right is at issue.

27. Moses H. Cone Memorial Hosp. v. Mercury Constr. Corp., 103 S. Ct. 927, 935 (1983). See also Allied Paper v. United Gas Pipe Line Co., 561 F.2d 821, 825 (Temp. Emer. Ct. App. 1977) (offering no analysis other than a cite to Cohen v. Beneficial Indus. Loan Corp., 337 U.S. 541 (1949)). For a discussion of the collateral order doctrine, see supra $\S 12$ of this Interlocutory Restatement, notes $10-13$ and accompanying text.

28. Moses H. Cone Memorial Hosp. v. Mercury Constr. Corp., 103 S. Ct. 927, 935 (1983).

29. 437 U.S. 655 (1978). 
courts. Thus, interlocutory appeal was available only when the lower court had a duty, rather than discretion, to hear a claim. ${ }^{30}$ While rule $(C)(1)$ of the black letter of this section authorizes interlocutory review of stays even based on lower court discretion when no further proceedings are contemplated, ${ }^{31}$ the Will holding should still allow immediate appeal of at least some stays where the surrender of federal jurisdiction is only partial. ${ }^{32}$

Illustration 17-6. $\mathrm{P}$ brings a federal antitrust suit, combined with other claims, in federal court. The judge stays the action pending the outcome of a state suit based on state antitrust law. P appeals. Because the other claims will remain to be heard in federal court, the stay is not effectively terminal as defined in comment c. The appeal, however, should be entertained to protect the right to a federal forum since the judge is without the power to abstain inasmuch as the federal antitrust claim is exclusive to federal jurisdiction. ${ }^{33}$

g. Effect of Injunction. It has long been contended that a stay is the equivalent of an injunction and hence appealable. The Supreme Court, however, since Enelow v. New York Life Insurance Co. has recognized a distinction between the use by a court of its power to control behavior of others by injunction and the use of its inherent power to control its own conduct by a stay. ${ }^{34}$ An order involving commands to parties is an injunction even if "both" proceedings are in the same court. Thus, courts have held that a stay is the equivalent of such an injunction, and therefore appealable, if the action in which the order is made is one which would have been considered "at law" before the fusion of law and equity and the stay is sought to permit a prior determination of an equitable defense or counterclaim. ${ }^{35}$ These requirements are rarely met in the context of parallel proceedings in other forums, generally because the alternate litigation merely involves the same issues as the litigation stayed and thus cannot be equated with an equitable defense or counterclaim. ${ }^{36}$ The distinction is insignificant as well as archaic and has been

30. Id. at 661-64. Some lower courts seemingly have tried to expand the limits of this restriction. E.g., State Farm Mut. Auto. Ins. Co. v. Scholes, 601 F.2d 1151, 1154-55 (10th Cir. 1979); see also Frederick L. v. Thomas, 578 F.2d 513 (3d Cir. 1978).

31. See supra comment c; Moses H. Cone Memorial Hosp. v. Mercury Constr. Corp., 103 S. C.t. 927 (1983). For an example of a court of appeals applying Moses Cone in a case where Will previously would have been used to justify interlocutory appeal, see Silberkleit v. Kantrowitz, 413 F.2d 433 (9th Cir. 1983).

32. For a discussion of partial surrender or merely delayed exercise of federal jurisdiction, see supra notes 9-10 and accompanying text, plus I/lustrations 17-2 and 17-3.

33. Cf. Selma-Kingsburg-Fowler County Sanitation Dist. v. United States Dist. Ct., 604 F.2d 643 (9th Cir. 1979); Cotler v. Inter-County Orthopaedic Ass'n, 526 F.2d 537 (3d Cir. 1975).

34. 293 U.S. $379,381-82$ (1935).

35. E.g., Jackson Brewing Co. v. Clarke, 303 F.2d 844, 845 (5th Cir.), cert. denied, 371 U.S. 891 (1962).

36. Id. See also United States v. Georgia Pac. Corp., 562 F.2d 294, 296 (4th Cir. 1977); Hines v. D'Artois, 531 F.2d 726, 729 (5th Cir. 1976); Cotler v. Inter-County Orthopaedic Ass'n, 526 F.2d 537, 54041 (3d Cir. 1975). This doctrine appears to have been argued as a basis for appealability of a stay with decreasing frequency recently. When the stay is denied, however, at least one court has found it to have more vitality. In Microsoftware Computer Sys. v. Ontel Corp., 686 F.2d 531, 536 (7th Cir. 1982), the Seventh Circuit held that when a stay of contract suit (thus "at law") in federal court was sought because of the pendency of identical state proceedings, the "defense" interposed was actually that of unnecessary and wasteful duplication of lawsuits, an equitable claim, such that the order denying the stay was immediately appealable as equivalent to denial of an injunction. Most courts, however, look instead to the actual issues in a second suit--here contract and thus at law-in characterizing the defense asserted. E.g., Wal- 


\section{disregarded in this Interlocutory Restatement. ${ }^{37}$}

A stay, however, may be appealable as an injunctive order if it has the effect of precluding consideration of a request for preliminary injunctive relief. ${ }^{38}$ One circuit has rejected this position and denied review. ${ }^{39}$ The suit at bar there, however, involved no specific pending motion for a preliminary injunction but only a general prayer for injunctive relief. ${ }^{40}$

When a specific denial of a preliminary injunction is properly before it under 28 U.S.C. $\$ 1292(a)(1)$, a court will generally exercise its discretion to consider the propriety of the stay also because the two orders generally will be interlocked. ${ }^{41}$

Illustration 17-7. P brings a diversity action in federal court including, as part of the relief sought, a request for a preliminary injunction against D's nuisance. A state court suit involving substantially the same issues is pending at the same time. The federal court stays the litigation before it in deference to the state court proceeding. P appeals. The appeal should be entertained because the refusal to exercise federal jurisdiction has the effect of denying $\mathrm{P}$ his temporary injunction. ${ }^{42}$

h. Denial of Stay. An order refusing to stay the action at hand pending the outcome of another proceeding is not a final decision. ${ }^{43}$ The traditional congressional concern with piecemeal review clearly applies, as the action would continue if there were no appeal. Such a refusal to stay proceedings is subject to review upon final decision ${ }^{44}$ and if erroneous may be cause for reversal. ${ }^{45}$ Denial of a

lace v. Norman Indus., 467 F.2d 824 (5th Cir. 1972); see also Texaco v. Cottage Hill Operating Co., 709 F.2d 452, 454 (7th Cir. 1983) (distinguishing Microsoftware when the state proceeding involved different parties and would not make the federal litigation unnecessary but would merely make it less complex).

Also courts have held that assertion of the primary jurisdiction of an administrative agency is always an equitable defense such that denial of a stay will be immediately appealable as equivalent to denial of an injunction, H.W. Caldwall \& Son, Inc. v. United States $e x$ rel. John H. Moon \& Sons, Inc., 407 F.2d 21,22 (5th Cir. 1969), but again it is by no means clear that this is a majority position. E.g., Allied Air Freight v. Pan Am. World Airways, 340 F.2d 160, 161 (2d Cir.), cert. denied, 381 U.S. 924 (1965).

37. Cf. infra $\$ 18$ of this Interlocutory Restatement, comment $c$ (discussing the Enlow-Ettelson doctrine in the context of stays pending arbitration).

38. Gray Line Motor Tours v. City of New Orleans, 498 F.2d 293 (5th Cir. 1974). Clean Air Coordinating Comm. v. Roth-Adam Fuel Co., 465 F.2d 323 (7th Cir. 1972), cert. denied, 409 U.S. 1117 (1973); Weiss v. Duberstein, 445 F.2d 1297 (2d Cir. 1971); Carter v. American Tel. \& Tel. Co., 365 F.2d 486 (5th Cir. 1966) (stay pending administrative proceedings), cert. denied, 385 U.S. 1008 (1967); Glen Oaks Utils. v. City of Houston, 280 F.2d 330 (5th Cir. 1960). Cf. infra $\$ 20$ of this Interlocutory Restatement, comment $b$ (failure to rule on motion subject to interlocutory review as equivalent to denial of the preliminary injunction).

39. Dellinger v. Mitchell, 442 F.2d 782 (D.C. Cir. 1971).

40. The significance of this distinction has been affirmed by subsequent Supreme Court decisions cautioning that the "effect of denying an injunction" rationale is to be confined to instances where the appellant may suffer "serious, perhaps irreparable, consequence." Carson v. American Brands, Inc., 450 U.S. 79, 84-85 (1981); compare infra $\$ 30$ of this Interlocutory Restatement, comment d.

41. Mercury Motor Express v. Brinke, 475 F.2d 1086 (5th Cir. 1973). See also Wilkins v. Rogers, 581 F.2d 399 (4th Cir. 1978); Taunton Gardens Co. v. Hills, 557 F.2d 877 (1st Cir. 1977). See generally supra $\S 12$ of this Interlocutory Restatement, comment $b$.

42. Goldberg v. Carey, 601 F.2d 653 (2d Cir. 1979).

43. United States v. Chelsea Towers, 404 F.2d 329 (3d Cir. 1968). Review of the denial of a stay on occasion has been sought through some of the methods discussed supra for review of grants of stays. See, e.g., supra note 36.

44. Record Revolution No. 6, Inc. v. City of Parma, 638 F.2d 916 (6th Cir. 1980), vacated, 456 U.S. 968 (1982). 
stay, like grant of a stay, may be reviewed incidental to a permissible interlocutory appeal, for example, from an order concerning an injunction. ${ }^{46}$ Furthermore, though no cases appear to have reached the point, it would be consistent with notions of federalism, comity, and respect for the integrity of state functions to entertain interlocutory appeal to compel a stay if the matter at bar were unquestionably ill-suited for federal involvement at the time. Such a situation might arise, for example, if a Burford abstention ${ }^{47}$ were erroneously refused.

i. Certification. Certification for interlocutory appeal under 28 U.S.C. $\S 1292(\mathrm{~b}){ }^{48}$ in the context of stays pending other proceedings, seems rarely to have been requested. ${ }^{49}$ Sometimes such review clearly would not advance the termination of the litigation on the merits, as required by that statute. ${ }^{50}$ In one case where certification was allowed, the court had abstained from a request for an injunction of state criminal proceedings, ${ }^{51}$ to the extent temporary relief had also been sought, the appeal could have been sustained as from the effective denial of an injunction. ${ }^{52}$

\section{§ 18. Arbitration.}

(A) AN ORDER COMPELLING OR REFUSING TO COMPEL ARBITRATION IS REVIEWABLE ONLY ON APPEAL FROM A FINAL DECISION. SUCH AN ORDER IS A FINAL DECISION IF ENTERED IN A PROCEEDING BROUGHT ONLY TO SECURE SUCH RELIEF.

(B) AN ORDER GRANTING OR DENYING A STAY OF ARBITRATION PROCEEDINGS PENDING TRIAL IS REVIEWABLE ON APPEAL FROM A FINAL DECISION OR ON INTERLOCUTORY APPEAL TO ADJUDICATE ARBITRABILITY.

(C) AN ORDER GRANTING OR DENYING A STAY OF JUDICIAL PROCEEDINGS PENDING THE OUTCOME OF ARBITRATION IS REVIEWABLE ON APPEAL FROM A FINAL DECISION OR ON INTERLOCUTORY APPEAL TO ADJUDICATE ARBITRABILITY, EXCEPT THAT INTERLOCUTORY APPEAL IS NOT AVAILABLE IF THE JUDICIAL PROCEEDING IN WHICH THE STAY IS SOUGHT IS A SUIT IN EQUITY OR ADMIRALTY.

45. D'Iorio v. County of Delaware, 592 F.2d 681 (3d Cir. 1978).

46. E.g., Frederick L. v. Thomas, 557 F.2d 373 (3d Cir. 1977). There are actually two rationales by which such review might be justified. See generally supra $\S 12$ of this Interlocutory Restatement, comment $b$ (see particularly note 86 and accompanying text).

47. See supra note 6 .

48. For a discussion of the requirements of this statutory provision, see supra $\S 11$ of this Interlocutory Restatement.

49. But see Deaktor v. L.D. Schreiber \& Co., 479 F.2d 529, 530 (7th Cir.), rev'd on the merits, 414 U.S. 113 (1973).

50. First Del. Valley Citizens Television, Inc. v. CBS, Inc., 398 F. Supp. 917 (E.D. Pa. 1975)

51. Polk v. Ellington, 309 F. Supp. 1349 (W.D. Tenn. 1970).

52. See supra notes $38-40$ and accompanying text. 


\section{COMMENT}

a. Orders Compelling or Refusing to Compel Arbitration. An order compelling or refusing to compel arbitration is immediately appealable if issued in an action brought "solely to obtain such an order."

When arbitrability is the only issue in dispute, "[o]nce the parties are directed to arbitration, judicial involvement in the controversy . . . ends."'2 Thus, either grant or denial of the arbitration request is a final judicial decision.

When an order directing arbitration is made during a lawsuit, however, such as a suit for damages, "in the normal course of judicial procedure there will be a later final order or judgment from which an appeal can be taken by a person aggrieved by the prior order to arbitrate." 3 Therefore, such an order is interlocutory and not appealable. ${ }^{4}$ Arbitration must be "not merely a step in judicial enforcement of a claim nor auxiliary to a main proceeding, but the full relief sought." 5

Illustration 18-1. $\mathrm{P}$, a union, brings an action against $\mathrm{D}$, an employer, to compel arbitration under a provision of their collective bargaining agreement. The district court orders arbitration, and D appeals. The appeal should be heard. The order is an appealable final decision as it represents the full relief sought. ${ }^{6}$

Illustration 18-2. $\mathrm{P}$ sues $\mathrm{D}$ for breach of contract. The district court enters an order denying P's motion to compel arbitration pursuant to the U.S. Arbitration $\mathrm{Act}^{7}$ and retains jurisdiction to try the contract claim. $\mathrm{P}$ appeals. The appeal should be dismissed because although the district court has refused to compel arbitration, it has not dismissed the action and is proceeding to trial and ultimate final decision. ${ }^{8}$

The Supreme Court has on one occasion approved incidental appellate determination of a motion to compel arbitration in conjunction with review of an appealable stay order. ${ }^{9}$ Though the issue had not been reached at the trial level, the Supreme Court refused to disturb the appellate court's exercise of discretion in declaring arbitrability, in part because of the special interest in speedy determinations envisioned by Congress in legislation concerning arbitration. ${ }^{10}$

b. Stay of Arbitration. The stated black letter rule reflects the view of most

1. 15 C. Wright, A. Miller \& E. Cooper, Federal Practice And Procedure $\$ 3914$, at 553 (1976). Cf. infra $\S 23$ of this Interlocutory Restatement, text accompanying notes $27-31$; infra $\S 43$ of this Interlocutory Restatement, comment $c$.

2. Gavlik Constr. Co. v. H.F. Campbell Co., 526 F.2d 777, 782 (3d Cir. 1975).

3. Rogers v. Schering Corp., 262 F.2d 180, 182 (3d Cir.), cert. denied, 359 U.S. 991 (1959).

4. Standard Chlorine, Inc. v. Leonard, 384 F.2d 304 (2d Cir. 1967).

5. Goodall-Sanford, Inc. v. United Textile Workers, 353 U.S. 550, 551 (1957).

6. Goodall-Sanford, Inc. v. United Textile Workers, 353 U.S. 550 (1957).

7. 9 U.S.C. $\S \S 1-14$ (1982).

8. John Thompson Beacon Windows Ltd. v. Ferro, Inc., 232 F.2d 366 (D.C. Cir. 1956).

9. Moses H. Cone Memorial Hosp. v. Mercury Constr. Corp., 103 S. Ct. 927 (1983). (See supra $§ 17$ of this Interlocutory Restatement for a discussion of appealability of stays.) For an example of incidental review of a motion to compel arbitration in connection with review of an injunction, see Erving $v$. Virginia Squires Basketball Club, 468 F.2d 1064 (2d Cir. 1972). See generally $\S 12$ of this Interlocutory Restatement, comment b.

10. Moses H. Cone Memorial Hosp. v. Mercury Constr. Corp., 103 S. Ct. 927, 944 (1983). The Court also pointed to the apparent lack of prejudice to the parties. The issue had been briefed, and there were no 
courts of appeals that an order staying an arbitration proceeding pending trial is an injunction, thereby making its grant or denial subject to interlocutory appeal under 28 U.S.C. $\$ 1292(a)(1) .{ }^{11}$ The reasoning is that a stay of arbitration enjoins proceedings in a separate tribunal, thereby affecting actions of the litigants outside the court proceedings. As the Ninth Circuit has said,

This is not a case of a court's staying or refusing to stay its own hand in deference to proceedings going forward in another forum. The order was not an exercise by a court of its inherent power to control its own proceedings. Here the court was asked (and declined) affirmatively to interfere with proceedings in another forum; to exercise its equity powers to halt action of its litigants outside of its own court proceedings- the classic form of injunction. That arbitration is not a mere extension of court proceedings but involves a separate tribunal seems clear. ${ }^{12}$

Illustration 18-3. $\mathrm{P}$, a licensor, initiates an arbitration proceeding, allegedly pursuant to the licensing agreement, against $\mathrm{D}$, the licensee. $\mathrm{D}$ files a court action to enforce the agreement and moves to enjoin the arbitration. This motion is denied, and $\mathrm{D}$ appeals. The appeal should be entertained because the order effectively denies a preliminary injunction. ${ }^{13}$

Illustration 18-4. $\mathrm{P}$, an employer, brings suit against $\mathrm{D}$, a union, for violation of a no-strike provision in a collective bargaining agreement. D desires arbitration proceedings. The district court enjoins D from pursuing any proceedings, including arbitration, arising out of the contract breach. D appeals. The appeal should be heard. The order is appealable because the court is using its equity powers to control another tribunal. This is tantamount to a preliminary injunction. ${ }^{14}$

The Second Circuit, however, has adopted for three reasons ${ }^{15}$ a contrary rule ${ }^{16}$ as to appealability of stays of arbitration proceedings. First, based on language from Baltimore Contractors $v$. Bodinger, interlocutory review of injunctive orders is seen as a method of permitting litigants to challenge "orders of serious, perhaps irreparable, consequence," 17 and a stay of arbitration is not considered to "rise to

factual issues requiring determination by a jury. Id. The U.S. Arbitration Act is codified at 9 U.S.C. $\S \S 1$ 14 (1982).

11. 16 C. Wright, A. Miller, E. CoOper \& E. Gressman, Federal Practice and Procedure $\S 3923$, at 58 (1977) [hereinafter cited as C. WRIGHT \& A. MILLER]. Cf. supra $\$ 17$ of this Interlocutory Restatement, at comment $b$ (no dispute that order staying proceedings in another court or before an administrative agency is appealable under 28 U.S.C. $\S 1292(a)(1))$.

12. A. \& E. Plastik Pak Co. v. Monsanto Co., 396 F.2d 710, 713 (9th Cir. 1968). See also Firestone Tire \& Rubber Co. v. International Union of Rubber Workers, 476 F.2d 603 (5th Cir. 1973); Alberto-Culver Co. v. Scherk, 484 F.2d 611, 614 (7th Cir.), rev'd on ocher grounds, 417 U.S. 506 (1973).

13. A. \& E. Plastik Pak Co. v. Monsanto Co., 396 F.2d 710 (9th Cir. 1968). See infra $\S 20$ of this Interlocutory Restatement on preliminary injunctions.

14. Firestone Tire \& Rubber Co. v. International Union of Rubber Workers, 476 F.2d 603 (5th Cir. 1973).

15. 15 C. WRIGHT \& A. Miller, supra note 11 , at 58-60.

16. Greater Continental Corp. v. Schechter, 422 F.2d 1100 (2d Cir. 1970) (denial of stay); Lummus Co. v. Commonwealth Oil Ref. Co., 297 F.2d 80 (2d Cir. 1961), cert. denied, 368 U.S. 986 (1962) (grant of stay). In Lummus, although the order granting the stay was found nonappealable, the court issued a writ of mandamus to vacate the order. The fact that the First Circuit had previously settled the issue of arbitrability contrary to the district judge's ruling was considered an exceptional circumstance calling for use of the writ.

17. 348 U.S. 176, 181 (1955). 
that level."18 Second, speedy determination of an issue is considered one of the principal advantages of arbitration, and the delay caused by allowing interlocutory review of a refusal to stay arbitration would defeat this advantage. Thus, if a refusal to stay arbitration is not an injunctive order for this reason, an order granting such a stay cannot be injunctive either. ${ }^{19}$ Finally, an order staying arbitration may be distinguished from an order enjoining proceedings in another court (which would be immediately appealable) in that arbitration does not produce an enforceable result without further judicial action. ${ }^{20}$

The First Circuit has taken an intermediate position. An order denying a stay of arbitration is not appealable as an injunction because an unnecessary arbitral proceeding is not considered a serious, irreparable consequence and because an opposite result would negate the advantages of arbitration. ${ }^{21}$ On the other hand, an order granting a stay of arbitration is appealable 22 as it is seen as "an injunction in the 'classic sense' since it effectively deprives at least one of the parties of one of the principal objects for which he contracted-that is, a relatively expeditious and inexpensive preliminary resolution of any controversy." 23

The Third Circuit and, recently, the Eighth Circuit have also refused to find the denial of a stay of arbitration appealable as an injunction. ${ }^{24}$ Although the Third Circuit agreed that such an order might literally be characterized in that manner, an unnecessary arbitration proceeding was not seen as "the kind of injury against which [28 U.S.C.] $§ 1292(a)(1)$ is intended to guard." 25 The Third Circuit did not indicate how it would rule on the appealability of the grant of a stay of arbitration, and the Eighth Circuit specifically reserved the question. ${ }^{26}$

c. Orders Staying Judicial Proceedings Pending Arbitration. At present, appealability of an order granting or denying an order to stay judicial proceedings pending arbitration is governed by the infamous Enelow-Ettelson doctrine, ${ }^{27}$ as fur-

18. Lummus Co. v. Commonwealth Oil Ref. Co., 297 F.2d 80, 85-86 (2d Cir. 1961), cert. denied, 368 U.S. $986(1962)$.

19. Id.

20. Id. For a discussion of stays of proceedings in other courts, see supra $\S 17$ of this Interlocutory Restatement, comment $b$.

21. New England Power Co. v. Asiatic Petroleum Corp., 456 F.2d 183, 186-87 (1st Cir. 1972).

22. Lummus Co. v. Commonwealth Oil Ref. Co., 280 F.2d 915 (Ist Cir.), cert. denied, 364 U.S. 911 (1960); New England Power Co. v. Asiatic Petroleum Corp., 456 F.2d 183 (1st Cir. 1972). In Lummus, the Court considered the merits of the appeal without discussing the appealability of the order granting the stay of arbitration. In New England Power Co., however, the court cited Lummus as implicitly holding that an order enjoining arbitration is appealable. Id. at 186.

23. New England Power Co. v. Asiatic Petroleum Corp., 456 F.2d 183, 186 (1st Cir. 1972).

24. Stateside Mach. Co. v. Alperin, 526 F.2d 480 (3d Cir. 1975); Mellon Bank, N.A. v. PritchardKeang Nam Corp., 651 F.2d 1244 (8th Cir. 1981).

25. Stateside Mach. Co. v. Alperin, 526 F.2d 480, 484 (3d Cir. 1975).

26. Mellon Bank, N.A. v. Pritchard-Keang Nam Corp., 651 F.2d 1244, 1250 n.6 (8th Cir. 1981)

27. The doctrine was first stated in Enelow v. New York Life Ins. Co., 293 U.S. 379 (1935). In an action at law, the defendant insurance company claimed fraud as an affirmative equitable defense. The court determined to hear the defense first. This order was found appealable as an injunction because it enjoined proceedings at law, although law and equity were so merged that the equitable defense had been brought in the action at law. Chief Justice Hughes stated:

[T] he court, exercising what is essentially an equitable jurisdiction, in effect grants or refuses an injunction restraining proceedings at law precisely as if the court had acted upon a bill of complaint in a separate suit for the same purpose. . . [A]lthough interlocutory, it was appealable. 
ther defined and stated in Baltimore Contractors $v$. Bodinger. ${ }^{28}$ The general rule, succinctly restated by the Fifth Circuit Court of Appeals, is that

[a]n order staying or refusing to stay proceedings in the District Court is appealable under $\$ 1292$ (a) (1) only if (A) the action in which the order was made is an action which, before the fusion of law and equity, was by its nature an action at law; and (B) the stay was sought to permit the prior determination of some equitable defense or counterclaim. ${ }^{29}$

Stays pending arbitration are generally found to be appealable because arbitration is an equitable defense ${ }^{30}$ and because it is generally asserted in a contract action brought at law. ${ }^{31}$ Those cases which have dismissed appeals from stays pending arbitration have involved original actions considered to be primarily equitable. ${ }^{32}$

Illustration 18-5. $\mathrm{P}$ brings an action against $\mathrm{D}$, his former employer, for D's alleged breach of a promise to repurchase shares of stock bought by $\mathrm{P}$

Id. at 383 .

This doctrine was reaffirmed in a similar case, Ettelson v. Metropolitan Life Ins. Co., 317 U.S. 188 (1942), after the adoption of the Federal Rules of Civil Procedure and the merger of law and equity:

The plaintiffs are . . . in no different position than if a state equity court had restrained them from proceeding in the law action. . . . The relief afforded by [present statute 28 U.S.C. 1292(a)(1)] . . looks to the substantial effect of the order made.

Id. at 192 .

In City of Morgantown v. Royal Ins. Co., 337 U.S. 254 (1942), the Supreme Court seemed to reject the historical analogy. In an equity suit brought to reform an insurance policy, the insured counterclaimed for his loss. The Court entered an order striking the insured's demand for jury trial and set the case for trial to the court. The ensuing appeal was dismissed:

This is not a situation where a "chancellor" in denying a demand for jury trial can be said to be enjoining a "judge" who has cognizance of a pending action at law. This is rather a case of a judge making a ruling as to the manner in which he will try one issue in a civil case pending before himself. The fiction of a court with two sides, one of which can stay proceedings in the other, is not applicable where there is no other proceeding in existence to be stayed. The ruling from which the appeal in this case was prosecuted is an order interlocutory in form and substance.

Id. at $257-58$.

28. 348 U.S. 176 (1955). In an equitable action for an accounting, the district court refused to stay its proceedings pending arbitration because the original action to be enjoined was not brought at law:

Whether the district court was right or wrong in its ruling . . . [on] arbitration proceedings, it was simply a ruling in the only suit pending. . . . It was a mere order and not an injunction as that word is understood through the Enelow and the Ettelson cases as a stay through equitable principles of a common law action.

Id. at 184 .

29. Jackson Brewing Co. v. Clarke, 303 F.2d 844, 845 (5th Cir.), cert. denied, 371 U.S. 891 (1962).

30. Shanferoke Coal \& Supply Corp. v. Westchester Serv. Corp., 293 U.S. 449, 452 (1935).

31. 16 C. WRight \& A. MILleR, supra note 11 , at 56 . See, e.g., Zell v. Jacoby-Bender, Inc., 542 F.2d 34 (7th Cir. 1976); Gavlik Constr. Co. v. H.F. Campbell Co., 526 F.2d 777 (3d Cir. 1975).

The same result is reached as to noncontract actions for damages which are characterized as actions at law. See, e.g., Varo v. Comprehensive Designers, 504 F.2d 1103 (9th Cir. 1974); Thompson v. House of Nine, 482 F.2d 888 (5th Cir. 1973).

32. 16 C. WRIGHT \& A. Miller, supra note 11, at 56-57. See, e.g., Baltimore Contractors v. Bodinger, 348 U.S. 176 (1955); Danford v. Schwabacher, 488 F.2d 454 (9th Cir. 1973)

The Enelow-Ettelson doctrine was also once prominent in determining the appealability of grants or denials of stays deferring to proceedings in other courts, see supra $\S 17$ of this Interlocutory Restatement, note 37 and accompanying text; but it is rarely raised in that context now, at least when the stay is granted, because of the growth of a variety of other doctrines more likely to sustain appealability. See id., comments c$f$. Some of these doctrines, specifically the Moses Cone doctrine of effective finality (from Moses H. Cone Memorial Hosp. v. Mercury Constr. Corp., 103 S. Ct. 927 (1983), discussed supra $\$ 17$ of this Interlocutory Restatement, notes 5-14 and accompanying text and illustrations), are being used to support the appealability of certain arbitration decisions that might not necessarily be subject to interlocutory review under the black letter of this section. E.g., Cincinnati Gas \& Elec. Co. v. Shaw, 706 F.2d 155, 158 (6th Cir. 1983). 
during his employment. The district court denies D's motion for a stay of the damage action pending arbitration, and $\mathrm{D}$ appeals. The appeal should be heard because the complaint "sounds in contract," an action at law, and the claim to arbitration is an equitable defense. ${ }^{33}$

The rule as presently applied causes many problems for appellate courts and has been severely criticized. ${ }^{34}$ Even when restating the rule, the Supreme Court recognized the problem:

The reliance on the analogy of equity power to enjoin proceedings in other courts has elements of fiction in this day of one form of action. The incongruity of taking jurisdiction from a stay in a law type and denying jurisdiction in an equity type proceeding springs from the persistence of outmoded procedural differentiations. Some simplification would follow from an assumption or denial of jurisdiction in both. ${ }^{35}$

The Court declined to take this step, however, deferring to Congress. ${ }^{36}$

One problem with the general rule is that the appealability of identical issues and consequences depends upon whether the original action is framed as equitable or legal. As one court of appeals complained, "There is room for dissatisfaction with a rule that tolerates opposite results depending upon the pure fortuity of the race to the courthouse." 37 Especially strange results can occur in diversity suits. For example, in one case an action was originally brought in state court as an equity proceeding under a Massachusetts statute. As such, an order staying the proceeding would not have been appealable. Upon removal to federal court, however, where nomenclature was determined by federal law, the action was declared to be at law, therefore making a stay order appealable. ${ }^{38}$

Another major problem is identification of an action as "legal" or "equitable" many decades after merger. It is difficult to find an historically accurate analogy to many modern hybrid suits. ${ }^{39}$ This distinction is also still made to determine the availability of trial by jury, but the importance accorded to that right has led to a policy of resolving doubtful cases in that context in favor of an "at law" analogy. Policy respecting interlocutory appeal does not have such a cherished spot in our legal system and thus would not seem to justify a presumption favoring one characterization over the other. ${ }^{40}$

In the many cases in which an issue could have been raised originally as an

33. Bear v. Hayden Stone, Inc., 526 F.2d 734 (9th Cir. 1975).

34. See, e.g., Wallace v. Norman Indus., 467 F.2d 824, 827 (5th Cir. 1972); Travel Consultants v. Travel Management Corp., 367 F.2d 334 (D.C. Cir.), cert. denied, 386 U.S. 912 (1966).

The latter case is a wonderful example of the strange results which can follow from an application of the general rule. In a suit originally brought seeking specific performance, the defendant counterclaimed for damages for breach of contract and the trial court stayed its own proceedings pending arbitration. When the defendant appealed the stay order, the court accepted jurisdiction to review the order as it applied to the legal counterclaim but not as it applied to the original equitable claim. While the court recognized "the anomaly in taking jurisdiction of the appeal from one part of the order but not of the appeal of the other part," it felt compelled to do so by the settled rule of Baltimore Contractors. Id. at 337-38.

35. Baltimore Contractors v. Bodinger, 348 U.S. 176, 184 (1955).

36. Id. at 185 .

37. Chapman v. International Ladies' Garment Workers' Union, 40l F.2d 626, 628 (4th Cir. 1968).

38. Limbach Co. v. Gwyn Constr. Corp., 544 F.2d 1104 (1st Cir. 1976), cert. denied, 430 U.S. 916

39. 16 C. WRIGHT \& A. MILLER, supra note 11 , at 61

40. Id. Cf. infra text accompanying note 43 . 
action at law or in equity, courts have used a number of tests to determine the characterization. Many allow appeal if the action is "predominantly" or "essentially" at law. ${ }^{41}$ Others deny appeal unless the equitable relief requested is incidental. ${ }^{42}$ For example, a suit principally seeking money damages will be considered an action at law for determining the appealability of a stay order even though an accounting may also be requested. The accounting would be considered incidental to the suit for damages. In cases in which it is impossible to determine whether legal or equitable elements predominate, several courts have adopted a policy of resolving doubts in favor of an equitable characterization in order to strictly limit opportunities for interlocutory appeals. ${ }^{43}$

When a declaratory judgment has been requested, courts have to seek the "basic nature of the suit in which the issues . . . would have arisen" had there been no Declaratory Judgment Act. ${ }^{44}$ Thus, as one judge put it, courts have been placed "in the unenviable position not only of solving modern procedural problems by the application of labels which have no currency, but also of considering the nature of lawsuits which were never brought." 45

Orders by courts in admiralty granting or denying stays of proceedings before them have consistently been held not to be injunctions within the meaning of 28 U.S.C. $\S 1292(a)(1)$ even if based on equitable defenses or counterclaims. ${ }^{46}$ The rationale is that, although admiralty courts may apply equitable principles, they do not have "general equitable jurisdiction" and do not issue injunctions. ${ }^{47}$ Furthermore, the Supreme Court has determined that an admiralty court may delay an action before itself pending outcome of another proceeding (such as arbitration) without seeking the aid of equity. ${ }^{48}$ Such orders are therefore considered to be "merely calendar orders" 49 which regulate the order of trial proceedings and are thus interlocutory and not appealable.

d. Review on Final Decision. A party against whom arbitration is sought does not waive his right to challenge arbitrability by failing to bring court proceedings to enjoin the arbitration or by participating in the arbitral hearing ${ }^{50}$ as long as he raises timely objection and does not agree to be bound by the arbitrator's decision

41. See, e.g., Ephraim Freightways v. Red Ball Motor Freight, 376 F.2d 40 (10th Cir.), cert. denied, 389 U.S. 829 (1967); Alexander v. Pacific Maritime Ass'n, 332 F.2d 266 (9th Cir.), cert. denied, 379 U.S. 882 (1964).

42. See, e.g., Thompson v. House of Nine, 482 F.2d 888 (5th Cir. 1973); Standard Chlorine, Inc. v. Leonard, 384 F.2d 304 (2d Cir. 1967).

43. 16 C. Wright \& A. Millek, supra note 11, at 62-63. See, e.g., Danford v. Schwabacher, 488 F.2d 454, 457 (9th Cir. 1973); Stateside Mach. Co. v. Alperin, 526 F.2d 480, 485 (3d Cir. 1975).

44. 16 C. WRIGHT \& A. Miller, supra note 11, at 64. See, e.g., American Safety Equip. Corp. v. J.P. Maguire \& Co., 391 F.2d 821, 824 (2d Cir. 1968). The Declaratory Judgment Act was passed in 1934, ch. 512, 48 Stat. 955 (codified as amended at 28 U.S.C. \$§ 2201-2202 (1976 \& Supp. IV 1980)).

45. Diematic Mfg. Corp. v. Packaging Indus,, 516 F.2d 975, 978 (2d Cir.), cert. denied, 423 U.S. 913 (1975).

46. Penoro v. Rederi A/B Disa, 376 F.2d 125, 129 (2d Gir.), cert. denied, 389 U.S. 852 (1967).

47. Schoenamsgruber v. Hamburg Am. Line, 294 U.S. 454, 457-58 (1935).

48. Id.

49. Penoro v. Rederi A/B Disa, 376 F.2d 125, 131 (2d Cir.), cert. denied, 389 U.S. 852 (1967).

50. Local 719, Am. Bakery \& Confectionery Workers v. National Biscuit Co., 378 F.2d 918, $921-22$ (3d Cir. 1967). 
on arbitrability. ${ }^{51}$ This is consistent with the general rule that failure to take an interlocutory appeal does not waive the right to review of an issue after final decision. ${ }^{52}$

Illustration 18-6. $\mathrm{P}$, a labor union, brings an action against $\mathrm{D}$, an employer, to declare void an arbitration award. D counterclaims for confirmation of the award. The district court should not grant summary judgment for $\mathrm{D}$ but should reach the merits as to arbitrability because $\mathrm{P}$ did not waive his right to raise that issue by submitting to arbitration, assuming he properly preserved his objection to that proceeding and never thereafter indicated a willingness to forego judicial review. ${ }^{53}$

B. Review of Orders Regarding Provisional and Partial Remedies and Sanctions

$\S$ 19. Provisional Security.

(A) AN ORDER DENYING OR VACATING A PROVISIONAL SEIZURE OF A PARTY'S PERSON OR PROPERTY AS SECURITY FOR ANY JUDGMENT OR COSTS IS REVIEWABLE ON INTERLOCUTORY APPEAL TO PROTECT THE SUBSTANTIVE RIGHTS OF THE APPELLANT AS ESTABLISHED BY LAWS PROVIDING FOR SUCH PROVISIONAL SECURITY.

(B) AN ORDER GRANTING OR REFUSING TO VACATE A PROVISIONAL SEIZURE OF A PARTY PERSON OR PROPERTY AS SECURITY FOR ANY JUDGMENT OR COSTS IS REVIEWABLE ON INTERLOCUTORY APPEAL TO PREVENT

(1) OVEREXTENSION OF THE POWER OF A DISTRICT COURT IN PROVIDING SUCH PROVISIONAL SECURITY,

(2) IRREPARABLE HARM TO THE SUBSTANTIVE RIGHTS OF THE APPELLANT, OR

(3) DENIAL OF THE CONSTITUTIONAL RIGHT TO NOTICE AND HEARING PRIOR TO SEIZURE.

\section{COMMENT}

a. Denial of Provisional Remedy. A nondiscretionary order releasing or refusing to require security is appealable; this result has been explained as an application of the collateral order doctrine. ${ }^{1}$ When the issue is pretrial security, an error in the

51. Reeves v. Tarvizian, 351 F.2d 889, 891-92 (1st Cir. 1965).

52. See supra $\S 9$ of this Interlocutory Restatement, notes $223-26$ and accompanying text; infra $\S 20$ of this Interlocutory Restatement, comment d.

53. Reeves v. Tarvizian, 351 F.2d 889 (1st Cir. 1965). See also supra $\$ 9$ of this Interlocutory Restatement, Illustration 9-2.

1. See e.g., United States v. Shriver, 645 F.2d 221, 222 (4th Cir. 1981); United States v. Alcon Laboratories, 636 F.2d 876, 882 (Ist Cir.), cert. denied, 451 U.S. 1017 (1981); Lowe v. Pate Stevedoring Co., 595 F.2d 256, 257 (5th Cir. 1979) (per curiam); FDIC v. Greenberg, 487 F.2d 9, 10 n.3 (3d Cir. 1973); American Oil Co. v. McMullin, 433 F.2d 1091, 1096 (10th Cir. 1970); Maryland Tuna Corp. v. The MS Benares, 429 
order cannot be corrected on appeal from a final decision because by that time, the right to seizure will always be moot. Similarly, if the attachment is sought to secure a possible judgment, denial or release could allow the defendant to render the property unavailable, making later appeal fruitless.

Illustration 19-1. P brings suit against D, a foreign shipping company, for nondelivery of cargo and attaches D's vessel to secure the claim. The district court, finding that the wrong company's vessel has been attached, grants a motion to dissolve the attachment. $\mathrm{P}$ appeals. The appeal should be entertained because the order violates P's right to security, which cannot be protected by appeal from a final decision; should the dissolution later be found erroneous, it may be difficult or impossible to attach the vessel again. ${ }^{2}$

Illustration 19-2. $\mathrm{P}$ brings a stockholders' derivative suit against D. A state statute requires the posting of security for costs in such actions. The district court holds the statute inapplicable in diversity cases and rules that the suit should proceed without any posting of security. D appeals. The appeal should be entertained because the order infringes the statutory rights of $\mathrm{D}$ and, if wrongly decided, cannot be corrected on appeal from a final decision. ${ }^{3}$

It is generally held, however, in light of the Supreme Court's dictum in Cohen $v$. Beneficial Industrial Loan Corp. (the leading case establishing the appealability of orders denying or vacating attachments), ${ }^{4}$ that interlocutory appeal is not available to review a trial court's exercise of discretion pursuant to a statute in making the decision to release or refuse security, as opposed to its determination as to its power to grant such provisional relief. ${ }^{5}$ Appeals in such instances would cause

F.2d 307, 317 n.6 (2d Cir. 1970); Farrell v. Piedmont Aviation, 411 F.2d 812, 815 (2d Cir.) (dictum), cert. denied, 396 U.S. 840 (1969); Suess v. Stapp, 407 F.2d 662, 663 (7th Cir. 1969). Cases decided before the formalization of the collateral order doctrine, see supra $\S 12$ of this Interlocutory Restatement, notes 10-13 and accompanying text, followed the same rule for the same reasons. See, e.g., Jacobson v. Coon, 165 F.2d 565 (6th Cir. 1948) (appealability assumed); Cold Metal Process Co. v. McLouth Steel Corp., 126 F.2d 185 (6th Cir. 1942) (appealability assumed); The Attualita, 238 F. 909, 910-11 (4th Cir. 1916) (per curiam).

2. Swift \& Co. Packers v. Compania Colombiana del Caribe, S.A., 339 U.S. 684 (1950).

3. Cohen v. Beneficial Indus. Loan Corp., 337 U.S. 541 (1949).

4. 337 U.S. 541,547 (1949):

We do not mean that every order fixing security is subject to appeal. . . . If the right were admitted or clear and the order involved only an exercise of discretion as to the amount of security, a matter the statute makes subject to reconsideration from time to time, appealability would present a different question.

For examples of cases citing this passage, see Bancroft Navigation Co. v. Chadade S.S. Co., 349 F.2d 527, 529 (2d Cir. 1965), and also Donlon Indus. v. Forte, 402 F.2d 935, 936 (2d Cir. 1968).

5. Donlon Indus. v. Forte, 402 F.2d 935, 936 (2d Cir. 1968). See also United States v. Bedford Assocs., 618 F.2d 904, 916 n.23 (2d Cir. 1980), cert. denied, 456 U.S. 914 (1982). The order in Bedford was eventually reviewed incidental to interlocutory review of a preliminary injunction, see supra $\S 12$ of this Interlocutory Restatement, comment b. Cf. Dayco v. Foreign Transactions Corp., 705 F.2d 38 (2d Cir. 1983).

Decisions left to trial court discretion may also sometimes be denied interlocutory review as involving entanglement with the merits impermissible under the separability requirement of the collateral order doctrine. See supra $\S 12$ of this Interlocutory Restatement, text at note 11. For example, in Sobol v. Heckler Cong. Comm., 709 F.2d 129, 130-31 (1st Cir. 1983), an order dissolving an attachment was held not subject to immediate appeal because the ruling apparently was based on a determination by the district judge that the plaintiff was not likely to succeed on the merits of his claim. 
waste and delay because the standard of review would be abuse of discretion, making reversal unlikely, and because any appellate ruling would be based on the individual facts and would have no applicability beyond the given case. ${ }^{6}$ Similarly, interlocutory appeal is not available to review an order providing inadequate security, also a determination within the discretion of the trial judge, ${ }^{7}$ unless the security is so manifestly inadequate as to deny effectively the rights of the attacking party.

b. No Risk from Lack of Security. An order vacating or denying an attachment is not subject to immediate review when there is no possibility of irreparable harm. ${ }^{8}$ In such circumstances interlocutory appeal would not serve its underlying purposes; ${ }^{9}$ the reason for review is lacking if there is no risk of loss of security upon vacation or denial of the attachment. There is, therefore, no appealable final decision within the meaning of 28 U.S.C. $\$ 1291 .^{10}$

Illustration 19-3. $\mathrm{P}$ sues $\mathrm{D}$ over some property which $\mathrm{D}$ purchased at a foreclosure sale but for which $\mathrm{P}$ has refused to turn over the title. $\mathrm{P}$ purportedly acquires jurisdiction by attachment of the property. D's motion to vacate the attachment is granted, and $P$ appeals. $P$ subsequently acquires personal jurisdiction over $\mathrm{D}$ pursuant to the Texas long-arm statute. The appeal should then be dismissed. Since $\mathrm{P}$ still retains title to the property, there is no risk of loss of the security should $\mathrm{P}$ prevail in the case, and thus there is no need for review. ${ }^{11}$

c. Grant of Provisional Remedy. An order granting security generally is not reviewable. ${ }^{12}$ The traditional justification is that if a party is unsuccessful in asserting his claim to the property seized, it will be returned to the garnishee with no ill effect. ${ }^{13}$ Modern cases point out that "the rights of the parties can be ade-

6. Donlon Indus. v. Forte, 402 F.2d 935, 937 (2d Cir. 1968).

7. Bancroft Navigation Co. v. Chadade S.S. Co., 349 F.2d 527, 529-30 (2d Cir. 1965). Note, however, that amount of security may not be discretionary under some statutes. E.g., Baxter v. United Forest Prods. Co., 406 F.2d 1120, 1125 (8th Cir.) (per curiam), cert. denied, 394 U.S. 1018 (1969).

8. See Capital Bancshares v. North Am. Guar. Ins. Co., 433 F.2d 279, 282 (5th Cir. 1970); 21 Turtle Creek Square, Ltd. v. New York State Teachers' Retirement Sys., 404 F.2d 31, 33 (5th Cir. 1968).

9. See generally supra $\S 12$ of this Interlocutory Restatement, comment a.

10. 21 Turtle Creek Square, Ltd. v. New York State Teachers' Retirement Sys., 404 F.2d at 31,33 (5th Cir. 1968).

11. 21 Turtle Creek Square, Ltd. v. New York State Teachers' Retirement Sys., 404 F.2d 31 (5th Cir. 1968).

12. See, e.g., Swift \& Co. Packers v. Compania Colombiana del Caribe, S.A., 339 U.S. 684, $688-89$ (1950) (dictum); Drys Shipping Corp. v. Freights, Sub-Freights, 558 F.2d·1050, 1051 (2d Cir. 1977); W.T. Grant Co. v. Haines, 531 F.2d 671, 678 (2d Cir. 1976); Rosenfeldt v. Comprehensive Acc. Serv. Corp., 514 F.2d 607, 610-11 (7th Cir. 1975); Financial Servs., v. Ferrandina, 474 F.2d 743, 745-46 (2d Cir. 1973); West v. Zurhorst, 425 F.2d 919, 921 (2d Cir. 1970); American Mortgage Corp. v. First Nat'l Mortgage Co., 345 F.2d 527, 528 (7th Cir. 1965); Flegenheimer v. General Mills, 191 F.2d 237, 240 (2d Cir. 1951). Contra Chabot v. National Sec. \& Research Corp., 290 F.2d 657, 658 (2d Cir. 1961) ("[a]ttempt at distinction based on the circumstance that in Cohen the order of the District Court had denied security whereas here the order required it, flies in the face of reason").

13. See Cushing v. Laird, 107 U.S. 69, 76 (1883). The other reasons usually given for disallowing immediate appeal from orders of attachment are that the courts of appeals are already overburdened, see, e.g., West v. Zurhorst, 425 F.2d 919 (2d Cir. 1970), and should not be subjected to piecemeal appeals. See e.g., American Mortgage Corp. v. First Nat'l Mortgage Co., 345 F.2d 527, 528 (7th Cir. 1965). 
quately protected while the litigation on the main claim proceeds." 14 For example, an available method of minimizing the temporary hardship to the owner of an attached ship is to allow him to substitute cash, securities, bonds, or the like for the seized vessel. Furthermore, should the attached party ultimately prevail on the merits, he may recover the accrued interest and dividends. ${ }^{15}$

Illustration 19-4. $\mathrm{P}$ sues D, a corporation, for breach of contract and moves for an attachment of D's bank accounts. The attachment is granted and D appeals. The appeal should be dismissed since an order granting an attachment is not a final decision and there are no exceptional circumstances meriting immediate review. The rights of $\mathrm{D}$ can be adequately protected on review after final decision. ${ }^{16}$

d. Overextension of Power of the Court. An order concerning seizure of persons or property which the district court was without jurisdiction to issue is reviewable on interlocutory appeal. ${ }^{17}$ As explained in De Beers Consolidated Mines v. United States, "[w]hen a court has no judicial power to do what it purports to do-when its action is not mere error but usurpation of power - the situation falls precisely within the allowed use of [the writ of mandamus]." 18 The dissent in De Beers warned that now "every interlocutory order which is wrong can be reviewed here under [28 U.S.C. $§ 1651$,]" and that the decision thus "open[ed] the flood gates to review of interlocutory decrees." 19 This prophecy has not come true, as an examination of the subsequent case law reveals. ${ }^{20}$

Appeals from attachment orders issued without jurisdiction have also been justified under the collateral order doctrine. ${ }^{21}$ For example, in Baxter $v$. United Forest Products Co., the district court clearly did not comply with the relevant Iowa statute $^{22}$ and hence lacked power to enter the attachment order. ${ }^{23}$ The court of appeals explained its exercise of interlocutory appellate jurisdiction thus: "The issue here is not one related to the proper exercise of the court's discretion as to the amount of security to be posted. The question which makes this matter reviewable is whether the law permits a trial court to circumvent the Iowa law of attachment altogether."24 Such grants of immediate review, however, have generally been limited to cases where the violation of the relevant statutory requirements was manifest.

14. Swift \& Co. Packers v. Compania Colombiana del Caribe, S.A., 339 U.S. 684,689 (1950).

15. Drys Shipping Corp. v. Freights, Sub-Freights, 558 F.2d 1050,1051 n.2 (2d Cir. 1977). Thus, though the provisional attachment order itself is moot after a final decision, the collateral order doctrine does not allow an immediate appeal since the harm caused by an erroneous attachment may still be addressed and damages granted. See id.

16. American Mortgage Corp. v. First Nat'l Mortgage Co., 345 F.2d 527 (7th Cir. 1965).

17. See, e.g., De Beers Consol. Mines v. United States, 325 U.S. 212, 217 (1945).

18. Id.

19. Id. at 225 (Douglas, J., dissenting).

20. See, e.g., Seguros Banvenez, S.A. v. S/S Oliver Drescher, 715 F.2d 54, 56 (2d Cir. 1983).

21. For a discussion of the requirements of the collateral order doctrine, see supra $\S 12$ of this Interlocutory Restatement, notes $10-13$ and accompanying text.

22. Application of state attachment provisions is required by Rule 64 of the Federal Rules of Civil Procedure.

23. 406 F.2d 1120 (8th Cir.) (per curiam), cert. denied, 394 U.S. 1018 (1969).

24. Id. at 1125 
Illustration 19-5. $\mathrm{P}$ brings a diversity action against $\mathrm{D}$ to enjoin a nuisance. On motion, the court issues an order garnishing D's bank account. Such an attachment of assets in an injunction suit is beyond the power of the district court under New York law (applicable under Rule 64 of the Federal Rules of Civil Procedure). D appeals. The appeal should be entertained to prevent the overreaching of the district court. ${ }^{25}$

Illustration 19-6. $\mathrm{P}$, a private corporation, sues $\mathrm{D}$, a foreign government, for breach of contract and attaches D's vessel. $D$ is immune from liability and is not subject to having its ship attached. D appeals. The appeal should be heard to prevent interference in the realm of international relations beyond the power of the district court. ${ }^{26}$

e. Irreparable Harm. An order granting or refusing to vacate an attachment or requiring a party to post security is also immediately appealable when it threatens irreparable harm to the substantive rights of the appellant. ${ }^{27}$ This exception is generally limited to situations involving parties who are either indigent or suffering severe cash flow problems. ${ }^{28}$

Illustration 19-7. P sues D; his indigent tenant, for rent. D removes the action to the federal court and files a motion for leave to proceed in forma pauperis. The district court grants the motion but holds that $\mathrm{D}$ is not thereby relieved of the burden of posting removal bond, as required by 28 U.S.C. $\S 1446(d)$. D appeals. The appeal should be entertained to protect the substantial right of indigent $\mathrm{D}$ to a federal forum. ${ }^{29}$

f. Denial of Due Process. When a garnishee's constitutional rights to due process are violated by the garnishment procedure, an indirect method of immediate

25. Cf. Sobol v. Heckler Cong. Comm., 709 F.2d 129, 130 (1st Cir. 1983) (inapplicability of state security statute to the injury alleged suggested as alternative basis for trial court order dissolving attachment)

26. Ex parte Republic of Peru, 318 U.S. 578 (1943).

27. See, e.g., Pasquarella v. Santos, 416 F.2d 436, 437 (1st Cir. 1969); Baxter v. United Forest Prods. Co., 406 F.2d 1120, 1123-24 (8th Cir.) (per curiam) (garnishee's funds attached without garnishor posting statutorily-required double-value security bond), cert. denied, 394 U.S. 1018 (1969); Solomon v. Bruchhausen, 305 F.2d 941, 943-44 (2d Cir. 1962) (seamen improperly required to post security in admiralty wage claim action in contravention of congressional policy of free access of seamen to courts), cert. denied, 371 U.S. 951 (1963)

28. One additional case wherein the allowance of an appeal from an order requiring posting of security could possibly be explained by the threat of irreparable injury is Buckeye Union Ins. Co. v. Wilmoth (In re United States $e x$ rel. St. Paul A.M.E. Church Hous. Corp.), 541 F.2d 463 (4th Cir. 1976) (per curiam). See 15 C. Wright, A. Miller, \& E. Cooper, Federal Practice and Procedure $\$ 3911$, at 224 at n.64 (Supp. 1982). In Buckeye Union, however, the district court ordered three indemnitors to post $\$ 1,000,000$-or only as much as they were capable of upon showing cause for the deficiency. This "escape clause" would seem to make any hardship inadequate to justify an immediate review. The court's per curiam opinion justified the appeal as a final collateral order under Cohen, citing as its only authority $9 \mathrm{~J}$. MoOre, B. Ward, \& J. Lugas, MoOre's Federal Practice \ 110.13[5] (2d ed. 1968). The cases cited by that treatise actually reaffirm the general rule of nonappealability of orders granting attachments. The citations illustrate only the hardship and overextension of power exceptions discussed herein. The flat statement of Buckeye Union that "[a]n order requiring or refusing to require the posting of security during the pendency of litigation is 'collateral' and is appealable under the doctrine of Cohen, " 541 F.2d at 464 , is overbroad and misleading.

29. Pasquarella v. Santos, 416 F.2d 436 (1st Cir. 1969). 
review may be available through a collateral suit to enjoin the garnishment. ${ }^{30} \mathrm{~A}$ refusal by a federal district judge to enjoin a state court garnishment is immediately appealable under 28 U.S.C. $§ 1291$ (a)(1) as the denial of an injunction. ${ }^{31}$ Review should be equally available when the underlying garnishment order is entered by a federal court, particularly since that court, under Rule 64 of the Federal Rules of Civil Procedure, may be applying the same allegedly defective state garnishment procedure. Thus, although no court of appeals has considered the matter, direct interlocutory appeal could provide an appropriate vehicle for protecting the garnishee's constitutional rights to due process. Analogy may be made to mandamus review of district court orders granting venue transfers without giving the parties the opportunity to be heard ${ }^{32}$ or infringing on the seventh amendment right to trial by jury. ${ }^{33}$

Illustration 19-8. P brings a contract action against D. Proceeding in the manner provided for by state legislation, the district court issues an ex parte writ of attachment against $D$. D moves to vacate the attachment on the ground that his rights to notice and a hearing were denied. The district court refuses to vacate, and $\mathrm{D}$ appeals. The appeal should be heard in order to enforce D's constitutional procedural rights.

g. Civil Arrest. The rules governing appealability of orders concerning property seizures also apply to cases of civil arrest or body execution ${ }^{34}$ where the defendant himself is seized and imprisoned as security pending judgment. ${ }^{35}$ Thus, an order vacating or refusing to grant a civil arrest is appealable as a final decision since the release of the arrestee leaves the arresting party without an effective remedy, ${ }^{36}$ and an order which grants or refuses to vacate a civil arrest order is not subject to immediate review ${ }^{37}$ since it is analogous to both the attachment of a vessel $^{38}$ and bail for a defendant charged with a crime-the defendant can post alternate security and go free. The exception allowing immediate appeal when there is a threat of irreparable harm or severe hardship, however, would seem particularly appropriate in cases involving indigents, because the arrestees would not be able to post security.

Illustration 19-9. $\quad \mathrm{P}$ brings an action against $\mathrm{D}$ for fraud, seeking $\$ 15,000$ in damages. Pursuant to a state civil arrest statute, $D$ is arrested by the marshal and placed in custody with bail set at $\$ 15,000$. D's motion to

30. E.g., Fuentes v. Shevin, 407 U.S. 67 (1972).

31. Note that the injunction may have to go to the act of seizure rather than to any pending or future state court attachment proceedings because of the statutory ban, 28 U.S.C. $\$ 2283$ (1976) (discussed supra $\S 17$ of this Interlocutory Restatement, note 3 and accompanying text), on federal court injunctions of state proceedings. See Fuentes v. Shevin, 407 U.S. 67, 71 n.3 (1972).

32. See supra $\S 15$ of this Interlocutory Restatement, comment $f$.

33. See infra $\S 25$ of this Interlocutory Restatement, comment $b$.

34. A body execution or civil arrest often takes the form of a writ of capias ad satisfaciendum (or "ca. sa.").

35. See Crooker v. Knudsen, 232 F. 857, 858-59 (9th Cir. 1916); Stroheim v. Deimel, 77 F. 802, 804-05 (7th Cir.) (dictum), cert. denied, 166 U.S. 721 (1897).

36. Stroheim v. Deimel, 77 F. 802, 805 (7th Cir.), cert. denied, 166 U.S. 721 (1897).

37. See Crooker v. Knudsen, 232 F. 857 (9th Cir. 1916).

38. See supra comment c. 
vacate the arrest is denied, and he appeals. The appeal should be dismissed since the arrest and denial of release are not final decisions. D will be released upon posting $\$ 15,000$ as alternate security. ${ }^{39}$

\section{§ 20. Preliminary Injunctions and Temporary Restraining Orders.}

(A) AN ORDER GRANTING, CONTINUING, MODIFYING, REFUSING, OR DISSOLVING A PRELIMINARY INJUNCTION IS REVIEWABLE ON INTERLOCUTORY APPEAL TO PREVENT IRREPARABLE HARM TO THE SUBSTANTIAL RIGHTS OF THE APPELLANT OR ON APPEAL FROM A FINAL DECISION UNLESS MOOTED BY ENTRY OF PERMANENT INJUNCTIVE RELIEF.

(B) AN ORDER GRANTING OR DENYING A TEMPORARY RESTRAINING ORDER IS REVIEWABLE ONLY ON INTERLOCUTORY APPEAL TO PREVENT AN OVEREXTENSION OF POWER BY THE DISTRICT COURT OR A LOSS OF THE APPELLANT'S SUBSTANTIAL RIGHTS NECESSARILY RESULTING FROM ADHERENCE TO THE ORDER EVEN FOR THE BRIEF TIME REQUIRED FOR AN ADVERSARY HEARING BEFORE THE COURT WHICH ISSUED IT.

CAVEAT: THE TRIAL COURT'S CHARACTERIZATION OF AN ORDER AS EITHER A PRELIMINARY INJUNCTION OR AS A TEMPORARY RESTRAINING ORDER IS NOT CONTROLLING FOR THE PURPOSE OF DETERMINING APPEALABILITY.

\section{COMMENT}

a. Preliminary Injunctions. Title 28 U.S.C. § 1292(a)(1) specifically provides for interlocutory review of district court orders concerning injunctions. ${ }^{1}$ This statute has been interpreted by the Supreme Court to allow interlocutory appeal of preliminary injunctions, ${ }^{2}$ and courts of appeals continue to follow this position without qualification. ${ }^{3}$ The statute reflects the traditions of equity and is justified

39. See Crooker v. Knudsen, 232 F. 857 (9th Cir. 1916).

1. 28 U.S.C.A. $\$ 1292(a)(1)$ (West Supp. 1983) provides in general that "[t]he courts of appeals shall have jurisdiction of appeals from . . . [i]nterlocutory orders of the district courts . . or of the judges thereof, granting, continuing, modifying, refusing or dissolving injunctions, or refusing to dissolve or modify injunctions, except where direct review may be had in the Supreme Court . . . ."

2. Deckert v. Independence Shares Corp., 311 U.S. 282 (1940).

3. See, e.g., Peabody Coal Co. v. Local Union Nos. 1734, 1508 \& 1548, UMW, 484 F.2d 78, 83 (6th Cir. 1973); Dorfmann v. Boozer, 414 F.2d 1168, 1171 n.7 (D.C. Cir. 1969); Smith v. Grady, 411 F.2d 181, 186 (5th Cir. 1969); of. United States v. Bedford Assocs., 618 F.2d 904, 914-16 (2d Cir. 1980) (party in whose favor preliminary injunction was entered could appeal when the order was conditional), cert. denied, 456 U.S. 914 (1982). In United States v. Shaheen, 445 F.2d 6, 7 (7th Cir. 1971) (per Stevens, J.), a writ of ne exeat republica was appealable under 28 U.S.C. $\$ 1292$ (a) since it was "in the nature of an injunction." The court suggested in dictum, id. at $7 \mathrm{n} .2$, that the appellate court's jurisdiction might also be supported by the collateral order doctrine (discussed supra $\S 12$ of this Interlocutory Restatement, notes 10-13 and accompanying text).

When a claim for preliminary injunctive relief accompanies a claim for damages and the request for an injunction adds nothing of substance but is merely defensive, then denial of the requested injunction is not appealable. Western Geophysical Co. v. Bolt Assoc., 463 F.2d 101, 104 (2d Cir.), cert. denied, 409 U.S. 1040 (1972). The allowance of interlocutory appeals under 28 U.S.C. $\S 1292(a)(1)$ represents "a narrow excep- 
by the substantial importance to the parties of the power being exercised by the district court in granting or withholding provisional injunctive relief.

A grant or denial of a preliminary injunction will be reversed on appeal only if the district court abused its discretion or applied an improper legal standard. ${ }^{4}$ As explained by the Supreme Court,

The award of an interlocutory injunction by courts of equity has never been regarded as strictly a matter of right, even though irreparable injury may otherwise result to the plaintiff. . . Even in suits in which only private interests are involved the award is a matter of sound judicial discretion . . . .5.

This standard of review is identical to that generally employed by an appellate court in reviewing the final decisions of a district court: Factual determinations will be reversed only if "clearly erroneous" 6 while the district court's conclusions of law are not given such deference and are reversed upon a contrary conclusion by the court of appeals. ${ }^{7}$

Illustration 20-1. $\mathrm{P}$ brings suit against $\mathrm{D}$ to rescind a fraudulent sale and seeks to enjoin $\mathrm{D}$ from transferring or otherwise disposing of the proceeds during the pendency of the action. However the district court rules, the party adversely affected may appeal, and the court of appeals will appraise the facts and law to evaluate the propriety of the district court's action. The substantal rights of both parties are at stake and cannot be fully protected by review after final decision. ${ }^{8}$

b. Failure to Rule. A trial court's failure, without good cause, to rule on a motion for a preliminary injunction within a reasonable time is reviewable. ${ }^{9}$ Such a failure has the same effect as denial of the injunction, ${ }^{10}$ and the effect, not the form, of the district court's action (or lack thereof) should govern. Parties are entitled to rulings on their motions. If, however, the delay in ruling on the motion is

tion to the policy of the basic final judgment rule, 'a wisely sanctioned principle against piecemeal appeals." "Id. To allow appeals from surplus injunctive causes of action would frustrate the final decision rule in cases otherwise involving only money damages. "The great advantages [of the final decision rule] in the administration of federal justice dictate against a reliance on the strict letter of $\S 1292(a)(1)$ which would cause [that] exception to encroach unduly upon the [final decision] rule." Id.

4. E.g., Yakus v. United States, 321 U.S. 414, 440 (1944); SEC v. First Fin. Group, 645 F.2d 429,433 34 (5th Cir. 1981); Levesque v. Maine, 587 F.2d 78, 80 (1st Cir. 1978); Merrell-National Laboratories v. Zenith Laboratories, 579 F.2d 786, 791-92 (3d Cir. 1978); Waste Management, Inc. v. Deffenbaugh, 534 F.2d 126, 129 (8th Cir. 1976).

5. Yakus v. United States, 321 U.S. 414, 440 (1944).

6. See FED. R. CIV. P. 52(a).

7. See 9 C. Wright \& A. Miller, Federal Practice and Procedure $\$ 2588$ (1971). See generally United States v. Mississippi Valley Generating Co., 364 U.S. 520, 526 (1961); supra $§ 9$ of this Interlocutory Restatement.

8. Cf. Deckert v. Independence Shares Corp., 311 U.S. 282 (1940).

9. City of Parma v. Levi, 536 F.2d 133, 135 (6th Cir. 1976) (dictum); United States v. City of Jackson, 519 F.2d 1 147, $1153-54$ (5th Cir. 1975) (dictum); Commercial Sec. Bank v. Walker Bank \& Trust Co., 456 F.2d 1352, 1355 (10th Cir. 1972); United States v. Lynd, 301 F.2d 818, 822 (5th Cir.), cert. denied, 371 U.S. 893 (1962).

10. United States v. Lynd, 301 F.2d 818, 822 (5th Cir.), cert. denied, 371 U.S. 893 (1962). Similarly, the outright staying of a proceeding in which preliminary injunctive relief is sought is immediately appealable as constituting the denial of an injunction. See supra $\S 17$ of this Interlocutory Restatement, note 38 and accompanying text. 
plausibly justifiable, the appeal may be dismissed. ${ }^{" 1}$

Illustration 20-2. $\quad \mathrm{P}$ brings a class action employment discrimination suit against $\mathrm{D}$, a city, seeking a preliminary injunction against D's continued use of certain hiring tests. The U.S. Department of Justice subsequently enters into negotiations with $P$ and $D$ in an attempt to obtain a consent decree. The trial judge conducts an in camera inspection of the civil service tests. Eleven months later, the judge still has not ruled on the motion for a preliminary injunction. $\mathrm{P}$ appeals from this failure to rule. The appeal should be dismissed. As long as there is plausible reason for the delay, the failure to decide is not tantamount to rejection of the motion for relief. ${ }^{12}$

c. Mootness of Preliminary Injunction. If the issues involved in an order concerning a preliminary injunction are moot by the time of review, the appeal generally will not be entertained. ${ }^{13}$ Voluntary cessation of allegedly illegal conduct by the defendant does not necessarily make the denial of an injunction moot, however, as the defendant is free to return to his old ways. ${ }^{14}$ Cessation will give rise to mootness when the defendant carries the heavy burden of proving that, under the circumstances, "there is no reasonable expectation that the wrong will be repeated." 15 When, on the contrary, temporary injunctive relief is granted, expiration of the order will not moot the appeal if the circumstances giving rise to the injunction are capable of recurring and the short time duration of the order otherwise will always prevent review. ${ }^{16}$

Illustration 20-3. P sues D, alleging copyright infringement, and seeks to enjoin certain scheduled performances by $\mathrm{D}$. The district court, acting before the first scheduled performance, denies the preliminary injunction. $\mathrm{P}$ appeals, while the performances continue as scheduled to the end of their run. Because the allegedly infringing performances are financial failures and the proper standards for enjoining an infringing performance have subsequently been clarified, the appeal should be dismissed as moot: The circumstances here make it unlikely $\mathrm{D}$ will renew the infringing activities. ${ }^{17}$

d. Review on Final Decision. An appellant does not waive his right to raise on final appeal issues disputed with respect to the preliminary injunction even if he

11. United States v. City of Jackson, 519 F.2d 1147, 1153-54 (5th Cir. 1975).

12. See United States v. City of Jackson, 519 F.2d 1147 (5th Cir. 1975).

13. E.g., Robert Stigwood Group, Ltd. v. Hurwitz, 462 F.2d 910, 912-13 (2d Cir. 1972); cf. Milonas v. Williams, 648 F.2d 688, 689 n.1 (10th Cir. 1981) (per curiam), cert. denied, 103 S. Ct. 1524 (1983); SEC v. First Fin. Group, 645 F.2d 429, 433 (5th Cir. 1981).

14. United States v. W.T. Grant Co., 345 U.S. 629, 632-33 (1953).

15. Id. at 633 (footnotes omitted).

16. See infra note 50 and accompanying illustration.

17. Robert Stigwood Group, Ltd. v. Hurwitz, 462 F.2d 910 (2d Cir. 1972). Note that though the appeal in Stigwood was dismissed as moot, the court of appeals vacated the district court's order as "an appropriate exercise of our judicial power. . . to insure that [the district court's decision] can have no precedential value." $I d$. at 914 n.8. 
does not avail himself of interlocutory review. ${ }^{18}$ The language of the statute is permissive, allowing a party to take an interlocutory appeal but in no way requiring the appeal to be taken on pain of waiving the issues raised with respect to the preliminary injunction. ${ }^{19}$

An appeal from a preliminary injunction is moot, strictly speaking, if the final decision has resulted in a permanent injunction. ${ }^{20}$ In such an instance, however, the only practical effect is that the issues are raised in an appeal from the permanent injunction. ${ }^{21}$

Illustration 20-4. $\mathrm{P}$ sues $\mathrm{D}$, alleging plagiarism, and seeks a preliminary injunction and an accounting. The district court grants P's preliminary injunction, determining the issue of alleged copyright infringement in P's favor. D does not appeal until forty-eight days after the district court's order is entered but before the accounting. The appeal should be dismissed as untimely. ${ }^{22}$ The district court subsequently completes the accounting and grants a permanent injunction. D files a timely appeal from this final decision. D's appeal should be entertained as to all issues not moot. D did not, by failing to obtain earlier interlocutory review, waive the right to review of the issues of copyright infringement and injunctive relief. ${ }^{23}$

e. Temporary Restraining Orders. Interlocutory review under 28 U.S.C. $\S 1292$ (a)(1) does not extend to decisions as to temporary restraining orders as such orders are not considered "injunctions" within the meaning of the statute. ${ }^{24}$ The

18. E.g., Victor Talking Machine Co. v. George, 105 F.2d 697, 699 (3d Cir.), cert. denied, 308 U.S. 611 (1939). See also supra $\S 9$ of this Interlocutory Restatement, notes 223-26 and accompanying text; of. supra $\S 18$ of this Interlocutory Restatement, comment d.

19. Victor Talking Machine v. George, 105 F.2d 697 (3d Cir.), cert. denied, 308 U.S. 611 (1939). The court quotes the old language of 28 U.S.C. $\$ 227$ (1934) (precursor of 28 U.S.C. $\$ 1292(a)$ ) as follows:

Where, upon a hearing in a district court, or by a judge thereof in vacation, an injunction is granted, continued, modified, refused, or dissolved by an interlocutory order or decree, or an application to dissolve or modify an injunction is refused, . . . an appeal may be taken from such interlocutory order or decree to the circuit court of appeals... .

105 F.2d at 698-99. This interpretation has not been changed by the 1948 revision of the Judicial Code. See 16 C. Wright, A. Miller, E. Cooper, \& E. Gressman, Federal Practice and Procedure $\S 3921$, at 12 n.12 (1977). The current language of 28 U.S.C. $\$ 1292$ (a)(1) is quoted supra note 1 . For cases where issues concerning preliminary injunctions were raised on appeal after final disposition, see Sea Union of Professional Airmen v. Alaska Aeronautical Indus., 625 F.2d 881, 884 n.3 (9th Cir. 1980); Merrell-National Laboratories v. Zenith Laboratories, 579 F.2d 786, 791 (3d Cir. 1978); Jacksonville Port Auth. v. Adams, 556 F.2d 52, 57 n.15 (D.C. Cir. 1977); Tincher v. Piasecki, 520 F.2d 851, 854 n.3 (7th Cir. 1975); Caradelis v. Refineria Panama, S.A., 384 F.2d 589, 591 n.1 (5th Cir. 1967) (28 U.S.C. § 1292(a)(3)); Hook v. Hook \& Ackerman, Inc., 233 F.2d 180, 182 (3d Cir. 1956), cert. denied, 352 U.S. 960 (1957)

20. See, e.g., Milonas v. Williams, 648 F.2d 688, 689 n.1 (10th Cir. 1981) (per curiam) (note that the permanent injunction here was not yet a final decision because the issue of at torney's fees was still pending; review was under 28 U.S.C. $\$ 1292$ (a)(1) (see infra $\S 22$ of this Interlocutory Restatement, comment a)), cert. denied, 103 S. Ct. 1524 (1983); SEC v. First Fin. Group, 645 F.2d 429, 433 (5th Cir. 1981).

21. See SEC v. First Fin. Group, 645 F.2d 429, 433 (5th Cir. 1981). The scope of review on appeal from the permanent injunction is "at least as broad." Id.

22. For a discussion of the time for appeal, see supra $\S 13$ of this Interlocutory Restatement, notes 22 24 and accompanying text.

23. See Victor Talking Machine Co. v. George, 105 F.2d 697 (3d Cir.), cert. denied, 308 U.S. 611 (1939).

24. E.g., Sampson v. Murray, 415 U.S. 61, 86 n.58 (1974); In re Brotherhood of Ry., Airline \& S.S. Clerks, 605 F.2d 1073, 1074 (8th Cir. 1979); Clarkson Co. v. Shaheen, 544 F.2d 624, 627 n.4 (2d Cir. 1976); Sohappy v. Smith, 529 F.2d 570, 572 (9th Cir. 1976); Drudge v. McKernon, 482 F.2d 1375, 1376 (4th Cir. 
underlying rationale for this rule has been summarized as follows:

The practical reasons for not generally allowing appeals from temporary restraining orders are that (1) they are usually effective for only very brief periods of time, far less than the time required for an appeal (which accounts for the paucity of cases on this point), and are then generally supplanted by appealable temporary or permanent injunctions, (2) they are generally issued without notice to the adverse party and thus the trial judge has had opportunity to hear only one side of the case, and (3) the trial court should have ample opportunity to have a full presentation of the facts and law before entering an order that is appealable to the appellate courts. ${ }^{25}$

f. Overextension of Power or Loss of Substantial Right. Interlocutory appeal may be available to review temporary restraining orders allegedly beyond the powers of the district courts. ${ }^{26}$ This avenue of review through mandamus is quite limited, however, for "[e]ven in such cases appellate courts are reluctant to interfere with the decision of a lower court on jurisdictional questions which it was competent to decide and which are reviewable in the regular course of appeal."27 The writ will issue "only in the exceptional case where there is a clear abuse of discretion or usurpation of judicial power," lest the exception swallow the rule. ${ }^{28}$

Also, a temporary restraining order is immediately reviewable when, despite its short (twenty-day maximum ${ }^{29}$ ) duration, the restrained party may suffer irreparable harm to substantial rights. ${ }^{30}$

Illustration 20-5. P, a group of welfare recipients, brings suit to compel mailing of delayed checks. P's request for a temporary restraining order is denied. $\mathrm{P}$ appeals. The appeal should be heard in light of the recipients' desperate economic situations. ${ }^{31}$

Illustration 20-6. $\mathrm{P}$ sues $\mathrm{D}$, a governmental entity, and is granted an order temporarily restraining $\mathrm{D}$ from awarding to a third party a contract to which $\mathrm{P}$ believes himself entitled. The court subsequently dis-

1973) (per curiam); Lowe v. Warden \& Comm'r of Holman Prison Unit, 450 F.2d 9, $11-12$ (5th Cir. 1971); Leslie v. Penn Central R.R., 410 F.2d 750 (6th Cir. 1969) (per curiam); Grant v. United States, 282 F.2d 165, 167 (2d Cir. 1960); St. Helen v. Wyman, 222 F.2d 890, 891 (9th Cir. 1955).

25. Connell v. Dulien Steel Prods., 240 F.2d 414, 418 (5th Cir. 1957), cert. denied, 356 U.S. 968 (1958).

26. See, e.g., In re Brotherhood of Ry., Airline \& S.S. Clerks, 605 F.2d 1073, 1074 (8th Cir. 1979) (district court order not beyond its jurisdiction as limited by Norris-LaGuardia Act, 29 U.S.C. $\$ \S 101-115$ (1976), and thus mandamus refused; dictum states that mandamus would have issued, however, if the district court had in fact lacked jurisdiction); Truck Drivers Local Union No. 807 v. Bohack Corp., 541 F.2d 312, 317 (2d Cir. 1976) (mandamus issued to dissolve district court's temporary restraining order since Norris-LaGuardia Act deprived district court of jurisdiction).

27. Roche v. Evaporated Milk Ass'n, 319 U.S. 21, 26 (1943).

28. In re Brotherhood of Ry., Airline \& S.S. Clerks, 605 F.2d 1073, 1075 (8th Cir. 1979) (citing Bankers Life \& Casualty Co. v. Holland, 346 U.S. 379 (1953)).

29. A temporary restraining order is effective for ten days and may be extended for another ten days for good cause shown; the restrained party must consent to any longer period of time. FED. R. CIV. P. 65(b) (quoted infra note 64).

30. Coalition for Basic Human Needs v. King, 654 F.2d 838, 839-40 (1st Cir. 1981) (per curiam); H.K. Porter Co. v. Metropolitan Dade County, 650 F.2d 778, 781-82 (5th Cir. 1981); Environmental Defense Fund, Inc. v. Andrus, 625 F.2d 861, 862 (9th Cir. 1980); In re Vuitton et Fils S.A., 606 F.2d 1, 3 (2d Cir. 1979) (per curiam); Virginia v. Tenneco, Inc., 538 F.2d 1026, 1030 (4th Cir. 1976); Spencer Cos. v. Armonk Indus., 489 F.2d 704, 706 (1st Cir. 1973); Berrigan v. Sigler, 475 F.2d 918, 919 (D.C. Cir.) (per curiam), stay granted, 410 U.S. 902 (1973); Wirtz v. Powell Knitting Mills Co., 360 F.2d 730, 732 (2d Cir. 1966); Woods v. Wright, 334 F.2d 369, 373-74 (5th Cir. 1964).

31. Coalition for Basic Human Needs v. King, 654 F.2d 838 (1st Cir. 1981) (per curiam). The court characterized this case as involving "highly unusual circumstances." Id. at 840 . 
solves the temporary restraining order. $\mathbf{P}$ appeals. This appeal should be entertained if $\mathrm{D}$ will be free to award the disputed contract to the third party, effectively mooting P's equitable cause of action. ${ }^{32}$

Illustration 20-7. P, a manufacturer of expensive, distinctive leather goods, files 100 actions alleging trademark infringement against defendants who sell goods made to look like P's. In many similar past suits by $P$, however, when a temporary restraining order was issued with notice, the defendant would dispose of the goods for cash before the order could become effective, thus mooting the case. To foreclose this possibility in the instant action, $\mathrm{P}$ applies for an ex parte temporary restraining order; but the district court refuses to issue such a command without notice. $P$ appeals, urging that notice will effectively deprive it of protection for its substantive rights. The appeal should be entertained and the trial court may indeed be required to issue an ex parte temporary restraining order since that may be the only way to halt the defendants" "shell game" and protect P's trademark. ${ }^{33}$

g. Ostensible Preliminary Injunction Not Appealable. The district court's labeling of an order as either a preliminary injunction or a temporary restraining order does not bind the court of appeals when deciding appealability. ${ }^{34}$ Instead, the appellate court will examine the content and effect of the order in question. ${ }^{35}$ To do otherwise would allow form to prevail over substance. ${ }^{36}$ As explained by the Supreme Court in Sampson v. Murray, "[a] district court, if it were able to shield its orders from appellate review merely by designating them as temporary restraining orders rather than as preliminary injunctions, would have virtually unlimited authority over the parties in an injunctive proceeding." 37

If an order may arguably be characterized as a preliminary injunction but violations of the alleged injunction are not punishable by contempt, then the order is not immediately appealable. ${ }^{38}$ Without the threat of sanctions, the order is merely advisory and therefore without sufficient imminence to justify an immediate appeal. ${ }^{39}$

32. H.K. Porter Co. v. Metropolitan Dade County, 650 F.2d 778 (5th Cir. 1981).

33. In re Vuitton et Fils S.A., 606 F.2d 1 (2d Cir. 1979) (per curiam). The court stated that "this case is not only 'extraordinary,' it approaches the bizarre." Id. at 3 n.5.

34. See, e.g., Sampson v. Murray, 415 U.S. 61, 86-87 (1974); Melanson v. John J. Duane Co., 605 F.2d 31, 33 (1st Cir. 1979); Waste Management, Inc. v. Deffenbaugh, 534 F.2d 126, 129 (8th Cir. 1976); GlenArden Commodities v. Costantino, 493 F.2d 1027, 1030 n.2 (2d Cir. 1974) (dictum); Morning Tel. v. Powers, 450 F.2d 97, 99 (2d Cir. 1971), cert. denied, 405 U.S. 954 (1972); Smith v. Grady, 411 F.2d 181 , 186 (5th Cir. 1969); National Mediation Bd. v. Airline Pilots Ass'n, 323 F.2d 305 (D.C. Cir. 1963).

35. Smith v. Grady, 411 F.2d 181, 186 (5th Cir. 1969).

36. Similarly, court labels as to "trustee" versus "receiver" are not controlling as to whether an order is immediately appealable under 28 U.S.C. $§ 1292(a)(2)$, see infra $\$ 21$ of this Interlocutory Restatement, notes 11-12 and accompanying text, nor are labels as to "summary judgment" versus "dismissal for failure to state a claim" or question of "law" versus question of "fact." See supra $\S 9$ of this Interlocutory Restatement, notes $19-20,35 \& 59$ and accompanying text.

37. 415 U.S. $61,86-87$ (1974).

38. See United States v. Ryan, 402 U.S. 530, 534 (1971); Rodgers v. United States Steel Corp., 508 F.2d 152, 160-61 (3d Cir.), cert. denied, 423 U.S. 832 (1975).

39. See United States v. Ryan, 402 U.S. 530, 534 (1971) 
Illustration 20-8. D, in an action for breach of contract, is served with a subpoena duces tecum ordering him to produce documents kept in a foreign country. Foreign law prohibits removal of such documents without permission, so $\mathrm{D}$ moves to quash the subpoena. The district court denies D's motion and orders him either to attempt to obtain permission to remove the documents or to make them available for inspection there. D appeals. The appeal should be dismissed. Though it may be argued that the order was a preliminary injunction, ordering an affirmative act, and therefore subject to immediate review under 28 U.S.C. $\S 1292(a)(1)$, interlocutory appeal is not permitted because the order was merely informative, telling D what options were possible to comply with the subpoena. Because D will not be prosecuted for contempt for simply failing to obtain the needed foreign consent, there is no additional burden placed on the defendant by the order. ${ }^{40}$

Similarly, an ostensible preliminary injunction which is essentially a protective order is not immediately appealable. ${ }^{41}$ As explained by the Second Circuit,

it [is] better, in line with . . prior decisions, to continue to read $\S 1292(a)(1)$ as relating to injunctions which give or aid in giving some or all of the substantive relief sought by the complaint ... and not as including restraints or directions in orders concerning the conduct of the parties or their counsel, unrelated to the substantive issues in the action, while awaiting trial. ${ }^{42}$

Any broadening of the scope of 28 U.S.C. $\S 1292(\mathrm{a})(1)$ beyond injunctions to encompass orders which are in reality protective orders "would seem quite inconsistent with the federal policy of finality." 43

Illustration 20-9. D, in an SEC action, makes a motion to enjoin the SEC from "harrassing and annoying" him with civil and criminal prosecutions. The motion is denied by the district court. D appeals. The appeal should be dismissed. D's characterization of the district court's action as the denial of a preliminary injunction is not controlling. The defendant's motion is properly identified as a request for a protective order, so the order denying it is interlocutory and nonappealable. ${ }^{44}$

h. Ostensible Temporary Restraining Order Appealable. If the trial court, in considering an ostensible temporary restraining order, addresses the merits, determining that a party is or is not entitled to preliminary relief, then its order is tantamount to a grant or denial of a preliminary injunction and appeal will be allowed under 28 U.S.C. $\S 1292(a)(1) .{ }^{45}$ "In such a situation nothing is to be gained by requiring an appellant to go through the moiions of re-applying for permanent injunctive

40. United States v. Ryan, 402 U.S. 530 (1971).

41. See SEC v. Sloan, 535 F.2d 679, 681 (2d Cir. 1976) (per curiam), cert. denied, 430 U.S. 966 (1977); International Prods. Corp. v. Koons, 325 F.2d 403, 406-07 (2d Cir. 1963).

42. International Prods. Corp. v. Koons, 325 F.2d 403, 406 (2d Cir. 1963).

43. Id. at 407 .

44. SEC v. Sloan, 535 F.2d 679 (2d Cir. 1976) (per curiam), cert. denied, 430 U.S. 966 (1977). For a discussion of the appealability of protective orders, see infra $\S 38$ of this Interlocutory Restatement.

45. Levesque v. Maine, 587 F.2d 78, 79-80 (1st Cir. 1978); Kimball v. Commandant 12th Naval Dist., 423 F.2d 88, 89 (9th Cir. 1970). 
relief in the trial court." 46

Illustration 20-10. P, a sailor, sues the Navy to establish in-service conscientious objector status. He requests a temporary restraining order barring his removal from the naval district pending action on his request for such status. Both sides fully argue the motion, and the district court, in denying the temporary restraining order, addresses the merits in a manner that makes denial of the sailor's entitlement to any relief implicit. $\mathrm{P}$ appeals. The appeal should be entertained under 28 U.S.C. $\S 1292(a)(1)$ as the district court has already in effect denied any right to a preliminary injunction. ${ }^{47}$

Similarly, when both sides have presented substantial arguments before the district court concerning a motion for a temporary restraining order, the resulting grant or denial again more closely resembles the decision on a preliminary injunction and is thus immediately appealable under 28 U.S.C. $\S 1292(a)(1) .{ }^{48}$ As explained by the Fourth Circuit, an immediate appeal may be taken "when . . . the TRO was entered after full hearing in which [all parties] fully participated and the TRO bespeaks of the nature of a preliminary injunction, although of limited duration, rather than an order entered ex parte or on less than a full presentation of the facts." 49

Illustration 20-11. $\mathrm{P}$, a state, brings an action to prevent $\mathrm{D}$, a natural gas supplier, from implementing a gas curtailment plan filed with a federal agency. $P$ requests a temporary restraining order. The district court hears arguments from counsel for $P, D$, and the federal agency and grants the temporary restraining order, requiring $D$ to provide full natural gas allotments for the eight-day duration of the order. D appeals. D's appeal should be entertained under 28 U.S.C. $\S 1292(a)$ (1) because the temporary restraining order served the function of a preliminary injunction, being issued after a full hearing on the merits. ${ }^{50}$

Illustration 20-12. P, an environmental group, brings an action to prevent certain demonstration flights and requests a temporary restraining order. The evidence presented at the hearing is limited owing to time constraints and the novel nature of the problem. The district court denies the temporary restraining order pending further hearings. $\mathrm{P}$ appeals. The appeal should be dismissed because the evidence presented to the district court was not sufficiently complete for the hearing to be equated with that for a preliminary injunction. The general rule of nonappeala-

46. Kimball v. Commandant 12th Naval Dist., 423 F.2d 88, 89 (9th Cir. 1970).

47. Kimball v. Commandant 12th Naval Dist., 423 F.2d 88 (9th Cir. 1970).

48. See Sampson v. Murray, 415 U.S. 61, 87 (1974); Environmental Defense Fund, Inc. v. Andrus, 625 F.2d 861, 862 (9th Cir. 1980); Virginia v. Tenneco, Inc., 538 F.2d 1026, 1029-30 (4th Cir. 1976); Massachusetts Air Pollution \& Noise Abatement Comm. v. Brinegar, 499 F.2d 125, 126 (1st Cir. 1974) (per curiam); Connell v. Dulien Steel Prods., 240 F.2d 414, 417-18 (5th Cir. 1957), cert. denied, 356 U.S. 968 (1958).

49. Virginia v. Tenneco, Inc., 538 F.2d 1026, 1030 (4th Cir. 1976).

50. Virginia v. Tenneco, Inc., 538 F.2d 1026 (4th Cir. 1976). Note that the order would have expired before the appeal could be heard; the issue, however, was not moot since it presented a problem likely to recur yet likely to perpetually evade review. Id. at 1031 . 
bility of decisions concerning temporary restraining orders thus prevails. The proper remedy is further evidentiary hearings prior to the grant or denial of a preliminary injunction, not premature appellate review. ${ }^{51}$

Some courts allow appeal from a ruling on a temporary restraining order when the parties were merely presented with the opportunity for a substantial evidentiary hearing, even if they offered little or no evidence. ${ }^{52}$ This is appropriate in situations involving "a motion for which [further] factual development [is] irrelevant, the hearing [is] not ex parte, and time [is] exceedingly short." 53 This rule is sensible, as it prevents potential abuses; otherwise a party who was confident of success even with only a minimal presentation of evidence could prevent appellate review of the grant or denial of a temporary injunctive order by simply withholding evidence at the district court hearing.

Illustration 20-13. A broadcasting company brings an action for a temporary restraining order to compel the prosecutor in a pending criminal case to permit duplication of audiotape evidence for broadcast on the news. The motion is denied without argument from any of the parties to the original action, although they are present at the hearing. The broadcasting company appeals. The appeal should be entertained because all interested persons had the opportunity to argue and all relevant facts were fully developed. ${ }^{54}$

Also, when there are no factual issues open at the time the appeal would be taken such that subsequent additional hearing would be useless, the temporary restraining order is appealable as a preliminary injunction. ${ }^{55}$ The legal issues are ripe for appellate review on the record established. ${ }^{56}$ Such circumstances may arise when there has been a full adversary hearing, or a sufficient opportunity therefor, in regard to the temporary restraining order, so that all relevant facts have been developed, ${ }^{57}$ or when, due to the passage of time, there are no longer relevant facts in dispute. ${ }^{58}$

Illustration 20-14. P, a group of welfare recipients, brings an action to compel the state to mail delayed welfare checks and moves for a temporary restraining order. When the motion is argued to the district court, a genuine factual issue exists as to the extent of the welfare recipients' deprivation since the checks have then only been withheld for two days. The

51. Massachusetts Air Pollution \& Noise Abatement Comm. v. Brinegar, 499 F.2d 125 (1st Cir. 1974) (per curiam).

52. See, e.g., Belo Broadcasting Corp. v. Clark, 654 F.2d 423, 426 (5th Cir. 1981)

53. Id.

54. Belo Broadcasting Corp. v. Clark, 654 F.2d 423 (5th Cir. 1981).

55. See Coalition for Basic Human Needs v. King, 654 F.2d 838, 839-40 (Ist Cir. 1981) (per curiam); Belo Broadcasting Corp. v. Clark, 654 F.2d 423, 426 (5th Cir. 1981).

56. See generally Sampson v. Murray, 415 U.S. 61,87 (1974); Belo Broadcasting Corp. v. Clark, 654 F.2d 423, 426 (5th Cir. 1981); Virginia v. Tenneco, Inc., 538 F.2d 1026, 1030 (4th Cir. 1976).

57. See Belo Broadcasting Corp. v. Clark, 654 F.2d 423 (5th Cir. 1981). This situation overlaps other exceptions allowing appeals of temporary restraining orders as discussed supra notes 48-54 and accompanying text.

58. See Coalition for Basic Human Needs v. King, 654 F.2d 838 (1st Cir. 1981) (per curiam) 
temporary restraining order is denied. $\mathrm{P}$ appeals. By the time the court of appeals reaches its decision the indigent plaintiffs will have been without funds for thirteen days and harm will no longer be contestable. The order is reviewable as a preliminary injunction as further hearings would serve no purpose. ${ }^{59}$

When a decision concerning an ostensible temporary restraining order requires that an affirmative act be undertaken, the decision is immediately appealable as a preliminary injunction. ${ }^{60}$ The basic purpose of a temporary restraining order is to "preserve the status quo pending further proceedings."61 When an order seeks an affirmative act it operates like a mandatory injunction; immediate appeal is allowed under 28 U.S.C. $\S 1292(a)(1)$ to protect the rights of the parties. ${ }^{62}$

Illustration 20-15. P, a college student, brings an action against $\mathrm{D}$, his college, seeking to enjoin $\mathrm{D}$ from suspending him without a prior hearing. The suit, however, is not filed until the day after the suspension goes into effect. P's motion for a temporary restraining order is granted, and D appeals. The "temporary restraining order" is immediately appealable under 28 U.S.C. $\$ 1292(a)(1)$ because it grants affirmative substantive relief by compelling reinstatement of $\mathrm{P} .63$

Finally, whenever an ostensible temporary restraining order extends without party consent well beyond the twenty-day time limit set by Rule 65(b) of the Federal Rules of Civil Procedure, ${ }^{64}$ the order should be appealable under 28 U.S.C.

59. Cf. id. For a discussion of other aspects of this case, see supra notes 30-31 and accompanying text.

60. Adams v. Vance, 570 F.2d 950, 953 (D.C. Cir. 1978) (per curiam); Belknap v. Leary, 427 F.2d 496, 498 (2d Cir. 1970); Stricklin v. Regents of the Univ. of Wis., 420 F.2d 1257, 1259 (7th Cir. 1970). Several other cases allowing appeals from temporary restraining orders requiring affirmative acts have found appellate jurisdiction on other bases. See, e.g., Coalition for Basic Human Needs v. King, 654 F.2d 838 (1st Cir. 1981) (temporary restraining order compelling state to mail welfare checks); Belo Broadcasting Corp. v. Clark, 654 F.2d 423 (5th Cir. 1981) (temporary restraining order compelling clerk of court to make audio tapes available to the news media); Levesque v. Maine, 587 F.2d 78 (1st Cir. 1978) (temporary restraining order compelling state to reinstate employee).

61. Adams v. Vance, 570 F.2d 950, 953 (D.C. Cir. 1978) (per curiam).

62. Id.

63. Stricklin v. Regents of the Univ. of Wis., 420 F.2d 1257 (7th Cir. 1970).

64. A temporary restraining order which lasted twenty-eight days was held not sufficiently over the twenty-day limit of Rule 65(b) to merit allowance of an appeal. See Connell v. Dulien Steel Prods., 240 F.2d 414, 418 (5th Cir. 1957), cert. denied, 356 U.S. 968 (1958). FeD. R. CiV. P. Rule 65(b) reads as follows:

(b) Temporary Restraining Order; Notice; Hearing; Duration. A temporary restraining order may be granted without written or oral notice to the adverse party or his attorney only if (1) it clearly appears from specific facts shown by affidavit or by the verified complaint that immediate and irreparable injury, loss, or damage will result to the applicant before the adverse party or his at torney can be heard in opposition, and (2) the applicant's attorney certifies to the court in writing the efforts, if any, which have been made to give the notice and the reasons supporting his claim that notice should not be required. Every temporary restraining order granted without notice shall be indorsed with the date and hour of issuance; shall be filed forthwith in the clerk's office and entered of record; shall define the injury and state why it is irreparable and why the order was granted without notice; and shall expire by its terms within such time after entry, not to exceed 10 days, as the court fixes, unless within the time so fixed the order, for good cause shown, is extended for a like period or unless the party against whom the order is directed consents that it may be extended for a longer period. The reasons for the extension shall be entered of record. In case a temporary restraining order is granted without notice, the motion for a preliminary injunction shall be set down for hearing at the earliest possible time and takes precedence of all matters except older matters of the same character; and when the motion comes on for hearing the party who obtained the temporary restraining order shall proceed with the 
$\S 1292(a)(1)$ as a preliminary injunction. ${ }^{65}$

Illustration 20-16. P files an action to prevent D from creating a competing company in violation of an agreement and moves for a temporary restraining order. The motion is granted on February 21 and is still in effect on July 9, when D files a motion to dissolve the order. The "temporary restraining order" is dissolved on August 13, and $\mathrm{P}$ appeals. The appeal should be entertained because the "temporary restraining order" extended beyond the time limits of Rule $65(\mathrm{~b})$ and so must be treated as a preliminary injunction. 66

\section{§21. Receiverships.}

(A) AN ORDER APPOINTING A RECEIVER OR REFUSING TO WIND UP OR TO TAKE STEPS TO ACCOMPLISH THE PURPOSE OF A RECEIVERSHIP IS REVIEWABLE ON INTERLOCUTORY APPEAL TO PREVENT IRREPARABLE HARM TO THE SUBSTANTIAL RIGHTS OF THE APPELLANT.

(B) AN ORDER REFUSING TO APPOINT A RECEIVER OR TO REINSTATE OR VACATE A RECEIVERSHIP OR AUTHORIZING A RECEIVER TO TAKE ADMINISTRATIVE ACTION IS REVIEWABLE ONLY ON APPEAL FROM A FINAL DECISION.

\section{COMMENT}

a. Nature of Receivership. The statutory provision governing interlocutory review of receiverships, 28 U.S.C. $\S 1292(a)(2),{ }^{1}$ speaks only to "the ordinary

application for a preliminary injunction and, if he does not do so, the court shall dissolve the temporary restraining order. On 2 days' notice to the party who obtained the temporary restraining order without notice or on such shorter notice to that party as the court may prescribe, the adverse party may appear and move its dissolution or modification and in that event the court shall proceed to hear and determine such motion as expeditiously as the ends of justice require.

65. See, e.g., Sampson v. Murray, 415 U.S. 61, 86 (1974) (unlimited duration); Melanson v. John J. Duane Co., 605 F.2d 31, 33 (1st Cir. 1979) (still in effect after three years); Clements Wire \& Mfg. Co. v. NLRB, 589 F.2d 894, 896-97 (5th Cir. 1979) (order granting "temporary injunction" for "a reasonable period of time"); National City Bank v. Battisti, 581 F.2d 565, 568 (6th Cir. 1977) (per curiam); Truck Drivers Local Union No. 807 v. Bohack Corp., 541 F.2d 312, 316-17 (2d Cir. 1976) (temporary restraining order in effect until decision of bankruptcy judge); Waste Management, Inc. v. Deffenbaugh, 534 F.2d 126, 129 (8th Cir. 1976) (appeal from dissolution of seventeenth-month temporary restraining order); Pauls v. Secretary of the Air Force, 457 F.2d 294, 298 (1st Cir. 1972) (order effective until final disposition of litigation); Commercial Sec. Bank v. Walker Bank \& Trust Co., 456 F.2d 1352, 1354-55 (10th Cir. 1972) ("for a reasonable period of time"); Morning Tel. v. Powers, 450 F.2d 97, 99 (2d Cir. 1971) (unlimited duration), cert. denied, 405 U.S. 954 (1972). Cf. Pennsylvania Motor Trúck Ass'n v. Port of Philadelphia Marine Terminal Ass'n, 276 F.2d 931, 931-32 (3d Cir. 1960) (per curiam) (court of appeals is without jurisdiction to hear appeal from "temporary restraining order" of unlimited duration when order was issued only eighteen days earlier).

66. Waste Management, Inc. v. Deffenbaugh, 534 F.2d 126 (8th Cir. 1976).

1. This subsection provides that appellate courts shall have jurisdiction to hear appeals from "[i]nterlocutory orders appointing receivers, or refusing orders to wind up receiverships or take steps to accomplish the purpose thereof, such as directing sales or other disposals of property." 28 U.S.C.A. $\S 1292(a)(2)$ (West Supp. 1983). It is the successor to several prior enactments. The Act of June 6, 1900, ch. 803, 31 Stat. 660, provided for interlocutory appeal from an orders appointing a receiver "upon a hearing in equity." The Act of February 13, 1925, ch. 229, $\$ 129,43$ Stat. 936, 937, added jurisdiction of 
equity receiver, or to some similar official of statutory authority."2 An early case described the typical equity receivership as being "in the nature of 'executions before judgment,' and in effect either ousting parties from the possession of property or injuriously controlling the management and disposition of property."3 An equity receiver is a person specially appointed by the court to take control of and manage property involved in litigation for the purpose of preserving it until final disposition of the suit. ${ }^{4}$ Such a receiver is an officer of the court whose responsibilities are defined by statute. ${ }^{5}$

A court will frequently appoint an equity receiver to hold property subject to a lien in a foreclosure action ${ }^{6}$ or to prevent the impairment of corporate assets incident to a stockholder suit. ${ }^{7}$ An equity receivership, however, "is only a means to reach some legitimate end sought through the exercise of the power of a court of equity. It is not an end itself." "The appointment determines no substantive right, nor is it a step in the determination of such a right."9 Still, the appointment of a receiver is a drastic remedy that is only employed on a plain showing of some threatened loss or injury to the property. ${ }^{10}$

The designation of the court-appointed holder of the property as a "trustee" is not determinative of the right of appeal under 28 U.S.C. $\$ 1292(a)(2) .{ }^{11}$ "A receiver by any other name, or by no name, is still a receiver," 12 and a designation to the contrary does not prevent appeal. ${ }^{13}$

Illustration 21-1. P, a bank creditor, brings suit against $\mathrm{D}$, an individual bank stockholder, for recovery of the statutory double stock liability. ${ }^{14}$ The court finds the bank insolvent and finds a deficiency of assets requiring contribution from the stockholders. The court appoints a receiver to protect and enforce the rights of the creditors against the

\footnotetext{
appeals from interlocutory orders refusing to wind up pending receiverships or refusing to take the appropriate steps to accomplish the purposes thereof. The statutory provision was drawn into its present form (based on former 28 U.S.C. $\S 227$ ) in the 1948 revision of the Judicial Code, ch. 646, $\S 1,62$ Stat. 869, 929, and was amended again by the Federal Courts Improvement Act of 1982, Pub. L. No. 97-164, § 125, 96 Stat. 25, 36, to require that appeals in certain types of cases be taken only to the newly established Court of Appeals for the Federal Circuit (see supra $\$ 2$ of this Interlocutory Restatement, comment $c$ ).

2. Martin v. Partridge, 64 F.2d 591, 592 (8th Cir. 1933).

3. Gulf Ref. Co. v. Vincent Oil Co., 185 F.2d 87, 89 (5th Cir. 1911).

4. 12 C. Wright \& A. Miller, Federal Practice and Procedure $\$ 2981$ (1973)

5. See 28 U.S.C. 959(b) (Supp. V 1981).

6. E.g., Garden Homes, Inc. v. United States, 200 F.2d 299 (1st Cir. 1952); Williams v. Southern Cotton Oil Co., 45 F.2d 387 (5th Cir. 1930).

7. E.g., Macon Lumber Co. v. Bishop \& Collins, 229 F.2d 305 (6th Cir. 1956); Skirvin v. Mesta, 141 F.2d 668 (10th Cir. 1944).

8. Gordon v. Washington, 295 U.S. 30, 37 (1935)

9. Pusey \& Jones Co.v. Hanssen, 261 U.S. 491, 497 (1923). 1944).

10. Gordon v. Washington, 295 U.S. 30, 39 (1935); Skirvin v. Mesta, 141 F.2d 668, 673 (10th Cir.

11. United States v. Sylacauga Properties, 323 F.2d 487, 490 (5th Cir. 1963). A similar policy is followed as to the mislabeling of summary judgments versus dismissals for failure to state a claim and questions of law versus questions of fact, supra $\S 9$ of this Interlocutory Restatement, notes 19-20, 35 \& 39 and accompanying text, and preliminary injunctions versus temporary restraining orders, supra $\$ 20$ of this Interlocutory Restatement, commenl $g \mathcal{G}^{\circ} \mathrm{h}$.

12. United States v. Sylacauga Properties, 323 F.2d 487, 490 (5th Cir. 1963).

13. Piambino v. Bailey, 610 F.2d 1306, 1327, (5th Cir. 1980), cert. denied, 449 U.S. 1011 (1980).

14. 12 U.S.C. $\$ 812$ (repealed 1971).
} 
stockholders. D appeals. The appeal should be dismissed. The order is not governed by 28 U.S.C. $\$ 1292(\mathrm{a})(2)$ because the arrangement imposed by the court does not constitute an ordinary equity receivership. The order contemplates passing no control over D's property to the receiver pending the final determination of the controversy; it only transfers a right of action whereby the court-appointed official operates as a representative of the creditors. ${ }^{15}$

Illustration 21-2. P, a creditor, brings suit against $\mathrm{D}$ to foreclose a real estate mortgage. The court appoints a receiver with broad general powers to operate and manage the mortgaged property pending foreclosure and with additional authority to collect rents and profits during that time. D appeals. The appeal should be entertained. The order is governed by 28 U.S.C. $\$ 1292(a)(2)$ because it establishes an equity receivership. ${ }^{16}$

The equity receiver prerequisite has on occasion been employed in a manner ${ }^{17}$ so as to defeat the purposes of 28 U.S.C. $\S 1292(\mathrm{a})(2)$. For example, in Florida $v$. United States, the court appointed a receiver to hold the stock of a life insurance corporation but refused to grant receivership over the corporation itself. ${ }^{18}$ The receiver, who thus controlled all the voting power of the stock, called a stockholders' meeting and appointed a new board with himself as president. He then asked the federal marshal to seize all the corporate records for him. Appeal was not allowed because the corporation was not, strictly speaking, under an equity receivership; the receiver had obtained control of the corporation's assets and records through his capacity as an "authorized managing officer of the corporation," which did not constitute the appointment of a receiver. ${ }^{19}$ The court should have disregarded the rule of strict construction and recognized that the practical effect of the maneuver was to place the corporation in receivership. To foreclose appeal was contrary to the purpose of 28 U.S.C. $\S 1292(a)(2)$ to relieve parties from improper interlocutory orders affecting control over property. ${ }^{20}$

b. Appointment of Receiver. An order appointing a receiver is expressly reviewable under 28 U.S.C. $\S 1292(a)(2) .{ }^{21}$ The courts uniformly accept these appeals ${ }^{22}$ and have expanded this category to allow appeals in analogous situations. For example, in McLeod $v$. Hayward the court recognized that a refusal to vacate an appointment of a receiver made by a state court before removal is in effect an interlocutory order appointing a receiver and thus should be similarly appealable. ${ }^{23}$ Also, in Mitchell $v$. Lay the court held that an appellant who is invol-

15. Martin v. Partridge, 64 F.2d 591, 592 (8th Cir. 1933).

16. Garden Homes, Inc. v. United States, 200 F.2d 299 (1st Cir. 1952)

17. Florida v. United States, 285 F.2d 596, 600 (8th Cir. 1960).

18. 285 F.2d 596 (8th Cir. 1960).

19. Id. at 600 .

20. Martin v. Partridge, 64 F.2d 591, 592 (8th Cir. 1933).

21. The statutory language is quoted supra note 1 .

22. See, e.g., SEC v. First Fin. Group, 645 F.2d 429 (5th Cir. 1981); United States v. Cedar-Riverside Land Co., 592 F.2d 470 (8th Cir. 1979); Macon Lumber Co. v. Bishop \& Collins, 229 F.2d 305 (6th Cir 1956); Waylyn Corp. v. Casalduc, 219 F.2d 888 (1st Cir. 1955).

23. 17 F.2d 900, 901 (5th Cir. 1927). 
untarily brought into court after the appointment of a receiver, without the opportunity or right to challenge such appointment, should be able to seek review of his motion to vacate the receivership. ${ }^{24}$ The court noted that such a party's "first opportunity to be heard with reference to the appointment of a receiver is upon his application to have the receivership vacated." 25 Courts, however, have refused to extend review to those parties who had notice and could have intervened in original lawsuits. ${ }^{26}$ These decisions represent a willingness on the part of courts to go beyond the literal language of 28 U.S.C. $\S 1292(a)(2)$ to fulfill the spirit of its purpose.

c. Refusal to Appoint Receiver. An order refusing to appoint a receiver is not subject to interlocutory review ${ }^{27}$ and a denial of a motion to reinstate a receivership is similarly nonappealable. ${ }^{28}$ This result reflects a disfavoring of receiverships due to a regard for property rights. A party seeking a remedy must await full trial on the merits before gaining control of his adversary's property. The language of the cases does, however, seemingly contemplate that orders refusing receivers be reviewed on appeal from the final decision. ${ }^{29}$

d. Refusal to Wind Up Receivership. Section 1292(a)(2) of 28 U.S.C. also explicitly makes an order refusing to wind up a receivership subject to interlocutory appeal. ${ }^{30}$ Common orders encompassed within this language include denial of a petition to discharge the receiver and terminate the receivership ${ }^{31}$ and denial of a request for a final accounting and distribution of assets. ${ }^{32}$ Because under Rule 66 of the Federal Rules of Civil Procedure a receiver who has been appointed cannot be dismissed except by order of the court, interlocutory appeal from denial of a motion to wind up a receivership provides an important safeguard to the parties involved.

The courts have again been willing to expand this category of reviewable orders to analogous situations to ensure that this safeguard is available when necessary. In United States $v$. Sylacauga Properties, for example, the court found an indefinite continuance granted in a foreclosure action appealable when an order winding up the receivership should have been granted. ${ }^{33}$ The court thus recognized that in some circumstances indefinitely continuing the receivership is tantamount to refusing to discharge the receiver.

e. Refusal to Vacate. An interlocutory appeal does not lie from an order

24. 48 F.2d 79 (9th Cir. 1930), cert. denied, 283 U.S. 864 (1931).

25. Id. at 85 . To deny review in this instance would be equivalent to denying review of the initial appointment of a receiver in that the appellant would have no chance to obtain an interlocutory appellate determination of his rights.

26. Coskery v. Roberts \& Mander Corp., 189 F.2d 234, 236-37 (3d Cir. 1951).

27. United States v. Otley, 116 F.2d 958, 958-59 (9th Cir. 1940).

28. Id.

29. See Texas Co. v. Central Fuel Oil Co., 194 F. 1, 22 (8th Cir. 1912).

30. The statutory language is quoted supra note 1 . See infra text accompanying note 37 for a discussion of distinguishing characteristics of a motion to wind up a receivership.

31. See, e.g., Skirvin v. Mesta, 141 F.2d 668, 672 (10th Cir. 1944).

32. See, e.g., Kindy v. Koenke, 216 F.2d 907, 910 (8th Cir. 1954).

33. 323 F.2d 487, 490-91 (5th Cir. 1963). 
denying a motion to vacate the appointment of a receiver, ${ }^{34}$ although the language of the cases apparently contemplates that review may be had on final decision. ${ }^{35}$ This rule prevents repeated or delayed appeals to challenge the original appointment. ${ }^{36}$

Because of this difference in appealability, the distinction between an order denying a motion to vacate the original appointment and an order refusing to wind up a pending receivership is important.

"To wind up a pending receivership" has a clear meaning: it presupposes a receivership in course of administration which because of changed circumstances ought not to be continue. "To vacate a receivership" indicates, on the other hand, a termination with such retroactive effect as may be feasible, an annulment if possible. The one looks to the future; the other, to the past. ...

An order, therefore, denying a motion, in form "to wind up," but in substance "to vacate," the receivership, based solely upon the illegality or impropriety of the original order appointing a receiver, would not be appealable. Such an appeal cannot be obtained by indirect means. ${ }^{37}$

f. Administrative Orders During Receivership. An order authorizing the receiver to take administrative action consistent with conducting the receivership is not immediately appealable. ${ }^{38}$ Such an order is designed to effectuate the provisions of the appointment; ${ }^{39}$ again the unavailability of interlocutory review avoids delay by forcing the parties to present all their objections when the receivership is first established. The language of the commentators seemingly contemplates that such orders may be reviewed on final decision. ${ }^{40}$

Illustration 21-3. $\mathrm{P}$ brings suit against $\mathrm{D}$, and a receiver is appointed. The court orders $\mathrm{D}$ to turn over to the receiver certain books of account, inventories, funds, and lease agreements. D appeals. The appeal should be dismissed because the order merely authorizes an administrative action necessary for the receivership to accomplish its purpose of safeguarding the enterprise. The order does not create or extend the life of a receivership. ${ }^{41}$

Illustration 21-4. $\mathrm{P}$ brings suit against $\mathrm{D}$, and a receiver, $\mathrm{R}$, is appointed. The court denies R's application for authority to intervene in and prosecute a separate action allegedly brought on a chose of action, the title of which was given to him by his appointment. $\mathrm{R}$ appeals. The appeal should be dismissed as the denial went to an "administrative" function of

34. United States v. Chelsea Towers, 404 F.2d 329, 330 (3d Cir. 1968); Coskery v. Roberts \& Mander Corp., 189 F.2d 234 (3d Cir. 1951); Skirvin v. Mesta, 141 F.2d 668, 672 (10th Cir. 1944).

35. See Skirvin v. Mesta, 141 F.2d 668, 672 (10th Cir. 1944).

36. Coskery v. Roberts \& Mander Corp., 189 F.2d 234, 236 (3d Cir. 1951).

37. Grand Beach Co. v. Gardner, 34 F.2d 836, 838 (6th Cir. 1929). Cf. supra notes $11-13$ and accompanying text.

38. See, e.g., Wark v. Spinuzzi, 376 F.2d 827 (5th Cir. 1967); Belleair Hotel Co. v. Mabry, 109 F.2d 390 (5th Cir. 1940).

39. Waylyn Corp. v. Casalduc, 219 F.2d 888, 889 (1st Cir. 1955).

40. 12 C. WRight \& A. Miller, supra note $4, \S 2986$, at 48 .

41. See United States v. Beasley, 558 F.2d 1200, 1201 (5th Cir. 1977); Garden Homes, Inc. v. United States, 200 F.2d 299, 300 (1st Cir. 1952). See also IIT v. Vencap, Ltd., 519 F.2d 1001, 1020 (2d Cir. 1975) (order authorizing disbursement by receiver not appealable as it was a foreseeable part of the receiver's management function). 
the receivership within the discretionary control of the trial court. ${ }^{42}$

g. Refusal to Take Steps to Accomplish the Purposes. The final category of orders made explicitly appealable by 28 U.S.C. $§ 1292(a)(2)$ is those refusing to "take steps to accomplish the purpose" of the receivership. ${ }^{43}$ Interlocutory review in such instances safeguards the parties' interests in having the receivership terminated within a reasonable period of time. Application of this provision is illustrated by $S E C$ v. Lincoln Thrift Association, in which the court reviewed the creditor's motion to transfer the pending proceeding to a bankruptcy court or, in the alternative, to issue an order requiring an election of a new board of trustees and a creditors committee to carry out the liquidation of the assets of the companies in the existing receivership. ${ }^{44}$

h. Temporary or Ex Parte Receiverships. The statute and case law do not make it clear whether a temporary ex parte order should qualify as one appointing a receiver for the purpose of determining appealability. Until amended as part of the 1948 revision of the Judicial Code, the statute only applied to orders "issued upon a hearing." 45 A similar requirement also applied as to immediate review of injunctions. Today temporary restraining orders (i.e., "ex parte" injunctions) are not appealable; ${ }^{46}$ therefore, it could be argued that for the same reasons ex parte orders creating receiverships should not be appealable. ${ }^{47}$ (This presumes, of course, that the ex parte order similarly will be specifically limited to a brief period of time and will contemplate prompt hearing and determination of whether the appointment should be continued. ${ }^{48}$ ) The same difficulties confronted by the court in reviewing a temporary restraining order are also present in an appeal from an ex parte receivership. An early case addressed the problem:

We incline to think that the nature of the order is important. If it grants on emergency a temporary receivership and provides for an early hearing touching its permanency, the order is but tentative, and does not represent the settled action of the court, and like a temporary restraining order is not appealable. But, if it appoints permanent receivers deliberately and finally with no provision for a hearing, there is a refusal in advance to hear which may well be considered sufficient to justify an appeal. . . An appeal cannot be prevented by thus creating the receivership ex parte and then refusing to complete the hearing of a motion to vacate it. ${ }^{49}$

Another case has held appointment of a temporary receiver appealable because of the sweeping character of the order and because the hearing provided for in the order was to determine whether the order was to be dissolved rather than whether the order was to be continued in force. ${ }^{50}$

\footnotetext{
42. Des Arc \& Powhatan Bridge Co. v. Austin Bridge Co., 94 F.2d 494, 495 (8th Cir. 1938).

43. The statutory language is quoted supra note 1 .

44. 577 F.2d 600, 602 (9th Cir. 1978).

45. See supra note 1 .

46. See supra $\S 20$ of this Interlocutory Restatement, comment e.

47. See id., text accompanying note 25 .

48. 16 C. Wright, A. Miller, E. Cooper \& E. Gressman, Federal Practice and Procedure $\S 3925$ (1977). Note that an ostensible temporary restraining order is appealable when it in fact is more properly characterized as a preliminary injunction. Supra $\S 20$ of this Interlocutory Restatement, comment

49. Marion Mortgage Co. v. Edmunds, 64 F.2d 248, 250-51 (5th Cir. 1933).

50. Williams Holding Co. v. Pennell, 86 F.2d 230 (5th Cir. 1936).
} h. 


\title{
\$22. Partial Remedies.
}

AN ORDER CONCLUSIVELY DETERMINING THAT A PARTY IS LIABLE AND PROVIDING FOR A PARTIAL REMEDY BUT SUBJECT TO FURTHER PROCEEDINGS TO DETERMINE THE SCOPE OF FULL RELIEF IS REVIEWABLE ON FINAL DECISION OR ON INTERLOCUTORY APPEAL TO PREVENT IRREPARABLE HARM TO THE SUBSTANTIAL RIGHTS OF THE APPELLANT IF THE PARTIAL RELIEF GRANTED IS

\author{
(1) AN INJUNCTION, OR \\ (2) A TRANSFER OF PROPERTY THAT HAS BEEN A SUBJECT \\ OF THE DISPUTE.
}

\section{COMMENT}

a. Generally; Permanent Injunctions. An order which, while determining liability and granting some relief, is subject to further proceedings to determine the complete award, is generally not subject to immediate review. ${ }^{1}$ Such an order is interlocutory, as litigation over the extent of the parties' liabilities will not have terminated; ${ }^{2}$ appeal will be available when the final award has been determined. ${ }^{3}$

Such an order will be immediately appealable, however, under 28 U.S.C. $\S 1292(a)(1)$ when it involves the grant or denial of permanent ${ }^{4}$ injunctive relief. $^{5}$ This rule applies, without the need for a designation of partial finality under Rule 54(b) of the Federal Rules of Civil Procedure, ${ }^{6}$ even when issues remain pending as to liability on separate claims. ${ }^{7}$ An order is not immediately appealable, however,

1. The Palmyra, 23 U.S. (10 Wheat.) 502 (1825).

2. See Boeing Co. v. Van Gemert, 444 U.S. 472, 480 n.5 (1980). Note, however, that after years of disagreement and reversals of ground, the circuits seem to be settling on the position that issues as to liability for or the amount of attorney fees are collateral and that their resolution is not necessary to a final appealable decision. Abrams v. Interco, Inc., 719 F.2d 23, 25-27 (2d Cir. 1983). The Supreme Court decision in White v. New Hampshire Dep't of Employment Sec., 455 U.S. 445 (1982) (motion for attorney fees does not seek to "amend" judgment such that the ten-day filing period of Rule 59(e) of the Federal Rules of Civil Procedure applies), is seen as requiring such a result. Abrams, 419 F.2d at 26-27; Cox v. Flood, 683 F.2d 330, 331 (10th Cir. 1982); Halderman v. Pennhurst State School \& Hosp., 673 F.2d 628, 644 (3d Cir. 1982). For cases representative of (or still following) the position that a decision is not final until both liability as to and the amount of attorney fees has been determined, see Crowley v. Shultz, 704 F.2d 1269, 1271-72 (D.C. Cir. 1983); deMouy v. Ingvoldstad, 664 F.2d 21, 22 (3d Cir. 1981) (per curiam); Croker v. Boeing Co., 662 F.2d 975, 983 (3d Cir. 1981) (en banc); Richerson v. Jones, 551 F.2d 918, 922 (3d Cir. 1977).

3. Perkins v. Fourniquet, 47 U.S. (6 How.) 206, 209 (1848); The Palmyra, 23 U.S. (10 Wheat.) 502, 503-04 (1825).

4. For a discussion of the appealability of preliminary injunctions and temporary restraining orders, see supra $\$ 20$ of this Interlocutory Restatement.

5. E.g., Payne v. Travenol Laboratories, 673 F.2d 798, 806-07 (5th Cir.), cert. denied, 103 S. Ct. 451 (1982); Barrett v. Grand Trunk W. R.R., 581 F.2d 132, 134 (7th Cir. 1978), cert. denied, 440 U.S. 946 (1979); Equal Employment Opportunity Comm'n v. International Longshoremen's Ass'n, 511 F.2d 273, 276-77 (5th Cir.), cert. denied, 423 U.S. 994 (1975).

6. For a discussion of the operation of this rule, see supra $\S 4$ of this Interlocutory Restatement (see particularly note 8 ).

7. Atlantic Richfield Co. v. Oil, Chem. \& Atomic Workers Int'l Union, 447 F.2d 945, 947 (7th Cir 1971); e.g., Association of Co-op Members v. Farmland Indus., 684 F.2d 1134, 1137 (5th Cir. 1982), cert. denied, 103 S. Ct. 1428 (1983); Adashunas v. Negley, 626 F.2d 600, 602-03 (7th Cir. 1980). 
when it merely arises in the context of an action in which a permanent injunction has been requested but does not rule on the propiriety of such relief. ${ }^{8}$ Failure to seek available interlocutory review does not waive the right to raise issues as to injunctive relief on appeal from a final decision. ${ }^{9}$

b. Transfer of Property. An order granting a partial remedy is a final decision, and thus appealable, when it falls within the "peculiar circumstances" 10 of Forgay $v$. Conrad. 1 The doctrine therein originated by the Supreme Court deals with orders that direct that property be immediately transferred, thus subjecting losing parties to irreparable harm because appeal would not normally be available as accounting remains. ${ }^{12}$

In Forgay, an assignee in bankruptcy sought to set aside as fraudulent certain conveyances of land and slaves to the defendants and to have an accounting of rents and profits of the property while in the defendant's possession. The lower court issued an order requiring the immediate delivery of the property to the plaintiff, to be distributed to the creditors, and directed a master to take an account of the rents and profits owed. In finding such an order immediately appealable, Chief Justice Taney wrote for a unanimous Supreme Court:

The question upon the motion to dismiss is whether this is a final decree, within the meaning of the acts of Congress. Undoubtedly, it is not final, in the strict, technical sense of that term. But this court has not heretofore understood the words "final decrees" in this strict and technical sense, but has given to them a more liberal, and, as we think, a more reasonable construction, and one more consonant to the intention of the legislature.

For here the decree not only decides the title to the property in dispute, and annuls the deeds under which the defendants claim, but also directs the property in dispute to be delivered to the complainant, and awards execution. And according to the last paragraph in the decree, the bill is retained merely for the purpose of adjusting the accounts referred to the master. In all other respects, the whole of the matters brought into controversy by the bill are finally disposed of as to all of the defendants. . . If these appellants, therefore, must wait until the accounts are reported by the master and confirmed by the court, they will be subjected to irreparable injury. For the lands and slaves which they claim will be taken out of their possession and sold, and the proceeds distributed among the creditors of the bankrupt, before they can have an opportunity of being heard in this court in defence [sic] of their rights. ${ }^{13}$

Chief Justice Taney also warned, however, that an order as in Forgay was highly undesirable and that trial courts should avoid decrees that required a choice between either denying review with a resulting possibility of irreparable injury or granting review by attributing finality and thereby creating the potential for several appeals in a single action. ${ }^{14}$ The doctrine of Forgay v. Conrad was unanimously

8. Liberty Mut. Ins. Co. v. Wetzel, 424 U.S. 737, 744 (1976); Dohlen v. Kramer Mechanical \& Eng'g Prods. Co., 303 F.2d 293, 294-95 (10th Cir. 1961). Cf. infra $\S 28$ of this Interlocutory Restatement, notes 910 and accompanying text; infra $\S 30$ of this Interlocutory Restatement, comment $d$.

9. See supra $\S 9$ of this Interlocutory Restatement, notes 223-26 and accompanying text; supra $\S 20$ of this Interlocutory Restatement, notes 18-19 and accompanying text.

10. McGourkey v. Toledo \& O. Cent. Ry., 146 U.S. 536, 547 (1892); see also Craighead v. Wilson, 59 U.S. (18 How.) 199, 202 (1856).

11. 47 U.S. (6 How.) 201 (1848)

12. The Court has subsequently acknowledged the "interlocutory" nature of orders thus reviewed. Craighead v. Wilson, 59 U.S. (18 How.) 199, 202 (1856); see also Republic Natural Gas Co. v. Oklahoma, 334 U.S. 62, 68 (1948).

13. Forgay, 47 U.S. (6 How.) at 203-04.

14. Id. at 205. 
reaffirmed in Thomson $v$. Dean ${ }^{15}$ and is now established beyond question. ${ }^{16}$

To be immediately appealable under Forgay, an order must make a final determination of rights to property in controversy, award immediate transfer of such property to the prevailing party, and be complete except for an accounting as to the property. ${ }^{17}$ The requirement of a final determination ${ }^{18}$ gives support to the label of "finality" necessary to the grant of review and lends a "sense of completeness" to the adjudication:

The effect of the act when done is to invest the transferees with all the rights of ownership. It changes the property in the stock as absolutely and as completely as could be done by execution on a decree for sale. It looks to no future modification or change of the decree. ${ }^{19}$

As a practical matter, however, this requirement is insignificant because a trial court is unlikely to order immediate delivery of property to an opposing party without first ascertaining a final right of possession. Such an order, if made, would probably be subject to correction through a prerogative writ under the all writs statute. ${ }^{20}$

The requirement that the order mandate delivery of the property ${ }^{21}$ goes to ensure that the appellant is in danger of irreparable harm. The Forgay doctrine does not apply where the property remains in the hands of the appellant or is tranferred to a third party for safekeeping. ${ }^{22}$ For example, the order in a companion case to Forgay was not immediately reviewable because the trial court had only determined the rights of the parties and had referred the matter to a master for an accounting without actual transfer of the property. ${ }^{23}$ The appellant thus lacked a special danger of irreparable injury because "these interlocutory orders and decrees remain under the control of the [trial court], and subject to their revision, until the master's report comes in and is finally acted upon by the court." 24

The concern with irreparable injury further requires that the order transferring property be capable of immediate execution to warrant review. ${ }^{25}$ Also, Forgay applies only when the court mandates the transfer of property; an order

15. 74 U.S. (7 Wall.) 342, 345-46 (1869) ("[T]he degree of finality essential to the right of appeal has been sometimes pushed quite to the limit of construction.").

16. See, e.g., Brown Shoe Co. v. United States, 370 U.S. 294, 306-08 (1962); Radio Station WOW v. Johnson, 326 U.S. 120,125 n.2 (1945); McGourkey v. Toledo \& O. Cent. Ry., 146 U.S. 537,548 (1892).

17. Forgay, 47 U.S. (6 How.) at 204-05.

18. See also, e.g., Radio Station WOW v. Johnson, 326 U.S. 120, 125 n.2 (1945); Thomson v. Dean, 74 U.S. (7 Wall.) 342, 345 (1869).

19. Thomson v. Dean, 74 U.S. (7 Wall.) 342, 345 (1869).

20. 28 U.S.C. $\S 1651$ (1976). See supra $\S 12$ of this Interlocutory Restatement, text accompanying notes 17-36.

21. See also Thomson v. Dean, 74 U.S. (7 Wall.) 342, 346 (1869). Note that the language of the cases also contemplates payment of money which the defendant denies is due as a transfer of property. Forgay, 47 U.S. (6 How.) at 205.

22. Forgay, 47 U.S. (6 How.) at 204

23. Perkins v. Fourniquet, 47 U.S. (6 How.) 206, 208-09 (1848).

24. Id. Accord Pulliam v. Christian, 47 U.S. (6 How.) 209, 212 (1848) ("There is no sale or change of the property ordered which can operate injuriously to the parties. Under such circumstances, the decree not being final as to the whole matter in controversy, the appeal must be dismissed."); see also Rexford $\mathrm{v}$. Brunswick-Balke-Collender Co., 228 U.S. 339, 345-46 (1913); Craighead v. Wilson, 59 U.S. (18 How.) 199 (1856).

25. See also Radio Station WOW v. Johnson, 326 U.S. 120, 125 n.2 (1945); Carondelet Canal \& Navigation Co. v. Louisiana, 233 U.S. 362 (1914); Thomson v. Dean, 74 U.S. (7 Wall.) 342, 346 (1869). 
portending irreparable harm on another basis, for example an injunction followed by an accounting, is not governed by Forgay. ${ }^{26}$

Finally, the Forgay doctrine goes no further than to ignore the accounting for the purpose of according finality, and thus appealability. ${ }^{27}$ If there are independent reasons for holding the order interlocutory-that is, other matters remain to be determined by the trial court-then immediate review will not be available. ${ }^{28}$ Appellate courts pay careful attention to the "peculiar circumstances" of the Forgay case. ${ }^{29}$

c. Multiple Parties or Claims. An order otherwise subject to review under Forgay is not immediately appealable when the litigation remains pending as to independent claims or parties. Such situations are governed by Rule 54(b) of the Federal Rules of Civil Procedure, which conditions review upon designation by the trial court of a partial final decision. ${ }^{30}$

We do not regard Forgay, decided many years prior to the adoption of Rule 54(b), as being beyond its reach. Rather, we interpret Rule $54(\mathrm{~b})$ as an efficient procedural device with which the district court can impose finality to its partial adjudication of a multi-claim action where warranted. In this way, Rule 54(b) removes the substantial uncertainty which accompanied the question of finality before its adoption. ${ }^{31}$

Illustration. $\mathrm{P}$ brings suit against $\mathrm{D}$, asserting two claims: The first seeks to set aside certain conveyances of land as fraudulent and to obtain an accounting for damages; the second alleges breach of a separate contract. The court orders the land returned to $P$ and orders an accounting but sets the contract claim for trial. D appeals. The appeal should be dismissed even though the order transferring the property would be appealable under Forgay if that claim had been brought separately. Under Rule 54(b), the presence of the second claim prevents appeal absent a designation of partial finality by the trial court.

This difference in appealability between single and multiple claims is not easily explained. The same danger of irreparable harm is present in both situations. Therefore, trial courts should be receptive to motions for partial finality under Rule 54(b); and perhaps interlocutory appeal should even be available in such situations, though this is not the present law.

d. Condemnation Exception. The Forgay doctrine does not apply to allow appeal before the determination of just compensation when the United States condemns

26. Keystone Manganese \& Iron Co. v. Martin, 132 U.S. 91 (1889); Barnard v. Gibson, 48 U.S. (7 How.) 650 (1849).

27. Radio Station WOW v. Johnson, 326 U.S. 120, $125 \mathrm{n} .2$ (1945) ("In short, the rationale of [Forgay and its progeny] is that a judgment directing immediate delivery of physical property is reviewable and is to be deemed dissociated from a provision for an accounting even though that is decreed in the same order. In effect, such a controversy is a multiple litigation allowing review of the adjudication which is concluded because it is independent of, and unaffected by, another litigation with which it happens to be entangled.").

28. See also McGourkey v. Toledo \& O. Cent. Ry., 146 U.S. 536, 548 (1892); Thomson v. Dean, 74 U.S. (7 Wall.) 342,346 (1869).

29. See supra cases cited note 10 .

30. See supra $\S 4$ of this Interlocutory Restatement (compare particularly note 8 ) for a discussion of Rule 54(b).

31. United Bonding Ins. Co. v. Stein, 410 F.2d 483, 485 n.2 (3d Cir. 1969). 
property: "[O]rdinarily in condemnation proceedings appellate review may be had only upon an order or judgment disposing of the whole case, and adjudicating all rights, including ownership and just compensation, as well as the right to take the property." 32 There is no chance of irreparable harm in such cases because the action is in the nature of an exchange rather than a pure transfer and there is no danger of insolvency of the transferee. An appeal may be completely avoided if the compensation is satisfactory to the property owner. ${ }^{33}$ Interestingly, when the court orders the government to return property to a citizen during a condemnation action, the Forgay doctrine does apply to permit an appeal. ${ }^{34}$

e. Time for Appeal. Several cases have held that a party who fails to seek immediate review of an order appealable under Forgay will be precluded from raising such issues on appeal from the final decision. ${ }^{35}$ One rationale advanced in support of this proposition is the need to protect purchasers at foreclosure sales. ${ }^{36}$ The opposite result, however, would be more consistent with the purposes of the Forgay doctrine. The rule was intended to protect nonprevailing parties from irreparable harm, and the court benefits from a party's decision to delay appeal until final decision because the risk appears negligible. The order to immediately deliver property is only an interlocutory order and like other interlocutory orders should not compel an appeal but should be reviewable on appeal from a final decision. ${ }^{37}$

\section{$\S 23$. Orders Imposing Contempt Sanctions.}

(A) AN ORDER TO SHOW CAUSE WHY A PARTY OR NONPARTY SHOULD NOT BE PUNISHED FOR OR DETERRED FROM CONTEMPT IS REVIEWABLE ON INTERLOCUTORY APPEAL ONLY TO PREVENT AN UNDERLYING MANIFEST ABUSE OF JUDICIAL POWER.

(B) AN ORDER IMPOSING OR REFUSING TO IMPOSE CRIMINAL SANCTIONS FOR CONTEMPT OF COURT OR REFUSING TO ISSUE AN ORDER TO SHOW CAUSE WHY CRIMINAL CONTEMPT SANCTIONS SHOULD NOT BE IMPOSED IS A FINAL DECISION.

(C) AN ORDER IMPOSING OR REFUSING TO IMPOSE CIVIL SANCTIONS FOR CONTEMPT OF COURT ON A PARTY OR REFUSING

32. Catlin v. United States, 324 U.S. 229, 233 (1945); see also Republic Natural Gas Co. v. Oklahoma, 334 U.S. 62,69 n.2 (1948) ("[T] he general rule [is] that condemnation orders prior to determination of just compensation are not appealable.").

33. Republic Natural Gas Co. v. Oklahoma, 334 U.S. 62, 71 (1948).

34. United States v. Certain Real Estate, 217 F.2d 920, 928 (6th Cir. 1954).

35. E.g., Durkin v. Mason \& Dixon Lines, 202 F.2d 425 (6th Cir. 1953); Delta Drilling Co. v. Arnett, 186 F.2d 481 (6th Cir. 1950), cert. denied, 340 U.S. 954 (1951).

36. Citibank, N.A. v. Data Lease Fin. Corp., 645 F.2d 333 (5th Cir. 1981).

37. 15 C. Wright, A. Miller, \& E. Cooper, Federal. Practice and Procedure $\$ 3910$, at 466 (1976); 9 J. Moore, B. Ward \& J. Lucas, MoOre's Federal Practice f 110.11, at 150 (2d ed. 1983). Note that a party may waive the statutory right of immediate review of a preliminary injunction without jeopardizing the right to raise those issues on appeal from a final decision. See supra $\S 18$ of this Interlocutory Restatement, comment d; supra $\$ 20$ of this Interlocutory Restatement, comment d; see generally supra $\$ 9$ of this Interlocutory Restatement, notes 223-26 and accompanying text. In contrast, an order designated by the district court as a partial final decision must be appealed at that time. See supra $\S 4$ of this Interlocutory Restatement, notes 63-64 and accompanying text. 
TO ISSUE AN ORDER TO SHOW CAUSE WHY CIVIL CONTEMPT SANCTIONS SHOULD NOT BE IMPOSED ON A PARTY IS REVIEWABLE ONLY ON APPEAL FROM A FINAL DECISION: SUCH AN ORDER IS A FINAL DECISION IF ENTERED IN A PROCEEDING BROUGHT ONLY TO SECURE SUCH RELIEF.

(D) AN ORDER IMPOSING OR REFUSING TO IMPOSE CIVIL SANCTIONS FOR CONTEMPT OF COURT ON A NONPARTY OR REFUSING TO ISSUE AN ORDER TO SHOW CAUSE WHY CIVIL CONTEMPT SANCTIONS SHOULD NOT BE IMPOSED ON A NONPARTY IS A FINAL DECISION.

\section{COMMENT}

a. Necessity of Sanctions; Show Cause Orders. An order which finds a person or party in contempt but does not impose any sanctions is not appealable as a final decision under 28 U.S.C. $§ 1291 .{ }^{1}$ As explained by the Eighth Circuit, "[u]ntil a sentence or sanction has been made to exist as to a contempt adjudication, the situation is lacking in the elements of operativeness and consequence necessary to be possessed by any judicial order to enable it to have the status of a final decision under $\S 1291$."2 The trial court may still vacate the contempt order or refuse to impose sanctions, making any appeal unnecessary. ${ }^{3}$ Thus, to allow review before imposition of sanctions would be a waste of limited appellate court resources.

Similarly, an order to show cause why a party or nonparty should not be held in contempt is not a final decision and thus is generally not subject to immediate review. ${ }^{4}$ Any appeal is premature because the district court may still find that no contempt has occurred. ${ }^{5}$ However, interlocutory appeal may be available when the show cause order is a manifest invasion of a substantial right or clear error such that requiring contempt proceedings as a prerequisite for appellate review would be an unnecessary hardship. ${ }^{6}$

Illustration 23-1. $\quad \mathrm{D}$ is sued for an alleged minimum wage violation. D files three interrogatories requesting the names of those employees who reported the violations to the Labor Department. The Secretary of Labor refuses, claiming informer's privilege in conformity with well established principles. The Secretary does, however, provide a witness list. The district court, disregarding the claim of privilege, orders the

1. E.g., United States Steel Corp. v. Fraternal Ass'n of Steel Haulers, 601 F.2d 1269, 1273 (3d Cir. 1979); Rosenfeldt v. Comprehensive Acct. Serv. Corp., 514 F.2d 607, 611 (7th Cir. 1975); SEC v. Naftalin, 460 F.2d 471, 475 (8th Cir. 1972); Massengale v. United States, 278 F.2d 344, 345 (6th Cir. 1960) (per curiam); Comptone Co. v. Rayex Corp., 251 F.2d 487, 488 (2d Cir. 1958) (per curiam); Western Pac. R.R. Corp. v. Western Pac. R.R. Co., 216 F.2d 513, 515 (9th Cir. 1954); In re Eskay, 122 F.2d 819, 824 (3d Cir. 1941).

2. SEC v. Naftalin, 460 F.2d 471, 475 (8th Cir. 1972)

3. See United States Steel Corp. v. Fraternal Ass'n of Steel Haulers, 601 F.2d 1269, 1273 (3d Cir. 1979).

4. River Valley, Inc. v. Dubuque County, 507 F.2d 582, 584-85 (8th Cir. 1974) (per curiam); Burkett v. Chandler, 505 F.2d 217, 224 (10th Cir. 1974) (dictum), cert. denied, 423 U.S. 876 (1975).

5. See Burkett v. Chandler, 505 F.2d 217, 224 (10th Cir. 1974), cert. denied, 423 U.S. 876 (1975)

6. Id.; United States v. Hemphill, 369 F.2d 539, 543 (4th Cir. 1966). 
Secretary to appear in person to show cause why he should not be held in contempt. The secretary appeals. The appeal should be entertained because the underlying order is manifestly contrary to the right of the Secretary. The right can be fully protected only by aborting the contempt proceeding. ${ }^{7}$

Illustration 23-2. A private nonprofit corporation is granted permission to proceed in forma pauperis. The Director of the Administrative Office of the U.S. Courts refuses to pay the corporation's fees, claiming only natural persons are entitled to so proceed. The district court issues an order to show cause why the Director should not be held in contempt. The Director appeals. The appeal should be dismissed because the order, though perhaps erroneous, is not clearly beyond the power of the district court. To obtain review the Director must await punishment for contempt and appeal from the sanctions imposed. ${ }^{8}$

b. Distinction Between Civil and Criminal Contempt. The availability of immediate review for an order imposing contempt sanctions will in some instances depend upon the distinction between civil and criminal contempt as long recognized by the Supreme Court. ${ }^{9}$ Criminal contempt, sanctions are those which are "punitive in . . . nature, in which the [g]overnment and the public are interested," whereas civil contempt sanctions are "remedial and coercive in . . character, in which those chiefly concerned are individuals whose private rights and remedies are undertaken to be protected and enforced." 10 A recent decision has pointed out that " $[\mathrm{t}]$ he hallmark of civil contempt is that the sanction imposed is only contingent and coercive." 11 If imprisonment is used as a civil sanction, it cannot be for a definite term but must be contingent upon some action by the party cited. ${ }^{12}$ Criminal contempt punishes for past actions, while civil contempt coerces for future compliance. ${ }^{13}$

c. Party and Nonparty Criminal Contempt Sanctions. An order imposing criminal contempt sanctions is final and thus appealable whether or not the person punished for contempt is a party to the civil proceeding in which the contumacious act was committed. ${ }^{14}$ It is "well established that criminal contempt proceedings are

7. United States v. Hemphill, 369 F.2d 539 (4th Cir. 1966).

8. River Valley, Inc. v. Dubuque County, 507 F.2d 582 (8th Cir. 1974) (per curiam). Note that any sanctions would be immediately appealable because the Director is not a party to the underlying action. See infra comments $c$ gेe.

9. See, e.g., Doyle v. London Guar. \& Accident Co., 204 U.S. 599, 604-05 (1907); Bessette v. W.B. Conkey Co., 194 U.S. 324, 328-29 (1904).

10. Doyle v. London Guar. \& Accident Co., 204 U.S. 599, 605 (1907) (emphasis added) (quoting Bessette v. W.B. Lonkey Co., 194 U.S. 324, 328 (1904) (quoting In re Nevitt, 117 F. 448 , 458 (8th Cir. 1902))). Thus, it is the nature of the relief sought that is determinative of whether a contempt proceeding is criminal or civil. Penfield Co. v. SEC, 330 U.S. 585, 590 (1947).

11. International Bus. Machs. Corp. v. United States, 493 F.2d 112, 115 (2d Cir. 1973), cert. denied, 416 U.S. 995 (1974).

12. See Shillitani v. United States, 384 U.S. 364, 368-69 (1966); Gompers v. Bucks Stove \& Range Co., 221 U.S. 418, 442-44 (1911); Parker v. United States, 153 F.2d 66, 70 (1st Cir. 1946)

13. Pabst Brewing Co. v. Brewery Workers Local Union No. 77, 555 F.2d 146, 149 (7th Cir. 1977) (citing Shillitani v. United States, 384 U.S. 364, 370 (1966))

14. Bray v. United States, 423 U.S. 73, 75-76 (1975) (per curiam); In re Irving, 600 F.2d 1027, 1031 (2d Cir.), cert. denied, 44 U.S. 866 (1979); Pabst Brewing Co. v. Brewery Workers Local Union No. 77, 555 F.2d 
'independent of the main action' and any conviction therein is 'a final order and appealable." "15 As explained by the Supreme Court, "[p]roceedings at law for criminal contempt are between the public and the defendant, and are not a part of the original cause." 16

Similarly, an order dismissing a criminal contempt action without the imposition of sanctions or refusing to issue a show cause order ${ }^{17}$ is a final decision. Such a decision, however, if reaching the merits as to the alleged contemnor's guilt, may still be nonreviewable because of the limitations on government appeals imposed by the Double Jeopardy Clause ${ }^{18}$ and the Criminal Appeals Act. ${ }^{19}$ Review will be available, for example, when the trial court has merely held the allegations of the contempt application insufficient to support a claim of contumacy. ${ }^{20}$

Illustration 23-3. The general counsel of the National Labor Relations Board is ordered to turn over union membership applications. The general counsel refuses, claiming the documents are privileged. The district court finds the general counsel in contempt and imposes a fine of $\$ 10,000$. The general counsel appeals. The appeal should be heard because the sanction imposed is punitive, a criminal contempt sanction, and hence is a final decision. The fine is unconditional and cannot be purged by compliance with the district court's previous discovery order. ${ }^{21}$

d. Party Civil Contempt Sanctions. An order imposing or refusing to impose only civil contempt sanctions on a party is not immediately appealable. ${ }^{22}$ A civil sanc-

146, 149-50 (7th Cir. 1977); Pennsylvania v. Local 542, Int'l Union of Operating Eng'rs, 552 F.2d 498, 501 n.6 (3rd Cir.), cert. denied, 4334 U.S. 822 (1977); Carbon Fuel Co. v. United Mine Workers, 517 F.2d 1348, 1349 (4th Cir. 1975).

15. Carbon Fuel Co. v. United Mine Workers, 517 F.2d 1348, 1349 (4th Cir. 1975) (quoting Wright, Civil and Criminal Contempt in the Federal Courts, 17 F.R.D. 167, 176 (1955))

16. Gompers v. Bucks Stove \& Range Co., 221 U.S. 418, 445 (1911).

17. A show cause order is considered the equivalent of an information charging criminal contempt; thus, the refusal to issue such an order is appealable on the same basis as the dismissal of the contempt charges. United States v. Sanders, 196 F.2d 895, 897 (10th Cir.), cert. denied, 344 U.S. 829 (1952).

18. U.S. CONST, amend. V.

19. See United States v. Martin Linen Supply Co., 485 F.2d 1143, 1145 (5th Cir. 1973), cert. denied, 415 U.S. 915 (1974); United States v. Kelsey-Hayes Co., 476 F.2d 265, 266 (6th Cir. 1973). The Criminal Appeals Act, 18 U.S.C. $\$ 3731$ (1982), provides:

In a criminal case an appeal by the United States shall lie to a court of appeals from a decision, judgment, or order of a district court dismissing an indictment or information as to any one or more courts, except that no appeal shall lie where the double jeopardy clause of the United States Constitution prohibits further prosection.

20. United States v. Sander, 196 F.2d 895, 895 (10th Cir.), cert. denied, 344 U.S. 829 (1952). See also United States v. Goldman, 277 U.S. 299 (1928).

21. See In re Irving, 600 F.2d 1027 (2d Cir.), cert. denied, 444 U.S. 866 (1979). Note that in the actual case the district court also imposed a second separate contempt order requiring the general counsel to pay $\$ 1,000$ per day until the documents were produced. This order, being coercive in nature and capable of purgation upon compliance, was a civil contempt order. Appeal from it was allowed once the court of appeals determined that the general counsel was not a party. Id. For a discussion of the nonparty status of an attorney for a party, see infra comment $e$.

22. E.g., Fox v. Capital Co., 299 U.S. 105, $107-08$ (1936); Doyle v. London Guar. \& Accident Co., 204 U.S. 599, 603 (1907); United States v. Westinghouse Elec. Corp., 648 F.2d 642, 651 (9th Cir. 1981); Union of Professional Airmen v. Alaska Aeronautical Indus., 625 F.2d 881, 883 (9th Cir. 1980); In re Murphy, 560 F.2d 326, 332-33 n.10 (8th Cir. 1977) (dictum); SEC v. Sloan, 535 F.2d 679, 680 (2d Cir. 1976) (per curiam), cert. denied, 430 U.S. 966 (1977); Cromaglass Corp. v. Ferm, 500 F.2d 601, 604 (3d Cir. 1974); International Bus. Machs. Corp. v. United States, 493 F.2d 112, 114-15 (2d Cir. 1973), cert. denied, 416 U.S. 
tion proceeding, given its coercive purpose, is part of the main ongoing litigation; a decision either way therefore is not final, ${ }^{23}$ and the general policy against piecemeal appeals ${ }^{24}$ prevails. A civil contempt decision as to a party is subject to review on appeal from a final disposition of the case. ${ }^{25}$

Illustration 23-4. D, a corporation, is ordered to produce documents during discovery in an antitrust case. D refuses, claiming the documents are protected by the attorney-client and work product privileges. The district court rules that $\mathrm{D}$ has waived any such privileges and enters an order imposing a fine of $\$ 150,000$ per day until D complies with the discovery order. D appeals. The appeal should be dismissed. Because the sanctions are only contingent and coercive, with a remedial purpose of enforcing the opposing party's rights, the order is a civil contempt order and is not immediately appealable. ${ }^{26}$

An order imposing or refusing to impose only civil contempt sanctions on a party may, however, be a final decision if entered in a proceeding brought only to secure such relief. ${ }^{27}$ When contempt sanctions are the only object of the suit, such an order finally adjudicates the rights asserted, ${ }^{28}$ and no further relief will be available through district court action. ${ }^{29}$ Such a proceeding may arise, for example, when an administrative agency seeks to enforce a subpoena issued during an inves-

995 (1974); SEC v. Naftalin, 460 F.2d 471, 475 (8th Cir. 1972); Hodgson v. Mahoney, 460 F.2d 326, 328 (1st Cir.) (per curiam), cert. denied, 409 U.S. 1039 (1972); Vincent v. Local 294, Int'l Bhd. of Teamsters, 424 F.2d 124, 127-28 (2d Cir. 1970) (dictum); Southern Ry. v. Lanham, 403 F.2d 119, 124 (5th Cir. 1968) (dictum). But of. Ransburg Electro-Coating Corp. v. Ionic Electrostatic Corp., 431 F.2d 947, 948-49 (4th Cir. 1970) (possible exception for appeal from civil contempt orders arising from patent infringement cases under old 28 U.S.C. $\S 1292(a)(4)$ (now 28 U.S.C.A. $\$ 1292(c)(2)$ (West Supp. 1983)).

Nonappealability is the general rule as to orders concerning other types of discovery sanctions. See infra $\S 39$ of this Interlocutory Restatement. However, the disallowance of immediate appeal as of right for parties subject solely to civil contempt sanctions is criticized by commentators. See 15 C. WRIGHT, A. Milier, \& E. CoOper, Federal Practice \& Procedure $\$ 3917$ (1976 \& Supp. 1982) [hereinafter cited as C. WRIGHT \& A. MILLER]. The Supreme Court ignored the question of appealability in Sibbach $v$. Wilson \& Co., 312 U.S. 1 (1941), in which the plaintiff appealed from a coercive civil sanction-imprisonment until she should comply with the district court's order to submit to a physical examination. The court of appeals had not addressed the issue either, 108 F.2d 415 (7th Cir. 1939). Considerations of hardship may explain the allowance of the appeal, and such hardship (particularly in cases where the sanction is imprisonment) may in time develop into an articulated exception from the general rule of nonappealability. See 15 C. WRIGHT \& A. Miller, supra, at 623-21. That time has not yet arrived, however, and Sibbach is best viewed as an anomalous treatment of an unconsidered issue. The subsequent decisions, as cited above, have continued to enunciate a rule of nonappealability of party civil contempt sanctions, frequently without reference to Sibbach.

23. Union of Professional Airmen v. Alaska Aeronautical Indus., 625 F.2d 881, 883 (9th Cir. 1980); SEC v. Naftalin, 460 F.2d 471, 475 (8th Cir. 1972); Southern Ry. v. Lanham, 403 F.2d 119, 124 (5th Cir. 1968).

24. Parker v. United States, 153 F.2d 66, 69 (1st Cir. 1946).

25. Id.

26. International Bus. Machs. Corp. v. United States, 493 F.2d 112, 114-15 (2d Cir. 1973), cert. denied, 416 U.S. 995 (1974).

27. E.g., Penfield Co. v. SEC, 330 U.S. 585, 591 (1947); Lamb v. Cramer, 285 U.S. 217,221 (1932); Gilbert v. Johnson, 490 F.2d 827, 829 (5th Cir. 1974) (per curiam); United States v. Martin Linen Supply Co., 485 F.2d 1143, $1148-49$ (5th Cir. 1973), cert. denied, 415 U.S. 915 (1974). Cf. supra $\S 18$ of this Interlocutory Restatement, notes 1.8 and accompanying text; infra $\S 43$ of this Interlocutory Restatement, comment $c$.

28. Lamb v. Cramer, 285 U.S. 217,221 (1932).

29. Penfield Co. v. SEC, 330 U.S. 585, 591 (1947). 
tigation $^{30}$ or a prevailing party seeks to enforce a judgment already final. ${ }^{31}$

Illustration 23-5. An administrative agency issues a subpeona to $\mathrm{D}$, a company officer, to produce documents in conjunction with an investigation of that company. D refuses to comply, and the agency files an application in district court seeking coercive civil contempt sanctions. The court imposes only a nominal criminal fine, and the agency appeals. The appeal should be entertained because all issues as to the civil contempt sanction, the only relief sought, have been finally adjudicated and no further relief is available from the district court. ${ }^{32}$

A party punished for civil contempt may also incidentally obtain interlocutory review when the sanctions arise from disobedience to an order which is itself immediately appealable. ${ }^{33}$ Not all courts have allowed appeal in this situation; ${ }^{34}$ however, when reviewing the pendent civil contempt order in conjunction with the order which gave rise to it will not disrupt the main litigation, there is no good reason to delay hearing the contempt appeal. To require a second, separate appeal after a final disposition of the underlying case would actually thwart the policy against piecemeal appeals. ${ }^{35}$ When an immediate appeal of the civil contempt order would frustrate its coercive function and interfere with the progress of the main trial, however, the court of appeals should adhere to the general rule against immediate appeal of civil contempt sanctions. ${ }^{36}$

Illustration 23-6. $\mathrm{P}$, an employer, is involved in a labor dispute with $\mathrm{D}$, a union, concerning the transfer of specialized workers to different job sites. $\mathrm{P}$ applies for and is granted a temporary restraining order prohibiting overtime boycotts protesting such transfers. This order is extended indefinitely by consent of $D$. The overtime boycott is then settled. Six months later, $\mathrm{D}$ commences a new strike against $\mathrm{P}$ regarding an entirely separate dispute. The district court holds $\mathrm{D}$ in civil contempt of the restraining order entered in the previous labor dispute and imposes coercive fines, increasing in amount daily, until the strike should end. D appeals,

30. Id.

31. E.g., Gilbert v. Johnson, 490 F.2d 827 (5th Cir. 1974) (per curiam); Vincent v. Local 294, Int'l Bhd. of Teamsters, 424 F.2d 124 (2d Cir. 1970).

32. Penfield Co. v. SEC, 330 U.S. 585 (1947).

33. See, e.g., Blaylock v. Checker Oil Co., 547 F.2d 962, 966 (6th Cir. 1976) (remedial civil contempt order which arose from violation of a preliminary injunction); Latrobe Steel Co. v. United Steelworkers, 545 F.2d 1336, 1340 (3d Cir. 1976) (coercive civil contempt order which arose from violation of a preliminary injunction); Peabody Coal Co. v. Local Union Nos. 1734, 1508 \& 1548, UMW, 484 F.2d 78, 83-85 (6th Cir. 1973) (coercive civil contempt orders which arose from violation of a preliminary injunction); New York Tel. Co. v. Communication Workers, 445 F.2d 39, 44-45 (2d Cir. 1971) (coercive civil contempt orders which arose from violation of an ostensible temporary restraining order, which was reviewable as a preliminary injunction). See also supra $\$ 12$ of this Interlocutory Restatement, note 80 and accompanying text.

34. See, e.g., Windsor Power House Coal Co. v. District 6 UMW, 530 F.2d 312, 317 (4th Cir.), cert. dismissed, 429 U.S. 876 (1976).

35. See Peabody Coal Co. v. Local Union Nos. 1734, 1508 \& 1548, UMW, 484 F.2d 78, 84-85 (6th Cir. 1973).

36. See Windsor Power House Coal Co. v. District 6 UMW, 530 F.2d 312, 316-17 (4th Cir.) (coercive civil contempt order intended to bring miners back to work), cert. dismissed, 429 U.S. 876 (1976). 
asserting that the temporary restraining order is in effect a preliminary injunction subject to review under 28 U.S.C. $\$ 1292(a)(1)$. The appeal should be entertained, ${ }^{37}$ and review should extend to the contempt sanctions. Since the temporary restraining order was not entered in the present case, immediate review of the contempt order will not interfere with any ongoing proceedings. ${ }^{38}$

e. Nonparty Civil Contempt Sanctions. An order imposing or refusing to impose only civil contempt sanctions against a nonparty is immediately appealable as a final decision under 28 U.S.C. $\S 1291 .^{39}$ When a nonparty seeks immediate review, the orderly progress of the main case is unaffected by the appeal. ${ }^{40}$ In addition, the nonparty will lack standing to appeal from the final decision so the contempt judgment is regarded as final as to him. ${ }^{41}$

The status of an individual as a nonparty is questioned primarily in two situations: (1) officers and directors of corporate parties, and (2) attorneys for parties. Officers or directors of a corporate party are not considered parties to the action for the purposes of appeal and thus may immediately appeal any civil contempt sanctions imposed upon them. ${ }^{42}$ Unless the officers are named as parties in the action, they have no standing to appeal from a final decision in the main case involving the corporation; thus, without immediate review they have no right of review at all, and the contempt sanction orders are final as to them. ${ }^{43}$ The same rationale applies to allow attorneys for parties to bring immediate appeals as nonparties when they are subject to civil contempt sanctions. ${ }^{44}$ This result may be avoided where it is possible to join the corporate officers or the attorneys in question as individual defendants in the underlying action. ${ }^{45}$

37. For a discussion of the appealability of this ostensible temporary restraining order, see supra $\$ 20$ of this Interlocutory Restatement, comment $h$.

38. New York Tel. Co. v. Communications Workers, 445 F.2d 39 (2d Cir. 1971). Note that the court actually used appeal incident to an injunction as an alternate rationale. The sanction also could have been characterized as a final decision in the prior action from which the temporary restraining order arose since all other issues therein had been settled and no further relief could be had from that court. See supra text accompanying notes 27-32.

39. E.g., Liew v. Breen, 640 F.2d 1046, 1048 (9th Cir. 1981); ITT Community Dev. Corp. v. Barton, 569 F.2d 1351, 1352 n. 1 (5th Cir. 1978); In re Murphy, 560 F.2d 326, 332 n.10 (8th Cir. 1977); International Bus. Machs. Corp. v. United States, 493 F.2d 112, 115 n.1 (2d Cir. 1973) (dictum), cert. denied, 416 U.S. 995 (1974); United States v. Fried, 386 F.2d 691, 694 (2d Cir. 1967); Kiersted v. Hadden (In re Manufacturers Trading Corp.), 194 F.2d 948, 955 (6th Cir. 1952).

40. International Bus. Machs. Corp. v. United States, 493 F.2d 112, 115 n.1 (2d Cir. 1973), cert. denied, 416 U.S. 995 (1974).

41. David v. Hooker, Ltd., 560 F.2d 412, 415-16 (9th Cir. 1977). Cf. supra $\S 1$ of this Interlocutory Restatement, notes $24-29$ and accompanying text.

42. Fenton v. Walling, 139 F.2d 608, 610 (9th Cir. 1943), cert. denied, 321 U.S. 798 (1944) (officers of party bank). The nonparty status of officers of a corporate party was implicitly assumed in Alexander $v$. United States, 201 U.S. 117, 122 (1906). See also In re Irving, 600 F.2d 1027, 1032 (2d Cir.) (general counsel of NLRB not a party), cert. denied, 444 U.S. 866 (1979).

43. Fenton v. Walling, 139 F.2d 608, 610 (9th Cir. 1943), cert. denied, 321 U.S. 798 (1944).

44. See In re Irving, 600 F.2d 1027, 1032 (2d Cir.), cert. denied, 444 U.S. 866 (1979); In re Murphy, 560 F.2d 326, 332-33 n.10 (8th Cir. 1977); Cromaglass Corp. v. Ferm, 500 F.2d 601, 604 (3d Cir. 1974) (dictum). For the suggestion that an attorney in such situations should be treated as a party to preclude immediate review, see Independent Investor Protective League v. Touche Ross \& Co., 542 F.2d 156, 158 (2d Cir. 1976).

45. See In re Attorney General of the United States, 596 F.2d 58, 62-64 (2d Cir.) (Attorney General 
f. Mixed Civil and Criminal Sanctions. When a contempt order imposes both criminal and civil sanctions against a contemnor, the punitive, criminal aspect of the mixed sanction governs, allowing immediate appeal of the entire order. ${ }^{46}$ The rationale is the same as that for "pure" criminal contempt appeals: The criminal contempt proceeding is a separate action with the government and the contemnor as parties.

Illustration 23-7. $\quad \mathrm{P}$ brings suit in equity against $\mathrm{D}$ and is granted a preliminary injunction. D violates this injunction and is found in contempt. The district court orders $\mathrm{D}$ to pay a fine of $\$ 2,000$, with $\$ 1,500$ to go to $\mathrm{P}$ as compensation for the cost of prosecuting the contempt charge and $\$ 500$ to be paid to the United States. D appeals. The appeal should be entertained because the part of the order requiring a fine of $\$ 500$ to be paid to the government is punitive and thus criminal in nature. Accordingly, the presence of criminal contempt dominates and governs the availability of review. The propriety of the civil, remedial portion of the sanction should also be considered by the appellate court. ${ }^{47}$

C. Review of Orders Regarding Judges, Magistrates, Masters, and Jurors

$\S 24$. Disqualification of Judges and Magistrates.

(A) AN ORDER OF A JUDGE OR MAGISTRATE DISQUALIFYING HIMSELF IN A PROCEEDING IS REVIEWABLE ONLY ON CERTIFIED INTERLOCUTORY APPEAL.

(B) AN ORDER OF A JUDGE OR MAGISTRATE REFUSING TO DISQUALIFY HIMSELF IS REVIEWABLE ON APPEAL FROM A FINAL DECISION OR ON INTERLOCUTORY APPEAL

(1) TO PREVENT PROCEEDINGS BEFORE A JUDGE OR MAGISTRATE WHOSE IMPARTIALITY IS MANIFESTLY SUSPECT, OR

(2) TO SUSTAIN AN AFFIDAVIT OF BIAS WHICH IS LEGALLY SUFFICIENT UNDER SECTION 455(b) OF THE JUDICIAL CODE.

\section{COMMENT}

a. The Disqualification Statutes. There are two statutes under which a judge

barred from immediate appeal of civil contempt order since named in his official capacity as a party defendant; review allowed by mandamus, however, due to the extraordinary nature of the case-a suit by a political party against the United States and the Attorney General, inter alia), cert. denied, 444 U.S. 903 (1979).

46. E.g., Penfield Co. v. SEC, 330 U.S. 585, 591 (1947); Nye v. United States, 313 U.S. 33, 42-43 (1941); Union Tool Co. v. Wilson, 259 U.S. 107, 110 (1922); In re Merchants' Stock \& Grain Co., 223 U.S. 639, 642 (1912); In re Christensen Eng'g, 194 U.S. 458, 461 (1904); Hickman v. Taylor, 153 F.2d 212,214 n.1 (3d Cir. 1945), affd, 329 U.S. 495 (1947). This rule, of course, is unnecessary with respect to a nonparty, who may immediately appeal both criminal and civil contempt sanctions anyway. E.g., In re Irving, 600 F.2d 1027, 1032 n.3 (2d Cir.), cert. denied, 444 U.S. 866 (1979).

47. See In re Merchants' Stock \& Grain Co., 223 U.S. 639 (1912). 
may be disqualified,' 28 U.S.C. $\S 144^{2}$ and 28 U.S.C. $\S 455 .^{3}$ The former, 28 U.S.C. $\S 144$, which applies only to district judges, provides that a party may file an affidavit of prejudice and requires disqualification if the affidavit is sufficient. Section 455 of title 28 , on the other hand, is a direction to justices, judges, and magistrates to disqualify themselves on their own motions if necessary. In reaction to public interest in judicial ethics, Congress revised this latter section in 1974 to subsume the substantive ground for disqualification under 28 U.S.C. $§ 144$. "Thus as things now stand, Section 455 is the basic provision on disqualification . . . and Section 144 provides a procedure by which a litigant can assert that a judge is disqualified because of bias or prejudice." 4

The general command under 28 U.S.C. $\S 455(\mathrm{a})$ is that a judge shall disqualify himself when his "impartiality might reasonably be questioned." An objective standard is to be used, and a judge must disqualify himself whenever there is a reasonable factual basis for doubting his impartiality. ${ }^{5}$ Subsection 455(b), as amended to eliminate "uncertainty and ambiguity," sets forth specific situations and circumstances which, in addition to the general standard, require disqualification. ${ }^{7}$ Subsection $455(\mathrm{e})^{8}$ reflects the difference between those two prior subsec-

1. There is also a statute forbidding a judge from hearing an appeal from "the decision of a case or issue tried by him." 28 U.S.C. $\S 47$ (1976).

2. 28 U.S.C. $\S 144$ (1976). In pertinent part:

Whenever a party to any proceeding in a district court makes and files a timely and sufficient affidavit that the judge before whom the matter is pending has a personal bias or prejudice either against him or in favor of any adverse party, such judge shall proceed no further therein, but another judge shall be assigned to hear such proceeding

3. 28 U.S.C. $\S 455$ (1976). In pertinent part:

(a) Any justice, judge, magistrate, or referee in bankruptcy of the United States shall disqualify himself in any proceeding in which his impartiality might reasonably be questioned.

(b) He shall also disqualify himself in the following circumstances:

(1) Where he has a personal bias or prejudice concerning a party, or personal knowledge of disputed evidentiary facts concerning the proceeding;

(2) Where in private practice he served as lawyer in the matter in controversy, or a lawyer with whom he previously practiced law served during such association as a lawyer concerning the matter, or the judge or such lawyer has been a material witness concerning it;

(3) Where he has served in governmental employment and in such capacity participated as counsel, advisor or material witness concerning the proceeding or expressed an opinion concerning the merits of the particular case in controversy;

(4) He knows that he, individually or as a fiduciary, or his spouse or minor child residing in his household, has a financial interest in the subject matter in controversy or in a party to the proceeding, or any other interest that could be substantially affected by the outcome of the proceeding;

(5) He or his spouse, or a person within the third degree of relationship to either of them, or the spouse of such a person:

(i) Is a party to the proceeding, or an officer, director, or trustee of a party;

(ii) Is acting as a lawyer in the proceeding;

(iii) Is known by the judge to have an interest that could be substantially affected by the outcome of the proceeding;

(iv) Is to the judge's knowledge likely to be a material witness in the proceeding.

4. 13 C. Wright, A. Miller \& E. Cooper, Federal Practice and Procedure $\$ 3541$, at 344 (1975) [hereinafter cited as C. WRIGHT \& A. MILLER].

5. H.R. REPORT No. 1453, 93d Cong., 2d Sess. 9, reprinted in 1975 U.S. Code Conc. \& AD. News $6351,6354-55$.

6. Id. at 6355 .

7. See supra note 3 for the language of this subsection.

8. 28 U.S.C. $\$ 455$ (1976). In pertinent part: 
tions by allowing waiver of disqualification under 28 U.S.C. $\$ 455$ (a) if preceded by full disclosure on the record of the basis for disqualification. However, there can be no waiver under 28 U.S.C. $\S 455(\mathrm{~b})$.

b. Grant of Judicial Disqualification. A judge's decision to disqualify himself should not be reviewable at any stage since it cannot be prejudicial error to substitute one qualified judge for another. ${ }^{9}$ The Seventh Circuit in Hampton v. City of Chicago recently stated this proposition in declining to review a judge's recusal:

[W] fail to conceive of any interest which the plaintiffs have as litigants for review of . . . [the] recusal order. The effect of his decision to step aside is merely to have the case reassigned to another judge of the district court . . . While plaintiffs have a right to have their claim heard by the district court, they have no protectable interest in the continued exercise of jurisdiction by a particular judge. ${ }^{10}$

The Hampton opinion considered and rejected the various methods of acquiring review of the recusal. Although it recognized that the order was a final disposition of the question of the judge's participation, the court refused to accept the appeal as being from a final decision under 28 U.S.C. $\$ 1291 .^{\prime \prime}$ Such application of the collateral order doctrine was rejected ${ }^{12}$ for the same reason the court denied the request for mandamus:

Our refusal to grant mandamus to review a grant of recusal is again premised on the lack of a protectable interest which a party litigant has in the issue. Use of mandamus to protect a litigant's right to an unbiased district judge does not compel our use of it to review a recusal. ${ }^{13}$

Finally, the court concluded, "[i]f . . . a party has no protectable interest in a recusal order, it would follow that we would decline leave to appeal under [28 U.S.C. \$] 1292(b) even if a certificate had been given by the district judge." 14

Other circuits, however, have been willing to extend interlocutory review to grants of judicial disqualification upon certification of the question by the trial judge. ${ }^{15}$ In each of two recent cases in which the Fourth and Tenth Circuits respectively accepted certified appeals, the district judge had disqualified himself under 28 U.S.C. $\S 455$ (b) as having a financial interest as a consumer because a

(e) No justice, judge, mágistrate, or referee in bankruptcy shall accept from the parties to the proceeding a waiver of any ground for disqualification enumerated in subsection (b). Where the ground for disqualification arises only under subsection (a), waiver may be accepted provided it is preceded by a full disclosure on the record of the basis for disqualification.

9. 13 C. WRIGHT \& A. MILleR, supra note $4, \S 3553 ; 15$ id., $\S 3914$ (1976). In an unusual decision, the Sixth Circuit has recognized the grant of a motion to disqualify, as opposed to denial of the motion, as a final, appealable order. The court did recognize special circumstances in the case "wherein [the judge] has already entered a decree in equity, which decree he has a continuing responsibility to administer, along with a substantial background of experience." Kelley v. Metropolitan County Bd. of Educ., 479 F.2d 810 , 811 n.1 (6th Cir. 1973).

At least one court has suggested that it would not find such factors determinative in accepting appellate jurisdiction. Hampton v. City of Chicago, 643 F.2d 478 (7th Cir. 1981).

10. 643 F.2d 478, 479 (7th Cir. 1981).

11. Id. at 480 .

12. Id. For a discussion of the collateral order doctrine, see supra $\$ 12$ of this Interlocutory Restatement, notes 10-13 and accompanying text.

13. Hampion, 643 F.2d at $481-82$.

14. Id. at 479 n.3.

15. See supra $\S 11$ of this Interlocutory Restatement for a discussion of certified appeals pursuant to 28 U.S.C. $\S 1292$ (b). 
particular outcome could conceivably lower his utility rates. ${ }^{16}$ In each case, the court of appeals determined that such an insubstantial, contingent interest would not force the judge's disqualification. Both circuits noted that the practical effect of accepting the judge's recusal would be the disqualification of all judges within that district, ${ }^{17}$ and the inconvenience and delay resulting from such decisions seemed to be a factor in acceptance of the appeals. ${ }^{18}$ In another recent disqualification case, the Third Circuit accepted a certified appeal from an order of a district judge recusing himself from a hearing to determine the amount of attorney's fees to be awarded. ${ }^{19}$

c. Denial of Motion to Disqualify. A judge's refusal to disqualify himself is reviewable on an appeal from a final decision ${ }^{20}$ or in conjunction with review of an independent interlocutory order that is in itself appealable. ${ }^{21}$ However, it is generally held that the denial of the motion to disqualify him is not in itself a final order and is therefore not immediately appealable as of right. ${ }^{22}$ Attempts to achieve interlocutory review under the collateral order doctrine have been unavailing. ${ }^{23}$

Most appellate courts have been willing to issue a writ of mandamus to deal with an erroneous denial of judicial disqualification when the circumstances could be considered exceptional. ${ }^{24}$ This practice seems to be based upon the desire to uphold the integrity of the judicial system and bolster public confidence in the courts. As noted in the concurring opinion in Green v. Murphy,

The very special, challenging and often sensational charge of partiality in the administration of justice ... should receive final adjudication at first opportunity, if only in the interest of public confidence in the courts. Moreover, a trial is not likely to proceed in a very satisfactory way if an unsettled claim of judicial bias is an ever present source of tension and irritation. . . [ [T] his postponement of decision hurts the administration of justice, even though the court reserves the right to pass upon the matter after trial. ${ }^{25}$

This proposition has been reiterated by courts in those circuits, such as the Second

16. In re Virginia Elec. \& Power Co., 539 F.2d 357 (4th Cir. 1976); In re New Mexico Natural Gas Antitrust Litig., 620 F.2d 794 (10th Cir. 1980).

17. In re New Mexico Natural Gas Antitrust Litig., 620 F.2d 794, 797 (10th Cir. 1980); In re Virginia Elec. \& Power Co., 539 F.2d 357, 364 (4th Cir. 1976).

18. In fact, the Fourth Circuit indicated that it would issue a writ of mandamus to deal with such a serious problem. In re Virginia Elec. \& Power Co., 539 F.2d 357, 365 (4th Cir. 1976).

19. Haas v. Pittsburgh Nat'l Bank, 627 F.2d 677 (3d Cir. 1980).

20. Berger v. United States, 255 U.S. 22 (1921); United States v. Avila, 443 F.2d 792 (5th Cir. 1971).

21. In re Grand Jury Investigation, 486 F.2d 1013 (3d Cir. 1973); 13 C. WRIGHT \& A. MILLER, supra note $4, \S 3553$, at 384 . See also discussion and contrary cases supra $\S 12$ of this Interlocutory Restatement, note 88 and accompanying text.

22. 13 C. Wright \& A. Miller, supra note 4, at 385. See, e.g., Rosen v. Sugarman, 357 F.2d 794, 796 (2d Cir. 1966); General Tire \& Rubber Co. v. Watkins, 331 F.2d 192, 198 (4th Cir.), cert. denied, 377 U.S. 952 (1964); Collier v. Picard, 237 F.2d 234 (6th Cir. 1956).

23. In re Corrugated Container Antitrust Litig., 614 F.2d 958, 960-61 (5th Cir. 1980). Although one court found the collateral order argument "not altogether unpersuasive," it considered mandamus a more appropriate method of obtaining review. Rosen v. Sugarman, 357 F.2d 794, 796 (2d Cir. 1966).

24. 13 C. WRIGHT \& A. MilleR, supra note 4 , at 386.

25. 259 F.2d 591, 595 (3d Cir. 1958) (Hastie, J., concurring). The Third Circuit normally does not issue the writ to deal with judicial disqualification questions. Judge Hastie, however, felt that this particular affidavit of prejudice was insufficient to require disqualification and that the appellate court should have made this ultimate determination at that time rather than postponing it until after a final decision had been rendered. 
Circuit, which do acknowledge their power to issue mandamus to review denial of judicial disqualification:

This court has long since taken the position that there are few situations more appropriate for mandamus than a judge's clearly wrongful refusal to disqualify himself. . . . A claim of personal bias and prejudice strikes at the integrity of the judicial process, and it would be intolerable to hold that the disclaimer of prejudice by the very jurist who is accused of harboring it should itself terminate the inquiry until an ultimate appeal on the merits. ${ }^{26}$

Before reviewing by mandamus, courts require a showing of a special circumstance, such as "the complexity, number and probable duration of the cases involved" and a desire not to leave "such a serious charge unresolved throughout . . . lengthy litigation." ${ }^{27}$ Because of the nature of the disqualification charge and the importance accorded impartiality of a trial judge, however, such a test may not be difficult to meet. ${ }^{28}$

The Third, Sixth, and Seventh Circuits have consistently asserted their refusal to consider applications for writs to review denials of judicial disqualification, ${ }^{29}$ stating three basic reasons. ${ }^{30}$ First, a judge's refusal to disqualify himself is held to be properly within his discretion and therefore not subject to review by mandamus, which has been said to lie only to control a judge's ministerial duties or jurisdiction. ${ }^{31}$ Second, an adequate remedy is available on appeal from a final decision. ${ }^{32}$ Finally, the delay, inconvenience, and expense of retrial, even after a lengthy or involved original trial, are not deemed sufficient reasons for allowing mandamus: The legislative policy against piecemeal appeals is seen as overriding. ${ }^{33}$

Despite this consistent pattern of denying the routine use of mandamus, many courts go on to give reassurance that on the facts presented the judge's refusal to disqualify himself was a meritorious decision. ${ }^{34}$ Thus, there is a lack of reality in a

26. In re International Bus. Machs. Corp., 618 F.2d 923, 926-27 (2d Cir. 1980).

27. Pfizer Inc. v. Land, 456 F.2d 532, 537 (8th Cir. 1972).

28. Comment, Disqualification for Interest of Lower Federal Court Judges: 28 U.S.C. $\$ 455,71$ MICH. L. REV. 538,549 (1973).

29. The Third Circuit did use the writ of mandamus to review a refusal to disqualify in Rapp v. Van Deusen, 350 F.2d 806 (3d Cir. 1965). The judge, as respondent on review of an earlier transfer order, had used the attorneys for the successful parties as his counsel in preparing answers. The court specified that this departure from its previous policy against use of mandamus was necessary only because the claim of disqualification resulted "from matters which were brought into existence by order of this court" and because a transfer of the case would preclude review by that circuit after final decision. Id. at 810 .

30. Comment, supra note 28 , at 548 .

31. Albert v. United States Dist. Ct., 283 F.2d 61, 62 (6th Cir. 1960), cert. denied, 365 U.S. 828 (1961). This decision was followed in a recent Sixth Circuit case, City of Cleveland v. Krupansky, 619 F.2d 576, 577 (6th Cir. 1980). See also Green v. Murphy, 259 F.2d 591, 593 (3d Cir. 1958); Korer v. Hoffman, 212 F.2d 211 (7th Cir. 1954).

32. Green v. Murphy, 259 F.2d 591, 594 (3d Cir. 1958); Korer v. Hoffman, 212 F.2d 211, 214-15 (7th Cir. 1954). See also Albert v. United States Dist. Ct., 283 F.2d 61, 62 (6th Cir. 1960), cert. denied, 365 U.S. 828 (1961).

33. Green v. Murphy, 259 F.2d 591, 594 (3d Cir. 1958). The Seventh Circuit considered this argument appealing but suggested that it was being made in the wrong forum. Rather, one should petition Congress to change its policies to support interlocutory appeal. Korer v. Hoffman, 212 F.2d 211,215 (7th Cir. 1954). Cf. supra $\S 15$ of this Interlocutory Restatement, note 13 and accompanying text; supra $\S 16$ of this Interlocutory Restatement, note 61 and accompanying text; supra $\S 17$ of this Interlocutory Restatement, note 25 and accompanying text.

34. For example, in Albert v. United States Dist. Ct., 283 F.2d 61, 63 (6th Cir. 1960), cert. denied, 365 U.S. 828 (1961), the Court of Appeals stated: 
form of appellate action which denies appellate jurisdiction which is in fact being exercised. The black letter stated here reflects reality, if not all the verbiage of court of appeals opinions.

Moreover, the amendment of 28 U.S.C. $\$ 455$ permits a clearer resolution of the problem in situations to which it applies. The rule stated in the black letter here reflects the decision in SCA Services v. Morgan, in which the Seventh Circuit reconsidered its longstanding policy of not issuing writs of mandamus in cases involving denials of judicial disqualification. ${ }^{35}$ The writ in that case was sought to require the district judge to disqualify himself under 28 U.S.C. $\S 455$ because his brother was a member of a law firm appearing in the proceedings. The court of appeals found that the judge should have disqualified himself under 28 U.S.C. $\S 455$ (b)(5) (iii) ${ }^{36}$ since a favorable outcome in the proceeding would have justified higher fees for the law firm such that the brother's interest could have been "substantially affected."'37 Having also found the provision requiring disqualification mandatory, ${ }^{38}$ the court reversed its policy against issuing writs of mandamus to secure judicial disqualification. Its decision rested upon the difference in the amended statute:

Traditionally, we have been extremely reluctant to make use of the extraordinary remedy of mandamus . . . and have heretofore not made the extraordinary writs . . . available for review of a trial judge's ruling on a motion for disqualification for bias or prejudice under 28 U.S.C. $\$ 144$... . Nonetheless, we find that the specificity and legislative intent of section 455 are sufficiently different from section 144 as to warrant a departure from our previous position. Since disqualification is mandatory for several reasons, we find... failure to recuse. . . an abuse of discretion. 39

It should be noted that although this decision found reason to disqualify under both 28 U.S.C $\$ 455(\mathrm{a})$ and (b), the court put special emphasis upon the mandatory nature of the recusal. Since disqualification is not strictly mandatory under 28 U.S.C. $\$ 455(a),{ }^{40}$ the Seventh Circuit's new willingness to issue writs of mandamus may and should extend only to cases involving mandatory disqualification of the judge in the certain specific circumstances found in 28 U.S.C. $\S 455$ (b).

Petitioner's burden to establish a clear and indisputable right to interlocutory appeal $^{41}$ thus may be made lighter by use of the amended version of 28 U.S.C. $\S 455$ - at least under subsection (b). Since the statute sets out specific circumstances which require judicial disqualification, the petitioner only has to assert facts that fit his case within one of the specified disqualifications. The petitioner is thus relieved from alleging any personal bias or prejudice on the judge's part. For

We have carefully examined the affidavit of personal bias and prejudice and are of the opinion that we would not be justified in issuing a writ of mandamus or prohibition. We do not believe that the facts alleged in the petition are sufficient to establish any bias or prejudice personal to the District Judge.

35. 557 F.2d 110 (7th Cir. 1977).

36. The language of this subsection is quoted supra note 3 .

37. SCA Servs., 557 F.2d at 115 . The court further found that there was "a reasonable basis for the finding of the appearance of partiality under the facts and circumstances of this case," which required disqualification of the judge under 28 U.S.C. $\S 455($ a). Id. at 116.

38. Id. at 117.

39. Id. at 117-18.

40. See supra note 8 and accompanying text.

41. Cf. Texaco, Inc. v. Chandler, 354 F.2d 655 (10th Cir. 1965). 
example, in a recent case, a court of appeals held that a district judge should be disqualified under 28 U.S.C. $\$ 455(\mathrm{~b})(2),{ }^{42}$ even though the petitioners had "affirmatively stated" that the judge had no personal bias or prejudice, because "[t]he legislative history indicates that disqualification under this statutory provision is mandatory."43

Illustration. $\mathrm{P}$ brings an action against $\mathrm{D}$ to recover for services rendered. D files an affidavit of bias reciting the fact that the judge, while in private practice, was a partner of counsel for $\mathrm{P}$ and that the litigation at bar was pending during such association. The judge refuses to disqualify himself. D appeals. The appeal should be entertained to prevent a violation of 28 U.S.C. $\$ 455$ (b) (2), ${ }^{44}$ since disqualification is mandatory as the affidavit of bias is legally sufficient under that subsection.

\section{§ 25. Right to Jury Trial.}

(A) AN ORDER GRANTING A DEMAND FOR TRIAL BY JURY IS REVIEWABLE ONLY ON APPEAL FROM A FINAL DECISION.

(B) AN ORDER STRIKING A JURY DEMAND IS REVIEWABLE ON APPEAL FROM A FINAL DECISION, ON CERTIFIED APPEAL, OR ON INTERLOCUTORY APPEAL TO PROTECT THE RIGHT OF THE APPELLANT TO TRIAL BY JURY.

\section{Comment}

a. Jury Demand Sustained. An order granting a demand for jury trial is not subject to interlocutory review. A party loses no right by suffering a jury trial, as it is now well settled that, although the right to jury trial is guaranteed by the Constitution, there is no corresponding right to a nonjury trial. ${ }^{1}$ In Beacon Theatres $v$. Westover the Supreme Court stated, "[T] one, while no similar requirement protects trial by the court."' Although most courts had previously assumed that there was no right to a nonjury trial, ${ }^{3}$ the Seventh Circuit had in one case read article III, section 2, which extends the judicial power of the federal courts to "cases in law and equity," as freezing the right to jury trial and the right to nonjury trial at the moment of the ratification of the Constitution. ${ }^{4}$ There is, however, no indication from historical records that this phrase was meant to do anything more than grant federal courts the powers which then existed in law and equity courts. ${ }^{5}$ A contrary interpretation would make the

42. The language of this subsection is quoted supra note 3 .

43. In re Rodgers, 537 F.2d 1196, 1198 (4th Cir. 1976).

44. For the text of this subsection, see supra note 3 .

1. Beacon Theatres v. Westover, 359 U.S. 500, 510 (1959).

2. Id.

3. See, e.g., Hurwitz v. Hurwitz, 136 F.2d 796, $798-99$ (D.C. Cir. 1943); Great Am. Ins. Co. v. Johnson, 27 F.2d 71 (4th Cir.), cert. denied, 278 U.S. 629 (1928).

4. Michaelson v. United States ex rel. Chicago, St. P., M. \& O. Ry., 291 F. 940, 946 (7th Cir. 1923). The Supreme Court reversed the decision without reaching this question. 266 U.S. 42, 65 (1924).

5. Note, The Right to a Nonjury Trial, 74 HaRv. L. REV. 1176, 1177-78 (1961). 
seventh amendment superfluous. ${ }^{6}$

Furthermore, interlocutory appeals of grants of jury trials would cause unnecessary delay, since such orders are reviewable after final decision and error, if not harmless, may be remedied without even the inconvenience of a new trial.

Where an action at law is erroneously tried in equity, very different questions are raised upon appeal from those which arise where a suit in equity is erroneously tried at law. In the latter case the court, if satisfied that the proper result was reached, may treat the error as harmless. In the former, it must send the case back for a new trial, because of the constitutional guaranty of trial by jury. ${ }^{7}$

The use of a jury will be harmless error if the appellate court upon review of the evidence and the jury verdict, finds the former supports the latter. ${ }^{8}$ The judgment on the verdict may then be affirmed.

Inappropriate use of jury trial may, however, result in a failure of the judge to make independent findings of fact-where these are required, a judgment based on a verdict may be reversed and remanded to the trial judge with instructions to make such findings and conclusions. ${ }^{9}$

b. Jury Demand Struck. The general rule has been that an order which strikes a demand for jury trial and places a case on the nonjury calendar is not a final order and therefore is not appealable. ${ }^{10}$ Under certain circumstances, the decision to try nonjury (equitable) issues before trying jury (law) issues may be reviewed upon interlocutory appeal as an injunction under the Enelow-Ettelson doctrine. ${ }^{11}$ This incongruous doctrine, however, is now rarely used in the context of denial of jury trial since use of the writ of mandamus to obtain interlocutory review has

6. Id. at 1178 .

7. Great Am. Ins. Co. v. Johnson, 27 F.2d 71, 71(4th Cir.), cert. denied, 278 U.S. 629 (1928).

The importance accorded the right to a new trial before a jury is illustrated by Fitzgerald $v$. United States Lines Co., 374 U.S. 16 (1963) (involving a statutory right to jury trial on the issue of negligence under the Jones Act). A seaman sued a shipowner for negligence, unseaworthiness, and maintenance and cure and demanded a jury trial. The district court submitted the unseaworthiness and negligence issues to a jury, which found for the shipowner. The issue of maintenance and cure was then tried to the court, which found for the seaman. The court of appeals affirmed the decisions on all three issues. The Supreme Court granted certiorari on the limited question of whether the maintenance and cure issue should have been submitted to the jury and determined that while normally it would have been proper for the trial court to decide that issue, because in this case there were issues properly triable to a jury and all issues arose from the same set of facts, all issues should have been tried to a jury. Furthermore, even though the jury's verdict on the negligence and unseaworthiness claims was not to be disturbed, the maintenance issue, normally not triable to a jury by itself, was to be remanded to be heard before a jury. "Our holding is that it was error to deprive the seaman of the jury trial he demanded, and he is entitled to relief from this error by having the kind of trial he would have had in the absence of error." Id. at 21-22.

8. Note, supra note 5, at 1185. See, e.g., Hurwitz v. Hurwitz, 136 F.2d 796 (D.C. Cir. 1943).

9. Note, supra note 5, at 1185 . E.g., Cargill, Inc. v. Commodity Credit Corp., 275 F.2d 745, 750-51 (2d Cir. 1960)

10. 9 C. Wright \& A. Miller, Federal Practice and Procedure $\S 2322$, at 104 (1971). See, e.g., Western Geophysical Co. of Am. v. Bolt Assocs., 440 F.2d 765 (2d Cir. 1971); Zalzneck v. Sias, 248 F.2d 952 (6th Cir. 1957); Zamore v. Goldblatt, 201 F.2d 738 (2d Cir. 1953).

11. Under this doctrine, a decision to stay proceedings on an action commenced "at law" and triable to a jury while an "equitable" defense or counterclaim is considered by the court is appealable as an injunction. However, a decision to stay an original equitable action pending consideration of a legal defense or counterclaim is not. This doctrine originated in Enelow v. New York Life Ins. Co., 293 U.S. 379 (1935), and Ettelson v. Metropolitan Life Ins. Co., 317 U.S. 188 (1942). It was further explained in Baltimore Contractors v. Bodinger, 348 U.S. 176, 182-84 (1955). For further discussion of the present-day application of the Enelow-Elleson doctrine, see supra $\S 18$ of this Interlocutory Restatement, comment $c$. 
become routine. ${ }^{12}$ It is this latter procedure which is reflected in the black letter here.

The Supreme Court has made it clear that a denial of jury trial by a district court judge is an appropriate situation for use of mandamus. In Beacon Theatres $v$. Westover, a number of factual issues were common to the equitable complaint and the legal counterclaim. ${ }^{13}$ Allowing the judge to determine the common issues first in trying the equitable claim might have denied the opportunity for later jury determination of the factual issues under the doctrine of res judicata or collateral estoppel. However, the court of appeals held that the district court had acted within its discretion in setting the order of trial and refused to issue a writ. ${ }^{14}$ In reversing this decision, the Supreme Court stated, "Whatever differences of opinion there may be in other types of cases, we think the right to grant mandamus to require jury trial where it has been improperly denied is settled." 15 Even the dissenting opinion began by recognizing this right: "There can be no doubt that a litigant is entitled to a writ of mandamus to protect a clear constitutional or statutory right to a jury trial." 16

The explanation for this unusual willingness to provide interlocutory review by mandamus seems to be based on the importance of the right to jury trial. The Supreme Court recognized this favored status in Beacon Theatres: "Maintenance of the jury as a fact finding body is of such importance and occupies so firm a place in our history and jurisprudence that any seeming curtailment of the right to a jury trial should be scrutinized with the utmost care."17

Three years later, in Dairy Queen, Inc. v. Wood, the Supreme Court had occasion to reiterate this position. ${ }^{18}$ In that case, the district court had denied jury trial on issues common to the equitable claim and the legal defense because it termed the legal issues "incidental" to the equitable action. When the court of appeals denied the request for mandamus, the Supreme Court "granted certiorari because the action of the Court of Appeals seemed inconsistent with protections already clearly recognized for the important constitutional right to trial by jury in our previous decisions."19 The Court went on to again approve mandamus as the accepted method for acquiring such interlocutory review, recognizing the "responsibility of the Federal Courts of Appeals to grant mandamus where necessary to protect the constitutional right to trial by jury. . . ."20 Relying upon these two decisions, an appellate court will now routinely grant mandamus for interlocutory appeal of denial of jury trial as the "proper method for seeking review of such an order." 21

In fact, the courts of appeals have interpreted these rulings to require imme-

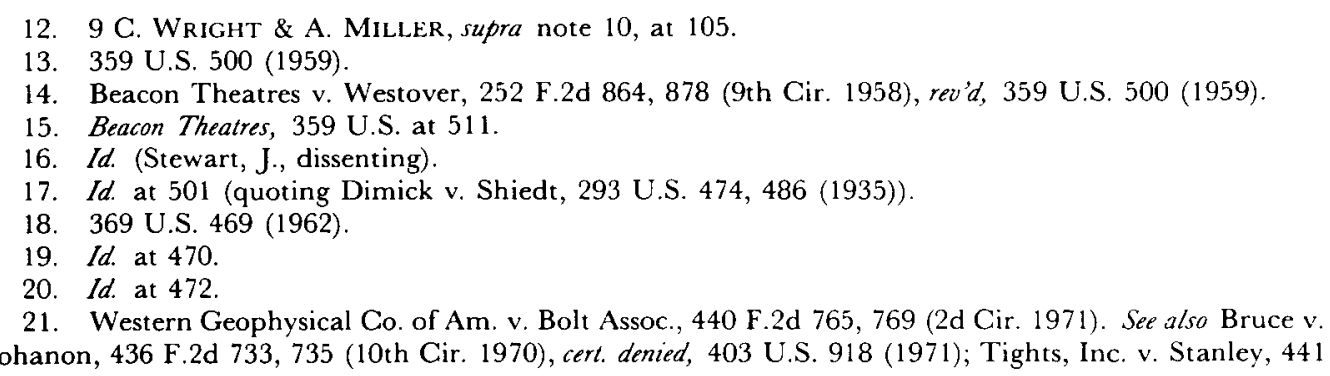


diate review of denials of jury trial even when it is difficult to determine whether such a right exists. In Filmon Process Corp. $v$. Sirica, the suggestion that the court could deny the writ of mandamus without deciding whether there was a right to jury trial was rejected. ${ }^{22}$ The D.C. Circuit Court of Appeals found that

it is a fair inference that even on an application for an extraordinary writ for pre-trial relief the Supreme Court expects the courts of appeals to make a determination whether or not there is a right of trial by jury, regardless of whether the question is a close or complicated one, and that the Court would not welcome a doctrine whereby a party's constitutional right to jury trial was trammeled in fact because a court of appeals determined that the issue was doubtful and that it need not and would not decide whether or not the party had the right of trial by jury. ${ }^{23}$

The rule as to use of mandamus for interlocutory appeal also applies in cases involving a statutory (as opposed to a constitutional) right to jury trial. As the First Circuit stated, "[T]he lower court would be equally unlawful . . . in denying . . . a statutory right to a jury trial . . . at least insofar as it would influence a decision to grant mandamus."'24

c. Certification. An order granting or denying a trial by jury may be reviewed on interlocutory appeal if the district judge certifies a "controlling question of law as to which there is substantial ground for difference of opinion" as required under 28 U.S.C. $\S 1292(\mathrm{~b}){ }^{25}$ This method is still occasionally used despite the routine availability of mandamus. ${ }^{26}$

$\S 26$. Selection of Jurors.

(A) AN ORDER SUSTAINING OR OVERRULING A CHALLENGE TO THE ARRAY OF JURORS PRESENTED FOR VOIR DIRE EXAMINATION IS REVIEWABLE ON APPEAL FROM A FINAL DECISION OR ON INTERLOCUTORY APPEAL TO PREVENT MANIFEST VIOLATION OF THE STATUTORY STANDARDS FOR JURY SELECTION.

(B) AN ORDER SUSTAINING OR OVERRULING A CHALLENGE TO AN INDIVIDUAL JUROR OR AN ORDER SUSTAINING OR OVERRULING AN OBJECTION TO QUESTIONS OR PROCEDURE EMPLOYED IN THE EXAMINATION OF JURORS IS REVIEWABLE ONLY ON APPEAL FROM A FINAL DECISION.

\section{Comment}

a. Challenge to Array. An order disposing of a challenge to an array of jurors

F.2d 336 (4th Cir.) (appropriateness of mandamus assumed without discussion), cert. denied, 404 U.S. 852 (1971).

22. 379 F.2d 449 (D.C. Cir. 1967).

23. Id. at $450-51$.

24. In re Union Nacional de Trabajadores, 502 F.2d 113, 116 n.1 (1st Cir. 1974). The writ was subsequently recalled when a Supreme Court decision (Muniz v. Hoffman, 422 U.S. 454 (1974)) established that there was no such statutory right to jury trial.

25. For a discussion of the statutory requirements for certified appeal, see supra $\$ 11$ of this Interlocutory Restatement.

26. See, e.g., Ross v. Bernard, 396 U.S. 531, 532 (1970); Swofford v. B. \& W., Inc., 336 F.2d 406, 407 n. 1 (5th Cir. 1964). 
is at present reviewable only on appeal from a final decision. Statutory amendments limiting the discretion of trial judges in this area, however, suggest that interlocutory review might now be more successfully sought.

Impartial justice depends upon the selection of impartial jurors for service on grand and petit juries. Until 1968 there was great diversity among, and little supervision over, federal districts as to methods used for such selection, although Congress had established independent federal qualifications for federal jurors. ${ }^{1}$ In 1967, Senator Tydings informed the Senate that because few guidelines were provided for the implementation of the selection process, "many district judges are uncertain of their role in supervising the selection machinery."'2 They were often not even aware of the selection methods employed in their districts because broad powers would be delegated to court clerks or jury commissioners who operated independently to relieve the judges of additional burdens. "And as the President stated in transmitting the 1967 Civil Rights bill to Congress "experience has shown that [the present] laws do not provide sufficient guidance for jury commissioners across the nation ...." ",4

Thus, in formulating the the Jury Selection and Service Act of $1968^{5}$ "to provide improved judicial machinery for the selection of Federal juries,"6 Congress clearly defined the roles of judges, clerks, and jury commissioners in an attempt to eliminate statutory vagueness. ${ }^{7}$ Congress hoped to combine uniformity of selection method with local flexibility by allowing each district court to adopt a "local plan" consistent with the provisions of the statute. ${ }^{8}$ Such plans were to be based on two general principles: "(1) random selection of juror names from voter lists . . . ; and (2) determination of juror disqualifications, excuses, exemptions and exclusions on the basis of objective criteria only."9

Thus, the Act replaces the subjective discretion of the judge or jury commissioner with objective standards which must be followed. For example, officials often treated statutory qualification requirements as minimum standards to which subjective ideas of juror qualifications could be added. Because this practice could produce discriminatory results, such additional qualifications are now prohibited. ${ }^{10}$

Even where the Act specifically grants discretionary power to an official, further objective criteria are provided to police such discretion. For example, 28

1. These qualifications were established by amendment to 28 U.S.C. $\S 1861$ through the Civil Rights Act of 1957, Pub. L. No. 85-315, $\S 152,71$ Stat. 634, 638. See Judicial Conf. of the U.S., Report of the Commitlee on the Operation of the Jury System, 42 F.R.D. 353, 355 (1967).

2. Id.

3. Id. at 359 .

4. Id. at 355 .

5. Pub. L. No. 90-274, 82 Stat. 53 (codified at 28 U.S.C. $\$ \S 1861-1869$ (1976)).

6. H.R. ReP. No. 1076, 90th Cong., 2d Sess., reprinted in 1968 U.S. CoDE CoNG. \& AD. News 1792.

7. Id. at 1793 .

8. 28 U.S.C. $§ 1863$ (1976). In pertinent part:

(a) Each United States district court shall devise and place into operation a written plan for random selection of grand and petit jurors that shall be designed to achieve the objectives of sections 1861 and 1862 of this title, and that shall otherwise comply with the provisions of this title.

9. H.R. REP. NO. 1076, supra note 6, at 1793 .

10. Id. at 1794 . 
U.S.C. $§ 1866(c)(5)$ confers the rather broad power to exclude from jury service those persons whose service would be "likely to threaten the integrity of jury deliberations." 11 The number of prospective jurors excluded under this clause, however, may not exceed one percent of those persons returning juror qualification forms within the specified period (under the local plan) for two consecutive fillings of the master jury wheel. Furthermore, the names of all persons excluded under the clause together with detailed explanations for such exclusions must be forwarded immediately to the circuit's judicial council so that any misapplication may be redressed. ${ }^{12}$

The Act also establishes the procedure for challenging compliance with the statutory provisions. ${ }^{13}$ The Attorney General and the defendant in criminal trials and both parties in civil trials may challenge the selection process. The provisions of the Act, however, work in several ways "to reduce the possibility that such challenges will be used for dilatory purposes." 14 First, time limitations require that challenges be offered before voir dire begins or within seven days of the discovery of grounds for the challenge (or the possibility of discovery of such grounds by the

11. 28 U.S.C. $\$ 1866(c)(5)$ (1976). In pertinent part:

[A]ny person summoned for jury service may be . . (5) excluded upon determination by the court that his service as a juror would be likely to threaten the secrecy of the proceedings, or otherwise adversely affect the integrity of jury deliberations. No person shall be excluded under clause (5) of this subsection unless the judge, in open court, determines that such is warranted and that exclusion of the person will not be inconsistent with sections 1861 and 1862 of this title. The number of persons excluded under clause (5) of this subsection shall not exceed one per centum of the number of persons who return executed jury qualification forms during the period, specified in the plan, between two consecutive fillings of the master jury wheel. The names of persons excluded under clause (5) of this subsection, together with detailed explanations for the exclusions, shall be forwarded immediately to the judicial council of the circuit, which shall have the power to make any appropriate order, prospective or retroactive, to redress any misapplication of clause (5) of this subsection.

12. Id. See also H.R. REP. NO. 1076, supra note 6 , at 1804.

13. 28 U.S.C. $\S 1867$ (1976). In pertinent part:

(a) In criminal cases, before the voir dire examination begins, or within seven days after the defendant discovered or could have discovered, by the exercise of diligence, the grounds therefor, whichever is earlier, the defendant may move to dismiss the indictment or stay the proceedings against him on the ground of substantial failure to comply with the provisions of this title in selecting the grand or petit jury.

(b) In criminal cases, before the voir dire examination begins, or within seven days after the Attorney General of the United States discovered or could have discovered, by the exercise of diligence, the grounds therefor, whichever is earlier, the Attorney General may move to dismiss the indictment or stay the proceedings on the ground of substantial failure to comply with the provisions of this title in selecting the grand or petit jury.

(c) In civil cases, before the voir dire examination begins, or within seven days after the party discovered or could have discovered, by the exercise of diligence, the grounds therefor, whichever is earlier, any party may move to stay the proceedings on the ground of substantial failure to comply with the provisions of this title in selecting the petit jury.

(d) Upon motion filed under subsection (a), (b), or (c) of this section, containing a sworn statement of facts which, if true, would constitute a substantial failure to comply with the provisions of this title, the moving party shall be entitled to present in support of such motion the testimony of the jury commission or clerk, if available, any relevant records and papers not public or otherwise available used by the jury commissioner or clerk, and any other relevant evidence.

(e) The procedures prescribed by this section shall be the exclusive means by which a person accused of a Federal crime, the Attorney General of the United States or a party in a civil case may challenge any jury on the ground that such jury was not selected in conformity with the provisions of this title.

14. H.R. ReP. No. 1076 , supra note 6 , at 1805. 
exercise of due diligence), whichever is earlier. ${ }^{15}$ Such challenges are to be made by motion "accompanied by a sworn statement of facts which, if true, demonstrate a substantial failure to comply with the statutory guide." 16

Second, various features of the Act combine to lessen the role of discretion and make the disposition of challenges a speedier and more uniform process.

$[P]$ rocedural regularity is the measure of validity of the selection system, . . . an appropriate measure since the [Act] sets up a largely mechanical process in which the role of human discretion is minimized. . . The specific and comprehensive nature of the provisions of the act and the local plan will assure that there are readily available standards against which the selection procedures may be measured. ${ }^{17}$

The lack of discretion allowed judges in deciding motions challenging the array on statutory grounds ${ }^{18}$ was recently illustrated in the Fifth Circuit. In a proceeding on motions to dismiss indictments for noncompliance with jury selection requirements, a district court held "that a showing of reasonableness, or exigent or compelling circumstances, authorizes the district court, in the exercise of sound discretion, to entertain a challenge filed out of time."19 However, the weight of authority called for the time provisions to be strictly construed. ${ }^{20}$ In reversing the district court, the Fifth Circuit emphasized strict compliance with the statutory provisions with no room for judicial discretion. "This timeliness requirement . . . is to be strictly construed, and failure to comply precisely with its terms forecloses a challenge under this Act."21 Citing a previous decision, the court found justification for this strict requirement. "In the Act, Congress set out a uniform, relatively strict scheme for jury selection. Congress included a new remedy for substantial violations .... As a price for this remedy, Congress was entitled to exact strict compliance with formal procedural rules." 22

These limitations on district judges' discretion suggest, as reflected in the black letter here, that interlocutory appeal should be available to enforce the standards imposed by the amended statutes governing juror selection. Although this question has not yet been raised in the courts, the importance of the strong legislative policy underlying the Jury Selection and Service Act and the specificity with which the policy is carried out in that legislation signal a proper area for interlocutory review. Recently, the Seventh Circuit found such features in the amended judicial disqualification statute ${ }^{23}$ important enough to cause it to reverse a longstanding policy against issuing writs of mandamus to review a denial of judicial

15. 28 U.S.C. $\$ 1867$ (1976) (quoted supra note 13).

16. Id. See also H.R. ReP. No. 1076, supra note 6, at 1806.

17. H.R. REP. No. 1076, supra note 6, at 1805.

18. Note that the time limitations of 28 U.S.C. $\S 1867$ apply only to statutory challenges-not constitutional challenges-to arrays of jurors.

19. United States v. Northside Realty Assoc., 510 F. Supp. 668, 672 (N.D. Ga.) (emphasis added), rev'd sub nom. United States v. Bearden, 659 F.2d 590 (5th Cir. 1981), cert. denied, 456 U.S. 936 (1982).

20. Id. at 671 .

21. United States v. Bearden, 659 F.2d 590, 593 (5th Cir. 1981), cert. denied, 456 U.S. 936 (1982).

22. Id. at 595 (citing United States v. Kennedy, 548 F.2d 608, 613 (5th Cir.), cert. denied, 434 U.S. 865 (1977)).

23. 28 U.S.C. $\S 455$ (1976). See supra $\$ 24$ of this Interlocutory Restatement, comment a. 
disqualification. ${ }^{24}$ The court found that refusal to follow the specific, mandatory requirements of the statute was itself an abuse of discretion properly addressed by issuance of the writ. ${ }^{25}$

b. Voir Dire. An order determining a challenge to an individual juror, following questioning to uncover bias under Rule 47(a) of the Federal Rules of Civil Procedure, ${ }^{26}$ is reviewable only on appeal from a final decision. Such determinations will not be disturbed absent a showing of clear abuse of discretion. ${ }^{27}$

Counsel may challenge prospective jurors for cause if such jurors appear to be biased or fail to meet the statutory qualifications. ${ }^{28}$ All such challenges are determined by the court. ${ }^{29}$ Each party to a civil suit also has three peremptory challenges; 30 " $[t]$ he traditional right of peremptory challenge recognizes that matters of bias or prejudice may be sensed or suspected without possibility of proof, and therefore permits counsel to exercise his inarticulate instinctive judgment . . . ." 31 It is reversible error if a party is effectively denied use of all his peremptory challenges by reason of expending one to remove a juror the judge has erroneously refused to strike for cause. ${ }^{32}$

Illustration 26-1. $\mathrm{P}$, an employee of a ship repair contractor, brings an action against $\mathrm{D}$, a shipowner, for personal injuries. $\mathrm{D}$ is defended by his insurer. $P$ challenges a juror for cause on the ground that he is a general agent for a similar casualty insurance company. The district court overrules the challenge for cause, and $P$ appeals. The appeal should be dismissed. The order is not final and may be reviewed upon appeal from a

24. SCA Servs. v. Morgan, 557 F.2d 110 (7th Cir. 1977). See supra $§ 24$ of this Interlocutory Restatement, notes 35-40 and accompanying text.

25. SCA Servs. v. Morgan, 557 F.2d 110, 117-18 (7th Cir. 1977).

26. FED. R. CIV. P. 47 (a). In pertinent part:

(a) Examination of jurors.

The court may permit the parties or their attorneys to conduct the examination of prospective jurors or may itself conduct the examination. In the latter event, the court shall permit the parties or their attorneys to supplement the examination by such further inquiry as it deems proper or shall itself submit to the prospective jurors such additional questions of the parties or their attorneys as it deems proper.

Rule 24(a) is the corresponding Federal Rule of Criminal Procedure and is essentially identical.

27. 9 C. Wright \& A. Miller, Federal Practice and Procledure $§ 2483$, at 472 (1971).

28. 28 U.S.C. $\$ 1866$ (c)(4) (1976). In pertinent part: "|A|ny person summoned for jury service may be . . . (4) excluded pursuant to the procedure specified by law upon a challenge by any party for good cause shown

29. 28 U.S.C. $\S 1870$ (1976). In pertinent part, "All challenges for cause or favor, whether to the array or panel or to individual jurors, shall be determined by the court."

30. 28 U.S.C. $§ 1870$ (1976). In pertinent part, "In civil cases, each party shall be entitled to three peremptory challenges. Several defendants or several plaintiffs may be considered as a single party for the purposes of making challenges, or the court may allow additional peremptory challenges and permit them to be exercised separately or jointly."

31. Kiernan v. Van Schaik, 347 F.2d 775, 779 (3d Cir. 1965).

32. Compare Stroud v. United States, 251 U.S. 15, 21 (1919) (when defendant was granted twenty peremptory challenges by statute, but in fact was allowed twenty-two such challenges and it does not appear that any objectionable juror actually sat, his right to exercise peremptory challenges was not abridged to his prejudice by the erroneous ruling as to the challenge for cause) with Chestnut $v$. Ford Motor Co., 445 F.2d 967, 972-73 (4th Cir. 1971) (plaintiff used all peremptory challenges, including one to remove juror that the judge erroneously refused to strike for cause, thereby effectively reducing his number of challenges). 
final decision. Inasmuch as the voir dire ruling was not a clear violation of federal law or an abuse of discretion, however, the judgment will not be reversed. ${ }^{33}$

Illustration 26-2. $\mathrm{P}$ brings a product liability suit against $\mathrm{D}$, a corporation. During voir dire, $\mathbf{P}$ challenges a juror for cause on the ground that the juror owns stock in $\mathrm{D}$. The judge refuses to strike the juror. $\mathrm{P}$ uses all his peremptory challenges, applying one to remove this juror. After losing at trial, $\mathbf{P}$ raises the voir dire issue upon appeal of the final decision, citing well-settled law disqualifying jurors having a stake in the outcome of litigation. The error in refusing to strike the juror is cause for reversal as $\mathrm{P}$ was thus denied full use of his peremptory challenges. ${ }^{34}$

Similarly, an order deciding a challenge to voir dire questions or procedure is reviewable only on appeal from a final decision; the trial court has broad supervisory discretion in this area. It may conduct the examination or it may permit counsel to do so, ${ }^{35}$ and it has wide discretion in ruling on the substantive content of questions. $^{36}$ In the leading case on the subject, the Supreme Court stated:

It is equally true that a suitable inquiry is permissible in order to ascertain whether the juror has any bias, opinion, or prejudice that would affect or control the fair determination by him of the issues to be tried. That inquiry is conducted under the supervision of the court, and a great deal must, of necessity, be left to its sound discretion. ${ }^{37}$

Thus, a reasonable restraint of questioning will be not held to be reversible error absent a showing of prejudice. ${ }^{38}$

Occasionally, however, an appellate court will reverse on appeal after final decision, finding that a trial court abused its discretion by limiting the questioning too severely. Perhaps the best known example is Kiernan $v$. Van Schaik. ${ }^{39}$ The Third Circuit in that case held that the rejection of questions relating to prospective jurors' associations with casualty insurers was an abuse of discretion. The trial court had relied on a local practice which denied the use of voir dire to assist counsel in exercising the right of peremptory challenge and greatly limited its use in aid of the right to challenge for cause. The appellate court found that

$[t]$ he rejection of appropriate questions on voir dire for such erroneous reasons amounts to an abuse of discretion. . . . A jury's impartiality may not be assumed without inquiry . . . [Jurors] must often be unaware of their own disqualification in specific cases. . . . Litigants therefore have the right, at the least, to some surface information regarding the prospective jurors. Such information may uncover ground for challenge for cause. If it does not, it will be available in the intelligent use of the peremptory challenge . . . .40

Illustration 26-3. $\mathrm{P}$ brings a negligence action against $\mathrm{D}$, an auto manufacturer. The district court controls the voir dire examination and

33. See Lusich v. Bloomfield S.S. Co., 355 F.2d 770 (5th Cir. 1966).

34. Chestnut v. Ford Motor Co., 445 F.2d 967 (4th Cir. 1971).

35. 9 C. WRIGHT \& A. MiLleR, supra note $27, \S 2482$, at 468.

36. Goosman v. A. Duie Pyle, Inc., 320 F.2d 45, 49-50 (4th Cir. 1963); Spells v. United States, 263 F.2d 609, 612 (5th Cir. 1959).

37. Connors v. United States, 158 U.S. 408, 413 (1895).

38. Langley v. Turner's Express, Inc., 375 F.2d 296, 297 (4th Cir, 1967).

39. 347 F.2d 775 (3d Cir. 1965).

40. Id. at 779 . 
declines to inquire of prospective jurors whether they have been involved in accidents similar to the one that is the subject of the litigation. $P$ appeals. The appeal should be dismissed. The district court's action is erroneous, but the error is one that may be rendered harmless by the outcome of the trial. If the issue arises on appeal after final decision, the error will be regarded as reversible error. ${ }^{41}$ Note that the availability of peremptory challenges cannot minimize the prejudice to $\mathrm{P}$ because there is no informed way in which $\mathrm{P}$ can exercise those challenges to strike unidentified jurors who may be properly disqualified by reason of their involvement in such accidents.

\section{§27. References.}

(A) AN ORDER GRANTING A REFERENCE TO A MASTER IS REVIEWABLE ON APPEAL FROM A FINAL DECISION OR ON INTERLOCUTORY APPEAL TO PREVENT A MANIFEST ABDICATION OF JUDICIAL RESPONSIBILITY.

(B) AN ORDER GRANTING A REFERENCE TO A MAGISTRATE IS REVIEWABLE ON APPEAL FROM A FINAL DECISION OR ON INTERLOCUTORY APPEAL TO PREVENT MANIFEST VIOLATION OF STATUTORY LIMITS ON THE ROLE OF MAGISTRATES.

(C) AN ORDER REFUSING TO REFER AN ISSUE TO A MASTER OR MAGISTRATE IS NOT REVIEWABLE.

\section{COMment}

a. Reference to Special Master. An order granting a reference to a special master, made pursuant to Rule 53(b) of the Federal Rules of Civil Procedure, ${ }^{1}$ is not a final decision. ${ }^{2}$ If a party makes a timely objection, the propriety of the reference will be reviewable on appeal from a final decision. ${ }^{3}$ This objection must be made to the district judge; an objection before the special master is not sufficient. ${ }^{4}$ Objection must have been made by the party who eventually seeks review of the reference on appeal. ${ }^{5}$

Interlocutory review is authorized by the Supreme Court holding in La Buy $v$.

41. Fietzer v. Ford Motor Co., 622 F.2d 281 (7th Cir. 1980).

1. Rule 53(b) provides:

(b) Reference. A reference to a master shall be the exception and not the rule. In action to be tried by a jury, a reference shall be made only when the issues are complicated; in actions to be tried without a jury, save in matters of account and of difficult computation of damages, a reference shall be made only upon a showing that some exceptional circumstance requires it.

2. 9 C. Wright \& A. Miller, Federal. Practice and Procedure $\S 2615$, at 813 (1971). See, e.g., Deckert v. Independent Shares Corp., 311 U.S. 282, 290-91 (1940); Williams v. Maxwell, 396 F.2d 143, 144 (4th Cir. 1968).

3. 9 C. WRight \& A. Miller, supra note 2, $\S 2615$, at 813. See, e.g., Macri v. United States ex rel. John H. Maxwell Co., 353 F.2d 804, 808-09 (9th Cir. 1965).

4. Hayes v. Foodmaker, Inc., 634 F.2d 802, 803 (5th Cir. 1981)

5. Objection to the reference by the defendant does not preserve the right of review of the issue on appeal by the plaintiff. McGraw-Edison Co. v. Central Transformer Corp., 308 F.2d 70, 72 (8th Cir. 1962). 
Howes Leather Co. ${ }^{6}$ that "the courts of appeals have discretionary power to issue writs of mandamus to compel vacating an order of reference in appropriate cases." Mere error in application of Rule 53(b) will not justify interlocutory intervention. ${ }^{8}$ Clear abuse of discretion is necessary and may be found when the court's action "is so palpably improper as to place it beyond the scope of the rule invoked [such that] the rules have been practically nullified by a district judge." 9

In $L a B u y$, a federal district judge had two civil antitrust actions pending before him for which he had conducted many hearings on preliminary pleas and motions. Faced with the prospect of a six-week trial and citing an extremely congested calendar as the requisite exceptional circumstance, the judge entered an order of reference sua sponte over the objection of all parties. The court of appeals found the order to be beyond the court's power under Rule 53(b) as it constituted a refusal by the judge "to try the causes in due course." ${ }_{10}$ The Supreme Court concurred with the finding of abuse of discretion since the parties were being deprived of "a trial before the court on the basic issues involved in the litigation," a situation which constituted "little less than an abdication of the judicial function." 11

Although the La Buy opinion did not specify what circumstances would justify reference to a master, it did indicate several situations which would not qualify as exceptional under Rule 53(b). Calendar congestion does not justify a reference, nor does complexity of issues alone in a nonjury trial. ${ }^{12}$ Finally, the probability of a lengthy trial is not a ground for a reference. ${ }^{13}$

Since the La Buy Court encouraged the supervision of the district courts by the appellate courts $^{14}$ and also discussed the Seventh Circuit's repeated warnings against the heavy use of references by its district judges, ${ }^{15}$ some commentators have assumed that an appellate court's grant of review by mandamus will generally depend upon a finding that the district court has been consistently making erroneous references. ${ }^{16}$ Rather, however, the language in $L a B u y$ seems to be a direction to appellate courts to test the reference against the limits of Rule 53(b) and grant mandamus whenever the actions of the trial court "transcend a mere error to constitute a nullification of the rule for trial by reference as the exceptional case." 17 Improper references have been vacated "despite the absence of any gen-

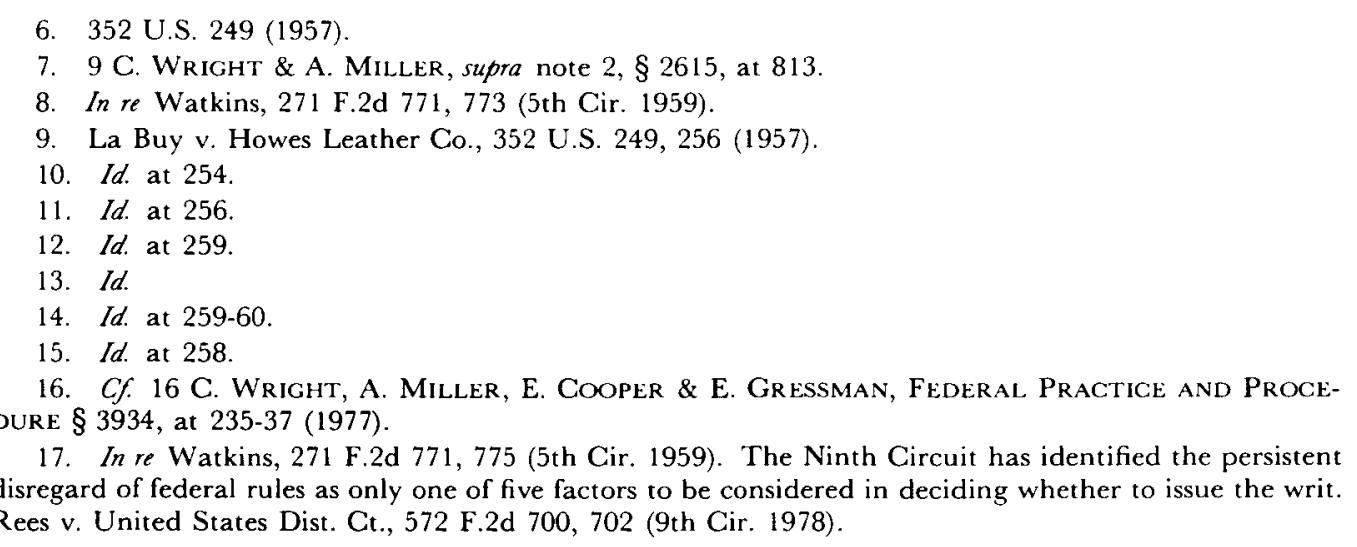


eral pattern of improper references in the district court under review." 18

Illustration. P brings suit against D, asserting claims based on two promissory notes and an open account. The district judge refers the entire case to a master for determination of all facts and law at issue, stating that the suit is too complicated for a jury of laymen to understand without expert analysis. $\mathrm{P}$ and/or $\mathrm{D}$ appeals. The appeal should be entertained because the validity of the promissory notes is merely a factual-legal determination of a kind traditionally decided by judge or jury; the accounting can be referred to a master if necessary after validity has been determined. Such a comprehensive reference of all triable issues to a master nullifies the right to an effective trial before a court. ${ }^{19}$

b. Reference to Magistrate. An order granting a reference to a magistrate is reviewable on interlocutory appeal to prevent clear violation of limitations set out by the statute authorizing such references. The Magistrates $\mathrm{Act}^{20}$ was passed by Congress in 1968 to create "a system of full-time and part-time judicial officers who would perform various judicial duties under the supervision of the district courts in order to assist the judges of these courts in handling an ever-increasing workload." 21 Initial cases construing 28 U.S.C. $\$ 636(\mathrm{~b})$, the provision which detailed the jurisdiction and powers of the magistrates, limited those powers and duties on the basis of a judicial interpretation of Congressional intent ${ }^{22}$ and the Supreme Court's concern with "abdication of the decisionmaking responsibility" properly belonging to the district courts. ${ }^{23}$

In response, and in an effort to clarify the jurisdiction of federal magistrates, Congress amended 28 U.S.C. $\S 636(\mathrm{~b})$ in $1976^{24}$ to specify three categories of

18. Carrington, The Power of District Judges and the Responsibility of Courts of Appeals, $3 \mathrm{GA} . \mathrm{L} . \mathrm{REV} .507$, 513 (1969). See, e.g., In re Watkins, 271 F.2d 771 (5th Cir. 1959).

19. In re Watkins, 271 F.2d 771 (5th Cir. 1959). Note that the court's concern may have been intensified by the fact that the party's right to trial by jury was involved.

20. Federal Magistrates Act, Pub. L. No. 90-578, § 101, 82 Stat. 1107, 1108 (1968) (codified as amended at 28 U.S.C. $\S \S 631-639$ (1976 \& Supp. V 1981)).

21. H.R. Rep. No. 1609, 94th Cong., 1st Sess. 4, reprinted in 1976 U.S. Code ConG. \& AD. NEws 6162, 6164.

22. Id. at 6166. See, e.g., Wingo v. Wedding, 418 U.S. 46 (1974); TPO v. McMillan, 460 F.2d 348 (7th Cir. 1972).

In Wingo $v$. Wedding the Supreme Court, on appeal from a final decision, held that federal judges must personally conduct habeas corpus evidentiary hearings. This holding invalidated a local district court rule which authorized full-time magistrates to conduct such proceedings.

In TPO $v$. McMillan the court issued a writ of mandamus to vacate a reference to a magistrate because motions which might involve ultimate decisionmaking, such as motions to dismiss and motions for summary judgment, may not be delegated.

23. TPO v. McMillan, 460 F.2d 348, 357 (7th Cir. 1972) (citing La Buy v. Howes Leather Co., 352 U.S. 249 (1957)).

24. Act of Oct. 21, 1976, Pub. L. No. 94-577, § 1, 90 Stat. 2729, 2729 (codified as amended at 28 U.S.C. $\S 636$ (1976 \& Supp. V 1981)). In pertinent part:

(b) (1) Notwithstanding any provision of law to the contrary-

(A) a judge may designate a magistrate to hear and determine any pretrial matter pending before the court, except a motion for injunctive relief, for judgment on the pleadings, for summary judgment, to dismiss or quash an indictment or information made by the defendant, to suppress evidence in a criminal case, to dismiss or to permit maintenance of a class action, to dismiss for failure to state claim upon which relief can be granted, and to involuntarily dismiss an action. A judge of the court may 
duties for which reference would be appropriate. ${ }^{25}$ First, under 28 U.S.C. $\S 636(\mathrm{~b})(1)(\mathrm{A})$, a judge may, at his discretion and subject to the express exception of certain dispositive motions, assign pretrial matters to a magistrate to be heard and determined. The magistrate's decision is intended to be final but may be reversed by the district judge when shown to be clearly erroneous. Second, under 28 U.S.C. $\S 636(\mathrm{~b})(1)(\mathrm{B})$, a judge may at his discretion, assign the excepted dispositive motions and habeas corpus petitions to a magistrate for hearing and recommendation. The judge will then accept, reject, or modify the findings and recommendations, thereby retaining ultimate adjudicatory power. Finally, under 28 U.S.C. $\$ 636(\mathrm{~b})(2)$, a district judge may designate a magistrate to serve as a special master. Upon consent of the parties, such reference may be made without regard to the limitations of Federal Rule 53(b); but when reference is pursuant to Rule 53(b), appealability will be determined under the rules set out in comment $a$.

Given the specificity of the statute, interlocutory appeal would be appropriate to review a manifestly inconsistent assignment of duties and thus to limit magisterial jurisdiction to its proper scope. ${ }^{26}$ In the past appellate courts have issued writs of mandamus to vacate references thought to misinterpret preamendment 28 U.S.C. $§ 636(b) .{ }^{27}$ However, given also the clear legislative encouragement to the district courts to continue "innovative experimentation" in the use of magistrates under the amended statutes and the specific disapproval of appellate court decisions which have restricted the use of these statutes, it seems doubtful that assignments to magistrates will often be the occasion for reversal.

Congress, in 28 U.S.C. $\S 636(\mathrm{~b})(3)$, further authorizes the assignment to magistrates of additional duties not inconsistent with the Constitution and the laws of the United States and, in 28 U.S.C. $\$ 636(\mathrm{~b})(4)$, allows district courts to establish

reconsider any pretrial matter under this subparagraph (A) where it has been shown that the magistrate's order is clearly erroneous or contrary to law.

(B) A judge may also designate a magistrate to conduct hearings, including evidentiary hearings, and to submit to a judge of the court proposed findings of fact and recommendations for the disposition, by a judge of the court, of any motion excepted in subparagraph (A), of applications for post trial relief made by individuals convicted of criminal offenses and of prisoner petitions challenging conditions of confinement.

(C) The magistrate shall file his proposed findings and recommendations under subparagraph (B) with the court and a copy shall forthwith be mailed to all parties. . . . A judge of the court shall make a de novo determination of those portions of the report or specified proposed findings or recommendations to which objection is made. A judge of the court may accept, reject, or modify, in whole or in part, the findings or recommendations made by the magistrate. The judge may also receive further evidence or recommit the matter to the magistrate with instructions.

(2) A judge may designate a magistrate to serve as a special master pursuant to the applicable provisions of this title and the Federal Rules of Civil Procedure for the United States district courts. A judge may designate a magistrate to serve as a special master in any civil case, upon consent of the parties, without regard to the provisions of rule 53(b) of the Federal Rules of Civil Procedure for the United States district courts.

25. H.R. ReP. No. 1609, 94th Cong., 1st Sess. 9, reprinted in 1976 U.S. CodE Cong. \& Ad. News 6162 , 6169.

26. Compare the discussion of interlocutory appeals for violations of the judicial disqualification statute, 28 U.S.C. $\$ 455$, supra $\S 24$ of this Interlocutory Restatement, notes $35-40$ and accompanying text. See also supra $\$ 26$ of this Interlocutory Restatement, text accompanying notes 23-25.

27. TPO v. McMillan, 460 F.2d 348 (7th Cir. 1972). 
the rules under which magistrates are to operate. ${ }^{28}$ Experimentation with such rules must be consistent with the specific duties set forth in the statute. ${ }^{29}$ Appeal from final decision has been considered adequate to review the question of whether the local rules under which the magistrates are operating are consistent with the Constitution and other statutes, ${ }^{30}$ and mandamus has not issued to provide interlocutory review. ${ }^{31}$

Finally, amendment of the Magistrates Act in 1979 added 28 U.S.C. $\S 636(c),{ }^{32}$ which allows federal magistrates, when specifially designated by their district judges and with the consent of the parties, to try cases. This provision significantly increases ${ }^{33}$ the statutory jurisdiction of such magistrates by giving them complete and explicit authority to decide cases and enter final decisions. Appeal of such a final decision is available of right to the court of appeals for the circuit in which the magistrate sits $^{34}$ or, with consent of the parties upon initial reference, back to that district court. ${ }^{35}$ The district judge would then have the power to affirm, reverse, modify, or remand. ${ }^{36}$ This latter procedure is made available to allow faster ultimate resolution of cases without the expense of direct appeal. ${ }^{37}$

28. 28 U.S.C. $\S 636(\mathrm{~b})$ (1976 \& Supp. V 1981). In pertinent part:

(3) A magistrate may be assigned such additional duties as are not inconsistent with the Constitution and laws of the United States.

(4) Each district court shall establish rules pursuant to which the magistrates shall discharge their duties.

29. Taylor v. Oxford, 575 F.2d 152, 154 (7th Cir. 1978).

30. Wingo v. Wedding, 418 U.S. 46 (1974).

31. Vickers Motors v. Wellford, 502 F.2d 967, 969 (6th Cir. 1974).

32. Federal Magistrate Act of 1979, Pub. L. No. 96-82, $\$ 2,93$ Stat. 643, 643 (codified at 28 U.S.C. $\S 636$ (c) (Supp. V 1981)). In pertinent part:

(c) Notwithstanding any provision of law to to the contrary-

(1) Upon the consent of the parties, a full-time United States magistrate or a part-time United States magistrate who serves as a full-time judicial officer may conduct any or all proceedings in a jury or nonjury civil matter and order the entry of judgment in the case, when specially designated to exercise such jurisdiction by the district court or courts he serves.

33. The legislative history, however, suggests that the amendment merely codifies previous experiments under 28 U.S.C. $\S 636($ b) (2) \& (3). S. REP. No. 74, 96th Cong., 1st Sess. 4, reprinted in 1979 U.S. Code Cong. \& Ad. News 1469, 1473.

34. 28 U.S.C. $\S 636$ (c)(3) (Supp. V 1980):

(3) Upon entry of judgment in any case referred under paragraph (1) of this subsection, an aggrieved party may appeal directly to the appropriate United States court of appeals from the judgment of the magistrate in the same manner as an appeal from any other judgment of a district court. In this circumstance, the consent of the parties allows a magistrate designated to exercise civil jurisdiction under paragraph (1) of this subsection to direct the entry of a judgment of the district in accordance with the Federal Rules of Civil Procedure. Nothing in this paragraph shall be construed as a limitation of any party's right to seek review by the Supreme Court of the United States.

Note that the appeal will be handled procedurally in the same manner as if the district court had entered the final decision. See also S. REP. No. 74, supra note 33, at 1473.

35. 28 U.S.C. $\$ 636$ (c)(4) (Supp. V 1981):

(4) Notwithstanding the provisions of paragraph (3) of this subsection, at the time of reference to a magistrate, the parties may further consent to appeal on the record to a judge of the district court in the same manner as on an appeal from a judgment of the district court to a court of appeals. Wherever possible the local rules of the district court and the rules promulgated by the conference shall endeavor to make such appeal expeditious and inexpensive. The district court may affirm, reverse, modify, or remand the magistrate's judgment.

36. Id. For further discussion of appeals of magistrate's decisions to district judges, see supra $\S 2$ of this Interlocutory Restatement, comment $d$.

37. S. REP. NO. 74 , supra note 33 , at 1474. 
Questions have been raised as to the constitutionality of 28 U.S.C. $\S 636(\mathrm{c})$ in that it gives magistrates, who are not article III judges, authority to enter final decisions without de novo review by a district court. Congress, however, concluded, ${ }^{38}$ now with the concurrence of two circuits, ${ }^{39}$ that the requirement of the consent of the parties cured any defect. The Ninth Circuit, sitting en banc, has further held that the operation of such an alternate forum does not compromise the "essential independence of the judiciary" or violate the separation of powers doctrine because statutory provisions giving article III judiciary control over the management, composition, and operation of the magistrate system and allowing district courts to resume jurisdiction over specific cases on their own initiative are sufficient protection against the erosion of judicial power. ${ }^{40}$ Indeed, the Ninth Circuit praised the use of flexible, innovative methods of adjudication such as that set forth in 28 U.S.C. $\$ 636(\mathrm{c})$, thus strengthening the argument that assignments to magistrates will rarely occasion reversal.41

c. Refusal to Refer. The refusal to refer an issue to a master or magistrate is not reviewable. ${ }^{42}$ A litigant has no right similar to the right of trial to the court or by jury to have an issue determined by a master or magistrate. A trial judge has discretionary power to refer issues in appropriate circumstances but is not required by any rule ever to do so; thus, a refusal to refer can never be a reversible error. ${ }^{43}$

\section{Review of Dispositions Before Trial}

$\S 28$. Judgments on Pleadings and Summary Judgments.

(A) A JUDGMENT ON THE PLEADINGS OR SUMMARY JUDGMENT IS A FINAL DECISION.

(B) AN ORDER TERMINATING LITIGATION ON THE MERITS PRIOR TO TRIAL WITH RESPECT TO ONE OR MORE BUT FEWER THAN ALL PARTIES OR CLAIMS IS REVIEWABLE AS A PARTIAL FINAL DECISION IF SO DESIGNATED BY THE DISTRICT COURT BUT OTHERWISE IS REVIEWABLE ONLY ON APPEAL FROM A FINAL DECISION AS TO ALL CLAIMS AND PARTIES.

(C) AN ORDER REFUSING TO TERMINATE LITIGATION ON THE

38. Id. at 1473 .

39. Wharton-Thomas v. United States, 721 F.2d 922 (3d Cir. 1983); Pacemaker Diagnostic Clinic of Am., Inc. Instromedix, Inc., 725 F.2d 537 (9th Cir. 1984) (rehearing en banc reversing holding of earlier panel which, raising the issue sua sponte, found 28 U.S.C. $\S 636$ (c) unconstitutional).

40. Pacemaker Diagnostic Clinic of Am., Inc. v. Instromedix, Inc., 725 F.2d 537, 542 (9th Cir. 1984) (en banc). See also Wharton-Thomas v. United States, 721 F.2d 922, 927, 930 (3d Cir. 1983).

41. See supra text accompanying notes 26-27. The Ninth Circuit in Pacemaker Diagnostic Clinic of Am., Inc. v. Instromedix, Inc., 725 F.2d 537, 543 (9th Cir. 1984) (en banc), did imply that reversal might be warranted upon a finding that waiver of the right to an article III judge was not freely and voluntarily given because the alternative was the "imposition of serious burdens and costs on the litigant."

42. But see Bradshaw v. Thompson, 454 F.2d 75 (6th Cir.), cert. denied, 409 U.S. 878 (1972); Harrington v. Sorelle, 313 F.2d 10 (10th Cir. 1963). In each of these cases a refusal to refer was reviewed upon final decision; however, in both instances the appellate courts emphasized the district judges' discretion and declined to find an abuse of such.

43. Cf. supra $\S 25$ of this Interlocutory Restatement, comment a (denial of request for nonjury trial). 
MERITS PRIOR TO TRIAL IS REVIEWABLE ON CERTIFIED APPEAL OR ON INTERLOCUTORY APPEAL TO ENFORCE THE RIGHT OF

(1) THE APPELLANT TO AN ABSOLUTE IMMUNITY AGAINST SUIT BY THE CLAIMANT, OR

(2) THE MOVANT TO BE HEARD ON HIS MOTION TO TERMINATE LITIGATION PRIOR TO TRIAL.

(D) AN ORDER DISMISSING A COMPLAINT BUT NOT THE ENTIRE ACTION IS A FINAL DECISION IF THE COURT EXPRESSLY DETERMINES THAT THE COMPLAINT CANNOT BE PERFECTED BY AMENDMENT OR THE CLAIMANT ELECTS TO STAND ON HIS PLEADINGS.

\section{COMMENT}

a. Orders Terminating Litigation on the Merits Prior to Trial. An order granting judgment on the pleadings or summary judgment is a final decision because an order that terminates litigation on the merits prior to trial has the same degree of finality as the order which would have been entered had a trial been allowed to take place. In either case all that remains is for the court to execute judgment. ${ }^{1}$ The scope of review is broad since any error of law embodied in an order terminating litigation prior to trial is reversible error.

An order granting partial summary judgment on liability is not final because the merits as to some issues remain to be determined. Rule 56(c) of the Federal Rules of Civil Procedure expressly recognizes that an order which resolves the liability issue in favor of the plaintiff but which grants none of the relief prayed for is interlocutory, ${ }^{2}$ and the Supreme Court has held that such a partial summary judgment is not a final decision. ${ }^{3}$ An order of this nature, however, is suitable for certification for interlocutory appeal under 28 U.S.C. $§ 1292$ (b) if it involves a controlling question of law and, in the trial court's discretion, immediate review would be beneficial. ${ }^{4}$

Illustration 28-1. P sues D for breach of contract. On D's motion, the trial court enters partial summary judgment on the issue of damages, ruling that $\$ 100$ will fully compensate $\mathrm{P}$ for his losses. $\mathrm{P}$ appeals. The appeal should be dismissed for lack of a final decision because the issue of liability remains pending before the court.

b. Partial Disposition. When a case involves multiple claims or multiple parties, an order terminating litigation on the merits prior to trial with respect to one or more but fewer than all the claims or parties may be subject to interlocutory review as a partial final decision. ${ }^{5} \mathrm{~A}$ trial of the factual issues is still necessary with

1. See FED. R. Civ. P. 58; Catlin v. United States, 324 U.S. 229, 233 (1945).

2. FED. R. CIV. P. 56(c). Cf. supra $\$ 22$ of this Interlocutory Restatement, notes $1-3$ and accompanying text.

3. Liberty Mut. Ins. Co. v. Wetzel, 424 U.S. 737, 742 (1976)

4. E.g., Stong v. Bucyrus-Erie Co., 476 F. Supp. 224 (E.D. Wis. 1979). For a discussion of the requirements for certified appeal, see supra $\S 11$ of this Interlocutory Restatement.

5. See supra $\S 4$ of this Interlocutory Restatement. In addition, certification pursuant to 28 U.S.C. 
respect to some parties or claims, and it may in the trial court's discretion be desirable to postpone appeal of such a partial termination until after the remaining factual issues have been resolved. But where the district judge deems immediate review of such an order appropriate, he may designate the order as a partial final decision under Rule 54(b) of the Federal Rules of Civil Procedure.

Illustration 28-2. $\quad \mathrm{P}$ sues D on two counts of trade tort, one count under federal common law and the other under a federal statute. The trial court dismisses P's common law count for failure to state a claim upon which relief can be granted. $P$ appeals. The appeal should be dismissed. Unless the district court has designated partial finality, $\mathrm{P}$ may not appeal the order since his statutory claim remains pending.

c. Refusal to Terminate Litigation on the Merits Prior to Trial. An order denying judgment on the pleadings or summary judgment is not a final decision because an order that refuses to terminate litigation on the merits prior to trial indicates merely that a trial is necessary. ${ }^{6}$ Even though it may be true that, were the trial court order refusing to terminate the litigation erroneous, a reversal of the order on immediate appeal would dispense with a time-consuming and costly trial, the policy against piecemeal litigation prevails. ${ }^{7}$ A greater waste of judicial resources and lengthier litigation could result if either party were allowed to seek immediate review of an order that did not finally resolve the lawsuit. Allowing appeal from every such order would disrupt the proceeding in the trial court. ${ }^{8}$

Further, the rule against allowing interlocutory appeal of orders denying summary judgment applies even where the plaintiff seeks an injunction and the order has the effect of denying such relief. ${ }^{9}$ The court has merely decided that an issue of fact exists; the merits as to the requested relief remain to be adjudicated, and an injunction could still be entered. ${ }^{10}$ Therefore, the policy against piecemeal appeals applies with equal force in such instances. If a preliminary injunction is actually entered, however, an order refusing to dismiss the action for failure to state a claim may on occasion be reviewed incidental to interlocutory appeal of the injunction. ${ }^{11}$

Illustration 28-3. P sues D, an accountant, alleging injury caused by an error in a financial statement prepared by D. P's claim is based on a right of action implied from Section 17 of the Securities Exchange Act. ${ }^{12}$ D moves to dismiss for failure to state a claim, citing Supreme Court authority holding that there is no such implied right of action for dam-

$\S 1292(\mathrm{~b})$ may be avilable even when Rule 54(b) is applicable; see supra $\S 11$ of this Interlocutory Restatement, note 15 .

6. E.g., Chappell \& Co. v. Frankel, 367 F.2d 197, 199 (2d Cir. 1966).

7. Cf. Switzerland Cheese Ass'n v. E. Horne's Market, 385 U.S. 23, 25 (1966).

8. Cf. Peter Pan Fabrics v. Dixon Textile Corp., 280 F.2d 800, 805-06 (2d Cir. 1960) (Clark, J., dissenting).

9. Switzerland Cheese Ass'n v. E. Horne's Market, 385 U.S. 23 (1966).

10. Cf. Carson v. American Brands Co., 450 U.S. 79, 84-86 (1981); supra $\$ 17$ of this Interlocutory Restatement, notes 38-40 and accompanying text; infra $\S 30$ of this Interlocutory Restatement, comment $d$.

11. See generally supra $\S 12$ of this Interlocutory Restatement, comment b (see particularly notes $57,82 \&$ 89 and accompanying text).

12. 15 U.S.C. $\S 78 q(a)$ (1982). 
ages. ${ }^{13}$ The trial court denies D's motion. D appeals. The appeal should be dismissed because of the policy against piecemeal appeals. Trial of the issue of fact should not be postponed or disrupted by interlocutory appellate review of the ruling on sufficiency of the pleadings.

An order refusing to terminate the litigation on the merits prior to trial is, however, quite suitable for certification for interlocutory appeal under 28 U.S.C. $\S 1292$ (b) since such rulings present pure questions of law and immediate review may by clarification facilitate further proceedings or, alternatively, dispense with an unnecessary trial. ${ }^{14}$

An order that denies partial summary judgment is not final because it indicates not only that issues of material fact remain to be resolved ${ }^{15}$ but also that other unresolved issues of law remain upon which the outcome of the case depends. An order denying partial summary judgment is nonetheless susceptible of certification for interlocutory appeal under 28 U.S.C. § 1292(b). ${ }^{16}$

An order refusing to terminate the litigation on the merits prior to trial is not effectively reviewable on appeal from a final decision. Once such a decision has been entered, the issues presented in the motion to terminate the litigation prior to trial are merged into the final decision. The worthiness of the case for trial is moot. Review of the final decision, however, may of course include review of issues presented in the motion to terminate litigation prior to trial.

d. Absolute Immunity. An order refusing to terminate litigation prior to trial which has the effect of rejecting a party's contention that he is absolutely immune from suit is subject to interlocutory review. ${ }^{17}$ Such an order falls within the collateral order doctrine. ${ }^{18}$ When a party alleges absolute immunity from suit, he asserts the right not to be subjected to the risk and burden of prosecuting a trial, ${ }^{19}$ and an order rejecting such a claim is effectively nonreviewable on appeal from a final decision because by that time the party will have been subjected to the very burden of trial from which he alleges immunity. ${ }^{20}$

One appellate court has extended this doctrine to allow interlocutory appeal when a party's claim of qualified immunity is denied. ${ }^{21}$ Such review was justified as furthering the Supreme Court's emphasis in Marlow v. Fitzgerald ${ }^{22}$ on facilitating

13. Touche Ross \& Co. v. Redington, 442 U.S. 560 (1979).

14. For a discussion of the requirements for certified appeal, see supra $\S 11$ of this Interlocutory Restatement.

15. See FED. R. Civ. P. 56(c).

16. For a discussion of the requirements for certified appeal, see supra $\S 11$ of this Interlocutory Restatement.

17. See, e.g., Nixon v. Fitzgerald, 457 U.S. 731 (1982); Forsyth v. Kleindienst, 599 F.2d 1203 (3d Cir. 1979); Briggs v. Goodwin, 569 F.2d 10 (D.C. Cir. 1977), cert. denied, 437 U.S. 904 (1978); McSurely v. McClellan, 521 F.2d 1024 (D.C. Cir. 1975), rev'd in part on the merits on rehearing en banc, 553 F.2d 1277 (1976), cert. dismissed as impravidently granted, 438 U.S. 189 (1978); Rowley v. McMillan, 502 F.2d 1326 (4th Cir. 1974).

18. Forsyth v. Kleindienst, 599 F.2d 1203, 1207 (3d Cir. 1979). See supra $\S 12$ of this Interlocutory Restatement, notes $10-13$ and accompanying text.

19. Forsyth v. Kleindienst, 599 F.2d 1203, 1207 (3d Cir. 1979).

20. $I d$.

21. McSurley v. McClellan, 697 F.2d 309 (D.C. Cir. 1982).

22. 457 U.S. 800 (1982). The Supreme Court in this case eliminated the subjective prong of the 
summary judgment on immunity claims so as to shield government officials from the risks, distractions, and inhibitions of trial. ${ }^{23}$

Illustration 28-4. $\mathrm{P}$ sues $\mathrm{D}$, a foreign official whose diplomatic status is uncertain due to recent alteration within the political regime in D's country. D moves for summary judgment, asserting absolute diplomatic immunity. The trial court, refusing to recognize D's status as a diplomat, denies the motion. D appeals. The appeal should be heard to protect D's right not to be subjected to trial.

e. Right to Make Motion to Terminate Litigation. An order refusing to terminate litigation prior to trial is also subject to interlocutory review when the trial judge denies the motion on the ground that the movant was not as a procedural matter entitled to make it. ${ }^{24}$ Such an order is held to be within the collateral order doctrine, ${ }^{25}$ the movant's right to make the desired motion is not effectively protected on appeal from a final decision.

Illustration 28-5. In a shareholder derivative class action, the trial court designates one of the many firms representing individual plaintiffs as "lead counsel" and directs that firm to control the flow of documents provided to the court. A nonlead counsel, that is, an attorney who represents a plaintiff but who is not the lead counsel, files a motion for summary judgment. The court denies the motion as violative of its prior order appointing lead counsel. The movant appeals. The appeal should be heard to protect the procedural right to make the motion for summary judgment. ${ }^{26}$

f. Dismissal of Complaint But Not Entire Action. An order that dismisses a complaint without dismissing the entire action is not final ${ }^{27}$ because the claimant may amend his complaint, either as of right or by leave of court. ${ }^{28}$ An appeal will be allowed, however, when the order dismissing the complaint has the same effect as an order dismissing the entire action for failure to state a claim upon which relief can be granted. Although the formulation of the conditions that must exist before such dismissals will be treated similarly varies from court to court, ${ }^{29}$ generally

qualified immunity test because the factual question as to state of mind was ill-suited to summary judgment and thus, the party asserting the privilege was not being as sufficiently protected from the burdens of trial as contemplated by the purposes of the immunity.

23. McSurley v. McClellan, 697 F.2d 309, 316 (D.C. Cir. 1982).

24. See, e.g., Farber v. Riker-Maxson Corp., 442 F.2d 457 (2d Cir. 1971).

25. Id. at 459 n.1. See supra $\S 12$ of this Interlocutory Restatement, notes 10-13 and accompanying text.

26. Farber v. Riker-Maxson Corp., 442 F.2d 457 (2d Cir. 1971). Note that the order appointing lead counsel may also effectively be reviewed.

27. Petty v. Manpower, Inc., 591 F.2d 615 (10th Cir. 1979); Borelli v. City of Reading, 523 F.2d 950 (3d Cir. 1976).

28. FED. R. CIV. P. 15(a).

29. Compare Petty v. Manpower, Inc., 591 F.2d 615, 617 (10th Cir. 1979) (district court must issue the dismissal order with the intent to dismiss plaintiff's entire action) with Borelli v. City of Reading, 532 F.2d 950, 951-52 (3d Cir. 1976) ("[o]nly if the plaintiff cannot amend or declares his intention to stand on his complaint does the order become final and appealable") with Local 179, United Textile Workers v. Federal Paper Stock Co., 461 F.2d 849, 850 (8th Cir. 1972) (trial court clearly determined that action could not be saved by amendment) with Jackson v. Nelson, 405 F.2d 872, 873 (9th Cir. 1968) (special circumstances 
either (1) the court must expressly indicate that the complaint cannot be amended to state a claim or (2) the claimant must stand on his complaint, contending that it states a good cause of action. Where the claimant presents more than one claim, some but not all of which are dismissed, the dismissal cannot be appealed as a final decision under this subsection since the entire action has not been dismissed. ${ }^{30}$

§ 29. Joinder of Claims and Parties.

(A) AN ORDER DISMISSING OR REFUSING TO DISMISS A COUNTERCLAIM OR A CROSS-CLAIM IS REVIEWABLE ON APPEAL FROM A FINAL DECISION OR ON CERTIFIED APPEAL. SUCH A DISMISSAL IS REVIEWABLE AS A PARTIAL FINAL DECISION IF SO DESIGNATED BY THE DISTRICT COURT.

(B) AN ORDER DISMISSING AN ACTION FOR NONJOINDER IS A FINAL DECISION. AN ORDER GRANTING OR DENYING A MOTION TO ADD NEW PARTIES IS REVIEWABLE ON APPEAL FROM A FINAL DECISION OR ON CERTIFIED APPEAL.

(C) AN ORDER GRANTING OR DENYING A MOTION TO IMPLEAD A THIRD PARTY IS REVIEWABLE ON APPEAL FROM A FINAL DECISION OR ON CERTIFIED APPEAL. AN ORDER DISMISSING OR REFUSING TO DISMISS A THIRD PARTY ACTION IS REVIEWABLE ON APPEAL FROM A FINAL DECISION OR ON CERTIFIED APPEAL. SUCH A DISMISSAL IS REVIEWABLE AS A PARTIAL FINAL DECISION IF SO DESIGNATED BY THE DISTRICT COURT.

(D) AN ORDER GRANTING INTERVENTION .IS REVIEWABLE ON APPEAL FROM A FINAL DECISION OR ON CERTIFIED APPEAL. AN ORDER DENYING INTERVENTION IS A FINAL DECISION.

(E) AN ORDER DISMISSING AN ORIGINAL ACTION IN INTERPLEADER IS A FINAL DECISION. AN ORDER GRANTING INTERPLEADER IS REVIEWABLE ON APPEAL FROM A FINAL DECISION OR ON CERTIFIED APPEAL. WHEN THE STAKEHOLDER IS DISCHARGED, SUCH AN ORDER IS REVIEWABLE AS A PARTIAL FINAL DECISION IF SO DESIGNATED BY THE DISTRICT COURT.

\section{COMMENT}

a. General Kules Relating to Joinder; Certified Appeal. Generally, any order relating to joinder that adds a claim or a party or refuses to strike a claim or party is not final because it by its very nature indicates that claims remain to be adjudicated. Such an order broadens rather than terminates the litigation.

\footnotetext{
must make it clear that court determined the action could not be saved by any amendment of complaint which plaintiff could reasonably be expected to make). Compare also supra $\S 14$ of this Interlocutory Restatement, notes 2-4 and accompanying text; supra $\S 16$ of this Interlocutory Restatement, note 2 and accompanying text.

30. See, e.g., Fletcher v. Gagosian, 604 F.2d 637 (9th Cir. 1979). Such an order may, however, be appealable under procedures for designation of partial finality. See supra comment $b$; see also supra $\S 4$ of this Interlocutory Restatement.
} 
Many nonfinal orders relating to joinder, however, will be subject to certified interlocutory appeal under 28 U.S.C. $\$ 1292(\mathrm{~b}) .^{1}$ A district court ruling on joinder often turns on the substantive nature of the claim and the relationship between the parties; thus, the required controlling question of law will often be presented.'

b. Orders Dismissing Counterclaims and Cross-Claims. An order that dismisses a compulsory or permissive counterclaim is not a final decision so long as other claims remain pending. ${ }^{3}$ Such orders are clearly interlocutory since issues remain to be resolved, and review may be had on appeal from a final decision. ${ }^{4}$ This reasoning applies regardless of whether the dismissed counterclaim is compulsory or permissive, ${ }^{5}$ and regardless of whether the counterclaim is dismissed on the merits or for improper joinder. ${ }^{6}$ When the dismissal is on the merits, the order may be designated as a partial final decision under Rule 54(b) of the Federal Rules of Civil Procedure, in which case it will be immediately appealable. ${ }^{7}$ Such designation is warranted where resolution of the issues still pending depends on a final resolution of the questions presented by the dismissed counterclaim. ${ }^{8}$

The dismissal of a counterclaim is a final decision if all other claims have previously been dismissed or adjudicated. ${ }^{9} \mathrm{Or}$, when a counterclaim seeks a preliminary injunction and the dismissal constitutes a decision on the merits that the moving party is not entitled to such relief, the order will be immediately reviewable under 28 U.S.C. $\S 1292(a)(1)$ as having the effect of denial of an injunction. ${ }^{10}$

Illustration 29-1. P brings a statutory interpleader action against D1, D2, D3, and D4. D4 files a permissive counterclaim against $P$. The court

1. For a discussion of the requirements for certification, see supra $\S 11$ of this Interlocutory Restatement.

2. E.g., Sass v. District of Columbia, 316 F.2d 366 (D.C. Cir. 1963) (third party complaint). There may be some question as to the propriety of certification pursuant to 28 U.S.C. $\$ 1292(\mathrm{~b})$ when a designation of partial finality under Rule 54(b) of the Federal Rules of Civil Procedure may also be available. See supra $\S 11$ of this Interlocutory Restatement, note 15.

3. See, e.g., Bush v. United Benefit Fire Ins. Co., 311 F.2d 893 (5th Cir. 1963).

4. See, e.g., Public Serv. Comm'n v. Brashear Freight Lines, 312 U.S. 621, 626 (1941).

5. See Cold Metal Process Co. v. United Eng'g \& Foundry Co., 351 U.S. 445, 451 (1956). Prior law recognized that dismissals of permissive rather than compulsory counterclaims were more susceptible of immediate review since they were separable from and independent of the pending claims. Id. at 451-52. Rule 54(b) of the Federal Rules of Civil Procedure on partial final decisions abandons this distinction. Id.

6. For example, an order dismissing a counterclaim because it was asserted against a party not an "opposing party" under Rule 13 of the Federal Rules of Civil Procedure has been held not a final decision. First Nat'l Bank v. Johnson County Nat'l Bank \& Trust Co., 331 F.2d 325 (10th Cir. 1964); see also Bush v. United Benefit Fire Ins. Co., 311 F.2d 893 (5th Cir. 1963). A counterclaim might also be dismissed other than on the merits if, for example, it was not ripe (such as a claim of abuse of process in the pending suit) or it was asserted primarily to harass an adversary. Dismissals of such counterclaims likewise are not final decisions; the finality of such orders is diminished by the fact that the claims dismissed often may be brought subsequently in separate proceedings.

7. Cold Metal Process Co. v. United Eng'g \& Foundry Co., 35 I U.S. 445 (1956). When the counterclaim is dismissed for procedural reasons, Rule $54(\mathrm{~b})$ is not applicable because there has been no adjudication of a claim. See infra Illustrations 29-1, 29-4 $\xi^{\circ} 29-6$; cases cited infra notes $21,26 \& 32$; see also supra $\$ 4$ of this Interlocutory Restatement, notes 33-36 and accompanying text. Dismissal of a counterclaim usually will be on the merits since there is no requirement that the claim relate to the underlying action. See FED. R. CIV. P. 13(b).

8. See, e.g., Cold Metal Process Co. v. United Eng'g \& Foundry Co., 35 I U.S. 445, 450-51 (1956)

9. Cf. infra note 27 and accompanying text.

10. California v. Kleppe, 604 F.2d 1187, 1090-91 (9th Cir. 1979). See supra $\S 4$ of this Interlocutory Restatement, note 8; $c$. supra $\S 22$ of this Interlocutory Restatement, note 7 and accompanying text. 
dismisses the counterclaim on the ground that $\mathrm{P}$ and D4 are not "opposing parties" under Rule 13 of the Federal Rules of Civil Procedure. D4 appeals. The appeal should be dismissed. The order is not a final decision because the claims of the parties to the interpleader stake remain to be resolved. A designation of partial finality is not available because the dismissal of the counterclaim was procedural and the merits as to the claims asserted by $\mathrm{D} 4$ against $\mathrm{P}$ may be adjudicated in a separate action."

An order dismissing a cross-claim, like an order dismissing a counterclaim, by its nature indicates that other claims remain to be adjudicated, and hence it is not a final decision. ${ }^{12}$ Unlike dismissal of a counterclaim, however, dismissal of a cross-claim will often be for procedural reasons since there is a requirement that cross-claims be related to the subject matter of the original action. ${ }^{13}$ Thus, designation as a partial final decision under Rule 54(b) will be available less frequently since no claim will have been adjudicated-there will be no finality even as to the individual claim if dismissed on procedural grounds. ${ }^{14}$

Illustration 29-2. $\mathrm{P}$ sues $\mathrm{D} 1$ and D2. D1 files a cross-claim against D2.

The court dismisses the cross-claim. D1 appeals. The appeal should be dismissed in the absence of a designation of partial finality, if available, since the initial claims of $\mathbf{P}$ remain to be adjudicated.

c. Dismissal for Nonjoinder; Orders Adding or Refusing to Add Parties. An order dismissing an action for refusal to join an indispensable party under Rule 19(b) of the Federal Rules of Civil Procedure is a final decision ${ }^{15}$ because it terminates the action and resolves the lawsuit against the party who has refused to join the new party.

An order that adds or refuses to add new parties to the pending litigation is not final ${ }^{16}$ because in either case the order does not terminate the action or determine which party prevails. Such an order is reviewable on appeal from a final decision since addition of new parties or refusal to add new parties may be a ground for reversal. ${ }^{17}$ Review as a partial final decision under Rule 54(b) is not available since an order relating to additional parties reflects only a joinder ruling and does

11. First Nat'l Bank v. Johnson County Nat'l Bank \& Trust Co., 331 F.2d 325 (10th Cir. 1964) (note that a separate action as to the counterclaim had actually been commenced in another forum prior to the decision on the appeal).

12. Fairview Park Excavation Co. v. Al Monzo Constr. Co., 560 F.2d 1122, 1124 n.6 (3d Cir. 1977).

13. See FED. R. CiV. P. $13(\mathrm{~g})$.

14. See supra Illustration 29-1; infra Illustrations 29-4 \& 29-6; cases cited infra notes 21,26 \& 32; see also supra $\S 4$ of this Interlocutory Restatement, notes $33-36$ and accompanying text. Contra Blair v. Cleveland Twist Drill Co., 197 F.2d 842, 845 (7th Cir. 1952).

15. E.g., Kamni v. Cohen, 512 F.2d 1051 (2d Cir. 1975). Such an order has an interlocutdry ring to it insofar as a reviewing court will, on occasion, after affirming the dismissal remand the case to allow the reluctant party one more opportunity to join the indispensable party. See, e.g., id.

16. United States v. Taylor, 632 F.2d 530 (5th Cir. 1980) (denial of motion to join new party); Metalock Repair Serv. v. Harman, 216 F.2d 611 (6th Cir. 1954) (order directing joinder of additional parties).

17. See Prop-Jets, Inc. v. Chandler, 575 F.2d 1322, 1325 (10th Cir. 1978) (order joining a new party). Note that an order refusing to dismiss for failure to add on indispensable party may on occasion be reviewed incidentally in conjunction with an order otherwise subject to interlocutory appeal, such as an 
not finally adjudicate a claim. ${ }^{18}$

d. Impleader Orders. An order granting a motion to implead is not a final decision because it does not terminate the action and because it may be retracted by the district court pursuant to a motion for severance or a motion to dismiss or vacate the impleader action. ${ }^{19}$ Similarly, an order that denies a motion to implead is not final. ${ }^{20}$ Such an order does not terminate the action, and no decision on the merits is rendered. Rather, the order only indicates the impropriety of impleader as a joinder device, and the movant is always free to assert the disallowed claim in a separate proceeding. In addition, neither an order that grants or that denies a motion to implead may be designated as a partial final decision under Rule 54(b) because such an order will not enter a judgment on a claim. ${ }^{21}$

Illustration 29-3. P sues D. D moves to implead $\mathrm{T} / \mathrm{P}$, but the motion is denied. $\mathrm{D}$ appeals. The appeal should be dismissed since no decision on the merits has been reached and the underlying claim of $\mathrm{P}$ remains to be adjudicated.

Once a motion for impleader has been granted, an order that denies either a motion to dismiss the third party complaint or a motion to vacate the impleader action is not an appealable final decision because it does not terminate the action or adjudicate a claim. ${ }^{22}$

An order that grants either a motion to dismiss a third party complaint or a motion to vacate an impleader action also is not subject to interlocutory appeal, because of the policy against piecemeal litigation, as long as the underlying claim remains to be adjudicated. ${ }^{23}$ Such an order may, however, be reviewed promptly if it constitutes a judgment on the merits ${ }^{24}$ and is designated as a partial final decision under Rule 54(b). ${ }^{25}$ If the third party complaint is dismissed or impleader action vacated merely to uncomplicate the litigation or to allow the claim to be tried in a separate proceeding, for example, immediate review will not be available. ${ }^{26}$ The dismissed or vacated claim can be brought in a separate proceeding

injunction. See supra $\S 12$ of this Interlocutory Restatement, note 87 and accompanying text, plus comment $b$ generally.

18. See supra Illustration 29-1; infra lllustrations 29-4 \& 29-6; cases cited infra notes 21,26 \& 32; see also supra $\S 4$ of this Interlocutory Restatement, notes 33-36 and accompanying text.

19. 6 C. Wright \& A. Miller, Federal Practice and Procedure $\S 1463$ (1971).

20. Minnesota v. Pickands Mather \& Co., 636 F.2d 251, 252 n.2 (8th Cir. 1980) (order denying leave to file third party complaint not appealable even under "collateral order" doctrine); Melancon v. Insurance Co. of N. Am., 476 F.2d 594 (5th Cir. 1973).

21. Minnesota v. Pickands Mather \& Co., 636 F.2d 251, 252 n.2 (8th Cir. 1980). See also Seatrain Shipbuilding Corp. v. Shell Oil Co., 444 U.S. 572, 583 n.21 (1980).

22. Skelly Oil Co. v. Zimmerman, 332 F.2d 618 (10th Cir. 1964); Carlisle v. S.C. Loveland Co., 175 F.2d 418 (3d Cir. 1949).

23. Allegheny Airlines v. Le May, 448 F.2d 1341 (7th Cir.), cert. denied, 404 U.S. 1001 (1971); Thompson v. American Airlines, 422 F.2d 350 (5th Cir. 1970); Weinstock Hermanos \& Cia Ltda. v. American Aniline \& Extract Co., 406 F.2d 1327 (3d Cir. 1969); Woodby v. Chesapeake \& O. Ry., 345 F.2d 668 (6th Cir. 1965)

24. See supra Illustration 29-1; infra Illustrations 29-4 $619-6$; cases cited supra note 21 , infra notes 26 \& 32 ; see also supra $\S 4$ of this Interlocutory Restatement, notes 33-36 and accompanying text.

25. Panichella v. Pennsylvania R.R., 252 F.2d 452 (3d Cir. 1958); Capital Transit Co. v. District of Columbia, 225 F.2d 38 (D.C. Cir. 1955).

26. Cf. CBS Steel \& Forge Co. v. Shultz, 191 F.2d 683 (9th Cir. 1951); County Bank v. First Nat'l 
and the merits may then be reached. When, however, the third party claim is the only claim still pending before the court, for example, because the original action has been terminated, a subsequent dismissal or vacatur of that third party complaint becomes a final appealable decision. ${ }^{27}$

Illustration 29-4. P sues D. D impleads T/P. P moves to dismiss the third party complaint on the ground that it should have been brought in a separate action. The court grants P's motion. D appeals. The appeal should be dismissed. The order is not a final decision because P's claim against $\mathrm{D}$ remains before the court; and since the third party dismissal was on procedural grounds, no claim has been adjudicated, and the order may not be designated as a partial final decision under Rule 54(b).

While any order relating to impleader is subject to review on appeal from a final decision, ${ }^{28}$ consideration at that stage may be fruitless. Error, if any, may be perceived to be harmless since a disallowed claim may be brought in a separate proceeding in lieu of a remand of the original action. ${ }^{29}$ Even when error would not thus be found harmless, a trial court ruling relating to impleader will be reversed only for abuse of discretion. ${ }^{30}$

e. Intervention. An order that grants intervention is not appealable as a final decision ${ }^{31}$ because it broadens rather than terminates the litigation and it does not resolve any of the issues in the case on the merits. Such an order may not be designated as a partial final decision under Rule 54(b) because it does not adjudicate a claim. ${ }^{32}$

All orders denying intervention are in effect susceptible of immediate review as final decisions, although there is a split of authority on the form of such review. ${ }^{33}$ Some courts have found that an appeal lies only if the order denying intervention should be reversed; they will dismiss, rather than affirm, an appeal from a proper denial of intervention. ${ }^{34}$ A growing majority of courts, however, have taken the

Bank, 184 F.2d 152 (4th Cir. 1950); Baltimore \& O. Ry. v. United Fuel Gas Co., 154 F.2d 545 (4th Cir. 1946).

27. United States Fidelity \& Guar. Co. v. Perkins, 388 F.2d 771 (10th Cir. 1968); Paliaga v. Luckenbach S.S. Co., 301 F.2d 403 (2d Cir. 1962); Duke v. Reconstruction Fin. Corp., 209 F.2d 204 (4th Cir.), cert. denied, 347 U.S. 966 (1954).

28. 6 C. WRIGHT \& A. Miller, supra note 19, § 1463. See Horn v. Daniel, 315 F.2d 471 (10th Cir 1962) (appellate court found that the trial cour: erred in originally allowing impleader).

29. 6 C. WRIGHT \& A. Miller, supra note 19, § 1463.

30. See, e.g., Somportex Ltd. v. Philadelphia Chewing Gum Corp., 453 F.2d 435, 439 (3d Cir. 1971), cert. denied, 405 U.S. 1017 (1972); United States Fidelity \& Guar. Co. v. Perkins, 388 F.2d 771, 773 (10th Cir. 1968)

31. United States Fidelity \& Guar. Co. v. Lord, 585 F.2d 860 (8th Cir. 1978), cert. denied, 440 U.S. 913 (1979); In re Estelle, 516 F.2d 480 (5th Cir. 1975), cert. denied, 426 U.S. 925 (1976). But see Estelle v. Justice, 426 U.S. 925 (1976) (Rehnquist, J., dissenting from denial of certiorari) (a minority of the Court would have allowed a writ of mandamus to issue to review a district court order permitting the United States to intervene in a civil rights action by prisoners against correction officials where the United States as intervenor had no "claim" against the defendant officials).

32. Equal Employment Opportunity Comm'n v. American Tel. \& Tel. Co., 506 F.2d 735,742 (3d Cir. 1974). See also Estelle v. Justice, 426 U.S. 925 (1976) (dissent from denial of certiorari).

33. 7A C. Wright \& A. Miller, Federal Practice and Procedure $\S 1923$ (1972).

34. Sam Fox Publishing Co. v. United States, 366 U.S. 683 (1961); Sutphen Estates v. United States, 342 U.S. 19 (1951); Allen Calculators v. National Cash Register Co., 322 U.S. 137 (1944). Cf. infra $\$ 32$ of this Interlocutory Restatement, text accompanying notes 14-15. 
better view that a denial of intervention is a final decision which on appeal should be either reversed or affirmed. ${ }^{35}$ This emerging rule is to be preferred ${ }^{36}$ both analytically ${ }^{37}$ and as a means of assuring adequate protection of the interests of potential intervenors by forcing appellate courts to share responsibility on the merits. ${ }^{38}$

When intervention is attempted after a judgment has been rendered, an order denying such intervention is always treated as a final order ${ }^{39}$ because the litigation in the trial court has terminated and the intervenor has no further remedies there. An order denying intervention is to be distinguished from an order that grants intervention yet dismisses the intervenor's complaint; in the latter case, the order may be reviewable as a partial final decision if so designated under Rule 54(b). ${ }^{40}$

Illustration 29-5. P sues D. M files a motion to intervene, but the court denies the motion. $M$ appeals. The appeal should be entertained, because the order is a final decision as to $M$.

The scope of review of an order denying intervention depends on the type of intervention sought: Where intervention of right ${ }^{41}$ has been denied, the order will be reversed if the denial was erroneous; ${ }^{42}$ where permissive intervention ${ }^{43}$ has been denied, the order will be reversed only if the trial court clearly abused its discretion. ${ }^{44}$

f. Interpleader Orders. An order that dismisses an original action in interpleader is a final appealable decision ${ }^{45}$ since it terminates the proceeding in the trial court and determines that the plaintiff cannot recover. An order denying a request for interpleader asserted as a cross-claim or counterclaim, however, is not final since other claims remain pending before the court; such an order, if based on the merits rather than concerns with the structure of the litigation, may be review-

35. Hawaii-Pacific Venture Capital Corp. v. Rothbard, 564 F.2d 1343 (9th Cir. 1977); FMC Corp. v. Keizer Equip. Co., 433 F.2d 654 (6th Cir. 1970); Ionian Shipping Co. v. British Law Ins. Co., 426 F.2d 186 (2d Cir. 1970); Bumgarner v. Ute Indian Tribe, 417 F.2d 1305 (10th Cir. 1969); Union Cent. Life Ins. Co. v. Hamilton Steel Prods., 374 F.2d 820 (7th Cir. 1967); Stadin v. Union Elec. Co., 309 F.2d 912 (8th Cir. 1962); Philadelphia Elec. Co. v. Westinghouse Elec. Co., 308 F.2d 856 (3d Cir. 1962), cert. denied, 372 U.S. 936 (1963).

36. See 7A C. WRIGHT \& A. Miller, supra note 33, at $\$ 1923$; Shapiro, Some Thoughts on Intervention Before Courts, Agencies, and Arbitrators, 81 HARV. L. REV. 721, 748-51 (1968).

37. To rule that a denial of intervention is reviewable as an appealable final order only if the order should be reversed, see United States v. American Tel. \& Tel. Co., 642 F.2d 1285 (D.C. Cir. 1980), is contradictory since in order to judge whether the order must be reversed, it must be reviewed. Cf. Ionian Shipping Co. v. British Law Ins. Co., 426 F.2d 186 (2d Cir. 1970).

38. See 7A C. WRIGHT \& A. Miller, supra note 33, § 1923. That treatise notes that there has been only one case in which a denial of permissive intervention has been reversed solely because the trial court abused its discretion. Id. at 404 (Supp. 1983). See Crumble v. Blumenthal, 549 F.2d 462 (7th Cir. 1979).

39. E.g., United States v. Associated Milk Producers, 534 F.2d 113 (8th Cir. 1976). Cf. NAACP v. New York, 413 U.S. 345 (1973) (direct appeal to the Supreme Court taken from a postjudgment order denying intervention in an action under the Voting Rights Act of 1965).

40. Huckeby v. Frozen Food Express, 555 F.2d 542 (5th Cir. 1977).

41. See FED. R. Civ. P. 24(a).

42. E.g., Natural Gas Corp. v. El Paso Natural Gas Co., 386 U.S. 129 (1967).

43. See FED. R. Civ. P. 24(b).

44. Allen Calculators v. National Cash Register Co., 322 U.S. 137, 143 (1944).

45. See, e.g., Fulton v. Kaiser Steel Corp., 397 F.2d 580 (5th Cir. 1968); Underwriters at Lloyd's v. Nichols, 363 F.2d 357 (8th Cir. 1966). Such an action may be brought under either 28 U.S.C. $\S 1334$ (1976) or Rule 22 of the Federal Rules of Civil Procedure. 
able as a partial final decision if so designated under Rule 54(b). ${ }^{46}$

An order that decrees interpleader is not a final decision because, regardless of whether the stakeholder claims an interest in the stake, the litigation must continue to determine which party is entitled to such. ${ }^{47}$ Designation as a partial final decision under Rule 54(b) will be available only if the stakeholder is discharged; ${ }^{48}$ otherwise no claim will have been adjudicated. ${ }^{49}$

Illustration 29-6. P sues D1. D1 makes a motion to interplead P, D2, D3, and D4, claiming no interest in the stake. The court grants D1's motion and discharges D1. P appeals. The appeal should be dismissed; there is no final decision since the dispute among P, D2, D3, and D4 as to the stake remains to be resolved. If a claim has been adjudicated as to $\mathrm{P}$, however, review will be available if the order is designated as a partial final decision under Rule 54(b).

A decree of interpleader may be reviewed incidental to consideration of an otherwise immediately appealable order, such as an injunction, when the issues involved are sufficiently interrelated. ${ }^{50}$ The authorization, in cases of statutory interpleader, for courts to enjoin parties from prosecuting related proceedings in other forums ${ }^{51}$ may thus make interpleader orders in such situations effectively subject to interlocutory appeal. ${ }^{52}$

\section{$\S 30$. Class Certification.}

AN ORDER GRANTING OR DENYING CLASS CERTIFICATION IS REVIEWABLE ON APPEAL FROM A FINAL DECISION, ON CERTIFIED APPEAL, OR ON INTERLOCUTORY APPEAL TO PREVENT MANIFEST VIOLATION OF RELEVANT STANDARDS GOVERNING THE CONDUCT OF SUCH ACTIONS, EXCEPT THAT INSOFAR AS A FINAL DECISION IS REVERSED AND REMANDED THE CLASS ISSUE WILL NOT YET BE REACHED.

46. See 7 C. Wright \& A. Miller, Federal Practice and Procedure $\$ 1720$, at 493 (1972); supra Illustrations 29-1 \& 29-4; infra Illustration 29-6; cases cited supra notes 21,26 \& 32; see also supra $\S 4$ of this Interlocutory Restatement, notes 33-36 and accompanying text.

47. E.g., Great Am. Ins. Co. v. Bank of Bellevue, 366 F.2d 289 (8th Cir. 1966); Guerin v. Guerin, 239 F.2d 909 (9th Cir. 1956). See 7 C. Wright \& A. Miller, supra note 46, $\$ 1720$, at 493-94. A grant of interpleader asserted as a cross-claim or counterclaim also would not be final since the claims would remain pending before the court. An order decreeing interpleader has been held final, however, where the order also severed the interpleader action from other cross-claims and counterclaims before the court and then disposed of the interpleader action in the form of a judgment. See Hebel v. Ebersole, 543 F.2d 14 ( 7 th Cir. 1976). Such a result is plausible so long as the severance order is not entered solely to enhance the finality of the interpleader order, thereby possibly circumventing, or at least unnecessarily dispensing with, designation of partial finality under Rule 54(b).

48. E.g., Republic of China v. American Express Co., 195 F.2d 230 (2d Cir. 1952); see also Republic of China v. American Express Co., 190 F.2d 334, 338-40 (2d Cir. 1951).

49. Guerin v. Guerin, 239 F.2d 909, 913 (9th Cir. 1956).

50. See supra $\S 12$ of this Interlocutory Restatement, notes 39-78 and accompanying text.

51. See 28 U.S.C. $\S 2361$ (1976).

52. Guy v. Citizens Fidelity Bank \& Trust Co., 429 F.2d 828 (6th Cir. 1970); Tashire v. State Farm Fire \& Casualty Co., 363 F.2d 7 (9th Cir. 1966), rev'd on other grounds, 386 U.S. 523 (1967). 


\section{Comment}

a. Grant or Denial of Class Certification. The Supreme Court held in Coopers $\mathcal{F}^{2}$ Lybrand v. Livesay" that an order denying class certification is not a "final decision" within the meaning of 28 U.S.C. $\S 1291$ and is therefore not immediately appealable as a matter of right. The Court rejected the argument that an order denying class certification falls under the "collateral order" doctrine ${ }^{2}$ because such an order is subject to revision in the district court $^{3}$ and is effectively reviewable on appeal from a final decision ${ }^{4}$ and because class certification issues generally are closely intertwined with the merits of an action. ${ }^{5}$

The Court also rejected the argument that an order denying class certification is effectively final and thus appealable as sounding the "death knell" in that its practical implication likely will be to force termination of the litigation. ${ }^{5}$ A denial of class certification can often discourage an individual plaintiff from pursuing the claim because such a plaintiff then runs the risk of bearing the entire cost of the litigation himself if the court ultimately refuses to certify a class. ${ }^{7}$ Thus, the "death knell" doctrine was sometimes invoked when the plaintiff class presented a relatively small claim, ${ }^{8}$ making further litigation particularly improbable.

This practice was abandoned by the Supreme Court in Coopers $\mathcal{E}$ Lybrand for three reasons. First, the relvant statute ${ }^{9}$ provides that the appealability of an order depends on "finality" and not on the arbitrary determination that the amount in controversy is too small to sustain the claimant's incentive to pursue the litigation. ${ }^{10}$ Second, an in-depth inquiry into the impact of a decertification order on a litigant's practical ability to sustain the suit is a waste of judicial resources: The incremental benefit of allowing immediate appeal of those orders sounding the "death knell" is "outweighed by the impact of such an individualized jurisdictional inquiry on the judicial system's overall capacity to administer justice."11 Finally, the "death knell" doctrine "authorizes indiscriminate interlocutory review of decisions made by trial judges," 12 whereas the discretionary power to permit an interlocutory appeal is statutorily vested, in the first instance, in the trial courts rather than the courts of appeals. ${ }^{13}$

1. 437 U.S. 463 (1978).

2. Id. at 468-69. Certain orders relating to class administration, the assessment of the costs of notification, for example, may be immediately appealable as collateral. E.g., Oppenheimer Fund v. Sanders, 437 U.S. 340,347 n.8 (1978). For a discussion of the requirements of the collateral order doctrine, see supra $\S 12$ of this Interlocutory Restatement, notes 10-13 and accompanying text.

3. Fed. R. Civ. P. 23(c)(1).

4. Deposit Guar. Nat'l Bank v. Roper, 445 U.S. 326 (1980); United Airlines v. McDonald, 432 U.S. $385(1977)$.

5. See Mercantile Nat'l Bank v. Langdeau, 371 U.S. 555 (1963).

6. Coopers $\mathcal{E}^{2}$ Lybrand, 437 U.S. at 470-76. For earlier examples of the application of this doctrine, see Ott v. Speedwriting Publishing Co., 518 F.2d 1143 (6th Cir. 1975); Hartmann v. Scott, 488 F.2d 1215 (8th Cir. 1973); Eisen v. Carlisle \& Jacquelin, 370 F.2d 119 (2d Cir. 1966), cert. denied, 386 U.S. 1035 (1967).

7. Coopers $\mathcal{G}^{2}$ Lybrand, 437 U.S. at $469-72$.

8. See, e.g., Green v. Wolf Corp., 406 F.2d 291 (2d Cir. 1968), cert. denied, 395 U.S. 977 (1969).

9. 28 U.S.C. $\$ 1291$ (1976).

10. Copers \& Lybrand, 437 U.S. at $472-73$.

11. Id. at 473 .

12. Id. at 474 .

13. Id.; see 28 U.S.C. § 1292(b) (1976). 
The Supreme Court in Coopers $\mathcal{E}$ Lybrand also indicated by way of dicta that an order granting class certification is not appealable as a final decision. ${ }^{14}$ Previously at least one appellate court had allowed immediate review under the "reverse death knell" doctrine when the order required the nonclass party to spend tremendous amounts of time and money before seeking review of the class certification. ${ }^{15}$ The degree of finality of such an order seems even lower, however, than that of an order denying class certification, since it advances rather than potentially terminates the action ${ }^{16}$ and does not have the effect of putting some parties, for example, potential plaintiff class members, out of court. In addition, requiring the reviewing court to examine in each case the practical effect of a trial court's order on the ability and incentive of the party opposing the class to continue the suit would again place too great a strain on the administration of the judicial system. ${ }^{17}$

b. Overextension of Power. An order granting or denying class certification may be subject to interlocutory review to confine a court to the strictures of Rule 23 of the Federal Rules of Civil Procedure or relevant statutes affecting class certification. Such review, traditionally through mandamus, will be available only where the trial court ruling constitutes a "usurpation of power" or an "indisputable" abuse of discretion. ${ }^{18}$ The right to the writ must be clear. ${ }^{19}$ Thus, interlocutory appeal has been allowed when the class certification was inconsistent with special provisions of the Fair Labor Standards Act, under which the suit was brought, ${ }^{20}$ and when the certification improperly denied class members their rights to notice and to "opt out." 21 Repeated error in class certification has also been mentioned by one court issuing mandamus to vacate such an order. ${ }^{22}$

c. Certification. The Supreme Court has in dicta endorsed certified interlocutory appeal of class decertification orders under 28 U.S.C. $\S 1292(b) .{ }^{23}$ Some pre-

14. "[T]he Courts of Appeals have correctly concluded that orders granting class certification are interlocutory." 437 U.S. at 476.

15. See, e.g., Herbst v. International Tel. \& Tel. Corp., 495 F.2d 1308 (2d Cir. 1974).

16. Schickle \& Gersinger, Interlocutory Appeals Pursuant to 28 U.S.C. $\S 1292(b)$ and Their Use in Class Actions: Discretion Displaces the Death Knell, 15 U.S.F.L. REv. 321,332 (1981).

17. See supra text accompanying note 11 .

18. J.H. Cohn \& Co. v. American Appraisal Assocs., 628 F.2d 994, 998 (7th Cir. 1980) (refusing mandamus to force class certification). See also Bauman v. United States Dist. Ct., 557 F.2d 650 (9th Cir. 1977) (refusing mandamus to delete certain conditions in the class certification order); Sperry Rand Corp. v. Larson, 554 F.2d 868 (8th Cir. 1977). Even while refusing mandamus, however, and declining to engage in "in-depth" examination, Cohn, 628 F.2d at 998, courts do give some consideration to the propriety of the decision below. See, e.g., Spery, 554 F.2d 868. Cf. supra $\S 15$ of this Interlocutory Restatement, note 48 and accompanying text; see generally supra $\S 12$ of this Interlocutory Restatement, note 35 and accompanying text.

19. J.H. Cohn \& Co. v. American Appraisal Assocs., 628 F.2d 994; 997 (7th Cir. 1980).

20. Schmidt v. Fuller Brush Co., 527 F.2d 532, 535 (8th Cir. 1975). The provision of the Fair Labor Standards Act at issue is codified at 29 U.S.C. $\$ 216(\mathrm{~b})$ (Supp. V 1981).

21. Green v. Occidental Petroleum Corp., 541 F.2d 1335, 1338-39 (9th Cir. 1976).

22. McDonnell Douglas Corp. v. United States Dist. Ct., 523 F.2d 1083, 1087 (9th Cir. 1975) (also language that the certification order was "inconsistent with any tenable interpretation of Rule 23"). Such "supervisory" use of mandamus is discussed supra $\S 12$ of this Interlocutory Restatement, notes 25-27 and accompanying text.

23. Coopers $\mathcal{E}^{\circ}$ Lybrand, 437 U.S. at 475. Appellate courts approve of interlocutory appeals of both grants and denials of class certification pursuant to 28 U.S.C. $\$ 1292(\mathrm{~b})$. See DeMasi v. Weiss, 669 F.2d 114 , 119 (3d Cir. 1982); In re Alleghany Corp., 634 F.2d 1148, 1151 (8th Cir. 1980). The statute should be applied in the same manner in both instances because the appropriateness of certified appeal depends not 
vious appellate opinions had indicated that this statute presented the proper (and exclusive) avenue to immediate review, ${ }^{24}$ and in the wake of Coopers $\mathscr{G}^{2}$ Lybrand more courts are adopting this position. ${ }^{25}$ Only the exceptional class certification determination will warrant review pursuant to 28 U.S.C. $§ 1292(\mathrm{~b}),{ }^{26}$ however; and the cases most likely to meet the statutory requirements ${ }^{27}$ are those presenting novel issues or issues which have been resolved in conflicting ways by different courts. $^{28}$ The reluctance of courts to entertain certified interlocutory appeals presenting unresolved, complex issues of fact ${ }^{29}$ may foreclose review of many class certification determinations because procedural rules recommend that that issue be resolved early in the litigation ${ }^{30}$ when factual issues thus may not be sufficiently resolved for review. ${ }^{31}$

Illustration 30-1. More than a thousand separate product liability actions seeking compensatory and punitive damages are filed across the nation, including several hundred in one district. Defendants move in that district to certify the class of all plaintiffs seeking punitive damages, although most of those unnamed parties have no "minimum contacts" with the forum state. Relying heavily on the authority of commentators, the district court certifies the requested national class. The order may properly be certified for interlocutory appeal under 28 U.S.C. § 1292(b) because application of the minimum contacts doctrine to unnamed members of a plaintiffs' class is a troublesome and unresolved issue as to which there is substantial ground for difference of opinion and because affirmation of the class certification will save judicial energy and lead to more settlements. ${ }^{32}$

d. Effect of Denying Injunction. Some appellate courts once held certain orders

upon the status of the aggrieved party as class proponent versus class opponent but on the nature of the issues presented. See text infra.

24. See, e.g., Kramer v. Scientific Control Corp., 534 F.2d 1085 (3d Cir. 1976); Parkingson v. April Indus., 520 F.2d 650, 660 (2d Cir. 1975) (Friendly, J., concurring).

25. See, e.g., DeMasi v. Weiss, 669 F.2d 114, 119 (3d Cir. 1982); In re Alleghany Corp., 634 F.2d 1148, 1151 (8th Cir. 1980) ("Mandamus is an improper vehicle to obtain review of the class action certification ....").

26. For class certification orders meeting the statutory standards, see Deposit Guar. Nat'l Bank v. Roper, 445 U.S. 326, 329-31 (1980); Alabama v. Blue Bird Body Co., 573 F.2d 309 (5th Cir. 1978); Lunsford v. United States, 570 F.2d 221 (8th Cir. 1977); Unger v. Dunkin' Donuts of Am., 531 F.2d 1211 (3d Cir. 1976); Zahn v. International Paper Co., 569 F.2d 1033 (2d Cir. 1972); In re "Dalkon Shield" IUD Prods., 526 F. Supp. 887, 919 (N.D. Cal. 1981); Marks v. San Francisco Real Estate Bd., 69 F.R.D. 353 (N.D. Cal. 1975).

Recent cases refusing to certify for interlocutory appeal orders determining class certification issues include Letson v. Liberty Mut. Ins. Co., 31 Fed. R. Serv. 2d (Callaghan) 1497 (N.D. Ga. 1981); Arth Main St. Drugs v. Beer Distrib., 26 Fed. R. Serv. 2d (Callaghan) 91 (N.D. Ind. 1978); Mead v. United States Fidelity \& Guar. Co., 25 Fed. R. Serv. 2d (Callaghan) 743 (D. Minn. 1978); In re Folding Carton Antitrust Litig., 75 F.R.D. 727 (E.D. Ill. 1977).

27. See supra $\S 11$ of this Interlocutory Restatement.

28. See, e.g., Anschul v. Sitmar Cruises, 544 F.2d 1364, 1368 (7th Cir. 1976) (to be certified under 28 U.S.C. $§ 1292$ (b) questions of class status must be "unprecedented and difficult").

29. See, e.g., Slade v. Shearson, Hammill \& Co., 517 F.2d 398, 403 (2d Cir. 1974). See also supra $\$ 11$ of this Interlocutory Restatement, note 20 and accompanying text.

30. See FED. R. CIV. P. 23(c)(1).

31. See Schickle \& Gersinger, supra note 16 , at 362

32. In re "Dalkon Shield" IUD Prods., 526 F. Supp. 887 (N.D. Cal. 1981). 
denying class certification immediately reviewable under 28 U.S.C. $§ 1292(a)(1)$ as denials of injunctive relief; ${ }^{33}$ however, this grounds for appeal has now been limited, if not eliminated, by the Supreme Court. ${ }^{34}$ The rationale of these previous cases was that, when an injunction was the heart of the relief sought, the refusal to certify a class limited the scope of equitable relief to that to which the individual plaintiff was entitled and denied the broad injunction that would have been available to the class. ${ }^{35}$ Section 1292(a)(1), however, the Supreme Court held, was meant to be a narrow exception to the rule of finality, keyed to the need to allow challenge of interlocutory orders that could have serious and possibly irreparable consequences. $^{36}$ Thus, an order allegedly "equivalent" to a denial of injunctive relief was to be appealable only when that purpose would be servied. ${ }^{37}$ A denial of class certification, to the contrary, generally will be subject both to modification by the trial judge and to review after final decision. ${ }^{38}$ Furthermore, such an order does not touch on the merits of any claim for injunctive relief. ${ }^{39}$

e. Incidental Review. A ruling as to class certification may receive immediate review in conjunction with appellate consideration of an order, such as an injunction, properly subject to interlocutory appeal, when the two determinations are sufficiently interrelated. ${ }^{40}$ When an order, however, both includes a final decision, such as a dismissal or summary judgment, and determines a class certification issue, the latter ruling, although technically within the appellate court's jurisdiction, ${ }^{41}$ will not be reviewed if the final decision is reversed or vacated and the case is remanded. ${ }^{42}$ Reviewing the class certification determination in such a case lengthens the litigation unnecessarily and potentially wastes judicial resources because on remand the litigation may continue to an end without requiring review of the class certification order. ${ }^{43}$ Remanding a case after a final decision places the

33. E.g., Smith v. Merchants \& Farmers Bank, 574 F.2d 982, 983 (8th Cir. 1978); Jones v. Diamond, 519 F.2d 1090, 1095-97 (5th Cir. 1975).

34. Gardner v. Westinghouse Broadcasting Co., 437 U.S. 478 (1978). See also Carson v. American Brands, Inc., 450 U.S. 79 (1981). A class certification order has since been held immediately appealable as having the effect of an injunction in In re Federal Skywalk Cases, 680 F.2d 1175 (8th Cir.), cert. denied, 103 S. Ct. 342 (1982), but there the establishment of a federal class had the effect of halting a number of state proceedings arising out of the same accident.

35. Jones v. Diamond, 529 F.2d 1090, 1096-97 (5th Cir. 1975).

36. Gardner v. Westinghouse Broadcasting Co., 437 U.S. 478, 480 (1978). See also Carson v. American Brands, Inc., 450 U.S. 79, 84 (1981).

37. Carson v. American Brands, Inc., 450 U.S. 79, 84 (1981).

38. Gardner v. Westinghouse Broadcasting Co., 437 U.S. 478, 480 (1978). See, e.g., Deposit Guar. Nat'l Bank v. Roper, 445 U.S. 326 (1980); United Airlines v. McDonald, 432 U.S. 385 (1977).

39. Gardner v. Westinghouse Broadcasting Co., 437 U.S. $478,480-81$ (1978). Cf. supra $\$ 28$ of this Interlocutory Restatement, notes 9-10 and accompanying text.

40. For a discussion of the formulations used by the various circuits in determining when such pendent review is appropriate, see generally supra $\S 12$ of this Interlocutory Restatement, notes $39-78$ and accompanying text. Specific examples of the application of this practice to class certification decisions are found id. notes 56, 60, 69-70 and accompanying text and illustration plus notes 45 and 59.

41. Weil v. Investment Indicators, Research \& Mgmt., 647 F.2d 18, 26 (9th Cir. 1981).

42. See, e.g., id. (dismissal with prejudice); Marks v. San Francisco Real Estate Bd., 627 F.2d 947 (9th Cir. 1980) (dismissal); Bowe v. First of Denver Mortgage Investors, 613 F.2d 798 (10th Cir.) (dismissal for failure to prosecute), cert. denied, 447 U.S. 906 (1980); Blake v. City of Los Angeles, 595 F.2d 1367 (9th Cir. 1979) (summary judgment); Sullivan v. Pacific Indemn. Co., 566 F.2d 445 (3d Cir. 1977) (dismissal for failure to prosecute).

43. For example, the class order is still subject to revision by the trial court. FED. R. CIV. P. 23(c)(1). 
case in the same posture as if only a class certification order had been entered; the same considerations against allowing interlocutory appeals of class certification orders apply whether or not a final decision has once been entered.

Illustration 30-2. P brings a class action against D. D's motion to decertify the plaintiff class is granted. $P$ then fails to prosecute the action, and the district court dismisses. $\mathrm{P}$ appeals. The dismissal is a final decision ${ }^{44}$ and will be reviewed; but if the appellate court vacates that decision and remands the case, it should not reach the class certification issue, which is only incidentally before the court.

\section{\$31. Involuntary Dismissal.}

AN ORDER OF INVOLUNTARY DISMISSAL IS A FINAL DECISION. AN ORDER DENYING A MOTION FOR INVOLUNTARY DISMISSAL IS REVIEWABLE ON APPEAL FROM A FINAL DECISION.

\section{COMMENT}

a. Grant of Involuntary Dismissal. An order of involuntary dismissal under Rule 41 (b) of the Federal Rules of Civil Procedure, which authorizes the district court to dismiss an action for failure of the plaintiff to prosecute or comply with the rules or any order of the court, is an appealable final decision. ${ }^{1}$ The Rule explicitly provides that "[u]nless the court in its order for dismissal otherwise specifies, a dismissal under this subdivision. . . operates as an adjudication upon the merits."2 Such an order thus determines that the defendant has prevailed, terminates the proceeding in the district court, and leaves nothing for the court to do but execute the judgment. ${ }^{3}$ An order of involuntary dismissal is appealable whether entered on motion or sua sponte ${ }^{4}$ and whether entered with or without prejudice. $^{5}$

Illustration 31-1. $\mathrm{P}$ sues $\mathrm{D}$ but then procrastinates, causing the trial date to be delayed considerably. The trial court in due course dismisses the action for failure to prosecute. $P$ appeals. The appeal should be heard because the dismissal order is a final decision: It terminates the trial court proceedings and operates as an adverse adjudication on the merits.

b. Denial of Involuntary Dismissal. An order which denies a motion for involuntary dismissal is not a final decision ${ }^{6}$ because the action will continue to determine which party will prevail. Such an order is reviewable on appeal from a final

44. See infra $\S 31$ of this Interlocutory Restatement.

1. See, e.g., Link v. Wabash R.R., 370 U.S. 626 (1962).

2. FED. R. CIV. P. 41(b).

3. Cf. Catlin v. United States, 324 U.S. 229 (1945).

4. Compare Link v. Wabash R.R., 370 U.S. 626 (1962) (involuntary dismissal entered sua sponte was a final dscision) with Garden Homes v. Mason, 249 F.2d 71 (1st Cir. 1957) (involuntary dismissal entered on defendant's motion was a final decision).

5. Allied Air Freight v. Pan Am. World Airways, 393 F.2d 441, 444 (2d Cir. 1968).

6. Pearson v. Dennison, 353 F.2d 24, 28 (9th Cir. 1965). 
decision because an erroneous denial of a motion for involuntary dismissal is a ground for reversal. The scope of review on appeal will be limited to a determination of whether the trial court abused its discretion in refusing to dismiss the action $;^{7}$ the policy in favor of deciding cases on the merits, ${ }^{8}$ especially once a decision on the merits has been reached, will elevate the standard of abuse of discretion that must be shown for a reversal.

Illustration 31-2. $\mathrm{P}$ sues $\mathrm{D}$ but then procrastinates, causing the trial date to be delayed considerably. D makes a motion to dismiss the action for failure to prosecute, but the motion is denied. D appeals. The appeal should be dismissed. The order is not a final decision since the action in the trial court must continue to determine which party will prevail.

\section{§32. Voluntary Dismissal.}

(A) AN ORDER DISMISSING AN ACTION ON THE MOTION OF THE PLAINTIFF IS A FINAL DECISION. SUCH A VOLUNTARY TERMINATION, HOWEVER, IS APPEALABLE ONLY,

(1) IF THE DISMISSAL IS WITH PREJUDICE, BY THE PLAINTIFF IF PLAINTIFF SO MOVED FOR THE EXPRESS PURPOSE OF SEEKING EXPEDITIOUS REVIEW OF A PRIOR ADVERSE INTERLOCUTORY ORDER OR DETERMINATION THAT DOES NOT ADJUDICATE A CLAIM; OR,

(2) IF THE DISMISSAL IS WITHOUT PREJUDICE,

(a) BY THE PLAINTIFF TO REVIEW THE CORRECTNESS OF ANY CONDITION IN THE ORDER WHICH SEVERELY LIMITS HIS RIGHT TO BRING A SUBSEQUENT SUIT SUBSTANTIALLY SIMILAR TO THE ONE DISMISSED, WHICH IMPOSES PATENTLY UNREASONABLE ATTORNEY FEES, OR WHICH OTHERWISE HARMS HIS SUBSTANTIAL RIGHTS, OR

(b) BY THE DEFENDANT TO REVIEW THE CORRECTNESS OF MAKING THE ORDER WITHOUT PREJUDICE TO PLAINTIFF'S RENEWAL OF THE DISPUTE.

(B) AN ORDER DENYING A MOTION FOR VOLUNTARY DISMISSAL WITH PREJUDICE IS REVIEWABLE ON APPEAL FROM A FINAL DECISION, OR ON INTERLOCUTORY APPEAL TO ENFORGE THE RIGHT OF THE PLAINTIFF TO TERMINATE HIS OWN ACTION. AN ORDER DENYING A MOTION FOR VOLUNTARY DISMISSAL WITHOUT PREJUDICE IS NONREVIEWABLE.

(C) THE FILING OF AN EFFECTIVE NOTICE OF DISMISSAL TER-

7. Link v. Wabash R.R., 370 U.S. 626, 633 (1962). The Ninth Circuit considers "misuse" a better word than "abuse" to describe the standard of review; a reversal will lie if the trial court "made a mistake." Pearson v. Dennison, 353 F.2d 24, 28 n.6 (9th Cir. 1965).

8. See Sykes v. United States, 290 F.2d 555, 557 (9th Cir. 1961). 
MINATES THE ACTION WITHOUT APPEALABLE COURT ORDER. AN ORDER REFUSING TO VACATE A NOTICE OF DISMISSAL IS A FINAL DECISION. AN ORDER VACATING SUCH A NOTICE IS REVIEWABLE ON INTERLOCUTORY APPEAL TO PROTECT A PROPER NOTICE OF DISMISSAL FROM UNLAWFUL DISTURBANCE BY THE DISTRICT COURT.

\section{COMMENT}

a. Order of Voluntary Dismissal. An order granting voluntary dismissal of an action is a final decision ${ }^{1}$ because it terminates the litigation and precludes the plaintiff from any recovery on his claim. Such an order, however, is not final if it dismisses one or more but fewer than all the claims presented in the complaint, because the action then must continue to determine who will prevail on the remaining claims. ${ }^{2}$ A designation of partial finality under Rule 54(b) of the Federal Rules of Civil Procedure ${ }^{3}$ will be improper because seldom will there be no just reason for delaying review; the defendant seeks to avoid relitigation of the dismissed claims, yet the relitigation sought to be avoided will rarely take place before the defendant has the opportunity to appeal from a later complete final decision.

In any event, as to claims voluntarily dismissed, the posture of the action is the same as if the claims had never been brought. ${ }^{4}$ The general rule is a plaintiff cannot appeal an order of dismissal which he solicited; 5 and the defendant will not be "aggrieved" in the traditional sense of having suffered an adverse determination from which to appeal. Thus, appellate review is only available when certain negative consequences attach to the voluntary dismissal.

b. Appeal by Plaintiff When Dismissal Without Prejudice; Conditional. A plaintiff who takes a voluntary dismissal and retains the right to bring another suit on the same claim has suffered no injury as a result of the action and hence cannot maintain an appeal. 6 Such an injury warranting appeal may arise, however, when the order dismisses the action upon conditions which amount to "legal prejudice" to

1. See, e.g., Denny Concrete Co. v. Missouri Portland Cement Co., 472 F.2d 1040 (8th Cir. 1973); Noonan v. Cunard S.S. Co., 375 F.2d 69 (2d Cir. 1967).

2. Note that Rule 41(a) of the Federal Rules of Civil Procedure authorizes dismissal of actions; this has been interpreted to mean that a district court cannot dismiss fewer than all of the claims presented in the complaint. Harvey Aluminum v. American Cyanamid Co., 203 F.2d 105, 108 (2d Cir.), cerl. denied, 345 U.S. 964 (1953); Smith, Kline \& French Laboratories v. A.H. Robins Co., 61 F.R.D. 24, 28-29 (E.D. Pa. 1973); 5 J. Moore, J. Lucas \& J. Wicker, Moore's Federal Practice I 41.06-1 (2d ed. 1982). Yet orders granting voluntary dismissal of less than all of the claims are common. See, e.g., Management Investors v. United Mine Workers, 610 F.2d 384 (6th Cir. 1979); Ryan v. Occidental Petroleum Corp., 577 F.2d 298 (5th Cir. 1978)

3. See supra $\S 4$ of this Interlocutory Restatement. Rule 54(b) is not necessary to finality, of course, when a voluntary dismissal as to fewer than all claims follows a disposition on the merits of the other claims. Johnston v. Cartwright, 344 F.2d 773 (8th Cir. 1965).

4. Bomer v. Ribicoff, 304 F.2d 427, 428 (6th Cir. 1962); Humphreys v. United States, 272 F.2d 411 , 412 (9th Cir. 1959); A.B. Dick Co. v. Marr, 197 F.2d 498, 502 (2d Cir.), cert. denied, 344 U.S. 878 (1952).

5. Evans v. Phillips, 17 U.S. (4 Wheat.) 73 (1819); Management Investors v. United Mine Workers, 610 F.2d 384, 393 (6th Cir. 1979); of. United States v. Proctor \& Gamble Co., 356 U.S. 677, 680 (1958).

6. Le Compte v. Mr. Chip, Inc., 528 F.2d 601, 603 (5th Cir. 1976). 
the plaintiff. ${ }^{7}$ Rule 41 (a)(2) of the Federal Rules of Civil Procedure authorizes the dismissal of actions "upon such terms and conditions as the court deems proper;" typically these conditions will impose costs and/or attorney fees on the plaintiff" or, in the case of dismissal without prejudice, limit the circumstances under which the plaintiff can bring a similar, subsequent action. ${ }^{10}$ Where the conditions imposed are so severely adverse to the plaintiff as to amount to "legal prejudice," however, and the plaintiff has not acquiesced to such conditions, the order is appealable; the plaintiff has not received a "voluntary dismissal" in the sense he requested and the order, if erroneous, will be reversed." For example, "legal prejudice" has been found when the conditions to a dismissal required that any subsequent suit be brought in the same court, that plaintiff show extraordinary circumstances to justify reopening the case, and that plaintiff affirmatively demonstrate to the court's satisfaction that a valid cause of action could be maintained.'2 The imposition of patently unreasonable attorneys fees has also occasioned review and reversal. ${ }^{13}$

Administration of plaintiff appeals challenging conditions of dismissal exemplifies the endemic confusion surrounding the distinction between jurisdictional and nonjurisdictional dispositions. Courts have dismissed appeals from voluntary dismissals when they have found the detriment to the plaintiff to be less than a "legal prejudice," i.e., not reversible error, ${ }^{14}$ yet have taken jurisdiction to reverse when the appeal has had merit. This practice seems clearly misguided. Given the finality of the disposition and the fact that either way the decision is in reality reviewed on the merits, no purpose is served by concealing that reality in the language of lack of appellate jurisdiction when a court means to affirm a dismissal. ${ }^{15}$

Illustration 32-1. $\quad \mathrm{P}$ files an antitrust action. $\mathrm{P}$ thereafter files the same action in another district and moves to take a voluntary dismissal of the first action. The court grants his motion subject to the condition that $P$ promise not to bring yet a third action in yet another district. P appeals, challenging the legality of the condition imposed upon him. The appeal should be heard and result in an affirmation of the district court's order. The conditional order is final and $\mathrm{P}$ has standing to challenge the condition; the condition is, however, not unreasonable and imposes no "legal prejudice" on $\mathrm{P}$.

7. Le Compte v. Mr. Chip, Inc., 528 F.2d 601 (5th Cir. 1976).

8. FED. R. Clv. P. 41 (a) (2)

9. See, e.g., Yoffe v. Keller Indus., 580 F.2d 126 (5th Cir. 1978), cert. denied, 440 U.S. 915 (1979).

10. See, e.g., Le Compte v. Mr. Chip, Inc., 528 F.2d 601 (5th Cir. 1976). Le Comple catalogs other conditions typically imposed: that plaintiff produce documents; that plaintiff covenant not to sue; that plaintiff produce certain witnesses at trial. Id. at 603.

11. Id. at 604 .

12. Id.

13. Yoffe v. Keller Indus., 580 F.2d 126 (5th Cir. 1978) (dictum), cert. denied, 440 U.S. 915 (1979). The court also indicated in dictum that in such a case review may be obtained by means of a prerogative writ. Id. at 131 .

14. E.g., id.

15. A similar practice has sometimes been followed as to review of orders denying intervention. See supra $\S 29$ of this Interlocutory Restatement, notes 34-38 and accompanying text. 
c. Appeal by Plaintiff When Dismissal with Prejudice. A plaintiff who takes a voluntary dismissal with prejudice such that any subsequent action on his claims will be barred may not seek review. ${ }^{16}$ The order is not adverse to him as he has received what he sought, and he should not be heard to complain.

An appeal by the plaintiff is allowed when voluntary dismissal is solicited for the purpose of obtaining review of a prior adverse interlocutory order. ${ }^{17}$ The plaintiff thus risks an adverse judgment on his entire complaint in order to seek expeditious review of an order otherwise appelable only after final decision. If the appeal fails the plaintiff has sacrificed his claim on the merits. ${ }^{18}$

The benefits of this maneuver cannot be denied. ${ }^{19}$ Under certain circumstances an interlocutory order may, from a tactical standpoint, be virtually dispositive of the outcome of the litigation yet be nonreviewable prior to appeal from a final decision. For example, an interlocutory discovery order might preclude a plaintiff from lawful access to available evidence indispensable to his case. ${ }^{20}$ Pursuing the claim to judgment before raising the discovery issue on appeal might be wasteful, yet violating the discovery order to gain its immediate review would generally require the plaintiff to accept punishment for criminal contempt. ${ }^{21} \mathrm{By}$ taking a voluntary dismissal, the plaintiff avoids both those evils. ${ }^{22}$ Because of the risk to the merits of the claim, however, it follows that only where the issue to be reviewed is highly dispositive and where the plaintiff deems reversal highly likely will a plaintiff be inclined to take a voluntary dismissal.

Illustration 32-2. $\mathrm{P}$ brings a civil antitrust action against $\mathrm{D}$. Before trial both parties file for summary judgment. The trial court denies both motions in an order that also indicates that the relevant market for purposes of P's claim is the "franchise market" and not the "concession market" as $\mathrm{P}$ contends. $\mathrm{P}$ informs the court that its determination of the relevant market effectively terminates the litigation for him; and he requests, and receives, a voluntary dismissal with prejudice so he can appeal the order denying summary judgment, which is clearly interlocu-

16. Cf. Raceway Properties v. Empire Corp., 613 F.2d 656 (6th Cir. 1980). The appealability of such orders actually is not well settled because rarely are they handed down outside of the context of dismissals taken to review prior adverse interlocutory orders, to be discussed infra. Other dismissals with prejudice, such as those for failure to prosecute under Rule $41(\mathrm{~b})$ of the Federal Rules of Civil Procedure, are to be distinguished as being involuntary and thus appealable. See supra $\$ 31$ of this Interlocutory Restatement.

17. United States v. Proctor \& Gamble Co., 356 U.S. 677 (1958); Raceway Properties v. Empire Corp., 613 F.2d 656 (6th Cir. 1980) (note that the existence of a prior adverse interlocutory order will require that the dismissal be with prejudice)

18. Cf. infra note 30 and accompanying text.

19. Note, however, that an order relating to class certification may not be reviewed in a plaintiff's appeal from a subsequent voluntary dismissal order; either the voluntary dismissal will be affirmed, or, alternatively, it will be vacated or reversed and the case will be remanded without reviewing the class certification order. See supra $\$ 30$ of this Interlocutory Restatement, comment $e$.

20. See infra $\$ \S 37 \& 38$ of this Interlocutory Restatement for a discussion of appealibility of such orders.

21. See supra $\S 23$ of this Interlocutory Restatement for a discussion of the appealability of contempt sanctions and infra $\S 39$ of this Interlocutory Restatement for a discussion of the appealability of other discovery sanctions.

22. It also keeps the attorney from suffering a contempt sanction at his client's expense. By taking voluntary dismissal, only the client and not the attorney takes a substantial risk. 
tory and not otherwise subject to immediate review. ${ }^{23}$ Though $\mathrm{P}$ solicited the dismissal, and thus has suffered no ruling adverse to what he sought, the appeal should be entertained. If $\mathrm{P}$ is willing to risk his case on the merits to secure review, it is in the interest of efficient judicial administration to permit him to do so.

This maneuver has also been used to gain immediate review of a dismissal of one or more but fewer than all of the claims presented in a multi-claim complaint. $^{24}$ If, for example, a plaintiff brings an action in three counts against a defendant and the defendant successfully moves to have the first two claims stricken, some courts will allow the plaintiff to take a voluntary dismissal on the remaining count and appeal. This practice, however, has properly been rejected by other courts ${ }^{25}$ because it allows a plaintiff to circumvent the authority of a district judge under Rule 54(b) of the Federal Rules of Civil Procedure to determine when such a partial dismissal shall be a partial final decision, and thus appealable, because "there is no just reason for delay." 26 The clear language of the rule indicates that in the absence of such designation a decision adjudicating fewer than all of the claims shall not terminate the action. Courts rejecting such attempts to circumvent Rule 54(b) hold either that voluntary dismissal should be refused when the interlocutory order sought to be reviewed is a partial final decision not so designated by the district judge $\mathrm{j}^{27}$ or, in the alternative, that appeals from such voluntary dismissals should be dismissed. ${ }^{28}$

Illustration 32-3. $\mathrm{P}$ sues $\mathrm{D}$ in two counts, the first under a federal statute and the second under federal common law. The court grants a motion to dismiss the common law count for failure to state a claim on which relief can be granted. The court refuses to designate partial finality. $\mathrm{P}$ asks the court to enter a voluntary dismissal order on the remaining statutory count so that he can take an appeal to review the disposition of the common law count. If the trial court enters the voluntary dismissal order, P's appeal should be dismissed because he has attempted indirectly to accomplish what he could not do under Rule 54(b).

23. See supra $\S 28$ of this Interlocutory Restatement, comment $c$.

24. Division 241, Amalgamated Transit Union v. Suscy, 538 F.2d 1264 (7th Cir.), cert. denied, 429 U.S. 1029 (1976); Johnston v. Cartwright, 344 F.2d 773 (8th Cir. 1965). This of course assumes that dismissal of fewer than all of the claims presented in a complaint is proper under Rule 41 (a). See supra note 2. Cf. infra note 42 and accompanying text.

25. See, e.g., Management Investors v. United Mine Workers, 610 F.2d 384 (6th Cir. 1979); Ryan v. Occidental Petroleum Corp., 577 F.2d 298 (5th Cir. 1978). See also Fletcher v. Gagosian, 604 F.2d 637 (9th Cir. 1979) (notice of dismissal under Rule 41(a)(1) not appealable to obtain review of dismissal on the merits of one of two claims presented).

26. FED. R. Civ. P. 54(b). See supra $\$ 4$ of this Interlocutory Restatement.

27. See Ryan v. Occidental Petroleum Corp., 577 F.2d 298, 301-03 \& n.2 (5th Cir. 1978): "We are at a loss to explain the district court's certification [under Rule 54(b)], followed by retraction and permission of a voluntary dismissal. If the district court did not think certification appropriate, it could not properly arrive at the same result through the device of allowing a voluntary dismissal."

28. See Management Investors v. United Mine Workers, 610 F.2d 384 (6th Cir. 1979); Ryan v. Occidental Petroleum Corp., 577 F.2d 298 (5th Cir. 1978). See also Fletcher v. Gagosian, 604 F.2d 637 (9th Cir. 1979) (notice of dismissal under Rule 41(a) (1) not appealable to obtain review of dismissal on the merits of one of two claims presented) 
d. Appeal by Defendant When Dismissal Without Prejudice. A defendant will prefer that a voluntary dismissal be with prejudice ${ }^{29}$ so that the plaintiff will be precluded from relitigating the same claim in a subsequent proceeding; ${ }^{30}$ thus, a defendant may appeal a dismissal order to contend for prejudice. ${ }^{31}$ A defendant similarly may on final decision appeal an order voluntarily dismissing without prejudice fewer than all claims presented. ${ }^{32}$

Illustration 32-4. $\mathrm{P}$ sues D in district $\mathrm{X}$. Before trial, $\mathrm{P}$ sues D on the same claim in district $\mathrm{Y}$ and moves for a voluntary dismissal, without prejudice, of the action in district X. P's motion is granted. D appeals. The appeal should be entertained. The dismissal is final and adverse as to $\mathrm{D}$ because $\mathrm{P}$ is free to renew his claims.

The scope of review of an appeal by a defendant is limited to whether the trial court abused its discretion by entering the dismissal without prejudice. ${ }^{33}$ Such a dismissal should be affirmed unless the defendant can show that he will suffer some prejudice other than the prospect of subsequent relitigation. ${ }^{34}$

e. Denial of Voluntary Dismissal. An order denying a motion for voluntary dismissal is not final. ${ }^{35}$ If the denial is without prejudice, it is not subject to interlocutory appeal because there is no substantial interest to be protected by such review. On the other hand, if the denial is with prejudice, there is a possibility of interlocutory review to protect the right of the plaintiff to control the complete termination of his own action. ${ }^{36}$

Illustration 32-5. P brings a defamation action. $\mathrm{D}$ engages in extensive discovery, seeking evidence of the truth of the allegedly defamatory statements admittedly made by him. P moves for a voluntary dismissal with prejudice but $\mathrm{D}$ resists, seeking an opportunity to prove the truth of his statements. The district court denies the motion to dismiss, and $P$ appeals. The appeal should be entertained to consider the merit of P's contention that his right to control his own litigation has been violated by the court's order.

f. Notice of Dismissal. A properly filed notice of dismissal under Rule 41(a)(1)(i) of the Federal Rules of Civil Procedure is not reviewable by either party $^{37}$ as it automatically terminates the lawsuit. No action by the court is neces-

29. The court can order dismissal with prejudice. FED. R. CIV. P. 41 (a) (2).

30. See REstatement (SECOND) OF Judgments $§ 19$ (1982).

31. E.g., Denny Concrete Co. v. Missouri Portland Cement Co., 472 F.2d 1040 (8th Cir. 1973); Stern v. Barnett, 452 F.2d 211 (7th Cir. 1971).

32. See, e.g., Purer \& Co. v. Aktiebolaget Addo, 410 F.2d 871, 879 (9th Cir.), cert. denied, 396 U.S. 834 (1969); of. Johnston v. Cartwright, 355 F.2d 32 (8th Cir. 1966). See also discussion supra notes 2-3 and accompanying text.

33. See Denny Concrete Co. v. Missouri Portland Cement Co., 472 F.2d 1040, 1041 (8th Cir. 1973).

34. Stern v. Barnett, 452 F.2d 211, 213 (7th Cir. 1971); Johnston v. Cartwright, 355 F.2d 32, 39 (8th Cir. 1966). Cf. supra $\S 16$ of this Interlocutory Restatement, note 61 and accompanying text (and additional subsections cross-referenced therein).

35. Larsen v. Switzer, 183 F.2d 850 (8th Cir. 1950); Federal Sav. \& Loan Ins. Corp. v. Reeves, 148 F.2d 731 (8th Cir. 1945).

36. Smoot v. Fox, 340 F.2d 301 (6th Cir. 1964) (using mandamus).

37. See American Cynamid Co. v. McGhee, 317 F.2d 295, 297 (5th Cir. 1963) ("There is nothing the 
sary to effect the dismissal. ${ }^{38}$

A defendant may, however, challenge an improperly filed notice of dismissal ${ }^{39}$ by moving the district court to vacate such notice. If the district court refuses, the defendant can appeal; ${ }^{40}$ the denial of vacatur apparently will be deemed a final decision because the defendant is without further recourse in the district court. If a vacatur order is improperly entered (that is, plaintiff was entitled to dismiss under Rule 4l(a)(1)(i)), such vacatur is reviewable by the plaintiff as an order of the district court made without jurisdiction since the action should have been dismissed ${ }^{41}$ The vacatur order will be reversed, and the litigation will be terminated. Where the vacatur order is properly entered, however, the district court had jurisdiction to enter the vacatur and the order will be affirmed on appeal, causing the action to be remanded for further proceedings.

The practice of filing a notice of dismissal under Rule 41(a)(1)(i) in order to seek immediate review of a prior district court order dismissing one or more but fewer than all of the claims presented has been rejected. ${ }^{42}$ Such a procedure is inappropriate because of the absence of prejudice accompanying a dismissal by notice. Moreover, the notice of dismissal must be filed within time limits that virtually preclude the possibility of an adverse order prior to filing.

\section{§33. Default Judgments.}

(A) AN ORDER ENTERING A DEFAULT JUDGMENT OR REFUSING TO SET ASIDE A DEFAULT JUDGMENT PREVIOUSLY ENTERED IS A FINAL DECISION IF COMPLETE WITH RESPECT TO ALL CLAIMS AND PARTIES; SUCH AN ORDER THAT IS LESS THAN COMPLETE IS REVIEWABLE AS A PARTIAL FINAL DECISION IF SO DESIGNATED BY THE DISTRICT COURT BUT OTHERWISE IS REVIEWABLE ONLY ON APPEAL FROM A FINAL DECISION OR ON CERTIFIED APPEAL.

(B) AN ORDER REFUSING TO ENTER A DEFAULT JUDGMENT OR GRANTING A MOTION TO SET ASIDE A DEFAULT JUDGMENT PRE-

defendant can do to fan the ashes of that action into life and the court has no role to play. . . Its alpha and omega was the doing of the plaintiff alone."). Presumably a plaintiff does not desire immediate review of his notice of dismissal unless it is contested by the defendant.

38. Thorp v. Scarne, 599 F.2d 1169, 1171 n.1 (2d Cir. 1979). But see Fletcher v. Gagosian, 604 F.2d 637, 638-39 (9th Cir. 1979). In that case the court held that after one of two counts had been dismissed on the merits, plaintiff could not obtain review of that ruling by filing a notice of dismissal and appealing the notice as a final order. Id. Although the court was more concerned with the effect of such a maneuver in relation to Rule 54(b) (see supra notes 24-28 and accompanying text), it indicated that a notice of dismissal is not effective as an appealable order without some judicial participation. Id.

39. For example, the plaintiff may attempt to file a notice of dismissal after the defendant has answered. FED. R. CIV. P. 41(a)(1)(i).

40. Cf. Harvey Aluminum v. American Cyanamid Co., 203 F.2d 105 (2d Cir.), cert. denied, 345 U.S. 964 (1953).

41. Thorp v. Scarne, 599 F.2d 1169, $1171-1172$ (2d Cir. 1979); Littman v. Bache \& Co., 246 F.2d 490, 492 (2d Cir. 1957); e.g., D.C. Elecs. v. Nartron Corp., 511 F.2d 294 (6th Cir. 1975). Cf. infra $\$ 42$ of this Interlocutory Restatement, notes 20-23 and accompanying text; infra $\S 43$ of this Interlocutory Restatement, notes 6-8 and accompanying text.

42. Fletcher v. Gagosian, 604 F.2d 637 (9th Cir. 1979). Cf. supra comment $c$ 


\section{VIOUSLY ENTERED IS REVIEWABLE ON APPEAL FROM A FINAL DEGISION OR ON CER TIFIED APPEAL.}

\section{COMMENT}

a. Orders Granting or Refusing to Set Aside Default Judgments. A judgment by default has the same degree of finality ${ }^{1}$ as a judgment based on a jury verdict; each determines which party has prevailed and the amount of damages ${ }^{2}$ and leaves only execution of the judgment for the district court. ${ }^{3}$

An order denying a motion to set aside a default judgment is technically an order made after a final decision (the default judgment) which does not affect the prior decision's finality. ${ }^{4}$ Such an order is treated as an appealable final decision ${ }^{5}$ because it leaves the case in the same posture as if no motion to set aside had been made; hence it is equivalent to the default judgment itself.

When a case involves multiple claims or parties, a default judgment resolving one or more but fewer than all of the claims is not a final decision. ${ }^{6}$ The order must be designated as a partial final decision by the district court under Rule 54(b) of the Federal Rules of Civil Procedure to be subject to immediate review. ${ }^{7}$ Similarly, an order denying a motion to set aside a default judgment not complete with respect to all claims and parties is not a final decision because it does not affect the pending claims yet to be adjudicated. Such an order also must be designated as a partial final decision under Rule 54(b) to be reviewable prior to a final decision.

An order entering a default judgment not complete with respect to all claims or parties is reviewable on appeal from a final decision because error in such an order is a ground for reversal. Furthermore, a less-than-complete order of default judgment may be certified for interlocutory review pursuant to 28 U.S.C. $§ 1292$ (b) in those instances where the controlling question is one of law rather than, as is more likely, one of fact. ${ }^{8}$

Illustration 33-1. $\quad \mathrm{P}$ sues D1 and D2. D1 fails to defend the action, and the trial court enters a default judgment against D1. D1 appeals. The

1. The finality is not affected by the express provision in Rule 55 (c) of the Federal Rules of Civil Procedures that a default judgment may be set aside. FED. R. CIV. P. 60(b).

2. See FED. R. CIV. P. 55(b).

3. See Fed. R. Civ. P. 58. Cf. Catlin v. United States, 324 U.S. 229 (1945). See generally 15 C. Wright, A. Miller \& E. Cooper, Federal Practice and Procedure $\$ 3914$ (1976).

4. FED. R. CIV. P. 60(b)

5. See, e.g., Medunic v. Lederer, 533 F.2d 891 (3d Cir. 1976); Gomes v. Williams, 420 F.2d 1364 (10th Cir. 1970). See also Weedon v. Gaden, 419 F.2d 303 (D.C. Cir. 1969) (order refusing to vacate default judgment appealable as a final decision).

6. See supra $\S 4$ of this Interlocutory Restatement

7. See, e.g., United States v. Peerless Ins. Co., 374 F.2d 942 (4th Cir. 1967); Davis v. National Mortgage Corp., 349 F.2d 175 (2d Cir. 1965); Ferguson v. Bartels Brewing Co., 284 F.2d 855 (2d Cir. 1960).

8. Cf. Anderson v. Air West, Inc., 542 F.2d 1090, 1091-92 (9th Cir. 1976) (certified question whether court abused its discretion by imposing a default judgment and striking certain defenses as sanctions for failure to comply with a discovery order). For a discussion of the requirements for certification, see supra $\S 11$ of this Interlocutory Restatement. There may be some question, however, as to the propriety of appeal under 28 U.S.C. $\$ 1292(b)$ when a designation of partial finality may also be available. See id. note 15. 
appeal should be dismissed absent certification under 28 U.S.C. $\S 1292$ (b) or designation as a partial final decision. The default judgment is not a final decision because the claim against D2 remains before the court. The result is the same if Dl files a motion in the trial court to vacate the default judgment and seeks to appeal when that motion is denied.

Whether a default judgment is reviewed on direct appeal or on appeal from an order refusing to set it aside, the issue is whether the trial court erred in finding that the default was not the result of excusable neglect, mistake, inadvertence, or surprise. ${ }^{9}$ The discretion of the district court is to be narrowly construed, that is, where there is doubt as to whether the default judgment was properly entered, it should be vacated and remanded to allow the case to proceed to the merits. ${ }^{10}$

b. Orders Denying or Setting Aside Default Judgments. An order denying a motion to enter a default judgment or granting a motion to set aside a default judgment is not a final decision ${ }^{11}$ because in either case the action must continue to determine which party will prevail. Such an order is reviewable by the plaintiff on appeal from a final decision for the defendant since a determination that a default judgment should have been entered is a ground for reversal. Although such review is rarely sought, the few reported cases on point suggest that a district court's refusal to enter or set aside a default judgment must be clearly erroneous to be overturned on appeal ${ }^{12}$ because a trial court is in a better position than an appellate court to judge whether a defendant has failed to plead or otherwise defend an action. Certified interlocutory appeal pursuant to 28 U.S.C. $\$ 1292(\mathrm{~b})$ is again possible, although unlikely, because the correctness of denial of a default judgment turns largely on factual determinations, such that the required controlling questions of law will seldom be presented. ${ }^{13}$

Illustration 33-2. P sues D. D appears but fails to make a timely answer, and $\mathrm{P}$ files a motion for default judgment. The motion is denied, and $\mathrm{P}$ appeals. The appeal should be dismissed because the order by its very nature indicates that the action should continue. The result would be the same if the motion had been granted but then vacated. In either case the trial court would have ruled that the parties should continue the litigation.

c. Entry of Default. Entry of default by the clerk is interlocutory because, by

9. FED. R. CIV. P. 55(c), 60(b)

10. Medunic v. Lederer, 533 F.2d 891, 893-94 (3d Cir. 1976); Pulliam v. Pulliam, 478 F.2d 935,936 (D.C. Cir. 1973); Tolson v. Hodge, 411 F.2d 123, 130 (4th Cir. 1969); Rooks v. American Brass Co., 263 F.2d 166, 169 (6th Cir. 1959).

11. See, e.g., McNutt v. Cardox Corp., 329 F.2d 107 (6th Cir. 1964) (order denying motion for default judgment not appealable); Edwin Raphael Co. v. Maharam Fabrics Corp., 283 F.2d 310 (7th Cir. 1960) (order vacating default judgment interlocutory); see also Alexander v. Pacific Maritime Ass'n, 332 F.2d 266 (9th Cir. 1969) (order refusing to impose sanction of default interlocutory).

12. See Edwin Raphael Co. v. Maharam Fabrics Corp., 283 F.2d 310, 311 (7th Cir. 1960)

13. For a discussion of the requirements for certification, see supra $\S 11$ of this Interlocutory Restatement. But of. Anderson v. Air West, Inc., 542 F.2d 1090, 1091-92 (9th Cir. 1976). 
itself, it has no bearing on the outcome of the litigation. ${ }^{14}$ No judgment is entered by entry of default; ${ }^{15}$ on the contrary, the action continues, and a defendant against whom default is entered may prevail. Accordingly, there is no appellate review of any trial court order relating to entry of default either as a final decision or on interlocutory appeal. ${ }^{16}$ Furthermore, review of such an order on appeal from a final decision, although technically within appellate jurisdiction, is extremely unlikely because any error by the trial court relating only to entry of default will be harmless. That the clerk erroneously made or failed to make a default entry or that the trial court erroneously granted or denied a motion to set aside entry of default is not a ground for reversal.

Illustration 33-3. P sues three defendants, D1, D2, and D3, asserting one claim against each. D1, D2, and D3 each file answers and affirmative defenses, but D3 fails to appear at scheduled pretrial hearings. The court, on P's motion, orders the clerk to make an entry of default against D3 and, in addition, strikes D3's answer and affirmative defense and refers the case to a U.S. magistrate to determine damages. D3 appeals. The appeal should be dismissed. The order is not reviewable because it provides only for entry of default. ${ }^{17}$

E. Review of Orders Regarding Counsel

$\S 34$. Appointment of Counsel.

(A) AN ORDER APPOINTING COUNSEL FOR AN INDIGENT PARTY IS NONREVIEWABLE.

(B) AN ORDER REFUSING TO APPOINT COUNSEL FOR A PARTY CLAIMING INDIGENCY IS REVIEWABLE ON APPEAL FROM A FINAL DECISION, ON CERTIFIED APPEAL, OR ON INTERLOCUTORY APPEAL TO ENFORCE A RIGHT TO COUNSEL SPECIFICALLY PROVIDED BY CONTROLLING LEGISLATION.

\section{COMMENT}

a. Orders of Appointment. An order appointing counsel, generally pursuant to the in forma pauperis provision of 28 U.S.C. $\S 1915(\mathrm{~d})^{1}$ or the employment discrimination provision of 42 U.S.C. $\S 2000 \mathrm{e}-5(\mathrm{f})(1)(\mathrm{B}),{ }^{2}$ is nonreviewable. ${ }^{3}$

14. See FED. R. Civ. P. 55(a)

15. Rule 55 of the Federal Rules of Civil Procedure distinguishes entry of default (Rule 55(a)) and default judgment (Rule 55(b)); after entry of default, the clerk, or the court on the motion of a party, must take an additional step to enter a default judgment.

16. See Baker v. Limber, 647 F.2d 912 (9th Cir. 1981)

17. See id.

1. This section provides that in a civil case, "[t]he court may request an attorney to represent any such person unable to employ counsel and may dismiss the case if the allegation of poverty is untrue, or if satisfied that the action is frivolous or malicious." 28 U.S.C. $\$ 1915$ (d) (1976).

2. This section, part of Title VII of the Civil Rights Act of 1964 , provides in part that, "|ulpon application by the complainant and in such circumstances as the court may deem just, thc court may appoint an attorney for such complainant and may authorize the commencement of the femployment discrimination/ action without the payment of fees, costs or security." 42 U.S.C. $\S 20003-5(f)(1)(B)(1976)$. 
b. Refusal to Appoint. An order denying a motion for the appointment of counsel is not a final appealable decision within 28 U.S.C. $\S 1291 .^{4}$ Review is available on final decision for abuse of discretion, ${ }^{5}$ and improper failure to appoint will be reversible error. ${ }^{6}$ It is generally recognized that many pro se plaintiffs, denied counsel and unable to obtain interlocutory appeal, will nevertheless persevere and obtain final decisions from which appeals may then be taken. ${ }^{7}$ Although some litigants may be forced to drop otherwise meritorious claims for want of counsel, courts generally deem this consequence outweighed by the benefits of denying interlocutory appeal. ${ }^{8}$

c. Specific Right to Appointed Counsel. Interlocutory review will be available when an order denies a right to counsel asserted under legislation which both controls the substance of the litigation and specifically provides for such assistance to indigents. In those instances, trial judges will have less discretion, and immediate review is appropriate to enforce the statutory scheme. Thus, refusals of requests for counsel under 42 U.S.C. $§ 2000 \mathrm{e}-5(\mathrm{f})(1)$ (B) have been found subject to interlocutory review under the collateral order doctrine. ${ }^{9}$ Because these employment discrimination claims will have been subject to prior agency review, ${ }^{10}$ consideration of the propriety of appointing counsel may involve less entanglement with the merits. ${ }^{11}$ More importantly, this civil rights legislation represents a determination by Congress that such plaintiffs are presumptively incapable of handling the complex litigation involved ${ }^{12}$ and that expeditious vindication of their rights should be assured. ${ }^{13}$ As the House committee noted:

By including this provision $[\S 2000 \mathrm{e}-5(\mathrm{f})(1)(\mathrm{B})]$ in the bill, the Committee emphasizes that the nature of Title VII actions more often than not pits parties of unequal strength and resources against each other. The complainant, who is usually a member of a disadvantaged class, is opposed by an employer who not infrequently is one of the nation's major

3. There appear, however, to be no reported cases in which opposing counsel has attempted, at any stage of the litigation, to appeal from a court order appointing counsel pursuant to either 28 U.S.C. $\S 1915(\mathrm{~d})$ or 42 U.S.C. $\S 2000 \mathrm{e}-5(\mathrm{f})(\mathrm{l})(\mathrm{B})$.

4. See Appleby v. Meachum, 696 F.2d 145 (1st Cir. 1983) (rejecting applicability of the collateral order doctrine).

5. E.g., Slavin v. Curry, 690 F.2d 446 (5th Cir. 1982). See Appleby v. Meachum, 696 F.2d 145, 146 (1st Cir. 1983).

6. See Appleby v. Meachum, 696 F.2d 145, 146 (1st Cir. 1983).

7. See id.

8. Recognition of a right to interlocutory appeal from every denial of appointed counsel would provide a powerful incentive for trial judges to grant such motions uniformly for the sake of economy and efficiency. Such a practice might encourage judgment-proof indigents to press frivolous claims against highly solvent parties in hopes of forcing settlements.

9. See, e.g., Henry v. City of Detroit Manpower Dep't, 53 U.S.L.W. 2076 (6th Cir. July 20, 1984); Ivey v. Board of Regents of Univ. of Alaska, 673 F.2d 266, 269 (9th Cir. 1982); Bradshaw v. Zoological Soc'y, 662 F.2d 1301, 1305-14 (9th Cir. 1981); Hudak v. Curators of Univ. of Mo., 586 F.2d 105, 106 (8th Cir. 1978) (per curiam), cert. denied, 440 U.S. 985 (1979); Caston v. Sears, Roebuck \& Co., 556 F.2d 1305,1308 (5th Cir. 1977); Spanos v. Penn Cent. Transp. Co., 470 F.2d 806, 807 n.3 (3d Cir. 1972) (per curiam). For a discussion of the requirements of the collateral order doctrine, see supra $\S 12$ of this Interlocutory Restatement, notes $10-13$ and accompanying text.

10. See 42 U.S.C. $\$ 2000 \mathrm{e}-5$ (1976).

11. Bradshaw v. Zoological Soc'y, 662 F.2d 1301, 1307-08 (9th Cir. 1981). Whether the plaintiff's claim is meritless or frivolous is one factor to be considered in reviewing the denial of counsel. Il. at 1318 .

12. Id. at $1312-13$

13. Id. at 1315 . 
producers, and who has at his disposal a vast array of resources and legal talent. ${ }^{14}$

Federal courts have been unwilling to expand the right to interlocutory appeal to denial of motions for counsel taken pursuant to the in forma pauperis provisions of 28 U.S.C. $\S 1915$ (d). ${ }^{15}$ Such cases have been distinguished through the absence of a legislative determination under that provision that potential harm would be pervasive throughout the class of possible litigants such that more denials than not would warrant appeal and that expeditious review thus would be in all circumstances an overriding concern. ${ }^{16}$

d. Certification. An order refusing to appoint counsel may occasionally be suitable for certification for interlocutory appeal under 28 U.S.C. $\$ 1292\left(\right.$ b).$^{17}$ Although such a determination will usually be a matter of discretion or turn on factual disputes, ${ }^{18}$ discretion is still to be "guided by sound legal principles" such that a controlling question of law, necessary for certification, may be presented. ${ }^{19}$

\section{$\S 35$. Disqualification of Counsel.}

(A) AN ORDER DENYING A MOTION TO DISQUALIFY COUNSEL IS REVIEWABLE ON APPEAL FROM A FINAL DECISION, ON CERTIFIED APPEAL, OR ON INTERLOCUTORY APPEAL TO PROTECT A PARTY'S RIGHT TO PREVENT BREACH OF CONFIDENTIALITY BY FORMER COUNSEL.

(B) AN ORDER GRANTING A MOTION TO DISQUALIFY COUNSEL IS REVIEWABLE ON CERTIFIED APPEAL OR ON INTERLOCUTORY APPEAL TO PROTECT A PARTY'S RIGHT TO SELECT HIS COUNSEL.

\section{Comment}

a. Denial of Disqualification. The Supreme Court in Firestone Tire E Rubber Co. $v$. Risjord resolved a conflict among the circuits ${ }^{1}$ by holding that an order refusing to 2148

14. H.R. ReP. No. 238, 92d Cong., 2d Sess., reprinted in 1972 U.S. Codk ConG. \& AD. News 2137,

15. See, e.g., Appleby v. Meachum, 696 F.2d 145 (1st Cir. 1983); Randle v. Victor Welding Supply Co., 664 F.2d 1064 (7th Cir. 1981); Cotner v. Mason, 657 F.2d 1390 (10th Cir. 1981). But see Ray v. Robinson, 640 F.2d 474 (3d Cir. 1981). Robinson is the only recent case allowing interlocutory appeal pursuant to 28 U.S.C. $\$ 1915$ (d). The court, however, drew most of its support from the line of employment discrimination cases under 42 U.S.C. $\S 2000 e-5(\mathrm{f}(\mathrm{I})(\mathrm{B})$, as discussed above. Insofar as Robinson attempts to extend these holdings to cover appeals from requests for counsel pursuant to 28 U.S.C. $\S 1915$ (d), the reasoning appears to be faulty and has been specifically rejected, most recently by the Appleby court. 696 F.2d at 146 n.2.

16. Bradshaw v. Zoelogical Soc'y, 662 F.2d 1301, 1312-13 (9th Cir. 1981). See also Appleby v. Meachum, 696 F.2d 145, 146 n.2 (1st Cir. 1983).

17. See generally supra $\S 11$ of this Interlocutory Restatement.

18. For example, the factors to be considered when appointment of counsel is requested pursuant to 42 U.S.C. $\S 2000 \mathrm{e}-5(\mathrm{f})(1)(B)$ are the plaintiff's financial resources and efforts to obtain counsel and the merits of the claim. Bradshaw v. Zoological Soc'y, 662 F.2d 1301, 1318 (9th Cir. 1981). Similar factors are suggested by the language of 28 U.S.C. $\$ 1915$ (d), quoted supra note 1.

19. Cf. Bradshaw v. Zoological Soc'y, 662 F.2d 1301, 1303 (9th Cir. 1981) (issue as to effect of statutory provision for award of attorneys fees on plaintiff's claim of inability to obtain counsel; the district court actually declined to certify the question, but interlocutory review was available under the rule of comment $c$ here as the motion for appointment was made pursuant to 42 U.S.C. $\S 2000 \mathrm{e}-5(\mathrm{f})(1)(\mathrm{B}))$.

1. Prior to Firestone, five circuits had ruled that an order denying a motion to disqualify counsel was 
disqualify counsel in a civil case is not immediately appealable. ${ }^{2}$ The Court concluded that a denial of disqualification, while meeting the first two parts of the test for appealability under the collateral order doctrine, ${ }^{3}$ should not be subject to immediate review because it would not be "effectively unreviewable on appeal from final judgment."4

In addition, the Firestone Court noted that two other avenues of appeal remain open to parties seeking immediate review of orders denying disqualification of counsel. ${ }^{5}$ First, a party may seek certification for interlocutory review pursuant to 28 U.S.C. $\S 1292(\mathrm{~b})^{6}$ when the appeal will raise "an important, unresolved question of law." Second, in an extraordinary case, a party may seek a writ of mandamus. ${ }^{8}$ Courts have generally granted the writ in situations where irreparable harm could result absent immediate review, as where the moving party was faced with a potential breach of confidentiality by a former counsel in a position to provide privileged information to the opposing side. ${ }^{9}$ In such a case, even if the denial of disqualification were reversed on appeal from a final decision, it would be virtually impossible to disgorge from the opposing party the confidential information obtained from counsel and to prevent its use at retrial. Such a system would naturally erode public confidence in the attorney as a professional and in the judicial system as a whole.

b. Grant of Disqualification. Although the Supreme Court in Firestone specifically reserved the question of the immediate appealability of grants of disqualification of counsel, ${ }^{10}$ several lower courts have subsequently held such orders subject to interlocutory review under the collateral order doctrine. ${ }^{11}$ For example, in

not immediately appealable under 28 U.S.C. $\S 1291$. See In re Continental lnv. Corp., 637 F.2d 1 (1st Cir. 1980); Armstrong v. McAlpin, 625 F.2d 433 (2nd Cir. 1980), vacated on other grounds, 449 U.S. 1106 (1981); Melamed v. ITT Continental Baking Co., 592 F.2d 290 (6th Cir. 1979); Community Broadcasting of Boston, Inc. v. FCC, 546 F.2d 1022 (D.C. Cir. 1976); Cord v. Smith, 338 F.2d 516 (9th Cir. 1964). Five circuits permitted such appeals. See Westinghouse Elec. Corp. v. Kerr-McGee Corp., 580 F.2d 1311 (7th Cir.), cert. denied, 439 U.S. 955 (1978); MacKethan v. Peat, Marwick, Mitchell \& Co., 557 F.2d 395 (4th Cir. 1977); Kroungold v. Triester, 521 F.2d 763 (3d Cir. 1975); Fullmer v. Harper, 517 F.2d 20 (10th Cir. 1975); Uniweld Prods. v. Union Carbide Corp., 385 F.2d 992 (5th Cir. 1967), cert. denied, 390 U.S. 921 (1968).

2. 449 U.S. 368 (1981).

3. For a discussion of the requirements of the collateral order doctrine, see supra $\$ 12$ of this Interlocutory Restatement, notes $10-13$ and accompanying text.

4. Firestone, 449 U.S. at 375-76.

5. Id. at 378 n.13.

6. For a discussion of the requirements for certification, see supra $\S 11$ of this Interlocutory Restatement.

7. See In re Continental Inv. Corp., 637 F.2d 1, 7 (1st Cir. 1980); Armstrong v. McAlpin, 625 F.2d 433, 438 (2d Cir. 1980), vacated on other grounds, 449 U.S. 1106 (1981); Community Broadcasting of Boston, Inc. v. FCC, 546 F.2d 1022, 1028 n.40 (D.C. Cir. 1976).

8. See In Re Continental Inv. Corp., 637 F.2d 1, 7 (1st Cir. 1980); Armstrong v. McAlpin, 625 F.2d 433, 438 (2d Cir. 1980), vacated on other grounds, 449 U.S. 1106 (1981); Community Broadcasting of Boston. Inc. v. FCC, 546 F.2d 1022, 1028 (D.C. Cir. 1976); see generally, Comment, The Appealability of Orders Denying Motions for Disqualification of Counsel in the Federal Courts, 45 U. CHI. L. REv. 450, 468-80 (1978).

9. See, e.g., Unified Sewerage Agency v. Jelco, Inc., 646 F.2d 1339, 1344 (9th Cir. 1981).

10. 449 U.S. at 672 n.8.

11. See, e.g., Koller v. Richardson-Merrell, Inc., 737 F.2d 1038 (D.C. Cir. 1984); Interco Systems Inc. v. Omni Corporate Servs., 733 F.2d 253 (2d Cir. 1984); Freeman v. Chicago Musical Instrument Co., 689 F.2d 715, 717-19 (7th Cir. 1982); Ah Ju Steel Co. v. Armco, Inc., 680 F.2d 751, 753 (C.C.P.A. 1982); In re Coordinated Pretrial Proceedings, 658 F.2d 1355, 1356-58 (9th Cir. 1981), cert. denied, 455 U.S. 990 (1982): Glueck v. Jonathan Logan, Inc., 653 F.2d 746, 748 n.2 (2d Cir. 1981); but of. Flanagan v. United States, 104 S. C. 1051 (1984). Circuits that considered the question prior to Firestone had also agreed that a grant of 
Duncan v. Merrill Lynch, Pierce, Fenner E Smith, the Fifth Circuit noted that the Firestone Court had based its holding partly on the notion that " $[\mathrm{t}]$ he propriety of the District Court's denial of a disqualification motion will often be difficult to assess until its impact on the underlying litigation may be evaluated, which is normally only after final judgment." 12 The Duncan court felt that this rationale was inapplicable in the case of a grant of disqualification which, insofar as it served to deprive the losing party of his counsel altogether, had an effect that would be both "immediate and measurable."13 Furthermore, the Duncan court observed that it was fatuous to assume that review of a disqualification after final decision would provide adequate relief for a losing party. Such a procedure would force the unsuccessful litigant to prove, upon appeal, not only that the disqualification was improper, but also that it caused him to lose the case. ${ }^{14}$ Finally, the Duncan court noted that were the party suffering disqualification to prevail at trial, a right to appeal thus would provide no solace for the disqualified counsel who suffered damage both "to his reputation and to his pocketbook."15

An order granting a motion to disqualify counsel occasionally may also be certified for interlocutory appeal under 28 U.S.C. $\$ 1292(b) .{ }^{16}$ Such review was justified in one case on the grounds of the important problem of legal ethics involved and the potential delay and expense to the objecting party if a new counsel had to become familiar with the exhaustive case files already accumulated. ${ }^{17}$

F. Review of Trial Preparation Orders

§36. Pleadings: Matters of Form.

AN ORDER

(1) REQUIRING OR REFUSING TO REQUIRE A MORE DEFINITE STATEMENT OF ALLEGATIONS,

(2) STRIKING OR REFUSING TO STRIKE FACTUAL ALLEGATIONS,

(3) GRANTING OR DENYING LEAVE TO AMEND ALLEGATIONS, OR

(4) GRANTING OR DENYING LEAVE TO SUPPLEMENT ALLEGATIONS

disqualification was immediately appealable under the collateral order doctrine. See, e.g., Armstrong v. McAlpin, 625 F.2d 433, 440-41 (2d Cir. 1980), vacated on other grounds, 449 U.S. 1106 (1981); In re MultiPiece Rim Prods. Liab. Litig., 612 F.2d 377, 378 (8th Cir. 1980), vacated sub nom. Firestone Tire \& Rubber Co. v. Risjord, 449 U.S. 368 (1981); General Elec. Co. v. Valeron Corp., 608 F.2d 265, 266-67 (6th Cir. 1979), cert. denied, 445 U.S. 930 (1980); Board of Educ. v. Nyquist, 590 F.2d 1241, 1247 n.8 (2d Cir. 1979). For a discussion of the requirements of the collateral order doctrine, see supra $\$ 12$ of this Interlocutory Restatement, notes $10-13$ and accompanying text.

12. 646 F.2d 1020, 1027 (5th Cir.) (quoting 449 U.S. at 377), cert. denied, 454 U.S. 895 (1981).

13. Id. at 1027 .

14. Id.

15. Id.

16. For a discussion of the requirements for certified appeal, see supra $\S 11$ of this Interlocutory Restatement.

17. E.F. Hutton \& Co. v. Brown, 305 F. Supp. 371, 401-03 (S.D. Tex. 1969) (conflict of interest alleged when corporate counsel represented corporation in suit against former officer whom counsel had earlier represented individually as part of corporate role). 
IS REVIEWABLE ONLY ON APPEAL FROM A FINAL DECISION.

\section{COMMENT}

Rulings regarding the form of pleadings are generally nonreviewable. ${ }^{1}$ It is recognized that the aggrieved party will not suffer an irreparable injury since any necessary relief can be effectively secured on appeal from a final decision. Moreover, appellate courts are unwilling to become involved in the pleading process because their involvement could lead to an overemphasis on pleading technicalities. $^{2}$

Illustration. P files a personal injury action against D. D files a motion for a more definite statement. The court refuses D's motion. D files an appeal. The appeal should be dismissed. The appellate courts should not be embroiled in pleading maiters, and any harm suffered by D can be corrected on appeal from the final decision.

\section{§37. Orders Compelling or Refusing to Compel Discovery.}

(A) AN ORDER COMPELLING OR REFUSING TO COMPEL A PARTY TO PRODUCE DOCUMENTS OR THINGS, TO ALLOW THE INSPECTION OF PREMISES, TO ANSWER DEPOSITIONS OR INTERROGATORIES, OR TO SUBMIT TO OR REQUIRE A PERSON UNDER HIS CONTROL TO SUBMIT TO A PHYSICAL OR MENTAL EXAMINATION IS REVIEWABLE ON APPEAL FROM A FINAL DECISION, ON CERTIFIED APPEAL, OR ON INTERLOCUTORY APPEAL

(1) TO PREVENT COMPULSORY DISCLOSURE OF MATTER WHICH IS SUBJECT TO AN ABSOLUTE EVIDENTIARY PRIVILEGE, OR

(2) TO PROTECT A SUBSTANTIAL RIGHT OF PRIVACY.

(B) AN ORDER COMPELLING OR REFUSING TO COMPEL A NONPARTY WITNESS TO PRODUCE DOCUMENTS OR THINGS OR TO APPEAR AND ANSWER DEPOSITIONS OR TESTIFY AT TRIAL IS REVIEWABLE ON APPEAL FROM A FINAL DECISION OR ON CERTIFIED APPEAL. AN ORDER REFUSING TO COMPEL A NONPARTY TO PRODUCE INFORMATION IS A FINAL DECISION WHEN ENTERED IN A PROCEEDING ANCILLARY TO THE MAIN ACTION BROUGHT TO SECURE DISCOVERY.

(C) AN ORDER COMPELLING A NONPARTY TO PRODUCE DOCUMENTS OR THINGS AS TO WHICH ANOTHER PERSON CLAIMS A

1. See, e.g., Papilsky v. Berndt, 503 F.2d 554 (2d Cir. 1974) (motion to strike allegations from the complaint); CMAX, Inc. v. Hall, 290 F.2d 736 (9th Cir. 1961) (motion for a more definite statement). On occasion, a determination of a pleading motion may be reviewed incidental to appellate consideration of an order properly subject to interlocutory review. See supra $\S 12$ of this Interlocutory Restatement, notes 74-75 and accompanying text.

2. Libbey-Owens-Ford Glass Co. v. Sylvania Indus. Corp., 154 F.2d 814, 817 (2d Cir.), cert. denied, 328 U.S. 859 (1946). See also D'Ippolito v. Cities Serv. Co., 374 F.2d 643, 648 (2d Cir. 1967). 


\section{PRIVILEGE IS REVIEWABLE ON CERTIFIED APPEAL OR ON INTER- LOCUTORY APPEAL TO ENFORCE THAT PERSON'S RIGHT TO REFUSE DISCLOSURE.}

\section{COMMENT}

a. Discovery From Parties Generally. Courts of appeals generally hold that an order compelling or refusing to compel a party to provide discovery is not subject to interlocutory review. ${ }^{1}$ Any error can be reviewed after final decision, and allowing immediate appeal would provide opportunity for dilatory practices ${ }^{2}$ and could involve appellate courts in substantive issues of ongoing litigation since discovery is usually intertwined with the development of the merits of a case. ${ }^{3}$ Further, "[i]n a large and complicated lawsuit or series of lawsuits closely related, interlocutory review of such housekeeping matters as discovery would practically preclude termination of the litigation by settlement or trial within the normal lifespan of any of the parties, attorneys or judges."4

Illustration 32-1. $\mathrm{P}$ files suit against $\mathrm{D}$ to recover damages for physical injuries sustained in an automobile collision. $\mathrm{D}$ requests an order requiring $\mathrm{P}$ to undergo a psychiatric examination. The court refuses to order the examination. D appeals. The appeal should be dismissed because any error can be reviewed and corrected after final decision. ${ }^{5}$ Illustration 32-2. $P$ files suit against $\mathrm{D}$ for securities violations. $\mathrm{P}$ requests an order compelling $\mathrm{D}$ to answer depositions aimed at obtaining information necessary to establish standing and subject matter jurisdiction. The court refuses to compel discovery. $\mathrm{P}$ appeals. The appeal should be dismissed. P can continue to prosecute the suit in the district court and, if the case is dismissed for lack of standing or subject matter jurisdiction, seek review of the discovery order appeal from that dismissal. ${ }^{6}$

An order compelling discovery may be appealable if the party refuses to comply with the order and suffers a discovery sanction. Promiscuous and dilatory appeals are thus discouraged because "a party's sincerity . . . [is tested by] having to risk a [sanction] as a condition to appeal."7

b. Parties in Ancillary Proceedings. An order compelling a party to provide dis-

1. See, e.g., City of Cleveland v. Krupansky, 619 F.2d 572 (6th Cir. 1980); Miller v. Reighter, 581 F.2d 1181 (8th Cir. 1978); Plekowski v. Ralston-Purina Co., 557 F.2d 1218 (5th Cir. 1977); Ryan v. Commissioner, 517 F.2d 13 (7th Cir.), cert. denied, 423 U.S. 892 (1975); Donnelly v. Parker, 486 F.2d 402 (D.C. Cir. 1973); SEC v. Stewart, 476 F.2d 755 (2d Cir. 1973). But see In re Equal Employment Opportunity Comm'n, 709 F.2d 392 (5th Cir. 1983) (mandamus issued to vacate order compelling discovery of matters beyond the authority of the court to determine in summary subpoena enforcement proceedings; if. infra $\S 38$ of this Interlocutory Restatement, notes $22-24$ and accompanying text).

2. See American Express Warehousing v. Transamerica Ins. Co., 380 F.2d 277, 284 (2d Cir. 1967)

3. See Ryan v. Commissioner, 517 F.2d 13, 17 (7th Cir.), cert. denied, 423 U.S. 892 (1975).

4. American Express Warehousing v. Transamerica Ins. Co., 380 F.2d 277, 284 (2d Cir. 1967).

5. Cf. Donnelly v. Parker, 486 F.2d 402 (D.C. Cir. 1973)

6. This result is consistent with the rule presented and would not cause irreparable harm to P. But see Investment Properties Int'l v. IOS, Ltd., 459 F.2d 705 (2d Cir. 1972); $c$. Western Elec. Co. v. Stern, 544 F.2d 1196 (3d Cir. 1976) (mandamus issued to review order denying defendant discovery of information needed for defense).

7. Ryan v. Commissioner, 517 F.2d 13, 20 (7th Cir.), cert. denied, 423 U.S. 892 (1975). For discussions 
covery, though entered in a forum other than the one in which the original action is pending, is similarly not ripe for appeal. ${ }^{8}$ Immediate review may be obtained by defying the order and appealing from the ensuing sanction. ${ }^{9}$

The same rule seems to apply when the order in the ancillary proceeding refuses to compel discovery. ${ }^{10}$ Since both parties are before the court in the main proceeding, it is argued that adequate relief can be provided on appeal from that final decision. ${ }^{11}$ There is, however, conflict on this point, ${ }^{12}$ but the large number of appellate decisions growing out of one case allowing immediate review of a refusal to compel discovery in an ancillary proceeding counsels against this practice. ${ }^{13}$

c. Party Absolute Privilege. When an order compelling discovery is issued over a claim of absolute privilege, interlocutory review is available to protect the privilege. ${ }^{14}$ Though the Second Circuit has held to the contrary (and consistent with the rule governing discovery of nonprivileged matters) that a party must first refuse to comply with the discovery order and suffer a sanction to get appellate review, ${ }^{15}$ not all sanction orders are appealable. ${ }^{16}$ Since, absent review, the party claiming privilege may be forced to go ahead and make the challenged disclosures, interlocutory appeal is thus necessary to prevent such potential irreparable harm.

The absolute privileges that will be thus protected include the attorney-client and governmental privileges. ${ }^{17}$ A claim of work product privilege is not absolute, but qualified, and will not be protected by interlocutory review. ${ }^{18}$

Illustration 37-3. $\mathrm{P}$ brings suit against $\mathrm{D}$ and requests discovery of some correspondence between $\mathrm{D}$ and his attorney. $\mathrm{D}$ objects, claiming that the

of the appealability of orders imposing contempt and discovery sanctions respectively, see supra $\S 23$ and infra $\S 39$ of this Interlocutory Restatement.

8. Shaw v. Kellogg Co., 32 Fed. R. Serv. 2d (Callaghan) 583 (4th Cir. 1981); National Nut Co. v. Kelling Nut Co., 134 F.2d 532 (7th Cir. 1943). But of. Sheehan v. Doyle, 513 F.2d 895 (1st Cir. 1975), cert. denied, 423 U.S. 874 (1975).

9. Shaw v. Kellogg Co., 32 Fed. R. Serv. 2d (Callaghan) 583, 584 (4th Cir. 1981). For discussions of the appealability of orders imposing contempt and discovery sanctions respectively, see supra $\S 23$ and infra $\S 39$ of this Interlocutory Restatement.

10. Shattuck v. Hoegl, 555 F.2d 1118 (2d Cir. 1977). The law in this area has developed from actions for discovery in patent interference proceedings. Under 35 U.S.C.A. $§ 24$ (West Supp. 1982) the Federal Rules of Civil Procedure relating to discovery apply to contested cases in the Patent and Trademark Office and to ancillary proceedings for discovery conducted in the district courts.

11. Shattuck v. Hoegl, 555 F.2d 1118, 1121 (2d Cir. 1977). A different result would obtain if the witness were a nonparty over whom the main court could not extend its process. See infra text accompanying notes $30-32$.

12. See Natta v. Zletz, 379 F.2d 615 (7th Cir. 1967)

13. See Frilette v. Kimberlin, 508 F.2d 205, 210 n.8 (3d Cir. 1974), cert. denied, 421 U.S. 980 (1975)

14. See Diversified Indus. v. Meredith, 572 F.2d 596 (8th Cir. 1977) (attorney-client privilege); United States Board of Parole v. Merhige, 487 F.2d 25 (4th Cir. 1973) (governmental privilege), cert. denied, 417 U.S. 918 (1974); Hyde Constr. Co. v. Koehring Co., 455 F.2d 337 (5th Cir. 1972) (attorney-client privilege). Cf. infra $\S 38$ of this Interlocutory Restatement, notes $15-18$ and accompanying text.

15. See National Super Spuds, Inc. v. New York Mercantile Exch., 591 F.2d 174, 177 (2d Cir. 1979); see also Xerox Corp. v. SCM Corp., 534 F.2d 1031 (2d Cir. 1976).

16. See International Bus. Machs. Corp. v. United States, 493 F.2d 112 (2d Cir. 1973) (appeal from sanction order dismissed despite claim of attorney-client privilege). For a discussion of the appealability of discovery sanctions, see infra $§ 39$ of this Interlocutory Restatement.

17. See cases cited supra note 14.

18. See American Express Warehousing v. Transamerica Ins. Co., 380 F.2d 277, 280-81 (2d Cir. 1967). 
documents are protected by the attorney-client privilege. The court makes factual findings, determines that the documents are not privileged, and orders disclosure. D appeals. The appeal should be entertained to prevent a possible erroneous disclosure of privileged material.

d. Substantial Right of Privacy. Interlocutory review of orders compelling discovery is appropriate to protect substantive privacy rights. For example, the litigation in Schlagenhauf $v$. Holder ${ }^{19}$ grew out of a collision between a bus and a tractortrailer. One of the parties in the action asserted that Schlagenhauf, the bus driver, "was 'not mentally or physically capable' of driving a bus at the time of the accident."'20 Upon petition, the district court ordered Schlagenhauf to undergo examinations in the fields of internal medicine, ophthamology, neurology, and psychiatry, even though the only specific allegation made in support of the requested discovery was that Schlagenhauf's eyes and vision were impaired.21 The Supreme Court properly reviewed the district court's order, thereby preventing a possible erroneous denial of Schlagenhauf's right to privacy.

Unfortunately, the Court rested its decision to grant review on the fact that the order presented questions of first impression. ${ }^{22}$ The mere existence of such questions does not justify immediate appeal, however. The purpose of allowing interlocutory review of a discovery order is to prevent an irreparable breach of some privilege or right; any harm caused by the presence of a novel issue can be effectively reviewed on appeal after final decision. Interlocutory review has appropriately been used also to protect the privacy of plaintiffs who wish to proceed anonymously in order to prevent the retribution that some types of litigation, such as employment discrimination or minimum wage suits, may engender. ${ }^{23}$

e. Discovery From Nonparties Generally. An order compelling discovery from a nonparty is not subject to interlocutory review, ${ }^{24}$ as established in Alexander $v$. United States. ${ }^{25}$ In that case, which involved an antitrust action against twentythree corporations, the trial court ordered the officers of some of the defendant corporations to give testimony and to produce various books and records. When the witnesses refused to permit the use of the books and refused to answer certain questions on the ground of immateriality, ${ }^{26}$ the court entered an order compelling such discovery. The Supreme Court held the order nonappealable, noting that

the mere direction of the court to the witnesses to answer the questions put to them and to produce the written evidence in their possession is not a final decision; that it more appropriately is an interlocutory ruling or order in the principal suit, and that if the witnesses refuse to comply with it and the court then exercises its authority either to punish them or to coerce them into compliance that will give rise to another case or cases to which the witnesses will be parties on the one hand and the Government, as a sovereign vindicating

19. 379 U.S. 104 (1964).

20. Id. at 107 .

21. Id. at $120-21$.

22. Id. at 110 .

23. See, e.g., Doe v. Stegall, 653 F.2d 180 (5th Cir. 1981).

24. See Kaufman v. Edelstein, 539 F.2d 811 (2d Cir. 1976); Gialde v. Time, Inc., 480 F.2d 1295 (8th Cir. 1973); Belfer v. Pence, 435 F.2d 121 (9th Cir. 1970); Honig v. E.I. du Pont de Nemours \& Co., 404 F.2d 410 (5th Cir. 1968).

25. 201 U.S. 117 (1906).

26. Id. at 120 . 
the dignity and authority of one of its courts, will be a party on the other hand. I have no doubt that a judgment adverse to the witnesses in that proceeding or case will be a final decision and will be subject to review . . . .27

f. Nonparties in Ancillary Proceedings. An order compelling a nonparty to provide discovery, even when entered in an ancillary proceeding, ${ }^{28}$ is subject to review after final decision but not on interlocutory appeal. There are no cases on point, but inasmuch as the contempt avenue is an adequate means of review in the main proceeding, it should also be sufficient in an ancillary proceeding. Also, precluding interlocutory review of ancillary orders compelling nonparties to provide discovery is consistent with the rule applied to parties. ${ }^{29}$

An order refusing to compel discovery from a nonparty, when entered in an ancillary proceeding, however, is final and reviewable. ${ }^{30}$ Such an order is not amenable to effective review on appeal after a final decision. When an order compelling discovery has been improvidently granted, the appellate court can simply order a new trial and exclude the improper evidence. In contrast, when the order has denied discovery, appeal taken from the final decision in the main proceeding will be ineffective because, although the court of appeals can order a new trial, it will not have jurisdiciton to modify the ancillary court's discovery order or to direct discovery from a nonparty outside its compulsory process. ${ }^{31}$ Likewise, the ancillary appellate court could rectify an error in its discovery order on appeal after final decision in the main proceeding, but it would not have the power to order a new trial. ${ }^{32}$

Illustration 37-4. $\mathrm{P}$ sues $\mathrm{D}$ in a Michigan district court. W, a former officer of D, now lives in Florida. P takes W's deposition there, but W refuses to answer some of P's questions. The Florida district court denies P's request for an order compelling $\mathrm{W}$ to answer. $\mathrm{P}$ appeals. The appeal

27. Id. at 122 (quoting Circuit Judge Van Deventer). The separate case to which the Court refers would be a proceeding for criminal contempt; the appealability of such a sanction is discussed supra $\S 23$ of this Interlocutory Restatement, comment c (see text accompanying notes $42-43$ as to the status of corporate officers as nonparties). The Court thus advocates the same rationale as governs the appealability of nonprivileged matters from parties. As explained in Cobbledick v. United States, 309 U.S. 323 (1940), nonparty status does not affect the concerns underlying the final decision rule:

[T] $\mathrm{T}$ e right to a judgment from more than one court is a matter of grace and not a necessary ingredient of justice. Congress, from the very beginning has, by forbidding piecemeal disposition on appeal of what for practical purposes is a single controversy, set itself against enfeebling judicial administration. . .

In thus denying to appellate courts the power to review rulings at nisi prius, generally, until after the entire controversy has been concluded, Congress has sought to achieve the effective conduct of litigation .... It is the means for achieving a healthy legal system. As an instrument of such policy, the requirement of finality will be enforced not only against a party to the litigation but against a witness who is a stranger to the main proceeding.

Id. at $325-26$.

28. That is, a proceeding in a forum other than that in which the underlying action is to be tried.

29. See supra notes 8-9 and accompanying text.

30. See In re Multi-Piece Rim Prods. Liab. Litig., 653 F.2d 671, 676 (D.C. Cir. 1981); National Life Ins. Co. v. Hartford Accident \& Indem. Co., 615 F.2d 595, 597 (3d Cir. 1980); Republic Gear Co. v. BorgWarner Corp., 381 F.2d 551, 554-55 (2d Cir. 1967); Carter Prods. v. Eversharp, Inc., 360 F.2d 868, 870-72 (7th Cir. 1966).

31. See Republic Gear Co. v. Borg-Warner Corp., 381 F.2d 551, 554 (2d Cir. 1967).

32. See id. 
should be heard because any review of the Florida court's decision after final decision in the Michigan proceeding is inadequate.

Illustration 37-5. Same facts as Illustration 37-4 except that the Florida district court grants the order compelling discovery, and $W$ appeals. The appeal should be dismissed. W can test the order by defying it, suffering a contempt sanction, and appealing from the contempt order.

g. Nonparty Privilege. An order compelling discovery of information from a nonparty over the nonparty's claim of privilege is not subject to interlocutory review. ${ }^{33}$ Appellate review may be obtained by ignoring the order and suffering contempt, an avenue which, although unsatisfactory for protecting a party's privilege ${ }^{34}$ is sufficient to protect a nonparty because all contempt orders issued against nonparties are appealable. ${ }^{35}$

Illustration 37-6. $\mathrm{P}$ brings suit against $\mathrm{D}$, and the court grants an order compelling $\mathrm{W}$ to produce certain documents. W objects to the order, claiming the documents are privileged, and appeals. The appeal should be dismissed. W can obtain review by defying the discovery order, suffering a contempt citation, and appealing from the contempt order.

h. Privilege Asserted by a Third Party. When a privilege is asserted by a person other than the nonparty ${ }^{36}$ against whom the discovery order is directed, the order compelling discovery is subject to interlocutory review. ${ }^{37}$ The contempt avenue is not an alternative because the person who would risk the penalty does not have a privilege at stake and thus has no reason to expose himself to possible sanctions.

Illustration 37-7. P brings suit against D. The court grants an order, over $X$ 's claim of work product privilege, compelling $W$ to produce certain documents that he received from $X$. $X$ appeals. The appeal should be entertained because $X$ 's privilege will be irreparably lost unless interlocutory review is allowed-it is unlikely that $W$ will be willing to risk the imposition of contempt sanctions to protect X's privilege. ${ }^{38}$

i. Certification. An order compelling or refusing to compel discovery may be certified for interlocutory review pursuant to 28 U.S.C. $\$ 1292$ (b) when the requirements of that statute can be met. ${ }^{39}$ Seemingly this will be most likely when

33. See In re Grand Jury Subpoena For N.Y. State Income Tax Records, 607 F.2d 566 (2d Cir. 1979); contra Branch v. Phillips Petroleum Co., 638 F.2d 873 (5th Cir. 1981) (interlocutory review allowed so that government official asserting privilege would not be subject to contempt). To maintain consistency in the rule, the Branch holding is not followed by this Interlocutory Restatement. The practice of nonappeability does not apply when the President of the United States is the nonparty asserting a privilege. United States v. Nixon, 418 U.S. 683 (1974).

34. See supra note 16 and accompanying text.

35. See supra $\S 23$ of this Interlocutory Restatement, comments $c \hat{\mathcal{F}}^{\circ} e$.

36. A party from whom discovery is sought can, of course, appeal an absolute privilege claim as to such information asserted by a third person under the principles stated supra comment $c$.

37. Perlman v. United States, 247 U.S. 7 (1918).

38. See United States v. American Tel. \& Tel. Co., 642 F.2d 1285 (D.C. Cir. 1980); cf. Petrol Stops Northwest v. United States, 571 F.2d 1127 (9th Cir. 1978) (appeal allowed from order compelling disclosure of material gathered by a grand jury, third party asserting privilege).

39. These requirements are discussed supra $\S 11$ of this Interlocutory Restatement. 
a claim of privilege is raised, ${ }^{40}$ whether such discovery is then compelled ${ }^{41}$ or denied. ${ }^{42}$

\section{\$38. Protective Orders.}

(A) AN ORDER LIMITING DISCOVERY IS REVIEWABLE ON APPEAL FROM A FINAL DECISION, ON CERTIFIED APPEAL, OR ON INTERLOCUTORY APPEAL TO PROTECT THE SUBSTANTIAL RIGHTS OF PARTIES TO FREEDOM OF EXPRESSION OR EFFECTIVE COUNSEL. AN ORDER LIMITING DISCOVERY MAY BE A FINAL DECISION IN AN ANCILLARY PROCEEDING BROUGHT TO SECURE DISCOVERY.

(B) AN ORDER REFUSING TO LIMIT DISCOVERY IS REVIEWABLE ON CERTIFIED APPEAL OR INTERLOCUTORY APPEAL TO PREVENT

(1) COMPULSORY DISCLOSURE OF MATTER WHICH IS SUBJECT TO AN ABSOLUTE EVIDENTIARY PRIVILEGE, OR

(2) DISCOVERY OF INFORMATION RELEVANT ONLY TO ISSUES THE COURT HAS NO AUTHORITY TO DECIDE.

\section{COMMENT}

a. Generally Not Reviewable. Generally, the breadth of an order limiting discovery cannot be reviewed on interlocutory appeal. ${ }^{1}$ For example, in Borden Co. $v$. Sylk, a leading case concerning appealability of interlocutory discovery orders, the president of Borden's wholly-owned subsidiary refused to answer certain deposition questions about volume and prices. ${ }^{2}$ The district court entered an order compelling answers; but to protect the subsidiary from competitive damage, the court

40. Questions have been certified to clarify elements of claims or defenses when discovery has been resisted as beyond the scope of the action; generally, in such cases, had discovery been found appropriate, a privilege claim might have been raised. E.g., Christian Echoes Nat'l Ministry, Inc. v. United States, 404 F.2d 1066 (10th Cir. 1968) (inadequate record to determine if discovery sought within scope of action; work product and executive privileges also asserted in resisting request). A case in which the adequacy of the "good cause" showing was certified drew sharp dissent. Groover, Christie \& Merritt v. LoBianco, 336 F.2d 969, 974 (D.C. Cir. 1964) (Wright, J., dissenting) (claims of work product and attorney-client privilege also asserted).

41. E.g., Little Rock School Dist. v. Borden, Inc., 632 F.2d 700, 703 \& n.5 (8th Cir. 1980) (certified appeal of order compelling witnesses in civil antitrust case who had been granted immunity in a narrower price fixing case to testify over fifth amendment objections); Texas v. United States Steel Corp., 546 F.2d 626,628 (5th Cir.) (certified appeal of order compelling production, over assertions of grand jury secrecy, of transcripts of testimony by defendant's employees before such a body), cert denied, 434 U.S. 889 (1977).

42. E.g., Transamerica Computer Co. v. International Bus. Machs. Corp., 573 F.2d 646, 647 (9th Cir. 1978) (certified appeal of order refusing to compel production of documents over party's assertion of compulsion in prior disclosure such that privilege was not waived); see also North Carolina Elec. Membership Corp. v. Carolina Power \& Light Co., 666 F.2d 50, 51 (4th Cir. 1981) (certified question common to both, order refusing to compel discovery from party and protective order as to nonparty).

1. See Silberline Mfg. Co. v. International Nickel Co., 569 F.2d 1217 (3d Cir. 1977); SEC v. Research Automation Corp., 521 F.2d 585 (2d Cir. 1975); Kerr v. United States Dist. Ct., 511 F.2d 192 (9th Cir. 1975), affd, 426 U.S. 394 (1976); Time, Inc. v. Ragano, 427 F.2d 219 (5th Cir. 1970); Borden Co. v. Sylk, 410 F.2d 843 (3d Cir. 1969).

2. 410 F.2d 843 (3d Cir. 1969). 
directed that the information not be disclosed to the public or to any of Borden's competitors. ${ }^{3}$ The subsidiary appealed, attempting to prohibit any discovery of price information. The court dismissed the appeal stating:

Every interlocutory order involves, to some degree, a potential loss. That risk, however, must be balanced against the need for efficient federal judicial administration . . . . To accept the [appeal] . . . is to invite the inundation of appellate dockets with what have heretofore been regarded as nonappealable matters. It would constitute the courts of appeals as second-stage motion courts . ...4

Similarly, in SEC v. Research Automation Corp. ${ }^{5}$ the district court entered an order precluding the defendants from taking the depositions of various SEC attorneys. When the defendants sought immediate review of this order, the court of appeals dismissed their appeal because the order was interlocutory. ${ }^{6}$

b. Ancillary Proceedings. Appeals are properly allowed from protective orders as to nonparties issued in ancillary proceedings. ${ }^{7}$ The effect of an order entered in an ancillary proceeding is not reparable by an appeal from a final decision in the main litigation. Indeed, the appeal after final decision will generally be to a court of appeals that lacks appellate jurisdiction over the ancillary court. ${ }^{8}$

Illustration 38-1. $\mathrm{P}$ files an action in Virginia against D. D obtains a subpoena duces tecum requiring $\mathrm{W}$ to appear for a deposition in Colorado. W resists answering questions at the deposition, claiming the information constitutes a trade secret. The district court in Colorado enters a protective order forbidding inquiry into the privileged matter. D appeals. The appeal should be entertained because the only purpose of the proceeding in Colorado is to obtain discovery and the protective order finally determines whether discovery can be had. Furthermore, the Virginia final decision will have to be appealed to the Fourth Circuit, which will have no jurisdiction over the Colorado protective order, so appeal must be taken to the Tenth Circuit if the propriety of the protective order is to be reviewed.

An order granting or denying a motion to modify a protective order will be subject to interlocutory review when made by an intervenor whose purpose in intervening was to obtain discovery. ${ }^{9}$ When the order is modified, review ensures that the appellant's privileged information is still adequately protected. ${ }^{10}$ When

3. Id. at $844-45$

4. Id. at 846. See also Silberline Mfg. Co. v. International Nickel Co., 569 F.2d 1217 (3d Cir. 1977) (district court granted protective order that was narrower than requested; appeal seeking broader order was dismissed)

5. 521 F.2d 585 (2d Cir. 1975).

6. Id. at 590 .

7. See Marine Petroleum Co. v. Champlin Petroleum Co., 641 F.2d 984 (D.C. Cir. 1980); In re Westinghouse Elec. Corp.-Uranium Contracts Litig., 570 F.2d 899 (10th Cir. 1978); Carter Prods. v. Eversharp, Inc., 360 F.2d 868 (7th Cir. 1966). See also supra $\$ 37$ of this Interlocutory Restatement, comment f; compare id. comment $b$.

8. Cf. In re Corrugated Container Antitrust Litig., 662 F.2d 875 (D.C. Cir. 1981).

9. See Iowa Beef Processors v. Bagley, 601 F.2d 949, 953-54 (8th Cir. 1979). See also supra $\$ 1$ of this Interlocutory Restatement, note 20 and accompanying text.

10. Modification of a protective order in this context is similar to an initial denial of any protective order in the face of a privilege claim. Such a denial is appealable, as developed infra comment $d$. 
the order is final as to the intervenor; discovery was the only reason the intervenor entered the action, and in effect, the main litigation is an ancillary proceeding for the intervenor." This practice implicitly effectuates a policy of giving the intervenor a chance to obtain discovery without requiring that he wait through what may be a lengthy trial process.

Illustration 38-2. Relying on a protective order limiting disclosure to prevent competitive harm, $D$ reveals some trade secrets during discovery by $P$. State $X$ files another action concerning similar issues against $D$ in a different court. Wishing to complete discovery as fast as possible, State $\mathrm{X}$ then intervenes in the P-D action to obtain information discovered by $\mathrm{P}$ from D. The court grants State X's motion to modify the protective order so State $X$ can have access to the documents. $D$ appeals. The appeal should be heard because if the protective order were improperly modified, D could suffer irreparable harm from disclosure of its trade secrets.

Illustration 38-3. Same facts as in Illustration 38-2 except that the district court refuses to modify the order. State $X$ appeals. The appeal should be entertained because the intervenor's sole purpose in entering the litigation was to obtain discovery and the order is thus final as to him.

c. Overextension of Power. Interlocutory appeal lies to prevent overextension of court process. Thus, immediate review may be had if, for example, a protective order forbids disclosure of materials obtained independently of court-ordered discovery proceedings, because such an order may be an unconstitutional restraint on speech. ${ }^{12}$ Similarly, a protective order that interferes with an attorney's independent preparation of a case might impair the right to effective assistance of counsel. ${ }^{13}$

Illustration 38-4. In the course of discovery, $\mathrm{P}$ obtains through independent investigation a document containing information related to the deposition testimony of a government attorney. A protective order is entered prohibiting disclosure of the deposition testimony or of the document because the attorney testified as to privileged information. $P$ appeals. The appeal should be entertained, to protect P's constitutional right to disclose information. ${ }^{14}$

11. E.g., Martindell v. International Tel. \& Tel. Corp., 594 F.2d 291, 293-94 (2d Cir. 1979).

12. See In re San Juan Star Co., 662 F.2d 108 (1st Cir. 1981); Rodgers v. United States Steel Corp., 536 F.2d 1001 (3d Cir. 1976); International Prods. Corp. v. Koons, 325 F.2d 403 (2d Cir. 1963).

13. See International Bus. Machs. Corp. v. Edelstein, 526 F.2d 37 (2d Cir. 1975).

14. The portion of the order restricting disclosure of the independently obtained documents will be examined and probably reversed. The portion of the order prohibiting public disclosure of material obtained through court processes will not be reviewed because the parties implicitly waive their rights to disclose information obtained through these processes. See Rodgers v. United States Steel Corp., 536 F.2d 1001, 1006 (3d Cir. 1976); International Prods. Corp. v. Koons, 325 F.2d 403, 407 (2d Cir. 1963).

The court of appeals in In re San Juan Star Co., 662 F.2d 108 (1st Cir. 1981), did review the entire protective order. The underlying litigation in San Juan Star was to recover damages for the killing of two members of a Puerto Rican pro-independence group in alleged violation of their civil rights. The trial occurred during a time of heated political debate over Puerto Rico's future. To prevent publicity that might deny the defendants a fair trial, the trial court prohibited the attorneys from disclosing evidence 
Illustration 38-5. The district court enters an order prohibiting D's attorney from interviewing adverse witnesses unless opposing counsel or a court stenographer is present. The restrictions extend to interviews sought as part of an independent investigation to prepare the case. D appeals. The appeal should be entertained because the restrictions on D's attorney may infringe D's right to effective assistance of counsel.

d. Refusal to Limit Discovery. Interlocutory appeal is not allowed as a matter of course when a protective order is denied. Immediate review generally will be available when an absolute privilege, such as trade secrets, ${ }^{15}$ governmental privilege, ${ }^{16}$ or attorney-client privilege, ${ }^{17}$ is asserted; claims of attorney work-product privilege ${ }^{18}$ and complaints about the cost of complying with discovery, ${ }^{19}$ however, will not support appeals of orders refusing to limit discovery. ${ }^{20}$ An appeal may also be taken if discovery would increase risks to safety. ${ }^{21}$

Furthermore, interlocutory appeal will be available when the district court may be said to have overextended its powers. For example, in Equal Employment Opportunity Commission v. $K$-Mart Corp., the plaintiff administrative agency brought suit in federal court to enforce an investigative subpoena. ${ }^{22}$ The defendant corporation sought to depose agency officials as to the basis of the charges being investigated, and the district judge refused the plaintiff's request for a protective order excluding such inquiry from the scope of discovery. Summary subpoena enforcement proceedings, however, had been limited by judicial standard (and in this case also by statute) to the issues of whether the information sought by the subpeona was relevant to the investigation and whether such investigation was properly motivated. ${ }^{23}$ As defendants had no tenable claims to those points, the discovery

obtained through depositions to the press, the litigants, or any third party. Because of the newsworthiness of the trial, a newspaper's appeal was heard to determine if the harm the protective order was meant to prevent outweighed first amendment considerations. Id. at 113-18. An appeal by the plaintiff challenging the order's restriction of her access to depositions was taken in order to protect her ability to participate effectively in the litigation. Id. at 118 .

15. Cf. Covey Oil Co. v. Continental Oil Co., 340 F.2d 993 (10th Cir. 1965). In Covey an appeal was allowed to ensure adequate protection of the appellant's trade secrets, even though the trial court had issued a protective order. This specific holding has been rejected in this Interlocutory Restatement, see supra notes 1-6 and accompanying text, but the policy of preventing irreparable harm illustrated therein maintains its vitality and supports the use of interlocutory appeal when trade secrets are involved and a protective order is denied.

16. See United States Dep't of Energy v. Crocker, 629 F.2d 1341 (Temp. Emer. Ct. App. 1980).

17. See Harper \& Row Publishers v. Decker, 423 F.2d 487 (7th Cir. 1970), affd, 400 U.S. 348 (1971). Cf. supra $\S 37$ of this Interlocutory Restatement, comment $c$.

18. See American Express Warehousing v. Transamerica Ins. Co., 380 F.2d 277 (2d Cir. 1977)

19. Paramount Film Distrib. Corp. v. Civic Center Theatre, 333 F.2d 358 (10th Cir. 1964).

20. In some cases, a party moves to quash or limit depositions or interrogatories on the ground that the information sought is privileged but does not request a protective order limiting the use of the evidence to be discovered. Although the party's motion is technically for a protective order within Rule 26(c) of the Federal Rules of Civil Procedure and the asserted privilege is one that should be protected (i.e., trade secrets), an appellate court will often refuse to review the resulting district court action. In dismissing the appeal, however, the court may indicate that the district judge could limit the disclosure of the information and strongly suggest that the appellant request such an order. See Rowley v. McMillan, 502 F.2d 1326 (4th Cir. 1974); Chemical \& Indus. Corp. v. Druffel, 301 F.2d 126 (6th Cir. 1962).

21. See Belcher v. Bassett Furniture Indus,, 588 F.2d 904 (4th C.ir. 1978).

22. 694 F.2d 1055 (6th Cir. 1982).

23. Id. at 1065-66. 
sought was beyond the scope of the enforcement proceeding and the district judge was acting in excess of his authority in failing to appropriately limit discovery. ${ }^{24}$

Illustration 38-6. D causes a subpoenas duces tecum to be served on $\mathrm{W}$ (a nonparty) and $\mathrm{P}$ ordering production of information relating to trade secrets. $W$ and $P$ resist the subpoenas and seek protective orders barring inquiry into the trade secrets. The trial court refuses to issue the protective orders. $\mathrm{P}$ and $\mathrm{W}$ appeal. The appeal should be heard because otherwise $P$ and W's trade secrets will be disclosed, possibly causing irreparable harm to their competitive positions.

e. Certification. An order limiting refusing to limit discovery apparently may be certified for interlocutory appeal pursuant to 28 U.S.C. $§ 1292$ (b) when an issue of law, for example, the existence of a privilege, is controlling. ${ }^{25}$

\section{§ 39. Discovery Sanctions Against Parties}

(A) AN ORDER IMPOSING OR REFUSING TO IMPOSE SANCTIONS FOR THE FAILURE OF A PARTY TO COMPLY WITH A DISCOVERY ORDER IS REVIEWABLE ON APPEAL FROM A FINAL DECISION OR ON INTERLOCUTORY APPEAL TO PROTECT THE RIGHT OF APPELLANT TO NOTICE AND HEARING PRIOR TO THE IMPOSITION OF SANCTIONS. SUCH SANCTIONS MAY INCLUDE:

(1) AN ORDER THAT THE MATTERS REGARDING WHICH THE DISCOVERY ORDER WAS MADE OR ANY OTHER DESIGNATED FACTS SHALL BE TAKEN AS ESTABLISHED FOR THE PURPOSES OF THE ACTION,

(2) AN ORDER REFUSING TO ALLOW THE DISOBEDIENT PARTY TO SUPPORT OR OPPOSE DESIGNATED CLAIMS OR DEFENSES OR PROHIBITING HIM FROM INTRODUCING DESIGNATED MATTERS IN EVIDENCE,

(3) AN ORDER STAYING FURTHER PROCEEDINGS UNTIL THE DISCOVERY ORDER IS OBEYED, AND

(4) AN ORDER STRIKING OUT PLEADINGS OR PARTS THEREOF OR DISMISSING PART OF THE ACTION OR PROCEEDING.

AN ORDER OF THE LAST TYPE IS REVIEWABLE AS A PARTIAL FINAL DECISION IF SO DESIGNATED BY THE DISTRICT COURT.

(B) AN ORDER DISMISSING THE ACTION OF A PARTY FOR FAILURE TO COMPLY WITH A DISCOVERY ORDER IS A FINAL DECI-

24. Id. at 1067-68. Cf. In re Equal Employment Opportunity Comm in, 709 F.2d 392 (5th Cir. 1983) (mandamus issued to vacate order compelling similar discovery).

25. E.g., North Carolina Elec. Membership Corp. v. Carolina Power \& Light Co., 666 F.2d 50, 51 (4th Cir. 1981) (question certified as to constitutional privilege actually common to both a protective order and an order compelling discovery). Cf. supra $\S 37$ of this Interlocutory Restatement, comment $i$. For a discussion of the requirements for certification pursuant to 28 U.S.C. $\S 1292(b)$, see supra $\S 11$ of this Interlocutory Restatement. 
SION. AN ORDER REFUSING TO DISMISS IS REVIEWABLE ONLY ON APPEAL FROM A FINAL DECISION. AN ORDER RENDERING OR REFUSING TO RENDER A DEFAULT JUDGMENT AGAINST A PARTY FOR FAILURE TO COMPLY WITH A DISCOVERY ORDER IS REVIEWABLE TO THE EXTENT PROVIDED BY SECTION 33 OF THIS INTERLOCUTORY RESTATEMENT.

(C) AN ORDER IMPOSING OR REFUSING TO IMPOSE CONTEMPT SANGTIONS FOR FAILURE TO COMPLY WITH A DISCOVERY ORDER IS REVIEWABLE TO THE EXTENT PROVIDED BY $§ 23$ OF THIS INTERLOCUTORY RESTATEMENT.

\section{COMMENT}

a. Sanctions Restricting Presentation at Trial. An order imposing sanctions against a party under Rule 37(b) (2) or 37(d) of the Federal Rules of Civil Procedure is generally not subject to interlocutory review. In Hartley Pen Co. $v$. United States District Court, the Ninth Circuit, in dictum, stated that

[N]ot all of the [discovery] sanctions which the district judge might impose . . . are final and therefore appealable.... Some of these are clearly interlocutory and not final or appealable, such as a particular fact may be taken as established, or refusing to allow a party to support or oppose designated claims or defenses, or to prohibit from introducing certain evidence, or striking pleadings, or staying proceedings. ${ }^{1}$

This dictum has been followed with courts denying interlocutory review of orders that take facts as established, ${ }^{2}$ preclude the introduction of evidence, ${ }^{3}$ strike pleadings, ${ }^{4}$ or stay proceedings. ${ }^{5}$ The policies that underlie the limitation on piecemeal appeals counsel against interlocutory review of orders imposing or refusing to impose nonfinal discovery sanctions. Adequate appellate review of such sanctions can be had after final decision ${ }^{6}$ and may even be unnecessary if the complaining party prevails at trial.

Illustration 39-1. P serves interrogatories on D. After D fails to provide answers, $P$ requests, and the court grants, an order compelling $D$ to answer the interrogatories. Following a hearing, the court orders that certain matters inquired into in the interrogatories be taken as established and that $\mathrm{D}$ be precluded from introducing evidence on those matters. D appeals. The appeal should be dismissed because an order that takes facts as established or precludes the introduction of certain evidence is not a final decision.

b. Partially Final Sanctions. An order dismissing part of an action or striking

1. 287 F.2d 324, 329 (9th Cir. 1961).

2. See Evanson v. Union Oil Co., 619 F.2d 72 (Temp. Emer. Ct. App. 1980); Cromaglass Corp. v. Ferm, 500 F.2d 601 (3d Cir. 1974).

3. See Cromaglass Corp. v. Ferm, 500 F.2d 601 (3d Cir. 1974). But see Ohio v. Arthur Andersen \& Co., 570 F.2d 1370 (10th Cir.), cert. denied, 439 U.S. 833 (1978) (Tenth Circuit took an appeal from an order precluding the introduction of evidence.)

4. See United States v. Woodbury, 263 F.2d 784 (9th Cir. 1959). For review of an order striking pleadings as a partial final decision, see infra comment $b$.

5. See Zalatuka v. Metropolitan Life Ins. Co., 108 F.2d 405 (7th Cir. 1939).

6. See Evanson v. Union Oil Co., 619 F.2d 72, 74 (Temp. Emer. Ct. App. 1980). 
pleadings may be immediately appealable if the district court designates the order as a partial final decision under Rule 54(b) of the Federal Rules of Civil Procedure. ${ }^{7}$ An order adjudicating fewer than all the claims in an action is not final unless the district court expressly directs the entry of a partial final decision; ${ }^{8}$ until such an entry is made, the order may be revised.

Illustration 39-2. $\mathrm{P}$ brings an action against $\mathrm{D}$ alleging a violation of the federal securities laws and a violation of fiduciary duties imposed by state law. Because of P's failure to make discovery, the court enters an order dismissing the securities law claim. $\mathbf{P}$ appeals. The appeal should be dismissed absent designation as a partial final decision under Rule 54(b) because the order adjudicates fewer than all the claims.

c. Refusal to Impose Sanctions. An order refusing to impose sanctions for failure to comply with a discovery order, including an order refusing to dismiss an action or to enter default judgment, is not subject to interlocutory review. ${ }^{9}$ Concerns previously stated in regard to imposition of sanctions are equally relevant in this context. The unavailability of information sought can be assigned as error on appeal from final decision.

d. Protection of Right to Notice and Hearing. An order imposing sanctions against a party who has not received notice and a hearing regarding the motion for sanctions is subject to interlocutory review. This exception to the general rule derives from Equal Employment Opportunity Commission v. Carter Carburetor. ${ }^{10}$

In Carter Carburetor, the Equal Employment Opportunity Commission (EEOC) brought an action alleging that the defendant's company had discriminated on the basis of race and sex in certain employment policies. Carter Carburetor propounded interrogatories seeking identification of every individual who had been affected by the alleged discriminatory policies. The EEOC supplied some of the information requested and indicated that it would be unable to provide all the information until it completed discovery of Carter Carburetor's files. ${ }^{11}$ No formal objection to the EEOC's response nor motion to compel further answers was filed.

7. For a discussion of the requirements for Rule 54(b) designation, see supra $\$ 4$ of this Interlocutory Restatement. Such an order may also be subject to immediate review if certified for appeal pursuant to 28 U.S.C. $\S 1292(b)$. E.g., Anderson v. Air West, 542 F.2d 1090, 1091-92 (9th Cir. 1976). For a discussion of the requirements for certification, see supra $\S 11$ of this Interlocutory Restatement.

8. For an illustration of Rule 54(b)'s operation, compare Independent Inv. Protective League v. Touche Ross \& Co., 542 F.2d 156 (2d Cir. 1976) (no appeal prior to Rule 54(b) certification) with Independent Inv. Protective League v. Touche Ross \& Co., 607 F.2d 530 (2d Cir. 1978) (appeal allowed in same case after Rule 54(b) certification). But see Diaz v. Southern Drilling Corp., 427 F.2d 1118 (5th Cir. 1970) (default judgment that adjudicated fewer than all the claims appealable without Rule 54(b) certification as a collateral order).

9. See Alexander v. Pacific Maritime Ass'n, 332 F.2d 266 (9th Cir. 1964). But see Cine Forty-Second St. Theatre Corp. v. Allied Artists Pictures Corp., 602 F.2d 1062, 1065 (2d Cir. 1979) (question certified for interlocutory review as to whether gross negligence or dereliction, in contrast to willfulness, was sufficient to warrant contempt sanction of preclusion of evidence tantamount to dismissal as recommended by the magistrate but which the trial judge refused to impose; see supra $\S 11$ of this Interlocutory Restatement on certification pursuant to 28 U.S.C. $\$ 1292($ b)); see also United States v. Costello, 222 F.2d 656 (2d Cir. 1955) (appeal from denial of default judgment mistakenly allowed on the authority of a case that allowed appeal of a criminal contempt citation).

10. 577 F.2d 43 (8th Cir. 1978), cert. denied, 439 U.S. 1081 (1979).

11. Id. at 48 . 
Instead, Carter Carburetor filed a motion for sanctions, which the EEOC contended was premature. The parties held a meeting, as ordered by the court, but no agreement was reached. On the basis of an ex parte letter from Carter Carburetor and without ever hearing from the EEOC, the district court entered an order which precluded the EEOC from offering proof on certain matters, took certain facts to be established, and ordered the EEOC to reimburse Carter Carburetor for expenses incurred because of the failure to make discovery. ${ }^{12}$ Because of the absence of procedure in entering the order, the court of appeals issued a writ of mandamus commanding the trial judge to withdraw the sanctions. ${ }^{13}$

The court of appeals was justified in granting interlocutory appeal. ${ }^{14} \mathrm{~A}$ discovery sanction, although it can be reviewed and corrected after final decision, can be a severe burden to a party who must try what may have become a losing case. The imposition of sanctions ex parte is arguably a denial of due process. ${ }^{15}$ Moreover, a district court's failure to apprise itself, by means of the adversary process, of all the circumstances surrounding the alleged noncompliance with discovery may well lead to more frequent erroneous orders and more second trials.

Illustration 39-3. $\mathrm{P}$ serves interrogatories on $\mathrm{D}$. $\mathrm{D}$ fails to provide answers. $\mathrm{P}$ moves for an order taking facts inquired into as established and precluding proof on those facts. Without giving $\mathrm{D}$ an opportunity to explain the delay, the court grants the order. $D$ appeals. The appeal should be entertained to protect D's right to a hearing before sanctions are imposed, and the adversary hearing protects against avoidable error by the district court.

e. Dismissals and Defaults. An order dismissing an action with prejudice for failure to comply with a discovery order is a final decision. ${ }^{16}$ Furthermore, the Supreme Court has held that a plaintiff who voluntarily dismisses his complaint after failing to comply with a discovery order may obtain immediate appellate review. ${ }^{17} \mathrm{~A}$ default judgment entered as a discovery sanction is subject to appellate review as provided in Section 33 of this Interlocutory Restatement.

Illustration 39-4. $\mathrm{P}$ persistently fails to provide $\mathrm{D}$ with information required by an order compelling discovery. D requests that the court dismiss P's action. The court grants D's motion, and P appeals. The

12. Id. at $44-45,49$.

13. Id. at $48-49$.

14. It is unclear whether the EEOC moved for a rehearing before the district court. This discussion assumes a motion for rehearing was made and denied. If, however, the EEOC never asked for a rehearing the order should not have been appealable because it was not final on the hearing issue. The district court could have remedied the problem itself. Cf. supra $\S 15$ of this Interlocutory Restatement, comment $f$ (note particularly the Stames case cited in note 53).

Carter Carburetor is also unclear on the derivation of the right to notice and hearing. Rule 37 (a) (4) of the Federal Rules of Civil Procedure provides for a hearing before awarding expenses incurred in obraining an order compelling discovery. There is no comparable provision in Rule 37(b) or (d).

15. See North Ga. Finishing v. Di-Chem., Inc., 419 U.S. 601 (1975).

16. See Independent Inv. Protective League v. Touche Ross \& Co., 607 F.2d 530 (2d Cir. 1978). Cf. supra $\S 31$ of this Interlocutory Restatement.

17. United States v. Proctor \& Gamble Co., 356 U.S. 677 (1958). See supra $\$ 32$ of this Interlocutory Restatement, notes 17-23 and accompanying text and illustration. 
appeal should be heard because the order of dismissal is a final decision. ${ }^{18}$

f. Contempt Sanctions and Awards of Expenses. An order imposing or refusing to impose civil or criminal contempt sanctions for failure to comply with a discovery order $^{19}$ is reviewable as provided in Section 23 of this Interlocutory Restatement. An order imposing sanctions, newly authorized by Rule 26(g) of the Federal Rules of Civil Procedure, for bad faith certification by attorneys of discovery requests ${ }^{20}$ should be subject to interlocutory review as to such attorneys. As nonparties, they would not have standing to appeal from the final decision, ${ }^{21}$ and to allow immediate review would be consistent with the practice as to assessments of expenses against attorneys under Rules 37(a)(4) and 37(b)(2) of the Federal Rules of Civil Procedure. ${ }^{22}$

\section{$\S 40 . \quad$ Severance and Consolidation.}

AN ORDER GRANTING OR DENYING A MOTION TO CONSOLIDATE ACTIONS INVOLVING COMMON QUESTIONS OF LAW OR FACT OR AN ORDER GRANTING OR DENYING A MOTION FOR A SEPARATE TRIAL OF ANY CLAIM, CROSS-CLAIM, COUNTERCLAIM, THIRD PARTY CLAIM, OR SEPARATE ISSUE IS REVIEWABLE ONLY ON APPEAL FROM A FINAL DECISION.

\section{COMMENT}

a. Grant or Denial of Severance or Consolidation. Generally, an order granting or denying severance or consolidation is a nonreviewable interlocutory order. ${ }^{1}$ Courts of appeals are unwilling to review such orders because the district courts have "broad discretion in controlling the order of developing facts and issues"' and courts of appeals assume the district courts will properly identify the issues

18. Some sanction orders require dismissal of the action if discovery is not forthcoming within a certain time period. An issue may then arise as to whether review may be sought prior to the suit's actual dismissal. Compare Overby v. United States Fidelity \& Guar. Co., 224 F.2d 158 (5th Cir. 1955) (allowing appeal before the suit was actually dismissed) with Johann Maria Farina Gegenuber Den Neumarkt v. Roger \& Gallet, 296 F.2d 119 (2d Cir. 1961) (appeal taken prior to actual dismissal of the action dismissed as premature).

19. FED. R. CIV. P. 37(b).

20. FED. R. CIV. P. 26(g), reprinted in Amendments to the Federal Rules of Civil Procedure, 97 F.R.D. 165, 173 (Apr. 28, 1983) (effective Aug. 1, 1983). Attorneys under this Rule must now certify that discovery requests are consistent with the law, properly motivated, and not unduly burdensome. Sanctions for violations most likely will take the form of assessments of unnecessary expenses thus incurred by the opposing party.

21. See supra $\S 1$ of this Interlocutory Restatement, note 24 and accompanying text. Cf. supra $\S 23$ of this Interlocutory Restatement, comment $e$.

22. See supra $\S 1$ of this Interlocutory Restatement, notes $26-28$ and accompanying text.

1. See In re Master Key Antitrust Litig., 528 F.2d 5 (2d Cir. 1975) (severance and consolidation); NAACP v. Michot, 480 F.2d 547 (5th Cir. 1973) (consolidation); Nolfi v. Chrysler Corp., 324 F.2d 373 (3d Cir. 1963) (consolidation); Travelers Indem. Co. v. Miller Mfg. Co., 276 F.2d 955 (6th Cir. 1960) (severance); American Pac. Dairy Prods. v. District Ct., 217 F.2d 589 (9th Cir. 1955) (consolidation).

2. Schine v. Schine, 367 F.2d 685, 687 (2d Cir. 1966). 
and take the necessary steps to avoid confusion or prejudice. ${ }^{3}$ Since these orders are discretionary, they do not involve controlling questions of law that can be certified for appeal. ${ }^{4}$

Illustration 40-1. P files separate suits against D1 and D2 for injuries arising from a single transaction. D1 and D2 request a consolidated trial. The trial court orders consolidation over P's objections. $P$ appeals. The appeal should be dismissed. The matter has been entrusted to trial court discretion, and $\mathrm{P}$ has no substantial right in jeopardy. Any harm can be corrected on review after final decision.

Illustration 40-2. P files suit against D1. D1 joins D2 as a third party defendant. $P$ requests that the issues between $P$ and $D 1$ be tried separately from the issues between $\mathrm{D} 1$ and $\mathrm{D} 2$. The trial court enters an order denying $\mathrm{P}$ 's request. $\mathrm{P}$ appeals. The appeal should be dismissed for the same reasons discussed in Illustration 40-1.

b. Consolidation of the Complaint. The Second Circuit has allowed interlocutory review of consolidation orders that require the filing of a consolidated complaint. ${ }^{5}$ In Garber $v$. Randell the trial court ordered consolidation of three actions for pretrial purposes and ordered the plaintiffs to file an amended consolidated complaint. ${ }^{6} \mathrm{~A}$ defendant named in only one of the original complaints objected to its inclusion in the consolidated complaint. The court of appeals, holding the order to be appealable and reversing in part,

\begin{abstract}
drew the line between an order which merely requires the parties, in the interest of avoiding needless duplicative expenditure of time and money, to join in common pretrial discovery and preparation and an order which goes beyond these permissible objectives to deny a party his due process right to prosecute his own separate and distinct claims or defenses without having them so merged into the claims or defenses of others that irreparable injury will result. . . It . . appears that the effect of this consolidation may be to cause serious prejudice. . . .
\end{abstract}

In Katz v. Realty Equities Corp., however, while an order that required the filing of a consolidated complaint was affirmed on appeal, ${ }^{8}$ Judge Friendly registered a strong dissent from the grant of review: "Informing the bar that we will not upset an order of pretrial consolidation unless the case is a Chinese copy of Garber $v$. Randell is a good way of discouraging appeals from such orders until we take the proper step of holding the orders to be unappealable."9 No subsequent reported cases following Garber's holding on appealability have been found.

This Interlocutory Restatement reflects the position of Judge Friendly and rejects Garber. Appeal from an order to file a consolidated complaint is premature

3. See In re Master Key Antitrust Litig., 528 F.2d 5, 14 (2d Cir. 1975); Levine v. American Export Indus., 473 F.2d 1008, 1009 (2d Cir. 1973).

4. See supra $\S 11$ of this Interlocutory Restatement for a discussion of certified appeals.

5. See Katz v. Realty Equities Corp., 521 F.2d 1354 (2d Cir. 1975); Garber v. Randell, 477 F.2d 711 (2d Cir. 1973); $f$. MacAlister v. Guterma, 263 F.2d 65 (2d Cir. 1965) (appeal allowed from order denying motion for consolidated complaint).

6. 477 F.2d 711 (2d Cir. 1973).

7. Id. at 716 .

8. 521 F.2d 1354 (2d Cir. 1975).

9. Id. at 1364 (Friendly, J., dissenting). 
if the complaining party has not actually been prejudicially injured. Injury can occur only if the trial judge fails to prevent prejudice that causes the complaining party to lose at trial. The presence or absence of prejudice is determinable only after final decision; if prejudice is present, effective relief can be granted on appeal from the final decision. ${ }^{10}$ Interlocutory review of a consolidated complaint only disrupts the trial court's management of the litigation.

c. Incidental Review. Interlocutory review of a severance order may be had incidental to review of an appealable order." For example, in the trademark infringement action of Helene Curtis Industries v. Church $\mathcal{F}^{2}$ Dwight Co., Helene Curtis raised the affirmative defense that Church \& Dwight's use of the trademark in question violated the antitrust laws. ${ }^{12}$ Helene Curtis also filed a counterclaim seeking treble damages for the alleged antitrust violations. The trial court ordered separate trials of the issues raised in Church \& Dwight's complaint and of the antitrust issues raised by Helene Curtis. After the action had been pending for about one year, Church \& Dwight filed a motion for a preliminary injunction. The trial court held a hearing solely to determine if Helene Curtis infringed the trademark; the severance order precluded Helene Curtis from presenting evidence on its affirmative defense. The injunction was granted. On appeal from the preliminary injunction the court reviewed the merits of the severance order also as that holding was "basic to" the decision on the injunction. ${ }^{13}$

§ 41. Pretrial Orders.

AN ORDER, MADE AFTER A PRETRIAL CONFERENCE, WHICH CONTROLS THE COURSE OF THE TRIAL IS REVIEWABLE ONLY ON APPEAL FROM A FINAL DECISION.

\section{COMMENT}

a. Pretrial Orders. A pretrial order which will control the course of the trial is not subject to interlocutory review because "to make pretrial procedure effective appellate interference with trial court discretion must be kept to a minimum." In

10. Cf. American Pipe \& Constr. Co. v. Pence, 383 F.2d 568 (9th Cir.) (discussed infra $\S 41$ of this Interlocutory Restatement, notes $7-9$ and accompanying text), cert. denied, 393 U.S. 842 (1968).

11. See generally $\S 12$ of this Interlocutory Restatement, comment $b$.

12. 560 F.2d 1325 (7th Cir. 1977), cert. denied, 434 U.S. 1070 (1978).

13. Id. at 1335. In Helene Curtis the court stated that the severance order would be reviewable only if an abuse of discretion were shown. Id. The court then reviewed the merits of the order, found no abuse of discretion, and concluded that the severance order was not appealable. Id. at 1335-37. Such inconsistency between language and action is one reason for undertaking the drafting of this Interlocutory Restatement.

Incidental review of an order denying severance was also allowed in In re Japanese Elec. Prods. Antitrust Litig., 631 F.2d 1069 (3d Cir. 1980). The Third Circuit took a certified appeal of an order requiring a jury trial in a very complicated action. Sony, one of the defendants, had settled with one of the plaintiffs but remained a defendant in the consolidated action. Sony moved for a separate trial of the claims against it, asserting that "special circumstances render a jury incapable of deciding the claims against [it]" and that a decision by jury would violate due process. Id. at 1090. Since the court of appeals was deciding whether a jury trial of the entire consolidated action would violate due process, it held that Sony's claims on severance were also reviewable. Id. See $\S 11$ of this Interlocutory Restatement, comment $e$, for a discussion of scope of review of certified appeals.

1. Padovani v. Bruchhausen, 293 F.2d 546, 547 (2d Cir. 1961). Padovani reached a decision apparently 
addition, interlocutory review is denied because a deficiency in a pretrial order may be mooted by later events in the trial court or, if not mooted, effectively reviewed on appeal from a final decision.

For example, in Life Music, Inc. $v$. Edelstein the court issued a pretrial order tentatively defining the issues. ${ }^{2}$ The petitioner sought a writ of mandamus ordering the trial judge to set aside his order, arguing that because the court's definition of the issues was not expressly agreed to by the petitioner, the order was an abuse of discretion. ${ }^{3}$ In a brief discussion the court of appeals indicated that a trial court may find parties in agreement on some issues in the same way "[a] scholar may write that two of his fellows are in agreement, although each, cherishing some nuance of expression, loudly denies it."4 The court of appeals refused, however, to consider whether the trial judge erroneously found agreement between the parties and indicated that the petitioner would have an adequate remedy on appeal after final decision. ${ }^{5}$

Illustration. The court issues a pretrial order that requires $\mathrm{P}$ and $\mathrm{D}$ to submit school desegregation plans, which will be the subject of expert testimony at trial. If either $\mathrm{P}$ or $\mathrm{D}$ appeals, the appeal should be dismissed. The trial court has broad discretion to control the development and disposition of issues. Any harm can be corrected on review after final decision. ${ }^{6}$

Similarly, in American Pipe $\mathcal{E}$ Construction Co. v. Pence Judge Pence, who had responsibility for supervising twenty-seven antitrust actions in five districts, had entered a pretrial order which provided for three or more simultaneous trials before three district judges. ${ }^{7}$ The defendant sought interlocutory review of the order, claiming that simultaneous trials would confront it "with difficulties and burdens of such magnitude as to assure, in advance, that American will not have fair trials."8 The court of appeals refused to hear an appeal because there was no

contrary to the rule presented. The trial court had ordered the plaintiff to submit a number of pretrial statements prior to a pretrial conference. The defendant objected to the adequacy of those statements, and the court granted the defendant's motion for preclusion. The preclusion order severely limited the evidence that plaintiff could present at trial. Finding that the preclusion order could only lead to a judgment for the defendant at trial, the court of appeals allowed interlocutory review to avoid the expense of a predetermined trial.

Carried to its extreme, Padovani could justify interlocutory review of all pretrial orders (including discovery orders) to determine whether or not the order erroneously predetermines the outcome of the case. While this may lead to more "just" results in litigation as financially strapped parties will have less pressure to settle, it is contrary to the longstanding policy of postponing review if effective relief can be provided after final decision.

It is possible that Padovani was an attempt to lessen the pressure on a financially strapped plaintiff to settle. The plaintiff, a victim of cancer of the larynx, was suing a tobacco company for his damages, which were allegedly caused by smoking. Thus, Padovani may represent a narrow exception to what at times can be a harsh rule.

2. 309 F.2d 242 (2d Cir. 1962).

3. Id. at 243 .

4. Id.

5. Id. at 243.44 .

6. Bradley v. Milliken, 468 F.2d 902 (5th Cir.), cert. denied, 409 U.S. 844 (1972).

7. 383 F.2d 568 (9th Cir.), cert. denied, 393 U.S. 842 (1968).

8. Id. at 572 . 
basis for it to determine, prior to completion of the trials, that any overlapping would be so unreasonable as to constitute an abuse of discretion; that any overlapping would actually result in such prejudice as to render the trials unfair; or that a trial judge confronted with the possibility of substantial prejudice caused by overlapping trials would fail to adequately address the problem. Furthermore, even if substantial prejudice were to occur, American might still prevail on the merits. Should American lose on the merits it could appeal, and the issue of substantial prejudice from overlapping trials would be subject to review. ${ }^{9}$

b. Sanctions for Pretrial Misconduct. An order imposing sanctions, newly authorized by Rule 16(f) of the Federal Rules of Civil Procedure, ${ }^{10}$ for various misconduct as to pretrial conferences should generally be subject to immediate review as to nonparties but not as to parties. Sanctions available as to parties are similar to the discovery sanctions listed in the black letter to Section 39 of this Interlocutory Restatement;" the same practice-nonappealability except when the sanction is in effect a final decision-should be followed. ${ }^{12}$ The only sanctions available as to nonparties, specifically the attorneys involved, would be contempt or assessment of the opposing party's expenses arising from the misconduct. Since nonparties do not have standing to appeal from final decisions, such sanctions as to them would be subject to immediate review. ${ }^{13}$

G. Review of Posttrial Orders

§ 42. New Trials.

(A) AN ORDER DENYING A MOTION FOR NEW TRIAL IS A FINAL DECISION.

(B) AN ORDER GRANTING A NEW TRIAL IS REVIEWABLE ON APPEAL FROM A FINAL DECISION SUBSEQUENTLY RENDERED IN THE NEW TRIAL OR ON INTERLOCUTORY APPEAL TO PRESERVE A FAVORABLE JUDGMENT FROM UNLAWFUL DISTURBANCE BY THE DISTRICT COURT.

\section{COMMENT}

a. Grounds for New Trial. Rule 59 of the Federal Rules of Civil Procedure provides for the grant of a new trial but does not enumerate the grounds on which such an order might be based. The rule states merely that the district court may grant the new trial "in an action in which there has been a trial by jury, for any of

9. Id. at $572-73$.

10. FED. R. CIV. P. 16(f), reprinted in Amendments to the Federal Rules of Civil Procedure, 97 F.R.D. 165, 171 (Apr. 28, 1983) (effective Aug. 1, 1983). Sanctions are available for failure to obey a pretrial or scheduling order or to appear at or participate in good faith at a pretrial conference or for appearing at such conference unprepared. Id.

11. Such sanctions include a preclusion order, an order striking a pleading, an order staying the proceeding, and an order entering a default judgment. Id.

12. See generally supra $\S 39$ of this Interlocutory Restatement. A default judgment, for example, would be a final decision. Note also the exception as to the right to be heard prior to imposition of sanctions.

13. See supra $\S 1$ of this Interlocutory Restatement, notes $26-28$ and accompanying text; supra $\S 23$ of this Interlocutory Restatement, comment e. 
the reasons for which new trials have heretofore been granted in actions at law" or "in an action tried without a jury, for any of the reasons for which rehearings have heretofore been granted in suits in equity in the courts of the United States." Such reasons have been held to include, in a jury trial, denial of the proper mode of trial (jury or court), errors in jury selection, improper jury instruction or other comment or conduct by the trial judge, prejudicial remarks or conduct by counsel, erroneous admission or exclusion of evidence, perjury, newly discovered evidence, absence of a material witness, and the judge's conclusion that the jury verdict is excessive, inadequate, or against the weight of the evidence. ${ }^{2}$ In a nonjury trial, principal grounds are manifest error of law or fact and newly discovered evidence. ${ }^{3}$

A motion for a new trial must be filed within ten days after entry of judgment. ${ }^{4}$ The trial court may, within the same time, grant a new trial on its own motion and may, after giving the parties notice and an opportunity to be heard, grant a timely filed motion for a new trial for reasons not stated in the motion. ${ }^{5}$ Motions for directed verdict ${ }^{6}$ and judgment n.o.v. ${ }^{7}$ are not prerequisites to a motion for a new trial. $^{8}$

b. Denial of New Trial. An order denying a motion for a new trial is a final decision. ${ }^{9}$ It is, however, often said that such an order is not itself appealable. ${ }^{10} \mathrm{As}$ explained by the court in John E. Smith's Sons Co. v. Lattimer Foundry E Machine Co., this result obtains

not because the order is not a final decision within the meaning of Section 1291 . . ., for it is intrinsically final, but rather because it generally does not involve reviewable subject matter. Ordinarily the denial of a new trial either involves an exercise of discretion, which is unreviewable in the absence of a clear abuse of it, or redetermines questions of law and fact which were settled by the prior judgment of the court and which are, therefore, reviewable only on appeal from the original judgment. ${ }^{11}$

1. FED. R. CIV. P. 59(a).

2. See 6A J. Moore \& J. Lucas, Moore's Federal Practice 59.08 (2d ed. 1983).

3. See id. T 59.07. It should be noted that motions for new trials on grounds of newly discovered evidence, perjury, or absence of a material witness often cannot be filed within the ten-day time limit imposed by Rule 59(b), and relief, therefore, must often be sought under Rule 60(b) of the Federal Rules of Civil Procedure. For a discussion of relief from judgment under Rule $60(\mathrm{~b})$, see infra $\S 43$ of this Interlocutory Restatement.

4. FED. R. CIV. P. 59(b).

5. Id. $59(\mathrm{~d})$.

6. See id. $50(\mathrm{a})$.

7. See id. 50(b).

8. E.g., Urti v. Transport Commercial Corp., 479 F.2d 766, 769 (5th Cir. 1973); see also 6A J. MOORE \& J. LuCAS, supra note 2, ๆ 59.04[5], at 59-20.

9. This is at least true where the denial is made after the entry of judgment, as is usually the case, since it is then "a decision to let the judgment stand as previously entered, and . . . nothing further remains to be determined in the cause." Creedon v. Loring, 249 F.2d 714, 717 (Ist Cir. 1957). The same rationale provides the basis for the doctrine that an order denying a Rule 60 (b) motion for relief from judgment is a final decision. See infra $\S 43$ of this Interlocutory Restatement, comment a.

10. A timely filed motion for new trial under Rule 59 suspends the finality of the judgment and tolls the running of the time for appeal. Thus, appeal from the underlying judgment is still available when denial of the new trial motion restores finality. 6A J. MOORE \& J. LuCAS, supra note 2, If 59.15[1], at 59307 \& n.3. See also supra $\S 7$ of this Interlocutory Restatement, comment $a$.

11. 239 F.2d 815, 816 (3d Cir. 1956) (footnotes omitted). See also 6A J. MoORE \& J. LuCAs, supra note $2,959.15[1]$, at 59-314, noting that even when an order denying a new trial is reviewed on appeal from the underlying judgment, "the scope of review is quite narrow and this fact probably accounts for the general doctrine of non-appealability [of the order itself]." 
Despite this alleged nonappealability, appellate courts have allowed direct appeals from orders denying motions for new trials, asserting that such orders are appealable in certain exceptional circumstances, as where the district court has abused its discretion. ${ }^{12}$ It has been accurately observed that these appellate courts were likely confusing "appealability" with "reviewability," since the issue in these cases was scope of review and not the appealability of the order itself. ${ }^{13}$

This frequently discussed distinction between direct appeal and review on appeal from the underlying judgment is in practice an academic one. Both the underlying judgment and the order denying relief are ripe for appeal as soon as the motion for a new trial is disposed of, and the general rule is that a court of appeals will regard the technical mistake of appealing from the order itself instead of from the underlying judgment as harmless error and will treat the appeal as from the judgment. ${ }^{14}$ In effect, then, an order denying a new trial, which is intrinsically final and ripe for appeal anyway, is treated as such by the courts of appeals, in spite of the abundance of language in cases and commentary calling it unappealable.

Illustration 42-1. P wins a judgment against D. D files a timely motion for new trial, charging that the district court erred in admitting certain evidence. The motion is denied, and $\mathrm{D}$ appeals. The appeal should be allowed. While the appellate court may formally recognize the rule that review of the order may be had only on appeal from the underlying judgment, it will regard the appeal as if it had been taken from that judgment. Thus, the order of denial, in effect, is treated as a final decision.

The distinction between direct appeal and review on appeal from the underlying judgment is not relevant when the motion for a new trial is based on matters

12. E.g., Montgomery Ward \& Co. v. Duncan, 311 U.S. 243 (1940); Jordan v. Federal Farm Mort. Corp., 152 F.2d 642 (8th Cir. 1945).

13. 11 C. Wright \& A. Miller, Federal. Practice and Procedure $\$ 2818$, at $116-17$ (1973); 6A J. MOORE \& J. LUCAS, supra note 2, I 59.15[1], at 59-308 \& n.7. This notion is supported by the fact that many of these cases cite Fairmont Glass Works v. Cub Fork Coal Co., 287 U.S. 474 (1913), as precedent for allowing appeal from the order denying a new trial. In Faimont, however, the issue of the propriety of the order was properly before the court on appeal from the underlying judgment. The oft-cited discussion by $\mathrm{Mr}$. Justice Brandeis thus concerned the scope of review of the order and not its appealability. See id. at 481-83.

14. See, e.g., United States v. Ellicott, 223 U.S. 524, 539 (1912); Serzysko v. Chase Manhattan Bank, 461 F.2d 699, 701 (2d Cir.), cert. denied, 409 U.S. 883 (1972); Cromling v. Pittsburgh \& L.E. R. Co., 327 F.2d 142, 144 n.1 (3d Cir. 1963); Preble v. Johnson, 275 F.2d 275, 277 (10th Cir. 1960). Compare Bass v. Baltimore \& O. Terminal R. Co., 142 F.2d 779 ( 7 th Cir. 1944) (appeal from judgment as opposed to order denying motion for a new trial motion discussed without mention of doctrine of harmless error). Commentators view this case as no longer having value as precedent, $11 \mathrm{C}$. WRIGHT \& A. MILLER, supra note 13, $\S 2818$, at 118 n.46, having been expressly overruled by Hennessy v. Schmidt, 583 F.2d 302, 306 (7th Cir. 1978).

This application of the harmless error doctrine, while apparently the general rule now followed, is subject to certain qualifications. For example, the underlying judgment itself must be final, and it must be clear what judgment is involved. Courts also have said that the opposing party must not have been misled, Hennessy v. Schmidt, 583 F.2d 302, 306 (7th Cir. 1978); Peabody Coal Co. v. Local Union Nos. 1734, 1508, 1548, 484 F.2d 78, 81 (6th Cir. 1973), and that it must be apparent that appellant intended to appeal from the underlying judgment (as where the appeal specified errors occurring at trial). See Atlanta Coast Line R. Co. v. Mims, 199 F.2d 582, 583 (5th Cir. 1952). 
arising after the entry of judgrnent. ${ }^{15}$ Even courts adhering to the rule of nonappealability will allow direct appeal from an order denying such a motion because, for example, newly discovered evidence will not appear as part of the record supporting the judgment and thus will be effectively reviewable only on appeal from the order of denial. ${ }^{16}$

Illustration 42-2. $\mathrm{P}$ wins a judgment against $\mathrm{D}$. D files a timely motion for new trial on the basis of newly discovered evidence. The motion is denied, and D appeals. The appeal should be allowed from the order of denial itself. A review of the record on appeal of the underlying judgment would not disclose matters arising after entry of such judgment. Had the appeal been taken solely from the underlying judgment, however, the appellate court should regard it as also bringing up for review issues relating to the newly discovered evidence. ${ }^{17}$

c. Grant of New Trial. An order granting a new trial is interlocutory and nonappealable since it destroys the finality of the judgment and mandates further litigation. ${ }^{18}$ Review of the order is available only on appeal from the final decision entered after the new trial. ${ }^{19}$

An order granting a motion for a new trial, however, is itself appealable where it is alleged that the trial court lacked jurisdiction to rule on the motion. This exception is based on an old line of authority originating with the Supreme Court's decision in Phillips v. Negley. ${ }^{20}$ In that case, a motion to vacate judgment and order a new trial had been made and granted after the expiration of the trial court term during which the final decision had been entered. According to the thenprevailing rule, a court lacked jurisdiction to disturb a judgment rendered during an earlier term of court. The Supreme Court, stating that an appellate court has jurisdiction to hear an appeal from an order vacating a prior judgment and

15. See John E. Smith's Sons Co. v. Lattimer-Foundry \& Mach. Co., 239 F.2d 815, 816 (3d Cir. 1956); see also 11 C. WRIGHT \& A. MilleR, supra note $13, \S 2818$, at 117 \& n.45.

16. John E. Smith's Sons Co. v. Lattimer Foundry \& Mach. Co., 239 F.2d 815, 816 (3d Cir. 1956); Hamilton v. United States, 140 F.2d 679, 682 (D.C. Cir. 1944)

The cases could be read as requiring, on appeal from the underlying judgment, notice of appeal from the denial of the new trial itself in order properly to bring issues involving newly discovered evidence before the appellate court. If the technical mistake of appealing only from the underlying judgment is committed, however, the court should treat the error as harmless and hear an appeal from the new trial order also. See J. MOORE \& J. LuCAS, supra note 2, If 59.15[1], at 59-315 n.29; see also discussion supra note 14.

Another circumstance where appeal from an order denying a new trial is proper is illustrated by Marsh v. Illinois Cent. R. Co., 175 F.2d 498 (5th Cir. 1949). There, plaintiff won a jury verdict, and defendant moved for judgment n.o.v., and, in the alternative, a new trial. The district court granted judgment n.o.v. but refused to grant a conditional new trial (in the event of reversal of the judgment on appeal). Defendant's motion to amend the judgment to include such a conditional grant was denied. On plaintiff's appeal from the judgment and defendant's cross appeal from the denial of its motion, the court reversed the judgment and reversed the order denying defendant's motion for a new trial. Defendant's cross appeal under these circumstances may be seen as from denial of the new trial because defendant could not technically have obtained review by appealing from the underlying judgment, since that judgment was favorable. See 6A J. MOORE \& J. LuCAS, supra note 2, II 59.15[1], at 59-315.

17. See discussion supra note 16.

18. E.g., Wiggs v. Courshon, 485 F.2d 1281, 1282 (5th Cir. 1973); Pellarino v. Ford Motor Co., 424

F.2d 241 (6th Cir. 1970); see also 6A J. MOORE \& J. LuCAS, supra note 2, I| 59.15[1], at 59-319 n.36.

19. See, e.g., Duncan v. Duncan, 377 F.2d 49 (6th Cir. 1967).

20. 117 U.S. 665 (1886). 
granting a new trial only if the lower court has acted without jurisdiction, held that the lower court had indeed so acted and remanded with directions to dismiss the motion to vacate the judgment. ${ }^{21}$

The purpose of this widely recognized "lack of jurisdiction" exception is to grant immediate review in order to secure the appellant's right to protect the finality of a favorable judgment from an unlawful disturbance by the district court. If "jurisdiction" is lacking, the court is incapable of destroying the finality of its own judgment;"22 appeal is allowed because the question of jurisdiction "goes to the effect and finality of the judgment itself."'23

This exception, however, has been criticized as distorting the concept of finality and unnecessarily multiplying interlocutory appeals, ${ }^{24}$ and it has been suggested that if review is to be had at all it should be by means of extraordinary writ. ${ }^{25}$ Even the critics, though, recognize the rule's acceptance and widespread application by the courts. ${ }^{26}$

The circumstances in which a "lack of jurisdiction" will be found, however, appear to be quite limited. The cases generally apply the exception only where a party's filing of a motion for a new trial or the district court's grant of a new trial on its own motion was untimely. ${ }^{27}$

\footnotetext{
21. Id.

22. Gilliland v. Lyons, 278 F.2d 56 (9th Cir. 1960); see also Freid v. McGrath, 133 F.2d 350 (D.C. Cir. 1942).

23. Gilliland v. Lyons, 278 F.2d 56, 58 (9th Cir. 1960) (quoting Manning v. German Ins. Co., 107 F. 52, 54 (8th Cir. 1901)).

Some courts, in applying the "lack of jurisdiction" exception, have read Phillips to imply that an order which the district court lacked power to issue should be treated as a final decision and should for that reason be appealable. See, e.g., Stradley v. Cortez, 518 F.2d 488 (3d Cir. 1975); Demeretz v. Daniels Motor Freight, 307 F.2d 469, 471 (3d Cir. 1962). Other courts regard such an order as interlocutory, although appealable. E.g., Rinieri v. News Syndicate Co., 385 F.2d 818 (2d Cir. 1967) (appeal allowed from order granting relief from judgment; court cites Phillips as precedent). The Second Circuit, in discussing these differing views, said, "In the last analysis, little is at stake beyond a label; the significant point is that the order is appealable." Id. at 822 n.9.
}

24. See 6A J. MOORE \& J. LuCAS, supra note 2, If 59.15[1], at 59-319.

25. See id.; 11 C. WRIGHT \& A. MilleR, supra note $13, \S 2818$, at 114 .

Some courts have said that where a district court exceeds its jurisdiction, extraordinary writ is the proper medium for review. See Grace Lines v. Motley, 439 F.2d 1028, 1031 n.2 (2d Cir. 1971); Kanatser v. Chrysler Corp., 199 F.2d 610 (10th Cir.), cert. denied, 344 U.S. 921 (1952). It has also been said that where the "lack of jurisdiction" exception applies, either an appeal from the order or an extraordinary writ may be appropriate. Wiggs v. Courshon, 485 F.2d 1281, 1282 (5th Cir. 1973). But where there is no allegation of circumstances amounting to a "judicial usurpation of power," mandamus is inappropriate since adequate review is available after judgment in the new trial. Allied Chem. Corp. v. Daiflon, Inc., 449 U.S. 33,35 (1980) (per curiam).

26. See 7 J. MoOrE \& J. LuCAS, supra note 2, 1 60.30[3], at 432-33; 11 C. WRIGHT \& A. Miller, supra note $13, \S 2871$, at 260 n.97. Courts themselves may even criticize the rule while applying it:

$[H]$ owever doubtful the rationale of Phillips $v$. Negley may be, courts of appeals have repeatedly recognized its authority ... . We have no doubt that the rule which generally denies an immediate appeal from an order granting a new trial is salutary. We merely recognize that Phillips v. Negley has created one narrow, perhaps anomalous, exception to this rule.

Demeretz v. Daniels Motor Freight, 307 F.2d 469, 471, 472 (3d Cir. 1962).

27. See, e.g., Wiggs v. Courshon, 485 F.2d 1281 (5th Cir. 1973); Chicago \& N.W. Ry. v. Britten, 301 F.2d 400 (8th Cir. 1962); see also Demeretz v. Daniels Motor Freight, 307 F.2d 469 (3d Cir. 1962); Jackson v. Wilson Trucking Corp., 243 F.2d 212 (D.C. Cir. 1957). The "lack of jurisdiction" exception seems to be similarly limited when a motion for relief from judgment is involved. See infra $\S 43$ of this Interlocutory Restatement, notes 9-12 and accompanying text.

An additional basis for lack of jurisdiction was found in Tsai v. Rosenthal, 297 F.2d 614 (8th Cir. 1961). 
Illustration 42-3. $\mathrm{P}$ wins a judgment against $\mathrm{D}$. Two weeks after entry thereof, $\mathrm{D}$ files a motion for new trial. The motion is granted. $\mathrm{P}$ appeals. The appeal should be heard. Although the order destroyed the finality of the original judgment, it is reviewable on the ground that the district court was without power to grant a new trial in response to a motion filed more than ten days after entry of judgment. The order should be vacated and the original judgment reinstated.

Existing case law suggests that orders granting new trials are inappropriate for certification for immediate appeal under 28 U.S.C. $\S 1292(\mathrm{~b}) .{ }^{28}$ In the primary statement of this view, the Third Circuit in Steele v. Wiedemann Machinery Co., while hearing the appeal and holding that a new trial should not have been granted, said further that the purposes of 28 U.S.C. $\$ 1292($ b) were not served by such certifications. ${ }^{29}$ A finding, the court noted, as in the case before it, that the new trial order was erroneous would not finally dispose of the cause. Rather, it would create the possibility of a subsequent appeal, on other issues, by the party aggrieved by the underlying judgment. Thus, the Third Circuit suggested that a district court, faced with an uncertainty as to a controlling issue of law, should deny the motion for a new trial and open the way for an immediate appeal from the underlying final decision. ${ }^{30}$ The new trial issue could then be raised along with any other alleged defects in the judgment, and multiplication of appeals would be averted.

d. Standard of Review. The district court has wide discretion to grant or deny a motion for a new trial. Appellate courts give considerable deference to this discretion, and their review of such orders will be very narrow in scope. ${ }^{31}$ Review is generally available only for abuse of discretion ${ }^{32}$ or for failure to exercise discretion at all (as when the district judge is under the mistaken impression that he has no power to grant the motion). ${ }^{33}$ Even greater restraint may be used in reviewing an order granting or denying a new trial when the ground for the motion is that the jury verdict is against the weight of the evidence ${ }^{34}$ or that the amount of the ver-

In that case, a special jury verdict found only one of two codefendants liable for plaintiffs personal injuries. The district court on its own motion granted a new trial on the issue of damages and the apportionment thereof between the codefendants. Although the order was untimely, the court on appeal further said that the district court lacked jurisdiction in another sense: The district court's ruling was seen as an implicit determination, in contravention of the jury's findings, that both codefendants were liable to plaintiff. Since no motions had been filed for directed verdict or judgment n.o:v., the district court was without jurisdiction to reexamine the jury's findings. Thus, the district court's order granting a new trial as to damages was premised upon an act which it had no power to perform, and the court was therefore without jurisdiction to make the order.

28. For a general discussion of certified appeals, see supra $\S 11$ of this Interlocutory Restatement. Compare the discussion of certification of orders granting relief from judgment, infra $\S 43$ of this Interlocutory Restatement, text accompanying notes 14-15.

29. 280 F.2d 380 (3d Cir. 1960).

30. Id. at 383 . The denial of a new trial motion tolls the running of the time to appeal. See supra $\S 7$ of this Interlocutory Restatement, at comment $a$.

31. E.g., City of Richmond v. Atlantic Co., 273 F.2d 902, 916-17 (4th Cir. 1960). For a general discussion of review of trial court discretion, see supra $\$ 9$ of this Interlocutory Restatement, comment $i$.

32. E.g., Telfair v. Zim Israel Nav. Co. 428 F.2d 127 (5th Cir. 1970), cert. denied, 400 U.S. 1009 (1971); Duncan v. Duncan, 377 F.2d 49 (6th Cir. 1967). See also 11 C. WRIGHT \& A. Miller, supra note 13, $\S 2818$, at 119 n. 49 .

33. E.g., Magee v. General Motors Corp., 213 F.2d 899 (3d Cir. 1954).

34. See $11 \mathrm{C}$. WRIGHT \& A. Miller, supra note $13, \S 2819$. An appellate court is less likely to reverse 
dict is inadequate or excessive. ${ }^{35}$ In fact, appellate courts have only relatively recently begun to consider such orders reviewable at all. ${ }^{36}$

Some considerations involved in appellate review of a new trial motion where the issue is whether the jury verdict is against the weight of the evidence are illustrated in Compton v. Luckenbach Overseas Corp. ${ }^{37}$ In this case, plaintiff won a jury verdict in a personal injury suit. The trial judge, in spite of his finding that there was "overwhelming" evidence in defendant's favor, refused to grant a new trial. A majority in the court of appeals affirmed the district court's ruling on the ground that it was an unreviewable exercise of discretion. The dissent argued that, given the trial judge's finding of overwhelming evidence against the jury verdict, the judge was under a duty to grant a new trial. No review of the trial judge's finding as to the weight of the evidence was necessary; rather, the abuse of (or more accurately, failure to exercise) discretion lay in the judge's failure properly to act on the basis of his finding. ${ }^{38}$ The dissent appears to state the better view of those presented in that case; the modern view would also allow reversal based on an appellate court's determination that the trial judge abused his discretion in making his finding as to the weight of the evidence. ${ }^{39}$

Illustration 42-4. P sues for recovery for personal injuries suffered in the performance of his duties aboard D's ship. The jury finds D negligent and $P$ contributorily negligent to the extent of fifty percent of his damages. $\mathrm{P}$ moves for a new trial on the ground that the finding of contributory negligence is against the weight of the evidence. The district court denies the motion, and $P$ appeals. The court of appeals on careful examination of the record finds no evidence in support of the challenged finding. The appellate court should reverse and remand for a new trial to prevent enforcement of a judgment that is contrary to controlling law. ${ }^{40}$

\section{§43. Relief From Judgment.}

(A) AN ORDER DENYING RELIEF FROM JUDGMENT IS A FINAL DECISION.

(B) AN ORDER GRANTING RELIEF FROM JUDGMENT IS REVIEWABLE ON APPEAL FROM A FINAL DECISION SUBSEQUENTLY ENTERED IN THE REOPENED PROCEEDING, ON CERTIFIED APPEAL,

\footnotetext{
a denial than a grant of a new trial on this ground. A reversal of the former would entail overturning the jury's findings, in possible conflict with the seventh amendment, while a reversal of the latter would be, in effect, a reaffirmation of the jury's findings. Id. at 125-26.

35. See id. $\$ 2820$

36. See id. $\S 2819$, at $120-22$; id. $\S 2820$, at $127-30$.

37. 425 F.2d 1130 (2d Cir.), cert. denied, 400 U.S. 916 (1970).

38. Id. at 1134 (Moore, J., dissenting). The dissent noted that the standard applied by the trial court - that it "may not disturb the jury's verdict unless there was no substantial evidence to support it"was the proper standard for determining whether to enter judgment n.o.v. See FED. R. CIV. P. 50(b). It was not the proper standard for granting or denying a new trial. 425 F.2d at 1134 .

39. See 11 C. WRIGHT \& A. MILLER, supra note $13, \S 2819$, at 121.

40. Urti v. Transport Commercial Corp., 479 F.2d 766 (5th Cir. 1973).
} 
OR ON INTERLOCUTORY APPEAL TO PRESERVE THE FINALITY OF A FAVORABLE JUDGMENT FROM UNLAWFUL DISTURBANCE BY THE DISTRICT COURT. SUCH AN ORDER IS A FINAL DECISION IF IT IS ISSUED IN A PROCEEDING BROUGHT ONLY TO SECURE SUCH RELIEF OR IF IT INCLUDES NEW DISPOSITIVE ACTIONS OF THE DISTRICT COURT MANIFESTING A PURPOSE TO TERMINATE THE LITIGATION ON THE REVISED TERMS SO EXPRESSED.

\section{Comment}

a. Denial of Relief from Judgment. The denial of a motion under Rule 60(b) of the Federal Rules of Civil Procedure for relief from a final judgment or order, since it puts an end to any further action by the district court and leaves the final judgment or order in full force and effect, ${ }^{1}$ is a final appealable decision under 28 U.S.C. $\S 1291 .^{2}$

b. Grant of Relief from Judgment. An order granting a Rule 60(b) motion for relief from judgment generally serves merely to open up for further consideration an action previously disposed of by the district court, ${ }^{3}$ and in such cases it is purely interlocutory and not appealable. ${ }^{4}$ Review may be had on appeal from a final decision in the new proceeding, at which time the appellate court may determine whether it was error to reopen the original judgment. ${ }^{5}$

An order granting relief from judgment, however, may be reviewed on interlocutory appeal when it can be alleged that the district court lacked jurisdiction to rule on the Rule 60 (b) motion, as when the motion was not timely filed. This doctrine derives by analogy from a long line of authority originating with the Supreme Court's holding in Phillips $v$. Negley. 6 A comparable "lack of jurisdiction" exception exists as to review of orders granting new trials, ${ }^{7}$ and here, as in that context, this exception is criticized as unnecessarily multiplying appeals even as its critics acknowledge its substantial precedent. ${ }^{8}$

1. Greenspahn v. Joseph E. Seagram \& Sons, 186 F.2d 616 (2d Cir. 1951); see also Welden v. Grace Lines, 404 F.2d 76, 77 (2d Cir. 1968).

2. E.g., Cromelin v. Markwalter, 181 F.2d 948 (5th Cir. 1950).

3. See United States v. Agne, 161 F.2d 331 (3d Cir. 1947).

4. Crowe v. Ragnar Benson, Inc., 307 F.2d 73 (3d Cir. 1962); Daly v. Stratton, 304 F.2d 666 (7th Cir. 1962); Resnik v. LaPaz Guest Ranch, 289 F.2d 814 (9th Cir. 1961).

5. 11 C. Wright \& A. Miller, Federal Practice and Procedure $\$ 2871$, at 260 (1973); see Hamilton-Brown Shoe Co. v. Wolf Bros. \& Co., 240 U.S. 251, 258 (1916); Edwin Raphael Co. v. Maharam Fabrics Corp., 283 F.2d 310, 311 (7th Cir. 1960).

6. 117 U.S. 665 (1886); see also Radack v. Norwegian Am. Line Agency, 318 F.2d 538, 543 n.5 (2d Cir. 1963).

The Second Circuit also has held an order granting Rule 60(b) relief to be a collateral order (see supra $\S 12$ of this Interlocutory Restatement, notes 10-13 and accompanying text), and thus appealable, where it vacated a prior order which, pursuant to stipulation of the parties, had dismissed movant's appeal from the underlying judgment. Weilbacher v. J.H. Winchester \& Co., 197 F.2d 303 (2d Cir. 1952).

7. See supra $\S 42$ of this Interlocutory Restatement, notes $20-27$ and accompanying text. A fuller statement of the Phillips case is included therein.

8. See id., notes 24-26 and accompanying text. For an example of a case advocating use of mandamus in "lack of jurisdiction" situations in the relief from judgment context, see Butcher \& Sherrerd v. Welsh, 206 F.2d 259 (3d Cir. 1953).

Compare United States v. Agne, 161 F.2d 331 (3d Cir. 1947), in which the court stated, "We find no suggestion in the decisions we have examined that indicates that an order, not final in its nature, seems 
The "narrow, perhaps anomalous"9 exception created by Phillips has generally been confined to situations where the district court's lack of jurisdiction is premised on an untimely filing of the Rule $60(\mathrm{~b})$ motion. ${ }^{10}$ Some cases include language suggesting other grounds warranting appealability; but even in those cases, timeliness of filing appears to be the ultimate jurisdictional issue. The court in Rinieri v. Nezes Syndicate Co., for example, stated that a district court was without jurisdiction to grant relief from judgment if it acted "without any basis in law, disregarding the limitations placed upon the power to vacate provided in the provisions of Rule 60(b) . . . ." The Rule 60(b) motion in that case had been filed two and one-half years after a final judgment of dismissal, and movant's only possible basis for relief was Rule 60(b) (6), which contains a "reasonable time" limitation for filing. Thus, it appears that the court's inquiry into the existence of "exceptional circumstances" was aimed solely at determining whether two and one-half years was a "reasonable time" within which to request relief from judgment so as to bring the motion within the district court's jurisdiction under Rule 60 (b)(6). The court concluded that such exceptional circumstances were not present, that Rule 60(b)(6) could not therefore be properly invoked, and that the district court thus had had no "basis in law" and no jurisdiction to grant Rule 60 (b) relief. ${ }^{12}$ The district court's order was reversed.

Illustration 43-1. P wins a default judgment against D. Eighteen months after the judgment is entered, D files a motion under Rule 60(b)(1) for relief from judgment on the ground of excusable neglect. The district court grants the motion and reopens the proceeding. $\mathrm{P}$ appeals. The appeal should be entertained because the one-year time limit for motions based on excusable neglect makes D's motion untimely and the district court thus lacked jurisdiction to rule on it. The district court's decision must be reversed and the original judgment reinstated. ${ }^{13}$

Although no reported case has dealt with the matter, certified appeal from an order granting relief from judgment should be available if there is substantial doubt regarding the propriety of granting relief from judgment and a prospect that substantial time, litigation costs, and judicial energies might be saved by a

forthwith appealable because the court making it had no jurisdiction in the premises." Interestingly, however, as noted by the Third Circuit (in Deneretz v. Daniels Motor Freight, 307 F.2d 469 (3d Cir. 1962)), a later decision in which it applied the "lack of jurisdiction" exception in the new trial context), the Phillips case, from which the "no jurisdiction" doctrine was derived, was not cited as a relevant precedent to the court in Agne.

9. Demeretz v. Daniels Motor Freight, 307 F.2d 469, 472 (3d Cir. 1962).

10. See Hand v. United States, 441 F.2d 529 (5th Cir. 1971); Cavalliotis v. Salomon, 357 F.2d 157 (2d Cir. 1966); Radack v. Norwegian Am. Line Agency, 318 F.2d 538 (2d Cir. 1963); Daly v. Stratton, 304 F.2d 666 (7th Cir. 1962). A similarly limited application dominates in the new trial context. See supra $\$ 42$ of this Interlocutory Restatement, note 27 and accompanying text.

11. 385 F.2d 818 (2d Cir. 1967).

12. Id. at 823 .

13. Note that had this motion been filed at the same time, but under subdivision (4), (5), or (6) of Rule 60(b) (for which a "reasonable time" is the limit for filing), the court could well have found the motion to be timely and P's appeal would have been dismissed. See Cavalliotis v. Salomon, 357 F.2d 157 (2d Cir. 1966); Radack v. Norwegian Am. Line Agency, 318 F.2d 538 (2d Cir. 1963). 
prompt appellate ruling on the question. ${ }^{14}$ The danger of multiple appeals counseling against certification of new trial orders is not present here because the time for appeal from the underlying judgment will have expired. ${ }^{15}$

Illustration 43-2. $\mathrm{P}$ wins a judgment from D. D files a Rule 60(b) motion requesting relief from judgment on the ground that $\mathrm{P}$ used fraud and misrepresentation in securing perjured testimony which influenced the decision of the district court. At the Rule 60(b) hearing, D offers the testimony of witnesses who allegedly perjured themselves at trial but who now are willing to change their testimony. Since there is substantial doubt whether the proffered testimony should be heard and the requested relief granted on that basis, and since considerable time, litigation costs, and judicial energies might be saved if an erroneous grant of relief were corrected by a prompt appellate decision, the district court could properly certify the Rule 60(b) question for immediate appeal. ${ }^{16}$

c. Grant of Relief as Final Decision. An order granting relief from judgment is not always interlocutory, and, if it meets the usual tests of finality, will be appealable as a final decision. ${ }^{17}$ For example, immediate review would thus be available where the order granting Rule 60(b) relief included further action of the court which disposed of the case and left nothing more to be decided. ${ }^{18}$ In addition, it appears that where relief from judgment is granted in an independent action brought for the limited purpose of securing such relief, ${ }^{19}$ the order should be treated independently and thus be appealable as a final decision. The cases, however, though seemingly following this rule, do not discuss this aspect of the appealability issue. ${ }^{20}$

Illustration 43-3. $\mathrm{P}$ brings an action against $\mathrm{D}$ in a New York district court seeking relief, on the grounds of fraud and misrepresentation, from a judgment entered against him and in favor of $\mathrm{D}$ in an Ohio district court. The New York court enters an order permanently enjoining D from enforcing the judgment. D appeals. The appeal should be entertained because the New York court's order, although it grants relief from judgment, is a final disposition of P's independent action and is therefore appealable as a final decision. ${ }^{21}$

d. Scope of Review. On appeal from a Rule 60(b) determination, the decision to be made by the appellate court is whether the district court abused its discre-

14. For a fuller discussion of certified appeals, see supra $\$ 11$ of this Interlocutory Restatement.

15. See supra $\S 42$ of this Interlocutory Restatement, notes 28-30 and accompanying text.

16. Cf. Peacock Records, Inc. v. Checker Records, Inc., 365 F.2d 145 (7th Cir. 1966).

17. 7 J. Moore \& J. Lucas, Moore's Federal Practice $060.30[3]$ (2d ed. 1983).

18. See, e.g., United States v. Williams, 109 F. Supp 456 (W.D. Ark. 1952) (district court's Rule 60(b) order granted relief from a judgment quieting title in plaintiff and, based on a redetermination on the merits, entered judgment quieting title in defendant).

19. The power of the district court to entertain such an independent action is saved by Rule 60 (b).

20. $11 \mathrm{C}$. WRIGHT \& A. MILLER, supra note $5, \S 2871$. Cf. supra $\$ 18$ of this Interlocutory Restatement and text accompanying notes 1-8; supra $\S 23$ of this Interlocutory Restatement and text accompanying notes 27-31.

21. Hadden v. Rumsey Prods., 196 F.2d 92 (2d Cir. 1952). 
tion $^{22}$ in denying the Rule $60(\mathrm{~b})$ motion, ${ }^{23}$ and not whether the court was substantively correct in entering the judgment from which relief is sought; thus, the merits of the underlying judgment are not brought up for review. ${ }^{24}$ The rationale for this restriction is that since Rule $60(\mathrm{~b})$ is not intended to be a substitute for direct appeal from a final decision, ${ }^{25}$ appellate review of a denial of a Rule 60 (b) motion must be narrower in scope than review of the underlying decision so as not to vitiate the requirement of a proper and timely appeal from that decision. ${ }^{26}$

Occasionally, however, a court of appeals has examined the merits of the underlying judgment in hearing an appeal from a decision on a Rule 60(b) motion. In Silas $v$. Sears, Roebuck $\mathcal{E}^{\circ} \mathrm{Co}$., for example, plaintiff's action had been dismissed for failure of his attorney to prepare for and attend a pretrial conference, and plaintiff's motion for Rule 60(b) relief on the ground of excusable neglect was denied. ${ }^{27}$ The court held that under the circumstances, the issues and analysis involved in a consideration of the propriety of the district court's denial of the Rule 60(b) motion were identical with those that would be involved in an appeal from the dismissal order itself, so the court examined the merits of the dismissal in deciding to reverse the denial of Rule 60 (b) relief. ${ }^{28}$

Also, in Brennan v. Midwestern United Life Insurance Co., the court, while stating its approval of the general rule that an appeal of a Rule 60(b) denial does not bring up for review the merits of the underlying judgment, went on to hold that the particular circumstances of the class action before it made reconsideration of the merits necessary. ${ }^{29}$ The petitioners for Rule 60 (b) relief were absent class members whose claims had been dismissed with prejudice for failure to respond to mailed requests for discovery. The court examined the legality of the discovery orders and the procedures leading to dismissal for three reasons: First, the class action was still in progress and the defendent would not be subject to extraordinary hardship

22. Browder v. Director, Ill. Dep't of Corrections, 434 U.S. 257, 263 n.7 (1978); Cel-A-Pak v. California Agric. Labor Rel. Bd., 680 F.2d 664, 668 (9th Cir.), cert. denied, 103 S. Ct. 491 (1982); Phillips v. Insurance Co. of N. Am., 633 F.2d 1165,1167 (5th Cir. 1981); V.T.A., Inc. v. Airco, Inc., 597 F.2d 220,223 (10th Cir. 1979). The courts of appeals pay considerable deference to the district courts' discretion. $11 \mathrm{C}$. WRIGHT \& A. MILLER, supra note $5, \S 2872$, at 261 . For a general discussion of appellate review of trial court discretion, see supra $\$ 9$ of this Interlocutory Restatement, comment $i$.

23. An appellate court may also reverse the district court's denial of Rule 60(b) relief if the court refused to exercise its discretion at all, for example, if it thought it lacked power to rule on the motion, e.g., Sleek v. J.C. Penney Co., 292 F.2d 256, 258 (3d Cir. 1961), or if it erred as a matter of law, e.g., Stillwell v. Travelers Ins. Co., 327 F.2d 931 (5th Cir. 1964) (court applied erroneous standard in treating newly discovered evidence as opinion rather than fact).

24. Browder v. Director, III. Dep't of Corrections, 434 U.S. 257, 263 n.7 (1978); Wagner v. United States, 316 F.2d 871, 872 (2d Cir. 1963); Saenz v. Kenedy, 178 F.2d 417, 419 (5th Cir. 1949).

25. Edwards v. Joyner, 566 F.2d 960 (5th Cir. 1978); Demers v. Brown, 343 F.2d 427 (1st Cir. 1965).

It should also be noted that, unlike filing of a motion for new trial under Rule 59 of the Federal Rules of Civil Procedure, filing of a Rule 60(b) motion does not affect the finality of the judgment for purposes of appeal and thus does not toll the running of the time for appeal as provided by Rule 4(a) of the Federal Rules of Appellate Procedure. Browder v. Director, Ill. Dep't of Corrections, 434 U.S. 257, 263 n.7 (1978); Daily Mirror, Inc. v. New York News, Inc., 533 F.2d 53, 56 (2d Cir.), cert. denied, 429 U.S. 862 (1976). See also FED. R. Civ. P. 60(b) advisory committee note. See generally supra $\S 7$ of this Interlocutory Restatement, at comment a.

26. Silas v. Sears, Roebuck \& Co., 586 F.2d 382, 386 (5th Cir. 1978).

27. 586 F.2d 382 (5th Cir. 1978).

28. Id. at 386 .

29. 450 F.2d 999 (7th Cir. 1971), cert. denied, 405 U.S. 921 (1972). 
if the Rule 60 (b) relief were granted; ${ }^{30}$ second, the Rule $60(\mathrm{~b})$ motion alleged that the district court had no power to issue the discovery orders in question, thereby raising the contention that the dismissal was void and necessitating at least a primary inquiry into the merits of the dismissal;"31 and finally, because of the "unusual circumstances" of the case, principles of fairness warranted a review of the merits of the "drastic sanction" of dismissal with prejudice. ${ }^{32}$ After such an examination, the court affirmed the district court's denial of the Rule 60(b) motion.

31. Id. See V.T.C., Inc. v. Airco, Inc., 597 F.2d 220 (10th Cir. 1979) (review of denial of Rule 60(b)(4) motion alleging voidness of consent decree and injunction required examination of underlying decision, but only for validity, not for correctness).

32. Brennan, 450 F.2d 1003. 